\title{
IMPROVING AND PARAMETERISING \\ NITROGEN AND PHOSPHORUS MODELLING \\ FOR APPLICATION OF LUCI
}

IN NEW ZEALAND

By

Martha I. Trodahl

\begin{abstract}
A thesis
submitted to the Victoria University of Wellington

in fulfilment of the requirements for the degree of

Doctor of Philosophy
\end{abstract}

Victoria University of Wellington 



\begin{abstract}
Over the last 50 years freshwater and marine environments have become severely impaired due to contamination from pathogens, heavy metals, sediment, industrial chemicals and nutrients (MEA 2005b). In many countries, including New Zealand, increased nitrogen (N) and phosphorus $(\mathrm{P})$ loading to terrestrial and freshwater environments from diffuse nutrient sources are of particular concern (MEA 2005a; PCE 2015b; Steffen et al. 2015) and many governments now mandate control of diffuse nutrient loss to water. Water quality models are invaluable tools that can assist with decision making around this widespread issue through exploration of the current situation and future scenarios.

Many water quality models exist, functioning at a variety of temporal and spatial scales and varying in detail and complexity. However, few, if any, simultaneously represent sub-field to catchment scale processes and outcomes, both of which are required to fully address water quality issues associated with diffuse nutrient sources. Those that do, likely require extensive time and expertise to operate. Water quality models embedded in the Land Utilisation and Capability Indicator (LUCI), an ecosystem service decision support framework, offer the opportunity to overcome these limitations. Being highly spatially explicit, yet straightforward to use, they can inform and assist individual land owners, catchment managers and other stakeholders with planning, decision making and management of water quality at sub-field to landscape scale.
\end{abstract}

To model diffuse nutrient losses $\mathrm{LUCl}$, like many catchment scale water quality models, requires some form of estimated nutrient loss, or export coefficient, from land units within the catchment of interest. To be representative export coefficients must consider climate, soil, topography, and land cover and management variables. A number of methods of export coefficient derivation exist, although generally they consider only very limited geoclimatic, land cover and land management variables.

The principal aim of this study is development of algorithms capable of calculating New Zealand site specific $\mathrm{N}$ and $\mathrm{P}$ export coefficients from detailed geo-climatic, land cover and land management variables, for application in LUCI water quality models. Algorithms for pastoral land cover are developed from a large dataset comprising real pastoral farm input 
and output data from nutrient budgeting model OVERSEER. Algorithms are extended to land covers other than pasture, albeit in a limited manner. This is achieved through rescaling of the pastoral algorithms to account for relative differences in literature reported $\mathrm{N}$ and $\mathrm{P}$ losses from pasture and a variety of other New Zealand land covers. Application of the developed algorithms in LUCI water quality models results in positioning of export coefficients at the DEM grid square scale ( $\leq 15 \mathrm{~m} \times 15 \mathrm{~m}$ for New Zealand). In addition, intrabasin configuration is considered in $\mathrm{LUCl}$, at the same grid square scale, as water and nutrient flows are cascaded through the catchment. Application of the export coefficient calculating algorithms are applied to two contrasting New Zealand catchments. Tuapaka catchment, an 85ha agricultural foothill catchment in Manawatu, North Island, and Lake Rotorua catchment, a $502 \mathrm{~km}^{2}$ volcanic, mixed land cover catchment in Bay of Plenty, North Island.

This research is supported by Ravensdown, a farmer owned co-operative, which plans to use $\mathrm{LUCl}$ extensively to advise and assist farmers with water quality issues. The ability to model mitigation strategies in LUCl is an important capability. Therefore, this research also includes a review of five particularly important on-farm mitigation strategies, which will later be used by the wider LUCI development team to assist with better parameterisation and improved performance of mitigation options in $\mathrm{LUCl}$.

Application of the developed algorithms at farm to catchment scale in $\mathrm{LUCl}$ results in considerably more nuanced, detailed maps and data showing $\mathrm{N}$ and $\mathrm{P}$ sources and pathways, compared to LUCl's previously used 'one export coefficient per land cover' approach. Although results indicate absolute nutrient loss values are not always 'correct' compared to either OVERSEER predictions or in-stream water quality measurements, these differences appear comparable to those seen with similar water quality models. In addition, the issue of representativeness of OVERSEER predictions and in-stream water quality measurements exists.

Nevertheless improvement to absolute predictions is always an aim. This research indicates further improvements to LUCI water quality predictions could result from refinement of both pastoral and other land cover algorithms, and from improved representation of attenuation processes in LUCI, including groundwater representation. However, lack of measured on-land and in-stream $\mathrm{N}$ and $\mathrm{P}$ loss data is a major challenge to both algorithm 
refinement and to evaluation of results. In addition, more detailed spatial data would provide more nuanced results from algorithm application.

Although the algorithm application context in this research is LUCI water quality models applied in New Zealand, this does not preclude application of the developed algorithms in other export coefficient based, catchment scale water quality models. Using spatial data pertaining to climate, soil, topographic and land management variables, land units of combined variables can be identified and the algorithms applied, resulting in explicitly positioned export coefficients that can be fed into the catchment scale water quality model of interest. Therefore, developments made here potentially represent a wider contribution to catchment scale modelling using export coefficients. 


\section{ACKNOWLEDGEMENTS}

There are a number of people I would like to thank for their contribution to this research. Firstly, I would like to thank my supervisors Dr Bethanna Jackson and Dr Julie Deslippe for their extensive guidance, expertise, advice and support. I am also very grateful for generous financial support from Ravensdown, Callaghan Innovation, and the Irene Pestov Memorial Scholarship. In addition, wider support from Ravensdown is acknowledged and very much appreciated. This took many forms including the opportunity to attend organisational and industry training courses, and through advice and guidance around agricultural industry practice and knowledge. In particular, Alister Metherell, Ants Roberts and Mike White are thanked.

I would like to thank my co-authors and others who assisted with data, local knowledge and editing of the papers presented in the Appendix A. Bay of Plenty Regional Council is thanked for access to information and data that contributed to and assisted with application of LUCI in the Lake Rotorua catchment. In particular Alastair MacCormick was very helpful. Thanks also goes to Lucy Burkitt and Mike Bretherton from Massey University. Their time and generous access to data related to Tuapaka farm and catchment is appreciated.

Thanks goes to my office mates - Dr Deb Maxwell and Keith Miller. Your assistance with MATLAB and ArcGIS is particularly appreciated. In addition, the opportunity to talk about topics other than work was welcome. I would also like to thank the wider members of the Hydro Group for listening and giving feedback on presentations, and I have also enjoyed hearing about your research.

Finally, I would like to thank my family. Thanks to my parents, Margaret and Joe, for their support and encouragement (and coffee most mornings with Joe). An especially big and appreciative thanks goes to my husband Kiran, and my daughters, Nyah and Shivani - your support and patience through this process has been amazing. 


\section{TABLE OF CONTENTS}

1 INTRODUCTION

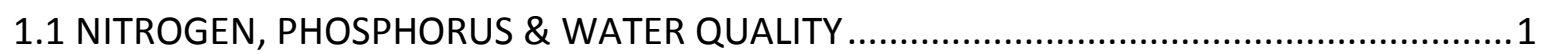

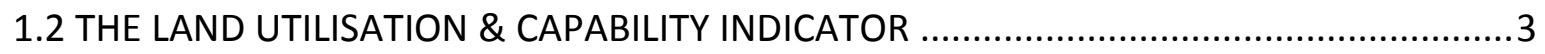

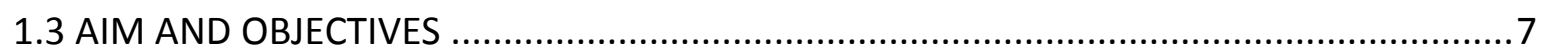

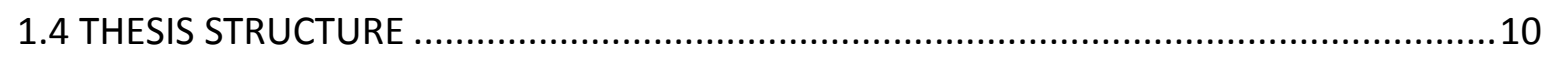

2 LITERATURE REVIEW: WATER QUALITY MODELLING USING EXPORT COEFFICIENTS ..........11

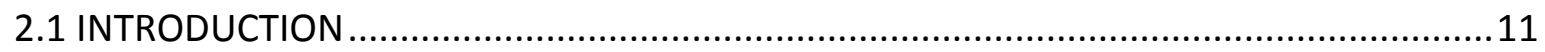

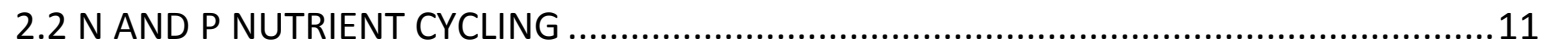

2.3 WATER QUALITY MODELLING WITH A FOCUS ON NEW ZEALAND ...............................18

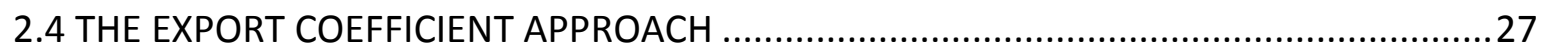

3 DEVELOPMENT OF A NEW EXPORT COEFFICIENT APPROACH FOR NEW ZEALAND USING

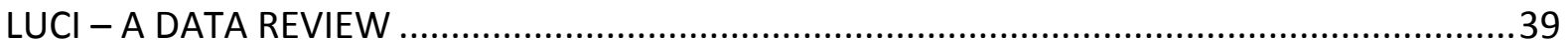

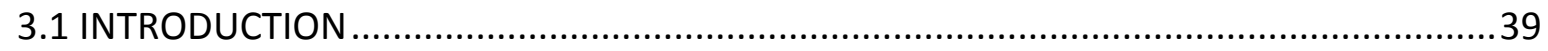

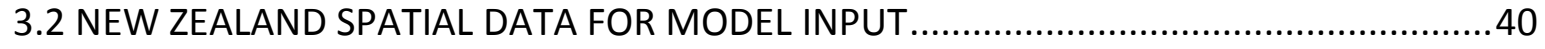

3.3 IN-STREAM WATER QUALITY DATA FOR CATCHMENT SCALE MODEL EVALUATION ....44

3.4 A REVIEW OF NEW ZEALAND DATA WITH POTENTIAL FOR USE IN EXPORT

COEFFICIENT ALGORITHM DEVELOPMENT AND PARAMETERISATION ............................47

4 THE RAVENSDOWN DATASET: EXPLORATION OF THE DATA AND UNDERLYING OVERSEER

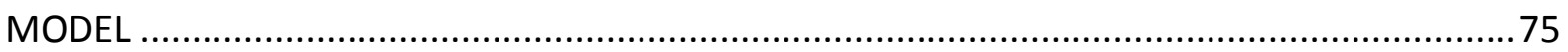

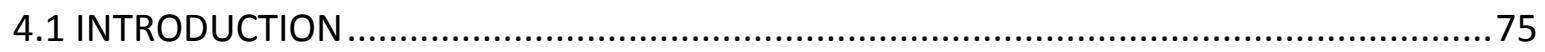

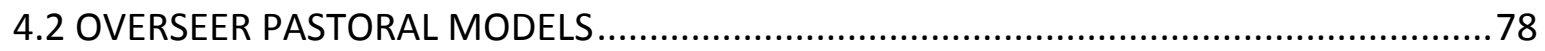

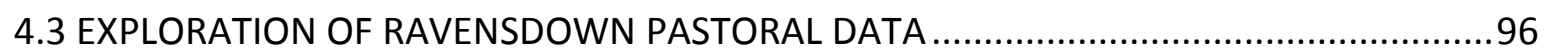

4.4 INVESTIGATION OF THE SOIL P LOSS COMPONENT OF OVERSEER ..........................121

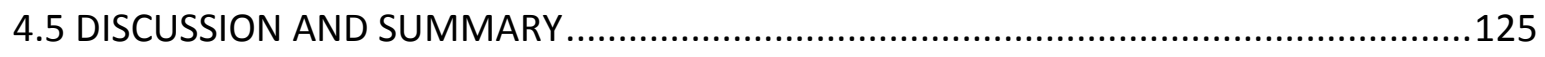




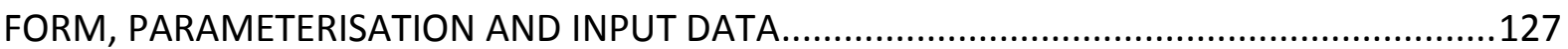

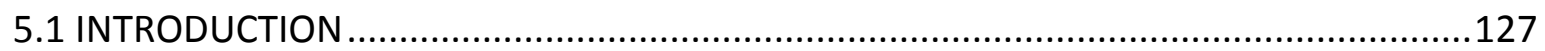

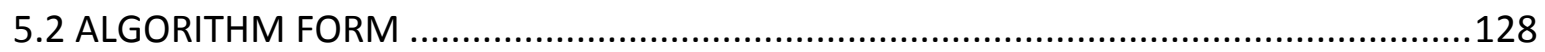

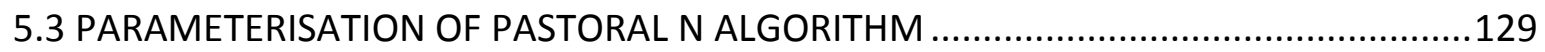

5.4 PARAMETERISATION OF LAND COVER MULTIPLIERS (LCM) .................................137

5.5 REGIONAL SCALE INPUTS TO N AND P PASTORAL ALGORITHMS ..............................141

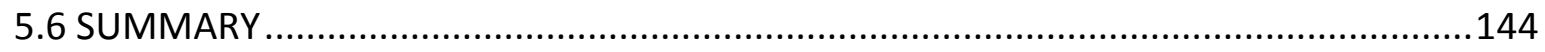

6 INVESTIGATE AND PARAMETERISE FIVE IDENTIFIED NITROGEN AND PHOSPHORUS

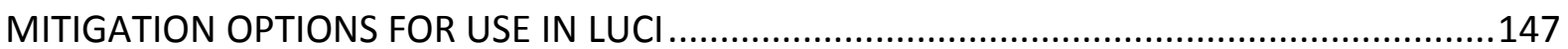

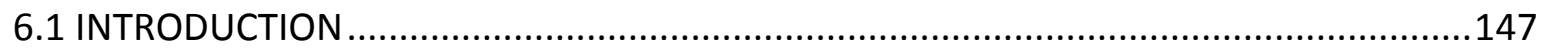

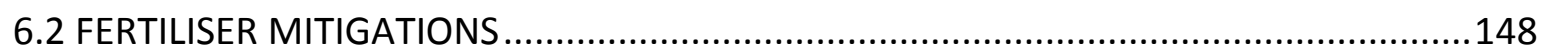

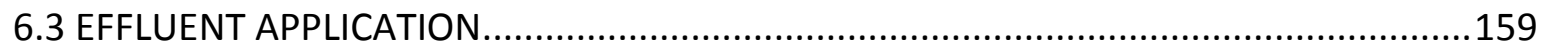

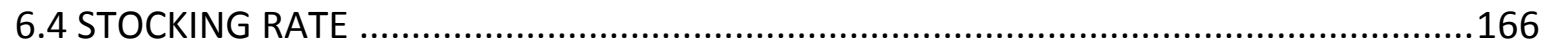

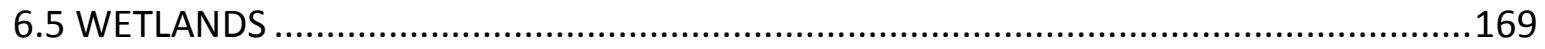

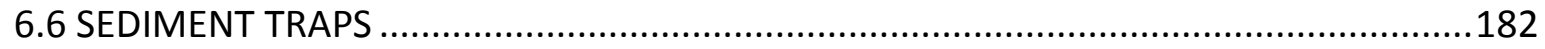

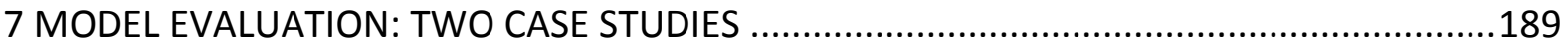

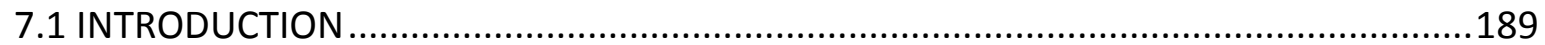

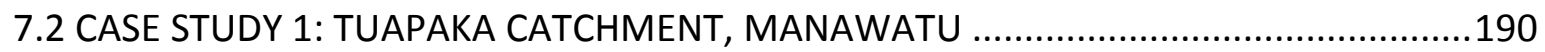

7.3 CASE STUDY 2: LAKE ROTORUA CATCHMENT, BAY OF PLENTY ................................197

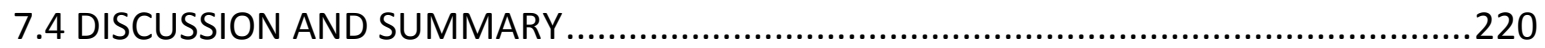

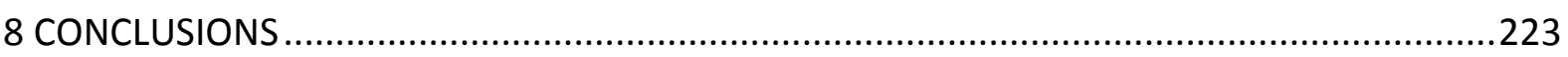

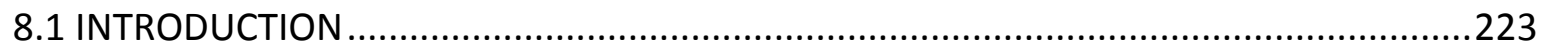

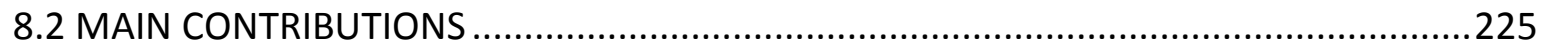

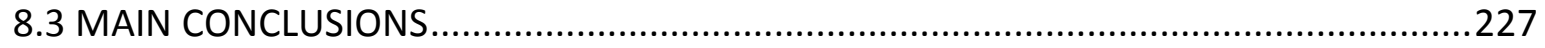

8.4 RECOMMENDATIONS FOR FUTURE WORK AND DEVELOPMENT ….........................233 


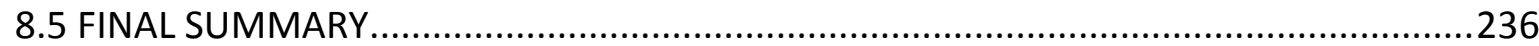

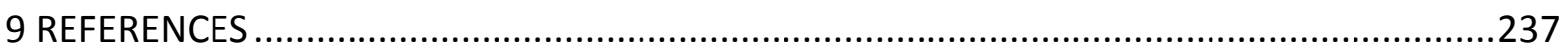

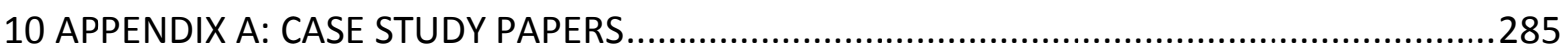




\section{INTRODUCTION}

\subsection{NITROGEN, PHOSPHORUS \& WATER QUALITY}

Appreciation of the vital nature of ecosystem services provided by the environment is increasing, as is recognition of the extent of anthropogenic damage to these services (MEA 2005b; Folke et al. 2011). Water purification by the environment is an essential regulating ecosystem service. However, over the last 50 years natural fresh water provisioning has been severely impaired due to contamination from pathogens, heavy metals, sediment, industrial chemicals and nutrients (MEA 2005b). In European and North American countries, parts of Asia, Australia and New Zealand, increased nitrogen $(\mathrm{N})$ and phosphorus $(\mathrm{P})$ loading to terrestrial and freshwater environments are of particular concern (MEA 2005a; Steffen et al. 2015). Nutrient losses to water in these areas must be curbed to avoid the risk of threshold related abrupt environmental change that could undermine freshwater and marine ecosystem resilience (Rockström et al. 2009; Steffen et al. 2015). Such change could impact on humanity's ability to access clean water, and grow or harvest food from terrestrial and aquatic environments.

In the last century, both the $\mathrm{N}$ and $\mathrm{P}$ nutrient cycles have become highly altered by human activities, especially, but not exclusively, due to modern agricultural practices. It is now estimated that the rate of global $\mathrm{N}$ cycling has doubled due to human $\mathrm{N}$ fixation, through both industrial fixation for $\mathrm{N}$ fertiliser production and increased use of $\mathrm{N}$ fixing plants (Fowler et al. 2013). For $P$, it is estimated that annual release into the environment is now three times that of natural P cycling (Bennett and Schipanski 2012). Increased agricultural $\mathrm{N}$ and $\mathrm{P}$ use has enabled agricultural expansion and intensification, thereby increasing crop and animal production to feed a growing human population, and one with a growing appetite for meat and dairy products (Foley et al. 2011; Neset and Cordell 2012; Fowler et al. 2013). However, associated negative water quality impacts are now a major concern in many countries (Mateo-Sagasta and Burke 2010) and governments are responding by implementing water quality regulations and limits, many of which target agricultural landscapes (MFE 2013; EuropeanCommission 
2014; NZ Govt 2014; White et al. 2015). In New Zealand decreasing freshwater water quality is also the trend (PCE 2013) and concern over the impact of intensified rural land management on water quality is increasing, as is frequently highlighted in media reports (Buxeda 2017; Mitchell 2017; Radio NZ 2017b; Young 2017).

\subsubsection{Agriculture and Water Quality Regulation in New Zealand}

Although over $85 \%$ of New Zealand's population live in urban areas (StatisticsNZ 2016), agricultural and rural landscapes play an important cultural and economic role in New Zealand society. Today, the primary sector contributes just over half of New Zealand's total annual export earnings, although it is highly dependent on international commodity markets, which are volatile (NZ Govt 2016). A variety of land uses, reflecting the variety of products sold, are found in rural New Zealand. Approximately $80.8 \%$ of rural productive land is pastoral (largely dairy, beef, sheep and deer), $15.5 \%$ is in commercial forest, $2.8 \%$ is in short-rotation crops, and $0.8 \%$ is in orchard, vineyard or other perennial crops (New Zealand Land Cover Database 2012). These figures reflect the enduring pastoral focus of New Zealand agriculture, and dairy farming is deemed particularly important economically. However, intensive pastoral land uses in New Zealand are linked to declining water quality (PCE 2015b) and the New Zealand agricultural sector is under increasing pressure to account more fully for enterprise impacts on water quality, and to take action to mitigate impacts. This is largely as a result of public pressure and recent reform and regulation of water management by the New Zealand Government.

Fresh water management reform began in New Zealand in 2009 with establishment of the Land and Water Forum, a collaborative, consensus-based group of stakeholders tasked with advising government. In 2011, the National Policy Statement for Freshwater Management (NPS-FM) was introduced, with amendments subsequently released in 2014. The NPS-FM defines national standards for fresh water quality and requires that all regional councils set regional objectives and limits for fresh water management. In doing this, local community and tangata whenua values associated with local water bodies must be considered (MfE 2016a). Regional councils have recently or are currently working through this process, and limits and objectives must be incorporated in regional plans and policy statements by 2025 (MfE 2016b). However, the setting of water quality 
limits and objectives and subsequent implementation of regional plans and policies, has proved to be challenging in some cases (Radio NZ 2017a). In particular, identifying individual actions required to rectify a collective diffuse water quality problem is a challenge.

\subsubsection{The Role of Water Quality Models}

Identifying individual responsibility for diffuse pollution sources and assessing the cumulative effect of these at the catchment scale is not straight forward. Nutrient cycles involve interconnected physical, chemical and biological processes functioning at a variety of temporal and spatial scales. Nutrient pathways from individual source points to water bodies are spatially and temporally varied and complex (Heathwaite 2003; Meals et al. 2010; Sharpley et al. 2013). Water quality models can assist with identification and quantification of nutrient sources, pathways to, and consequences for water bodies. Many water quality models exist and they function at a variety of temporal and spatial scales and vary in detail and complexity. However, few simultaneously represent sub-field to catchment scale processes and outcomes, both of which are required to address non-point source water quality issues. The few models that do integrate these spatial scales generally require extensive time and expertise to operate.

Water quality models embedded in the Land Utilisation and Capability Indicator (LUCI), an ecosystem service decision support framework, offer the opportunity to overcome these limitations. Being highly spatially explicit, yet straightforward to use, they inform and assist individual land owners, catchment managers and other stakeholders with planning, decision making and management of water quality at sub-field to landscape scale.

\subsection{THE LAND UTILISATION \& CAPABILITY INDICATOR}

\subsubsection{General Description}

LUCI, an extension of the Polyscape framework described in Jackson et al. (2013a), aims to investigate the cumulative impact of individual sub-field ecosystem service interventions within larger catchments. It shares a number of features in common with other decision support frameworks, but also has unique features that make it 
particularly suitable for evaluating the impacts of small-scale management at larger scales. This ability to simultaneously consider ecosystem services at site (sub-field) to landscape scale is identified as a particular strength of LUCl in comparative studies of multiple ecosystem service models (Bagstad et al. 2013; Sharps et al. 2017).

The LUCI framework considers impacts of land use on multiple ecosystem services in a holistic and spatially explicit manner. A number of ecosystem service stocks and associated indicators and processes are considered by LUCl and it determines how the configuration and placement of landscape features affect each of these. Individual ecosystem services (including $\mathrm{N}$ and $\mathrm{P}$ to water) can be assessed and the interrelationships between ecosystem services analysed to identify trade-offs and synergies between them (Fig 1.1). LUCl uses readily available national data and is computationally efficient, accomplishing highly spatially explicit catchment-scale analyses within minutes to hours. Minimum data requirements for $\mathrm{LUCl}$ are a digital elevation model (DEM), land cover and soil data. However, applications can be easily supplemented with additional national or local data if it is available. Table 1.1 summarises LUCl default input data for New Zealand applications. Maps and data summarising the results of each analysis are generated with each $\mathrm{LUCl}$ application to assist with analysis and interpretation.

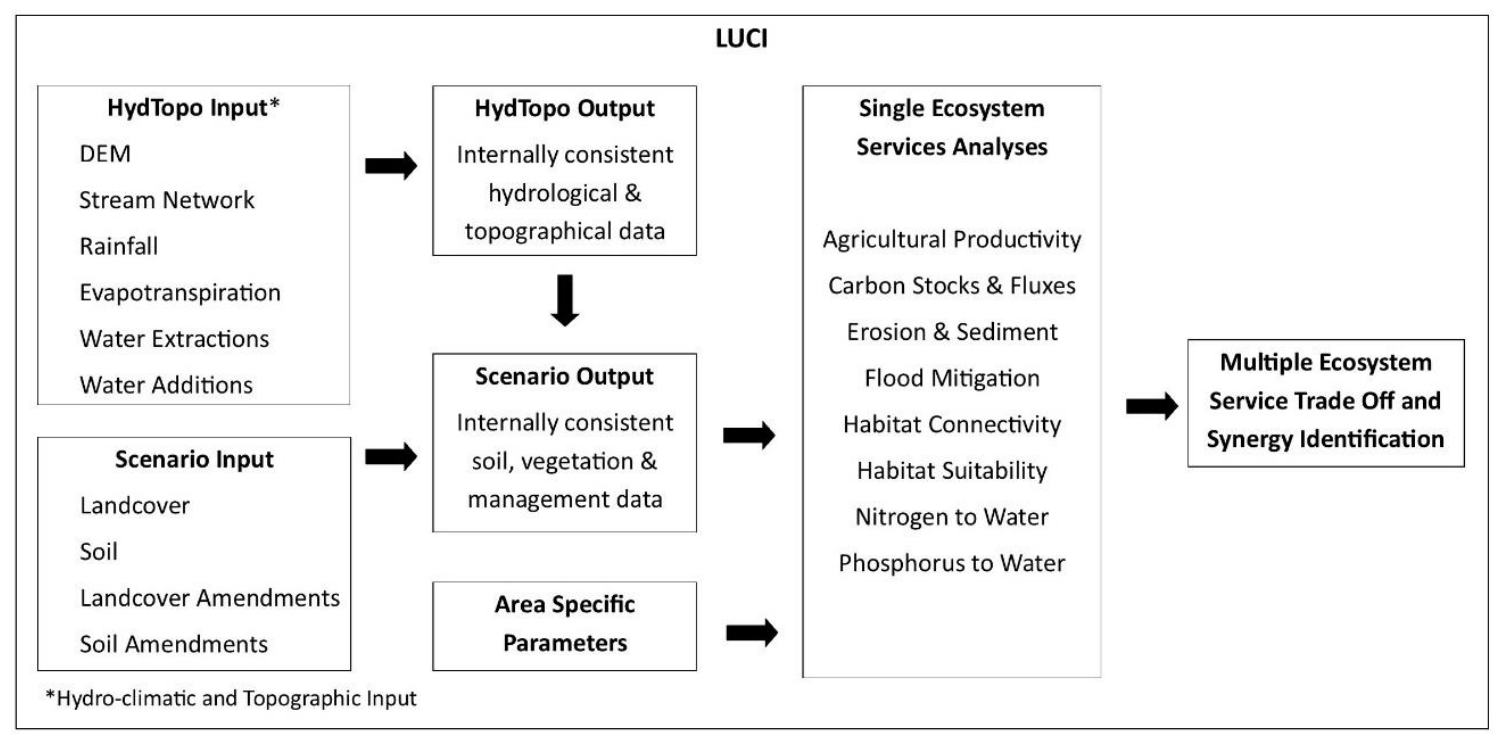

Figure 1.1 LUCI process diagram 
$\mathrm{LUCl}$ is readily applicable to a number of countries and a wide range of environments, and has been extensively applied in New Zealand (Ballinger 2011; Scott 2015; Jackson et al. 2016; Marapara, 2016; Trodahl et al. 2016), Wales (Jackson et al. 2013a; Robinson et al. 2013; Emmett et al. 2014; Emmett et al. 2015; Emmett et al. 2016), and elsewhere (Bhatterei 2009; Jackson et al. 2013b; Benavidez et al. 2016).

Table 1.1 Summary of LUCl default input data for New Zealand

\begin{tabular}{|c|c|c|c|c|}
\hline $\begin{array}{c}\text { Data Type } \\
\text { (Name) }\end{array}$ & $\begin{array}{l}\text { Period } \\
\text { Covered }\end{array}$ & $\begin{array}{l}\text { Data } \\
\text { Type }\end{array}$ & Resolution & $\begin{array}{c}\text { Information } \\
\text { On-line? }\end{array}$ \\
\hline $\begin{array}{l}\text { DEM } \\
\text { (NZSoSDEM v1) }\end{array}$ & 2011 & Raster & $15 \mathrm{~m} \times 15 \mathrm{~m}$ & Yes $^{1}$ \\
\hline $\begin{array}{l}\text { Stream network } \\
\text { (REC) }\end{array}$ & 2010 & $\begin{array}{l}\text { Vector } \\
\text { Polyline }\end{array}$ & Variable & Yes $^{2}$ \\
\hline Rainfall & $1960-2004$ & Raster & $1000 \mathrm{~m} \times 1000 \mathrm{~m}$ & No \\
\hline Evapotranspiration & $1960-2004$ & Raster & $500 \mathrm{~m} \times 500 \mathrm{~m}$ & No \\
\hline $\begin{array}{l}\text { Land Cover } \\
\text { (LCDB4) }\end{array}$ & $2012 / 13$ & $\begin{array}{l}\text { Vector } \\
\text { Polygon }\end{array}$ & $\begin{array}{c}\text { Variable - from } \\
\text { Spot-5 satellite } \\
\text { imagery }\end{array}$ & Yes $^{3}$ \\
\hline $\begin{array}{l}\text { Soil } \\
\text { (NZFSL) }\end{array}$ & $\begin{array}{c}\text { Based on } \\
\text { soil surveys } \\
\text { from 1930's- } \\
\text { present }\end{array}$ & $\begin{array}{l}\text { Vector } \\
\text { Polygon }\end{array}$ & $\begin{array}{c}\text { Variable } \\
\text { depending on } \\
\text { original soil map } \\
\text { resolution }\end{array}$ & Yes $^{4}$ \\
\hline $\begin{array}{l}\text { Soil } \\
\text { (S-Map) }\end{array}$ & $\begin{array}{l}\text { Based best } \\
\text { available soil } \\
\text { survey and } \\
\text { spatial } \\
\text { information }\end{array}$ & $\begin{array}{l}\text { Vector } \\
\text { Polygon }\end{array}$ & $\begin{array}{c}\text { Variable but } \\
\text { generally finer } \\
\text { than NZFSL }\end{array}$ & $Y_{e s}^{5}$ \\
\hline \multicolumn{5}{|c|}{ 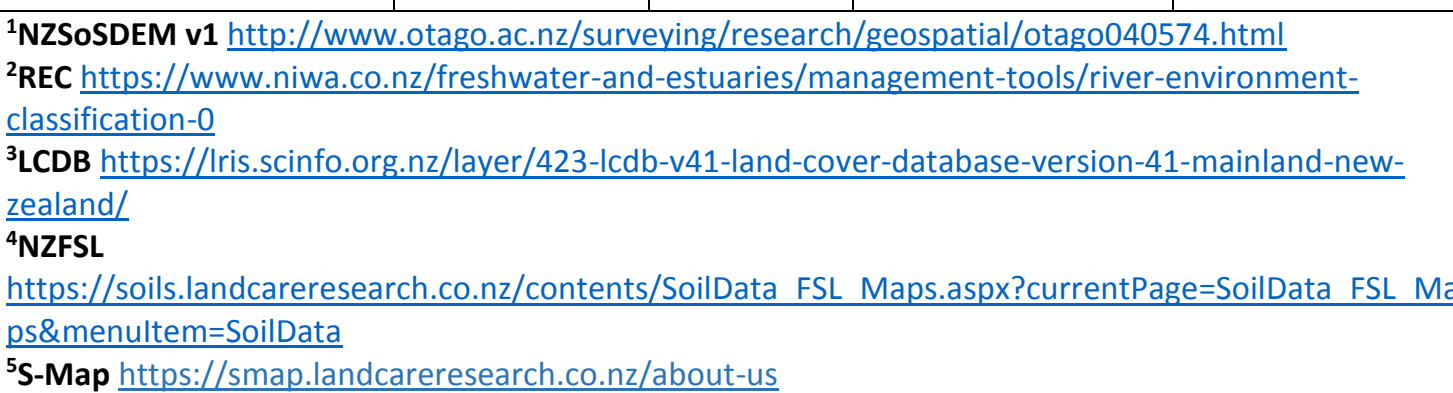 } \\
\hline
\end{tabular}

In 2014 collaboration began between LUCI developers and Ravensdown, a New Zealand farmer-owned co-operative. The aim of the collaboration is development of a bespoke version of $\mathrm{LUCl}$ for the co-operative that incorporates detailed farm management 
information into the framework to enhance LUCl's capabilities to support on-farm decision making (Jackson et al. 2016; Trodahl et al. 2016). These improvements will assist New Zealand farmers and other land managers with decision making around ecosystem services, with a particular focus on water quality.

\subsubsection{LUCI Water Quality Models}

Water quality models within LUCI use an enhanced, spatially representative export coefficient approach to model total nitrogen (TN) and total phosphorus (TP) exports to water. Export coefficients are defined as the "mass of a [contaminant] per unit area per unit time" (White et al. 2015) and are most often quantified in $\mathrm{kg} \mathrm{ha}^{-1} \mathrm{yr}^{-1}$. LUCl spatially positions export coefficients in association with land cover categories at the DEM scale. Particulate and dissolved nutrients are then cascaded through the landscape with water and sediment. For every DEM scale grid cell in the landscape and stream network, cumulative annual nutrient load and annual average concentration is calculated. The model identifies spatially explicit nutrient sources, pathways, and current and potential 'sinks' where nutrients can be intercepted, avoiding entry to the stream network. A proportion of water and nutrients is also routed to groundwater reserves. Currently these reserves exit back to water bodies via a simple linear reservoir.

A criticism of models employing an export coefficient approach is that they often consider only land cover, but climate, soil, topography, and land management are also significant influencing nutrient export variables (Khadam and Kaluarachchi 2006; Shi et al. 2006; Ding et al. 2010; Abell et al. 2011; Robinson and Melack 2013; White et al. 2015). This issue has been addressed using a variety of methods. For example, tailoring export coefficients to reflect regional geo-climatic landscape units (Johnes et al. 2007; Greene et al. 2015), weighting export coefficients according to variation in precipitation, terrain or vegetation (Shi et al. 2006; Ding et al. 2010; Wang et al. 2015), and through the development of export coefficients for representative farm types using field/farm scale models that consider climate, soil and agricultural management variables (Anthony et al. 2012; Semadeni-Davies et al. 2016).

A key goal of this thesis is the development of algorithms to derive site-specific $\mathrm{N}$ and $\mathrm{P}$ export coefficients to account for important site-specific variables and their 
combinations. My approach shares some similarities with Anthony et al. (2012) and Semadeni-Davies et al. (2016), in that field-scale farm models are used to account for farm management in a variety of climate, soil, and topographic settings. However, rather than developing representative farms that are then simulated in field/farm scale models to derive representative export coefficients, I use a large dataset of real pastoral farm input and output data from a field/farm scale model, OVERSEER, which is 'mined' to derive algorithms capable of calculating $\mathrm{N}$ and $\mathrm{P}$ losses for any value and combination of climate, soil, topography and land management. Spatial climate, soil, topography and farm data is used as input to the algorithms to calculate export coefficients unique to a particular site. Further, I extend this approach, albeit in a limited manner, to land covers other than pasture.

Application of the developed $\mathrm{N}$ and $\mathrm{P}$ algorithms in $\mathrm{LUCl}$ water quality models results in consideration and positioning of export coefficients at the DEM grid square scale. However, this does not preclude application of the developed algorithms in other export coefficient based, catchment scale water quality models. Using spatial data pertaining to climate, soil, topographic and land management variables, land units of combined variables can be identified and the algorithms applied, resulting in explicitly positioned export coefficients that can be fed into catchment scale water quality models. Therefore, developments made here potentially represent a wider contribution to catchment scale modelling using export coefficients.

\subsection{AIM AND OBJECTIVES}

\subsubsection{Research Aim}

My aim is to develop algorithms to derive $\mathrm{N}$ and $\mathrm{P}$ export coefficients that account for all combinations of influential nutrient loss variables associated with climate, soil, topography and land management, and to apply these algorithms in LUCl water quality models to improve predictive ability. The algorithms are developed using New Zealand data and implementation of these algorithms in $\mathrm{LUCl}$ water quality models results in consideration and positioning of export coefficients at the DEM grid square scale $(\leq 15 \mathrm{~m}$ x 15 m for New Zealand). 


\subsubsection{Research Objectives}

The four objectives of my thesis are discussed on the following page. The work flow and interconnections between the objectives is illustrated in Figure 1.2.

\section{Objective 1: Data Review}

I review the New Zealand data required to fulfil the aim of this research. Three categories of data are sought for review:

1. Data detailing $\mathrm{N}$ and $\mathrm{P}$ losses for a variety of New Zealand climates, soils, topography, land cover and land uses for use in Objective 2.

2. Spatial data (suitable for use in ArcGIS) for identification and positioning of important nutrient loss variables and their combinations.

3. In-stream water quality data against which to assess output from the $\mathrm{N}$ and $\mathrm{P}$ algorithms applied in $\mathrm{LUCl}$.

\section{Objective 2: Algorithm Development and Parameterisation}

Data identified as suitable for algorithm development in Objective 1, Data Category 1, are more fully explored and algorithms developed and parameterised in preparation for application in LUCl. This involves 3 steps:

1. Identification of algorithm input variables and algorithm forms

2. Parameterisation of algorithm constants

3. Parameterisation of default regional algorithm inputs

\section{Objective 3: Parameterisation of 5 Categories of Mitigations Available in LUCI}

An important aspect of modelling $\mathrm{N}$ and $\mathrm{P}$ losses at farm to catchment scale is assessment of options to reduce nutrient losses. This has been identified as particularly important by Ravensdown. I investigate five categories of mitigations, including documenting the quantified effect of strategies, where possible. The resulting data will be used by the wider LUCI development team to update and improve mitigations already featured in $\mathrm{LUCl}$ and to develop new ones. Mitigations I explore include: 
1. Reduced and strategic fertiliser application

2. Reduced and strategic effluent application

3. Reduced stocking rate

4. Wetland and riparian margin development and management

5. Sediment traps

\section{Objective 4: Algorithm Application in LUCI Water Quality Models}

I apply the developed $\mathrm{N}$ and $\mathrm{P}$ algorithms, integrated into LUCI water quality models, to two New Zealand case study catchments:- Tuapaka catchment in Manawatu and Lake Rotorua catchment in Bay of Plenty. Results are explored and model performance assessed.

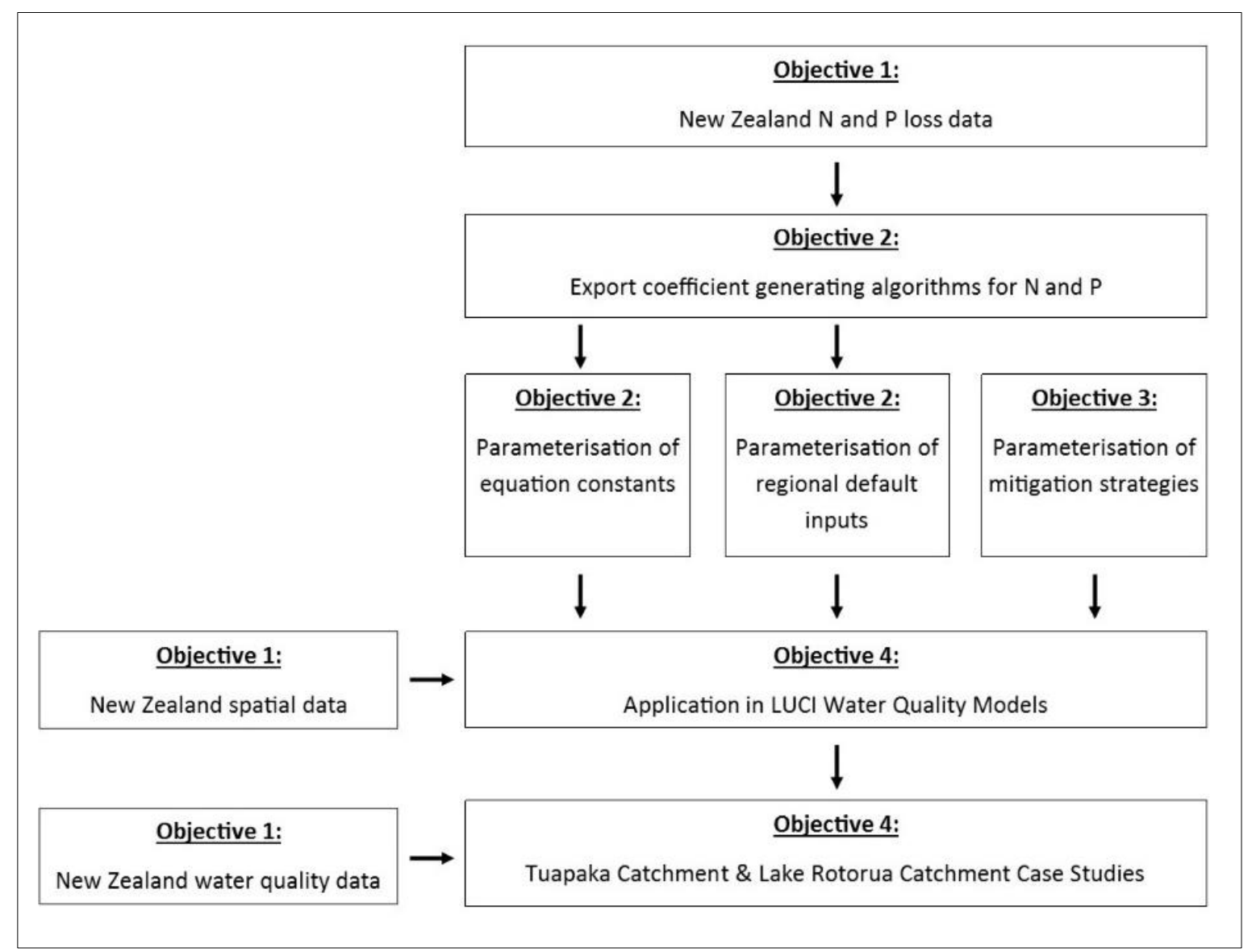

Figure 1.2 Process diagram illustrating the flow of work and interconnections between objectives for this research 


\subsection{THESIS STRUCTURE}

Following this introductory chapter, Chapter 2 provides theoretical context through introduction and review of nutrient cycling and water quality modelling literature. In particular, catchment scale water quality models and the export coefficient approach to water quality modelling are reviewed and discussed.

Chapter 3 introduces and summarises the 3 broad categories of data discussed in Objective 1 - spatial data identifying important nutrient loss variables, in-stream water quality data for New Zealand and data detailing $\mathrm{N}$ and $\mathrm{P}$ losses for a variety of New Zealand climates, soils, topography, land cover and land uses.

Chapter 4 provides a detailed investigation of data identified as suitable for algorithm development including exploration and identification of algorithm inputs and forms. This is followed by Chapter 5 where algorithm constants and regional default input data are parameterised.

In Chapter 6 five broad categories of farm-scale nutrient mitigations are explored and, where possible, their effects quantified. This data will be used by the wider LUCI development team to update and improve current water quality mitigations in $\mathrm{LUCl}$ and to develop new mitigations.

Chapter 7 reports output and results from application of the developed $\mathrm{N}$ and $\mathrm{P}$ algorithms in LUCI water quality models. Two New Zealand catchments are featured: Tuapaka, an 85ha agricultural foothill catchment in Manawatu, North Island, and Lake Rotorua, a $502 \mathrm{~km}^{2}$ volcanic, mixed land cover catchment in Bay of Plenty, North Island. Conclusions and recommendations for further development and extension of the work reported here are summarised and discussed in Chapter 8. 


\section{LITERATURE REVIEW: WATER QUALITY MODELLING USING EXPORT COEFFICIENTS}

\subsection{INTRODUCTION}

There is a clear need to reduce $\mathrm{N}$ and $\mathrm{P}$ loading to terrestrial and freshwater environments, particularly in many developed countries (MEA 2005a; Rockström et al. 2009). New Zealand is no different in this regard (PCE 2013; PCE 2015b) and recent legislative water quality reforms (NZ Govt 2017) hopefully pave the way for action to improve water quality outcomes.

Water quality modelling has a clear role to play assisting and guiding land management decision making to improve this issue. LUCI water quality models, in particular, are suited for this purpose due their fine spatial scale and ease and speed of application. However, improvement to the predictive ability of LUCI N and P models is sought through development of an export coefficient approach to water quality modelling that better accounts for site-specific climate, soil, topography, and land management, as well as land cover or use, and this aim is developed in following chapters. In this chapter relevant background literature pertaining to $\mathrm{N}$ and $\mathrm{P}$ cycling (Section 2.2), water quality modelling (Section 2.3) and the export coefficient approach (Section 2.4), is surveyed and discussed. Both the unique attributes LUCI brings to water quality modelling and the need for a new approach to export coefficient water quality modelling, are highlighted.

\subsection{N AND P NUTRIENT CYCLING}

$\mathrm{N}$ and $\mathrm{P}$ nutrient cycles are complex and incorporate many of Earth's biotic and abiotic cycles and processes. Both individually, and in combination, $\mathrm{N}$ and $\mathrm{P}$ are highly influential determinants of biomass production in both terrestrial and aquatic ecosystems (Li et al. 2016). To discuss these cycles, and their interactions, in full detail is beyond the scope of this research. However, a brief review of these cycles, as they relate to land use and water quality, is presented. For fuller detail on this broad subject the reader is guided to the many books and literature available (Galloway et al. 2003; 
Marschner and Zdenko 2007; Filippelli 2008; Galloway et al. 2008; Harpole et al. 2011; Galloway et al. 2013; Li et al. 2016).

\subsubsection{The Nitrogen Cycle}

Nitrogen is the most abundant element on Earth. It is found in many forms and species, transformations occur over short time frames and are often microbially mediated (Bottomley and Myrold 2007; Robertson and Groffman 2007). It is a key control of productivity in terrestrial, freshwater and marine environments (Vitousek et al. 1997), but not necessarily the only limiting factor. Synergistic interactions between $\mathrm{N}$ and $\mathrm{P}$ have also been shown to co-limit biomass production (Harpole et al. 2011; Li et al. 2016). The majority of $\mathrm{N}$ is found in gaseous $\mathrm{N}_{2}$ form, which is unavailable to most organisms. Nitrogen fixation, via natural or human methods, begins the cycle of transformations from $\mathrm{N}_{2}$, into biologically available forms of $\mathrm{N}$, ultimately ending with return to the atmosphere as $N_{2}$ (Galloway et al. 2003; Groffman and Rosi-Marshall 2012) (Figure 2.1).

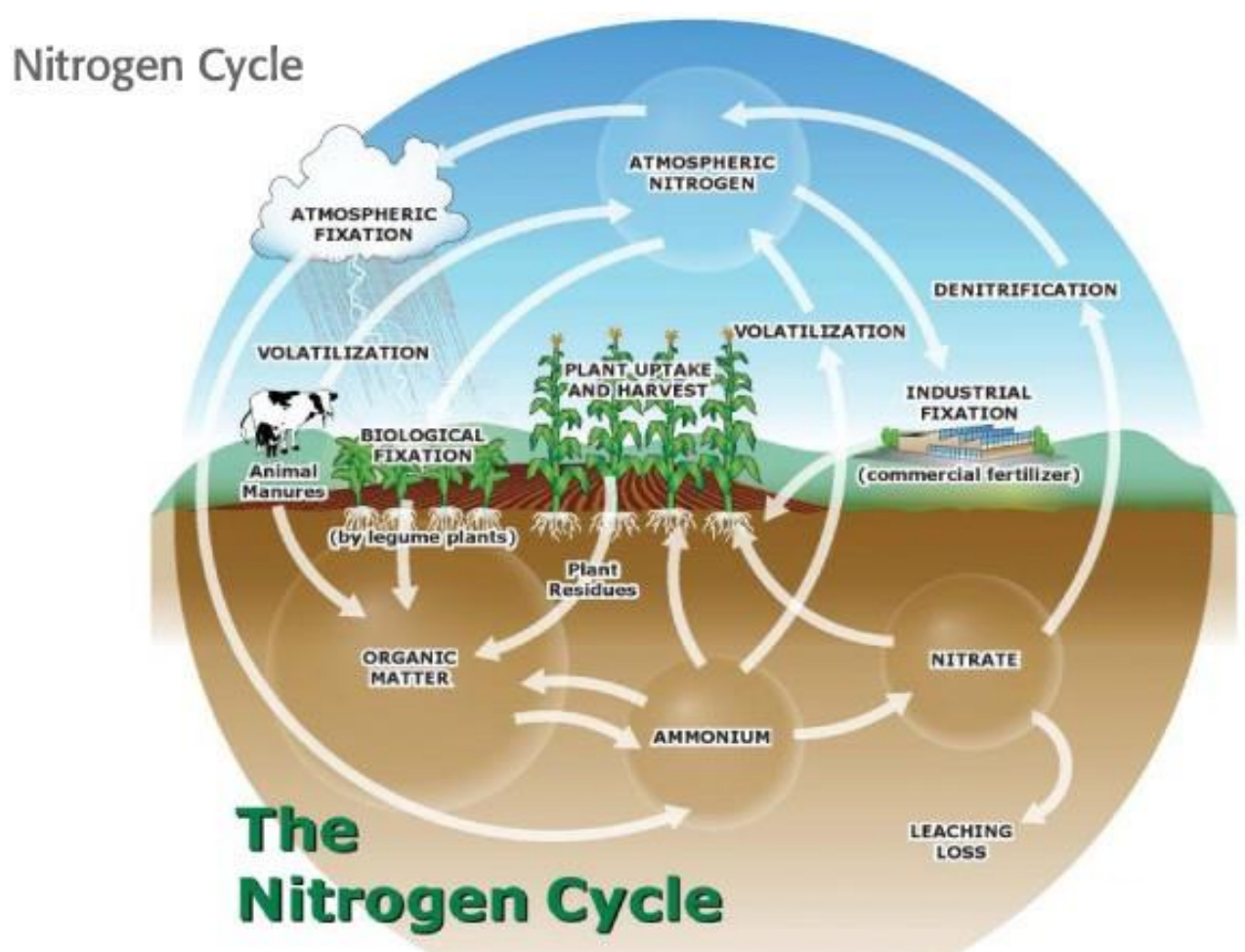

Figure 2.1 The Nitrogen Cycle (University of Delaware 2017) 
Under stable natural conditions, $\mathrm{N}$ fixation and emissions to the atmosphere, via volatilisation and denitrification, are approximately equal. $\mathrm{N}$ is fixed predominantly by microbes, through biological nitrogen fixation (BNF), which is sometimes associated with leguminous plants (Bottomley and Myrold 2007; Groffman and Rosi-Marshall 2012). However, to increase food production over the last century, anthropogenic manipulation of the $\mathrm{N}$ cycle has surged through increased use of the Haber-Bosch process (industrial nitrogen fixation) to create $\mathrm{N}$ fertilisers, and increased planting of legumes in agricultural systems (Vitousek et al. 1997; Galloway et al. 2008).

Plant available $\mathrm{N}$ species include ammonium $\left(\mathrm{NH}_{4}{ }^{+}\right)$and nitrate $\left(\mathrm{NO}_{3}{ }^{-}\right)$. Although both are highly soluble, in soil positively charged $\mathrm{NH}_{4}{ }^{+}$leaches less readily due to attraction to soil particles, which are generally negatively charged. In contrast, negatively charged $\mathrm{NO}_{3}{ }^{-}$is easily leached as soil water drains. $\mathrm{NO}_{3}{ }^{-}$leaching represents the main avenue by which $\mathrm{N}$ is lost to water from the terrestrial environment, although particulate and dissolved N are also lost in surface runoff (Groffman and Rosi-Marshall 2012). The amount of $\mathrm{N}$ leaching is determined by soil solution $\mathrm{NO}_{3}{ }^{-}$concentration and soil drainage. A key determinant of soil solution $\mathrm{NO}_{3}{ }^{-}$is $\mathrm{N}$ input to the soil. Soil water drainage is determined by water inputs (i.e. precipitation and irrigation) and soil permeability. Land management variables such as timing of irrigation and presence of drains influence soil water drainage (Dingman 2002; Cameron et al. 2013).

$\mathrm{N}$ inputs to land include synthetic fertilisers, organic fertilisers, BNF, crop residues left in situ, supplementary animal feed and atmospheric deposition of oxidised $\mathrm{N}\left(\mathrm{NO}_{\mathrm{x}}\right)$ (Howarth et al. 2012; Cameron et al. 2013). (Although in New Zealand atmospheric $\mathrm{NO}_{\mathrm{x}}$ inputs are considered minor (Price et al. 2003)). Animal excretions also add $\mathrm{N}$ to the soil system. Some authors suggest these simply represent recycling of fertiliser, BNF, supplementary feed etc., so need not be explicitly included in $\mathrm{N}$ budgets or models (Howarth et al. 2012). However, excretions, particularly dairy cow urine patches, are small highly concentrated areas of $\mathrm{N}$ that are particularly prone to $\mathrm{N}$ leaching (Williams and Haynes 1990; Betteridge et al. 2010; Moir et al. 2011; Cameron et al. 2013) and at the field scale evidence suggests livestock excrete preferentially in certain spatial zones creating N leaching 'hotspots' (Haynes and Williams 1993; Betteridge et al. 2010). Therefore, a number of authors suggest explicit accounting of animal excretions and 
excretion patterns is essential when considering $\mathrm{N}$ leaching, particularly as spatial resolution of investigations increase (McGechan and Topp 2004; Snow et al. 2009; Bryant et al. 2011).

Increased anthropogenic $\mathrm{N}$ fixation and input, particularly to agricultural systems, has created a net increase of $\mathrm{N}$ in the terrestrial environment, which flows on to effect aquatic and atmospheric environments. Galloway et al. (2003) term this imbalance and movement of excess $N$ 'the nitrogen cascade'. Pernicious effects of the nitrogen cascade are seen in receiving waterbodies where primary productivity may be $\mathrm{N}$ limited under natural conditions, but flourishes to problematic levels with influx of excess $\mathrm{N}$. This leads to eutrophication and creation of hypoxic or anoxic conditions resulting in 'dead zones', as seen in parts of the North American Great Lakes, the Baltic Sea and Gulf of Mexico (Chislock et al. 2013; Rabotyagov et al. 2014). Human health impacts associated with elevated levels of nitrate in drinking water are of further concern (Grizzetti et al. 2011).

Alarmingly, Rockström et al. (2009) suggest anthropogenic $\mathrm{N}$ fixation should decrease by at least $75 \%$ to avoid the risk of crossing $\mathrm{N}$ related thresholds that may trigger nonlinear, abrupt environmental change at the planetary scale. Although, reductions are not required worldwide because fertilisation rates are highly variable. Over-fertilisation is common in North America, Western Europe, China and India, while under-fertilisation occurs in Africa, Eurasia and parts of South America (Bindraban et al. 2015).

\subsubsection{The Phosphorus Cycle}

Like $\mathrm{N}, \mathrm{P}$ is a key primary productivity control in terrestrial, freshwater and marine environments. P additions to land can increase food plant productivity, yet also negatively affect aquatic systems through increased primary production leading to eutrophication and the development of hypoxic or anoxic conditions (McDowell et al. 2004; Bennett and Schipanski 2012).

$\mathrm{P}$ is weathered from rock over geological timescales and ultimately deposited in marine sediments, which are uplifted and subjected to erosion again (Figure 2.2). Within this longer P cycle, biogeochemical cycling via sorption, desorption, and plant and microbe uptake and expiration, repeatedly occurs at shorter timescales (Bennett and Schipanski 2012; Sharpley et al. 2013) (Figure 2.2 and 2.3). Plants access P from the soil solution, 
which is maintained at low $\mathrm{P}$ concentrations. $\mathrm{P}$ additions to soil (including fertilisers, effluents, crop residue left in situ, supplementary animal feed, animal excreta and atmospheric deposition of $\mathrm{P}$ laden dust) enter the soil solution and excess $\mathrm{P}$ is adsorbed onto, and in some cases absorbed into, Al and Fe oxide containing soil particles. Adsorbed $\mathrm{P}$, is weakly bonded to soil particles and readily moves back into soil solution when P concentration drops. As such it is considered plant available (labile). Adsorbed P can become absorbed into soil particles over time, after which it is considered plant unavailable (non-labile). Soil P sorption, or retention, ability depends on Al and Fe oxide presence, which varies according to soil type (Bennett and Schipanski 2012).

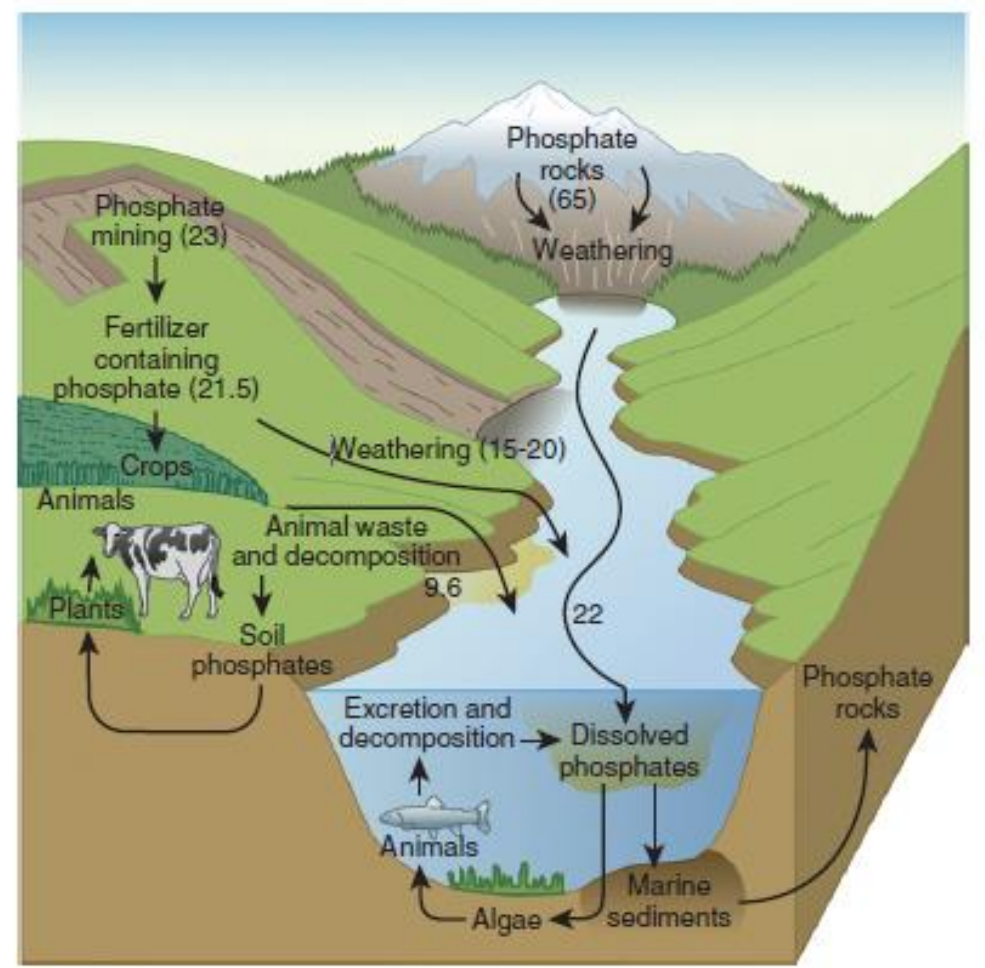

Figure 2.2 The phosphorus cycle (Bennett and Schipanski 2012)

Because of close association between $\mathrm{P}$ and soil minerals, $\mathrm{P}$ loss to water via surface runoff and erosion has historically been considered the most important $\mathrm{P}$ loss mechanism and a focus for P research and management (McDowell et al. 2004; Bennett and Schipanski 2012; King et al. 2015). As a result, a dominant surface runoff 'critical source area' (CSA) approach to managing P loss within a catchment has prevailed, whereby CSA's are spatially identified according to soil, topographic and management 
factors. However, dissolved and subsurface P losses have been shown to be greater than initially thought and management of these losses must be more widely considered (Sims et al. 1998; McDowell et al. 2004; Kleinman et al. 2011; King et al. 2015). Temporally P loss is highly variable with episodes and pulses of surface and subsurface P movement, usually at the beginning of hydrological events (Kleinman et al. 2011; King et al. 2015). This makes $\mathrm{P}$ particularly challenging to model in terms of water quality.

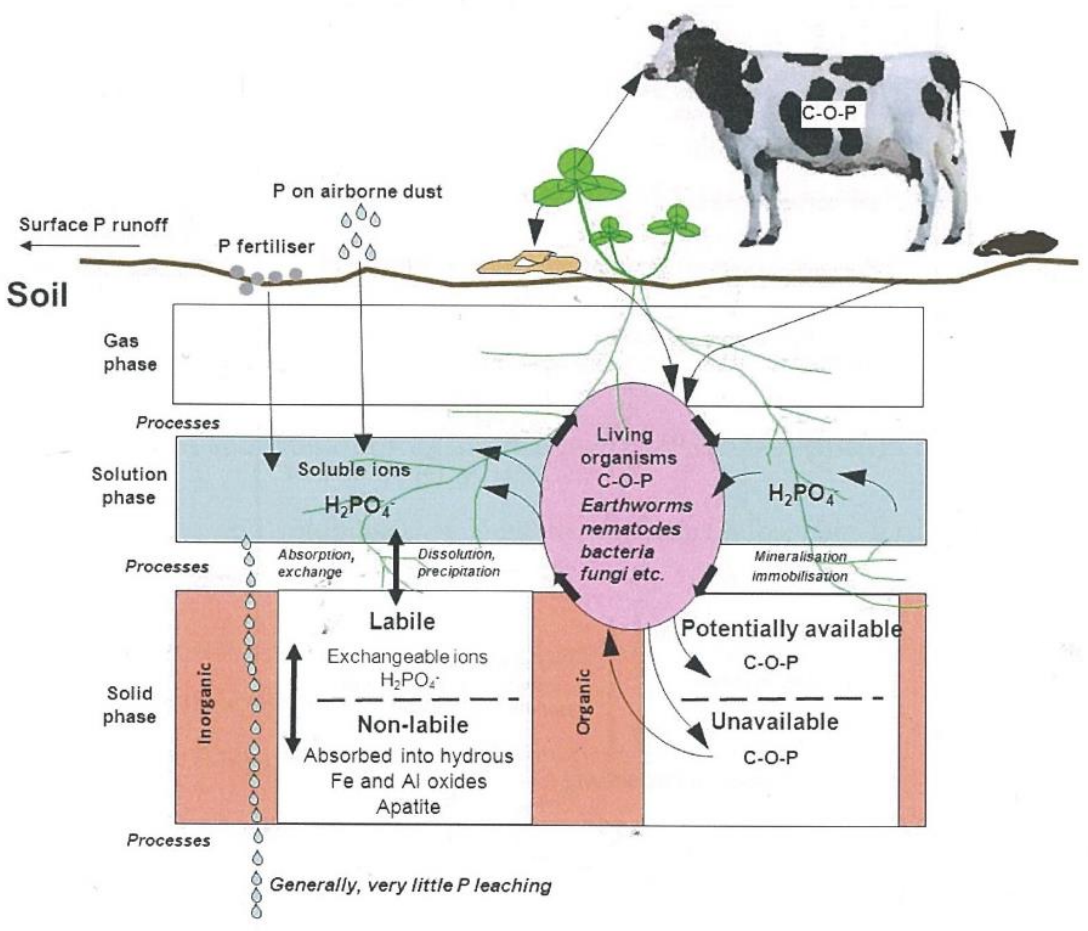

Figure 2.3 In-soil P cycling (FLRC 2015)

Key controls of $\mathrm{P}$ loss include meteorological and hydrological events, topography and land cover (which influence erosion), soil $\mathrm{P}$ reserves and capacity for $\mathrm{P}$ retention, the presence of subsurface drains or macro-pores, and land management variables such as timing and/or type of irrigation and fertiliser application and tillage practices (Sims et al. 1998; Hart et al. 2004; McDowell et al. 2004; Kleinman et al. 2011; King et al. 2015;

Kleinman et al. 2015).

Although policy to control P loss has been in place in some catchments for two to three decades (e.g. Chesapeake Bay and Lake Erie basin, USA, and the Baltic Sea), concern is developing about a lack of receiving waterbody improvement (Sharpley et al. 2013). This may be due to the sporadic nature of P loss as it cycles thorough periods of 'storage' and movement events, difficulty controlling dissolved P losses, and the inability or lack of 
enthusiasm of farmers and land managers to implement $P$ controls due to financial or policy constraints or due to a lack of evidence that controls will work. Certainly water body improvement as a result of best management practice (BMP) at field scale may take decades to fully play out at catchment scale - a fact that many people are unaware of (Jarvie et al. 2013; Sharpley et al. 2013; Kleinman et al. 2015). In addition, waterbody conditions can result in resuspension of stored $\mathrm{P}$ in bed sediment, and hypoxic conditions can reduce the $P$ retention capacity of sediments (Andersen et al. 2017).

It is estimated current $\mathrm{P}$ loss to the ocean is 8-9 times natural rates of $\mathrm{P}$ loss, largely as a result of P fertiliser application (Filippelli 2008; Rockström et al. 2009; Bennett and Schipanski 2012). Like N, a global decrease in P losses to aquatic environments is highly desirable to avoid crossing thresholds that may trigger non-linear, abrupt environmental change at the planetary scale (Rockström et al. 2009). However, in under-fertilised regions carefully managed increases in agricultural P use would be beneficial by increasing food supply to local populations (Bindraban et al. 2015).

The above summaries identify the urgent need to better control $\mathrm{N}$ and $\mathrm{P}$, particularly in the agricultural environment. Models and tools, such as those discussed and developed in following chapters, are integral to progress towards this goal, although difficulty in fully representing nutrient cycling in models must be acknowledged, particularly for $P$. This is due to both temporal and spatial variability at a variety of scales, and thresholds associated with nutrient transformation and loss. For example, at small scale local soil conditions and microbial activity can be highly heterogeneous (Paul 2007; van Groenigen et al. 2015), and nutrient interactions which influence nutrient losses can occur, both between $\mathrm{N}$ and $\mathrm{P}$ and with other macro- and micronutrients (Bindraban et al. 2015). Additionally, some small scale interactions and processes are not fully understood, including their impact at wider scales (van Groenigen et al. 2015), making their representation difficult in catchment scale water quality models.

Wider societal and cultural barriers to controlling $\mathrm{N}$ and $\mathrm{P}$ also exist. These largely stem from political and social unwillingness to fully account for environmental resources and their degradation in our economic models (Wijkman and Rockström 2012; PCE 2015b). Water quality models are fundamental to informing and guiding decision making, but cannot improve water quality unless subsequent action on the ground is taken. 
Currently in New Zealand debate around how best to improve water quality is lively and $\mathrm{LUCl}$ water quality models are particularly well placed to assist.

\subsection{WATER QUALITY MODELLING WITH A FOCUS ON NEW ZEALAND}

A plethora of water quality models estimating nutrient loads to water bodies exist, varying in detail, nature, elements of the hydrological cycle included, state (steady or dynamic), temporal scale, spatial scale, and data requirements (Tsakiris and Alexakis 2012). Commonly models are classified according to the extent of process detail included. Simple, 'black box' empirical approaches may fit observations well, but provide little process understanding and should not be applied in situations dissimilar to those they have been 'trained' on. Process based models can be simple or detailed. Simpler models are more spatially and temporally lumped with fewer input requirements. Detailed physically-based models simulate hydrological and contaminant processes at finer spatial and temporal scales and provide more detailed process understanding. However, they have larger data input requirements and take more time and expertise to run. It is often assumed that more detail will provide more accurate model results. However, the construction and evaluation of complex models is often hampered by a lack of available data (Bergström and Graham 1998; Beven 2009; Beven 2012). In reality, many water quality models combine aspects of simpler vs. complex approaches, occupying an intermediary position between these extremes. A full review of available models is beyond the scope of this investigation however, and the reader is guided to summaries and comparative literature between individual models and model approaches, such as Alexander et al. (2002b), Bouraoui and Grizzetti (2014), Pechlivanidis et al. (2011), and Schoumans et al. (2009).

Here a review of point, farm and catchment scale water quality models is undertaken with emphasis on those applied in New Zealand. Review of this range of models at variable scales is necessary because this research thesis develops water quality models that can be used at sub-field to catchment scale, and the developed models are based on OVERSEER, a farm scale nutrient model. In addition, many catchment scale water quality models rely on point to farm scale nutrient models to estimate field to farm scale nutrient losses. To better understand the catchment scale models discussed in Section 2.3.2, relevant point to farm scale models are introduced and discussed in Section 2.3.1. 
This model review also highlights LUCl's potential to fill gaps in New Zealand's current water quality modelling landscape.

\subsubsection{Point to Farm Scale Models}

\section{SPASMO (Soil Plant Atmosphere System Model)}

Developed in New Zealand by Plant and Food Research, SPASMO models soil profile water, microbe, contaminant and nutrient solute movement in a 1 dimensional soil profile (Clark et al. 2012). Water inputs include rainfall and irrigation, and water outputs include loss via plant uptake, evaporation, runoff and drainage. Soil profile carbon, nitrogen and phosphorus nutrient budgets consider plant growth and uptake, nutrient exchanges and transformations, nutrient and organic material recycling via the soil biomass, and fertiliser and effluent additions. Soil water solute concentration and nutrient leaching losses are calculated daily and reported at field scale (Clark et al. 2012; Envirolink 2015). SPASMO is intended for expert use only and is not freely available. The model has been applied in New Zealand to investigate nutrient losses from productive land (Rosen et al. 2004; Dominati et al. 2014; Clothier and Green 2017) as well as losses of other contaminants and for water footprinting (Clothier et al. 2006; Herath et al. 2013). Horticultural nutrient losses derived from SPASMO have been incorporated into catchment scale water quality models (Woods et al. 2006a; Cichota and Snow 2009; Envirolink 2015) and it has potential, in future, to inform the new export coefficient approach developed here.

\section{OVERSEER}

OVERSEER is a freely available annual nutrient budgeting model which considers nutrient movement (including $\mathrm{N}$ and $\mathrm{P}$ ) onto, around and off of a farm. Developed with input from AgResearch, Plant \& Food, Landcare Research and NIWA, it originally aimed to assist pastoral farmers to determine fertiliser requirements. Today OVERSEER also models arable and fodder crops and quantifies nutrient losses to water and greenhouse gas emissions. It is therefore useful for identifying potential environmental impacts. A large body of research pertaining to nutrient movement and loss from the New Zealand farm environment is considered in OVERSEER and its underlying databases. However, because it is intended for use by "non-experts" (e.g. farmers and farm consultants), the 
model inputs are minimal and easily obtained (Cichota and Snow 2009; Watkins and Selbie 2015; Wheeler 2016c).

OVERSEER is New Zealand's most widely known and used nutrient model and it is now extensively used by regional authorities to assess farm nutrient losses for regulatory purposes. Concern around OVERSEER's appropriateness for this purpose have been expressed (Arbuckle 2015) and OVERSEER developers are responding with guidance and explanation of uncertainties and limitations associated with the model (Watkins and Selbie 2015). OVERSEER is non-spatial, which is a limitation because in reality nutrient loss is highly spatially varied and spatial identification of nutrient sources, pathways and sinks is an important step towards identification of appropriate mitigation strategies.

OVERSEER is used extensively to develop models in this study and further description of OVERSEER pastoral model functioning is found in Section 4.2. Additional information is also available from OVERSEER's website (OVERSEER 2017a) and Watkins and Selbie (2015).

\section{MitAgator}

MitAgator, developed by Ballance Agri-nutrients, couples OVERSEER, national databases and GIS software to produce maps of N, P, sediment and microbial (E. coli) farm losses. A map package, combining and spatially positioning OVERSEER farm files and national spatial data, is used as input to the MitAgator engine, which contains algorithms to estimate losses of contaminants to surface waterways. The $\mathrm{N}$ and $\mathrm{P}$ algorithms are modified, "spatially relevant" versions of those used in OVERSEER and described in McDowell et al (2005; 2008), Rutherford and Wheeler (2011) and Wheeler et al (2011). Output consists of maps categorising predicted loss into five $20 \%$ categories. The highest loss category represents critical source areas (CSA), which are particularly targeted for mitigations. Mitigation options can then be applied and reductions in loss investigated. Mitigations are assessed in terms of effectiveness and cost (Stafford and Peyroux 2013; McDowell et al. 2015; Risk et al. 2015; McDowell et al. 2016b). $\mathrm{N}$ and $\mathrm{P}$ model results have been assessed against plot to catchment scale losses for a range of 6 soil orders and 5 land uses. Results indicate MitAgator predictions are less accurate as rainfall and scale increase (McDowell et al. 2016b). 
MitAgator aims to assist Ballance customers with land management decisions. In this respect it will play a similar role as that envisaged for LUCI by Ravensdown. Once fully operational, MitAgator is expected to initially only be available to Ballance customers, but more widely available in in the future. Key differences between MitAgator and LUCI include fine spatial representation and the ability to model water and nutrient pathways and sinks within the landscape.

\subsubsection{Catchment Scale Models}

Many catchment scale water quality models exist and are in use around the world. Here the focus is largely on catchment scale models used in New Zealand, although a brief description of a further few catchment scale water quality models is provided for additional breadth. These descriptions highlight both LUCl's highly spatially detailed nature, compared to other catchment scale water quality models, and that some form of diffuse nutrient loss estimation, or export coefficient, is required for many catchment scale water quality models.

Commonly referenced catchment scale water quality models in comparative summaries include SWAT, SPARROW, MONERIS, HBV-NP and INCA (Alexander et al. 2002b; Breuer et al. 2008; Schoumans et al. 2009; Bouraoui and Grizzetti 2014; Wellen et al. 2015) although this is far from an exhaustive list. SWAT and SPARROW are US developed, have been applied in New Zealand and are described in more detail below. MONERIS is a German developed, semi-empirical, conceptual model that quantifies point source and diffuse nutrient emissions to river catchments and has been applied to over 450 river systems, largely in Europe (MONERIS 2017). Spatially it functions at the 'analytical unit' (validated at $50 \mathrm{~km}^{2}$, but in theory could be as small as $1 \mathrm{~km}^{2}$ ), which are aggregated to represent the catchment. Diffuse nutrient losses are determined for each analytical unit by multiplying estimated losses from various sources e.g. crops, pasture, urban etc., by the area of those sources within the analytical unit. Temporally results can be reported at monthly, yearly or long-term scale (Venohr et al. 2011). MONERIS is freely available (MONERIS 2017).

HBV-NP is based on Swedish hydrological model HBV, a semi-distributed surfacegroundwater model which functions at sub-basin scale with intra-basin sub-units 
defined according to elevation and vegetation (but not geographic position) and a daily time step (Lindström et al. 1997). The nutrient sub-model determines soil water nutrient concentration according to combinations of land use and soil and routes these to the hydrological model. Erosional losses are also considered for $\mathrm{P}$ and point source nutrient losses from wastewater treatment plants and industry are included (Arheimer et al. 2005). HBV-NP has been superseded by HYPE (Jackson-Blake et al. 2016), which offers more detailed soil processing, but like HBV-NP does not define intra-basin geographic position of sub-units (SMHI 2017).

INCA is a UK developed, dynamic process-based model that predicts water quality (including $\mathrm{N}$ and $\mathrm{P}$ ) and quantity in rivers and catchments. INCA has been applied largely in the UK and Europe, with applications also in the Americas, Australia and Asia (INCA 2017). The model functions at a daily time step (Wade et al. 2002; Whitehead et al. 2011) and Whitehead et al. (2011) state users can choose semi- or fully-distributed spatial representation. However, further description of the fully distributed version of the model only appears for INCA-P (Whitehead et al. 2011; Jackson-Blake et al. 2016), making it somewhat unclear if this capability is actually available in INCA-N. Further detail around the 'fully-distributed' version of the model indicates sub-catchments are broken in to landscape classes or functional units where nutrient inputs, plant uptake, soils and flow pathways are similar. In reality, land use and/or soil type are all that is considered. Nutrient output from each landscape class is derived by determining output for a $1 \mathrm{~km}^{2}$ class cell (based on estimated nutrient inputs and plant/soil processes) and multiplying that by the class area within the sub-catchment. Total sub-catchment nutrient losses are the sum of losses from each landscape class within the catchment and are routed to the stream network (Wade et al. 2002; Whitehead et al. 2011; Jackson-Blake et al. 2016). INCA is freely available for non-commercial use, but requires considerable inputs and expertise to operate (Jackson-Blake et al. 2016).

\section{SWAT (Soil and Water Assessment Tool)}

SWAT is a widely used model developed over 30 years by the US Department of Agriculture (USDA). It is an example of a more physically-based model and is described as a 'continuous-time dynamic model based on mathematical descriptions of physical, biogeochemical and hydro-chemical processes, combining elements of both physical and 
semi-empirical processes' (Krysanova and White 2015). It aims to quantify the impact of land management on water, sediment and contaminants (including $\mathrm{N}$ and $\mathrm{P}$ ) in complex landscapes with variable soil, land use and management. SWAT's smallest spatial unit is the hydrological response unit (HRU), defined as a non-contiguous area within a subbasin consisting of similar land use, soil type and slope class. HRU's are not spatially identified and do not interact at the sub-basin level. Rather nutrient loading from each $\mathrm{HRU}$ is calculated separately, then summed to determine total sub-basin loading to the river network (SWAT 2017). Temporally SWAT functions at a daily time step.

Hydrological flows and processes represented in the model include precipitation, surface runoff, percolation, evapotranspiration and groundwater flow (Krysanova and White 2015; SWAT 2017). SWAT is freely available, but requires expert knowledge to apply. Global applications of the model in a wide range of environments have been made and a wide body of literature is available from SWAT's website (SWAT 2017).

In New Zealand it has been applied in a mixed land use sub-catchment of Lake Rotorua. Results of this study indicate measured monthly TN and TP concentrations were not well replicated by SWAT. However, simulated mean daily concentrations during a high rainfall event compared to concentrations derived from high frequency (1-2 hour) sampling during the event, showed TN was comparable, although TP concentration was considerably under predicted. The authors found parameter sensitivity between base flow and quick flow conditions were problematic, highlighting the uncertainty that can be associated with parameterising water quality models, particularly as model complexity increases (Me et al. 2015). SWAT was also applied to the Motueka catchment to assess the likely effects of land use change on hydrological flows, but nutrient losses were not considered (Cao et al. 2009).

\section{SPARROW (Spatially Referenced Regressions on Watershed Attributes)}

SPARROW is designed to predict long term average values of water quality characteristics using statistical non-linear regression methods that relate in-stream water measurements (contaminant concentration and water flow) to upstream sources. The smallest spatial unit in the model is the river reach linked to contributing catchments (unlikely to be less than 1-10's $\mathrm{km}^{2}$ ). Temporally SPARROW predicts annual average water quality values. Nutrient output from various land covers and uses within 
the river reach are estimated, and land to water delivery is based on reach characteristics such as soil permeability, slope, rainfall etc. (Schwarz et al. 2006; USGS 2009). SPARROW does not model specific physical, chemical or hydrological processes. It is reasonably easy to apply, although expert knowledge is an advantage and a precursor to application is access to input databases detailing water measurements, soil, land use and precipitation for the area of interest.

In New Zealand SPARROW was applied to the Waikato catchment where predicted TN and TP stream yields were 'typically' within $30 \%$ or less of measured yields (Alexander et al. 2002a). Elliott et al. (2005) applied SPARROW nationally and state the model predicts TN loads well ( $R^{2}$ of 0.956 and RMSE of 0.33 ) with TP load less well predicted $\left(R^{2}\right.$ of 0.9 and RMSE of 0.58). These studies appear to have been groundwork for development of the Catchment Land Use for Environmental Sustainability model (CLUES), which links a number of models to SPARROW and is discussed below.

\section{ROTAN (Rotorua and Taupo Nitrogen Model)}

Developed by NIWA, ROTAN (Rotorua and Taupo Nitrogen Model) models N loss from the Lake Rotorua catchment. It is GIS-based and estimates the effects of land use change and $\mathrm{N}$ mitigations on $\mathrm{N}$ export to waterbodies (Rutherford et al. 2009). The model is based on Swedish hydrology model HBV (Envirolink 2015).

Temporally ROTAN runs on a daily time-step and 'functional units' (areas of similar topography, land cover, land use, soil drainage and rainfall within the catchment) are defined and assigned an OVERSEER derived nitrogen export rate $\left(\mathrm{kg} \mathrm{N} \mathrm{ha}^{-1} \mathrm{yr}^{-1}\right)$. This is then routed through the landscape to groundwater, rivers and the lake (Rutherford et al. 2009). Rutherford et al. (2009; 2011) used ROTAN to assess historical, current and future $\mathrm{N}$ loads to Lake Rotorua, aiming to determine the magnitude of land use change required to significantly decrease future $\mathrm{N}$ loads to the lake. They estimated it would take 35 years to reduce $\mathrm{N}$ loads to Lake Rotorua to a target of $405 \mathrm{tN} / \mathrm{yr}$, but note that this assumes required land use changes occurred all at the same time (Rutherford et al. 2011). ROTAN is not generally available, requires expert application and aims to inform catchment managers. 


\section{CLUES (Catchment Land Use for Environmental Sustainability)}

CLUES, developed by NIWA, is a nationally applicable, GIS based, catchment scale model that aims to assess the impact of land use change and land management on stream water quality (TN, TP, sediment and E. coli) and a range of socio-economic indicators. CLUES water quality component links SPARROW, SPASMO, and OVERSEER with spatial data pertaining to land cover and use, and physiographic characteristics. The model functions at the reach scale (typical reach length is between $500-1500 \mathrm{~m}$ ) with an annual time step and land uses within each reach are accounted for by total area, but not spatially identified or positioned (Woods et al. 2004; Elliott et al. 2008; Semadeni-Davies et al. 2016). Nineteen land uses are defined by CLUES including 8 pastoral land uses, 6 crops ( 3 short-rotation and 3 perennial), exotic forest, native forest, scrubland, urban and 'other'.

$\mathrm{N}$ and $\mathrm{P}$ losses for pastoral land uses within a reach are estimated by a simplified version of OVERSEER and are a function of stocking rate, fertiliser, rainfall, soil order and topography (Semadeni-Davies et al. 2016). Default regional farm stocking rates and fertiliser inputs are derived from Ministry of Agriculture and Forestry (MAF) regional model farm data and Livestock Improvement Corporation data (Woods et al. 2006a). Dominant soil order and average slope for each reach are determined from the New Zealand Land Resources Inventory (LRI) (Semadeni-Davies et al. 2016). Although not explicitly stated, it appears that only one dominant soil order and slope value is identified for each reach.

$\mathrm{N}$ leaching losses from crop and horticultural land uses were derived from SPASMO based on the relevant crop types and a range of rainfall and soil types. The results are collated in lookup tables and combined with continuous rainfall functions in CLUES to derive estimates of crop and horticultural losses within any specific reach (SemadeniDavies et al. 2016). P losses from crop and horticultural land uses are not mentioned in CLUES latest user manual suggesting they may not be included in the model.

Nutrient losses from OVERSEER and SPASMO are fed into SPARROW, which determines nutrient loads from all land uses, other than pasture and crop, and routes nutrient loads downstream where they accumulate and decay (Semadeni-Davies et al. 2016). It is not clear how SPARROW estimates nutrient loads from other land uses. Presumably 
estimates of regional or national nutrient losses for forested, scrub, urban and other land uses for New Zealand have been collated from literature or other data sources.

CLUES is intended for use by water and land managers and policy makers. It has been applied nationally and in Auckland, Manawatu, Waikato, Bay of Islands, Lake Rotorua, Hurunui, Oreti and Mataura catchments (Elliott et al. 2005; Elliott et al. 2011; SemadeniDavies and Elliot 2014; Envirolink 2015; NIWA 2015; Semadeni-Davies et al. 2015; Elliott et al. 2016).

Where CLUES predicted and measured $\mathrm{N}$ and $\mathrm{P}$ concentrations and loads are compared, results are variable (Monaghan et al. 2010b; Elliott et al. 2011; Semadeni-Davies et al. 2015), (as is commonly found with catchment scale water quality models (Alexander et al. 2002b; Letcher et al. 2002; Baginska et al. 2003; Schoumans et al. 2009) - a point returned to in Chapter 7). However, the focus of a number of CLUES based studies is comparison between current and future land use scenarios and predicted and measured water quality comparisons are not made because relative differences between scenarios is the more important focus (Monaghan et al. 2010b; Elliott et al. 2011; Parshotam et al. 2013).

\section{Three Important Points Highlighted by this Summary:}

In this section a range of catchment scale water quality models are described ranging from simpler models with little process representation, such as MONERIS and SPARROW, to increasingly detailed and complex models such as INCA and SWAT. These descriptions highlight three standout points in relation to my thesis:

\section{Spatial Resolution}

None of the catchment scale models described above function at anywhere near the same fine spatial scale as LUCI (15 m x15 m or less for New Zealand) and none simultaneously model sub-field to catchment area at that scale.

\section{Spatial Configuration}

Due to lack of spatial detail, none of the models explicitly consider landscape configuration within sub-basins and therefore, do not consider intra-basin water and nutrient flow between landscape units. However, landscape configuration at this scale 
clearly influences water quality (Lee et al. 2009; Jackson et al. 2013a). For example, a forested area below agricultural land on a hillslope will receive water and nutrients from the agricultural land and will likely provide some mitigation against nutrient losses. In contrast, a forested area above agricultural land on a hillslope cannot mitigate nutrient losses from the agricultural land. Landscape configuration is very important and, unlike most other catchment scale water quality models, LUCl explicitly considers this.

\section{Most Catchment Scale Water Quality Models Require Export Coefficients}

All, but the most detailed, catchment scale water quality models, require some form of estimated diffuse nutrient loss, or export coefficient, from land units within the catchment of interest. Therefore, the method and models developed for $\mathrm{LUCl}$ water quality models in proceeding chapters, have wider applicability and relevance to catchment scale water quality modelling.

Points 1 and 2 highlight the real contribution $\mathrm{LUCl}$ can make to the water quality modelling 'landscape'. Not only does it function at fine spatial resolution and explicitly consider spatial relationships and configuration at fine scale, but it is also comparatively quick to run, making it ideal for sub-field to catchment modelling and decision making. In addition, Point 3 highlights the ubiquity of the export coefficient approach (even if many do not term it this), making it clear the new approach developed here is of potential use to many catchment scale water quality models.

The following section explores the export coefficient concept further including defining what export coefficients are, how they are derived and used, and assumptions associated with their use. This section highlights how and why development of a new export coefficient approach is worthwhile.

\subsection{THE EXPORT COEFFICIENT APPROACH}

\subsubsection{Export Coefficients Defined}

Water quality modelling using export coefficients stems from investigations into connections between phosphorus loading and lake eutrophication in Europe and the US by Vollenweider (1968). Export coefficients are variously described as the rate at which a contaminant is exported from a particular source (Johnes 1996; Hanrahan et al. 2001; 
Uncles et al. 2002), the expected annual contaminant input to a waterbody per unit of source (Reckhow et al. 1980), and the mass of a contaminant per unit area per unit time (lerodiaconou et al. 2005; Zobrist and Reichert 2006; Ongley et al. 2010; Lu et al. 2013; Robinson and Melack 2013; White et al. 2015). The terms 'specific yield' and 'generation rate' are also used to describe these losses (Cooke 1979; Baginska et al. 2003). Export coefficients are most commonly reported for total nitrogen (TN) and total phosphorus (TP), but are also found for various $\mathrm{N}$ and $\mathrm{P}$ species, total suspended solids (TSS), chloride and potassium (Lin 2004; Zobrist and Reichert 2006; White et al. 2015). While TSS is certainly an important factor in P losses, the focus of this thesis is $\mathrm{N}$ and $\mathrm{P}$ export coefficients only.

The vast majority of export coefficients in literature are reported in $\mathrm{kg}$ contaminant $\mathrm{ha}^{-1}$ $\mathrm{yr}^{-1}$. However, the export coefficients in Johnes' (1996) model are multiplied by land use area, animal population or human population, and nutrient inputs to that land use or by the livestock/human population (Eqn 1). Accordingly, the export coefficient is a dimensionless proportion of inputs per unit area. Later, however, Johnes (1996) uses two forms of export coefficient - the proportional of inputs form and the mass of contaminant per unit area per unit time form.

$$
L=\sum_{i=1}^{n} E_{i}\left[A_{i}\left(I_{i}\right)\right]+p
$$

Where, $L=$ loss of nutrients; $E=$ export coefficient for nutrient source I; $A=$ area of catchment occupied by land use type $I$, or number of livestock type I, or number of people; I=input of nutrients to source I; $p=$ input of nutrients from precipitation.

Eqn. 1.

Zobrist and Reichart (2006), distinguish between these two types of coefficients. They describe the dimensionless proportion of contaminant input as a "transfer coefficient", which represents transfer and transformation processes only. In contrast, "export coefficients" describe mass contaminant discharged per area and time, which includes contaminant input as well as transfer and transformation processes. Transfer coefficients are useful when modelling the effects of changes in contaminant input, but 
they are difficult to determine and rarely found in the literature. In contrast, export coefficients must be changed to model changes in contaminant input, but are reported much more frequently in the literature. Additionally, Robinson and Melack (2013) found export coefficients to be better predictors of catchment exports than transfer coefficients. In what follows 'export coefficient' refers to the mass of contaminant discharged per area and time.

\subsubsection{Export Coefficient Use in Catchment Scale Models}

Following on from Vollenweider's (1968) initial lake modelling, interest in the export coefficient approach, commonly also referred to as the unit-area load approach, appears to have become particularly popular in North America (Dillon and Kirchner 1975; Rast and Lee 1983; Clesceri et al. 1986; Frink 1991; Chambers and Dale 1997; Winter and Duthie 2000; Ongley et al. 2010) and several compilations and reviews of $\mathrm{N}$ and $\mathrm{P}$ export coefficients from North American literature were developed (Uttormark et al. 1974; Reckhow et al. 1980; Beaulac and Reckhow 1982; Lin 2004).

In 1989 Johnes and O'Sullivan applied Jørgensen's (1980) 'export coefficient approach' in the UK. Shortly thereafter, Johnes (1996) presented her modified export coefficient model (ECM) - an extension of the original Vollenweider and Jørgensen models taking more detailed account of variable nutrient sources from agricultural land uses and livestock production systems. Johnes' work appears to have popularized the ECM outside of North America with a number of authors in a variety of countries referencing her work as influential (Worrall and Burt 1999; Hanrahan et al. 2001; Uncles et al. 2002; lerodiaconou et al. 2005; Ding et al. 2010; Wang et al. 2015). However, Australia's Catchment Management Support System (CMSS), a unit-area load model with the addition of an in-stream attenuation function, was developed at around the same time (Marston et al. 1995; Baginska et al. 2003; Broad and Corkrey 2011), and may have also contributed to the popularisation of the EC approach.

Described as a simple, empirically based, 'black box', catchment scale water quality model (Sharpley et al. 2002; Cherry et al. 2008; Radcliffe et al. 2009; Bouraoui and Grizzetti 2014), the ECM aims to predict nutrient load at any point in the stream network, as a function of nutrient exports from each source within the contributing 
catchment, using Equation 1 (Johnes 1996). The model assumes $\mathrm{N}$ and $\mathrm{P}$ losses are directly and linearly linked to $\mathrm{N}$ and $\mathrm{P}$ inputs associated with land use. Losses occur between $\mathrm{N}$ and $\mathrm{P}$ inputs and outputs, but how, why and where these losses occur is never elucidated. The approach also assumes losses do not vary with soil, topography, land management etc., that climate events are unimportant, and that lagged, stored, or legacy $\mathrm{N}$ and $\mathrm{P}$ do not exist. As such, variability with time is not well represented and model output represents annual average losses only.

The main benefits of the ECM are its simplicity, ease of use and comparatively low data requirements, which make it an attractive catchment scale modelling option (Heathwaite 2003; Drewry et al. 2006; Cherry et al. 2008; Broad and Corkrey 2011; Shen et al. 2012). However, while the use of simpler models is advocated, particularly where little local data is available for model parameterisation or calibration (Addiscott and Mirza 1998; Letcher et al. 1999), a lack of explicit consideration of influential nutrient export variables (eg. climate, soil, topography, and hydrology) and transfer and transformation functions and processes particularly associated with lagged, stored and legacy $\mathrm{N}$ and $\mathrm{P}$, are identified as ECM weaknesses (Khadam and Kaluarachchi 2006; Cherry et al. 2008; Ding et al. 2010; Robinson and Melack 2013).

Consequently, 'enhanced' ECMs have been developed by a number of authors to address some of the assumptions and simplifications inherent in the model. Johnes and Heathwaite (1997) account for variable delivery to the stream network with a distance decay parameter. Endreny and Wood (2003) weight export coefficients based on identified contributing and dispersal areas. Shi et al. (2006) weight export coefficients based on slope to account for run-off risk. Khadam and Kaluarachchi (2006) model hydrologic variability with an erosion-scaled approach to predict $\mathrm{P}$ export. Robinson and Melack (2013) augment the ECM approach with a watershed response function, which scales nutrient export by considering antecedent soil moisture conditions. Johnes et al. (2007) and Greene et al. (2015) developed regional geo-climatic landscape units to further enhance regional to national scale ECM applications in the UK. Ding et al. (2010) developed the Improved Export Coefficient Model (IECM) which includes a precipitation impact factor and a terrain impact factor which weight ECs. This was further improved by the addition of a vegetation factor (Wang et al. 2015). 
While the above models are described as modified ECMs, it is clear from Section 2.3 that many catchment scale water quality models rely on some form of estimated diffuse nutrient loss or export coefficient - a point also made by other authors (Grimvall and Stalnacke 1996; Alexander et al. 2002b; Shrestha et al. 2008; Lu et al. 2013). These models could be described as taking an export coefficient approach (ECA). The term 'ECA' is already found in literature and usually refers to ECM (Johnes 1996; Wilson 2005). However, a differentiation between these terms is suggested whereby ECM refers to a simpler Johnes (1996) type model and ECA refers to more complex models, that never-the-less use some form of nutrient export assumption to model diffuse pollution from specified land units.

\subsubsection{Export Coefficient Derivation}

A number of methods to derive export coefficients exist. The most commonly used method involves actual measurement of contaminant loss from a single land use plot, field or small catchment e.g. Mishra et al. (2006), Monaghan et al. (2002), Owens et al. (2003), Udawatta et al. (2002) and Vervoort et al. (1998). These studies do not routinely define calculated losses as 'export coefficients', yet the data they report are used as export coefficients (Uttormark et al. 1974; Reckhow et al. 1980; Baginska et al. 2003; Harmel et al. 2006). These investigations are typically constrained by a limited range and combination of climate, soil, topographic, land use and management types because the time and expense of instrumenting and monitoring many plots, fields and/or catchments is prohibitive. Studies are therefore frequently conducted on established research sites (White et al. 2015). Additionally, measurements occur at a variety of spatial and temporal scales using different measurement and analysis techniques, making it difficult to compare results between studies or to determine appropriate export coefficients for use (Uttormark et al. 1974; Beaulac and Reckhow 1982; Khadam and Kaluarachchi 2006).

To assist with identification of appropriate export coefficients, summaries of measurements are available for North America. Uttormark et al (1974) compiled the first thorough summary for a variety of North American forest, urban, agriculture and wetland land uses, concluding that export coefficients for only these four broad land use categories should be used. Reckhow and Beauleac (1980) updated the compilation and 
discussed and examined uncertainty associated with the variability and range of export data for a variety of land uses. Lin (2004) published a review of both export coefficient and event mean concentration data. More recently, the MANAGE (Measured Annual Nutrient loads from Agricultural Environments) on-line database was established. It summarises site characteristics and nutrient export data from many North American field-scale agricultural and forest measurement studies (Harmel et al. 2006; Harmel et al. 2008).

A second method of deriving export coefficients involves statistical analysis of in-stream water quality data for multi-land use catchments (McFarland and Hauck 2001; Zobrist and Reichert 2006; Shrestha et al. 2008; Vassiljev et al. 2008; Lu et al. 2013). Most commonly multiple regression analysis is used whereby measured in-stream nutrient load is apportioned to upstream land cover or uses based on the fractional land cover/use area of the total catchment (Omernik 1976; McFarland and Hauck 2001; Shrestha et al. 2008; Vassiljev et al. 2008) as presented in Equation 2.

$$
L_{i}=\beta_{1} X_{i, 1}+\beta_{2} X_{i, 2}+\cdots+\beta_{n} X_{i, n}+\varepsilon_{i}
$$

Where, $i=$ the individual sites used in the regression model; $L_{i}=$ the average time period (usually annual) loading at site i per hectare per time period; $\beta_{1}$ to $\beta_{n}=$ the export coefficient for $n$ types land uses ( $\mathrm{kg} / \mathrm{ha} /$ time period); $X_{i, 1}$ to $X_{i, n}=$ the fraction of land area above site $i$ represented by $n$ types of land uses and $\varepsilon I=$ the random error associated with the difference between the measured and predicted loadings that is not explained by the model for site $i$ (Shrestha et al. 2008). Eqn. 2.

Some studies extend this approach by estimating export coefficient probability based on the distribution of literature based export coefficients or fractional area of individual land uses over multiple catchments (Zobrist and Reichert 2006; Broad and Corkrey 2011; Lu et al. 2013). A first attempt at export coefficient derivation using this method was made by Omernik (1976) in US catchments. His success was variable. In particular, definition of export coefficients was difficult for more than two very broad categories: forest and agriculture plus urban. More recent studies define four broad land use 
categories including forest, urban, intensive agriculture and extensive agriculture (Zobrist and Reichert 2006; Shrestha et al. 2008; Lu et al. 2013).

The statistical derivation method is useful in regions with few single land use/cover field or small catchment studies. However, validating derived export coefficients and defining their uncertainty is problematic (McFarland and Hauck 2001; Lu et al. 2013).

Additionally, this method relies on appropriate long-term in-stream water quality data, preferably from multiple measurement locations within a catchment (Shrestha et al. 2008), and this is rarely available.

A third method of export coefficient derivation uses existing models to generate plot to field to farm scale export coefficients. This method is useful where catchment specific data is unavailable due to lack of measurement or due to data restrictions (Anthony et al. 2009). For example, SPASMO and OVERSEER are used to develop nutrient loss coefficients from New Zealand 'model' or regionally representative farms for use in catchment scale water quality modelling (Wilcock et al. 2006; Monaghan et al. 2007b; Elliott et al. 2008; Monaghan et al. 2009; Rutherford et al. 2009; Wilcock et al. 2009; Rutherford et al. 2011; Rutherford 2012; Wilcock et al. 2013; Semadeni-Davies et al. 2016). Section 2.3.2 describes how this approach is specifically applied in the CLUES catchment scale model.

Similarly, field scale models NCYCLE, NITCAT, MANNER and PSYCHIC are applied to a range of 'typical' farm types, combined with area specific climate and soil data, to derive nitrate- $\mathrm{N}$ and $\mathrm{P}$ loss coefficients for grassland and crop systems in catchment to national scale modelling in the UK (Lord and Anthony 2000; Anthony et al. 2009; Lord et al. 2009; Anthony et al. 2012). In the US, SWAT is used to develop agricultural export coefficients for broad ecoregions (White et al. 2015).

Validation of such modelled export coefficients can be difficult because plot to field scale measurements covering the full complement of climate, soil, topographic and management variables rarely exist for comparison. However, White et al $(2015 ; 2016)$ report SWAT simulated export coefficients compare favourably with plot, field and small catchment based measurements. Although their approach explained only 0.45 and 0.33 of the variation in TN and TP exports (White et al. 2015). 
Table 2.1 summarises literature reported, land cover linked export coefficients from a variety of regions and climates including the US (Loehr 1974; Reckhow et al. 1980; McFarland and Hauck 2001; White et al. 2015), UK (Johnes 1996; Shi et al. 2006), Europe (Loehr 1974) and Australia (Baginska et al. 2003; Broad and Corkrey 2011). Export coefficients featured are reported measured losses (Loehr 1974; Reckhow et al. 1980), derived from statistical analysis of land use area and in-stream measurements (McFarland and Hauck 2001; Broad and Corkrey 2011), and derived from SWAT (White et al. 2015). This table does not represent a complete survey of all export coefficient literature (much of which does not tabulate specific export coefficients used anyway), but it is presented to highlight the wide variety of export coefficients reported for a range land covers. Only broad land cover categories are used here because specific land covers identified in literature are very difficult to reconcile between studies.

Table 2.1 Summary of export coefficients reported in a selection of international literature for 8 broad land cover categories

\begin{tabular}{|c|c|c|c|c|}
\hline Land Cover & $\begin{array}{c}\text { Nitrogen Loss } \\
\text { (kg TN ha-1 } \mathrm{yr}^{-} \\
\text {1) }\end{array}$ & N References & $\begin{array}{c}\text { Phosphorus } \\
\text { Loss } \\
\left(\mathrm{kg} \mathrm{TP} \mathrm{ha}^{-1} \mathrm{yr}^{-1}\right)\end{array}$ & P References \\
\hline $\begin{array}{l}\text { Intensive/Improved } \\
\text { Grassland }\end{array}$ & $0.13-30.85$ & $1,2,5,6,8,9$ & $0-11.1$ & $1,2,3,4,5,6,7,8,9$ \\
\hline $\begin{array}{l}\text { Extensive/Unimproved } \\
\text { Grassland }\end{array}$ & $0.1-13$ & $3,5,6,8$ & $0-0.25$ & $3,5,6,7,8$ \\
\hline Cropland & $0.04-91.4$ & $1,2,5,6,8,9$ & $0-18.6$ & $1,2,3,5,6,7,8,9$ \\
\hline Orchard & $4.7-5.49$ & 5,8 & $0.02-0.3$ & $5,7,8$ \\
\hline $\begin{array}{l}\text { Feedlot and Manure } \\
\text { Storage }\end{array}$ & $4-7979.9$ & 1,2 & $0.8-795.2$ & 1,2 \\
\hline Urban & $1.48-63$ & $1,2,4,5,8,9$ & $0.065-20$ & $1,2,4,5,7,8,9$ \\
\hline Forest & $0.12-6.3$ & $1,2,3,4,5,6,8,9$ & $0-0.88$ & $1,2,3,4,5,6,7,8,9$ \\
\hline $\begin{array}{l}\text { Scrub, Shrub and } \\
\text { "Unused" }\end{array}$ & $0.5-6$ & 2,8 & $0.02-0.7$ & $2,7,8$ \\
\hline${ }^{1}$ Reckhow et al (1980) & \multicolumn{2}{|c|}{${ }^{4}$ McFarland \& Hauck (2001) } & \multicolumn{2}{|c|}{${ }^{7}$ White \& Hammond (2009) } \\
\hline 2 Loehr (1974) & \multicolumn{2}{|c|}{${ }^{5}$ Baginska et al (2003) } & \multicolumn{2}{|c|}{${ }^{8}$ Broad \& Corkrey (2011) } \\
\hline${ }^{3}$ Johnes (1996) & \multicolumn{2}{|c|}{${ }^{6}$ Shi et al (2006) } & \multicolumn{2}{|c|}{${ }^{9}$ White et a (2015) } \\
\hline
\end{tabular}

\subsubsection{Choosing and Using Export Coefficients}

Baginska et al. (2003) found modelled in-stream nutrient losses were highly dependent on export coefficient choice. The main issue around choosing and using export coefficients concerns whether export coefficients derived for one area are appropriate for use elsewhere (Broad and Corkrey 2011). When searching for export coefficients 
variables associated with climate, soil, topography, land use and management, and temporal and spatial measurement scale should be considered (Reckhow et al. 1980; Young et al. 1996; Baginska et al. 2003; White et al. 2015).

Of these variables measurement scale is important and must fit with the catchment model scale and process representation (Drewry et al. 2006; Soranno et al. 2014). Temporally, measurements over periods of less than a year (even if reported as $\mathrm{kg}$ nutrient $\mathrm{ha}^{-1} \mathrm{yr}^{-1}$ ) may not account for seasonal climate and land management variability (Reckhow et al. 1980). Spatially, as derivation area increases, export coefficients decrease because more terrestrial and in-stream attenuation processes are included (Grimvall and Stalnacke 1996; Drewry et al. 2006).

Early use of export coefficients described the contaminant load delivered from the source to the edge of the stream (Reckhow et al. 1980; Johnes 1996; Ongley et al. 2010) and implicitly included storage and transformation losses along source to sink pathways. In more recent literature the term 'export coefficient' is often used when referring to contaminant loss to edge of field and/or root zone only (Harmel et al. 2006; White et al. 2015). These export coefficients are appropriate for use in models that include more explicit representation of nutrient storage and transformation along source to sink pathways.

This evolution of export coefficients is indicative of the easiest scale at which single land use nutrient export data is collected and reflects catchment scale modelling changes, tending towards more complex and physically based models as computing power increased. However, it also highlights that export coefficients with a variety of underlying scale, process and transport assumptions, as well as variable climate, soil, topography, and land use and management, are found in literature. Care should be taken to make the appropriate choice of export coefficients for use in the catchment scale water quality model of interest.

However, whether such care is taken is uncertain. In addition, limited data, limits the range of export coefficients to choose from. A survey of export coefficient literature suggests that land use or cover is the most commonly matched variable, or in some cases, the only matched variable, when choosing export coefficients. For example, ECM 
studies for the UK clearly replicate land use export coefficients from a common few previous studies e.g. May et al. (2001), Hanrahan et al. (2001), Mattikalli and Richard (1996). Common export coefficient references include Cooke (1976), Gostick (1982) and Johnes (1996), who herself references export coefficients from the original studies in North America and continental Europe e.g. Vollenweider (1968) and Reckhow et al. (1980). It is unlikely that these few studies can supply appropriate export coefficients for such a range of locations with variable climate, soil, topography and land management. Accordingly, authors in regions outside North America and Europe note difficulty sourcing appropriate export coefficients from literature. Young et al. (1996) state little export coefficient data is available for Australia and, what is available, is almost exclusively derived from south-eastern Australia with little to no crop system data. Using European or North American data is possible, but differences in land and crop management as well as climatic conditions make this an unattractive option. Similarly, Ongley et al. (2010) note using North American or European based export coefficients introduces considerable uncertainty to ECM in China due to radically different agricultural management. Likewise, Jeje (2006) provides a review of export coefficients for use in Alberta, Canada and notes, although data is available for North America, little is available for cold climate prairie regions.

Methods of overcoming these issues, include modifying literature based export coefficients to account for different catchment attributes using 'expert knowledge' or meta-analysis of reported export coefficients to determine likely coefficients and uncertainty ranges. This second option is less subjective, but can be difficult due to a lack of sufficient literature based export coefficients for certain land cover/use categories and the uneven geographic coverage of published studies (Reckhow et al. 1980; Marston et al. 1995; Baginska et al. 2003; Broad and Corkrey 2011).

Indeed, it is likely difficulties sourcing appropriate export coefficients from literature has been a key motivator towards use of plot, field and farm scale nutrient models to derive nutrient losses. To date this approach has commonly involved plot/field/farm scale model runs for a variety of broadly representative land uses with broad geo-climatic characteristics e.g. dominant climate, soil, slope, within a sub-basin. Resulting export coefficients are then used as input to a catchment model. Typically export coefficients 
are associated with land use area within a reach or sub-basin and intra-basin configuration and flows are not considered, although this depends on the catchment model in question.

However, detailed spatial data around climate, soil, topography and land cover or use is now generally available at sub-national to global scale. This data facilitates spatially explicit identification of land units comprising of site-specific combinations of variables within the reach or sub-basin. In other words, detailed intra-reach or sub-basin variability can be considered, rather than only the dominant variables within a reach or sub-basin. Positioning of export coefficients that consider site specific variability at this scale could improve catchment scale modelling of diffuse pollution. However, sourcing export coefficients for each specific land unit is problematic because literature reported data is unlikely to cover the full gamut of variables and variable combinations, and running plot/field/farm scale models for all possible scenarios is also difficult.

Therefore, this research aims to develop algorithms that can be applied to specific land units of combined variables and can calculate export coefficients unique to that particular site. The developed algorithms can potentially be applied to any export coefficient based catchment scale water quality model. However, here they are applied in LUCl, which means climate, soil, topography and land management characteristics are considered and export coefficients positioned at the DEM grid square scale ( $\leq 15 \mathrm{~m} \times 15$ $m$ for New Zealand). In addition, LUCI explicitly considers spatial configuration of these gridded land units as nutrients and water are cascaded through the catchment. These qualities, coupled with the new algorithmic export coefficient approach, make LUCI water quality models particularly valuable decision support tools in the current struggle to reduce nutrient loss to water. However, export coefficient algorithm development, application and assessment of results is highly reliant on availability of suitable data. In Chapter 3 potential New Zealand data for these purposes are reviewed. 


\section{DEVELOPMENT OF A NEW EXPORT COEFFICIENT APPROACH FOR NEW ZEALAND USING LUCI - A DATA REVIEW}

\subsection{INTRODUCTION}

Theoretically the application of an export coefficient based water quality model is straightforward. However, as is clear from Section 2.4, locating appropriate export coefficient data is a confounding factor, particularly outside of North America and Europe. When choosing export coefficients from literature, land cover or use is generally considered with little to no reference to climate, soil, topography, and land management variables. Export coefficients derived from plot, field or farm models may consider these variables, but when applied at catchment scale, usually only a limited number of 'reference' plots, fields or farms are considered rather than specific, individual plots, field or farms. To better account for these highly spatially varied factors, a new approach to export coefficient derivation is proposed that uses spatial data to identify each and all combinations of important variables and derives export coefficients specific to spatial locations.

Here the aim is development of an algorithmic export coefficient approach that considers spatial variation in climate, soil, topography, land cover, land use and land management to calculate site specific export coefficients. The scale of export coefficient derivation will vary among catchment models, depending on scale of input data as well as the catchment model minimum spatial unit. In $\mathrm{LUCl}$ export coefficients are positioned at the DEM grid square scale ( $\leq 15 \mathrm{~m} \times 15 \mathrm{~m}$ in New Zealand) and cascaded through the catchment, accounting for intra-basin configuration and flows.

Such an algorithmic export coefficient approach relies on three categories of data:

1. Spatial input data on variables influencing $N$ and $P$ loss

2. In-stream water quality data for catchment scale model evaluation

3. Data for algorithm development and parameterization 
Data limitations in these three categories hamper full development, implementation and assessment of the export coefficient approach proposed here. However, an initial framework for the new approach is provided in following chapters, enabling further future development of the method as appropriate data become available.

This chapter summarises and evaluates New Zealand spatial input data (Section 3.2), measured in-stream water quality data (Section 3.3), and literature based data of potential use for algorithm development and parameterisation (Section 3.4). Figure 3.1 illustrates how the data reviewed in this chapter is used or will be used in LUCl's N and P water quality models.

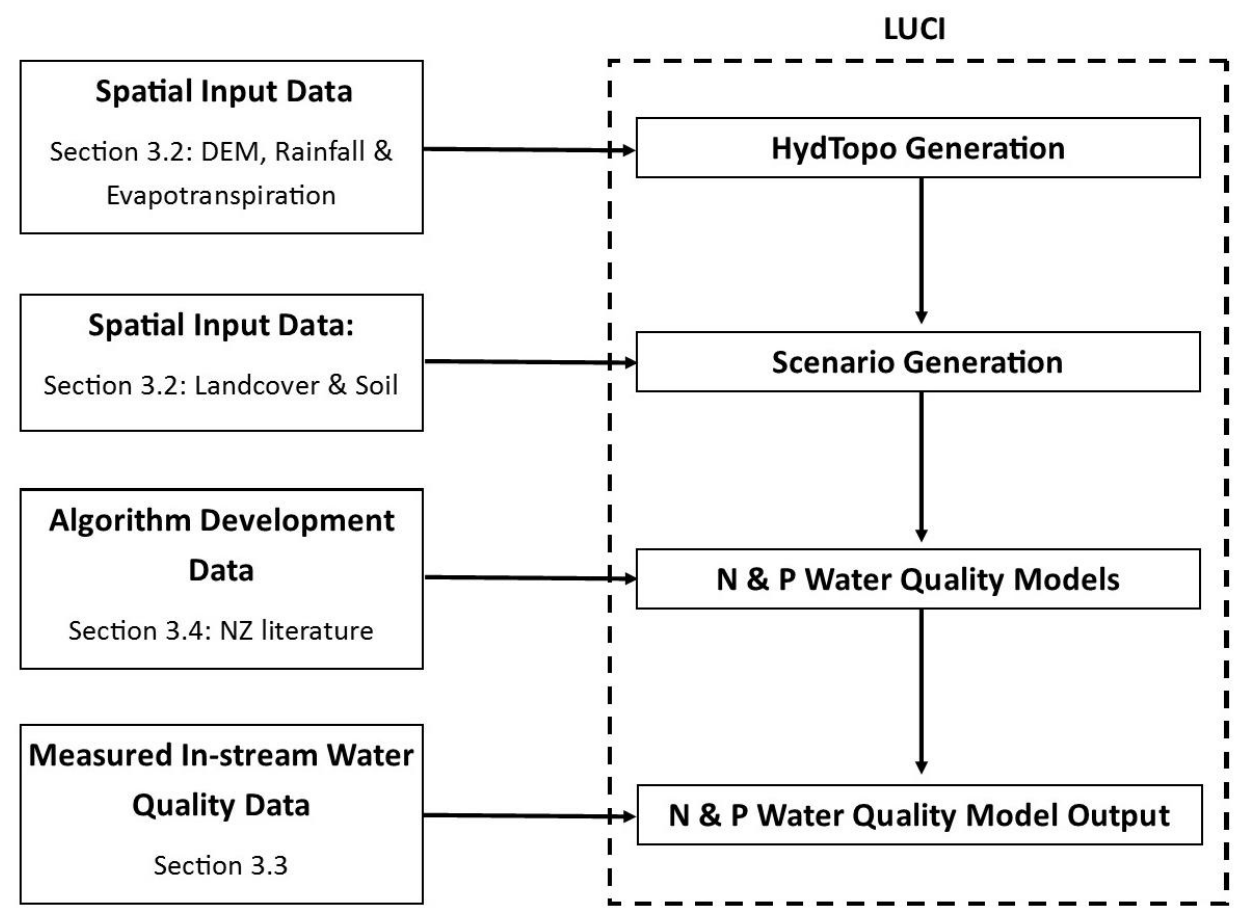

Figure 3.1 Diagram illustrating how the data reviewed in this chapter is used or will be used in LUCl's N and P water quality models

\subsection{NEW ZEALAND SPATIAL DATA FOR MODEL INPUT}

In Section 2.2 on nutrient cycling, important influences on nutrient loss to water were highlighted. These included precipitation, soil variables such as permeability and $\mathrm{P}$ retention, topography particularly slope, land cover, and land management including nutrient inputs, stocking rate, timing of fertiliser and irrigation application etc.

National spatial data pertaining to precipitation, soil, topography and land cover are available and specific layers are discussed below. Many of these layers are already 
general input to the LUCI framework, as specified in Section 1.2 and Table 1.1. Spatial land use data for New Zealand (Land Use New Zealand (LUNZ)) does exist and was created by Landcare Research for use in the CLUES model (Landcare Research 2003). The most recent version is based on 2012 land use statistics gathered from land owners for Agribase, a commercially created and owned 'national' (not all farms are included as inclusion is voluntary) spatial farm database (Timar 2016; Asurequality 2017). LUNZ is not permitted for general use in LUCl and there are potential issues around landowner privacy if results using LUNZ were published.

Rutledge et al. (2009) argue that New Zealand lacks a nationally consistent and comprehensive geospatial land use database and they investigated developing one. At this stage nothing has eventuated. Certainly usable national geospatial land use data would be a desirable model input because more specific management information could then be tied to specific spatial locations. For example, current pastoral land cover could be identified as sheep, beef, deer or dairy, all of which have quite different nutrient input and management profiles.

\subsubsection{Digital Elevation Models (DEM)}

Digital elevation models facilitate terrain analysis and in LUCI a DEM is essential. It determines the minimum spatial unit, slope and pathways of water and nutrient routing through the catchment. To-date DEM grid square resolution of $5 \mathrm{~m} \times 5 \mathrm{~m}$ has proven suitable for use in LUCI because detail is discerned, yet processing times are not onerous (Jackson et al. 2013a; Trodahl et al. 2017b). Unfortunately in New Zealand national DEM coverage at this scale is unavailable. However, many regional authorities hold LiDAR coverage of some or all areas within their jurisdictions and DEMs of fine resolution (e.g. $1 \mathrm{~m} \times 1 \mathrm{~m}$ ) can be built from these data. Generally regional authorities are generous with data sharing, but some restrictions on application and publication of data may exist. Land Information New Zealand (LINZ) also hold a number of freely available regional LiDAR derived DEM (LINZ 2017). Two lower resolution freely available national DEMs exist and are described below. 


\section{NZSOSDEM}

The National School of Surveying, Otago University, created this $15 \mathrm{~m} \times 15 \mathrm{~m}$ DEM in 2011. It is interpolated from contour line and height point data held in the LINZ topographic database using the ANUDEM method. This method and associated software was developed at Australian National University with a particular focus on ensuring a good shape and drainage structure in calculated DEMs (ANU 2017). Compared with other interpolation methods ANUDEM was found to represent hilly terrain particularly well (Arun 2013), making it an appropriate choice for New Zealand's terrain. Further information about the dataset, derivation and accuracy is available from Columbus et al (2011).

\section{NZ 8m DEM}

New Zealand map design studio, Geographix, created the NZ 8m DEM in 2012 and it is now freely available through the LINZ Data Service. The base contour line and height point data described above, were also used to generate this DEM. However, DEM development was primarily for cartographic visualisation and it is considered unsuitable for terrain analysis (LINZ 2016). Despite this, the 8m DEM has been used in Case Study 1 (Section 7.3), primarily because colleagues at Massey University provided location specific data based on this DEM. Additionally, LUCI hydrologically corrects input DEMs prior to analysis, which should correct terrain errors.

\subsubsection{Rainfall \& Evapotranspiration}

Climate point data are freely available through NIWA's national climate database, CliFlo, and could be used to develop spatial climate surfaces. However, LUCI developers are permitted to use NIWA developed national rainfall and evapotranspiration surfaces, which are unfortunately not freely available. These surfaces are used in this research.

The rainfall raster was developed from the national climate database annual rainfall point data from 1960-2004, using a second order derivative tri-variate thin plate smoothing spline interpolation model. Its resolution is $1000 \mathrm{~m} \times 1000 \mathrm{~m}$ and it was specifically developed for hydrological modelling in New Zealand. Tait et al (2006) provide further detail. 
The evapotranspiration surface was developed using potential evapotranspiration point data from the national climate database and the precipitation surface discussed above. Ratios between potential evapotranspiration and rainfall were calculated, and a water balance parameter applied, to estimate actual evapotranspiration (Woods et al. 2006b). The surface is based on 1960-2004 data and is $500 \mathrm{~m} \times 500 \mathrm{~m}$ resolution.

\subsubsection{Land Cover Data}

The New Zealand Land Cover Database (LCDB) provides freely available, multi-temporal, national coverage. The latest version (LCDB 4.1) features four time steps: - summer 1996/97, summer 2001/02, summer 2008-09 and summer 2012/13. Generated from ortho-rectified multi-spectral SPOT5 satellite imagery, 33 land cover classes are identified, ranging from urban to agricultural to productive and natural forests (New Zealand Land Cover Database 2012). These data provide good land cover information, but do not differentiate between land uses and this would be particularly beneficial for agricultural land uses. For example, LCDB identifies four agricultural land covers: shortrotation cropland, perennial crops, high producing grassland and low producing grassland. Within each of these, a wide variety of land uses and hence management practices are represented. Nutrient loss analysis would be enhanced if land use could be identified, as discussed at the beginning of this section.

\section{$\underline{\text { 3.2.4 Soil Data }}$}

\section{New Zealand Fundamental Soil Layer (NZFSL)}

The NZFSL contains information on soils throughout New Zealand. It is based on soil surveys conducted since the 1930's, as stored in the National Soils Database, which was combined by soil experts with polygon boundaries from the New Zealand Land Resource Inventory. Concern exists around the variety of survey methods and lack of expertise used to conduct the original soil surveys. Sixteen soil attributes are associated with each database polygon including soil water, drainage and $\mathrm{P}$ retention. However, in most cases only 3-5 broad categories are specified for each attribute and within each category minimum, mid and maximum values are quantified. Lilburne et al. (2014) are critical of the database because it lacks specific pedo-transfer functions and estimates of error, both of which are useful for environmental modelling purposes. 


\section{S-Map}

The above NZFSL concerns were the motivation to develop S-Map, a new soil database for New Zealand that better supports environmental and production modelling (Lilburne et al. 2014). Currently, S-Map does not provide national coverage and the full database including an attribute table with all soil properties is not freely available. As well as better quantifying soil properties and confidence of information accuracy, S-Map associates multiple soil types with each polygon. While this better reflects the highly heterogeneous nature of soil, it is an additional complication with using S-Map in models such as $\mathrm{LUCl}$. A project is currently underway investigating how best to consider this issue in $\mathrm{LUCl}$.

However, for the purposes of this research the NZFSL is used to spatially reference soil order categories only. Fifteen broad soil orders for New Zealand are described and defined in the New Zealand Soil Classification (Hewitt 2010).

Overall national spatial data available to the wider public and the LUCI project provides sufficient input for initial model development. However, a finer national DEM, national land use data, and S-Map with national coverage and a full attribute table, would likely enhance model capability and results.

\subsection{IN-STREAM WATER QUALITY DATA FOR CATCHMENT SCALE MODEL EVALUATION}

To assess water quality models at catchment scale, in-stream predictions are compared with measured in-stream water quality data. This section reviews and evaluates available in-stream water quality data for New Zealand.

\subsubsection{The National River Water Quality Network (NRWQN)}

The NRWQN aims to monitor water quality trends throughout New Zealand. Monitoring began in January 1989 at 77 sites on 35 major river systems. Most river systems have two sampling sites, a lightly impacted, baseline site in the upper catchment and a more heavily impacted site in the lower catchment. Sites are visited monthly and a variety of physical, chemical and microbial variables tested including instantaneous flow and concentrations of ammoniacal nitrogen, nitrate, total nitrogen, dissolved reactive 
phosphorus and total phosphorus. Access to this data is freely available upon application to NIWA (Davies-Colley et al. 2011; NIWA 2017).

\subsubsection{Regional Authorities and Other Institutions}

Regional councils in New Zealand are tasked with managing water quality and allocation within their region. They generally also collect monthly water quality data and similar measurements to those listed above, although this can vary from council to council. At some sites on larger rivers, flow may be automatically monitored more frequently (e.g. every 5-15 mins). Regular water quality data held by regional councils generally covers a period of around 2 decades. Authorities are usually happy for this data to be used for research purposes, although some restrictions may apply.

Water quality data is also held by various other institutions e.g. local councils, research institutes and universities. These largely apply to limited areas and/or timeframes, but may be useful as comparative data for catchment scale models.

While this data is useful, uncertainties pertaining to representativeness of water quality measurements exist. Low frequency data collection and lack of collection during storm and flood events, which can account for a large proportion of annual load, are of particular concern (Letcher et al. 2002). For example, in Australia it is estimated that such events may be responsible for more than $60 \%$ of annual nutrient load (Baginska et al. 2003).

This is particularly the case for P which moves sporadically, often with long periods of incatchment storage (Jarvie et al. 2013; Sharpley et al. 2013). Comparing daily, weekly, and monthly P sampling strategies, Johnes et al. (2007) found monthly sampling was the least representative, with $\mathrm{P}$ concentration error ranging from more than twice, to less than half of 'actual' concentrations. Baginska (2003) suggests using 'routine' water quality sampling may overestimate $\mathrm{P}$ loads by $12-43 \%$.

Likewise, Sebestyen et al. (2014) found in-stream $\mathrm{NO}_{3}{ }^{-}$concentrations increased 25 fold during an autumn storm event following a dry summer period. During subsequent, closely spaced, similar magnitude storm events, $\mathrm{NO}_{3}{ }^{-}$concentration decreased with each event as stored $\mathrm{N}$ was flushed from the system. Conversely, Abel et al. (2013) found storm events in a groundwater dominated catchment resulted in reductions in $\mathrm{NO}_{3}{ }^{-}$ 
concentration, which they attribute to rainfall dilution of $\mathrm{NO}_{3}^{-}$in groundwater entering streams. Again, monthly in-stream sampling can miss such events or, in cases where samples are taken by hand, these events may be purposefully avoided (Johnes 2007; Krueger et al. 2012; Lloyd et al. 2016).

Harmel et al. (2010) found considerable temporal and spatial differences in $\mathrm{N}$ and $\mathrm{P}$ concentrations in small streams during storm events. They reiterate the importance of testing during these events, and suggest multiple temporal and spatial in-storm samples are collected to improve representativeness.

Nutrient loads, derived from collected concentration and flow data, are calculated in a variety of ways, which introduces further uncertainty. Letcher et al. (2002) evaluated averaging, ratio and regression load estimation methods and found substantial differences, but decline to recommend a 'best method' because there is no way to determine the 'true' load. Abell et al. (2013) also compared averaging, ratio and regression load estimation methods using high-frequency sampling data and concluded regression techniques are most accurate.

Predictions from water quality models suffer from considerable absolute error when compared with instream measurements (Drewry et al. 2006). This may be due to model and input data short comings, but is also likely due to unrepresentative in-stream measurements. Indeed, Letcher et al. (2002) suggest improving water quality data collection is the next step to improving catchment scale water quality modelling. Specifically, they recommend better temporal coverage through more frequent longterm sampling, including during events, and better spatial coverage with multiple nested sampling sites within catchments. This would greatly assist with calibration and validation of catchment scale water quality models.

Despite evidence suggesting monthly in-stream sampling is less than optimal, this data is all that is currently available for catchment scale assessment of the water quality models developed and tested here. Suffice to say, in-stream measurement uncertainty, as discussed above, must be considered when comparing predicted and measured data in Chapter 7. 


\subsection{A REVIEW OF NEW ZEALAND DATA WITH POTENTIAL FOR USE IN EXPORT COEFFICIENT ALGORITHM DEVELOPMENT AND}

\section{PARAMETERISATION}

In order to develop algorithms that can derive export coefficients for the full variety of possible climate, soil, topography, land cover and land management combinations, data pertaining to $\mathrm{N}$ and $\mathrm{P}$ area-specific losses to water for all variable combinations is required. In this section New Zealand literature reported $\mathrm{N}$ and $\mathrm{P}$ losses are reviewed and considered in terms of suitability for algorithm development.

As discussed in Section 2.4.3 there are three general methods of deriving export coefficients: actual measurement from single land use plot, field or small catchments, statistical derivation from multi-land use catchments, and derivation from existing plot, field or farm scale models. Here the aim is identification of literature reporting actual measured losses, in $\mathrm{kg}$ total nutrient $\mathrm{ha}^{-1} \mathrm{yr}^{-1}$, from single land cover isolated plot, field or small catchments for 6 broad land cover categories. The land cover categories are based on LCDB4 land cover groups (into which specific land cover classes fit) and on commonly identified export coefficient categories e.g. Table 2.1. They include pasture (intensive and extensive), exotic forest, indigenous forest, crops (short-rotation and perennial), urban and scrub.

However, problems with this approach are evident. As discussed in Section 2.4, traditionally export coefficients refer to nutrient export via surface and sub-surface pathways to the stream network and implicitly include any interim attenuation. This suggests in-stream nutrient loss measurements from single land cover or use catchments are most appropriate. However, New Zealand literature reporting TN and TP losses from single land cover or use catchments largely only include pasture and forest covers. Literature citing nutrient losses from short-rotation crops are available, but generally focus on point scale $\mathrm{N}$ leaching (particularly nitrate with concentration only reported) and often cover periods of less than a year due to crop management practices. Reported perennial crop losses tend to be based on a combination of modelled losses, in some cases validated with point scale measurements, and 'educated' estimates. Little literature reporting measured losses from urban land covers is available and what is 
available covers limited loss pathways. Losses from scrub are reported, but their exact provenance is not clear.

Consideration of catchment water quality model scale adds further complication. Many models, such as LUCI, function at finer than catchment or sub-basin scale and/or include separate attenuation terms. This suggests that small scale measurement of nutrient loss might be most appropriate to consider. However, again, New Zealand literature is limited in this respect. Most small scale measured losses reported in New Zealand literature cover pasture and crop land covers only and tend to include limited pathways and nutrient species or type. Most commonly leached concentrations of nitrate are reported.

As discussed in Section 2.4.4 scale is an important consideration. As spatial scale increases area-specific nutrient losses tend to decrease because more terrestrial and instream attenuation processes are included (Grimvall and Stalnacke 1996; Drewry et al. 2006). Identifying appropriate smaller spatial scale nutrient loss measurements for use in predictive catchment scale water quality models, is a perennial problem (Drewry et al. 2006) and cannot be resolved here. Due to limited data within land cover categories, this review takes a somewhat mixed scale/nutrient pathway/nutrient species approach. It is acknowledged that some uncertainty and a lack of comparability between land cover category losses may be an issue. Clearly, more comprehensive measurement data covering a wider variety of spatial scales, land covers and other variables, would be useful, but is unlikely due to the considerable time and money that would be required. Here literature reported losses at a variety of spatial scales are included, but temporally only reported annual area-specific losses are considered. Reported losses from single land cover isolated plot/field/catchments are preferred and, for land covers where this data is available, only this data is reported. Where no other data is available for a particular land cover, point scale measurements, and in some cases 'estimates' and modelled losses, are included. In addition, some studies only include nitrate or nitrate plus ammonium. These differences are highlighted and discussed where they occur. 


\subsubsection{Literature Providing Export Coefficient Summaries for Multiple Land Covers}

Interest in quantifying diffuse nutrient losses from a variety of land covers in New Zealand appears to have begun in the late 1970's, in tandem with similar interest overseas, and since this time a number of papers summarising New Zealand export coefficients have been published. Cooke (1979) provides the first collation and estimation of $\mathrm{NO}_{3}-\mathrm{N}$ and TP specific yield for 4 land cover categories (improved pasture, exotic forest, native forest and scrub) based on measured losses from 13 New Zealand catchments. Wilcock (1986) summarises export coefficients, referencing Cooke (1979) and others, to determine if agricultural runoff is a source of water pollution in New Zealand. Rutherford et al. (1987) provide a short summary table in wider discussion of river water quality and reference Cooke (1979) as the source. Elliott and Sorrell (2002) summarise export coefficients for 5 land uses ( 3 pasture based and 2 forested), which they state are updates since Cooke's (1979) and Wilcock's (1986) work. They do not state exactly which studies they use, but note that most are North Island based. DaviesColley and Wilcock (2004) provide a table of specific yields for 6 land use categories referenced to 3 studies (including Wilcock (1986)) in a general discussion of water quality in running waters. McDowell and Wilcock (2008) collate, discuss and reference New Zealand single land use isolated plot to catchment studies quantifying $\mathrm{N}$ and $\mathrm{P}$ losses. In particular, they quantify losses from different pasture grazing animals and forested areas. Their results indicate median $\mathrm{N}$ losses are, greatest to least, dairy $>$ deer \& mixed $>$ sheep $>$ non-agricultural. Median P losses are, greatest to least, deer \& mixed $>$ dairy > sheep > non-agricultural. Davis (2014) collates results of in-stream N losses from forested catchments. Export coefficients from these studies are further discussed and quantified in the following sections.

\subsubsection{Pastoral Land Covers}

High producing grassland (or improved pasture) is one of the more studied land covers in New Zealand nutrient loss literature, reflecting both its economic importance and concern with associated environmental impacts. New Zealand field to catchment studies of nutrient losses from high producing pasture are summarised in Tables 3.1-3.3. Table 3.1 details losses from dairy pasture, Table 3.2 details losses from sheep and beef pasture and Table 3.3 details losses from deer pasture. All tables give indications of a 
range of site variables. Overall $\mathrm{N}$ losses from pasture range from $0.8-50 \mathrm{~kg} \mathrm{~N} \mathrm{ha}^{-1} \mathrm{yr}^{-1} \mathrm{~N}$ losses from dairy pasture range from $13-56 \mathrm{~kg} \mathrm{~N} \mathrm{ha}^{-1} \mathrm{yr}^{-1}, \mathrm{~N}$ losses from sheep and beef pasture range from 0.8-12.1 $\mathrm{kg} \mathrm{N} \mathrm{ha}^{-1} \mathrm{yr}^{-1}$, and $\mathrm{N}$ losses from deer range from 0.42-4.16 $\mathrm{kg} \mathrm{N} \mathrm{ha}^{-1} \mathrm{yr}^{-1}$. (It should be noted that most studies report TN losses, but three studies report nitrate only or nitrate plus ammonium. Here results are simply summarised, without any attempt to estimate $\mathrm{TN}$ from results that only report $\mathrm{N}$ species). Overall $\mathrm{P}$ losses from pasture range from 0.1-10.5 $\mathrm{kg} \mathrm{P} \mathrm{ha}^{-1} \mathrm{yr}^{-1}$. P losses from dairy pasture range from 0.1-10.5 kg P ha-1 $\mathrm{yr}^{-1}, \mathrm{P}$ losses from sheep and beef pasture range from 0.2-1.6 kg $\mathrm{Pha} \mathrm{Fr}^{-1}$ and $\mathrm{P}$ losses from deer range from 0.18-2.99 $\mathrm{kg} \mathrm{P} \mathrm{ha}^{-1} \mathrm{yr}^{-1}$.

In order to develop algorithms based on important variables and their combinations, Tables 3.1-3.3 need to include a full range of variables and variable combinations. Looking only at soil order, it is clear a limited range is covered. Five soils orders are identified in Table 3.1 for dairy pasture, 5 soil orders in Table 3.2 for sheep and beef, and only 2 soil orders in Table 3.3 for deer. Overall, of the total 15 soil order classifications found in the New Zealand Soil Classification (NZSC), only 7 are featured here. (See Section 4.2.2 for more information about the NZSC). In addition, some studies feature multiple soil orders within the catchment, but measurement is at the catchment outlet only and exports from specific soils are not elucidated e.g. Davies-Colley and Nagels (2002), Lambert et al. (1985) and Wilcock et al. (1999; 2006).

In Table 3.1, there is a wide rainfall range from $1000-4800 \mathrm{~mm} \mathrm{yr}^{-1}$. However, this range is not evident for all of 5 individual soil orders. Rather each soil order has only one annual average rainfall, or a narrow range of rainfall, associated with it. Table 3.2 has an overall rainfall range of only $1000-1600 \mathrm{~mm} \mathrm{yr}^{-1}$ and it is also very limited within soil orders. Table 3.3 is limited to only 2 soil orders and 2 annual average rainfall amounts. Topography is also limited within each of the tables, but reflects where these pasture types are generally found. For example, Table 3.1 for dairy only features flat to rolling topography, Table 3.2 for sheep and beef only features easy to steep hill and Table 3.3 is limited to rolling to easy hill. Although these pasture types are typically found on the identified slopes, they are not exclusively found in these areas and any developed algorithms would need to consider the full slope range. 
Further limitation exists regarding regional location. Only 6 regions are included in Table 3.1-3.3 and within regions several studies cover the same location. For example, in Waikato, Toenepi catchment is featured in Wilcock (1999), Davies-Colley and Nagels (2002), and Wilcock (2006), both Wellington references are from the former Taita Experimental Station in Lower Hutt, and both McDowell $(2007 ; 2008)$ references in Otago feature the same catchment within AgResearch's Invermay farm. Additionally, a number of important pastoral regions are not covered e.g. Taranaki and Canterbury. Studies pertaining to these areas are available, but either do not report specific yield (Wilcock et al. 2009) or report losses from mixed land cover catchments (Monaghan et al. 2007b).

Figure 3.2 depicts all soil order and topography combinations and indicates which combinations are addressed in the literature summarised in Tables 3.1-3.3. This figure graphically highlights the lack of literature based evidence. Seven soil orders are not covered at all representing $14.5 \%$ of total high producing grassland (2012), only dairy studies are available for flat topography, no more than 3 studies are found for combinations where data is available, and some of the most prevalent soil orders have significant omissions of data. For example, no data is available for brown soils on flat land. While brown soils are often found on rolling to easy hill, there are significant areas on flat land in high producing grassland e.g. on some areas of the Canterbury Plains. A further example is the lack of literature pertaining to flat to rolling recent soils under a variety of rainfall regimes. Recent soils are found all over New Zealand including in drier eastern areas, yet the only data for flat to rolling recent soil losses relates to dairy farms in very high rainfall areas.

Table 3.4 reports $\mathrm{N}$ and $\mathrm{P}$ losses for pastoral land cover from the export coefficient summaries discussed in Section 3.4.1. These fit reasonably well with overall results from Tables 3.1-3.3. This is not surprising given many of the individual studies listed here are also included in the summaries. In general these losses also compare reasonably well with losses from international literature for intensive pasture of 0.13-30.85 kg TN ha-1 $\mathrm{yr}^{-}$ ${ }^{1}$ and 0-11.1 $\mathrm{kg} \mathrm{TP} \mathrm{ha}^{-1} \mathrm{yr}^{-1}$, as reported in Table 2.1. However, stand out areas of difference are evident from Table 3.1. Reported $\mathrm{N}$ losses of up to $50 \mathrm{~kg} \mathrm{~N} \mathrm{ha}^{-1} \mathrm{yr}^{-1}$ in Westland are clearly the result of an intensive land use (dairying) in an area of very high 
rainfall. Particularly high $\mathrm{N}$ losses are also reported by Houlbrooke et al. (2008) and Monaghan et al. (2000). Both studies feature dairy cattle with added fertiliser or effluent and are smaller field scale studies. Therefore, less uptake or storage of nutrients can occur between the nutrient source and the sampling location. This illustrates the effect of spatial scale as discussed above.

Literature featuring low producing grassland (unimproved or extensive pasture) is limited (Table 3.5), reflecting a greater focus on intensive grassland. Additionally, the one study found does not include $\mathrm{N}$ losses. Elliott and Sorrell (2002) provide N and $\mathrm{P}$ losses for 'low-intensity pasture'. Notably, Caruso's (2000) reported P loss is much lower than Elliott and Sorrell's (2002).

This brings in to question exactly what is categorised as low producing grassland. While it is well defined for New Zealand's LCDB (Thompson et al. 2003), low producing grassland is difficult to distinguish from high producing grassland through site descriptions in the literature. Elliott and Sorrell (2002) report extensive grassland losses that are similar to those reported in the international literature (Table 2.1) suggesting that their definition is aligned with wider international literature. Although they do not explicitly define what they mean by 'low-intensity pasture' or state where the data is from. Clearly low producing grassland in New Zealand requires both more study and better definition within the literature. 
Table 3.1 Reported dairy pasture losses of $\mathrm{N}$ and $\mathrm{P}$ from fields and small catchments in New Zealand, grouped according to soil order

\begin{tabular}{|c|c|c|c|c|c|c|c|}
\hline Land Use & Soil Order & $\begin{array}{c}\text { Rainfall } \\
\left(\mathrm{mm} \mathrm{yr}^{-1}\right)\end{array}$ & Topography & Region & $\begin{array}{c}\text { N Loss } \\
\left(\mathrm{kg} \mathrm{N} \mathrm{ha}^{-1} \mathrm{yr}^{-1}\right)\end{array}$ & $\begin{array}{c}\text { P Loss } \\
\left(\mathrm{kg} \mathrm{P} \mathrm{ha}^{-1} \mathrm{yr}^{-1}\right)\end{array}$ & References \\
\hline \multirow{8}{*}{$\begin{array}{l}\text { Dairy } \\
\text { Pasture }\end{array}$} & Allophanic & 1132 & Flat & Waikato & $13-35.3$ & $0.4-1.16$ & $\begin{array}{c}\text { Wilcock et al } \\
\text { (1999; 2006); } \\
\text { Davies-Colley \& } \\
\text { Nagels (2002) }\end{array}$ \\
\hline & Gley & 1132 & Flat & Waikato & $13-35.3$ & $0.4-1.16$ & $\begin{array}{c}\text { Wilcock et al } \\
\text { (1999; 2006); } \\
\text { Davies-Colley \& } \\
\text { Nagels (2002) }\end{array}$ \\
\hline & Melanic & 1132 & Flat & Waikato & $13-35.3$ & $0.4-1.16$ & $\begin{array}{c}\text { Wilcock et al } \\
\text { (1999; 2006); } \\
\text { Davies-Colley \& } \\
\text { Nagels (2002) }\end{array}$ \\
\hline & \multirow[t]{3}{*}{ Pallic } & \multirow[t]{3}{*}{1000} & \multirow[t]{2}{*}{ Flat } & Manawatu & $28-37$ & $0.3-2.6$ & $\begin{array}{l}\text { Houlbrooke et al } \\
(2003 ; 2008)\end{array}$ \\
\hline & & & & Southland & $30-56$ & $0.1-0.4$ & $\begin{array}{c}\text { Monaghan et al } \\
\text { (2000) }\end{array}$ \\
\hline & & & Rolling & Manawatu & $28-37$ & $0.3-2.6$ & $\begin{array}{c}\text { Houlbrooke et al } \\
(2003 ; 2008)\end{array}$ \\
\hline & \multirow{2}{*}{ Recent } & 3000 & Flat & Westland & $13-48$ & $1.5-10$ & $\begin{array}{c}\text { Davies-Colley \& } \\
\text { Nagels (2002) } \\
\end{array}$ \\
\hline & & $3000-4800$ & Rolling & Westland & $45-50$ & $7-10.5$ & $\begin{array}{c}\text { Davies-Colley \& } \\
\text { Nagels (2002); } \\
\text { Wilcock et al } \\
(2013)\end{array}$ \\
\hline
\end{tabular}


Table 3.2 Reported sheep and beef pasture losses of $\mathrm{N}$ and $\mathrm{P}$ from fields and small catchments in New Zealand, grouped according to soil order

\begin{tabular}{|c|c|c|c|c|c|c|c|}
\hline Land Use & Soil Order & $\begin{array}{c}\text { Rainfall } \\
\left(\mathrm{mm} \mathrm{yr}^{-1}\right)\end{array}$ & Topography & Region & $\begin{array}{c}\text { N Loss } \\
\left(\mathrm{kg} \mathrm{TN} \mathrm{ha}^{-1} \mathrm{yr}^{-1}\right)\end{array}$ & $\begin{array}{c}\text { P Loss } \\
\left(\mathrm{kg} \mathrm{TP} \mathrm{ha}^{-1} \mathrm{yr}^{-1}\right)\end{array}$ & References \\
\hline \multirow{11}{*}{$\begin{array}{c}\text { Sheep \& } \\
\text { Beef }\end{array}$} & \multirow[t]{2}{*}{ Allophanic } & 1200 & Easy Hill & Waikato & 7 & 1.3 & $\begin{array}{c}\text { Cooke \& Cooper } \\
\text { (1988), Cooke } \\
(1988)\end{array}$ \\
\hline & & 1580 & Easy Hill & Waikato & 1.2 & 0.2 & $\begin{array}{c}\text { Cooper \& } \\
\text { Thomsen (1988) }\end{array}$ \\
\hline & \multirow{4}{*}{ Brown } & 1000 & Easy Hill & Manawatu & 5.2 & 1.6 & Bargh (1978) \\
\hline & & 1200 & Easy Hill & Waikato & 7 & 1.3 & $\begin{array}{c}\text { Cooke \& Cooper } \\
(1988), \text { Cooke } \\
(1988)\end{array}$ \\
\hline & & 1271 & Easy Hill & Manawatu & $8.7-12.1$ & $0.7-1.5$ & $\begin{array}{c}\text { Lambert et al } \\
(1985)\end{array}$ \\
\hline & & 1600 & Steep Hill & Waikato & 10 & 1.5 & $\begin{array}{c}\text { Quinn \& Stroud } \\
(2002)\end{array}$ \\
\hline & Pallic & 1000 & Easy Hill & Manawatu & 5.2 & 1.6 & Bargh (1978) \\
\hline & Recent & 1200 & Easy Hill & Waikato & 7 & 1.3 & $\begin{array}{c}\text { Cooke \& Cooper } \\
(1988), \text { Cooke } \\
(1988)\end{array}$ \\
\hline & \multirow[t]{3}{*}{ Ultic } & 1200 & Easy Hill & Wellington & $\begin{array}{c}0.8-1.4 \\
(1.4=\text { nitrate } / \mathrm{N} \\
\text { only })\end{array}$ & 0.3 & $\begin{array}{c}\text { McColl et al } \\
\text { (1977), McColl \& } \\
\text { Gibson (1979) }\end{array}$ \\
\hline & & 1600 & Easy Hill & Waikato & \multirow[t]{2}{*}{10} & \multirow[t]{2}{*}{1.5} & \multirow{2}{*}{$\begin{array}{l}\text { Quinn \& Strouc } \\
\text { (2002) }\end{array}$} \\
\hline & & 1600 & Steep hill & Waikato & & & \\
\hline
\end{tabular}


Table 3.3 Reported deer pasture losses of $\mathrm{N}$ and $\mathrm{P}$ from fields and small catchments in New Zealand, grouped according to soil order

\begin{tabular}{|c|c|c|c|c|c|c|c|}
\hline Land Use & Soil Order & $\begin{array}{l}\text { Rainfall } \\
\left(\mathrm{mm} \mathrm{yr}^{-1}\right)\end{array}$ & Topography & Region & $\begin{array}{c}\text { N Loss } \\
\left(\mathrm{kg} \mathrm{TN} \mathrm{ha}^{-1} \mathrm{yr}^{-1} \mathrm{r}\right)\end{array}$ & $\begin{array}{c}\text { P Loss } \\
\left(\mathrm{kg} \mathrm{TP} \mathrm{ha}^{-1} \mathrm{yr}^{-1}\right)\end{array}$ & References \\
\hline \multirow{8}{*}{ Deer } & \multirow{4}{*}{ Brown } & \multirow[t]{2}{*}{687} & Rolling & \multirow{4}{*}{ Otago } & $0.44-4.16$ & \multirow[t]{2}{*}{$0.18-1.31$} & \multirow{8}{*}{$\begin{array}{l}\text { McDowell (2007; } \\
\text { 2008) }\end{array}$} \\
\hline & & & Easy Hill & & $\begin{array}{c}\text { (ammonium \& } \\
\text { nitrate only) }\end{array}$ & & \\
\hline & & \multirow[t]{2}{*}{949} & Rolling & & \multirow{2}{*}{$\begin{array}{c}0.42-1.63 \\
\text { (ammonium \& } \\
\text { nitrate only) }\end{array}$} & \multirow[t]{2}{*}{$0.22-2.99$} & \\
\hline & & & Easy Hill & & & & \\
\hline & \multirow{4}{*}{ Pallic } & \multirow[t]{2}{*}{687} & Rolling & \multirow{4}{*}{ Otago } & $0.44-4.16$ & $0.18-1.31$ & \\
\hline & & & Easy Hill & & $\begin{array}{c}\text { (ammonium \& } \\
\text { nitrate only) }\end{array}$ & & \\
\hline & & \multirow[t]{2}{*}{949} & Rolling & & \multirow{2}{*}{$\begin{array}{c}0.42-1.63 \\
\text { (ammonium \& } \\
\text { nitrate only) }\end{array}$} & \multirow[t]{2}{*}{$0.22-2.99$} & \\
\hline & & & Easy Hill & & & & \\
\hline
\end{tabular}


Area of High Producing Grassland on Soil Order $\left(\mathrm{km}^{2}\right)$ (from LCDB4 2012)

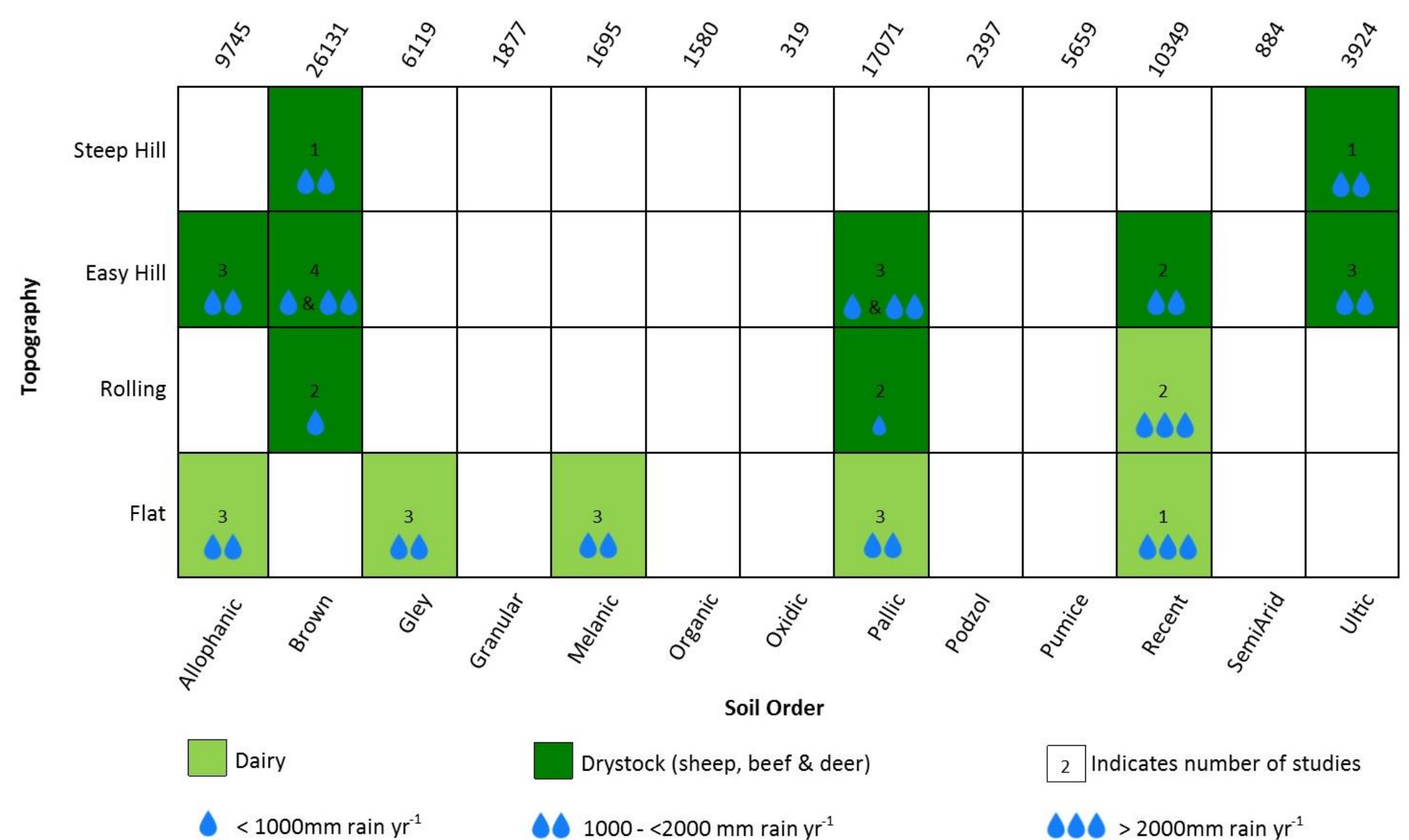

Figure 3.2 Graphical illustration of soil order and topography combinations and indicating combinations for which literature evidence of pastoral $\mathrm{N}$ and $\mathrm{P}$ losses exists (green squares). Within green squares the number of studies and annual average rainfall is given. 
Table 3.4 Export coefficients reported for High Producing Grassland in New Zealand from summary literature

\begin{tabular}{|c|c|c|c|}
\hline $\begin{array}{c}\text { N Loss } \\
\left(\mathrm{kg} \mathrm{TN} \mathrm{ha}^{-1} \mathrm{yr}^{-1}\right)\end{array}$ & $\begin{array}{c}\text { P Loss } \\
\left(\mathrm{kg} \mathrm{TP} \mathrm{ha}^{-1} \mathrm{yr}^{-1}\right)\end{array}$ & Land Use and Management & Reference \\
\hline $4-14$ & $0.3-1.7$ & Pasture & Cooke (1979) \\
\hline $4-14$ & $0.3-1.7$ & Grazed pasture & Wilcock (1986) \\
\hline $10.7-35.3$ & $0.6-1.3$ & Dairy & Elliott and Sorrell (2002) \\
\hline $2.6-19.5$ & $0.6-3.4$ & Hill pasture & Elliott and Sorrell (2002) \\
\hline $2.8-8.8$ & $0.3-0.6$ & Low-intensity pasture & Elliott and Sorrell (2002) \\
\hline 35 & 1.16 & Dairy & Davies-Colley and Wilcock (2004) \\
\hline $4-14$ & $0.3-1.7$ & Average grazed pasture & Davies-Colley and Wilcock (2004) \\
\hline 3 & 0.6 & Sheep & McDowell and Wilcock (2008) \\
\hline 8 & 1.5 & Deer & McDowell and Wilcock (2008) \\
\hline 27 & 1.9 & Dairy & McDowell and Wilcock (2008) \\
\hline 11 & 1.3 & Mixed animal & McDowell and Wilcock (2008) \\
\hline
\end{tabular}

Table 3.5 Reported N and P losses for low producing grassland in New Zealand

\begin{tabular}{|c|c|c|c|c|c|c|c|}
\hline Land Use & Soil Order & $\begin{array}{l}\text { Rainfall } \\
\left(\mathrm{mm} \mathrm{yr}^{-1}\right)\end{array}$ & Topography & Region & $\begin{array}{c}\text { N Loss } \\
\left(\mathrm{kg} \mathrm{TN} \mathrm{ha}^{-1} \mathrm{yr}^{-1}\right)\end{array}$ & $\begin{array}{c}\text { P Loss } \\
\left(\mathrm{kg} \mathrm{TP} \mathrm{ha}^{-1} \mathrm{yr}^{-1}\right)\end{array}$ & Reference \\
\hline Sheep & Unspecified & 690 & Mixed & Otago & & 0.048 & Caruso (2000) \\
\hline \multicolumn{5}{|c|}{ Summary } & $2.8-8.8$ & $0.3-0.6$ & Elliott and Sorrell (2002) \\
\hline
\end{tabular}




\section{$\underline{3.4 .3 \text { Exotic Forest }}$}

Table 3.6 summarises New Zealand studies of nutrient loss from exotic forest. Nitrogen losses range from 0.04-28 $\mathrm{kg} \mathrm{N} \mathrm{ha}^{-1} \mathrm{yr}^{-1}$ and $\mathrm{P}$ losses from 0.07-0.54 kg P ha-1 $\mathrm{yr}^{-1}$. (Again, it should be noted that most studies report TN losses, but two studies report nitrate only. As above, no attempt to estimate TN from $\mathrm{N}$ species is made). Data limitations and issues are similar to those discussed in Section 3.4.2. Only 5 soil orders are featured and a number of studies report losses from mixed soil order catchments, but do not disaggregate losses according to soil order e.g. Fahey and Jackson (1997), Quinn and Stroud (2002), Cooper and Thomsen (1988).

Rainfall range is limited and ranges from $1295-1677 \mathrm{~mm} \mathrm{yr}^{-1}$. Topography featured is steep for all except McColl et al (1977). This reflects the fact that forested land covers are found predominantly on hilly terrain. But again, this is not exclusively the case. Only 4 regions are featured in the data and 3 of these are in the North Island. In addition, both Bay of Plenty studies feature the same catchment. This data is insufficiently wide for use in development of export coefficient generating algorithms for the full range of locations and variables required.

Figure 3.3 depicts all soil order and topography combinations and indicates which combinations are addressed in the literature summarised in Tables 3.6. This figure graphically highlights the lack of literature based evidence. Nine soil orders are not covered at all representing $31 \%$ of total exotic forest (2012), only exotic forest on steep hill features for most soil orders and rainfall is limited to moderate annual average. It certainly is the case that exotic forest is often found on steeper slopes, although it is also not uncommon to find exotic forest on flatter land in otherwise difficult locations e.g. at high altitudes such as around the Volcanic Plateau. Table 3.7 reports losses in summary literature. Nitrogen losses range from 0.04-28 kg N ha-1 $\mathrm{yr}^{-1}$ and $\mathrm{P}$ losses from 0.01-1.2 $\mathrm{kg} \mathrm{P} \mathrm{ha}^{-1} \mathrm{yr}^{-1}$. Reported $\mathrm{P}$ losses in Table 3.7 are clearly different from those reported in Table 3.6. Table 3.7 lowest losses are from McDowell and Wilcock (2008). They mistakenly report losses from Cooper and Thomsen (1988) as $0.01 \mathrm{~kg} \mathrm{P} \mathrm{ha}^{-1} \mathrm{yr}^{-1}$ rather than $0.1 \mathrm{~kg} \mathrm{P} \mathrm{ha}^{-1} \mathrm{yr}^{-1}$ (actually reported as $9.5 \mathrm{~kg}$ $\mathrm{km}^{2} / \mathrm{yr}$ by Cooper and Thomsen (1988)). Table 3.7 highest losses of $1.2 \mathrm{~kg} \mathrm{P} \mathrm{ha}^{-1} \mathrm{yr}^{-1}$ are reported by Elliott and Sorrell (2002), but it is unclear where this data is from. Davis (2014) provides some insight into losses over the lifetime of a plantation forest, although 
unfortunately this is only for $\mathrm{N}$. Clearly he accesses a wider range of literature than is featured in Table 3.6. An attempt was made to track all of the relevant literature referenced by him. Some is featured in Table 3.6 and some was unable to be found.

Highest $\mathrm{N}$ and $\mathrm{P}$ losses reported here are higher than those featured in Table 2.1 for international literature. Possibly this is because exotic forest in New Zealand tends to be plantation forest on land less suitable for agriculture (i.e. with steeper topography and higher rainfall), it is often situated on previous pastoral land that may have high soil P from fertiliser applications, and it is more frequently disturbed than non-plantation forest. In addition, Davis (2014) indicates N losses from native forest on volcanic soils can be high. This may also be the case for exotic forest and results from Parfitt et al (2002) support this. 
Table 3.6 Reported exotic forest losses of N and P from catchments in New Zealand, grouped according to soil order

\begin{tabular}{|c|c|c|c|c|c|c|c|}
\hline Land Use & Soil Order & $\begin{array}{l}\text { Rainfall } \\
\left(\mathrm{mm} \mathrm{yr}^{-1}\right)\end{array}$ & Topography & Region & $\begin{array}{c}\text { N Loss } \\
\left(\mathrm{kg} \mathrm{TN} \mathrm{ha}^{-1} \mathrm{yr}^{-1}\right)\end{array}$ & $\begin{array}{c}\text { P Loss } \\
\left(\mathrm{kg} \mathrm{TP} \mathrm{ha}^{-1} \mathrm{yr}^{-1}\right)\end{array}$ & References \\
\hline \multirow{11}{*}{$\begin{array}{l}\text { Exotic } \\
\text { Forest }\end{array}$} & \multirow{2}{*}{ Brown } & 1550 & \multirow{2}{*}{ Steep Hill } & Nelson & 0.29 & 0.11 & $\begin{array}{c}\text { Fahey \& Jackson } \\
\text { (1997) }\end{array}$ \\
\hline & & 1600 & & Waikato & 2.07 & 0.58 & $\begin{array}{c}\text { Quinn \& Stroud } \\
\text { (2002) }\end{array}$ \\
\hline & \multirow{3}{*}{ Podzol } & 1550 & \multirow{3}{*}{ Steep Hill } & Nelson & 0.29 & 0.11 & $\begin{array}{c}\text { Fahey \& Jackson } \\
(1997)\end{array}$ \\
\hline & & 1580 & & Bay of Plenty & 1.31 & 0.095 & $\begin{array}{c}\text { Cooper \& } \\
\text { Thomsen (1988) }\end{array}$ \\
\hline & & 1677 & & Bay of Plenty & $<1-28$ (nitrate only) & & Parfitt et al (2002) \\
\hline & \multirow[t]{2}{*}{ Pumice } & 1580 & \multirow{2}{*}{ Steep Hill } & Bay of Plenty & 1.31 & 0.095 & $\begin{array}{c}\text { Cooper \& } \\
\text { Thomsen (1988) }\end{array}$ \\
\hline & & 1677 & & Bay of Plenty & $<1-28$ (nitrate only) & & Parfitt et al (2002) \\
\hline & \multirow[t]{2}{*}{ Raw } & 1580 & \multirow{2}{*}{ Steep Hill } & Bay of Plenty & 1.31 & 0.095 & $\begin{array}{c}\text { Cooper \& } \\
\text { Thomsen (1988) }\end{array}$ \\
\hline & & 1677 & & Bay of Plenty & $<1-28$ (nitrate only) & & Parfitt et al (2002) \\
\hline & \multirow[t]{2}{*}{ Ultic } & 1295 & Easy Hill & Wellington & 0.04 (nitrate only) & 0.07 & McColl (1977) \\
\hline & & 1600 & Steep Hill & Waikato & 2.07 & 0.58 & $\begin{array}{c}\text { Quinn \& Stroud } \\
(2002)\end{array}$ \\
\hline
\end{tabular}




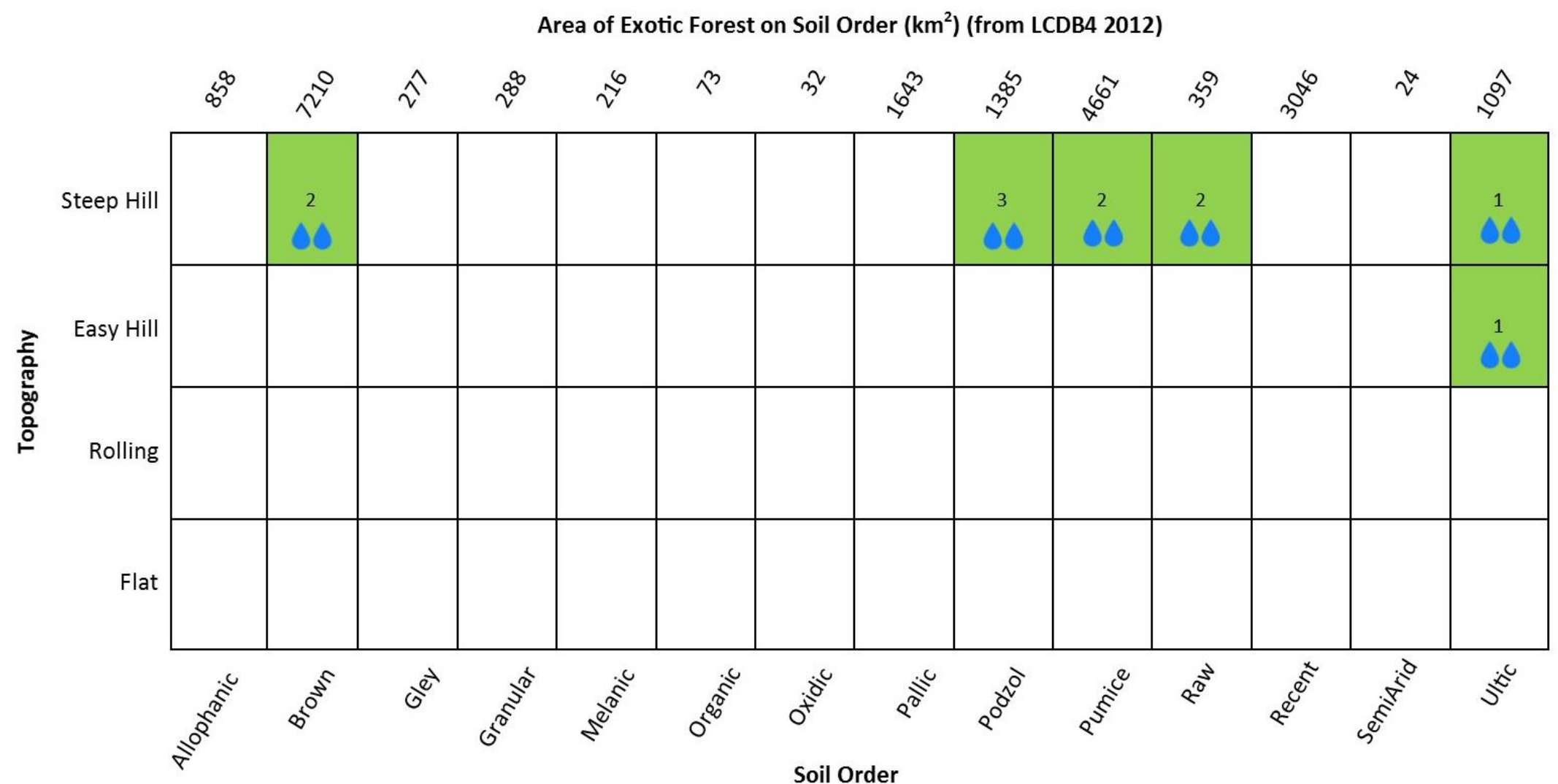

2 Indicates number of studies

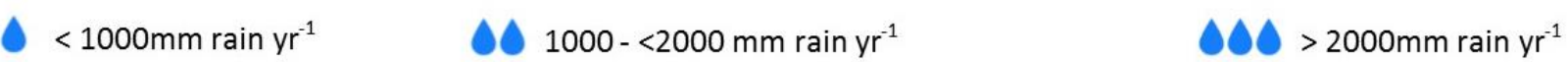

Figure 3.3 Graphical illustration of soil order and topography combinations and indicating combinations for which literature evidence of exotic forest $\mathrm{N}$ and $\mathrm{P}$ losses exists (green squares). Within green squares the number of studies and annual average rainfall is given. 
Table 3.7 Export coefficients reported for exotic forest in New Zealand from summary literature

\begin{tabular}{|c|c|c|c|}
\hline N Loss (kg TN ha-1 $\mathrm{yr}^{-1}$ ) & P Loss (kg TP ha ${ }^{-1} \mathrm{yr}^{-1}$ ) & Land Use and Management & Reference \\
\hline $0.4-5$ (nitrate) & $0.07-0.8$ & & Cooke (1979) \\
\hline & $0.07-0.2$ & Undisturbed plantation forest & $\begin{array}{c}\text { Wilcock (1986) } \\
\text { Davies-Colley and Wilcock (2004) }\end{array}$ \\
\hline 0.15 & & Undisturbed plantation forest & Davies-Colley and Wilcock (2004) \\
\hline $0.4-8$ & $0.06-0.8$ & Disturbed plantation forest & $\begin{array}{c}\text { Wilcock (1986) } \\
\text { Davies-Colley and Wilcock (2004) }\end{array}$ \\
\hline $0.04-1$ & $0.01-0.1$ & Exotic Forest & McDowell and Wilcock (2008) \\
\hline $0.6-8.5$ & $0.07-1.2$ & Exotic forest & Elliott and Sorrell (2002) \\
\hline 11.1 & & Planted on pasture $-\mathrm{Yr} 1$ & Davis (2014) \\
\hline 5.7 & & Planted on pasture $-\mathrm{Yr} 2$ & Davis (2014) \\
\hline $1-2$ & & Planted on pasture-Yr 3-5 & Davis (2014) \\
\hline$<1$ & & Planted on pasture-Yr 6-14 & Davis (2014) \\
\hline$<1-28$ & & Planted on pasture & Davis (2014) \\
\hline 3.9 & & Within 1 yr of harvest & Davis (2014) \\
\hline 4.5 & & The year after harvest & Davis (2014) \\
\hline
\end{tabular}




\section{$\underline{3.4 .4 \text { Indigenous Forest }}$}

Nutrient loss studies for indigenous land covers also are not sufficiently broad to support development of export coefficient generating algorithms. Table 3.8 reports $\mathrm{N}$ losses of 0.01 $7.1 \mathrm{~kg} \mathrm{~N} \mathrm{ha}^{-1} \mathrm{yr}^{-1}$ and $\mathrm{P}$ losses of 0.1-0.6 kg P ha-1 $\mathrm{yr}^{-1}$. (Again, note lowest losses for $\mathrm{N}$ are reported as nitrate-N only). Only 5 soil orders feature and a number of studies report losses from mixed soil order catchments, but do not disaggregate losses according to soil order e.g. Fahey and Jackson (1997), Quinn and Stroud (2002), Cooper and Thomsen (1988). Rainfall range is $1200-3000 \mathrm{~mm} \mathrm{yr}^{-1}$, but pumice and raw soil orders only feature one rainfall value each. Topography is limited to steep hill for all data, except McColl et al (1977) and only 6 regions are featured. While indigenous forest in New Zealand is found in steeper, higher elevation areas, and is more likely to receive higher rainfall, not all indigenous forest is characterised by these features. For example, Allen et al. (2013) note indigenous forest is found in wetter lowland areas, higher montane areas, may be virgin forest or regenerating, and is found from the sub-tropical north of the North Island to the colder southern South Island.

Figure 3.4 depicts all soil order and topography combinations and indicates which combinations are addressed in the literature summarised in Table 3.8. This graphically highlights the lack of literature based evidence. Nine soil orders are not covered at all representing $16 \%$ of total indigenous forest (2012) and only indigenous forest on steep hill features for most soil orders, although rainfall is a little more varied than for exotic forest. Table 3.9 features nutrient losses reported in summary literature of $0.01-12 \mathrm{~kg} \mathrm{~N} \mathrm{ha}^{-1} \mathrm{yr}^{-1}$ and 0.01-0.8 $\mathrm{kg} \mathrm{P} \mathrm{ha}^{-1} \mathrm{yr}^{-1}$. Compared to Table 3.8, Davis (2014) reports higher $\mathrm{N}$ losses from volcanic and very high rainfall areas and Elliott and Sorrell (2002) report higher and lower P losses, but it is unclear where these are from. P losses reported in Tables 3.8 and 3.9 are comparable to loses in Table 2.1 from international literature. $\mathrm{N}$ losses reported in Tables 3.8 and 3.9 are considerably higher than those reported in Table 2.1. This may be due to geo-climatic influence such as volcanic soils and high rainfall as discussed above. 
Table 3.8 Reported indigenous forest losses of $\mathrm{N}$ and P from catchments in New Zealand, grouped according to soil order

\begin{tabular}{|c|c|c|c|c|c|c|c|}
\hline Land Use & Soil Order & $\begin{array}{c}\text { Rainfall } \\
\left(\mathrm{mm} \mathrm{yr}^{-1}\right)\end{array}$ & Topography & Region & $\begin{array}{c}\text { N Loss } \\
\left(\mathrm{kg} \mathrm{TN} \mathrm{ha}^{-1} \mathrm{yr}^{-1}\right)\end{array}$ & $\begin{array}{c}\text { P Loss } \\
\left(\mathrm{kg} \mathrm{TP} \mathrm{ha}^{-1} \mathrm{yr}^{-1}\right)\end{array}$ & References \\
\hline \multirow{15}{*}{$\begin{array}{c}\text { Indigenous } \\
\text { Forest }\end{array}$} & \multirow{6}{*}{ Brown } & 1200 & \multirow{6}{*}{ Steep Hill } & Manawatu & 1.96 & 0.243 & Bargh (1977) \\
\hline & & 1550 & & Nelson & 0.29 & 0.11 & $\begin{array}{c}\text { Fahey \& Jackson } \\
\text { (1997) }\end{array}$ \\
\hline & & 1600 & & Waikato & 2.07 & 0.58 & $\begin{array}{c}\text { Quinn \& Stroud } \\
(2002)\end{array}$ \\
\hline & & 1663 & & Waikato & 0.8 & 0.24 & $\begin{array}{l}\text { Hughes \& Quinn } \\
\text { (2014) }\end{array}$ \\
\hline & & 2610 & & Westland & $1.55-2.24$ & $0.33-0.52$ & Neary (1978) \\
\hline & & 3000 & & Westland & 7.1 & 0.6 & $\begin{array}{c}\text { Davies-Colley \& } \\
\text { Nagels (2002) }\end{array}$ \\
\hline & \multirow{4}{*}{ Podzol } & 1550 & \multirow{4}{*}{ Steep Hill } & Nelson & 0.59 & 0.21 & Neary (1978) \\
\hline & & 1550 & & Nelson & 0.29 & 0.11 & $\begin{array}{c}\text { Fahey \& Jackson } \\
\text { (1997) }\end{array}$ \\
\hline & & 1580 & & Bay of Plenty & 3.67 & 0.1 & $\begin{array}{c}\text { Cooper \& } \\
\text { Thomsen (1988) }\end{array}$ \\
\hline & & 3000 & & Westland & 7.1 & 0.6 & $\begin{array}{c}\text { Davies-Colley \& } \\
\text { Nagels (2002) }\end{array}$ \\
\hline & Pumice & 1580 & Steep Hill & Bay of Plenty & 3.67 & 0.1 & $\begin{array}{c}\text { Cooper \& } \\
\text { Thomsen (1988) }\end{array}$ \\
\hline & Raw & 1580 & Steep Hill & Bay of Plenty & 3.67 & 0.1 & $\begin{array}{c}\text { Cooper \& } \\
\text { Thomsen (1988) }\end{array}$ \\
\hline & \multirow{3}{*}{ Ultic } & 1295 & Easy Hill & Wellington & 0.01 (nitrate) & 0.2 & $\begin{array}{l}\text { McColl et al } \\
\text { (1977) }\end{array}$ \\
\hline & & 1600 & \multirow{2}{*}{ Steep Hill } & Waikato & 2.07 & 0.58 & $\begin{array}{c}\text { Quinn \& Stroud } \\
(2002)\end{array}$ \\
\hline & & 1663 & & Waikato & 0.8 & 0.24 & $\begin{array}{l}\text { Hughes \& Quinn } \\
\text { (2014) }\end{array}$ \\
\hline
\end{tabular}




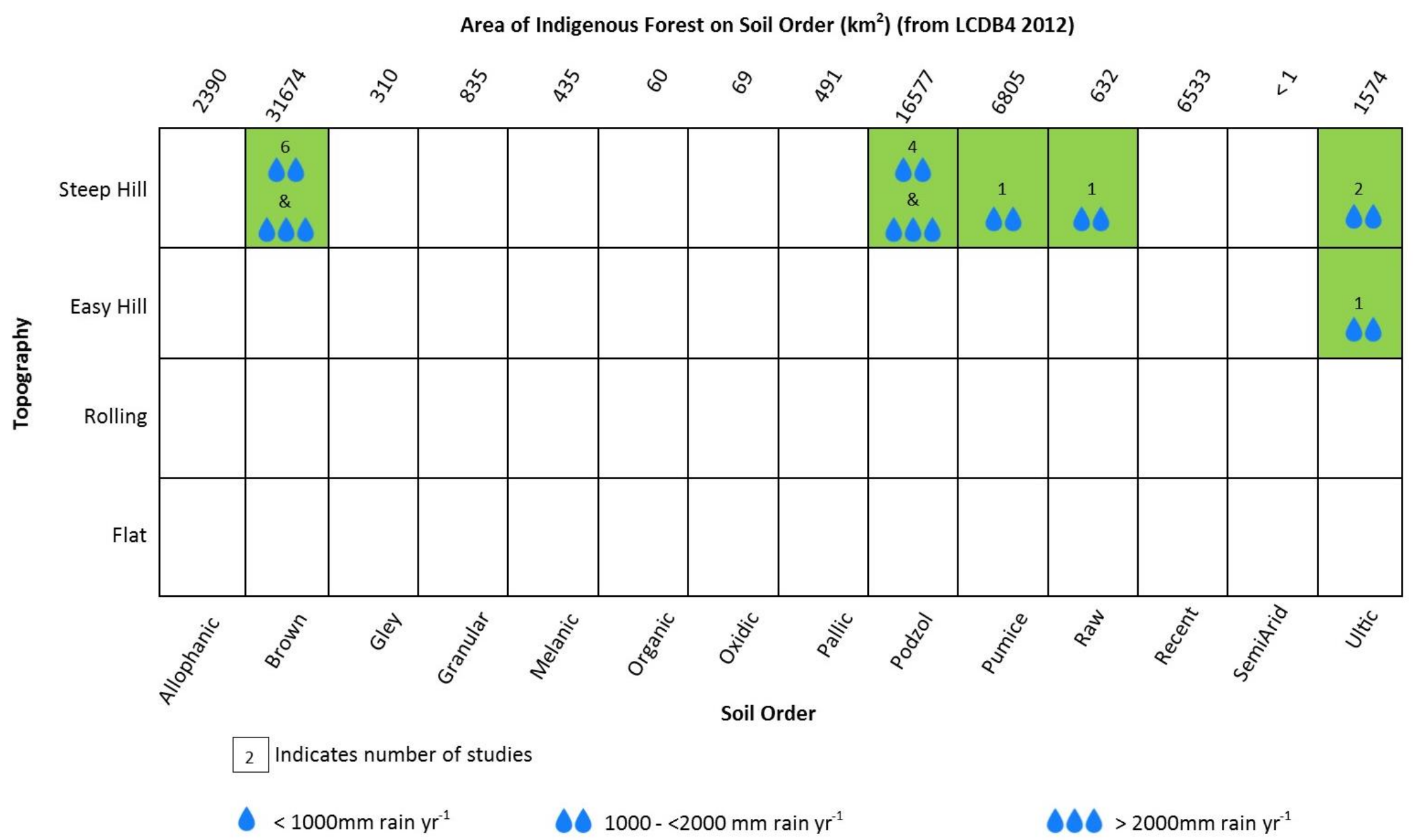

Figure 3.4 Graphical illustration of soil order and topography combinations and indicating combinations for which literature evidence of indigenous forest $\mathrm{N}$ and $\mathrm{P}$ losses exists (green squares). Within green squares the number of studies and annual average rainfall is given. 
Table 3.9 Export coefficients reported for indigenous forest in New Zealand from summary literature

\begin{tabular}{|c|c|c|c|}
\hline Reference $\mathbf{N}\left(\mathrm{kg} \mathrm{ha}^{-1} \mathrm{yr}^{-1}\right)$ & Reference $\mathrm{P}\left(\mathrm{kg} \mathrm{ha}^{-1} \mathrm{yr}^{-1}\right)$ & Land Use and Management & Reference \\
\hline $1.8-6.2$ & $0.04-0.68$ & & Cooke (1979) \\
\hline $2-6$ & $0.04-0.68$ & & Wilcock (1986) \\
\hline $0.6-5.8$ & $0.12-0.8$ & & Elliott and Sorrell (2002) \\
\hline $2-7$ & $0.04-0.68$ & & Davies-Colley and Wilcock (2004) \\
\hline $0.01-4$ & $0.01-0.6$ & & McDowell and Wilcock (2008) \\
\hline $0.25-5$ & & All NZ & Davis (2014) \\
\hline $0.25-2.5$ & & 'Normal' All NZ & Davis (2014) \\
\hline Up to 5 & & In volcanic areas & Davis (2014) \\
\hline Up to 12 & & West Coast & Davis (2014) \\
\hline $1.2-2.7$ & & Harvested indigenous & Davis (2014) \\
\hline
\end{tabular}




\subsubsection{Crops}

Data reporting measured annual nutrient losses from New Zealand crops is sparse and as discussed earlier in the introduction to this section, literature reported crop losses tend to focus on point scale leaching losses. Table 3.10 reports both short-rotation crop studies and estimated losses found in the New Zealand literature. $\mathrm{N}$ losses range from $0.2-226 \mathrm{~kg} \mathrm{~N} \mathrm{ha-}$ ${ }^{1} \mathrm{yr}^{-1}$ and $\mathrm{P}$ losses from 0-2 kg P ha-1 $\mathrm{yr}^{-1}$. A lack of breadth in terms of soil, rainfall, topography and management variables is evident. The data feature only 3 soil orders, 4 regions, and a limited range of crops. In addition, $\mathrm{N}$ measurements include only nitrate or nitrate plus ammonium and only leached $\mathrm{N}$ losses. Norris et al. (2017) is the one study that reports measured P losses, although these are leached losses only. Rutherford et al. (1987) estimate $\mathrm{P}$ losses of up to $2 \mathrm{~kg} \mathrm{P} \mathrm{ha}^{-1} \mathrm{yr}^{-1}$, but it is unclear where this is from. Clearly this data is insufficient for algorithm development. Modelled losses are found in literature, but not included here. For example, Gentile et al (2014) report SPASMO modelled crop losses near Gisborne of 13.7, 17.7 and $19.7 \mathrm{~kg}$ nitrate-N ha $\mathrm{yr}^{-1}$ and 2.4, 2.9 and $5.1 \mathrm{~kg} \mathrm{P}^{-1} \mathrm{yr}^{-1}$ for maize, squash and broccoli/lettuce respectively.

Difficulties deriving annual exports associated with specific short-rotation crops exist. Planting to harvest may only take 3-6 months, after which a different crop may be planted or the field may be left fallow. Therefore, questions arise around how and if specific crop nutrient loss data should be extrapolated to annual exports and, if and how, management following crop harvest should be included.

Compared with international literature losses reported in Table 2.1 of $0.04-91.4 \mathrm{~kg} \mathrm{~N} \mathrm{ha}^{-1} \mathrm{yr}^{-1}$ and 0-18.6 kg P ha-1 $\mathrm{yr}^{-1}$, New Zealand losses are high for $\mathrm{N}$, but low for $\mathrm{P}$. Higher $\mathrm{N}$ losses could reflect geo-climatic or management variables. Alternatively, it may reflect the effect of scale. Only point scale leached $\mathrm{N}$ losses are reported and it is likely little attenuation is included. Particulate losses are not included, but as highlighted in Section 2.2.1, leached losses likely make up the majority of $\mathrm{N}$ losses anyway. Conversely lower $\mathrm{P}$ losses reported here likely reflect the fact that only one study reports actual losses and it only includes leached P. As discussed in Section 2.2.2 surface loss of particulate $P$ is often significant. Data quantifying $\mathrm{N}$ and $\mathrm{P}$ losses from perennial crops in New Zealand is even sparser. Table 3.11 reports estimates of $\mathrm{N}$ losses of $5-50 \mathrm{~kg} \mathrm{~N} \mathrm{ha}^{-1} \mathrm{yr}^{-1}$ and $0.25 \mathrm{~kg} \mathrm{P} \mathrm{ha}^{-1} \mathrm{yr}^{-1}$. Clothier et al.'s 
(2017) estimates for grapevines provide the only estimate that is validated with measurements. A current study of kiwifruit may yield useful results but is not yet complete (Green et al. 2017). Again, using modelled losses may be an option. Gentile et al. (2014) report SPASMO modelled crop losses near Gisborne 5.3, 18.4 and $10.1 \mathrm{~kg}$ nitrate-N ha-1 $\mathrm{yr}^{-1}$ and $0.4,0.3$ and $0.2 \mathrm{~kg} \mathrm{P} \mathrm{ha}^{-1} \mathrm{yr}^{-1}$ for grapes, citrus and kiwifruit respectively.

Losses reported in international literature from Table 2.1 are 4.7-5.49 $\mathrm{kg} \mathrm{N} \mathrm{ha}^{-1} \mathrm{yr}^{-1}$ and 0.02-

$0.3 \mathrm{~kg} \mathrm{P} \mathrm{ha}^{-1} \mathrm{yr}^{-1}$ for orchards. P results reported here for New Zealand are similar, but $\mathrm{N}$ results are slightly higher. Whether this is a result of geo-climatic or management variables is difficult to assess. 
Table 3.10 Reported short-rotation crop losses of $\mathrm{N}$ and $\mathrm{P}$ in New Zealand

\begin{tabular}{|c|c|c|c|c|c|c|c|}
\hline Soil Order & $\begin{array}{l}\text { Rainfall } \\
\left(\mathrm{mm} \mathrm{yr} \mathrm{r}^{-1}\right)\end{array}$ & Topography & Region & Land Use & $\begin{array}{c}\text { N Loss } \\
\left(\mathrm{kg} \mathrm{TN} \mathrm{ha}^{-1} \mathrm{yr}^{-1}\right)\end{array}$ & $\begin{array}{c}\text { P Loss } \\
\left(\mathrm{kg} \mathrm{TP} \mathrm{ha}^{-1} \mathrm{yr}^{-1}\right)\end{array}$ & References \\
\hline \multirow{5}{*}{ Pallic } & \multirow{4}{*}{660} & \multirow{5}{*}{ Flat } & \multirow{5}{*}{ Canterbury } & Clover & $\begin{array}{c}10 \\
\text { (nitrate only) }\end{array}$ & & $\begin{array}{l}\text { Adams and Pattinson } \\
\text { (1985) }\end{array}$ \\
\hline & & & & Peas & $\begin{array}{c}90 \\
\text { (nitrate only) }\end{array}$ & & $\begin{array}{c}\text { Adams and Pattinson } \\
\text { (1985) }\end{array}$ \\
\hline & & & & Wheat & $\begin{array}{c}60 \\
\text { (nitrate only) }\end{array}$ & & $\begin{array}{c}\text { Adams and Pattinson } \\
\text { (1985) }\end{array}$ \\
\hline & & & & Wheat \& Clover & $\begin{array}{c}35 \\
\text { (nitrate only) }\end{array}$ & & $\begin{array}{l}\text { Adams and Pattinson } \\
\text { (1985) }\end{array}$ \\
\hline & $600-665$ & & & $\begin{array}{l}\text { Pasture, wheat, } \\
\text { barley rotation }\end{array}$ & $\begin{array}{c}14-140 \\
\text { (nitrate only) }\end{array}$ & & Webb et al. (2001) \\
\hline Variable & Variable & & $\begin{array}{c}\text { Canterbury } \\
\text { Manawatu } \\
\text { Hawkes Bay } \\
\text { Waikato }\end{array}$ & Variable & $\begin{array}{l}0.2-226 \text { (nitrate }+ \\
\text { ammonium only) }\end{array}$ & $0-0.56$ & Norris et al. (2017) \\
\hline \multicolumn{5}{|c|}{ Estimate } & $\begin{array}{c}60 \\
\text { (nitrate only) }\end{array}$ & & Parfitt et al. (2012) \\
\hline \multicolumn{5}{|c|}{ Estimate } & & Up to 2 & $\begin{array}{l}\text { Rutherford et al. } \\
\text { (1987) }\end{array}$ \\
\hline
\end{tabular}

Table 3.11 Reported perennial crop losses of $\mathrm{N}$ and $\mathrm{P}$ in New Zealand

\begin{tabular}{|c|c|c|c|c|c|c|c|}
\hline Soil Order & $\begin{array}{l}\text { Rainfall } \\
\left(\mathrm{mm} \mathrm{yr}^{-1}\right)\end{array}$ & Topography & Region & Land Use & $\begin{array}{c}\text { N Loss } \\
\left(\mathrm{kg} \mathrm{TN} \mathrm{ha}^{-1} \mathrm{yr}^{-1}\right)\end{array}$ & $\begin{array}{c}\text { P Loss } \\
\left(\mathrm{kg} \mathrm{TP} \mathrm{ha}^{-1} \mathrm{yr}^{-1}\right)\end{array}$ & References \\
\hline \multicolumn{4}{|c|}{ Estimate based on SPASMO and validated from fluxmeters } & Grapes & 8 (nitrate only) & 0.25 & $\begin{array}{c}\text { Clothier and Green } \\
(2017)\end{array}$ \\
\hline \multicolumn{4}{|c|}{ Estimate } & Grapes & 5 (nitrate only) & & Parfitt et al. (2012) \\
\hline
\end{tabular}




\subsubsection{Urban}

Davies-Colley and Wilcock (2004) provide New Zealand urban export coefficients, referenced to Williamson (1993), of 2.5-11 $\mathrm{kg} \mathrm{N} \mathrm{ha}^{-1} \mathrm{yr}^{-1}$ and 0.4-1.6 $\mathrm{kg} \mathrm{P} \mathrm{ha}^{-1} \mathrm{yr}^{-1}$ (Table 3.12). These are derived from storm water runoff in urban areas in the northern North Island. As such, these nutrient losses are limited to estimates of road runoff in a restricted climate area and the role of other nutrient loss pathways in cities is neglected e.g. leaching from gardens and parks, effects of sewage effluent etc. No other urban, New Zealand specific data was found. City and regional councils may hold more data.

Compared to international data for urban areas reported in Table 2.1 of $1.48-63 \mathrm{~kg} \mathrm{~N} \mathrm{ha}^{-1} \mathrm{yr}^{-1}$ and $0.065-20 \mathrm{~kg} \mathrm{P} \mathrm{ha}^{-1} \mathrm{yr}^{-1}$, the results in Table 3.12 are low. This could reflect a number of possible differences in New Zealand urban landscapes compared to elsewhere e.g. lower urban density, less fertiliser use in gardens and parks, and the presence of sewer treatment plants. However, it may also reflect the limited nature of Williamson's (1993) measurements, which clearly is not sufficient to support export coefficient algorithm development.

\section{$\underline{3.4 .7 \text { Scrub }}$}

Export coefficients for scrub (Table 3.13) are documented in Cooke (1979) and Rutherford et al. (1987) (who reference Cooke (1979)). Reported $\mathrm{N}$ loss is $6 \mathrm{~kg} \mathrm{~N} \mathrm{ha}^{-1} \mathrm{yr}^{-1}$ and $\mathrm{P}$ loss is $0.12-$ $1.2 \mathrm{~kg} \mathrm{P} \mathrm{ha}^{-1} \mathrm{yr}^{-1}$. Cooke's (1979) estimates are clearly based on data from the 13 catchments referenced in his study, although which ones is not specified. $\mathrm{N}$ losses here are comparable to those reported in Table 2.1 of $0.5-6 \mathrm{~kg} \mathrm{~N} \mathrm{ha}^{-1} \mathrm{yr}^{-1}$ for scrub. P losses are slightly higher than those reported in Table 2.1 of 0.02-0.7 kg P ha-1 $\mathrm{yr}^{-1}$ for scrub. Again, Cooke's (1979) data is insufficient for algorithm development.

Table 3.14 summarises the literature based $\mathrm{N}$ and $\mathrm{P}$ losses reported in Tables 3.1-3.13. Clearly for many land cover types there is a wide range of reported losses, while for others there is little range due to little data. In addition, some skewness within the data is highlighted in the differences between mean and median losses. This is particularly seen with $\mathrm{N}$ losses from high producing grassland, which is likely skewed by the inclusion of relatively intensive dairy studies. 
Table 3.12 Reported N and P losses for urban land cover in New Zealand

\begin{tabular}{|c|c|c|c|c|c|c|c|}
\hline Soil Order & $\begin{array}{c}\text { Rainfall } \\
\left(\mathrm{mm} \mathrm{yr}^{-1}\right)\end{array}$ & Topography & Region & Land Use & $\begin{array}{c}\text { N Loss } \\
\left(\mathrm{kg} \mathrm{TN} \mathrm{ha}^{-1} \mathrm{yr}^{-1}\right)\end{array}$ & $\begin{array}{c}\text { P Loss } \\
\left(\mathrm{kg} \mathrm{TP} \mathrm{ha}^{-1} \mathrm{yr}^{-1}\right)\end{array}$ & References \\
\hline & & & $\begin{array}{c}\text { Northern } \\
\text { New Zealand }\end{array}$ & $\begin{array}{c}\text { Urban } \\
\text { stormwater }\end{array}$ & $2.5-11$ & $0.4-1.6$ & Williamson (1993) \\
\hline
\end{tabular}

Table 3.13 Reported N and P losses for scrub in New Zealand

\begin{tabular}{|c|c|c|c|c|c|c|c|}
\hline Soil Order & $\begin{array}{c}\text { Rainfall } \\
(\mathbf{m m ~ y r})\end{array}$ & Topography & Region & Land Use & $\begin{array}{c}\text { N Loss } \\
\left(\mathbf{k g ~ T N ~ h a}^{-1} \mathbf{~ y r}^{-1}\right)\end{array}$ & $\begin{array}{c}\text { P Loss } \\
\left(\mathbf{k g ~ T P ~ h a ~}^{-1} \mathbf{y r}^{-1}\right)\end{array}$ & \begin{tabular}{c} 
References \\
\hline
\end{tabular} \\
\hline
\end{tabular}

Table 3.14 Summary data of New Zealand literature reported $\mathrm{N}$ and $\mathrm{P}$ losses for the 8 land covers investigated.

\begin{tabular}{|c|c|c|c|c|c|c|}
\hline \multirow[t]{2}{*}{ Landcover } & \multicolumn{3}{|c|}{ Nitrogen Loss (kg TN ha $\left.{ }^{-1} \mathrm{yr}^{-1}\right)$} & \multicolumn{3}{|c|}{ Phosphorus Loss (kg TP ha-1 $\mathrm{yr}^{-1}$ ) } \\
\hline & Mean & Median & Range & Mean & Median & Range \\
\hline High Producing Grassland & 19 & 10 & $0.42-56$ & 1.2 & 1.3 & $0.18-10.5$ \\
\hline Low Producing Grassland & 5.8 & 5.8 & $2.8-8.8$ & 0.3 & 0.3 & $0.05-0.6$ \\
\hline Exotic Forest & 1.4 & 1.31 & $0.04-28$ & 0.8 & 0.11 & $0.01-1.2$ \\
\hline Indigenous Forest & 2.8 & 2.07 & $0.01-12$ & 0.4 & 0.24 & $0.01-0.8$ \\
\hline Short-rotation Crops & 71.9 & 60 & $0.2-226$ & 0.85 & 0.56 & $0-2$ \\
\hline Perennial Crops & 6.5 & 6.5 & $5-8$ & 0.25 & 0.25 & 0.25 \\
\hline Urban & 6.8 & 6.8 & $2.5-11$ & 1 & 1 & $0.4-1.6$ \\
\hline Scrub & 6 & 6 & 6 & 0.12 & 0.12 & 0.12 \\
\hline
\end{tabular}




\subsubsection{Further Data Options}

Tables 3.1-3.13 indicate reported annual specific-area $\mathrm{N}$ and $\mathrm{P}$ losses from single New Zealand land covers is not sufficient to support development of export coefficient generating algorithms that consider all combinations of climate, soil, topography and land management variables. Further data could be obtained by applying a statistical approach to export coefficient derivation to water quality data from multi-land cover catchments as described in Section 2.4.3. This approach does have limitations, but it would expand the pool of potential data sources.

Diack (2015) measured river nutrient concentrations over 2 years for 71 mixed land cover catchments in the Southern Alps, New Zealand. Land covers featured include indigenous forest, grazed and ungrazed tussock grasslands, sub-alpine shrubland, alpine herbfield, gravel and rock, and snow and ice. She provides $\mathrm{NO}_{3}{ }^{-}, \mathrm{NH}_{4}{ }^{+}$and $\mathrm{PO}_{4}{ }^{3-}$ specific yields based on her in-stream measurements and estimates of stream discharge and catchment area from NIWA data. Even without disaggregating catchments according to land cover though, this data gives an excellent overview of $\mathrm{N}$ and $\mathrm{P}$ losses from largely pristine environments in the South Island. Reported specific yields range from 0-4.95 kg ha-1 $\mathrm{yr}^{-1}$ for $\mathrm{NO}_{3}^{-}, 0-0.59 \mathrm{~kg}$ ha-1 $\mathrm{yr}^{-1}$ for $\mathrm{NH}_{4}$ and 0-0.17 kg ha-1 $\mathrm{yr}^{-1}$ for $\mathrm{PO}_{4}^{3-}$. Clear differences in export are also noted between the west and east coasts, which is largely attributed to differences in runoff.

Taking a similar approach to Diack (2015), N and P concentrations from the NZRWQN could be used in combination with NIWA or LUCl derived river flows to estimate total N and P load for each sampling site. Export coefficients for land units of similar climate, soil, topography, land cover and management could then be statistically derived.

More recently McDowell et al (2017) developed estimates of specific yield for New Zealand based on instream water quality measurements and broad catchment characteristics from the River Environment Classification (REC). Catchment characteristics considered include stream order (Horton-Strahler classification), climate, topography, geology and land cover. This data no doubt gives some good insight into how nutrient losses are influenced by broad climate, topography, geology, land cover combinations, and also considers scale by including stream order. However, catchment characteristics are determined by the dominant climate, topography, geology, and land cover so are fairly broad brush. 
Where New Zealand specific data is lacking, reference to overseas export coefficients could be an option. For example it is possible that some Australian data may be relevant because both countries tend to use more extensive agricultural practices compared to the rest of the developed world. However, most of Australia's climate and soils are quite different to New Zealand's. Broad and Corkrey (2011) compiled Tasmanian export coefficients for 11 land cover or use categories, some of which appear similar to common New Zealand agricultural land covers or uses. In Australia, Tasmania, and areas in the south-east mainland, are likely most climatically similar to New Zealand with a temperate maritime climate (Kottek et al. 2006). No reference is made to soil, topographic or land management variables though. In addition, native plant areas are likely different to New Zealand's. Certainly comparison between reported international export coefficients in Table 2.1 and those documented for New Zealand in Tables 3.1-3.13, indicate overseas data may not be appropriate for use in New Zealand.

The data and methods described above are not investigated further here. However, using such data or methods to derive nutrient losses from a wider variety of land cover, climate, soil, topography and management combinations, is a future option.

\subsubsection{Summary}

Tables 3.1-3.4 and Tables 3.6-3.7 illustrate that nutrient loss data is most available for intensive pasture and forested land covers. However, Figures 3.2-3.4 indicate that even this is constrained to a few common geo-climatic areas and management types and certainly does not cover the required full range of climate, soil and topography.

Data for crops (Tables 3.10-3.11) is sparse, particularly for perennial crops, it includes 'estimates' and generally relates to point scale leached losses from few crop types only. Difficulties also arise with determining annual losses from specific short-rotation crops because crops are short-lived and multiple crop types can be grown in a single location over a year. Reported urban losses are restricted to storm water runoff and do not include the variety of urban nutrient sources and pathways that exist. Little data is available for extensive pasture and scrub. Other data options exist, but are not pursued here. For example, statistical derivation of nutrient losses based on in-stream measured losses from multi-land use catchments or use of overseas export coefficients. 
Overall, this review indicates there is insufficient measured annual specific-area nutrient loss data reported in New Zealand literature from which to develop and parameterise export coefficient generating $\mathrm{N}$ and $\mathrm{P}$ algorithms that consider all combinations of climate, soil, topography, land cover and land management. Instead, an alternative data source is used here. Access to a large (> 20000 samples) privately owned, OVERSEER database has been granted to LUCI developers. The database includes actual farm data from throughout New Zealand and features a wide variety of climate, soil, topographic, land cover and management combinations. This database, and the associated OVERSEER model, is explored in the following chapter (Chapter 4) and algorithms are developed and parameterised in Chapter 5. 


\section{THE RAVENSDOWN DATASET: EXPLORATION OF THE DATA AND UNDERLYING OVERSEER MODEL}

\subsection{INTRODUCTION}

Insufficient New Zealand based data, from literature and other public data sources, is available for development of an algorithmic export coefficient approach which considers all combinations of climate, soil, topography, land cover, and land management. However, an extensive, private dataset of OVERSEER input and output from more than 20000 sites (blocks) around New Zealand has been made available to LUCl developers and is used in this work for algorithm development.

As discussed in Section 2.4.3, OVERSEER has been used in the past to develop export coefficients and it is worth reiterating how the approach suggested here is novel by comparison. In past studies a 'model' farm approach has been used, whereby OVERSEER is applied to a limited range of typical farms with typical or dominant geo-climatic factors. Resulting $\mathrm{N}$ and $\mathrm{P}$ output is used as export coefficients for agricultural land in catchment scale water quality models (Wilcock et al. 2006; Monaghan et al. 2007b; Elliott et al. 2008; Monaghan et al. 2009; Rutherford et al. 2009; Wilcock et al. 2009; Rutherford et al. 2011; Rutherford 2012; Wilcock et al. 2013). In this study, OVERSEER data are explored and 'mined' to derive algorithms that quantify $\mathrm{N}$ and $\mathrm{P}$ losses based on variations in and combinations of climate, soil, topography, and land management. Spatial data are used to identify land units of combined variables to which the algorithms are applied, thereby explicitly positioning export coefficients. These can then be used in catchment scale water quality models, but are applied in LUCI water quality models in this study.

\subsubsection{Dataset Overview}

The dataset was provided by farmer co-operative, Ravensdown. It consists of inputs to and outputs from the OVERSEER model (Version 6.2.2) to 20833 blocks on 5954 New Zealand farms. The data summarises predictive and actual OVERSEER nutrient budgets created 
between 2011 and 2016 by Ravensdown farm consultants for Ravensdown clients and represents real farm systems.

The area, region and land use of all dataset blocks are summarised in Table 4.1. The data land area are fairly evenly divided between the North and South Islands with $44.7 \%$ and $53.3 \%$ respectively. Region is unspecified for $1.8 \%$ of the data. 14971 of the blocks are pastoral (dairy, sheep, beef and/or deer (SBD), or mixed pasture) and make up $95.1 \%$ of the total dataset land area. The remaining 5862 blocks are crops and fodder crops (crops eaten by grazing animals) and make up $2.6 \%$ and $2.3 \%$ respectively of the total dataset land area. Crop blocks are not considered further here, but could be used to derive algorithms for crop land covers in the future.

This study seeks to develop algorithms to calculate export coefficients for high producing pastoral land cover, which makes up $95.7 \%$ of total agricultural land and $33 \%$ of the total land area in New Zealand (New Zealand Land Cover Database 2012). As such, this work represents an improved method of export coefficient derivation applicable to a significant proportion of New Zealand.

Ravensdown pastoral data are $49.9 \%$ dairy and $41.8 \%$ SBD by area (Table 4.1 ) and represents approximately $35.7 \%$ of total dairy land and $8.5 \%$ of total other pastoral land in New Zealand (Statistics NZ 2012). Ravensdown supplies fertiliser as well as advice and guidance on fertiliser application to farmers. Therefore the Ravensdown pastoral data are likely to represent more intensive farm practices. However, as shown in Section 3.4.2, this is also a problem with literature based data. At this stage Ravensdown's pastoral data offers the biggest range of climate, soil, topography and land management variables and variable combinations for initial algorithm development and is therefore used here.

For each pastoral block more than 100 quantitative and qualitative variables are defined in the dataset, including farm location, soil type, climate information, nutrient inputs and model outputs. Some variables are user inputs to OVERSEER, some are intermediary OVERSEER calculations and some define final OVERSEER output. Variables associated with nutrients other than $\mathrm{N}$ and $\mathrm{P}$ are included in the dataset, but not considered here. Only OVERSEER derived $\mathrm{N}$ and $\mathrm{P}$ losses to water and input variables influencing these losses are of interest here. 
Table 4.1 Regional locations, area and land uses included in the Ravensdown dataset

\begin{tabular}{|c|c|c|c|c|c|c|c|}
\hline \multirow[b]{2}{*}{ Region } & \multirow[b]{2}{*}{$\begin{array}{c}\text { Area in } \\
\text { Dataset (ha) }\end{array}$} & \multirow[b]{2}{*}{ Area in Dataset (\%) } & \multicolumn{5}{|c|}{ Total Regional Area in Dataset in Particular Land Use (\%) } \\
\hline & & & Dairy Only & $\begin{array}{c}\text { SBD } \\
\text { (Sheep, Beef, } \\
\text { Deer) }\end{array}$ & Mixed Pastoral & Fodder & Cropping \\
\hline Northland & 55480 & 3.6 & 87.9 & 5 & 2.8 & 4.2 & 0.1 \\
\hline Auckland & 22303 & 1.5 & 68.3 & 21.5 & 6.7 & 3.0 & 0.5 \\
\hline $\begin{array}{l}\text { Waikato } \\
\text { Coromandel }\end{array}$ & 66373 & 4.3 & 77.3 & 9.7 & 7.5 & 3.6 & 1.9 \\
\hline Bay of Plenty & 11604 & 0.8 & 84.5 & 5.6 & 7.7 & 1.7 & 0.5 \\
\hline Central Plateau & 66988 & 4.4 & 40.5 & 53.9 & 2.0 & 3.5 & 0.1 \\
\hline $\begin{array}{l}\text { King Country } \\
\text { Taihape }\end{array}$ & 53864 & 3.5 & 14.1 & 79.3 & 3.1 & 3.3 & 0.2 \\
\hline Taranaki & 115292 & 7.5 & 92.5 & 3.1 & 2.9 & 1.5 & 0 \\
\hline $\begin{array}{l}\text { Manawatu } \\
\text { Wanganui }\end{array}$ & 65769 & 4.3 & 72.4 & 11.5 & 10.6 & 4.7 & 0.8 \\
\hline East Coast & 224498 & 14.7 & 26.3 & 70.2 & 1.9 & 1.2 & 0.4 \\
\hline Wellington & 1801 & 0.1 & 90.4 & 8.3 & 0 & 1.3 & 0 \\
\hline North Island & 683972 & 44.7 & 54.8 & 38.4 & 3.9 & 2.5 & 0.4 \\
\hline Marlborough & 10713 & 0.7 & 83.3 & 9.0 & 5.1 & 2.1 & 0.5 \\
\hline Nelson & 17402 & 1.1 & 93.5 & 2.7 & 2.7 & 1.1 & 0 \\
\hline Canterbury & 359199 & 23.5 & 43.8 & 40.6 & 5.1 & 2.2 & 8.3 \\
\hline $\begin{array}{l}\text { High Country } \\
(>300 \mathrm{~m})\end{array}$ & 194714 & 12.7 & 7.9 & 87.8 & 0.8 & 1.0 & 2.5 \\
\hline West Coast & 55179 & 3.6 & 95.9 & 3.2 & 0 & 0.9 & 0 \\
\hline Otago & 80111 & 5.2 & 50.2 & 43.9 & 1.9 & 3.0 & 1.0 \\
\hline Southland & 99805 & 6.5 & 82.3 & 11.2 & 2.6 & 3.4 & 0.5 \\
\hline South Island & 817123 & 53.3 & 45.7 & 44.8 & 3.1 & 2.0 & 4.4 \\
\hline Undefined & 26751 & 1.8 & 50.3 & 40.2 & 2.5 & 1.7 & 5.3 \\
\hline Total & 1527846 & 100 & 49.9 & 41.8 & 3.4 & 2.3 & 2.6 \\
\hline
\end{tabular}




\subsubsection{Multivariate Data Analysis}

Large datasets with numerous data samples and variables provide a rich source of information from which to further understanding and develop models. Many data analysis techniques are available and the nature of the data and problem will guide method selection (Hair et al. 2006). Here the aim is to determine how multiple variables influence a dependent variable ( $\mathrm{N}$ or $\mathrm{P}$ loss to water). Hair et al. (2006) state multivariate problems with one dependent variable are best addressed using a multiple regression approach. Here a multiple regression approach is initially pursued for both $\mathrm{N}$ and $\mathrm{P}$.

This chapter explores the Ravensdown pastoral data, and underlying OVERSEER model, to determine which independent variables and relationship forms should be included in $\mathrm{N}$ and $\mathrm{P}$ algorithms. It must be acknowledged from the outset that it is not the aim to fully replicate the complexity of the OVERSEER model and Mather (1976) states large multivariate datasets can often be sufficiently summarised by a few principle factors. Therefore, the aim in this chapter is identification of the most influential variables and representative functional forms that provide good approximations of OVERSEER output, for use in the $\mathrm{N}$ and $\mathrm{P}$ export coefficient algorithms.

Section 4.2 investigates OVERSEER pastoral $\mathrm{N}$ and $\mathrm{P}$ models, which underpin the data. Literature describing OVERSEER $\mathrm{N}$ and $\mathrm{P}$ pastoral models is reviewed including the most important model drivers, how soil characteristics are represented within the model, and functional form of bivariate relationships between $\mathrm{N}$ or $\mathrm{P}$ loss and a number of independent variables using the OVERSEER model. Section 4.3 explores the Ravensdown dataset. Principle component analysis identifies key factors evident within the data and bivariate relationship functional form is further explored. Section 4.4 revisits OVERSEER's P model in light of results from Section 4.3 and contributes to development of a P algorithm with an alternative approach to multiple regression. Results from this chapter guide algorithm forms which are presented in Chapter 5.

\subsection{OVERSEER PASTORAL MODELS}

The OVERSEER N and P pasture models are described in Watkins and Selbie (2015), Gray et al. (2016), McDowell et al. (2005) and on OVERSEER's website (OVERSEER 2017a), which includes a number of technical guides (Wheeler 2016c; Wheeler 2016b; Wheeler 2016a; 
Wheeler 2016d). What follows summarises these sources, but readers are directed to them for further details.

OVERSEER tracks the flow of nutrients into, out of and within a farm. A farm comprises a number of blocks, which are land units of similar climate, soil and management, into and out of which nutrients flow. Only block scale data relating to $\mathrm{N}$ and $\mathrm{P}$ movement are used for algorithm development.

Several sub-models exist within OVERSEER. Component sub-models estimate climate, hydrology, animal intake and excreta, and effluent dynamics, which all influence nutrient movement. Block sub-models represent the different types of block management e.g. pastoral, crop, cut and carry, and combine component sub-models to track nutrient movement into and out of blocks. Because only pastoral data is considered, only the pastoral block sub-model is further described (Section 4.2.1). At the largest scale, the farm sub-model sums all block models with other farm components such as feed-pads and effluent systems, to model nutrient movement into and out of the entire farm (Watkins and Selbie 2015).

Key OVERSEER assumptions are summarised in Table 4.2. The model boundary extends to the farm geographic boundary and to the bottom of the root zone of pasture plants $(60 \mathrm{~cm})$. The fate or impact of nutrients beyond this zone are not considered. Furthermore, on-farm in-stream nutrient transformations are not considered, transition periods from one farm system to another cannot be modelled, sediment, microbes and pathogens are not considered, and OVERSEER is not spatially explicit (Watkins and Selbie 2015).

Importantly, OVERSEER pastoral nutrient models are calibrated on a limited range of land use, soil and climate types - largely flat, dairy enterprises, on predominantly free-draining soils with moderate rainfall. Yet, as is evidenced in the dataset, a much wider range of conditions and enterprises are routinely modelled in OVERSEER. Watkins and Selbie (2015) state that OVERSEER is capable of modelling this wider variety of systems, but uncertainty of predictions increases in these cases. 
Table 4.2 Key assumptions of the OVERSEER model (Source: Watkins and Selbie 2015)

\section{OVERSEER Model Assumptions:}

- The farm is in a steady state

- Actual and reasonable inputs are entered into the model

- Output is annual average

- Good management practices are followed

- Animal production inputs are a factor in pasture production estimates

\subsubsection{Pastoral Block Model Descriptions}

\section{Nitrogen}

$\mathrm{N}$ loss to water from pastoral blocks in OVERSEER includes leaching from urine patches, background leaching, runoff via overland flow, direct deposition by animals into streams or drains, direct deposition of effluent pond discharge in to streams or drains, border dyke outwash, and septic tank outflow. Leaching is considered the main form of loss, particularly via urine patches, and background leaching is generally less than $15 \%$ of total $\mathrm{N}$ loss, but this increases if effluent is applied. (Watkins and Selbie 2015). However, Ravensdown's pastoral data indicates $72.3 \%$ of blocks have background leaching losses of $>15 \%$ of total $N$ loss. Of these, only $42.4 \%$ of the blocks receive effluent. In addition, approximately $48 \%$ of Ravensdown pastoral blocks include non-leached $\mathrm{N}$ losses. In $80 \%$ of cases, these losses amount to less than $10 \%$ of total $\mathrm{N}$ losses. This indicates background leaching losses and non-leached losses may be more prevalent than Watkins and Selbie (2015) suggest.

Figure 4.1 illustrates OVERSEER steps to estimate $\mathrm{N}$ leaching from a pasture block and it highlights that OVERSEER considers animals largely at the farm scale, rather than block scale. Total animal food requirements are estimated for the farm based on animal numbers and characteristics. The amount of food eaten equals total supplementary feed, plus total feed crops, plus the amount of pasture required to satisfy the number and type of animals present (Step 1, Fig. 4.1). Farm pasture growth is estimated from the amount required to satisfy animals after feed supplements and crops are given. 


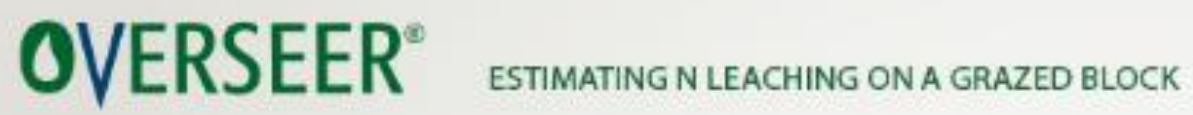

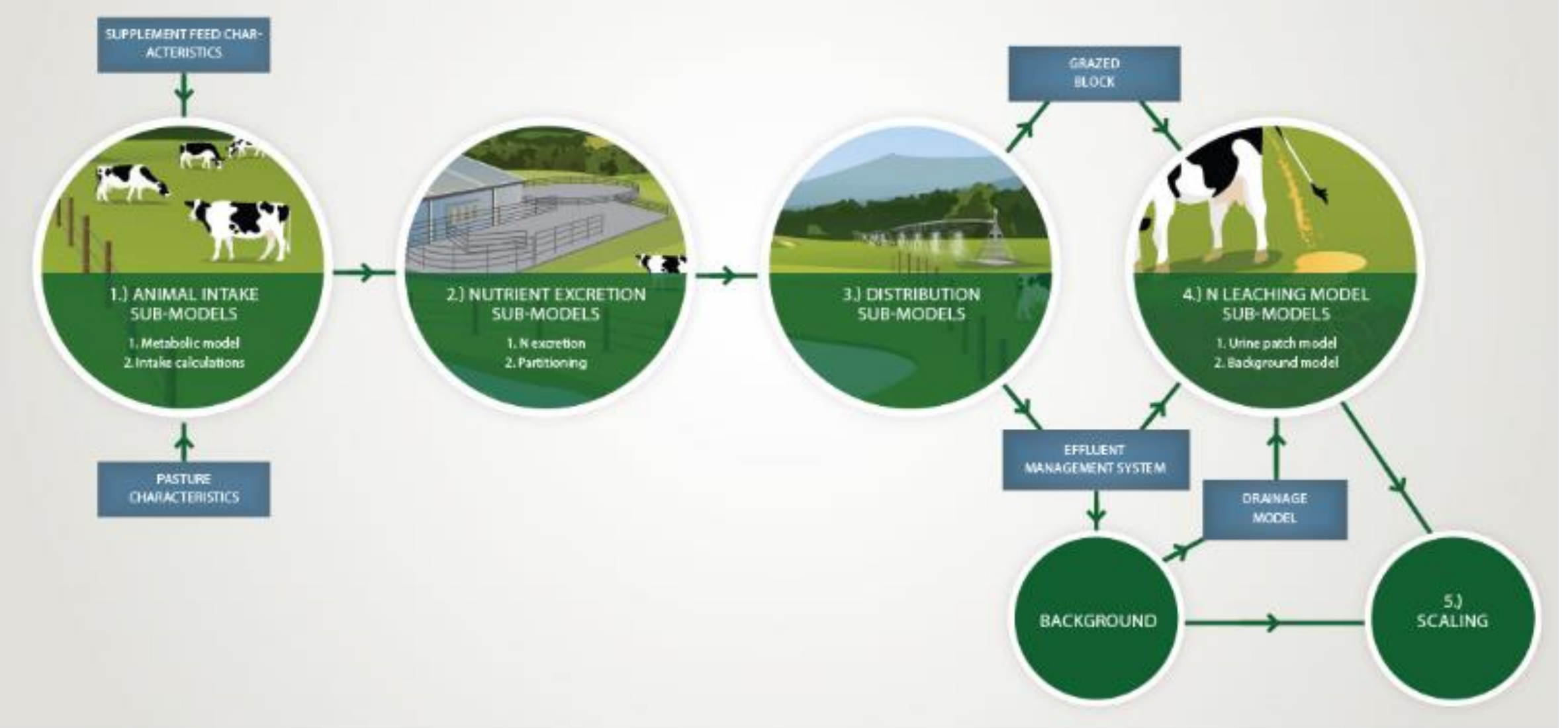

Figure 4.1 Steps to estimate $\mathrm{N}$ leaching from a pasture block in OVERSEER (OVERSEER 2017b) 
Animal excretions equal $\mathrm{N}$ intake (from the food eaten) minus $\mathrm{N}$ in product (i.e. milk, live weight gain etc.). This is apportioned to urine and dung based on diet and animal characteristics (Step 2, Fig. 4.1). Excretions are distributed around blocks, feedpads, milking sheds etc. according to time spent in these areas (Step 3, Fig. 4.1). Excretions on farm structures such as feedpads or milking sheds are sent to effluent management systems, while excretions on blocks can potentially be leached. The proportion of urinary $\mathrm{N}$ leached is estimated by the urine patch model. The proportion leached of other sources of $\mathrm{N}$ e.g. dung, fertiliser, effluent etc. is estimated by the background model. Drainage, based on a soil water balance, is integral to leaching sub-models (Step 4, Fig. 4.1). Final scaling is applied accounting for regular deposition of excreta $\mathrm{N}$ and irregular leaching due to drainage (Step5, Fig. 4.1) (Watkins and Selbie 2015).

\section{Phosphorus}

The OVERSEER pastoral $\mathrm{P}$ model takes a different approach to the $\mathrm{N}$ model, reflecting differences in nutrient sources, and timing and mechanisms of movement. It should also be noted that documentation of the model is less detailed than for OVERSEER's $\mathrm{N}$ model. However, the $\mathrm{P}$ model documentation does give some equations and parameters, which is in contrast to the $\mathrm{N}$ model documentation which is largely descriptive.

Described as a risk approach (Watkins and Selbie 2015), P loss is estimated from potential interaction between sources of $\mathrm{P}$ and influential transport variables including rainfall, slope and soil properties (Figure 4.2). Two categories of $\mathrm{P}$ loss are considered - background (soil) and incidental (fertiliser and effluent) (McDowell et al. 2005; Watkins and Selbie 2015; Gray et al. 2016).

Soil, or background, $\mathrm{P}$ sources are estimated by combining Olsen $\mathrm{P}$, soil 'structural vulnerability', and dissolved reactive P concentrations (which is calculated from Olsen P and P retention values), with a weighting factor derived from regression analysis of estimated and actual TP losses from various soil orders. Management variables considered include mole pipe drain presence and use of border dyke irrigation, both of which appear to increase $\mathrm{P}$ loss by a set amount e.g. mole tile drain presence adds $0.3 \mathrm{~kg} \mathrm{P} \mathrm{ha}^{-1} \mathrm{yr}^{-1}$ to $\mathrm{P}$ losses (McDowell et al. 2005; Gray et al. 2016). Fertiliser P losses are influenced by the amount and timing of applied P. Effluent $P$ losses are influenced by amount, speed and timing of application, as well as the presence of mole tile drains. Direct discharge to 
waterways from effluent ponds is also considered. Total block P loss is the sum of soil, fertiliser and effluent P losses (McDowell et al. 2005; Watkins and Selbie 2015; Gray et al. 2016).

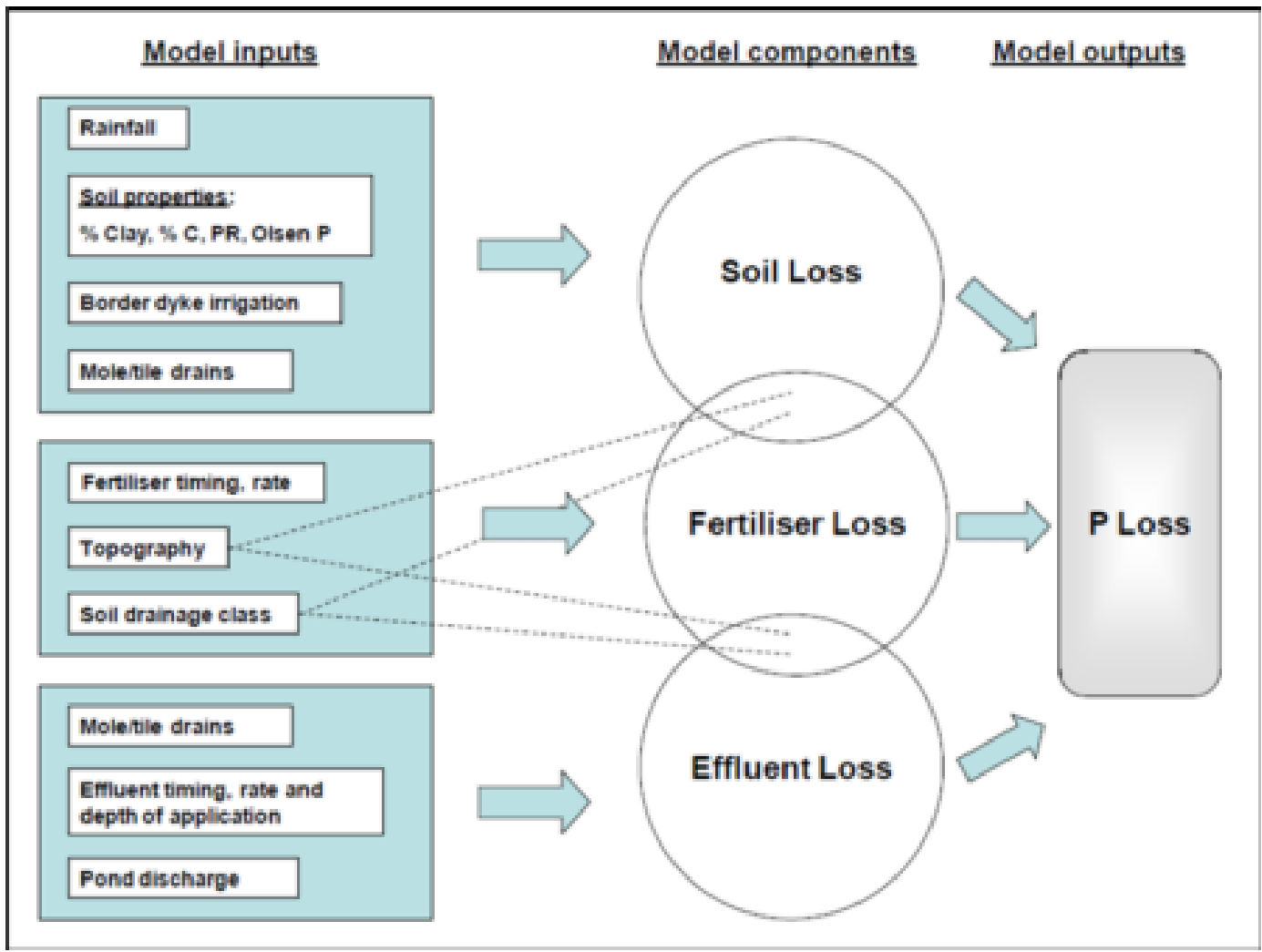

Figure 4.2 Diagram of OVERSEER P loss model (Watkins and Selbie 2015)

\subsubsection{Accounting for Soil Variables in OVERSEER}

Soil characteristics are important influences on actual $\mathrm{N}$ and $\mathrm{P}$ losses to water (as described in Section 2.2) and on the OVERSEER $\mathrm{N}$ and $\mathrm{P}$ models. In OVERSEER users can identify block soil type according to series, group, sibling or order. The following explains what these soil classifications are and how they relate to New Zealand's primary soil classification system, the New Zealand Soil Classification (NZSC).

Soil Series :- soil series names generally stem from original soil surveys and in some cases they correspond to more than one New Zealand Soil Classification (NZSC) category, so care must be taken with their use (Landcare Research 2017b). OVERSEER can only accept around 800 soil series names, which are automatically linked by OVERSEER to the appropriate NZSC soil order (Wheeler 2016a). 
Soil Group :- seven soil groups are defined in OVERSEER based on work related to OVERSEER's predecessor, OUTLOOK, and subsequent work related to fertiliser use in New Zealand (Wheeler 2016a). These soil groups appear to be used by agricultural scientists and the agricultural industry, but are not widely used by soil scientists (Wheeler 2016a).

Soil Order and Sibling :- soil order and sibling refer to soil categories within the NZSC. Soil order refers to the first soil category in the NZSC, of which there are 15 . Soil sibling refers to the fourth and fifth categories (Wheeler 2016a).

In OVERSEER default soil properties relating to water holding capacity, drainage, soil texture etc. are defined according to soil order or soil group and are found in Wheeler (2016a). Where only a soil group is entered, default soil values are based on the soil order within which the soil group falls. However, this is complicated by the fact that some soil groups relate to multiple soil orders. For example, the 'volcanic' soil group includes allophanic, granular and oxidic soil orders. In this case the default soil order values are 'combined' and may be weighted towards particularly prevalent soil orders (Wheeler 2016a). Where users have block soil value test results, these can be entered in to OVERSEER to override default values (Wheeler 2016a).

In the Ravensdown dataset default soil values are not included and Olsen $\mathrm{P}$ is the only included soil test result relating to $\mathrm{N}$ or $\mathrm{P}$. Soil sibling is not defined for any block and soil series is rarely defined. The majority of blocks within the dataset include both soil group and soil order. However, only soil order is used for this study for three reasons:

1. Soil order is connected to New Zealand's primary soil classification (NZSC)

2. Soil group default soil values in OVERSEER reference soil order default values anyway

3. Soil order is identified and spatially positioned in the NZFSL, which is the spatial soil data used in this research.

The NZSC defines 15 soil orders for New Zealand (Hewitt 2010) and Table 4.4 summarises their national coverage, drainage and $\mathrm{P}$ retention, which are referred to in this and subsequent chapters. For more information on soil order characteristics readers are directed to Hewitt (2010) and the New Zealand Soils Portal (Landcare Research 2017a). 
Table 4.4 New Zealand soil order coverage, drainage and P retention. Sources: McLaren \& Cameron (1996), Hewitt (2010) and Landcare Research (2017a).

\begin{tabular}{|c|c|c|c|}
\hline Soil Order & Location and \% National Cover & Drainage & P Retention \\
\hline Allophanic & $\begin{array}{l}\text { Predominant in North Island } \\
\text { volcanic ash. Cover } 5 \% \text { of NZ. }\end{array}$ & Good & High \\
\hline Brown & Nationwide. Cover $43 \%$ of NZ. & Good & Medium-High \\
\hline Gley & $\begin{array}{l}\text { Nationwide in low lying areas. } \\
\text { Cover } 3 \% \text { of NZ. }\end{array}$ & Poor to very poor & Medium-High \\
\hline Granular & $\begin{array}{l}\text { Found in northern NZ, } \\
\text { particularly Waikato and South } \\
\text { Auckland lowlands. Cover } 1 \% \text { of } \\
\text { NZ }\end{array}$ & Moderate & High \\
\hline Melanic & $\begin{array}{l}\text { Scattered throughout NZ. Cover } \\
1 \% \text { of NZ. }\end{array}$ & Moderate & Medium-High \\
\hline Organic & $\begin{array}{l}\text { Nationwide in wetlands and } \\
\text { under forests that produce acid } \\
\text { litter and with high rainfall. } \\
\text { Cover } 1 \% \text { NZ }\end{array}$ & $\begin{array}{c}\text { Variable } \\
\text { Peats - poor }\end{array}$ & Low \\
\hline Oxidic & $\begin{array}{l}\text { Auckland and Northland only. } \\
\text { Cover }<1 \% \text { NZ. }\end{array}$ & Variable & Medium-High \\
\hline Pallic & $\begin{array}{l}\text { In seasonally dry eastern areas } \\
\text { of North \& South Is and in } \\
\text { Manawatu. Cover } 12 \% \text { NZ }\end{array}$ & Moderate to poor & Low \\
\hline Podzol & $\begin{array}{l}\text { In areas of high rainfall in } \\
\text { association with forest } \\
\text { producing acid litter. Cover } 13 \% \\
\text { NZ. }\end{array}$ & Moderate & Low \\
\hline Pumice & $\begin{array}{l}\text { Central North Is, particularly } \\
\text { Volcanic Plateau. Cover } 7 \% \text { NZ. }\end{array}$ & Good & Medium-High \\
\hline Recent & $\begin{array}{l}\text { Nationwide on young surfaces } \\
\text { eg. floodplains. Cover } 6 \% \text { NZ. }\end{array}$ & Good & Low \\
\hline Semi-Arid & $\begin{array}{l}\text { In inland basins of Otago \& } \\
\text { southern Canterbury. Cover } 1 \% \\
\text { NZ. }\end{array}$ & Good & Low \\
\hline Ultic & $\begin{array}{l}\text { Northern North Is, Wellington, } \\
\text { Marlborough \& Nelson. Cover } \\
3 \% \text { NZ. }\end{array}$ & Poor & Low \\
\hline Raw & $\begin{array}{l}\text { Nationwide in alpine areas, river } \\
\text { beds, beaches and estuaries. } \\
\text { Cover } 3 \% \mathrm{NZ} \text {. }\end{array}$ & $\begin{array}{l}\text { Variable depending } \\
\text { on parent material }\end{array}$ & Low \\
\hline Anthropogenic & $\begin{array}{l}\text { In urban areas and mines. Cover } \\
<1 \% \mathrm{NZ} \text {. }\end{array}$ & Variable & Variable \\
\hline
\end{tabular}


The NZSC soil orders are not equally represented within the Ravensdown dataset. Table 4.5 shows the number of blocks that feature each soil order within the data. Anthropogenic and raw soils are not represented at all. In OVERSEER raw soils can be chosen as a soil order option, while anthropogenic soils cannot. Raw soils are presumably not present in the dataset because little farming is undertaken on them. Oxidic and semi-arid soils are represented, but with only 18 and 22 blocks respectively. This is presumably because oxidic soil covers $<1 \%$ of New Zealand land area in the Far North and around Auckland, while semi-arid soils are extensively drystock farmed, but few nutrient budgets are done on these farms (A.Roberts, personal communication, 27 November 2017).

Table 4.5 Number of pastoral blocks in the Ravensdown dataset included in each of the soil order categories

\begin{tabular}{|l|c|}
\hline \multicolumn{1}{|c|}{ Soil Order } & Number of Blocks \\
\hline Allophanic & 2203 \\
\hline Brown & 3141 \\
\hline Gley & 1715 \\
\hline Granular & 176 \\
\hline Melanic & 192 \\
\hline Organic & 287 \\
\hline Oxidic & 18 \\
\hline Pallic & 2801 \\
\hline Podzol & 178 \\
\hline Pumice & 510 \\
\hline Recent & 1996 \\
\hline Semi Arid & 22 \\
\hline Ultic & 252 \\
\hline Raw & 0 \\
\hline Anthropogenic & 0 \\
\hline
\end{tabular}

\subsubsection{Investigation of OVERSEER Functioning Using Bivariate Relationships}

This investigation aims to identify bivariate relationship forms between $\mathrm{N}$ and $\mathrm{P}$ losses and variables influencing those losses, to be used in multiple regression algorithms. To achieve this, OVERSEER (Version 6.2.2) is used to model a theoretical farm with 13 blocks of equal size, each featuring one of 13 soil orders (anthropogenic and raw soils are excluded). All blocks are treated in the same manner for each model run. Individual variables are slowly increased, while keeping remaining variables constant, and their effect on $\mathrm{N}$ or $\mathrm{P}$ losses 
recorded. Bivariate relationships are graphed in MATLAB and identified as sublinear, linear or superlinear (Figure 4.3) to show how increases in individual variables affect $\mathrm{N}$ or $\mathrm{P}$ loss.

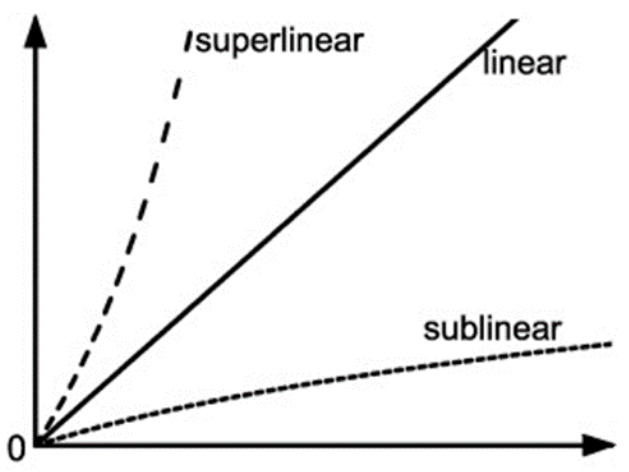

Figure 4.3 Illustrates a linear relationship and what is meant in this text by sublinear relationship (below the linear line) and superlinear relationship (above the linear line).

Sections 2.2 and 4.2.1 explain which variables influence $\mathrm{N}$ and $\mathrm{P}$ loss to water both in reality and in the OVERSEER model. Many, but not all, of these variables are quantitatively represented in the Ravensdown dataset. In consultation with the wider LUCI development and Ravensdown team, variables for exploration were chosen based on understanding of nutrient cycles, the OVERSEER model and with some consideration given to wider aims associated with future application of these models in LUCI by Ravensdown. $\mathrm{N}$ losses are explored in relation to annual average rainfall, irrigation, fertiliser $\mathrm{N}$, effluent $\mathrm{N}$ and stocking rate, which are all quantified in the Ravensdown dataset. P losses are explored in relation to annual average rainfall, irrigation, fertiliser $P$, effluent $P$, and Olsen $P$, which are all quantified in the Ravensdown dataset. As stated in Section 4.2.2, quantitative soil characteristics (except Olsen P) are not included in the Ravensdown dataset, yet soil variables do influence $\mathrm{N}$ and $\mathrm{P}$ losses. For the majority of blocks within the dataset, soil order is specified. Therefore, bivariate analysis is undertaken for each soil order to account for soil variables. Results are presented below.

\section{Nitrogen}

Figure 4.4 presents relationships between rainfall and irrigation, and $\mathrm{N}$ loss for the 13 soil orders featured in the Ravensdown dataset. A sub-linear relationship is seen for all soil orders, whereby $\mathrm{N}$ loss increases as rain only or plus irrigation increases and levels out or even decreases in some cases. The addition of irrigation has the effect of steepening the curve so losses are higher with rainfall plus irrigation compared to the same depth of rainfall 
only. Above $3000 \mathrm{~mm} \mathrm{yr}^{-1}$ of rain only or plus irrigation, there is some variability and it is surprising to see decreases and subsequent increases in $\mathrm{N}$ loss at these higher values. OVERSEER is calibrated for moderate annual mean rainfall $(<1200 \mathrm{~mm})$ (Watkins and Selbie 2015) and variable results at higher water inputs supports Watkins and Selbie's assertion of uncertainty increasing outside of calibrated ranges. In reality a minority of farms in New Zealand are subjected to rainfall or rainfall plus irrigation of this magnitude. For example only around 250 blocks in the Ravensdown dataset feature rainfall plus irrigation over $3000 \mathrm{~mm} \mathrm{yr}^{-1}$ and the majority of these are on the West Coast of the South Island. Soil order differences are clear, reflecting differences in soil drainage. For example, very permeable, well drained allophanic soils have high $\mathrm{N}$ losses and continue to lose $\mathrm{N}$ with high rainfall

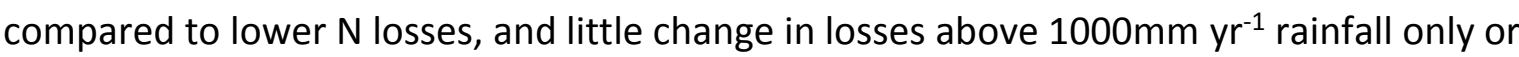
rainfall plus irrigation, from poorly drained gley soils.

Figure 4.5 illustrates relationships between fertiliser and effluent $\mathrm{N}$ application and $\mathrm{N}$ loss for 13 soil orders. The relationship looks very subtly super-linear. Again differences in magnitude of loss from different soil orders, reflect soil drainage. The relationship between stocking rate and $\mathrm{N}$ loss is shown in Figure 4.6. A clear linear relationship exists with magnitude of loss varying between soil orders, again reflecting soil drainage characteristics.

\section{Phosphorus}

Figure 4.7 shows relationships between rainfall and irrigation, and P loss for 13 soil orders. Like N, a sub-linear relationship exists between these variables for all soil orders. However, only one curve is seen and added irrigation results in a push up the single $\mathrm{P}$ loss curve rather than development of a second, steeper curve. Differences in magnitude of loss according to soil order reflects soil $\mathrm{P}$ retention. Low $\mathrm{P}$ retention soils, such as Organic, Pallic, Podzol and Ultic, lose $\mathrm{P}$ to a greater extent as rainfall and irrigation increase. Lower P loss are evident for medium to high P retention soils, such as Allophanic, Brown, Granular and Oxidic.

Figure 4.8 illustrates relationships between fertiliser and effluent $\mathrm{P}$ application and $\mathrm{P}$ loss. Relationships look linear although could be very subtly super-linear. Differences in magnitude of loss from different soil orders are evident and appear related to soil P retention. Olsen $\mathrm{P}$ against $\mathrm{P}$ loss is shown in Figure 4.9. Relationships are clearly close to linear with higher $\mathrm{P}$ loss from low $\mathrm{P}$ retention soils. A linear relationship between topography and P loss is evident for all soil orders in Figure 4.10. 


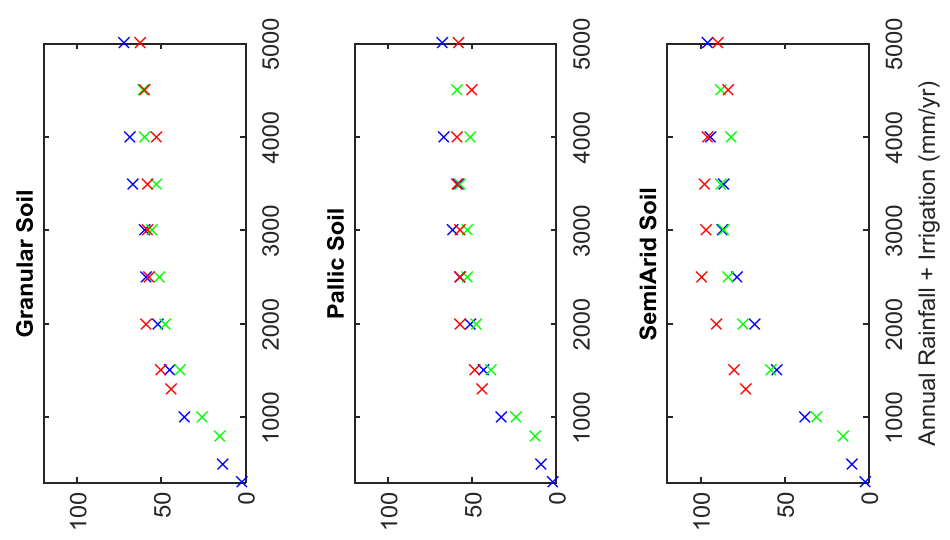

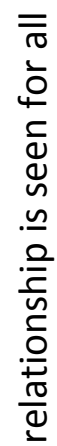

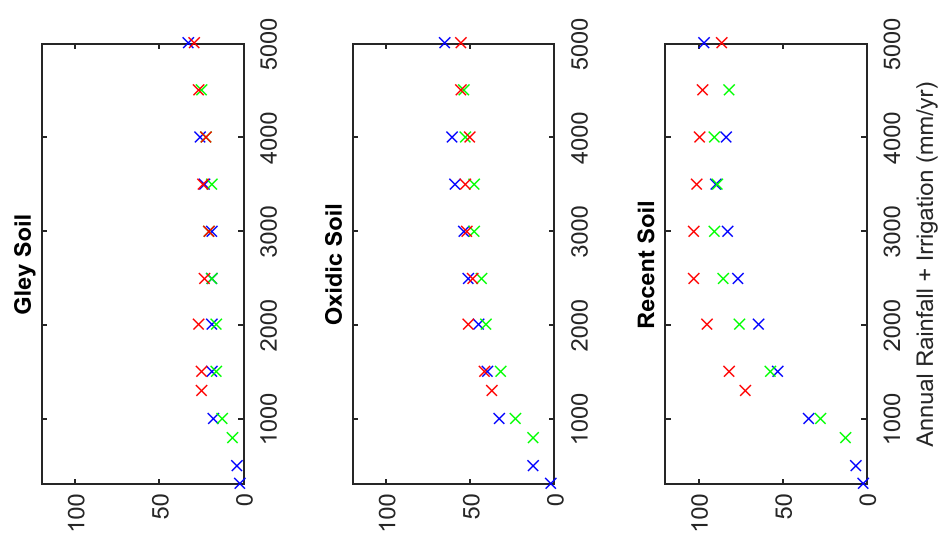

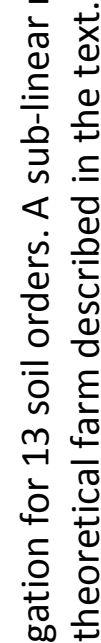

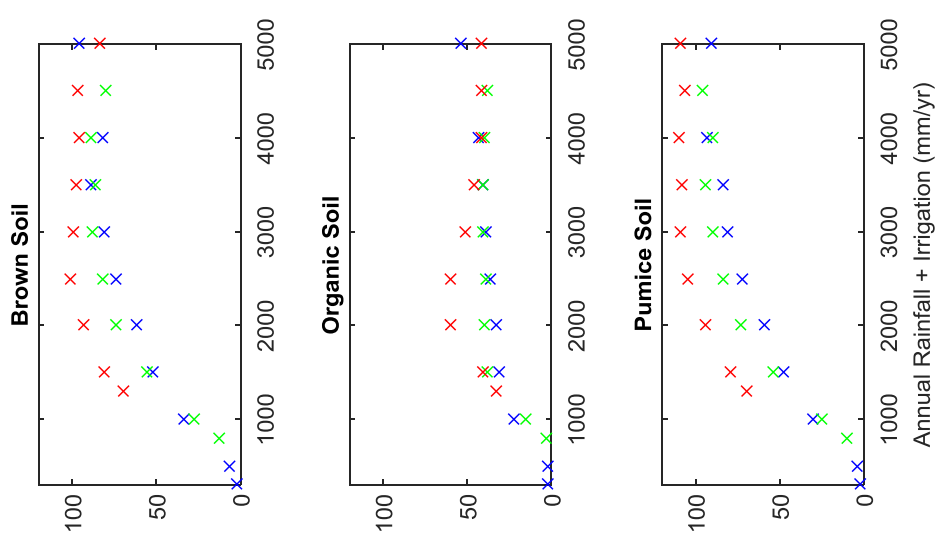

.로

능 둥

$\overline{\bar{\sigma}} 气$

든

즐

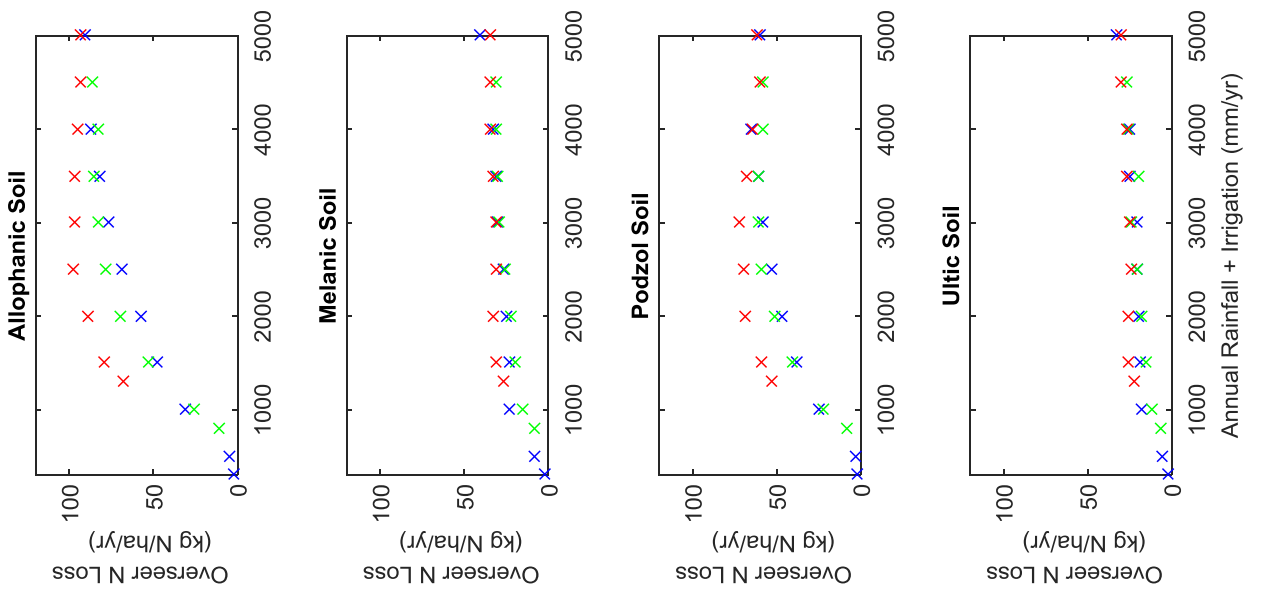




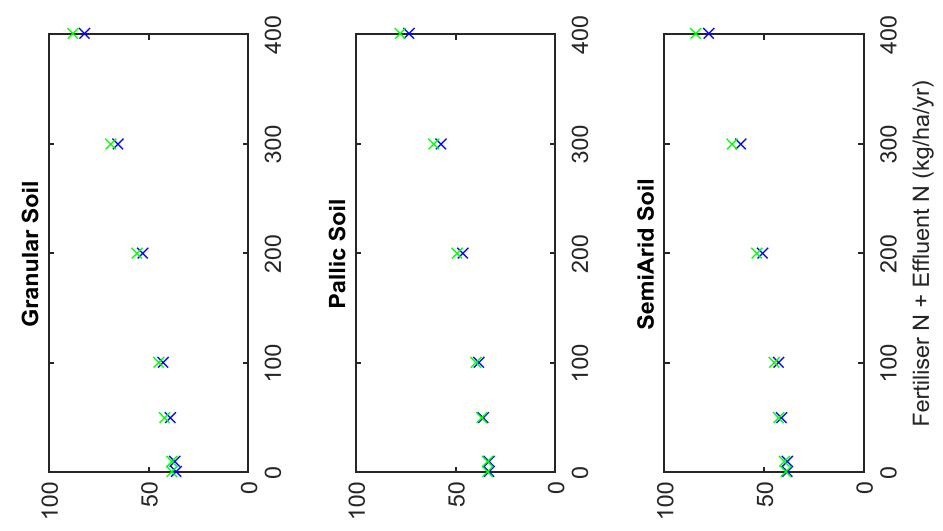

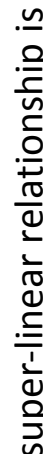

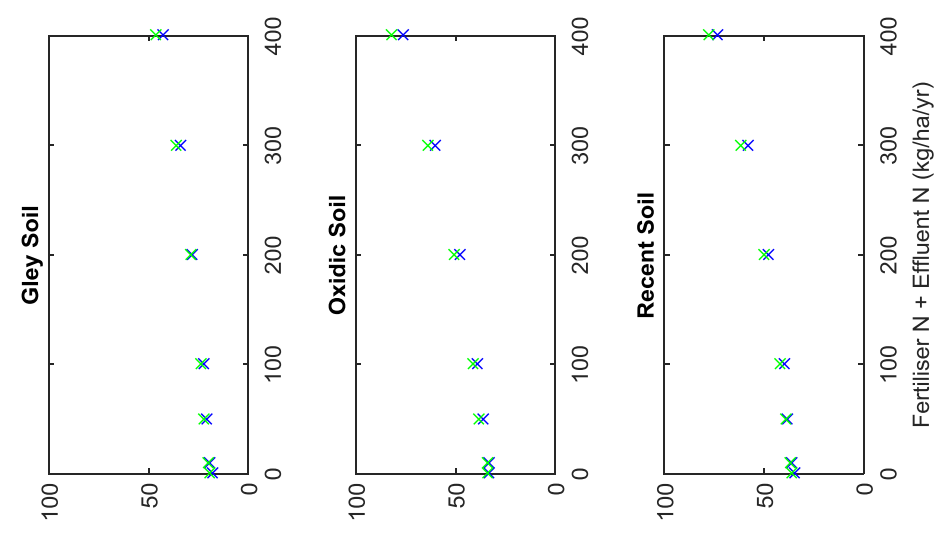

$\stackrel{+}{\stackrel{x}{*}}$

过

$\varangle . \subseteq$

vi

응

o ù

क̄

m ह

흔

$z$

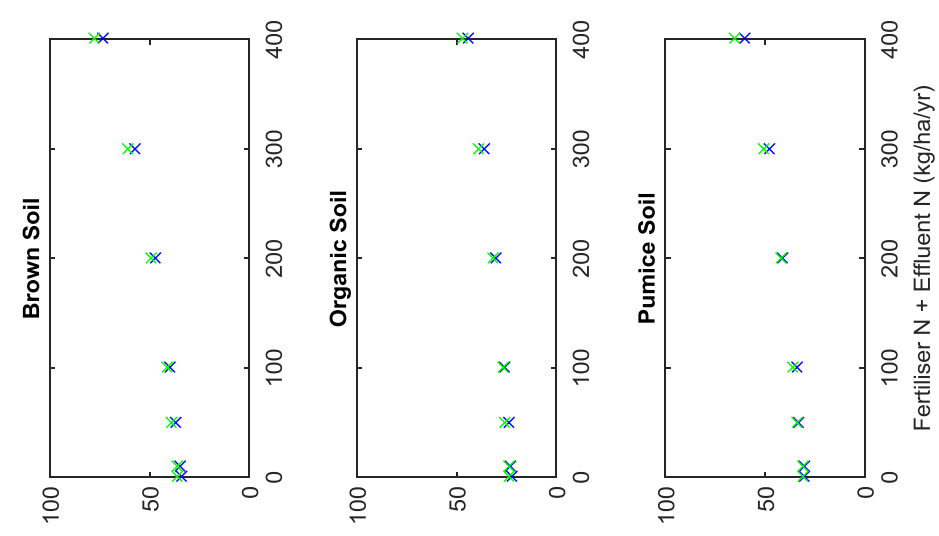

焉

(ब)

$\frac{c}{\pi}$

ㅇำ

高

氠

흔

पह

드 뚠

을

Ð

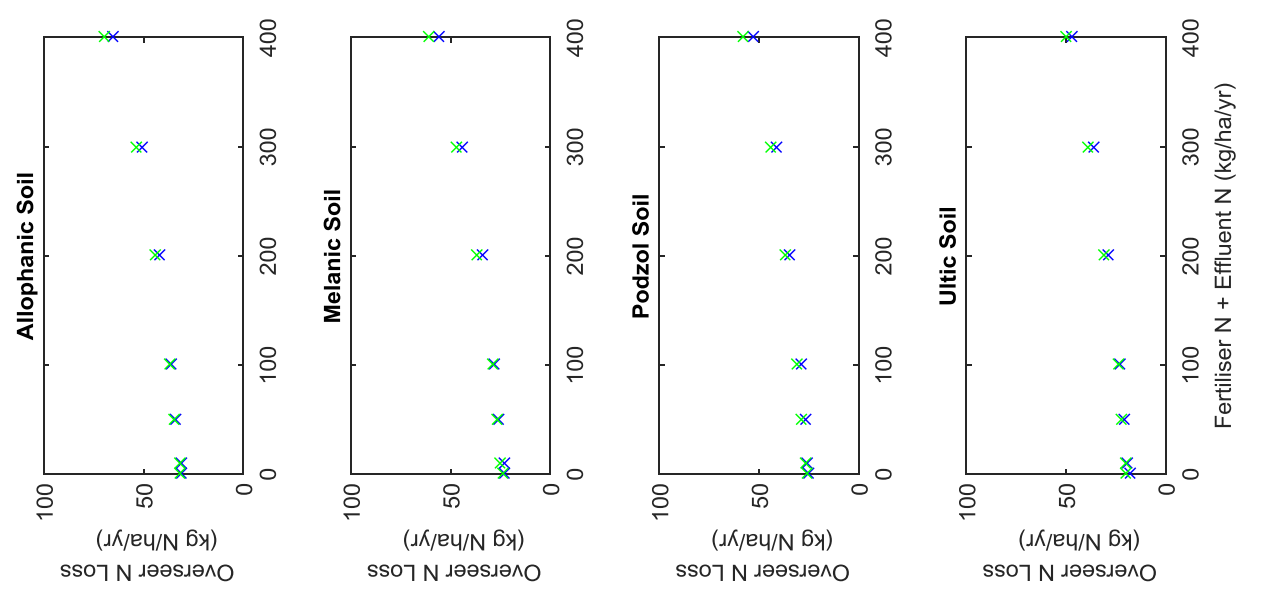

ปั

นิ 을

z

잉

3

동

든

은 등

ज

拧

(1)

光

نำ 

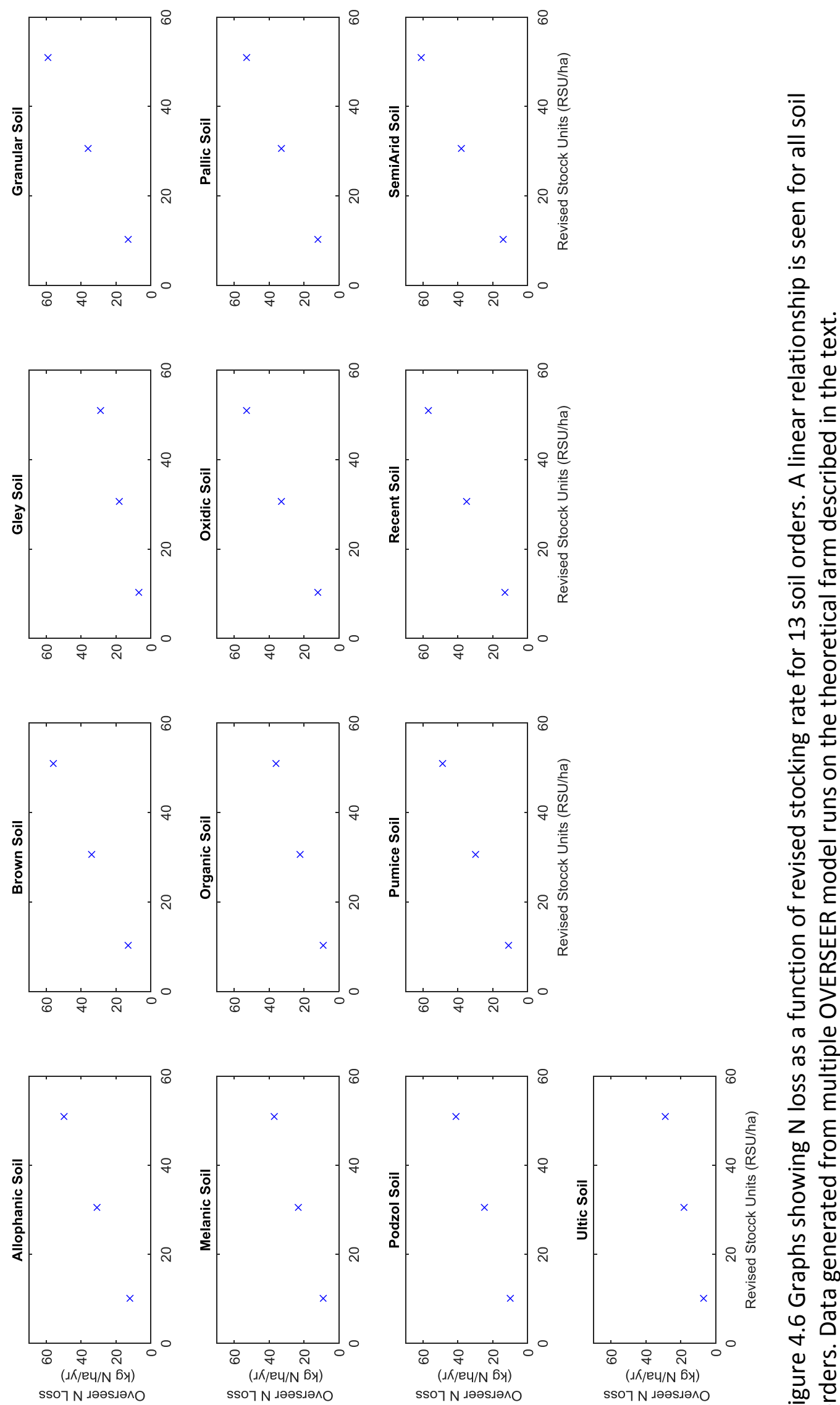

(⿻)

으음

กิ

z

0

०

水

นิ ญ

مه

iv

ด

$\forall$

는 ํㅣㄴ

문 

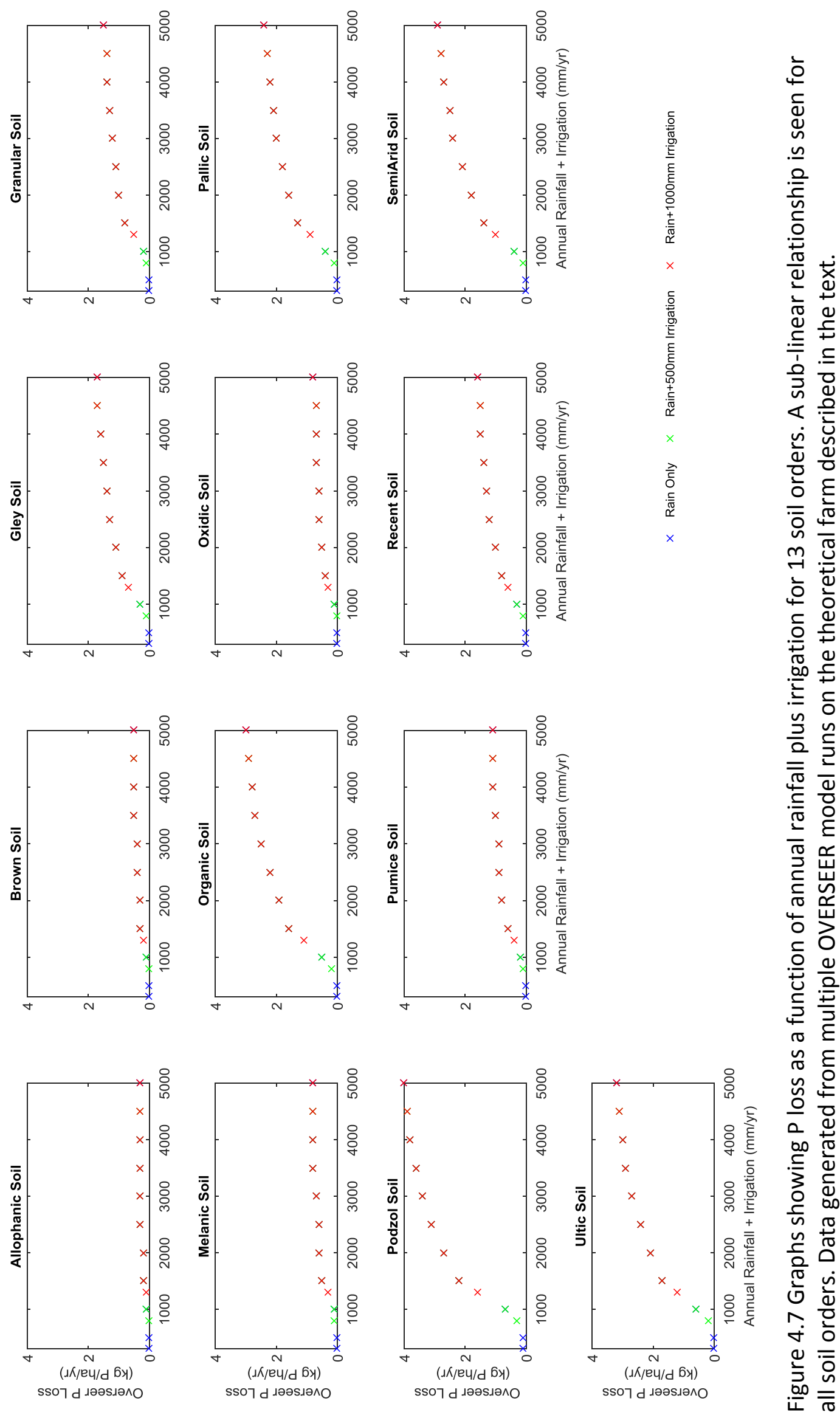


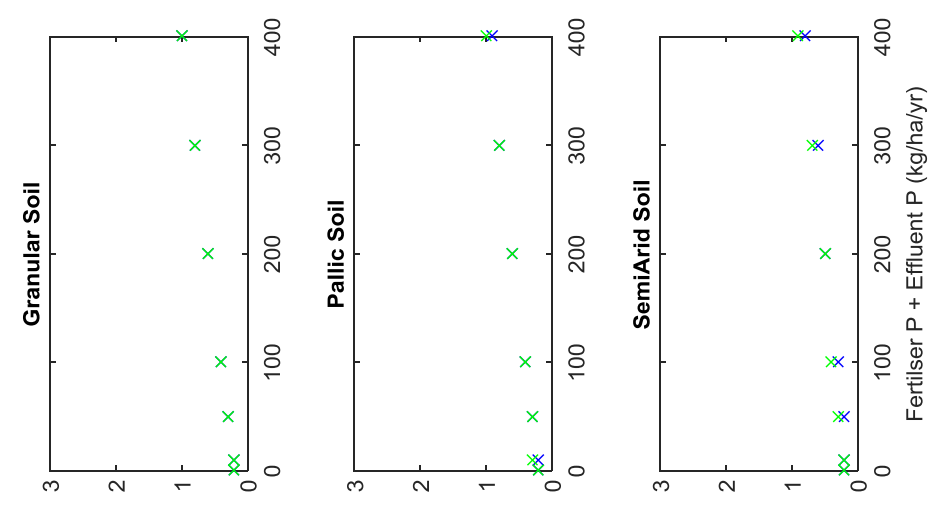

ते
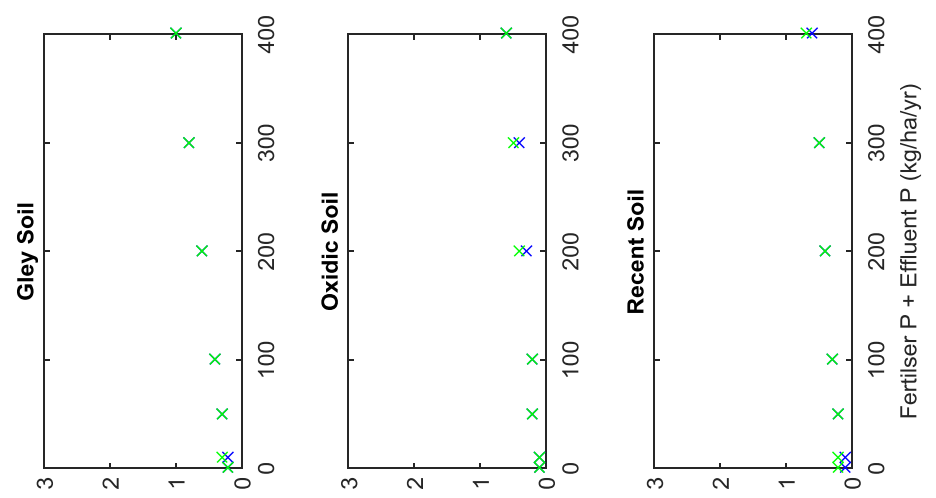

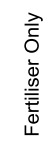

政

可

蛋

음

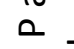

ষे

章
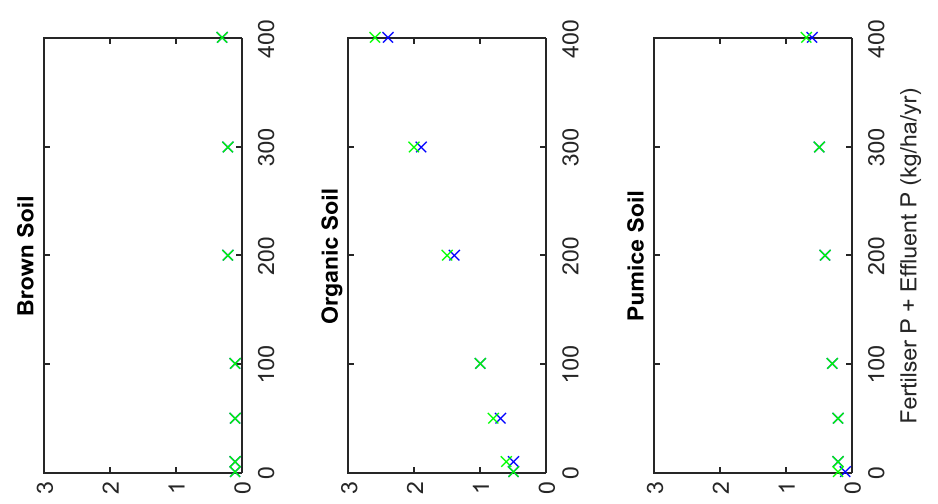

.

응 응

음

즐 ह

它

능

은 훙

额

$\underset{\pi}{0}$

要

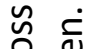
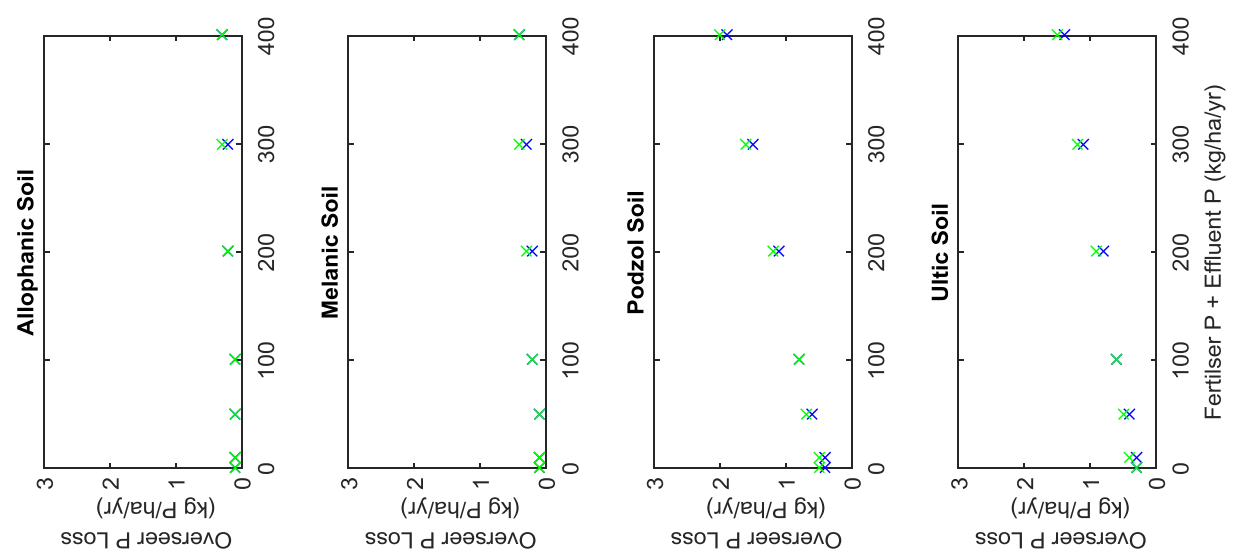

ㅁำ

bo .든

늘

施

동

$\frac{\pi}{6}$

ஸे ัญ

$\dot{\sigma}$.

选 $\frac{1}{2}$ 

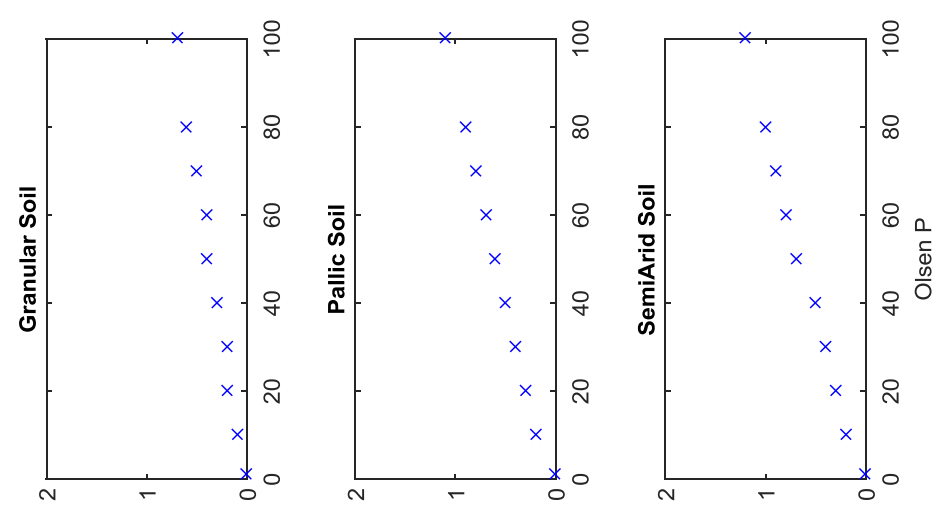

$\frac{0}{\pi}$
0
vi
$\frac{0}{0}$
$\frac{1}{0}$
$\frac{0}{0}$
$\frac{4}{\overline{0}}$
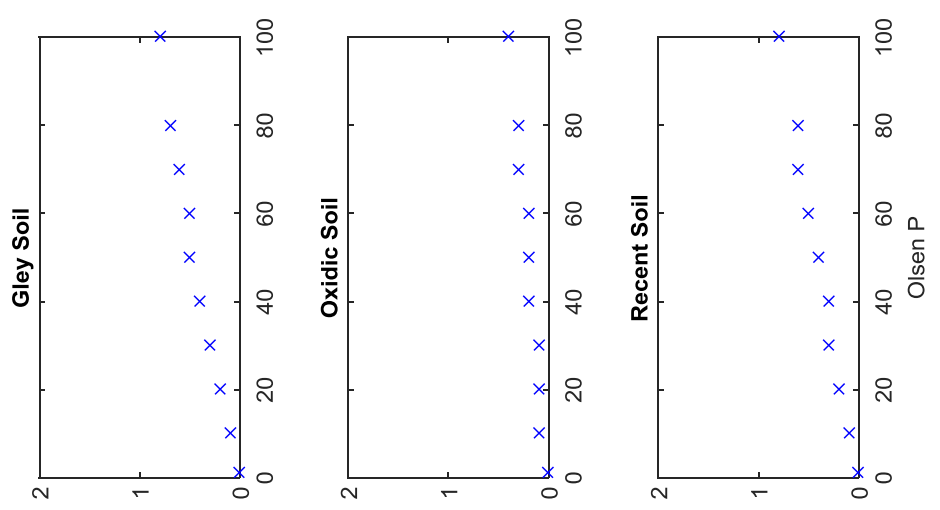

훈
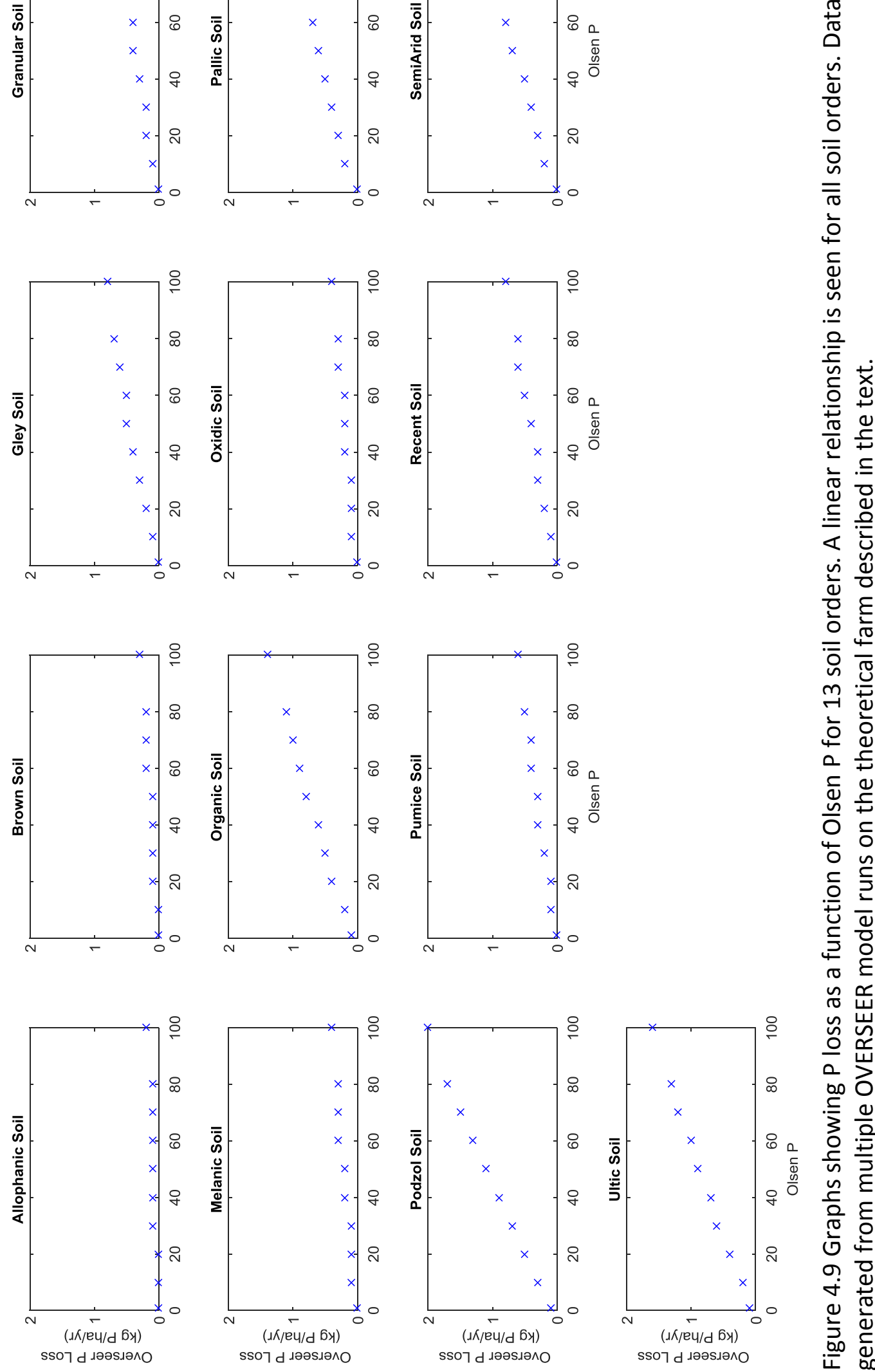

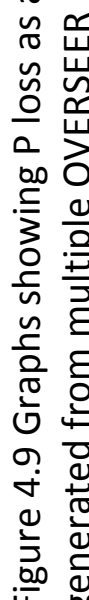



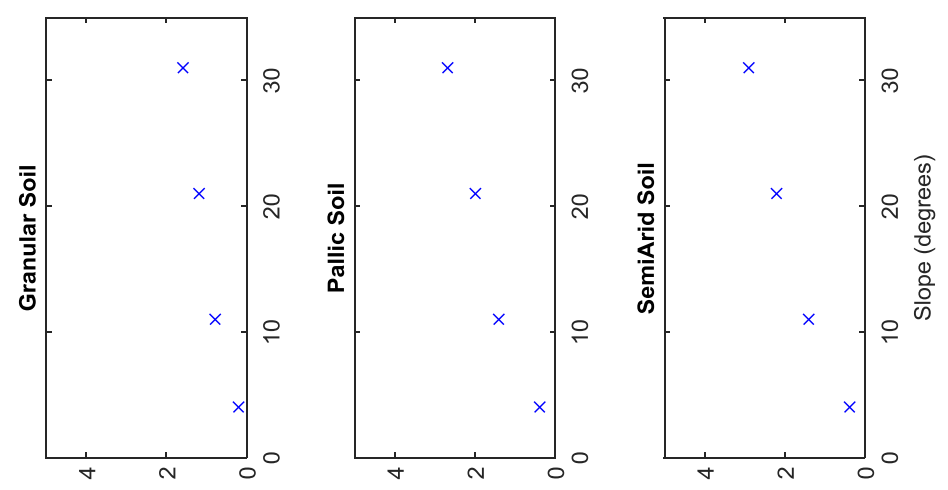

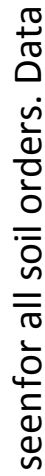
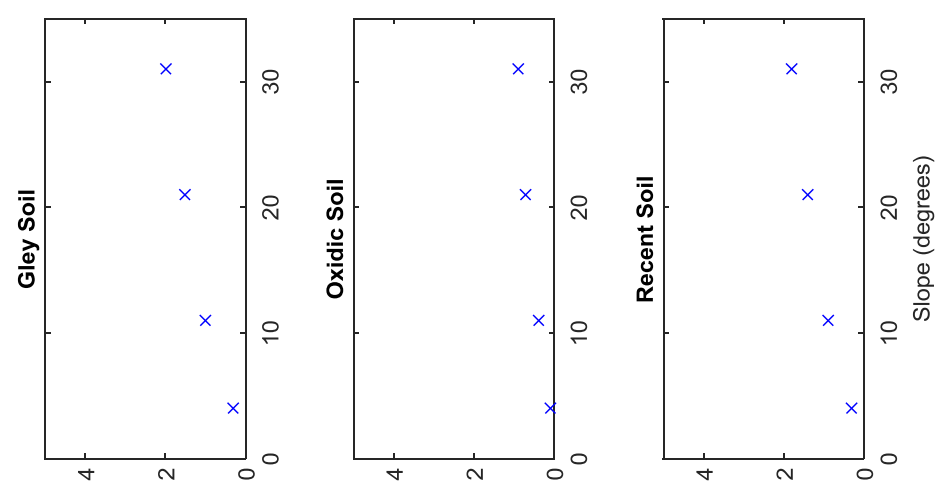

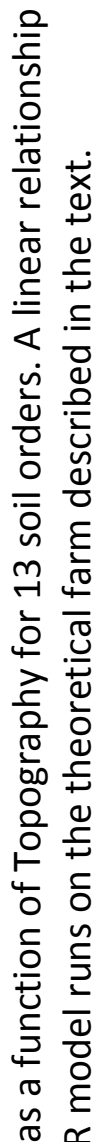

气ิ

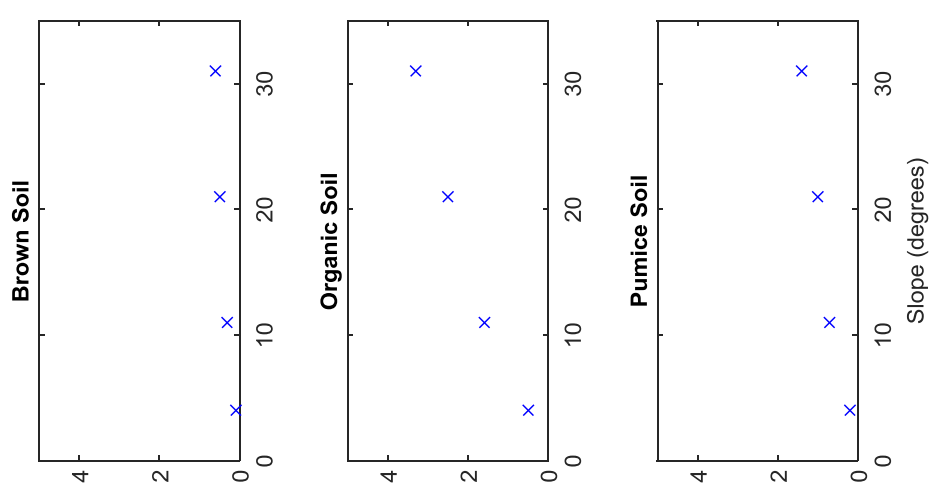

무 눔
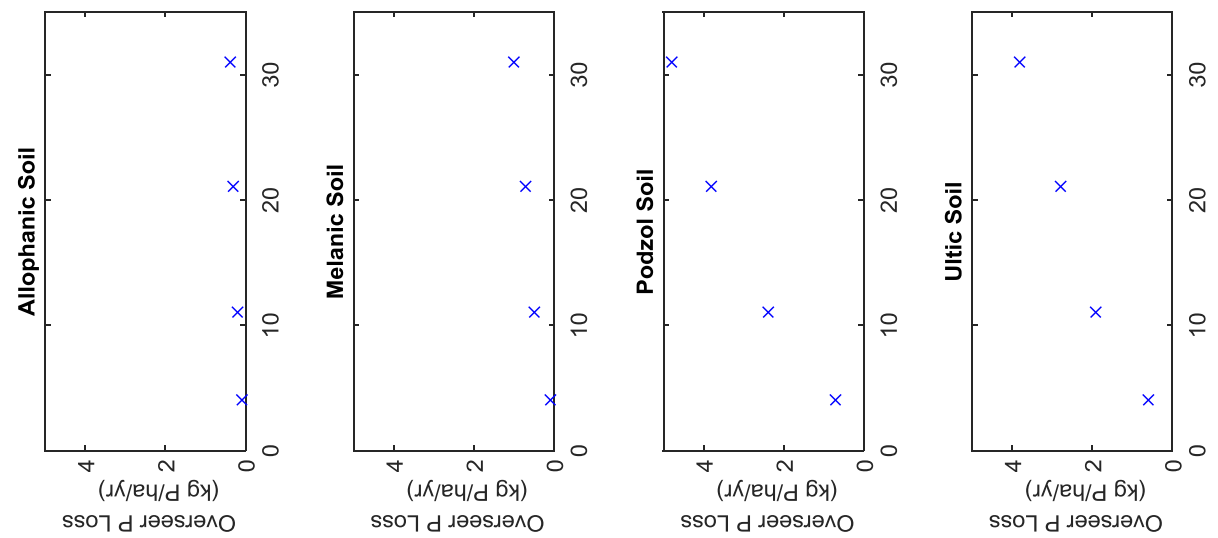

bo

3

号

กี ह

응

닝

04

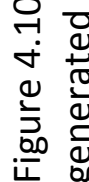




\subsection{EXPLORATION OF RAVENSDOWN PASTORAL DATA}

In this section, the Ravensdown pastoral data is explored. Section 4.3.1 applies principal component analysis (PCA) to the data which is divided into 14 groups, one for each of the 13 soil orders featured in the dataset and one including all data. Section 4.3.2 explores bivariate relationships between $\mathrm{N}$ or $\mathrm{P}$ loss and a number of variables within each of the 14 data groups.

\subsubsection{Principal Component Analysis}

Principle component analysis identifies variables within a dataset that explain most of the variation. It is used to explore data relationships and focus further investigations, particularly when using large datasets. PCA analyses the structure of a multivariate data cloud and identifies orthogonal vectors (eigenvectors) where data variance is greatest. Variance may be related to differences in one or a combination of data variables. The vector with maximum variance is the first principle component (PC1). The second PC is the vector with maximum variance that is orthogonal to the first PC. Each succeeding PC is the vector with maximum variance that is orthogonal to proceeding PCs (Mather 1976).

Each eigenvector has an associated eigenvalue indicating the degree of variance. Eigenvalues descend, in order, from highest values at PC1. For each PC, component coefficients indicate the degree to which individual data variables are related to the PC in question. Component coefficients range from -1 to 1 . Those close to 1 or -1 are highly related to a PC, while coefficients close to 0 are not. Where multiple variables are closely related to a PC and coefficients have the same sign, they are acting in the same direction. Opposite coefficient signs indicate variables are acting in opposite directions (Mather 1976). Here PCA is carried out in MATLAB on the Ravensdown dataset using variables associated with the $\mathrm{N}$ and P OVERSEER models. The aim is to explore the dataset and identify the most influential variables or combinations of variables using the 14 data groups (13 soil order data groups plus all data).

\section{Nitrogen}

For N, PCA is carried out twice for each of the 14 data groups because potential evapotranspiration (PET) is not consistently defined for each block in the Ravensdown dataset, yet investigation of the effect of PET influence is desired. One PET column is 
featured in the dataset and it records user defined PET for around $2 / 3$ of blocks. Where a user has not defined PET, the value in this column is 0. OVERSEER does assign default PET values based on regional location of blocks, but the default values are not included in the Ravensdown data.

The first PCA for N (PCA1) uses all blocks in each data group and 10 variables (rainfall, temperature, irrigation added, revised stock unit (RSU), fertiliser $\mathrm{N}$, effluent $\mathrm{N}, \mathrm{N}$ clover fixation, $\mathrm{N}$ in irrigation water, supplemental feed $\mathrm{N}$, and OVERSEER predicted $\mathrm{N}$ loss to water). The second PCA for N (PCA2) uses only blocks where user defined PET is present and 11 variables (those detailed above plus PET as variable 2 ). Table 4.6 presents the variables and associated component coefficients related to each PC for the 14 data groups from PCA1. Table 4.7 presents eigenvalues for the first 5 PC in each of the 14 data groups from PCA1. Figure 4.11 shows bivariate plots of principal components 1-5 from PCA1 for all data (i.e. data is not separated by soil order). The ten variables included in the analysis (in the order listed above) are represented by vectors $\mathrm{V}_{1}-\mathrm{V}_{10}$. Vector length and direction show how each variable relates to the two principal components graphed. Table 4.8 and 4.9 and Figure 4.12 present the same data, but from PCA2. Within the MATLAB generated component coefficient tables, it is clear variables with component coefficients over 0.75 are the only variable significantly contributing to the PC in question and most other variables have coefficients $<0.3$. In these cases, only the $>0.75$ variables are identified in Tables 4.6 and 4.8 . Where the highest component coefficient is $<0.75$, all of the variables with component coefficients $>0.3$ are identified in Tables 4.6 and 4.8 .

Table 4.6 indicates rainfall is the primary PC (PC1) for allophanic, brown, gley, granular, melanic, organic, oxidic, podzol, pumice, recent, ultic soils and all data, with component coefficients ranging from $0.85-0.996$. For pallic soils irrigation is PC1 with a component coefficient of 0.9281 , and for semi-arid soils, PC1 is related to irrigation and rainfall with component coefficients of 0.7287 and -0.6771 . Pallic and semi-arid soils are generally located in drier regions. Therefore it is unsurprising irrigation, rather than rainfall, is PC1 for pallic soils. For semi-arid soils irrigation and rainfall are inversely related to PC1. This likely indicates irrigation tends to be used when rainfall is low and is particularly evident in the data for this soil order. However, only 22 samples are analysed here and it is uncertain how generally indicative this is for semi-arid soils. 
Table 4.6 PCA1 variables and component coefficients related to PC1-5 for N for 14 data groups using 10 variables (excluding PET)

\begin{tabular}{|c|c|c|c|c|c|}
\hline Soil Order & PC1 & PC2 & PC3 & PC4 & PC5 \\
\hline $\begin{array}{l}\text { Allophanic } \\
n=2203\end{array}$ & $\begin{array}{l}\text { Rainfall } \\
0.9996\end{array}$ & $\begin{array}{c}\text { Effluent } \\
0.8598\end{array}$ & $\begin{array}{c}\text { Fertiliser } \\
0.7711\end{array}$ & $\begin{array}{c}\text { Irrigation } \\
0.9372\end{array}$ & $\begin{array}{c}\text { Clover N Fixation } \\
0.8255\end{array}$ \\
\hline $\begin{array}{l}\text { Brown } \\
n=3141\end{array}$ & $\begin{array}{c}\text { Rainfall } \\
0.946\end{array}$ & $\begin{array}{c}\text { Irrigation } \\
0.9297\end{array}$ & $\begin{array}{c}\text { Fertiliser } \\
0.9631\end{array}$ & $\begin{array}{c}\text { Effluent } \\
0.9763\end{array}$ & $\begin{array}{c}\text { Clover N Fixation } \\
0.963\end{array}$ \\
\hline $\begin{array}{l}\text { Gley } \\
n=1715\end{array}$ & $\begin{array}{l}\text { Rainfall } \\
0.9726\end{array}$ & $\begin{array}{c}\text { Irrigation } \\
0.9572\end{array}$ & $\begin{array}{l}\text { Effluent } \\
0.9126\end{array}$ & $\begin{array}{c}\text { Fertiliser } \\
0.9428\end{array}$ & $\begin{array}{c}\text { Clover N Fixation } \\
0.9156\end{array}$ \\
\hline $\begin{array}{l}\text { Granular } \\
n=176\end{array}$ & $\begin{array}{l}\text { Rainfall } \\
0.9922\end{array}$ & $\begin{array}{c}\text { Irrigation } \\
0.8236\end{array}$ & $\begin{array}{l}\text { Effluent } \\
0.8875\end{array}$ & $\begin{array}{c}\text { Fertiliser } \\
0.8296\end{array}$ & $\begin{array}{c}\text { Clover N Fixation } \\
0.9017\end{array}$ \\
\hline $\begin{array}{l}\text { Melanic } \\
n=192\end{array}$ & $\begin{array}{c}\text { Rainfall } \\
0.85\end{array}$ & $\begin{array}{c}\text { Irrigation } \\
0.8036 \\
\end{array}$ & $\begin{array}{c}\text { Fertiliser } \\
0.9388 \\
\end{array}$ & $\begin{array}{c}\text { Clover N Fixation } \\
0.9128 \\
\end{array}$ & $\begin{array}{c}\text { Effluent } \\
0.9275\end{array}$ \\
\hline $\begin{array}{l}\text { Organic } \\
n=287\end{array}$ & $\begin{array}{l}\text { Rainfall } \\
0.9908 \\
\end{array}$ & $\begin{array}{c}\text { Fertiliser } \\
0.8895 \\
\end{array}$ & $\begin{array}{c}\text { Effluent } \\
0.7943 \\
\end{array}$ & $\begin{array}{c}\text { Irrigation } \\
0.7321 \\
\end{array}$ & $\begin{array}{c}\text { Clover N Fixation } \\
0.892 \\
\end{array}$ \\
\hline $\begin{array}{l}\text { Oxidic } \\
n=18\end{array}$ & $\begin{array}{l}\text { Rainfall } \\
0.9794\end{array}$ & $\begin{array}{c}\text { Effluent } \\
0.9287\end{array}$ & $\begin{array}{c}\text { Fertiliser } \\
0.8779\end{array}$ & $\begin{array}{c}\text { Irrigation } \\
0.773 \\
\end{array}$ & $\begin{array}{c}\text { Clover N Fixation } \\
0.5148 \\
\end{array}$ \\
\hline $\begin{array}{l}\text { Pallic } \\
n=2801\end{array}$ & $\begin{array}{c}\text { Irrigation } \\
0.9281\end{array}$ & $\begin{array}{l}\text { Rainfall } \\
0.9397\end{array}$ & $\begin{array}{c}\text { Fertiliser } \\
0.9693\end{array}$ & $\begin{array}{c}\text { Effluent } \\
0.989\end{array}$ & $\begin{array}{c}\text { Clover N Fixation } \\
0.9826\end{array}$ \\
\hline $\begin{array}{l}\text { Podzol } \\
n=178\end{array}$ & $\begin{array}{l}\text { Rainfall } \\
0.9984\end{array}$ & $\begin{array}{c}\text { Fertiliser } \\
0.9065\end{array}$ & $\begin{array}{c}\text { Effluent } \\
0.9753\end{array}$ & $\begin{array}{c}\text { Irrigation } \\
0.9533\end{array}$ & $\begin{array}{c}\text { Clover N Fixation } \\
0.8998\end{array}$ \\
\hline $\begin{array}{l}\text { Pumice } \\
n=510\end{array}$ & $\begin{array}{l}\text { Rainfall } \\
0.9992 \\
\end{array}$ & $\begin{array}{c}\text { Effluent } \\
0.7836\end{array}$ & $\begin{array}{c}\text { Fertiliser, Effluent } \\
0.6921,0.5884\end{array}$ & $\begin{array}{c}\text { Irrigation } \\
0.9506\end{array}$ & $\begin{array}{c}\text { Clover N Fixation } \\
0.923 \\
\end{array}$ \\
\hline $\begin{array}{l}\text { Recent } \\
n=1996\end{array}$ & $\begin{array}{l}\text { Rainfall } \\
0.9867 \\
\end{array}$ & $\begin{array}{c}\text { Irrigation } \\
0.9728 \\
\end{array}$ & $\begin{array}{c}\text { Fertiliser } \\
0.9594 \\
\end{array}$ & $\begin{array}{c}\text { Effluent } \\
0.9769 \\
\end{array}$ & $\begin{array}{c}\text { Clover N Fixation } \\
0.954 \\
\end{array}$ \\
\hline $\begin{array}{l}\text { Semi Arid } \\
n=22\end{array}$ & $\begin{array}{c}\text { Irrigation, Rainfall } \\
0.7287,-0.6771 \\
\end{array}$ & $\begin{array}{c}\text { Rainfall, Irrigation } \\
0.7265,0.646\end{array}$ & $\begin{array}{c}\text { Fertiliser } \\
0.946 \\
\end{array}$ & $\begin{array}{c}\text { Clover N Fixation } \\
0.9601 \\
\end{array}$ & $\begin{array}{c}\text { Effluent } \\
0.9688 \\
\end{array}$ \\
\hline $\begin{array}{l}\text { Ultic } \\
n=252\end{array}$ & $\begin{array}{c}\text { Rainfall } \\
0.9971 \\
\end{array}$ & $\begin{array}{c}\text { Effluent } \\
0.8843\end{array}$ & $\begin{array}{c}\text { Fertiliser } \\
0.8191 \\
\end{array}$ & $\begin{array}{c}\text { Irrigation } \\
0.9917\end{array}$ & $\begin{array}{c}\text { Clover N Fixation } \\
0.9119 \\
\end{array}$ \\
\hline $\begin{array}{l}\text { All Data } \\
n=13491\end{array}$ & $\begin{array}{l}\text { Rainfall } \\
0.9806\end{array}$ & $\begin{array}{c}\text { Irrigation } \\
0.9628\end{array}$ & $\begin{array}{c}\text { Fertiliser } \\
0.9282\end{array}$ & $\begin{array}{c}\text { Effluent } \\
0.9438\end{array}$ & $\begin{array}{c}\text { Clover N Fixation } \\
0.9597\end{array}$ \\
\hline
\end{tabular}


Table 4.7 PCA1 eigenvalues for PC1-5 for N for 14 data groups using 10 variables (excluding PET)

\begin{tabular}{|c|c|c|c|c|c|}
\hline Soil Order & PC1 & PC2 & PC3 & PC4 & PC5 \\
\hline Allophanic & 224310.0 & 9579.5 & 5469.3 & 1612.1 & 1339.9 \\
\hline Brown & 263460.0 & 74240.0 & 9021.8 & 5211.1 & 2223.7 \\
\hline Gley & 159730.0 & 30565.0 & 9046.4 & 6680.8 & 2013.7 \\
\hline Granular & 466648.0 & 9621.3 & 6859.5 & 4463.4 & 1093.6 \\
\hline Melanic & 87018.0 & 37937.0 & 5814.2 & 2112.8 & 1601.3 \\
\hline Organic & 72869.0 & 7929.2 & 5329.4 & 4551.5 & 1225.3 \\
\hline Oxidic & 224350.0 & 97888.0 & 6696.3 & 3922.3 & 202.3 \\
\hline Pallic & 122880.0 & 28210.0 & 9373.2 & 3399.2 & 2254.7 \\
\hline Podzol & 458710.0 & 6026.6 & 3363.8 & 1932.2 & 1157.9 \\
\hline Pumice & 122440.0 & 7790.8 & 6529.0 & 4957.2 & 1577.0 \\
\hline Recent & 777270.0 & 100000.0 & 9545.5 & 4647.3 & 2340.2 \\
\hline Semi Arid & 117620.0 & 50964.0 & 9503.5 & 1374.9 & 742.5 \\
\hline Ultic & 50897.0 & 8008.8 & 5310.8 & 4044.7 & 1287.4 \\
\hline All Data & 360140.0 & 60136.0 & 8145.1 & 6041.6 & 2178.0 \\
\hline
\end{tabular}




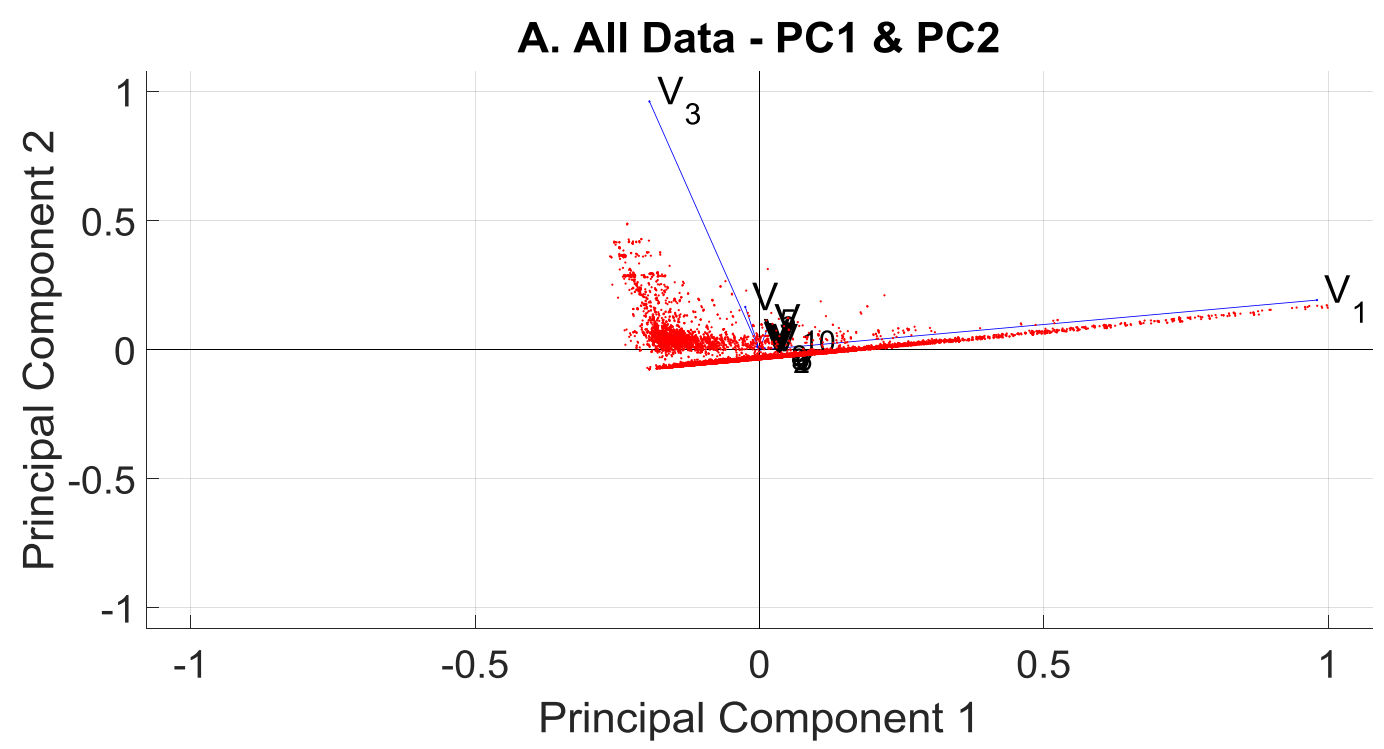

B. All Data - PC3 \& PC4

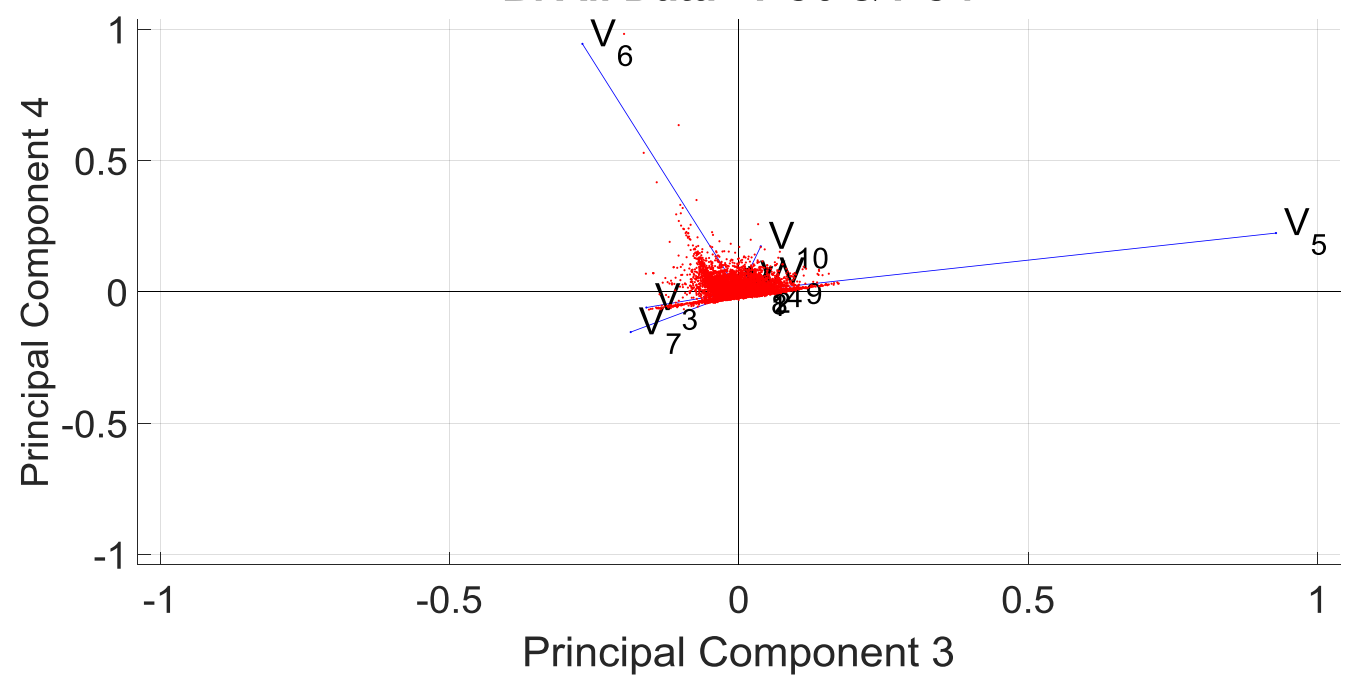

C. All Data - PC5 \& PC6

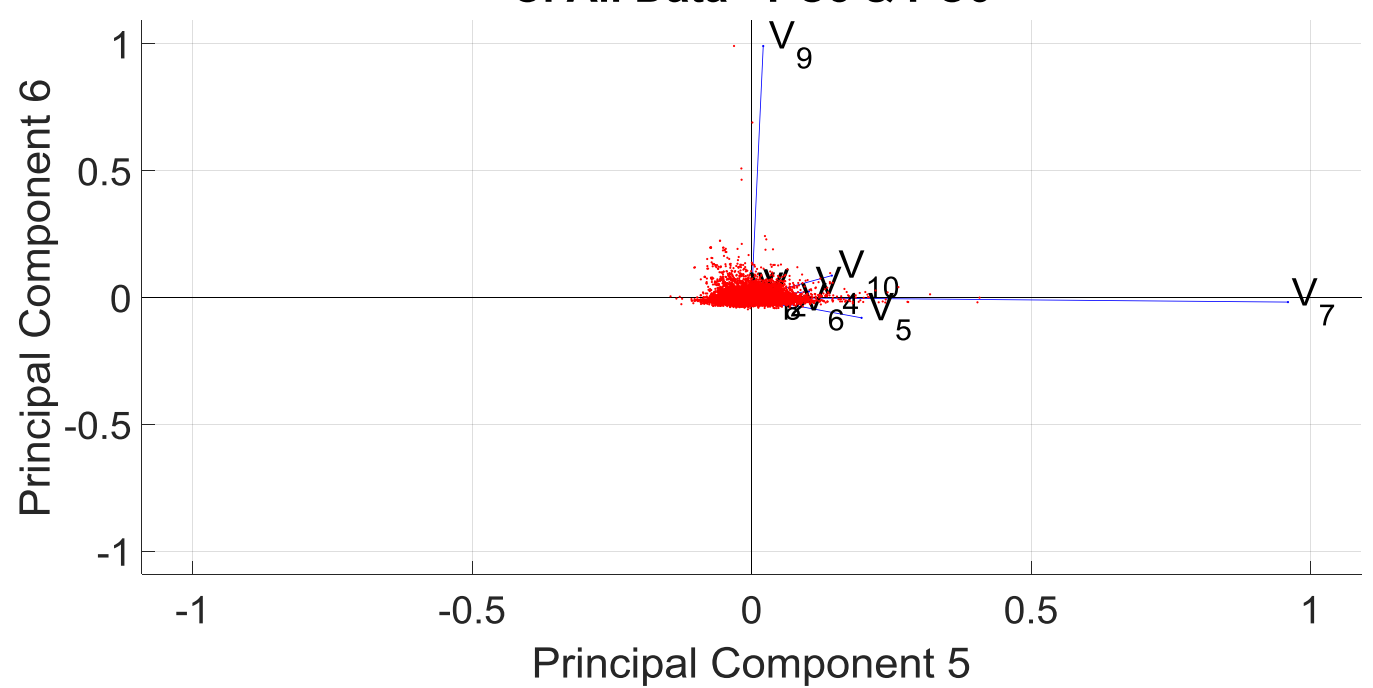

Figure 4.11 Bivariate plots of principal components 1 \& 2 (a.), 3 \& 4 (b.), and 5 \& 6 (c.) from PCA1. Variables 1-10 included in the analysis are represented by vectors $V_{1}-V_{10}$ and indicate with length and direction how each variable relates to the two principal components graphed 
PC2 is related to irrigation only for 5 soil orders (brown, gley, granular, melanic, and recent), with component coefficients ranging from 0.8036 to 0.9728 , and all data with a component coefficient of 0.9628 . For pallic soil rainfall only is related to PC2 with a component coefficient of 0.9397 , and rainfall and irrigation with component coefficients of 0.7265 and 0.646 is related to PC2 for semi-arid soils. For the 6 remaining soils (allophanic, organic, oxidic, podzol, pumice, recent and ultic), PC2 is fertiliser or effluent with component coefficients of 0.7836 to 0.9287 ) and irrigation is related to PC4. Allophanic, oxidic, podzols and pumice soils tend to be located in higher rainfall areas and organic and ultic soils tend to retain higher soil water content. Therefore, irrigation is likely less required and used on these soil orders, so shows less variability. Remaining PCs feature some combination of $\mathrm{N}$ inputs via fertiliser, effluent and clover $\mathrm{N}$ fixation. Differences in $\mathrm{PC}$ rankings of these variables for individual soil orders likely reflects the farm types and intensities found on these soils. For the 'all data' group, PC1-5 are rainfall, irrigation, fertiliser, effluent and clover fixation. Figure 4.11 confirms PC1-5 for all data are rainfall $\left(\mathrm{V}_{1}\right)$, irrigation $\left(\mathrm{V}_{3}\right)$, fertiliser $\left(V_{5}\right)$, effluent $\left(V_{6}\right)$ and clover $N$ fixation $\left(V_{7}\right)$.

Table 4.8 indicates for PCA2 that rainfall is PC1 for allophanic, brown, gley, granular, organic, oxidic, podzol, pumice, recent, ultic soils and all data all soil orders, with component coefficients of 0.9091 to 0.9993 . For pallic and semi-arid soils PC1 is irrigation with component coefficients of 0.9376 and 0.855 , and for melanic soils PC1 is related to rainfall and irrigation with component coefficients of 0.7469 and -0.608 . PET is present in the first five PCs for all soil orders, but this ranges from PC2 to PC5 indicating variable importance from soil to soil. PET is related to PC2 for podzol, semi-arid and ultic soil orders, to PC3 for brown, gley, melanic, pumice, semi-arid, and all data soil orders, to PC4 for allophanic, granular, pallic, and recent soil orders, and PC5 for granular and oxidic soil orders. Clearly PET influences data variance, but it is not clear there is a particular pattern of importance for soil orders based on climate or soil moisture variables. Like PCA1, the remaining PC's relate to fertiliser, effluent, and clover fixation and results for oxidic and semi-arid soil orders should be viewed with some caution due to low sample sizes. For the 'all data' group, PC1-5 are rainfall, irrigation, PET, fertiliser and effluent. Figure 4.12 confirms this showing rainfall as $V_{1}$, irrigation as $V_{4}$, PET as $V_{2}$, fertiliser as $V_{6}$ and effluent as $V_{7}$. 
Table 4.8 PCA2 variables and component coefficients related to PC1-5 for N for 14 data groups using 11 variables (including PET)

\begin{tabular}{|c|c|c|c|c|c|}
\hline Soil Order & PC1 & PC2 & PC3 & PC4 & PC5 \\
\hline $\begin{array}{l}\text { Allophanic } \\
n=1030\end{array}$ & $\begin{array}{l}\text { Rainfall } \\
0.9993\end{array}$ & $\begin{array}{l}\text { Effluent } \\
0.8622\end{array}$ & $\begin{array}{c}\text { Fertiliser } \\
0.7728\end{array}$ & $\begin{array}{c}\text { PET } \\
0.9933\end{array}$ & $\begin{array}{c}\text { Clover N Fixation } \\
0.8103\end{array}$ \\
\hline $\begin{array}{l}\text { Brown } \\
n=2065\end{array}$ & $\begin{array}{l}\text { Rainfall } \\
0.9091\end{array}$ & $\begin{array}{c}\text { Irrigation } \\
0.8943\end{array}$ & $\begin{array}{c}\text { PET } \\
0.9014 \\
\end{array}$ & $\begin{array}{c}\text { Fertiliser } \\
0.8607\end{array}$ & $\begin{array}{l}\text { Effluent } \\
0.9731\end{array}$ \\
\hline $\begin{array}{l}\text { Gley } \\
n=1239\end{array}$ & $\begin{array}{l}\text { Rainfall } \\
0.9474\end{array}$ & $\begin{array}{c}\text { Irrigation } \\
0.9348\end{array}$ & $\begin{array}{c}\text { PET } \\
0.9807\end{array}$ & $\begin{array}{c}\text { Fertiliser } \\
0.8444\end{array}$ & $\begin{array}{c}\text { Effluent } \\
0.8828\end{array}$ \\
\hline $\begin{array}{l}\text { Granular } \\
n=132\end{array}$ & $\begin{array}{l}\text { Rainfall } \\
0.9825\end{array}$ & $\begin{array}{c}\text { Effluent, Irrigation } \\
0.6688,-0.6557\end{array}$ & $\begin{array}{c}\text { Effluent, Irrigation } \\
0.6736,0.659\end{array}$ & $\begin{array}{l}\text { PET, Fertiliser } \\
0.666,0.6192\end{array}$ & $\begin{array}{c}\text { PET, Fertiliser } \\
0.7062,-0.6258\end{array}$ \\
\hline $\begin{array}{l}\text { Melanic } \\
n=150\end{array}$ & $\begin{array}{c}\text { Rainfall, Irrigation } \\
0.7469,-0.608\end{array}$ & $\begin{array}{c}\text { Irrigation, Rainfall } \\
0.743,0.6186\end{array}$ & $\begin{array}{c}\text { PET } \\
0.8688 \\
\end{array}$ & $\begin{array}{c}\text { Fertiliser } \\
0.8298\end{array}$ & $\begin{array}{c}\text { Clover N Fixation } \\
0.7688 \\
\end{array}$ \\
\hline $\begin{array}{l}\text { Organic } \\
n=183\end{array}$ & $\begin{array}{l}\text { Rainfall } \\
0.9816 \\
\end{array}$ & $\begin{array}{c}\text { Fertiliser } \\
0.9077 \\
\end{array}$ & $\begin{array}{c}\text { Irrigation } \\
0.7776 \\
\end{array}$ & $\begin{array}{c}\text { Irrigation, Effluent } \\
0.6946,-0.574\end{array}$ & $\begin{array}{c}\text { PET } \\
0.8571 \\
\end{array}$ \\
\hline $\begin{array}{l}\text { Oxidic } \\
n=11\end{array}$ & $\begin{array}{l}\text { Rainfall } \\
0.9798 \\
\end{array}$ & $\begin{array}{c}\text { Fertiliser } \\
0.8577\end{array}$ & $\begin{array}{c}\text { Irrigation, Rainfall } \\
0.6044,-0.4781\end{array}$ & $\begin{array}{c}\text { Effluent } \\
0.8658\end{array}$ & $\begin{array}{c}\text { PET, Clover N Fix } \\
0.7454,-0.4168\end{array}$ \\
\hline $\begin{array}{l}\text { Pallic } \\
n=1886\end{array}$ & $\begin{array}{c}\text { Irrigation } \\
0.9376\end{array}$ & $\begin{array}{l}\text { Rainfall } \\
0.9466\end{array}$ & $\begin{array}{c}\text { Fertiliser } \\
0.8807\end{array}$ & $\begin{array}{c}\text { PET } \\
0.9001\end{array}$ & $\begin{array}{l}\text { Effluent } \\
0.9854\end{array}$ \\
\hline $\begin{array}{l}\text { Podzol } \\
n=85\end{array}$ & $\begin{array}{l}\text { Rainfall } \\
0.9944\end{array}$ & $\begin{array}{c}\text { PET } \\
0.9529\end{array}$ & $\begin{array}{c}\text { Fertiliser } \\
0.885\end{array}$ & $\begin{array}{l}\text { Effluent } \\
0.966\end{array}$ & $\begin{array}{c}\text { Irrigation } \\
0.9494\end{array}$ \\
\hline $\begin{array}{l}\text { Pumice } \\
n=210\end{array}$ & $\begin{array}{l}\text { Rainfall } \\
0.9966 \\
\end{array}$ & $\begin{array}{c}\text { Fertiliser } \\
0.7949 \\
\end{array}$ & $\begin{array}{c}\text { PET } \\
0.8076\end{array}$ & $\begin{array}{c}\text { Effluent } \\
0.821 \\
\end{array}$ & $\begin{array}{c}\text { Irrigation } \\
0.8607\end{array}$ \\
\hline $\begin{array}{l}\text { Recent } \\
n=1343\end{array}$ & $\begin{array}{l}\text { Rainfall } \\
0.9815 \\
\end{array}$ & $\begin{array}{c}\text { Irrigation } \\
0.968 \\
\end{array}$ & $\begin{array}{c}\text { Fertiliser } \\
0.9236 \\
\end{array}$ & $\begin{array}{c}\text { PET } \\
0.9503 \\
\end{array}$ & $\begin{array}{l}\text { Effluent } \\
0.9756\end{array}$ \\
\hline $\begin{array}{l}\text { Semi Arid } \\
n=14\end{array}$ & $\begin{array}{c}\text { Irrigation } \\
0.855 \\
\end{array}$ & $\begin{array}{l}\text { Fertiliser, PET } \\
0.626,0.4925 \\
\end{array}$ & $\begin{array}{l}\text { PET, Fertiliser } \\
0.684,-0.6829\end{array}$ & $\begin{array}{c}\text { Effluent } \\
0.9071\end{array}$ & $\begin{array}{c}\text { Clover N Fix, Rainfall } \\
0.7056,0.5189\end{array}$ \\
\hline $\begin{array}{l}\text { Ultic } \\
n=113\end{array}$ & $\begin{array}{l}\text { Rainfall } \\
0.9788 \\
\end{array}$ & $\begin{array}{l}\text { PET, Effluent } \\
0.7248,0.646\end{array}$ & $\begin{array}{c}\text { Fertiliser, Effluent, Rainfall } \\
0.6143,-0.555,0.535\end{array}$ & $\begin{array}{c}\text { Fertiliser, Effluent } \\
0.7065,0.4556\end{array}$ & $\begin{array}{c}\text { Irrigation } \\
0.9891\end{array}$ \\
\hline $\begin{array}{l}\text { All Data } \\
n=8461\end{array}$ & $\begin{array}{l}\text { Rainfall } \\
0.9599\end{array}$ & $\begin{array}{c}\text { Irrigation } \\
0.9439\end{array}$ & $\begin{array}{c}\text { PET } \\
0.8337\end{array}$ & $\begin{array}{c}\text { Fertiliser } \\
0.7902\end{array}$ & $\begin{array}{l}\text { Effluent } \\
0.9782\end{array}$ \\
\hline
\end{tabular}


Table 4.9 PCA2 eigenvalues for PC1-5 for N for 14 data groups using 11 variables (including PET)

\begin{tabular}{|c|c|c|c|c|c|}
\hline Soil Order & PC1 & PC2 & PC3 & PC4 & PC5 \\
\hline Allophanic & 211310.0 & 8915.7 & 6386.4 & 4463.3 & 1467.1 \\
\hline Brown & 238810.0 & 75469.0 & 10373.0 & 9352.1 & 5358.4 \\
\hline Gley & 118170.0 & 31891.0 & 9423.1 & 7516.9 & 5291.9 \\
\hline Granular & 46274.0 & 9580.0 & 7357.4 & 4003.3 & 3258.5 \\
\hline Melanic & 98200.0 & 36867.0 & 9597.0 & 5498.0 & 2324.2 \\
\hline Organic & 52475.0 & 8210.2 & 5546.9 & 5218.9 & 3645.2 \\
\hline Oxidic & 353900.0 & 10060.0 & 4610.5 & 1182.6 & 725.4 \\
\hline Pallic & 134570.0 & 26282.0 & 10562.0 & 8070.5 & 3413.0 \\
\hline Podzol & 322500.0 & 1117.3 & 6685.2 & 4119.8 & 1967.9 \\
\hline Pumice & 70095.0 & 8527.3 & 7348.4 & 5064.8 & 4446.0 \\
\hline Recent & 632080.0 & 111200.0 & 10663.0 & 8132.6 & 4107.5 \\
\hline Semi Arid & 48909.0 & 14241.0 & 4891.5 & 994.2 & 669.9 \\
\hline Ultic & 57941.0 & 8484.6 & 8177.9 & 5489.8 & 3072.9 \\
\hline All Data & 287820.0 & 69726.0 & 10052.0 & 8420.6 & 5764.1 \\
\hline
\end{tabular}



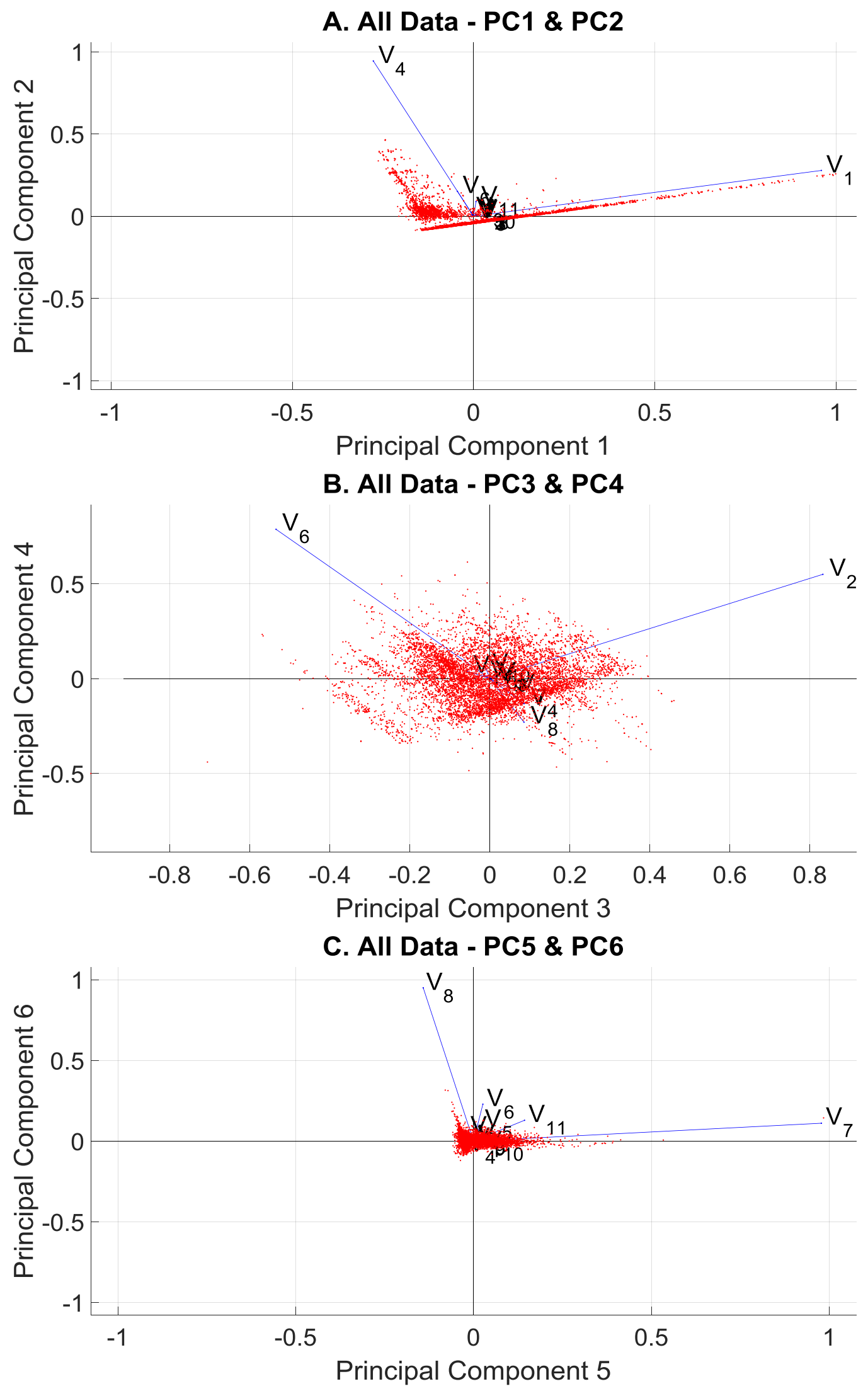

Figure 4.12 Bivariate plots of principal components 1 \& 2 (a.), 3 \& 4 (b.), and 5 \& 6 (c.) from $P C A 2$. Variables $1-11$ included in the analysis are represented by vectors $V_{1}-V_{11}$ and indicate with length and direction how each variable relates to the two principal components graphed. 
This analysis confirms the central role of hydrology and $\mathrm{N}$ inputs in the OVERSEER $\mathrm{N}$ model. In particular, rainfall, irrigation, fertiliser and effluent, as explored in Section 4.2.3, are principle components within the Ravensdown dataset and should remain in any further analysis and be included in the developed $\mathrm{N}$ algorithm. This analysis also suggests PET and clover fixation are influential and should also possibly be included in the $\mathrm{N}$ algorithm.

Barriers to inclusion of PET and clover fixation exist though. Neither variable is easily measured by model users. In OVERSEER clover $\mathrm{N}$ fixation is estimated internally based on user identified pasture block clover level (very low, low, medium, high, very high) (Wheeler 2016d). As described above, PET is either user identified or a regional default value is used. Where user defined PET is entered, it will be an estimate based on observed climate data and it is uncertain who has calculated the entered PET or where it is from. Additionally, where default PET is used, it is not recorded in the Ravensdown data. This means only blocks with user identified PET can be used for parameterisation if PET is included in the N algorithm. This could be particularly problematic for oxidic and semi-arid soils, which already have very few samples. Therefore, at this stage $\mathrm{N}$ fixation and PET are not considered further here, but could be included in future iterations of the $\mathrm{N}$ algorithms.

Conversely, RSU is included in bivariate analysis in Section 4.2.3, yet does not feature in the first 5 PC's for any soil order. It may be argued that stock numbers must be supported by enough feed, which is already represented by inclusion of water and $\mathrm{N}$ inputs and certainly co-dependence between these variables and stocking rate must be acknowledged. However, changes to RSU also represent an important mitigation strategy. Inclusion of this element in the algorithm is an obvious method of accounting for and modelling changes to $\mathrm{N}$ loss as a result of changes in stocking rate. For this reason it will be included in the developed $\mathrm{N}$ algorithm.

\section{Phosphorus}

The third PCA (PCA3) is carried out on all pastoral blocks in each data group using 10 variables (topography, rainfall, irrigation added, Olsen P, RSU, P added in fertiliser $\mathrm{P}$, effluent $P, P$ in irrigation water, supplemental feed $P$, and $P$ loss to water). Table 4.10 summarises the first 5 PC and associated component coefficients for each of the 14 data groups from PCA3. Table 4.11 presents eigenvalues for the first 5 PC in each of the 14 data groups from PCA3. Figure 4.13 shows bivariate plots of principal components 1-5 from PCA3 
for all data (i.e. data is not separated by soil order). The ten variables included in the analysis (in the order listed above) are represented by vectors $\mathrm{V}_{1}-\mathrm{V}_{10}$. Vector length and direction show how each variable relates to the two principal components graphed.

PC1 and PC2 comprise water inputs for all soil orders with rainfall as PC1 for allophanic, brown, gley, granular, melanic, organic, oxidic, podzol, pumice, recent, ultic soils and all data, with component coefficients ranging from $0.8666-1$. For pallic soils irrigation is PC1 with a component coefficient of 0.9408 . For semi-arid soils irrigation and rainfall are related to PC1 with component coefficients of 0.724 and -0.6897 . Again, this is not surprising given the prevalence of irrigation use on these soils. PC3-5 is some combination of fertiliser $\mathrm{P}$, effluent $\mathrm{P}$ and Olsen $\mathrm{P}$ for most soil orders. Although, $\mathrm{P}$ inputs from supplemental feed relate to PC4 for allophanic soils, to a lesser degree, but along with Olsen P. This likely reflects a number of farms with particularly high supplemental feed inputs on these soils. RSU relates to PC5 or PC4, for brown, melanic, pallic and semiarid soils. This is surprising given RSU is not included in the OVERSEER P model. PC1-5 for the 'all data' group are rainfall, irrigation, fertiliser, Olsen $\mathrm{P}$ and effluent. Figure 4.13 confirms this showing rainfall as $V_{2}$, irrigation as $V_{3}$, fertiliser as $V_{6}$, Olsen $P$ as $V_{4}$ and effluent as $V_{7}$.

Again, this analysis confirms the central role of rainfall, irrigation, fertiliser, effluent and soil properties such as Olsen P in the OVERSEER P model. However, topography, which McDowell et al (2005) and Watkins \& Selbie (2015) indicate is important in OVERSEER's P model, does not feature in PC1-5 for any soil order. This is likely due to a clear bias towards flatter land within the pastoral data. Within the dataset, the percent of blocks in each of the four slope categories of flat, rolling, easy hill and steep hill are $74 \%, 19 \%, 6 \%$ and $1 \%$, respectively, so little topographic variability is evident. Conversely, stocking rate, which is not mentioned in the OVERSEER P model literature, is PC4 and/or 5 for brown, melanic, pallic and semi-arid soils. It is unclear why this pattern emerges for these soils - possibly due to the range of farm types featured. Bivariate analysis of stocking rate changes, at 4 slope values, on P losses using OVERSEER indicates RSU does not influence P losses (Figure 4.14), yet topography does. Therefore RSU is not considered for inclusion in the P algorithms, while topography is. . 
Table 4.10 PCA3 variables and component coefficients related to PC1-5 for P for 14 data groups using 11 variables

\begin{tabular}{|c|c|c|c|c|c|}
\hline Soil Order & PC1 & PC2 & PC3 & PC4 & PC5 \\
\hline $\begin{array}{l}\text { Allophanic } \\
n=2203\end{array}$ & $\begin{array}{c}\text { Rainfall } \\
1 \\
\end{array}$ & $\begin{array}{c}\text { Irrigation } \\
0.9993 \\
\end{array}$ & $\begin{array}{c}\text { Fertiliser } \\
0.9004 \\
\end{array}$ & $\begin{array}{c}\text { Olsen } \mathrm{P}, \text { Supp Feed } \\
0.7229,0.5668\end{array}$ & $\begin{array}{c}\text { Effluent } \\
0.9662 \\
\end{array}$ \\
\hline $\begin{array}{l}\text { Brown } \\
n=3141\end{array}$ & $\begin{array}{l}\text { Rainfall } \\
0.9484\end{array}$ & $\begin{array}{c}\text { Irrigation } \\
0.9483\end{array}$ & $\begin{array}{c}\text { Fertiliser } \\
0.9846\end{array}$ & $\begin{array}{c}\text { RSU, Olsen P } \\
0.7093,0.6121\end{array}$ & $\begin{array}{c}\text { RSU, Olsen P } \\
0.6853,-0.6695\end{array}$ \\
\hline $\begin{array}{l}\text { Gley } \\
n=1715\end{array}$ & $\begin{array}{l}\text { Rainfall } \\
0.9738\end{array}$ & $\begin{array}{c}\text { Irrigation } \\
0.9737\end{array}$ & $\begin{array}{c}\text { Fertiliser } \\
0.9019\end{array}$ & $\begin{array}{l}\text { Olsen P } \\
0.7688\end{array}$ & $\begin{array}{c}\text { Effluent } \\
0.864\end{array}$ \\
\hline $\begin{array}{l}\text { Granular } \\
n=176\end{array}$ & $\begin{array}{l}\text { Rainfall } \\
0.994\end{array}$ & $\begin{array}{c}\text { Irrigation } \\
0.9941\end{array}$ & $\begin{array}{c}\text { Fertiliser, Effluent } \\
0.6201,-0.5505\end{array}$ & $\begin{array}{l}\text { Effluent } \\
0.8127\end{array}$ & $\begin{array}{c}\text { Fertiliser, Olsen } \mathrm{P} \\
0.7378,0.5909\end{array}$ \\
\hline $\begin{array}{l}\text { Melanic } \\
n=192\end{array}$ & $\begin{array}{l}\text { Rainfall } \\
0.8666 \\
\end{array}$ & $\begin{array}{c}\text { Irrigation } \\
0.8661 \\
\end{array}$ & $\begin{array}{l}\text { Olsen } \mathrm{P} \\
0.7766 \\
\end{array}$ & $\begin{array}{c}\text { Fertiliser } \\
0.79\end{array}$ & $\begin{array}{c}\text { Effluent, RSU } \\
0.6447,0.4489\end{array}$ \\
\hline $\begin{array}{l}\text { Organic } \\
n=287\end{array}$ & $\begin{array}{l}\text { Rainfall } \\
0.9911 \\
\end{array}$ & $\begin{array}{c}\text { Irrigation } \\
0.991 \\
\end{array}$ & $\begin{array}{c}\text { Fertiliser } \\
0.7644 \\
\end{array}$ & $\begin{array}{c}\text { Olsen } \mathrm{P}, \text { Fertiliser } \\
0.7117,0.6327\end{array}$ & $\begin{array}{l}\text { Effluent } \\
0.9845\end{array}$ \\
\hline $\begin{array}{l}\text { Oxidic } \\
n=18\end{array}$ & $\begin{array}{c}\text { Rainfall } \\
0.9913 \\
\end{array}$ & $\begin{array}{c}\text { Irrigation } \\
0.8093 \\
\end{array}$ & $\begin{array}{c}\text { Effluent } \\
0.8145\end{array}$ & $\begin{array}{c}\text { Fertiliser } \\
0.9822 \\
\end{array}$ & $\begin{array}{l}\text { Olsen P } \\
0.7913\end{array}$ \\
\hline $\begin{array}{l}\text { Pallic } \\
n=2801\end{array}$ & $\begin{array}{c}\text { Irrigation } \\
0.9408\end{array}$ & $\begin{array}{l}\text { Rainfall } \\
0.9408\end{array}$ & $\begin{array}{c}\text { Fertiliser } \\
0.9992\end{array}$ & $\begin{array}{l}\text { Olsen P } \\
0.8266\end{array}$ & $\begin{array}{c}\text { RSU, Olsen P } \\
0.6999,-0.5393\end{array}$ \\
\hline $\begin{array}{l}\text { Podzol } \\
n=178\end{array}$ & $\begin{array}{l}\text { Rainfall } \\
0.9999\end{array}$ & $\begin{array}{c}\text { Irrigation } \\
0.9993\end{array}$ & $\begin{array}{c}\text { Fertiliser } \\
0.9411\end{array}$ & $\begin{array}{l}\text { Olsen P } \\
0.8599\end{array}$ & $\begin{array}{l}\text { Effluent } \\
0.9583\end{array}$ \\
\hline $\begin{array}{l}\text { Pumice } \\
n=510\end{array}$ & $\begin{array}{l}\text { Rainfall } \\
0.9994 \\
\end{array}$ & $\begin{array}{c}\text { Irrigation } \\
0.9991 \\
\end{array}$ & $\begin{array}{l}\text { Olsen } \mathrm{P} \\
0.8276 \\
\end{array}$ & $\begin{array}{c}\text { Fertiliser } \\
0.8781 \\
\end{array}$ & $\begin{array}{c}\text { Effluent } \\
0.9754\end{array}$ \\
\hline $\begin{array}{l}\text { Recent } \\
n=1996\end{array}$ & $\begin{array}{l}\text { Rainfall } \\
0.9868 \\
\end{array}$ & $\begin{array}{c}\text { Irrigation } \\
0.9867 \\
\end{array}$ & $\begin{array}{c}\text { Fertiliser } \\
0.9994 \\
\end{array}$ & $\begin{array}{l}\text { Olsen P } \\
0.8868\end{array}$ & $\begin{array}{c}\text { Effluent } \\
0.908\end{array}$ \\
\hline $\begin{array}{l}\text { Semi Arid } \\
n=22\end{array}$ & $\begin{array}{c}\text { Irrigation, Rainfall } \\
0.724,-0.6897\end{array}$ & $\begin{array}{c}\text { Rainfall, Irrigation } \\
0.7238,0.6894 \\
\end{array}$ & $\begin{array}{c}\text { Fertiliser } \\
0.9639 \\
\end{array}$ & $\begin{array}{c}\text { Olsen P, RSU } \\
0.7205,-0.6522\end{array}$ & $\begin{array}{c}\text { RSU, Olsen P } \\
0.6888,0.5952\end{array}$ \\
\hline $\begin{array}{l}\text { Ultic } \\
n=252\end{array}$ & $\begin{array}{l}\text { Rainfall } \\
0.9978\end{array}$ & $\begin{array}{c}\text { Irrigation } \\
0.9976 \\
\end{array}$ & $\begin{array}{c}\text { Fertiliser, Olsen P } \\
0.7111,-0.6574\end{array}$ & $\begin{array}{c}\text { Olsen } \mathrm{P}, \text { Fertiliser } \\
0.7228,0.6385\end{array}$ & $\begin{array}{c}\text { Effluent } \\
0.9582\end{array}$ \\
\hline $\begin{array}{l}\text { All Data } \\
n=13491\end{array}$ & $\begin{array}{l}\text { Rainfall } \\
0.9811\end{array}$ & $\begin{array}{c}\text { Irrigation } \\
0.981\end{array}$ & $\begin{array}{c}\text { Fertiliser } \\
0.9934\end{array}$ & $\begin{array}{c}\text { Olsen P } \\
0.784\end{array}$ & $\begin{array}{l}\text { Effluent } \\
0.9536\end{array}$ \\
\hline
\end{tabular}


Table 4.11 PCA3 eigenvalues for PC1-5 for P for 14 data groups using 11 variables

\begin{tabular}{|c|c|c|c|c|c|}
\hline Soil Order & PC1 & PC2 & PC3 & PC4 & PC5 \\
\hline Allophanic & 224130.0 & 1579.6 & 504.7 & 365.8 & 154.5 \\
\hline Brown & 272590.0 & 72085.0 & 310.3 & 189.4 & 116.2 \\
\hline Gley & 159450.0 & 29848.0 & 325.6 & 191.7 & 150.5 \\
\hline Granular & 46497.0 & 8364.3 & 352.4 & 242.6 & 191.3 \\
\hline Melanic & 85782.0 & 35226.0 & 245.9 & 203.1 & 61.9 \\
\hline Organic & 72827.0 & 5029.8 & 471.7 & 228.3 & 83.4 \\
\hline Oxidic & 220750.0 & 3183.7 & 1806.7 & 157.1 & 20.5 \\
\hline Pallic & 119690.0 & 28004.0 & 939.5 & 128.6 & 53.2 \\
\hline Podzol & 457350.0 & 2215.8 & 495.6 & 167.4 & 80.9 \\
\hline Pumice & 122380.0 & 4989.3 & 639.6 & 330.7 & 148.2 \\
\hline Recent & 776950.0 & 97384.0 & 1569.7 & 150.4 & 71.4 \\
\hline Semi Arid & 116510.0 & 48624.0 & 246.2 & 57.2 & 32.5 \\
\hline Ultic & 50831.0 & 4022.9 & 320.7 & 200.6 & 113.0 \\
\hline All Data & 359820.0 & 58238.0 & 634.2 & 295.7 & 107.3 \\
\hline
\end{tabular}



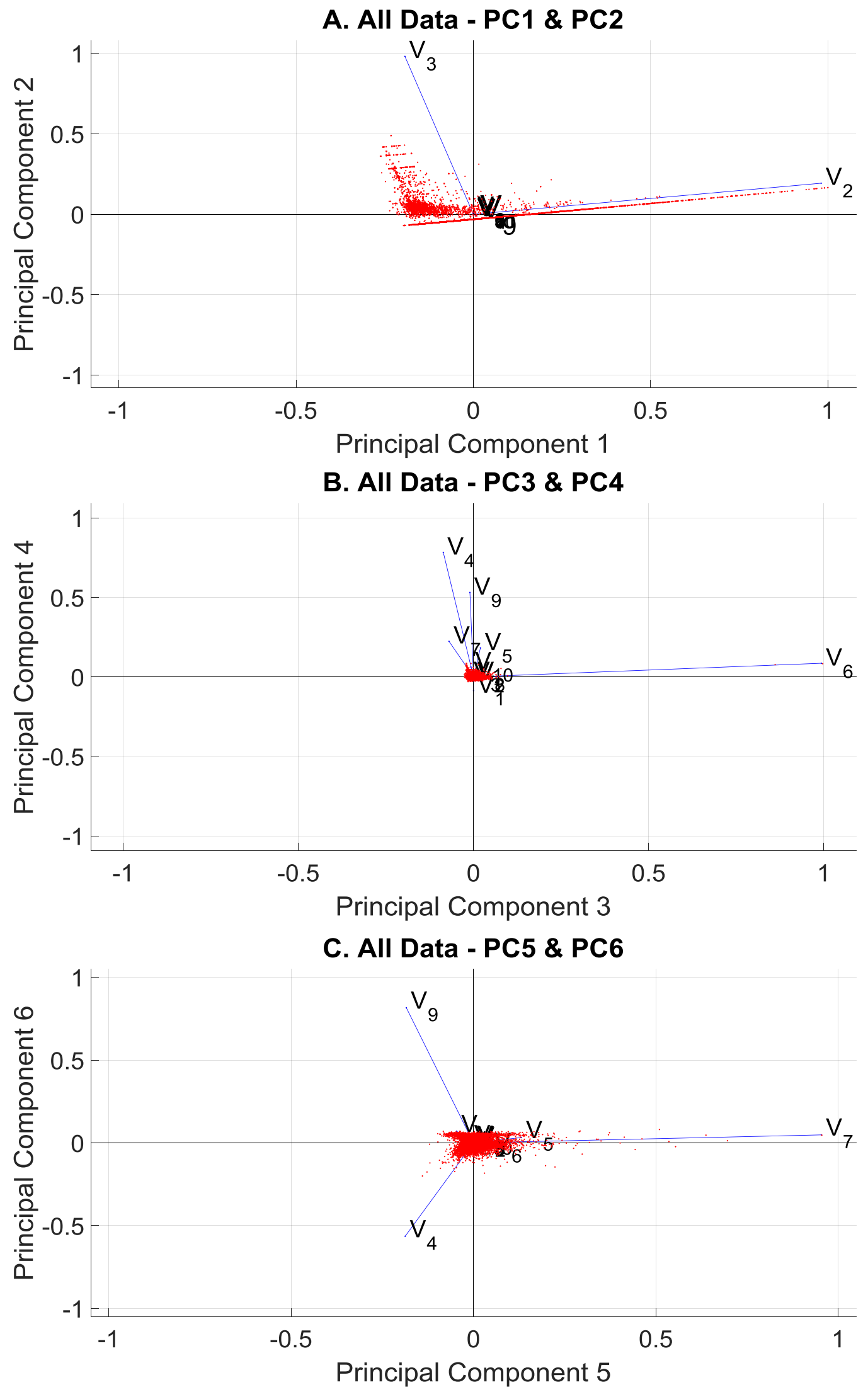

Figure 4.13 Bivariate plots of principal components 1 \& 2 (а.), 3 \& 4 (b.), and 5 \& 6 (c.) from PCA3. Variables 1-10 included in the analysis are represented by vectors $V_{1}-V_{10}$ and indicate with length and direction how each variable relates to the two principal components graphed. 

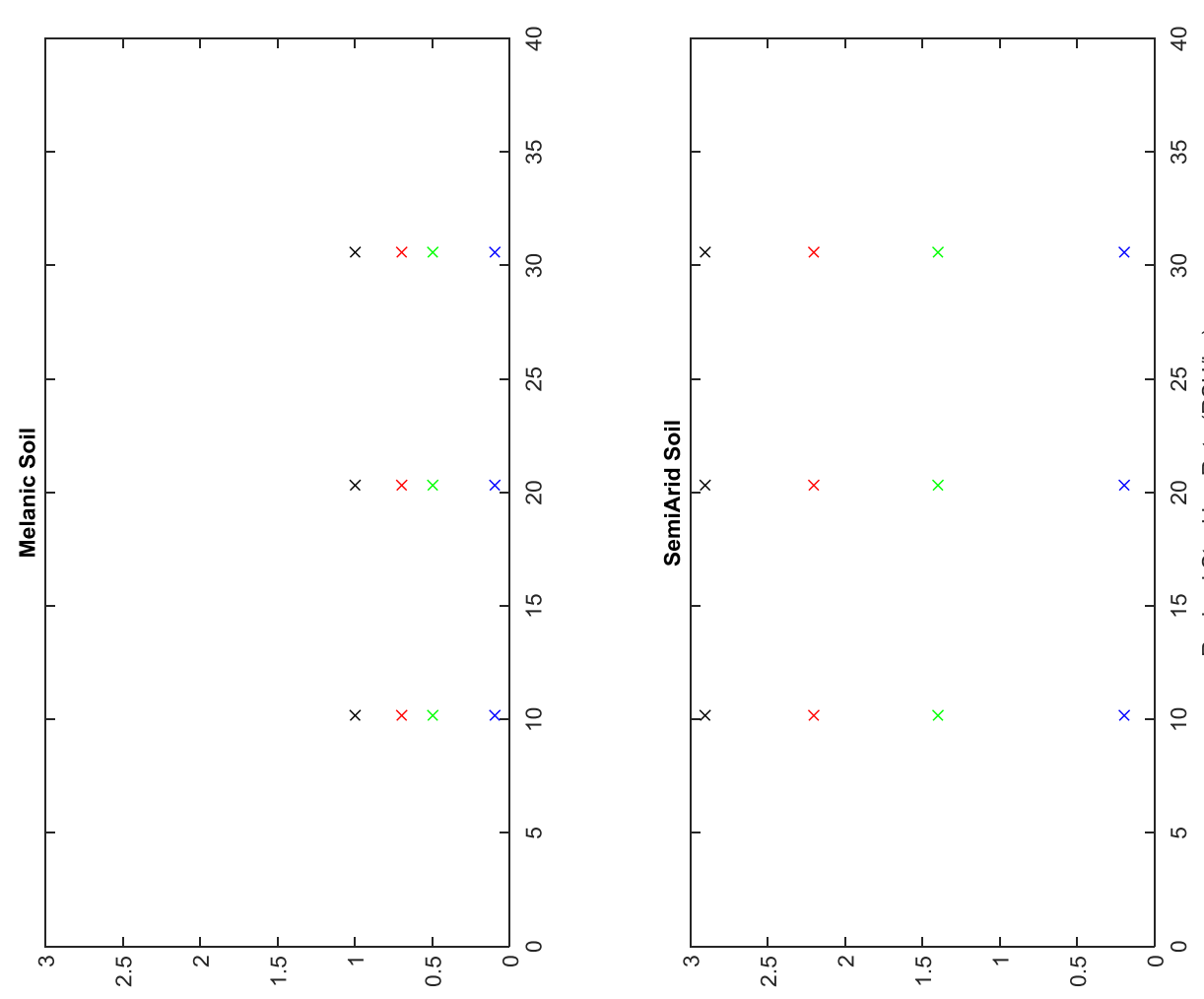

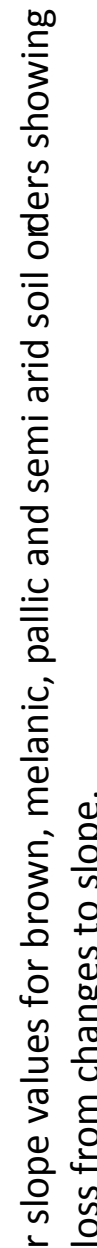
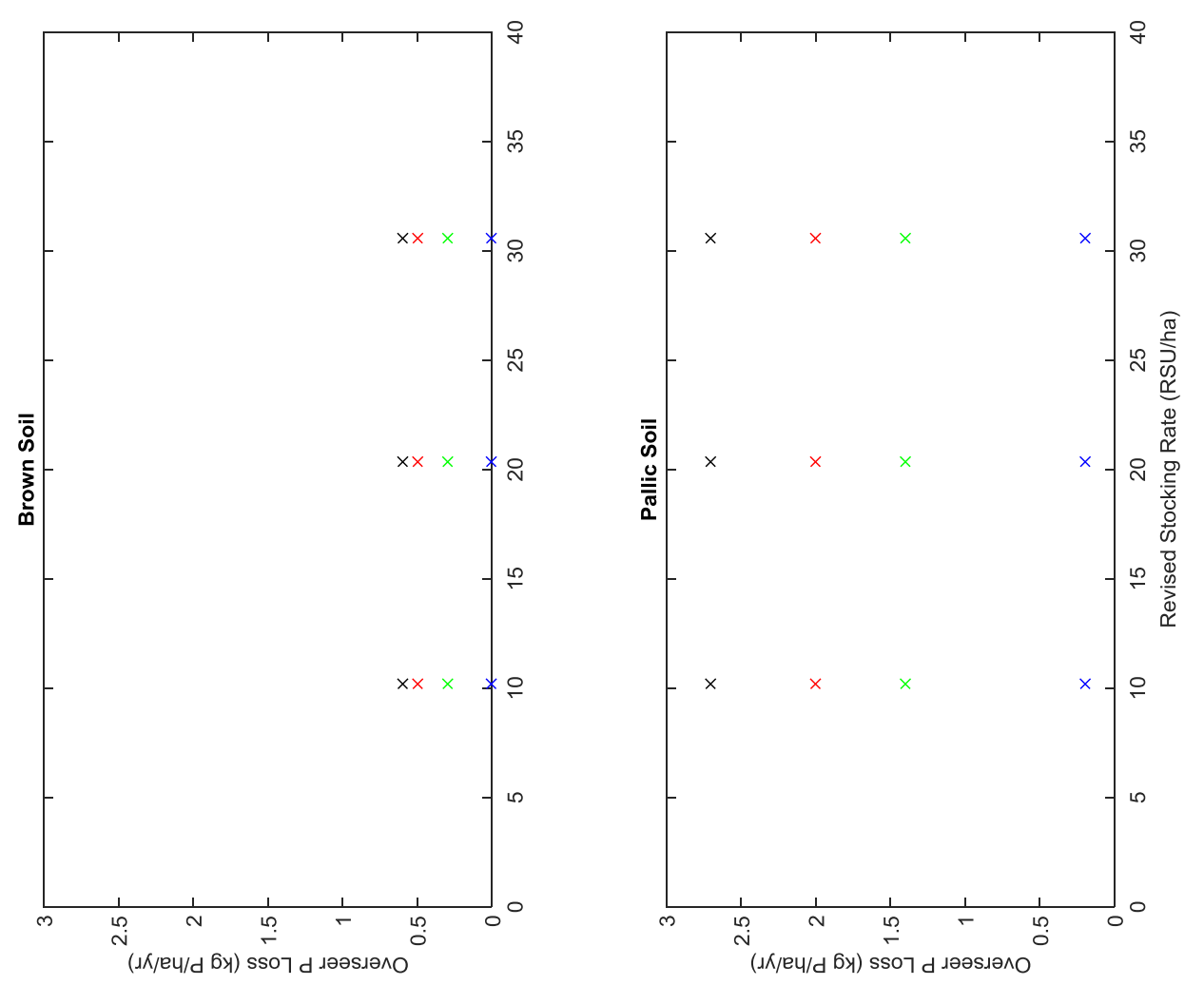

亏음

$+4$

วิ

$4 \frac{1}{0}$

ธ

正

ำ

苟

นิㅇ

a

일

ป

ह ํํㅇ

는

㟧苍

뚠

ว 잉

$\forall \mathrm{U}$

군

ํㅡㄴ 


\subsubsection{Bivariate Analysis of Ravensdown Pastoral Data}

In this section the Ravensdown pastoral data is further explored. Bivariate relationships between $\mathrm{N}$ or $\mathrm{P}$ loss and the influential variables identified in Sections 4.2.2 and 4.3.1 are investigated using 14 data groups - 13 for each soil order represented in the Ravensdown data and one for all data together. Of particular interest is whether the bivariate relationships, identified in Section 4.2.2, are seen in the Ravensdown data.

\section{Nitrogen}

The effects of rainfall, irrigation, fertiliser $\mathrm{N}$, effluent $\mathrm{N}$ and RSU on $\mathrm{N}$ losses to water are graphed using the 14 data groups from the Ravensdown pastoral dataset. Rainfall was initially investigated separately to irrigation. However, as Figure 4.15a indicates, for many soil orders a cluster of high $\mathrm{N}$ losses at low rainfall values is evident. Further investigation revealed these blocks are irrigated. A stronger relationship is seen when rainfall and irrigation are added and plotted against $\mathrm{N}$ losses (Figure 4.15b). Figure 4.16 features rainfall plus irrigation plotted against $\mathrm{N}$ loss for data within each soil order and all data together. In all cases positive relationships are seen - as rainfall plus irrigation increases, $\mathrm{N}$ losses increase. A sublinear relationship, as indicated in Figure 4.4, could be fitted to this data. However, high variance is clear.

(a)

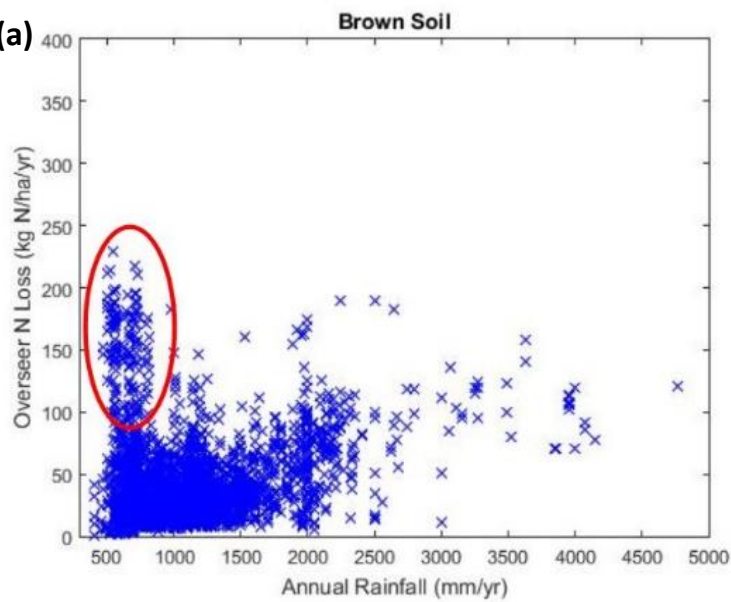

(b)

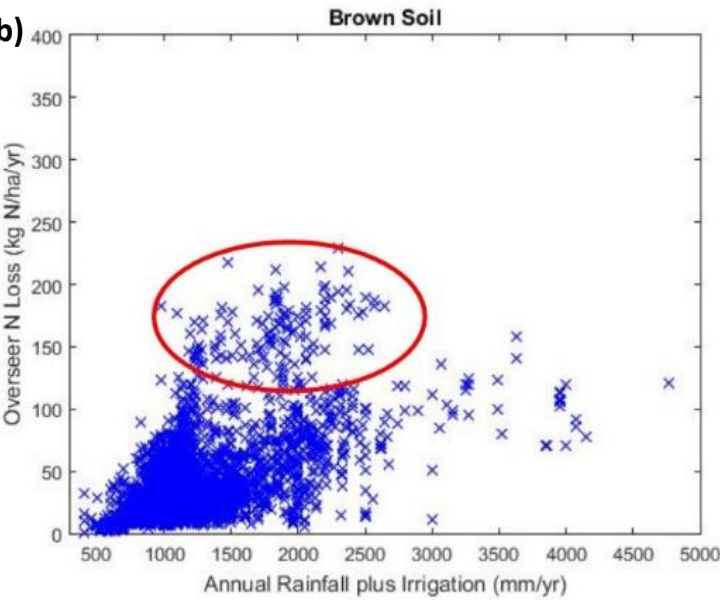

Figure 4.15 a. Rainfall plotted against $\mathrm{N}$ loss compared to $4.12 \mathrm{~b}$. Rainfall plus irrigation plotted against $\mathrm{N}$ loss. Points circled in red are mainly irrigated blocks. These graphs illustrate that a stronger relationship is seen when rainfall and irrigation are added and plotted against $\mathrm{N}$ losses.

Fertiliser was also initially investigated independently, but a cluster of effluent blocks with high $\mathrm{N}$ losses at low fertiliser application rates were seen. A less scattered relationship is seen when fertiliser $\mathrm{N}$ and effluent $\mathrm{N}$ are added. Figure 4.17 features fertiliser $\mathrm{N}$ plus 
effluent $\mathrm{N}$ plotted against $\mathrm{N}$ loss for data in each soil order and all data. In all cases positive relationships are seen - as fertiliser $\mathrm{N}$ plus effluent $\mathrm{N}$ increases, $\mathrm{N}$ losses increase. It is possible a super-linear relationship, as indicated in Figure 4.5, could be fitted to this data, particularly for brown, pallic and recent soils. However, for other soils a linear relationship appears to be appropriate. Figure 4.18 features RSU against $\mathrm{N}$ loss for all soil orders and all data and positive relationships are seen in all cases. A linear relationship, as indicated in Fig 4.6, could be fitted although, again, there is considerable variance.

In summary, all of the bivariate relationships graphed in Figures 4.16-4.18 indicate the relationships shown in Section 4.2.3 could fit. However, there is considerable variability in the majority of graphs.

\section{Phosphorus}

The effects of rainfall, irrigation, fertiliser $P$, effluent $P$, Olsen $P$ and topography on $P$ losses are graphed using the same 14 data groups from the Ravensdown pastoral data. As for $\mathrm{N}$, rainfall plus irrigation, and fertiliser $P$ plus effluent $P$ are investigated. Figure 4.19 features rainfall plus irrigation plotted against $P$ loss for 13 soil orders and all data. The sub-linear relationship shown in Figure 4.7 is not clear in Figure 4.19. Three soils (brown, gley and recent) feature two clusters of data - one at lower losses and another at higher losses. Investigation of the cluster at higher losses reveals no specific characteristic present that would account for higher losses. P retention appears to influence P losses from individual soil orders. Highly P retentive allophanic soil has lower P losses at all rainfall plus irrigation values, while low $\mathrm{P}$ retentive soils have higher losses e.g. pallic soil which exhibits a super linear relationship between rainfall plus irrigation and $\mathrm{P}$ losses. However, $\mathrm{P}$ retention cannot explain all variability seen. For example, highly P retentive granular soil shows more of a super linear rather than sub linear relationship.

Figure 4.20 features fertiliser P plus effluent P plotted against $P$ losses for all soil orders and all data. A relationship between these variables does not appear to exist, despite the linear to subtly super-linear relationship seen in Figure 4.8.

Figure 4.21 graphs Olsen $\mathrm{P}$ against $\mathrm{P}$ loss for all soil orders and all data. A generally positive linear relationship appears to exist, as seen in Figure 4.9. However, variance is high, particularly for low $P$ retentive soils. Figure 4.22 graphs topography against $P$ loss for all soil 
orders and all data. Relationships between topography and P loss are difficult to assess due to the highly categorised nature of topographic representation within OVERSEER and the Ravensdown dataset. Additionally the dataset is dominated by flat to rolling blocks, reflecting the predominance of agriculture, particularly dairy, on flatter topography. No clear relationships are seen in Figure 4.22.

The relationships seen in Section 4.2.3 for P loss are not seen within the Ravensdown dataset and individual soil orders appear to exhibit a variety of $\mathrm{P}$ loss behaviours. For example, high soil P retention clearly influences allophanic soil which show low $\mathrm{P}$ losses for all variables, while $\mathrm{P}$ losses in low $\mathrm{P}$ retention pallic soil are higher for all variables. Clearly $\mathrm{P}$ retention is influential between soil orders. Additionally, two groups of data are evident for some soils between rainfall plus irrigation and $\mathrm{P}$ loss. This possibly indicates an underlying threshold effect within the OVERSEER model associated with water inputs for these soils. Furthermore, the effect of slope is difficult to assess from OVERSEER or the Ravensdown data because only four slope classifications are specified and only one slope value per block can be specified.

In summary, above investigations of bivariate relationships using the Ravensdown dataset indicate that relationships seen in Section 4.2.3, using a theoretical farm in OVERSEER, are plausibly seen for $\mathrm{N}$, but not for $\mathrm{P}$. This suggests a multiple regression approach for $\mathrm{P}$ is not suitable. Indeed, this was further confirmed when an initially developed multiple regression approach for $\mathrm{P}$ was applied at farm and catchment scale in $\mathrm{LUCl}$ and found to perform inadequately. A number of possible reasons for inadequate performance exist including underlying assumptions and/or threshold effects associated with the OVERSEER model, and differences in scale and detail between OVERSEER and LUCI. For example, OVERSEER uses only 4 slope classifications with only one slope value per block, while LUCI derives slope value from the DEM and identifies individual grid square slope and within field topography. Therefore, the initially developed multiple regression approach for $\mathrm{P}$ was discarded and a new approach developed by other members of the LUCI development team, based on the investigation documented in the following section. 

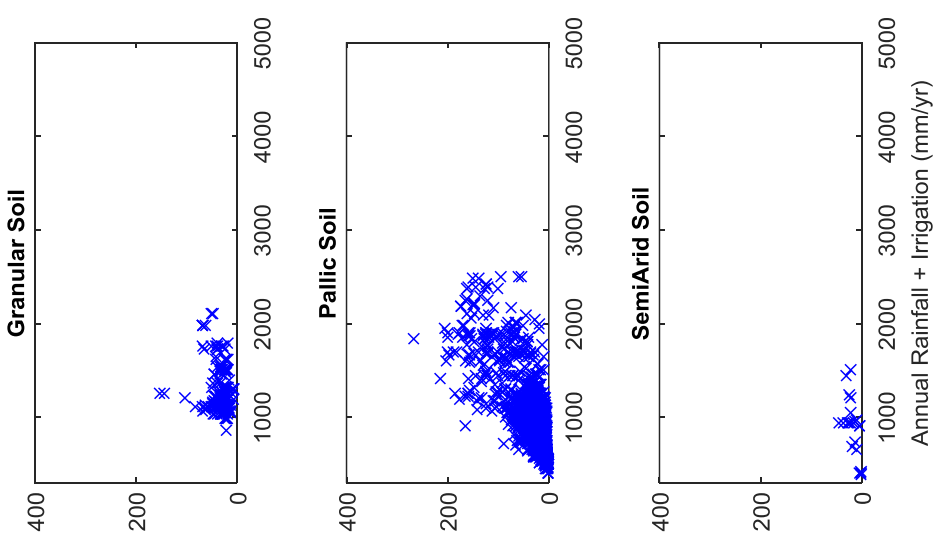

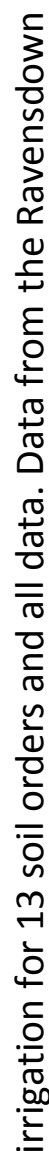
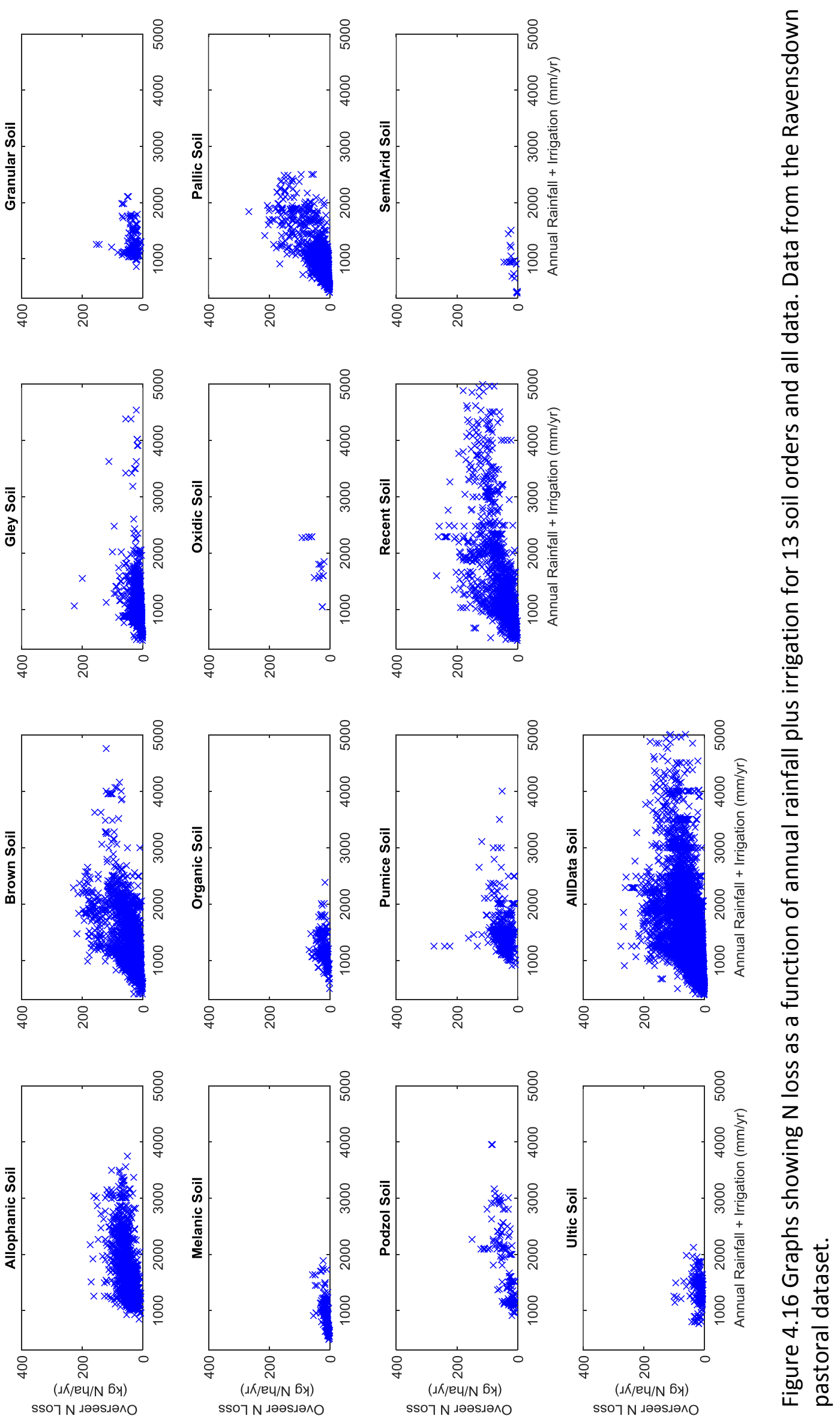


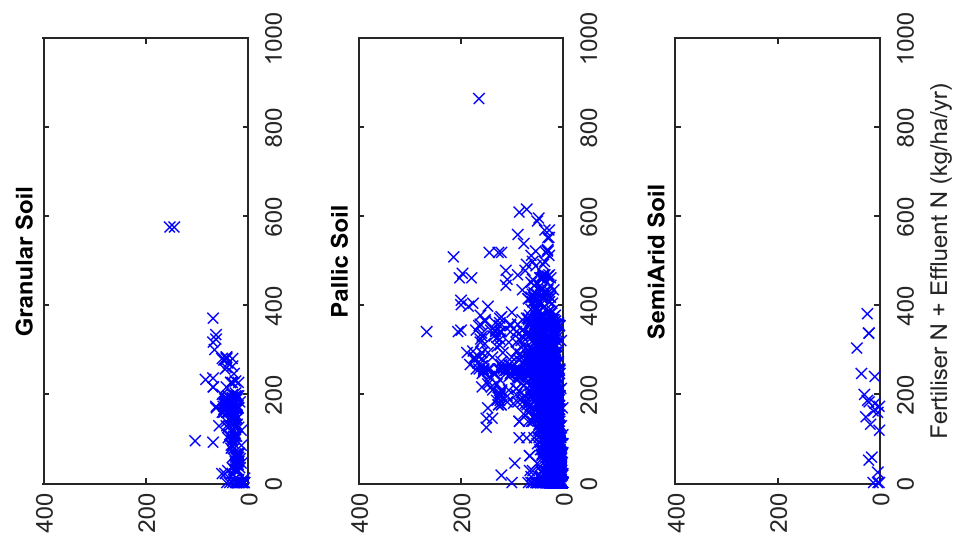

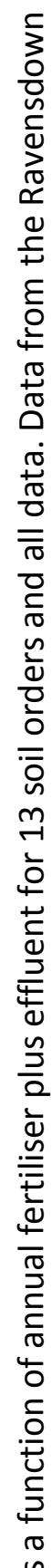
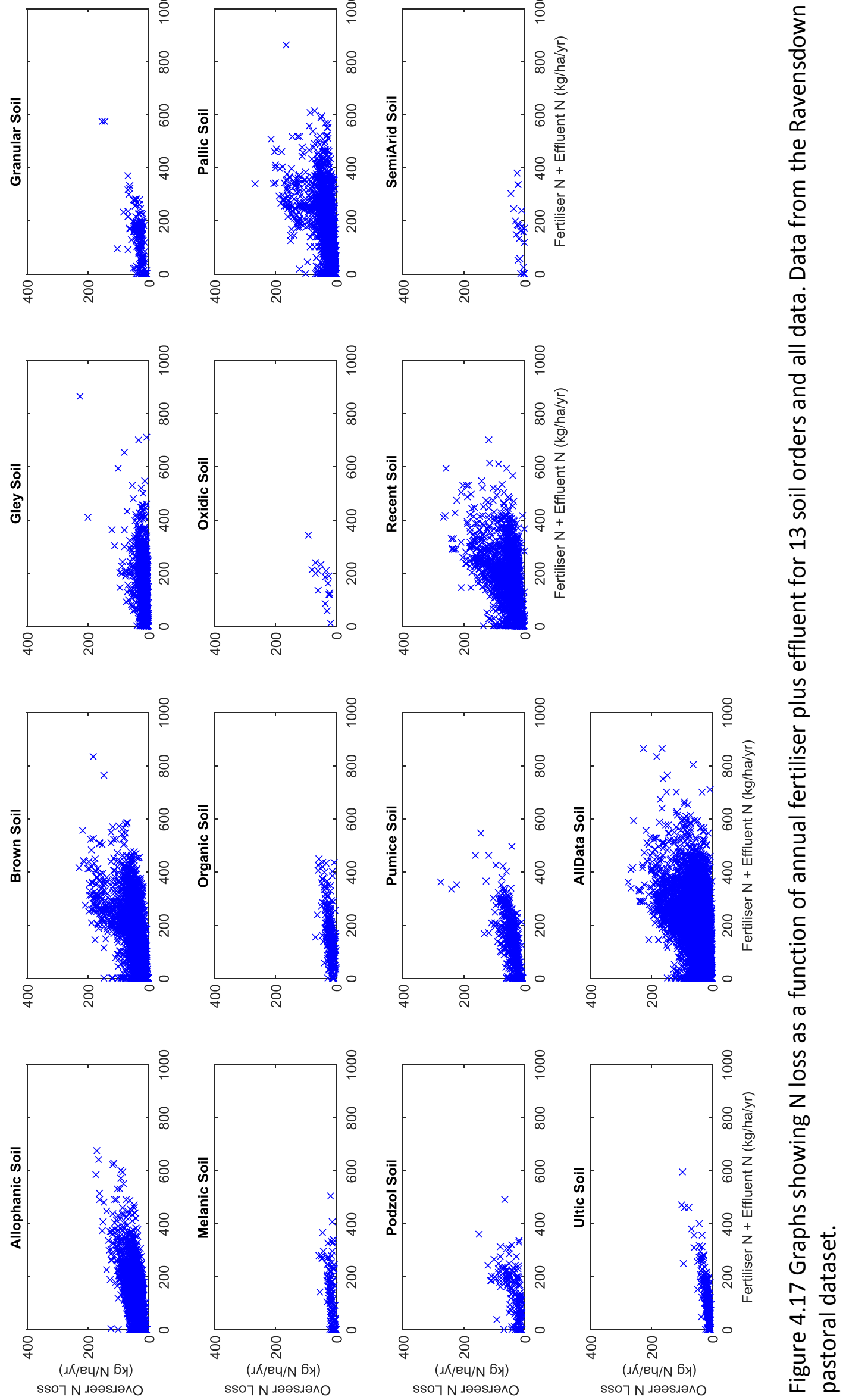

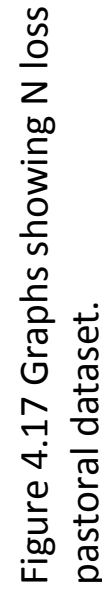



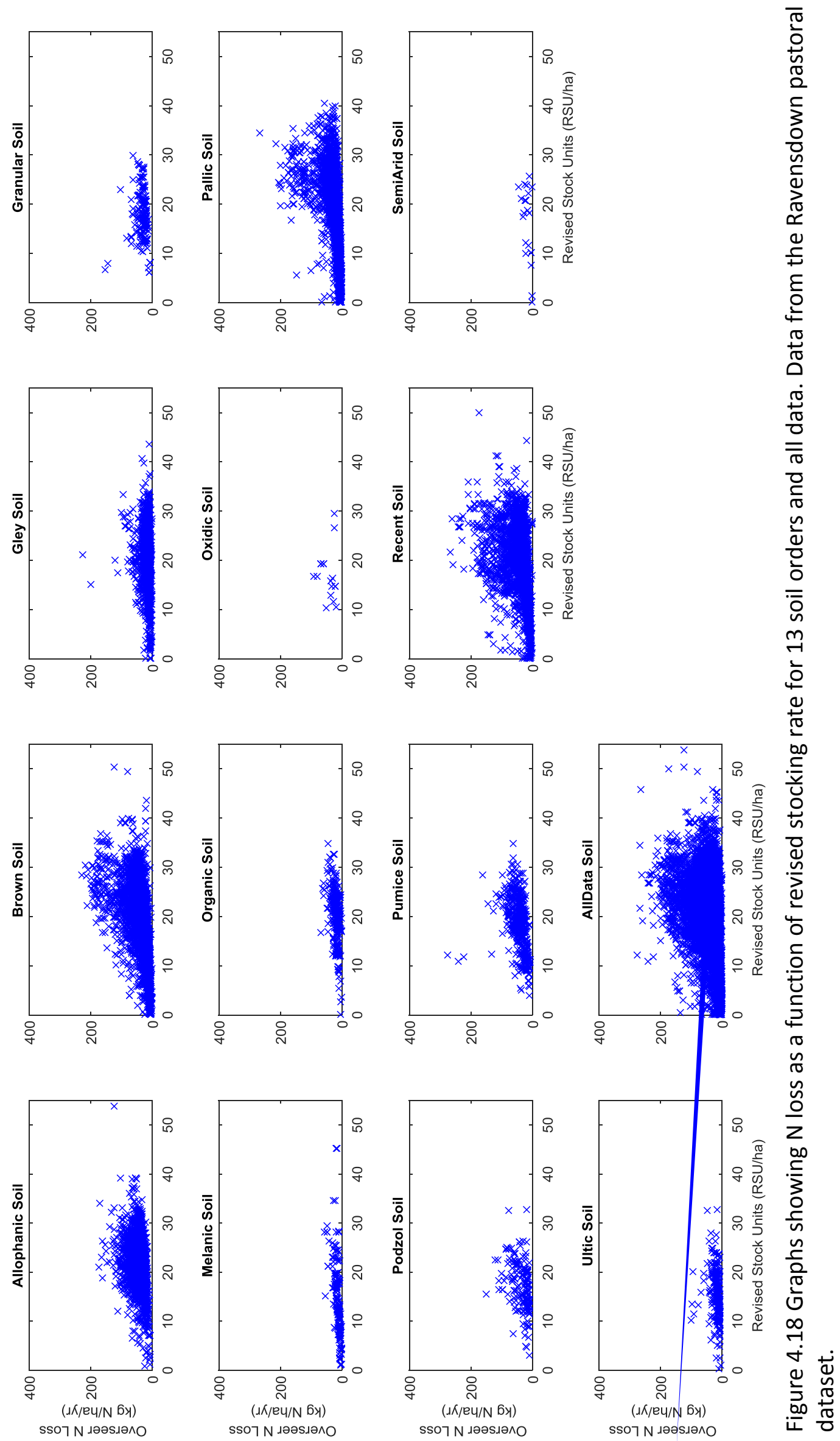

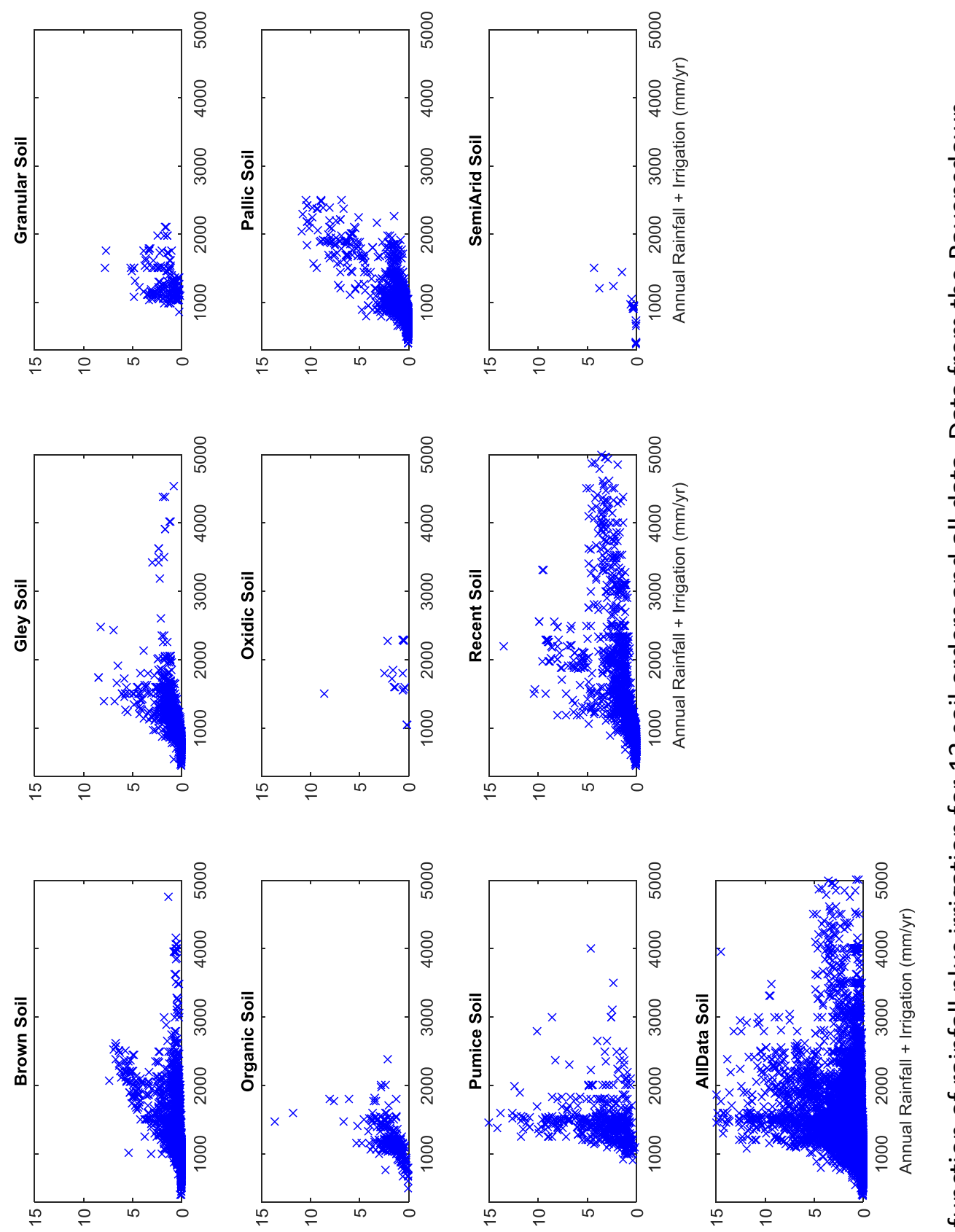

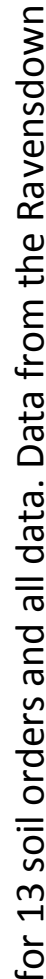
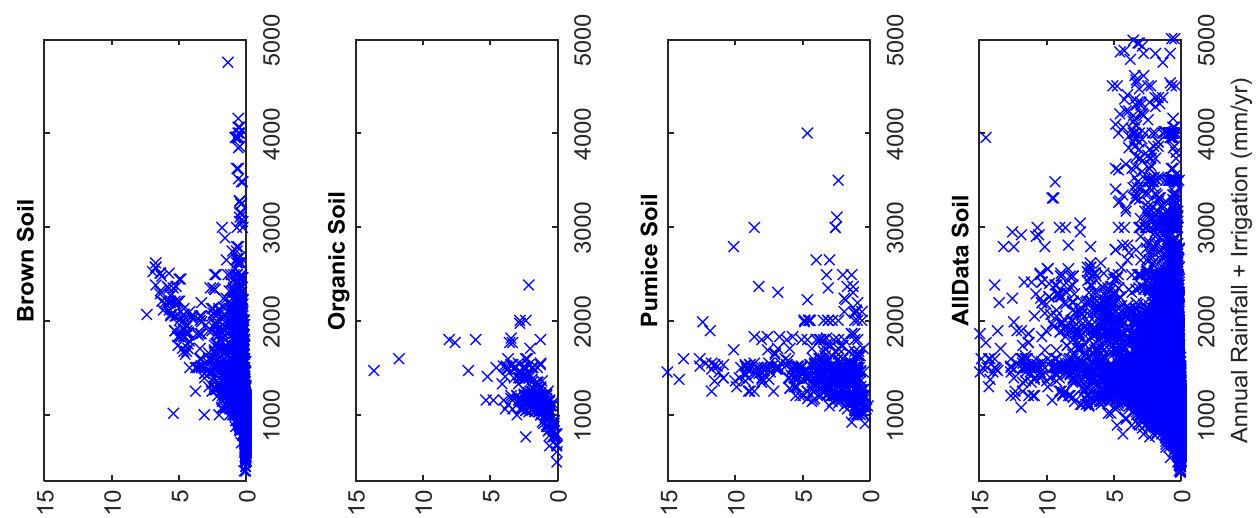

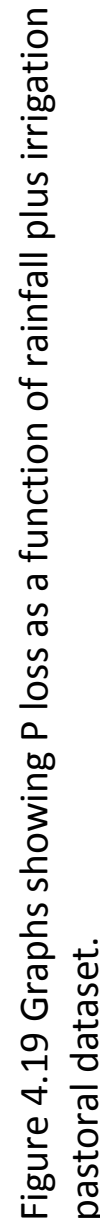
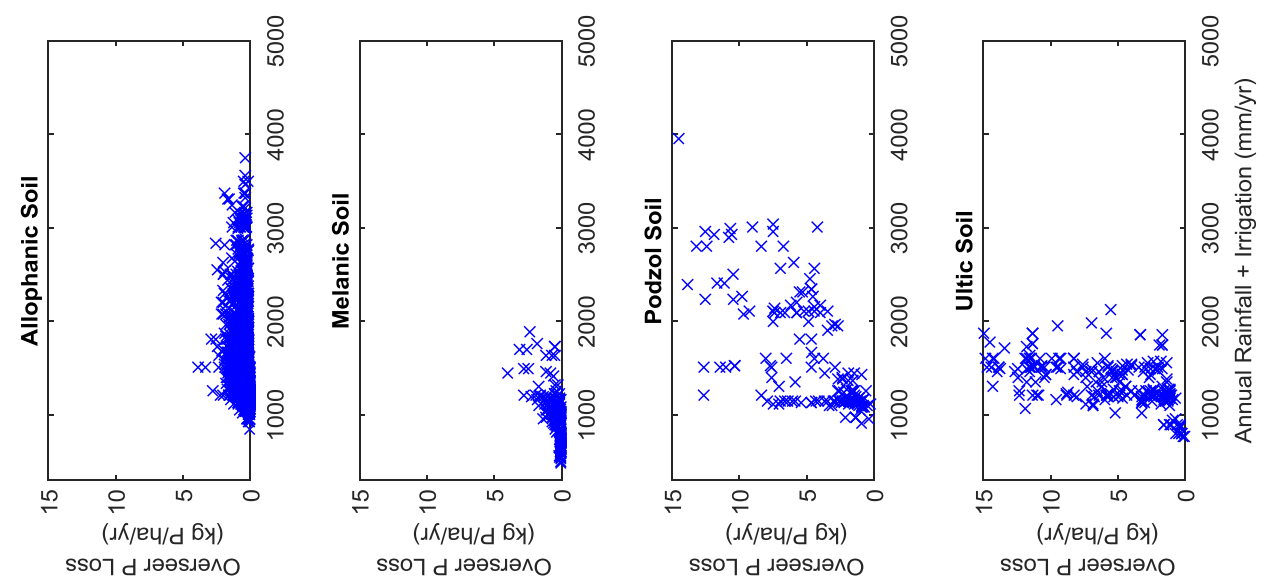


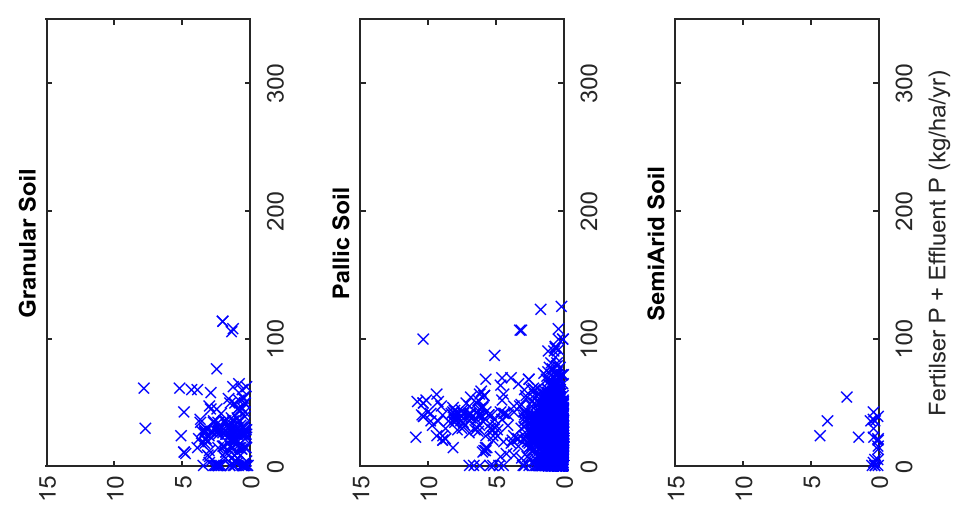

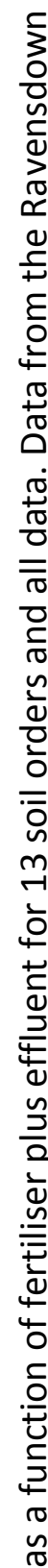
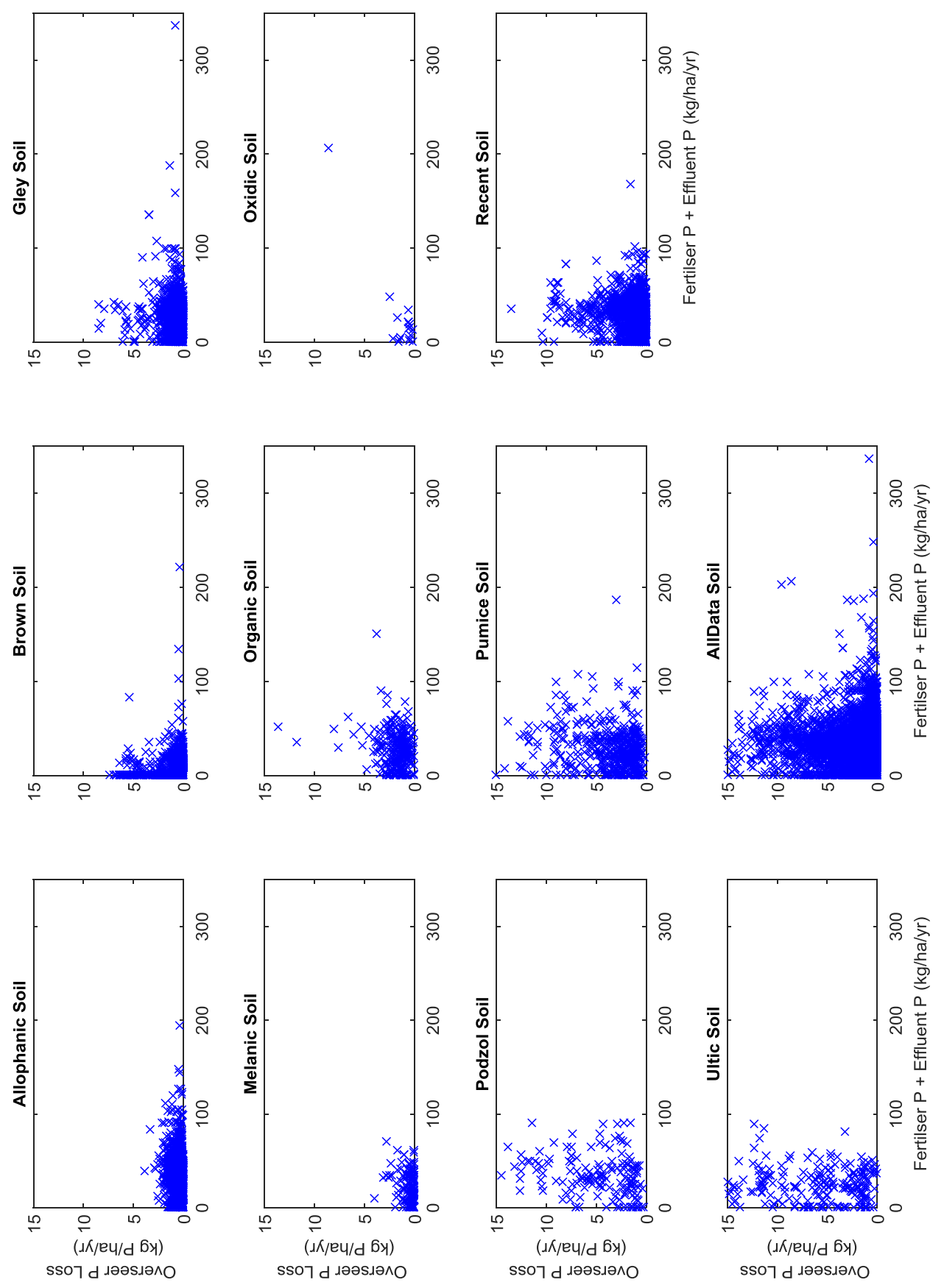

ํㅡ

$\frac{00}{3}$

放

등

는

윰

ํํㅇ

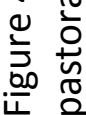



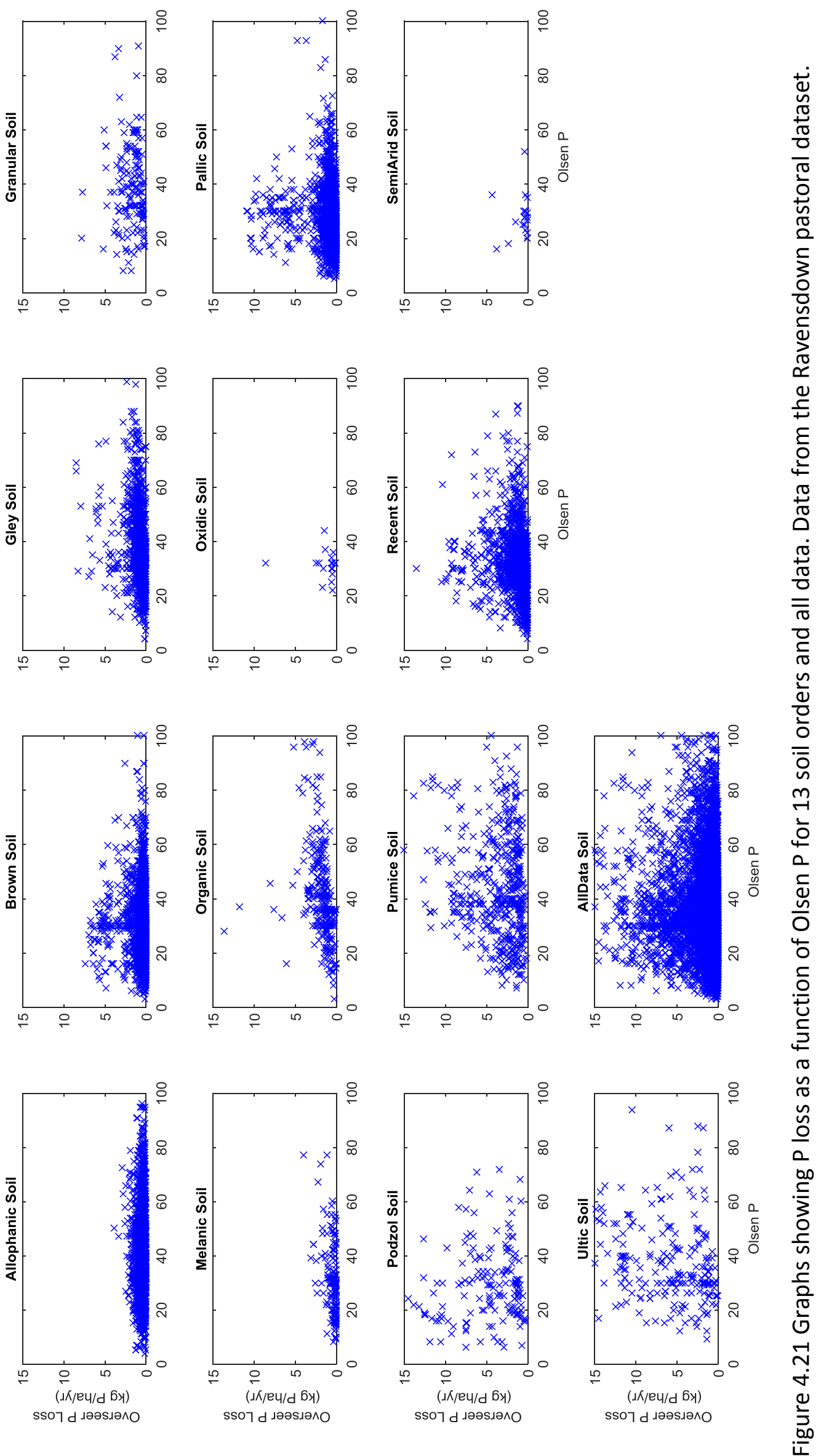

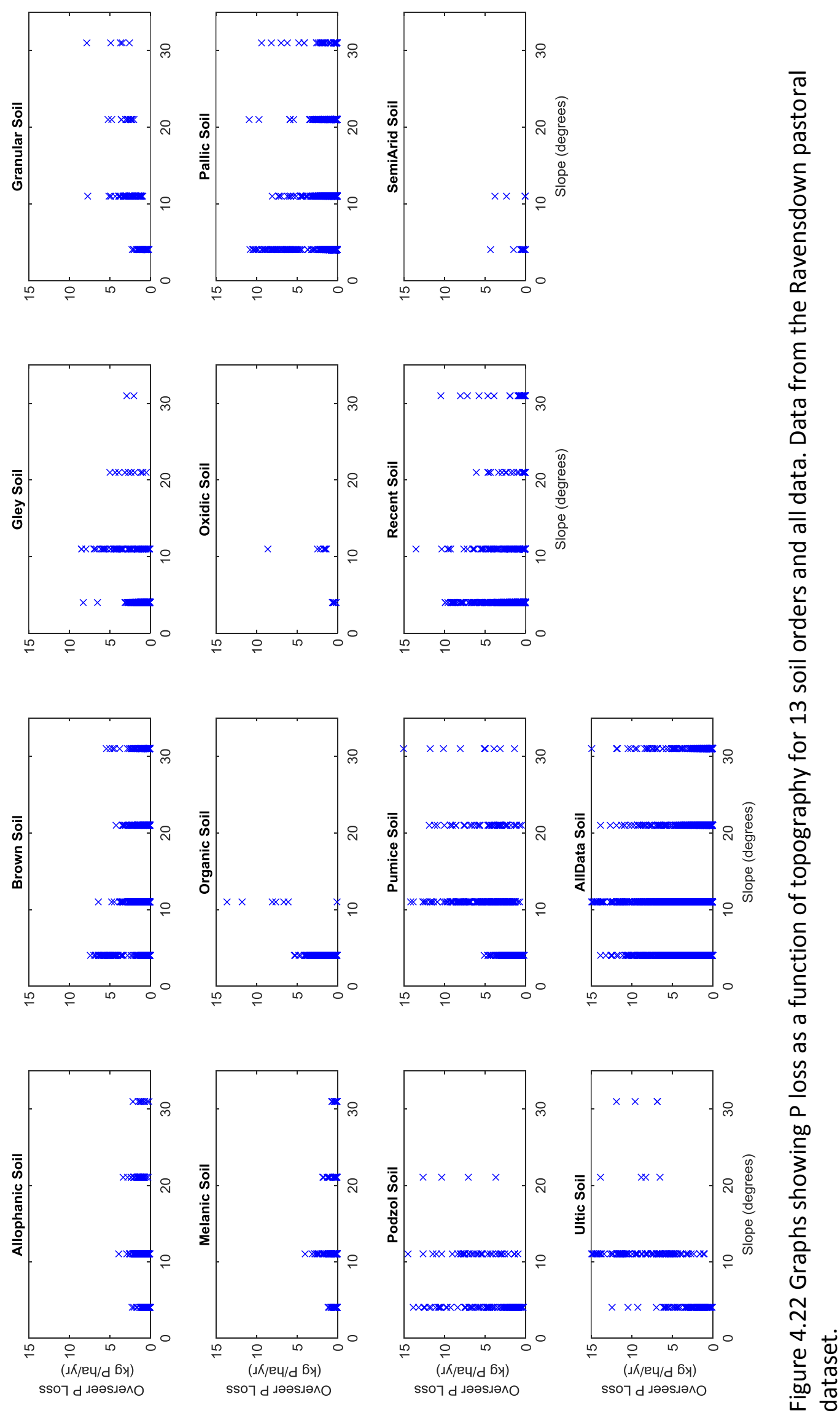


\subsection{INVESTIGATION OF THE SOIL P LOSS COMPONENT OF OVERSEER}

In an effort to better understand the mechanics of OVERSEER's P model, an attempt is made to replicate the soil P loss component of the model in Excel according to model descriptions in McDowell et al. (2005) and Gray et al. (2016) and soil terms from Wheeler (2016a). This investigation informed the broader $\mathrm{LUCl}$ development team in their effort to develop a $\mathrm{P}$ model that performed better than the initially developed multiple regression approach. Soil $\mathrm{P}$ loss is calculated for the same 13 soil orders used in above sections and compared to soil $\mathrm{P}$ loss results from the theoretical farm in OVERSEER.

This process presents some challenges and uncertainties. McDowell et al. (2005) and Gray et al. (2016) explicitly present equations for DRP and structural vulnerability. Further calculations are described in the text, but not always to the level of detail required to unpick the underpinning equations. This work therefore made some assumptions around soil variables and regressed 'weighting factors'. In addition, a number of 'typos' originally featured in the documentation, although all or most were fixed following subsequent communication with OVERSEER developers.

\subsubsection{Method}

Soil P loss is described in McDowell et al. (2005) as "a combination of" particulate P (PP) loss, DRP and a weighting factor derived from regression between actual and estimated TP losses. They do not specify the weighting factor, but do provide a figure showing measured TP concentrations against estimated TP concentrations for 11 soil types, including a regression equation. Investigation of the featured soil types, listed according to soil series, using the NZFSL indicate only 6 soil orders are represented. These include recent, gley, pallic, brown, melanic and allophanic. One soil series, 'Fleming', could not be clearly linked to a soil order. Gray et al. (2016) clarify that PP and DRP losses are summed, but do not elucidate the weighting factor used. Therefore, here background soil P losses are calculated as the sum of PP and DRP, and weighted according to a factor inferred from McDowell et al. (2005).

\section{Particulate P}

An equation for PP is not given by either McDowell et al. (2005) or Gray et al. (2016), but is inferred from the text. Here PP losses are calculated according to Equation 4.1. 
$P P=$ Structural Vulnerability $\times$ Gravimetric OlsenP $\times$ Transport Potential

Equation 4.1

Equations for structural vulnerability are given in McDowell et al. (2005) and Gray et al. (2016). However, they differ from each other. Here the equation in McDowell et al. (2005) is used, but is modified to follow the square root placement featured in Hewitt and Shepherd (1997), from which McDowell et al. (2005) developed their equation (Equation 4.2).

$$
S V=\frac{\left(\frac{A S C}{100}+\frac{\sqrt{\text { Carbon }}}{5}+\frac{\sqrt{\text { Clay }}}{8.5}-0.7\right)}{2.3}
$$

Where, soil order specific ASC (or P retention (PR)), Carbon and Clay are derived from Wheeler (2016a).

Equation 4.2

Gravimetric Olsen P is calculated according to the equation given in Wheeler (2016a) and shown in Equation 4.3.

Gravimetric Olsen $P$

$$
=\exp \frac{(\log (\text { VolOlsen } P)+1.69-0.0057 \times A S C-0.89 \times B D / 1000}{1.13}
$$

Where, Olsen P by volume (VolOlsenP) is 30 for all soil orders and soil order specific ASC (or P retention (PR)) and bulk density (BD)are derived from Wheeler (2016a)

Equation 4.3 
Transport potential is determined from slope. PP is multiplied by $0.15,0.5,0.75$ or 1 for flat, rolling, easy hill or steep hill (McDowell et al. 2005; Gray et al. 2016). Here PP is calculated for flat land only.

\section{$D R P$}

McDowell et al. (2005) provide an equation for DRP, which Gray et al. (2016) note has since been modified (Equation 4.4).

$$
D R P=0.022 \frac{\text { Gravimetric OlsenP }}{A S C}+0.022
$$

Where, Gravimetric Olsen P is calculated using Equation 5.3 and soil order specific ASC (or P retention (PR)) is derived from Wheeler (2016a)

Equation 4.4

DRP is multiplied by two transport potential factors:- excess precipitation and hydrological class. Equations are not specified by McDowell et al. (2005) or Gray et al. (2016), but are inferred from the text as Equations 5.5 and 5.6. Here rainfall of $1000 \mathrm{~mm}$ is used and no irrigation included.

$$
\text { Excess Precipitation }=\frac{\text { Rainfall }+ \text { Irrigation }}{680}
$$

Where, Rainfall and Irrigation are in $\mathrm{mm} / \mathrm{yr}$

Equation 4.5

Hydrological Class $=$ Soil Texture Index $\times$ Mean Slaking Index

Where Soil Texture Index and Mean Slaking Index are from Table 1 in Gray et al. (2016)

Equation 4.5 
Soil texture for each soil order is determined using percent clay, silt and sand from Wheeler (2016a) and the soil texture triangle (University of Idaho 2016). This is then used to determine which Soil Texture Index number (in Table 1 from Gray et al. (2016)) is appropriate for each soil order. The mean slaking index featured in Table 1 in Gray et al. (2016) lists organic soils twice ( 0.8 and 1$)$ and it is not clear which is the correct value for organic soil. Here 1 is used. In addition, the mean slaking index differs from that featured in McDowell et al. (2005). Furthermore, a 'hydroclass' is also given in Wheeler (2016a). While Wheeler's (2016a) hydroclass is not used here, it is possible this is used in the P model.

\subsubsection{Results and Discussion}

Table 4.3 compares OVERSEER derived soil P loss and Excel calculated soil P loss. P loss replicated in Excel are an order of magnitude higher than OVERSEER generated soil P loss for all soils except pallic, recent, semiarid and ultic. These four soils are all characterised by low P retention indicating some aspect of soil order specific variables likely contribute to discrepancies. This does not help to narrow down specifics though because many soil order variables are used in the above equations e.g. ASC, BD, \% clay/silt/sand, carbon content, mean slaking index etc. In addition, given the number of typos and discrepancies found in McDowell et al. (2005) and Gray et al. (2016), and the uncertainties and assumptions made here, it is not clear exactly which aspect of the calculations are responsible for the differences seen. Potentially any one or a combination of them could be responsible. A further area of uncertainty relates to the weighting factor derived from regression. Neither McDowell et al. (2005) nor Gray et al. (2016) give much in the way of specifics and it is clear from Figure 2 in McDowell et al. (2005) that this weighting factor is based on only a limited number of soil orders. It is unclear how the weighting factor is assigned to soil orders not represented in the regression analysis.

Despite uncertainties, this work contributes substantially to subsequent development of an alternative algorithm for $\mathrm{P}$, presented in Chapter 5 , which is more closely linked to McDowell et al.'s (2005) approach. It should be noted, that this further development of the $\mathrm{P}$ algorithm beyond a multiple regression approach was carried out by members of the LUCI development team with more extensive expertise in this area. Therefore, further $\mathrm{P}$ algorithm development is not presented here. However, the new P algorithm and parameterised constants are reported in Chapter 5 and used in the presented case studies. 
Table 4.3 Comparison between OVERSEER modelled P loss and author replicated soil P loss which is based on explanation of the OVERSEER P loss model in McDowell et al. (2005) and Gray et al. (2016).

\begin{tabular}{|l|c|c|}
\hline \multicolumn{1}{|c|}{ Soil Order } & $\begin{array}{c}\text { OVERSEER Soil P Loss } \\
\text { (kg P/ha/yr) }\end{array}$ & $\begin{array}{c}\text { Excel replicated Soil P Loss } \\
\text { (kg P/ha/yr) }\end{array}$ \\
\hline Allophanic & 0.1 & 1.7 \\
\hline Brown & 0.1 & 1.0 \\
\hline Gley & 0.3 & 1.5 \\
\hline Granular & 0.2 & 1.5 \\
\hline Melanic & 0.1 & 1.1 \\
\hline Organic & 0.5 & 3.1 \\
\hline Oxidic & 0.1 & 1.5 \\
\hline Pallic & 0.4 & 0.5 \\
\hline Podzol & 0.7 & 1.1 \\
\hline Pumice & 0.2 & 1.2 \\
\hline Recent & 0.3 & 0.5 \\
\hline SemiArid & 0.4 & 0.1 \\
\hline Ultic & 0.6 & 0.7 \\
\hline
\end{tabular}

\subsection{DISCUSSION AND SUMMARY}

This chapter aimed to identify input variables and functional forms for inclusion in export coefficient generating algorithms for $\mathrm{N}$ and $\mathrm{P}$ for pastoral land covers. These algorithms will quantify site specific pastoral $\mathrm{N}$ and $\mathrm{P}$ losses based on variations in and combinations of geoclimatic and land management variables. Spatial data is used to identify land units of combined variables to which the algorithms are applied, thereby explicitly positioning export coefficients which can be fed into catchment scale water quality models.

Algorithm input variables are identified using PCA analysis and OVERSEER model and nutrient loss understanding, with some consideration given to wider aims associated with future application of these models in LUCI by Ravensdown. Final $\mathrm{N}$ algorithm input variables are rainfall, irrigation, fertiliser $\mathrm{N}$, effluent $\mathrm{N}$ and $\mathrm{RSU}$. Final $\mathrm{P}$ algorithm input variables are rainfall, irrigation, fertiliser $P$, effluent $P$, Olsen $P$ and topography. Although further soil variables are included in underlying equations that contribute to the $\mathrm{P}$ algorithm, as discussed in Chapter 5.

Suitable algorithm form is less clear. Using a theoretical farm in OVERSEER, bivariate relationship form between identified input variables and nutrient loss was investigated, yielding clear results. However, the same bivariate relationships are not as clearly evident in 
actual farm data from the Ravensdown dataset. For N, the OVERSEER theoretical farm derived bivariate relationships could be fitted to the actual Ravensdown data, but with variance evident. For $\mathrm{P}$, the OVERSEER theoretical farm derived bivariate relationships are not seen in the Ravensdown data for many soil orders and variables, and subsequent application of the multiple regression approach for $\mathrm{P}$, at farm and catchment scale, indicated it was unsuitable. This prompted further investigation into OVERSEER's P model. In particular, functioning of the soil P loss component of the OVERSEER model is deciphered based on descriptions in OVERSEER literature and applied in a new $\mathrm{P}$ algorithm, developed and parameterised by other members of the LUCI development team.

The analyses presented here highlight some of the difficulties around using other models to develop export coefficients. Models vary in assumptions and complexity, which may or may not be explicitly reported in associated literature. Deciding how fully to replicate an underlying model and which inputs or aspects of a model to include is not always easy. In addition, issues related to scale can exist between models. For example, once applied at catchment scale, the initial multiple regression $\mathrm{P}$ algorithm appeared to have difficulty accounting accurately for topography. This is likely due to differences in topographic representation between OVERSEER and the Ravensdown data, and LUCI. OVERSEER only provides four slope options and only one dominant option can be allocated per block. Therefore the Ravensdown data also only records one dominant slope per block. In addition, it is biased towards flat to rolling slopes. In contrast, LUCl considers slope at the DEM grid square scale and accounts for detailed intra-block topography.

Here the aim is not full replication of OVERSEER, but sufficient replication using the most influential input variables to provide site specific representative export coefficients. For $\mathrm{N}$, a multiple regression approach using the five variables identified above appears sufficient, although this is evaluated further in following chapters. For $\mathrm{P}$, a multiple regression approach proved to be inappropriate and an alternative approach has been developed by the wider LUCI development team. These algorithms are presented and applied in following chapters. 


\section{EXPORT COEFFICIENT ALGORITHMS: FORM, PARAMETERISATION AND INPUT DATA}

\subsection{INTRODUCTION}

This chapter presents $\mathrm{N}$ and $\mathrm{P}$ export coefficient algorithms for pastoral land covers in New Zealand, based on investigations in Chapter 4 , and parameterises $\mathrm{N}$ algorithm constants. $\mathrm{A}$ similar algorithmic approach is desired for other land covers, but lack of suitable data prevents this. Instead, an alternative approach is developed based on the pastoral algorithms, but with the addition of a Land Cover Multiplier (LCM) derived from New Zealand literature reported export coefficients documented in Chapter 3. Using pastoral algorithms as a base for deriving other land cover export coefficients ensures important $\mathrm{N}$ and $\mathrm{P}$ loss variables are accounted for. The LCM then increases or decreases output from the algorithms to reflect reported differences in nutrient loss between pastoral land cover and the land cover in question.

Publicly available national spatial data defining farm inputs (e.g. fertiliser, effluent, irrigation etc.) featured in the pastoral algorithms do not exist. When working with individual farms or in small catchments where direct interaction with farmers is possible, actual OVERSEER files connected to GIS shapefiles outlining block and farm boundaries, are used. Where this is not possible and for input to the other land cover algorithms, alternative data is required. Therefore, spatial data detailing regional average algorithm inputs are developed here to overcome this issue.

Section 5.2 presents pastoral and other land cover algorithm forms for $\mathrm{N}$ and P. Section 5.3 parameterises pastoral $\mathrm{N}$ algorithm constants and compares OVERSEER derived predictions with $\mathrm{N}$ algorithm predictions using the Ravensdown data. LCM for other land cover algorithms are developed and presented in Section 5.4. Spatial regional farm input data is developed and presented in Section 5.5. 


\subsection{ALGORITHM FORM}

\subsubsection{Pastoral Algorithms}

Equations 5.1 and 5.2 present algorithms for $\mathrm{N}$ and $\mathrm{P}$ export coefficient generation on pastoral land covers based on investigations in Chapter 4. Again, it should be noted, that development of the presented $\mathrm{P}$ algorithm, beyond a multiple regression approach, was carried out by members of the LUCI development team with more extensive expertise in this area.

$$
\begin{aligned}
& N \text { Export Coefficient }_{\text {Pastoral }}= \\
& a_{1}(\text { rainfall }+ \text { irrigation })^{b_{1}}+a_{2}(\text { fertiliser }+ \text { effluent })^{b_{2}}+a_{3} R S U+c_{1}
\end{aligned}
$$

Equation 5.1

$$
\begin{aligned}
& \text { P Export Coefficient } \text { Pastoral }= \\
& {\left[\left(a_{1} \times S V \times \text { Slope } \times \text { Gravimetric Olsen } P+a_{2} \times D R P\right) \times \max ([\text { rainfall }+\right.} \\
& \text { irrigation } \left.\left.-c_{1}\right]^{b_{1}}, 0\right)+a_{3}(\text { fertiliser }+ \text { effluent })
\end{aligned}
$$

Equation 5.2

Model constants $a^{x}, b^{x}$ and $c$ for the $\mathrm{N}$ algorithm are derived and presented for each soil order and all data in Section 5.3 using the Ravensdown dataset. Model constants $a^{x}, b^{x}$ and $c$ for the $\mathrm{P}$ algorithm were derived separately to this study by other members of the LUCI development team, but final parameterised constants are presented here. Structural vulnerability (SV), gravimetric Olsen $\mathrm{P}$ and DRP, which are required as input to the above $\mathrm{P}$ algorithm, are all calculated according to the equations and method described in Section 4.4 .

\subsubsection{Other Land Covers}

Equations 5.3 and 5.4 represent algorithms for $\mathrm{N}$ and $\mathrm{P}$ export coefficient generation on other land covers. These are based on the pastoral algorithms presented above with the addition of an LCM. Each land cover class identified in the New Zealand LCDB4 is associated with an LCM, which is parameterised based on New Zealand export coefficients 
documented in Chapter 3. The LCM increases or decreases export coefficients derived from the pastoral algorithms, to reflect reported differences in nutrient loss between pastoral land and the land cover in question. Derivation of LCMs and their allocation to LCDB4 land cover classes, is described in Section 5.4.

$$
\begin{gathered}
N \text { Export Coefficient } \text { Other }_{\text {fing }}= \\
\left.\left(a_{1} \text { (rainfall }+ \text { irrigation }\right)^{b_{1}}+a_{2}(\text { fertiliser }+ \text { effluent })^{b_{2}}+a_{3} R S U+c_{1}\right) * L C M
\end{gathered}
$$

Equation 5.3

$$
\begin{gathered}
\text { P Export Coefficient } \text { Other }_{\text {E }}= \\
{\left[\left(a_{1} \times S V \times \text { Slope } \times \text { Gravimetric OlsenP }+a_{2} \times D R P\right) \times \max ([\text { rainfall }+\right.} \\
\text { irrigation } \left.\left.-c_{1}\right]^{b_{1}}, 0\right)+a_{3}(\text { fertilier }+ \text { effluent }) * L C M
\end{gathered}
$$

Equation 5.4

\subsection{PARAMETERISATION OF PASTORAL N ALGORITHM}

\subsubsection{Method}

Constants for the pastoral $\mathrm{N}$ algorithm are parameterised for each soil order using MATLAB function fmincon, an automatic constrained optimisation technique. This same method was used to parameterise the initial multiple regression $\mathrm{P}$ algorithm, but is not documented here due to replacement of the initial approach with the algorithm presented in Section 5.2.1, which was not parameterised by the author of this study.

The aim of parameter optimisation is to find a set of model parameters that minimise the difference between simulated and measured outputs (Smith and Smith 2007). In this case, minimisation is sought between simulated $\mathrm{N}$ loss from the developed pastoral $\mathrm{N}$ algorithm and predicted OVERSEER $\mathrm{N}$ loss in the Ravensdown dataset. It is assumed here that one optimal parameter set exists and is identified. However, it must be acknowledged that a 
number of potentially suitable parameter sets may exist. This is a commonly cited problem associated with environmental modelling (Beven 2009; Beven 2012).

Specifically, fmincon finds the minimum of a constrained nonlinear multivariable function. Here the nonlinear multivariable function is the nonlinear multiple regression algorithm, which requires constraint to ensure physically impossible outcomes are not generated e.g. negative $\mathrm{N}$ losses. A number of iterative optimisation algorithms are available in fmincon. Interior point is the default option and sequential quadratic programming (SQP) and active set are alternatives. Interior point uses linear algebra that does not store, or operate on, full matrices. This reduces storage requirements and processing time, however inaccuracies can develop. SQP and active set create full matrices and use dense algebra. Compared to interior point, inaccuracies are reduced, but storage and processing times are increased. For further information on these optimisation algorithms the reader is directed to Mathworks (2017). Here all three algorithms are tested and the results showing the least difference when compared to OVERSEER output, are reported.

Minimisation between simulated $\mathrm{N}$ loss from the pastoral algorithms and predicted OVERSEER $\mathrm{N}$ loss in the Ravensdown dataset is assessed according to an objective function, or mathematical measure of fit. Here normalised least squares, also reported as Nash Sutcliffe, is used. Normalised least square results can range from $0-\infty$ and the closer to ' 0 ', the better the fit. Nash-Sutcliffe results range from $-\infty-1$. A value of 1 indicates a perfect model, ' 0 ' indicates a model no better than simply using the mean, and negative results indicate performance worse than using the mean.

For each soil order, and all data, regressed $\mathrm{N}$ losses from the pastoral algorithms are plotted against OVERSEER $\mathrm{N}$ losses in the Ravensdown dataset, error in regression result is plotted against OVERSEER $\mathrm{N}$ losses and frequency distribution of regressed error is graphed. Mean error between regressed $\mathrm{N}$ losses and OVERSEER $\mathrm{N}$ losses are reported, as are lower and upper $95 \%$ confidence interval boundaries (assuming normal distribution) to indicate uncertainty of algorithm predictions. 


\section{$\underline{5.3 .2 \text { Results }}$}

\section{Nitrogen}

Very similar results are obtained from the three optimisation algorithms available with the fmincon MATLAB function. However, active set produces slightly better results for $\mathrm{N}$ and are reported here. Figure 5.1 features three graphs for each soil order:

a.) Regressed $\mathrm{N}$ is plotted against OVERSEER generated $\mathrm{N}$,

b.) Regression error (OVERSEER $\mathrm{N}$ less regressed $\mathrm{N}$ ) is plotted against OVERSEER $\mathrm{N}$,

c.) A histogram of regression error is presented.

A positive linear trend is seen in graphs a.) for most soil orders, indicating a similar magnitude of predicted loss between the developed $\mathrm{N}$ algorithm and OVERSEER $\mathrm{N}$ results. However, variance is evident and most soil orders display under prediction of regressed $\mathrm{N}$ at higher OVERSEER $\mathrm{N}$ values. This is particularly evident for brown, gley, pallic and recent soils.

This trend is also evident in graphs b.). Ideally, regression error should be randomly clustered around a horizontal line from ' 0 ' on the $y$-axis. However, for all soil orders a clear pattern is seen of regressed $\mathrm{N}$ over prediction at lower OVERSEER $\mathrm{N}$ values and regressed $\mathrm{N}$ under prediction at higher OVERSEER $\mathrm{N}$ values.

Histograms of error (c.) show highest frequencies clustered around ' 0 ' error for allophanic, gley, and ultic soil orders. Histograms of error for brown, granular, melanic, organic, pallic, podzol, pumice, recent soil orders and all data show highest frequencies clustered above ' 0 ' error indicating a large number of small over predictions by the $\mathrm{N}$ algorithm. Most soil orders display a longer tail of negative values indicating fewer, but larger, under predictions by the $\mathrm{N}$ algorithm. Histograms of error for oxidic and semi arid soils are difficult to assess because they include so few points.

Table 5.1 largely confirms the distributions seen in Figures 5.1 (c.). Mean error for allophanic, gley, and ultic soils are close to ' 0 ' and lower and upper 95\% confidence interval boundaries indicate less error spread and skewness and therefore, more certainty of algorithm predictions. Mean error for brown, granular, melanic, organic, pallic, podzol, pumice, recent soil orders and all data are above ' 0 ' and lower and upper $95 \%$ confidence 
interval boundaries indicate considerable spread and skewness. Skewness is particularly evident on brown, pallic and recent soil orders, which are common New Zealand soils found in many farming regions. As such, $\mathrm{N}$ loss OVERSEER data likely includes a number of high intensity farms. Less certainty around predictions for these soil orders is evident.

Table 5.2 summarises normalised least squares and Nash-Sutcliffe results generated during optimisation and further confirms results from Figure 5.1 and Table 5.1. Normalised least square results comparing regressed $\mathrm{N}$ and OVERSEER $\mathrm{N}$ predictions range from 7.06 to 26.62. Nash-Sutcliffe results range from -0.01 to -0.58 . These results indicate using mean $\mathrm{N}$ losses would produce 'better' results. However, that clearly would also preclude representing $\mathrm{N}$ loss variance as a function of identified variables that influence $\mathrm{N}$ loss. As mentioned in Chapter 4, regressed $\mathrm{N}$ is unlikely to fully replicate OVERSEER $\mathrm{N}$ anyway because the underlying algorithm does not include the full complexity of OVERSEER. In addition, it is also not clear that OVERSEER results are certain, particularly for climate, soil, management combinations where OVERSEER has not been validated. Therefore, the parameterised constants generated here are used in the pastoral $\mathrm{N}$ algorithm. They are not, however, presented here due to commercial sensitivity and privacy concerns with the Ravensdown dataset. If required they can be provided on request subject to agreement from the dataset owners, Ravensdown. Future investigation into algorithm improvement is always an option. 

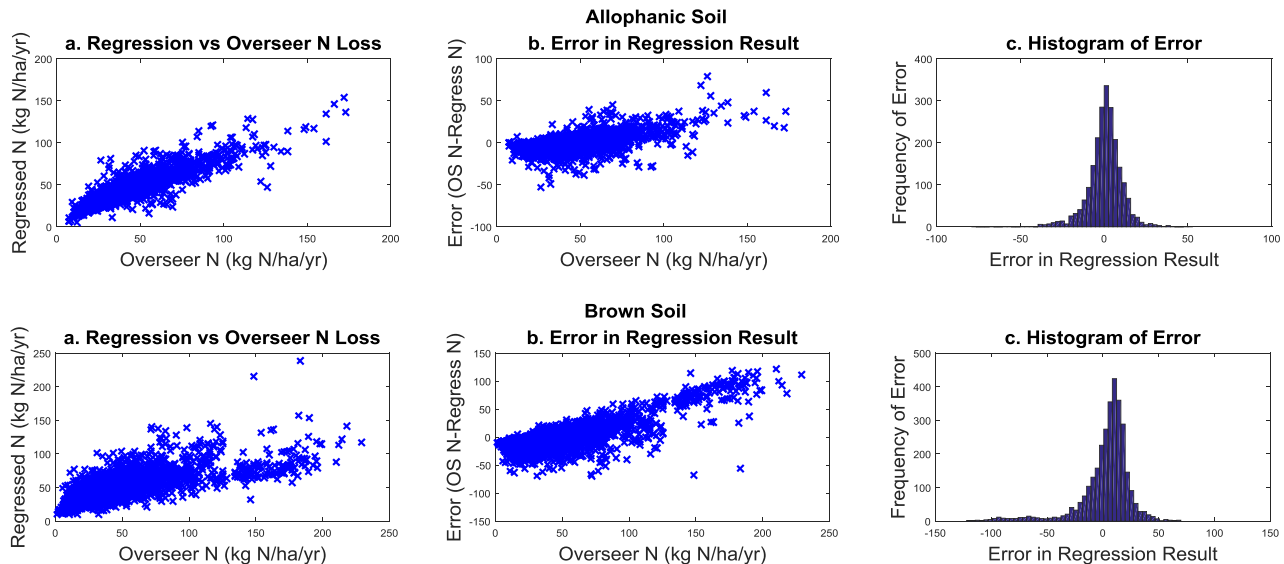

Brown Soi
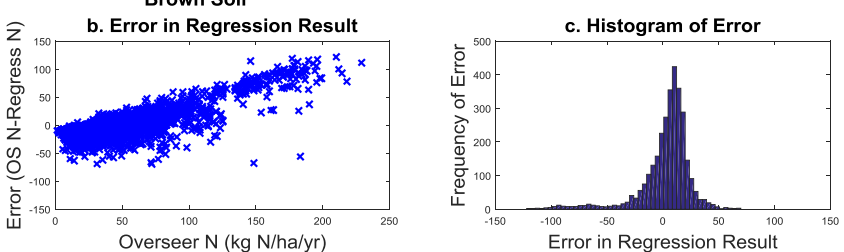

Gley Soil
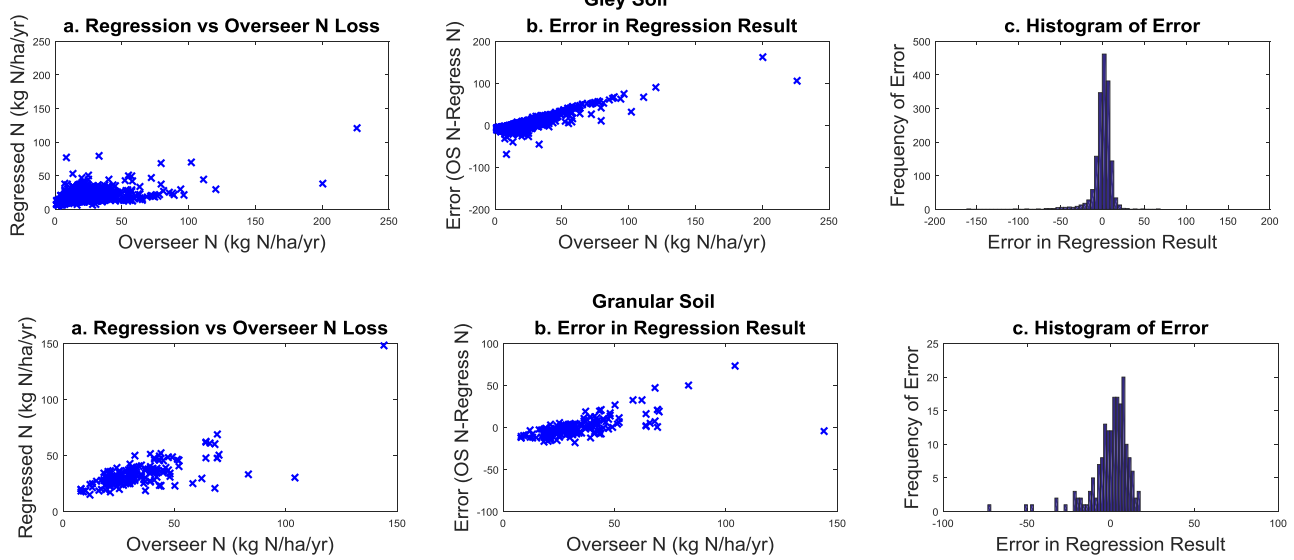

Melanic Soil
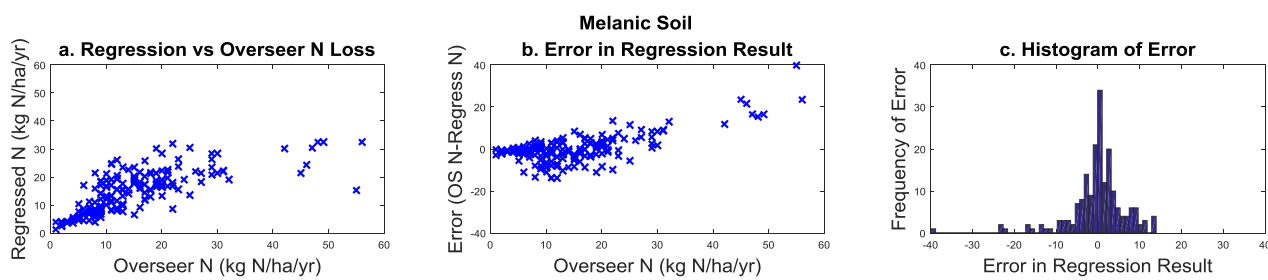

Organic sto
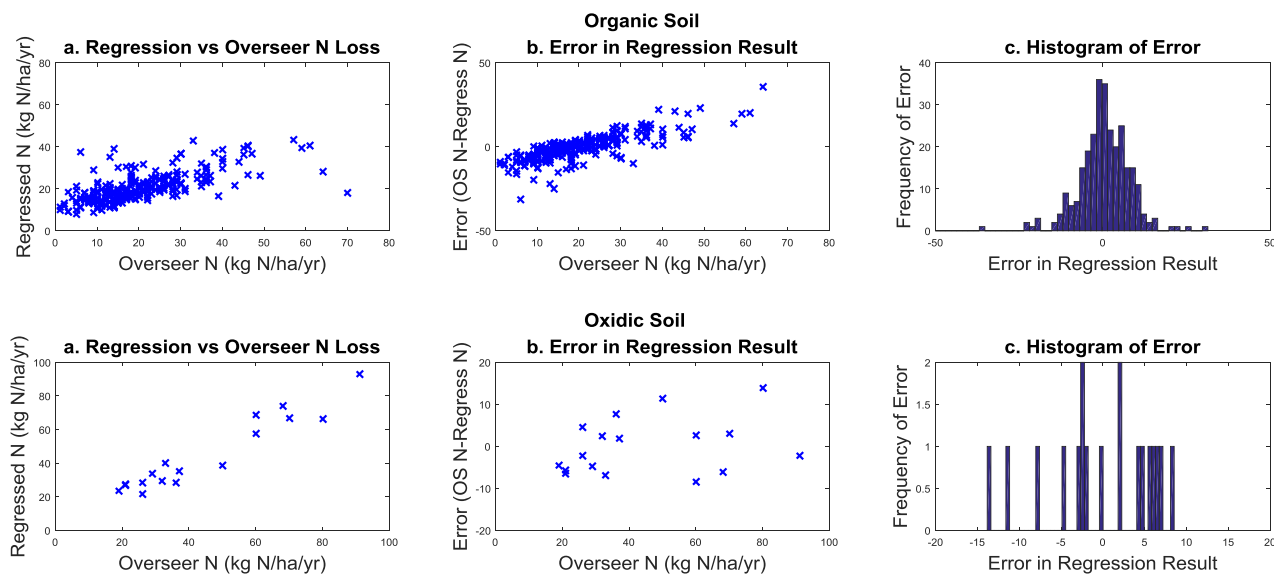

Figure 5.1 Graphs comparing regressed $\mathrm{N}$ results and OVERSEER $\mathrm{N}$ predictions. For each soil order and all data three graphs are presented a.) Regressed $\mathrm{N}$ results compared to OVERSEER N predictions, b.) Regression error plotted against OVERSEER N, and c.) Histograms of regression error (continued over page) 

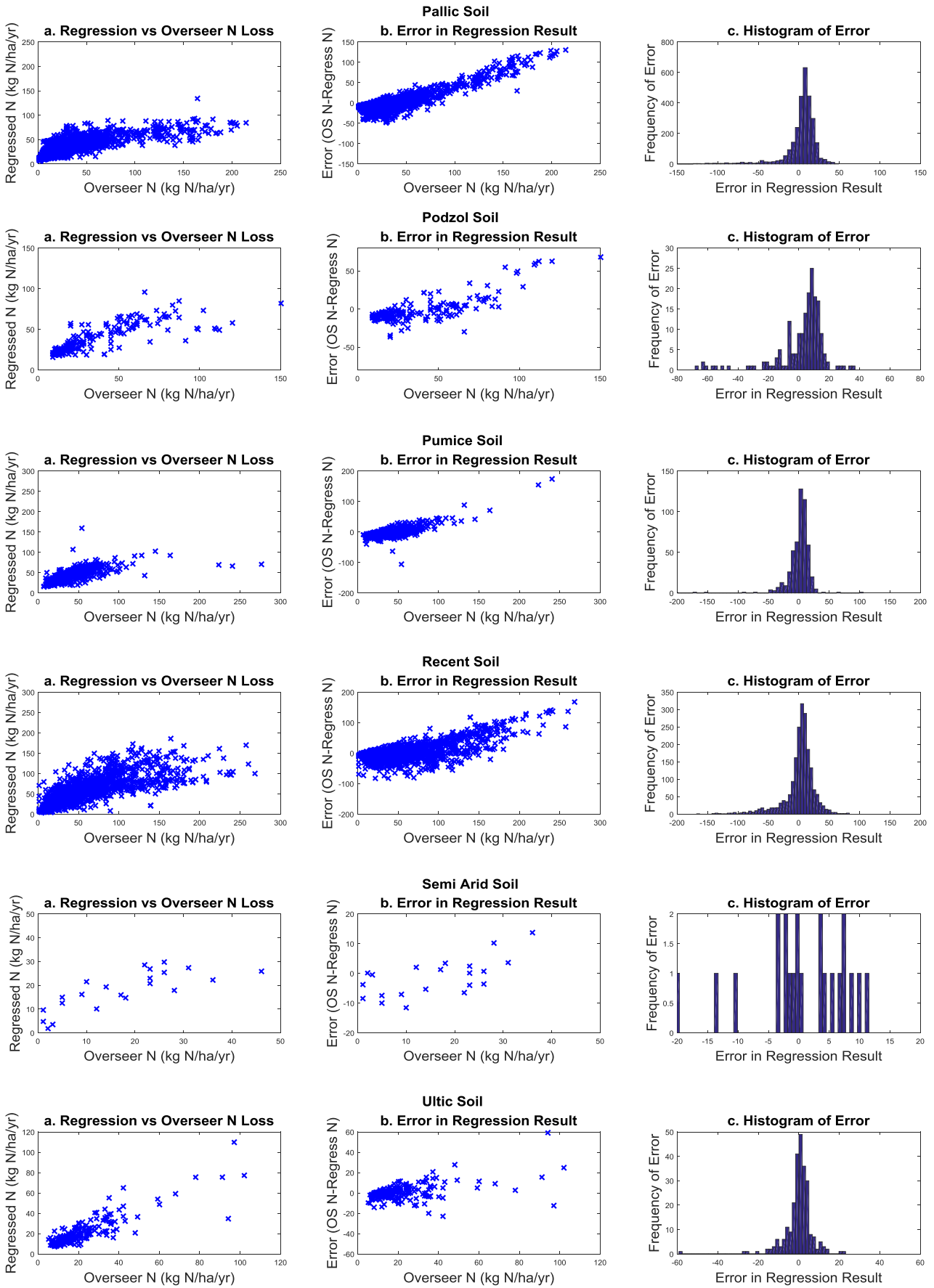

Ultic Soil
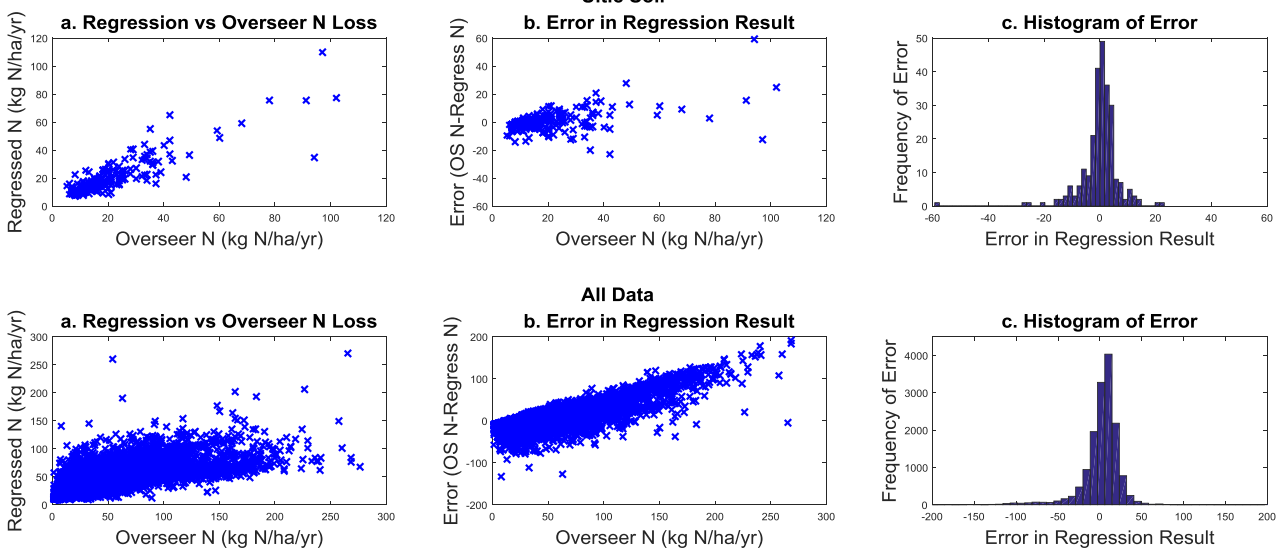

Figure 5.1 (continued) Graphs comparing regressed N results and OVERSEER N predictions. For each soil order and all data three graphs are presented a.) Regressed $\mathrm{N}$ results compared to OVERSEER $\mathrm{N}$ predictions, b.) Regression error plotted against OVERSEER $\mathrm{N}$, and c.) Histograms of regression error 
Table 5.1 Mean error between regressed $\mathrm{N}$ results and OVERSEER $\mathrm{N}$ and associated lower and upper $95 \%$ confidence interval boundaries

\begin{tabular}{|c|c|c|c|}
\hline Soil Order & $\begin{array}{l}\text { Mean Error } \\
\left(\mathrm{kg} \mathrm{N} \mathrm{ha}^{-1} \mathrm{yr}^{-1}\right)\end{array}$ & $\begin{array}{c}\text { Lower 95\% Confidence } \\
\text { Interval Boundary } \\
\left(\mathrm{kg} \mathrm{N} \mathrm{ha}^{-1} \mathrm{yr}^{-1}\right)\end{array}$ & $\begin{array}{c}\text { Upper 95\% Confidence } \\
\text { Interval Boundary } \\
\left(\mathrm{kg} \mathrm{N} \mathrm{ha}^{-1} \mathrm{yr}^{-1}\right)\end{array}$ \\
\hline Allophanic & 0.32 & -0.11 & 0.76 \\
\hline Brown & 2.39 & 1.57 & 3.22 \\
\hline Gley & 0 & -0.57 & 0.57 \\
\hline Granular & 0 & -1.76 & 1.75 \\
\hline Melanic & 0 & -0.96 & 0.95 \\
\hline Organic & 0.35 & -0.61 & 1.31 \\
\hline Oxidic & 0 & -3.22 & 3.22 \\
\hline Pallic & 2.97 & 2.2 & 3.75 \\
\hline Podzol & 1.83 & -0.67 & 4.34 \\
\hline Pumice & 0.67 & -1.1 & 2.44 \\
\hline Recent & 1 & -0.17 & 2.16 \\
\hline Semi Arid & 0.48 & -2.95 & 3.92 \\
\hline Ultic & 0.01 & -0.86 & 0.89 \\
\hline All Data & 2.08 & 1.73 & 2.44 \\
\hline
\end{tabular}

Table 5.2 Measures of fit (normalised least squares and Nash-Sutcliffe) between regressed N results and OVERSEER $N$, as generated during optimisation using MATLAB function fmincon.

\begin{tabular}{|l|c|c|}
\hline \multicolumn{1}{|c|}{ Soil Order } & Normalised Least Squares & Nash-Sutcliffe \\
\hline Allophanic & 10.43 & -0.27 \\
\hline Brown & 23.66 & -0.23 \\
\hline Gley & 12.03 & -0.02 \\
\hline Granular & 11.76 & -0.06 \\
\hline Melanic & 6.71 & -0.01 \\
\hline Organic & 8.24 & -0.05 \\
\hline Oxidic & 6.33 & -0.01 \\
\hline Pallic & 21.16 & -0.03 \\
\hline Podzol & 16.98 & -0.42 \\
\hline Pumice & 20.39 & -0.58 \\
\hline Recent & 26.62 & -0.2 \\
\hline Semi Arid & 7.59 & -0.01 \\
\hline Ultic & 7.06 & -0.44 \\
\hline All Data & 22.24 & -0.23 \\
\hline
\end{tabular}

\subsubsection{Discussion}

In Section 5.3.2 pastoral $\mathrm{N}$ algorithm constants are parameterised, using the Ravensdown pastoral dataset and an automatic optimisation function in MATLAB. In addition, parameterised constants for both the $\mathrm{N}$ and $\mathrm{P}$ algorithms are presented. Here specifics 
relating to $\mathrm{N}$ algorithm parameterisation results are discussed along with wider discussion that applies to both $\mathrm{N}$ and $\mathrm{P}$ algorithms.

Like all models, the developed algorithms represent simplified versions of reality. In addition, although based on and parameterised from OVERSEER data, they represent simplified versions of OVERSEER $\mathrm{N}$ models. As such, $\mathrm{N}$ losses predicted using the developed algorithms do not match OVERSEER predicted losses in all cases. While 'correct' prediction of nutrient losses is an important aim, sparse actual, measured nutrient loss data from the full variety of geo-climatic and management conditions is available for comparison. Therefore, neither the pastoral algorithms nor OVERSEER predictions can be robustly assessed for the myriad of existing climate, soil, topography and management variables, and their combinations. However, in the absence of data detailing 'real' losses at the variety of scales and climate, soil, topographic and management combinations required, aiming to replicate OVERSEER losses is likely a good second option. Not only is OVERSEER the most widely used nutrient model in New Zealand, but it is also based on New Zealand specific research and carries credibility amongst many users.

$\mathrm{N}$ algorithm over- and under-predictions (in relation to OVERSEER predictions) are an obvious first focus for algorithm improvement. Investigation of these two groups of data did not reveal they are associated with any particular land use, climate, topographic or management variables. Blocks with higher OVERSEER predicted losses are likely associated with more intensively managed farms. As such, they are more likely to use nutrient inputs and management variables that are represented in OVERSEER, but not in the developed algorithm e.g. supplemental feed and effluent management variables. Including such variables in developed algorithms may improve predictions. To include management variables associated with timing and rate of fertiliser and effluent applications may require sub-annual consideration of rainfall, irrigation, fertiliser and effluent application. Currently all algorithm input variables are total annual values. Inclusion of qualitative variables, such as drainage and irrigation type, may also pose challenges.

Further investigation of alternative algorithm forms may also yield algorithms better able to replicate OVERSEER predictions. Soil order specific algorithms, with soil order specific inputs and form, may also improve predictions. On a more aspirational level inclusion of more detailed soil processes, including soil microbial activity and P biogeochemical cycling, could 
improve algorithm predictions. This would require much more detailed soil data than is currently available and would likely require finer temporal detail than the current annual time step. Possibly this level of detail would be difficult to assimilate into catchment scale modelling without significantly increasing processing times. Ultimately though, none of these suggested improvements to algorithms can be properly assessed until more comprehensive data detailing actual losses from a wider variety of New Zealand pastoral climate, soil, topography and management types and combinations, is available. Not only would this help improve the algorithms presented here, but it would also allow more robust verification of OVERSEER predictions.

Parameterised pastoral $\mathrm{N}$ and $\mathrm{P}$ algorithms presented here likely represent an improved method of export coefficient derivation because they enable calculation of site specific export coefficients for a wide variety of geo-climatic and management variables. Certainly improving predictions from the developed algorithms is always a future focus. However, this may mean increasing algorithm complexity, and maintaining a simpler algorithm structure in the face of data scarcity is advocated by some environmental modellers (Beven 2009). In addition, due to a lack of alternative comparative data, predictions can largely only be assessed against OVERSEER predictions, which are also subject to some uncertainty. Therefore, the algorithms presented here represent those now applied in LUCI water quality models. They are further evaluated, at catchment scale, in Chapter 7.

\subsection{PARAMETERISATION OF LAND COVER MULTIPLIERS (LCM)}

\subsubsection{Method}

Here a LCM is allocated to every land cover category in LCDB4, except high producing grassland, based on $\mathrm{N}$ and $\mathrm{P}$ losses reported in Section 3.4. The mean of reported $\mathrm{N}$ or $\mathrm{P}$ loss is calculated for 11 land covers (urban, short-rotation crop, perennial crop, low producing grassland, indigenous forest, scrub, exotic forest-non harvested, exotic forest-harvested, and exotic forest-deciduous). LCM, presented for 10 land covers (high producing grassland is excluded), represent the ratio between mean nutrient losses from the land cover in question and high producing grassland. Multipliers less than 1 indicate land cover losses are generally less than high producing pasture. Multipliers greater than 1 indicate land cover losses are higher than high producing pasture. An attempt to further define multipliers 
within land cover categories according to site and management variables was investigated, but in all cases insufficient data was available.

An LCM for $\mathrm{N}$ and for $\mathrm{P}$ is allocated to all LCDB4 land cover classes, except high producing grassland, based on the closest equivalent amongst the 10 broad land covers that feature LCM. Land cover classes with no expected $\mathrm{N}$ or $\mathrm{P}$ losses are given a LCM of 0 .

\subsubsection{Results}

Average $\mathrm{N}$ and $\mathrm{P}$ losses, derived from reported losses featured in Section 3.4, are reported in Table 5.3 for each of the 11 broad land cover categories. These average losses are used to calculate $\mathrm{N}$ and P LCM, which are also reported in Table 5.3 for all land covers except high producing grassland. Table 5.4 reports LCM allocated to each LCDB4 land cover class.

Table 5.3 Average $\mathrm{N}$ and $\mathrm{P}$ losses, derived from reported losses featured in Section 3.4, and $\mathrm{N}$ and $\mathrm{P}$ LCM for 10 land cover categories, calculated from average $\mathrm{N}$ and $\mathrm{P}$ losses.

\begin{tabular}{|c|c|c|c|c|}
\hline Land Cover & $\begin{array}{c}\text { Average N Loss } \\
\text { (kg N/ha/yr) }\end{array}$ & $\begin{array}{c}\text { Average P Loss } \\
\text { (kg P/ha/yr) }\end{array}$ & N LCM & P LCM \\
\hline Urban & 6.8 & 1 & 0.36 & 0.83 \\
\hline Short-rotation Crop & 71.9 & 0.85 & 3.78 & 0.71 \\
\hline Perennial Crop & 6.5 & 0.25 & 0.34 & 0.21 \\
\hline $\begin{array}{c}\text { Low Producing } \\
\text { Grassland }\end{array}$ & 5.8 & 0.3 & 0.31 & 0.25 \\
\hline $\begin{array}{c}\text { Indigenous Forest } \\
\text { Scrub }\end{array}$ & 2.8 & 0.4 & 0.15 & 0.33 \\
\hline $\begin{array}{c}\text { Exotic Forest-Non } \\
\text { harvested }\end{array}$ & 1.6 & 0.7 & 0.32 & 0.58 \\
\hline Exotic Forest-Harvested & 1.2 & 0.02 & 0.08 & 0.02 \\
\hline $\begin{array}{c}\text { Exotic Forest- } \\
\text { Deciduous }\end{array}$ & 2.4 & 2.2 & 0.06 & 1.83 \\
\hline $\begin{array}{c}\text { High Producing } \\
\text { Grassland }\end{array}$ & 19 & 0.3 & 0.13 & 0.25 \\
\hline
\end{tabular}


Table $5.4 \mathrm{~N}$ and P LCM allocated to all LCDB4 land covers except high producing grassland

\begin{tabular}{|c|c|c|c|}
\hline $\begin{array}{l}\text { LCDB4 Land } \\
\text { Cover Code }\end{array}$ & LCDB4 Land Cover Name & N LCM & P LCM \\
\hline 1 & Built-up Area & 0.36 & 0.83 \\
\hline 2 & Urban Parkland/Open Space & 0.36 & 0.83 \\
\hline 5 & Transport Infrastructure & 0 & 0 \\
\hline 6 & Surface Mine or Dump & 0 & 0 \\
\hline 10 & Sand or Gravel & 0 & 0 \\
\hline 12 & Landslide & 0 & 0 \\
\hline 14 & Permanent Snow \& Ice & 0 & 0 \\
\hline 16 & Gravel or Rock & 0 & 0 \\
\hline 15 & Alpine Grass/Herbfield & 0 & 0 \\
\hline 20 & Lake or Pond & 0 & 0 \\
\hline 21 & River & 0 & 0 \\
\hline 22 & Estuarine Open Water & 0 & 0 \\
\hline 30 & Short-rotation Cropland & 3.78 & 0.71 \\
\hline 33 & Orchards, Vineyards or Other Perennial Crops & 0.34 & 0.21 \\
\hline 41 & Low Producing Grassland & 0.31 & 0.25 \\
\hline 43 & Tall Tussock Grassland & 0.31 & 0.25 \\
\hline 44 & Depleted Grassland & 0.31 & 0.25 \\
\hline 45 & Herbaceous Freshwater Vegetation & 0 & 0 \\
\hline 46 & Herbaceous Saline Vegetation & 0 & 0 \\
\hline 47 & Flaxland & 0.32 & 0.58 \\
\hline 50 & Fernland & 0.32 & 0.58 \\
\hline 51 & Gorse and/or Broom & 0.32 & 0.58 \\
\hline 52 & Manuka and/or Kanuka & 0.32 & 0.58 \\
\hline 54 & Broadleaved Indigenous Hardwoods & 0.15 & 0.33 \\
\hline 55 & Sub Alpine Shrubland & 0 & 0 \\
\hline 56 & Mixed Exotic Shrubland & 0.32 & 0.58 \\
\hline 58 & Matagouri or Grey Scrub & 0.32 & 0.58 \\
\hline 70 & Mangrove & 0 & 0 \\
\hline 64 & Forest-Harvested & 0.06 & 1.83 \\
\hline 68 & Deciduous Hardwoods & 0.13 & 0.25 \\
\hline 69 & Indigenous Forest & 0.15 & 0.33 \\
\hline 71 & Exotic Forest & 0.08 & 0.02 \\
\hline
\end{tabular}

Results in Table 5.3 indicate average $\mathrm{N}$ losses from all land cover except short-rotation crops are lower than average $\mathrm{N}$ losses from high producing grassland, with LCM ranging from 0.06 for exotic harvested forest to 0.36 from urban land cover. Average $\mathrm{N}$ losses from shortrotation crops are higher than average $\mathrm{N}$ losses from high producing grassland, with an LCM of 3.78. A number of variables could contribute to higher losses from short-rotation crops e.g. High fertiliser and irrigation use, and periods of fallow without plant uptake. 
For $\mathrm{P}$, results indicate average losses from all land covers except harvested exotic forest are lower than average losses from high producing grassland, with LCM ranging from 0.02 for non-harvested exotic forest to 0.83 for urban land cover. Average P losses from harvested exotic forest are higher than those from high producing grassland, with an LCM of 1.83. Again, this is not surprising given P loss is often associated with sediment movement and exotic plantation forest in New Zealand is frequently situated on steeper topography.

\section{$\underline{5.4 .3 \text { Discussion }}$}

Ideally an algorithmic export coefficient approach, similar to that developed and parameterised for pastoral land covers, is desired for other land covers. However, due to a lack of suitable data, this is not possible. Instead, an alternative approach is developed here based on the pastoral algorithms reported in Section 5.2.1 with the addition of a LCM. Using pastoral algorithms as a base for deriving other land cover export coefficients ensures important $\mathrm{N}$ and $\mathrm{P}$ loss variables are accounted for. The LCM increases or decreases pastoral algorithm output to reflect literature reported differences in nutrient loss between pastoral land cover and the land cover in question.

Although the general order of LCM above and below 1 and compared to high producing grassland, is expected, it is difficult to assess the absolute accuracy of the LCM developed here. LCMs for land covers with more nutrient export literature available are possibly more accurate e.g. indigenous forest, exotic forest and high producing grassland. Although it is clear, even in these cases, a limited range of climate, soil, topography and management variables and variable combinations are represented. For land covers with little available nutrient loss literature, accuracy is even less certain. This is particularly the case for urban, low producing grassland and scrub land covers. In addition, as discussed in Section 3.4, comparative scale issues exist. For example, reported losses from crops are largely based on point scale leaching losses only. The majority of reported losses from high producing grassland are based on small catchment scale losses and include a wider range of loss pathways and more attenuation processes. This may result in a calculated LCM for crops that is higher than it should be.

Comparing LCM recorded in Table 5.3 with LCM derived from mid-point $\mathrm{N}$ and P losses from international export coefficient data (reported in Table 2.1) shows particular differences for 
urban land cover. International data suggests urban losses for $\mathrm{N}$ and $\mathrm{P}$ are approximately double intensive pasture losses. This further illustrates the inadequacy of measured urban losses for New Zealand as discussed in Section 3.4.

Clearly LCM could be improved with more evidential data around all land covers and ideally this would include a range of climate, soil, topography and management variables and variable combinations measured either at a range of scales or at comparable scales. Ultimately though the aim is development of an algorithmic approach based on an extensive database similar in scope to the Ravensdown dataset. Certainly the full Ravensdown dataset includes crop and fodder crop data, which could be used to develop crop algorithms. It is also possible that modelled or measured data relating to both agricultural and forested land covers is held in New Zealand research institutes, but at this stage no such data has been found or made available to $\mathrm{LUCl}$ developers.

\subsection{REGIONAL SCALE INPUTS TO N AND P PASTORAL ALGORITHMS}

\section{$\underline{\text { 5.5.1 Method }}$}

Where the developed $\mathrm{N}$ and $\mathrm{P}$ loss models are applied at farm to small catchment scale, actual farm information from OVERSEER files may be available as model input. For applications where actual farm data is not available, alternative input must be used. In addition, input to the pastoral algorithms is required for other land covers. Therefore, in this section regional scale model inputs are developed for $17 \mathrm{New}$ Zealand climate regions (Figure 5.3) based on characteristics of high producing pastoral land cover in each region. In ArcGIS regional masks of high producing grassland are extracted from LCDB4. These are used to extract annual mean rainfall data for regional high producing grassland from NIWA's rainfall surface. Summary statistics based on extracted data are generated and the mean of annual mean rainfall for each region is used as rainfall input.

Regional mean irrigation depth, fertiliser $\mathrm{N}$ and $\mathrm{P}$ inputs, effluent $\mathrm{N}$ and $\mathrm{P}$ inputs and stocking rate are derived from the Ravensdown dataset. Olsen $\mathrm{P}$ is set to 25 for all regions. This is generally considered optimal Olsen P, but it is acknowledged that, like other regional inputs developed here, there will be variability. 


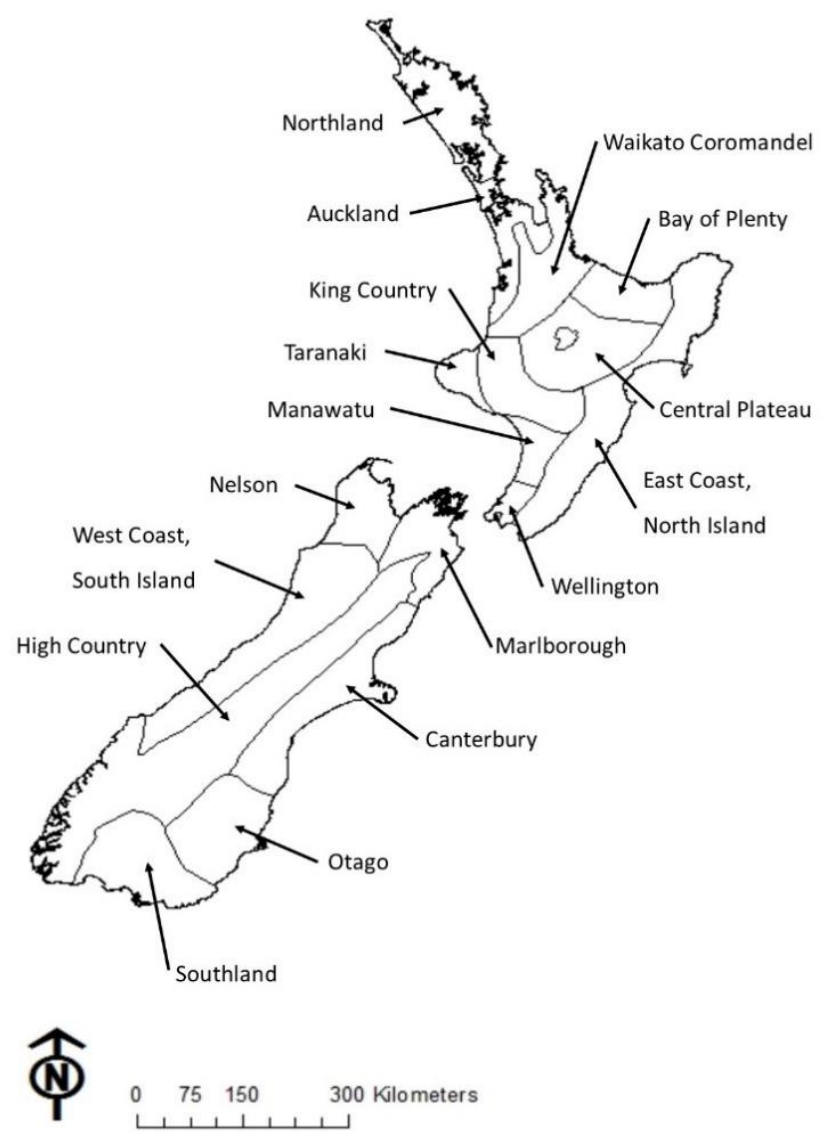

Figure 5.3 New Zealand climate regions, based on OVERSEER developed climate regions.

\section{$\underline{5.5 .2 \text { Results }}$}

Regional average rainfall, irrigation, fertiliser $N$, effluent $N, R S U$, fertiliser $P$, effluent $P$, and Olsen $\mathrm{P}$ are presented in Table 5.5. Regional mean average rainfall on high producing grassland ranges from $695.6 \mathrm{~mm} \mathrm{yr}^{-1}$ in Otago to $3073.4 \mathrm{~mm} \mathrm{yr}^{-1}$ on the South Island's West Coast. Regional annual average irrigation depth on high producing grassland ranges from 2.5 $\mathrm{mm} \mathrm{yr}^{-1}$ in Coromandel to $352.9 \mathrm{~mm} \mathrm{yr}^{-1}$ in Canterbury. Regional annual fertiliser $\mathrm{N}$ application on high producing grassland ranges from $99.6 \mathrm{~kg} \mathrm{~N} \mathrm{ha}^{-1} \mathrm{yr}^{-1}$ in the South Island's high country to $160.6 \mathrm{~kg} \mathrm{~N} \mathrm{ha}^{-1} \mathrm{yr}^{-1}$ in Nelson. Regional annual effluent $\mathrm{N}$ application on high producing grassland ranges from $19.9 \mathrm{~kg} \mathrm{~N} \mathrm{ha}^{-1} \mathrm{yr}^{-1}$ in the South Island's high country to 31.8 $\mathrm{kg} \mathrm{N} \mathrm{ha}^{-1} \mathrm{yr}^{-1}$ in Canterbury. Regional annual fertiliser $\mathrm{P}$ application on high producing grassland ranges from $14 \mathrm{~kg} \mathrm{P} \mathrm{ha}^{-1} \mathrm{yr}^{-1}$ in the South Island's high country to $35.2 \mathrm{~kg} \mathrm{P} \mathrm{ha}^{-1} \mathrm{yr}^{-1}$ in Taranaki. Regional annual effluent $\mathrm{P}$ application on high producing grassland ranges from $7 \mathrm{~kg} \mathrm{P} \mathrm{ha}^{-1} \mathrm{yr}^{-1}$ in the South Island's high country to $17.6 \mathrm{~kg} \mathrm{P} \mathrm{ha}^{-1} \mathrm{yr}^{-1}$ in Taranaki. Regional average stocking rate on high producing grassland ranges from $12.2 \mathrm{RSU}$ in Northland to 21.6 RSU in Canterbury. . 
Table 5.5 Regional default input values, developed as described in the text and used in the developed export coefficient $\mathrm{N}$ and $\mathrm{P}$ models where no farm specific data is available.

\begin{tabular}{|c|c|c|c|c|c|c|c|c|}
\hline Region & $\begin{array}{c}\text { Rainfall } \\
\left(\mathrm{mm} \mathrm{yr}^{-1}\right)\end{array}$ & $\begin{array}{l}\text { Irrigation } \\
\left(\mathrm{mm} \mathrm{yr} \mathbf{~}^{-1}\right)\end{array}$ & $\begin{array}{c}\text { N Fertiliser } \\
\left(\mathrm{kg} \mathrm{N} \mathrm{ha}^{-1} \mathrm{yr}^{-1}\right)\end{array}$ & $\begin{array}{c}\text { N Effluent } \\
\left(k^{\prime} \text { ha }^{-1} \mathrm{yr}^{-1}\right)\end{array}$ & $\begin{array}{c}\text { P Fertiliser } \\
\left(\mathrm{kg} \mathrm{P} \mathrm{ha}^{-1} \mathrm{yr}^{-1}\right)\end{array}$ & $\begin{array}{c}\text { P Effluent } \\
\left(\mathrm{kg} \mathrm{P} \mathrm{ha}^{-1} \mathrm{yr}^{-1}\right)\end{array}$ & $\begin{array}{c}\text { Stocking } \\
\text { Rate } \\
\text { (RSU) }\end{array}$ & Olsen P \\
\hline Auckland & 1441.5 & 9.8 & 134.8 & 27 & 20 & 10 & 15.8 & 25 \\
\hline Bay of Plenty & 1697.8 & 12.7 & 154.1 & 30.8 & 25.8 & 12.9 & 19.4 & 25 \\
\hline Canterbury & 729.6 & 352.9 & 159 & 31.8 & 18.3 & 9.2 & 21.6 & 25 \\
\hline Central Plateau & 1489.6 & 13.1 & 135.4 & 27.1 & 23.7 & 11.9 & 17.2 & 25 \\
\hline East Coast North Is & 1273 & 48.6 & 109.5 & 21.9 & 18.7 & 9.4 & 16.9 & 25 \\
\hline High Country & 884.3 & 154.8 & 99.6 & 19.9 & 14 & 7 & 16.9 & 25 \\
\hline King Country & 1296.9 & 11.9 & 111.2 & 22.2 & 23.2 & 11.6 & 16.1 & 25 \\
\hline Manawatu & 1020.6 & 79.4 & 134.3 & 26.9 & 18.9 & 9.4 & 15.8 & 25 \\
\hline Marlborough & 966.6 & 91.1 & 147.4 & 29.5 & 17.9 & 8.9 & 20 & 25 \\
\hline Nelson & 1750.4 & 46.5 & 160.6 & 32.1 & 23 & 11.5 & 16.1 & 25 \\
\hline Northland & 1483.9 & 12.1 & 112.4 & 22.5 & 18.8 & 9.4 & 12.2 & 25 \\
\hline Otago & 695.6 & 69.1 & 136.7 & 27.3 & 18 & 9 & 16.9 & 25 \\
\hline Southland & 1039.9 & 10.5 & 154.1 & 30.8 & 22.9 & 11.4 & 18.9 & 25 \\
\hline Taranaki & 1721.7 & 7.6 & 157.4 & 31.5 & 35.2 & 17.6 & 18.4 & 25 \\
\hline Waikato Coromandel & 1503.4 & 2.5 & 142.2 & 28.4 & 28.1 & 14 & 17.8 & 25 \\
\hline Wellington & 1345 & 32.3 & 130.4 & 26.1 & 18.5 & 9.3 & 12.9 & 25 \\
\hline West Coast South Is & 3073.4 & 7.4 & 136.8 & 27.4 & 20.2 & 10.1 & 18.1 & 25 \\
\hline
\end{tabular}




\section{$\underline{\text { 5.5.3 Discussion }}$}

As previously mentioned, it is difficult to assess the accuracy of developed regional inputs. It is acknowledged using the Ravensdown dataset to derive farm inputs may skew average regional inputs toward higher values because it likely features more intensive land uses. As an example, total national fertiliser application reported by Statistics NZ (2012) and divided by total hectares of high producing grassland from LCDB4 indicates approximately $9.4 \mathrm{~kg} \mathrm{~N}$ $\mathrm{ha}^{-1} \mathrm{yr}^{-1}$ and $13.6 \mathrm{~kg} \mathrm{P} \mathrm{ha}^{-1} \mathrm{yr}^{-1}$ is applied on average. Clearly, these figures are lower than those reported in Table 5.4, particularly for N. However, it should also be noted that only a select number of the most popular fertilisers are featured in Statistics NZ data and figures are farmer-reported. As such, they rely on farmers keeping and reporting accurate records of fertiliser applications. Comparison between the regional fertiliser inputs reported above for Manawatu and actual fertiliser applications to the Tuapaka catchment in Manawatu, which is largely a lower intensity cattle and sheep enterprise, indicates regional averages are reasonably appropriate for use in this catchment.

Spatial land use, rather than land cover, data would enable more management specific inputs to be linked to specific farm types. This would somewhat overcome the skew towards more intensive farm types. Again, investigation of either using spatial land use data or developing a method of elucidating likely 'land use', is an avenue for future improvement. However, a single set of regional inputs would still be required as input to other land cover algorithms

\subsection{SUMMARY}

$\mathrm{N}$ and $\mathrm{P}$ export coefficient algorithms for pastoral land cover presented in this chapter represent a new method of calculating site specific export coefficients that account for important geo-climatic and land management variables. Comparison of $\mathrm{N}$ algorithm predictions with OVERSEER predictions indicates improvements to algorithm predictive ability could be made, particularly for more intensively managed farms. However, predictions from the algorithms developed here and OVERSEER cannot be robustly evaluated due to insufficient measured nutrient losses from New Zealand pasture featuring the full variety of geo-climatic and land management variables. 
For other land covers, use of the pastoral algorithms in combination with LCM allows important nutrient loss variables to be accounted for, where they otherwise couldn't be. Ideally however, data specific to the variety of land covers found in LCDB4, from which land cover specific algorithms could be developed, would represent a real step forward. No adequate data has been located to-date, but it is possible some exists, particularly for forested land cover, which is one of the more researched New Zealand land covers.

Spatial data featuring regional averages of pastoral algorithm inputs has been developed to facilitate application of the algorithms for pasture, where OVERSEER data is not available, and for other land covers. The ability to spatially identify pastoral land uses would allow land use specific regional input averages to be used. This would better account for a range of farm types and intensities. However, a suitable input dataset would still be required for use in other land cover algorithms.

Further work refining the algorithms and input data presented here is desired. However, application of the presented algorithms at catchment scale, already represents a conceptual improvement to the export coefficient approach, even if absolute nutrient loss values are not 'correct'. Chapter 7 further investigates algorithm performance at catchment scale using LUCI water quality models in two New Zealand catchments. 


\section{INVESTIGATE AND PARAMETERISE FIVE IDENTIFIED NITROGEN AND PHOSPHORUS MITIGATION OPTIONS FOR USE IN LUCI}

\subsection{INTRODUCTION}

Assessing the likely effect of mitigation strategies to facilitate decision making, is an important objective of LUCI water quality models, particularly the versions developed for use by Ravensdown. In this chapter literature relating to five on-farm mitigation strategies is reviewed, investigated, and where possible effects are quantified. This data will be used by the wider $\mathrm{LUCl}$ development team to further develop and parameterise mitigation strategies that feature as options in LUCI water quality models.

Mitigation strategies target either nutrient sources or hydrological pathways carrying nutrients to waterbodies (McKergow et al. 2007). It is generally recommended a dual approach is taken, targeting both sources and hydrological pathways (Downes et al. 1997). This study investigates three source based mitigation strategies and two hydrological pathway strategies. These five strategies are identified as of particular interest to Ravensdown and they include:

1. Reduced and strategic fertiliser application (Section 6.2)

2. Reduced and strategic effluent application (Section 6.3)

3. Reduced stocking rate (Section 6.4)

4. Wetland and riparian margin development and management (Section 6.5)

5. Sediment traps (Section 6.6)

\section{Challenges to Quantifying Mitigation Effects for New Zealand Farms}

For a number of reasons, quantification of the effects of mitigations for New Zealand is challenging. As found in previous chapters, lack of data is a constraint. While literature describing mitigations is widespread, literature quantifying effectiveness is not as ubiquitous, particularly over a variety of soil orders, topography, climate conditions, and management variables. 
A second challenge relates to farm system complexity. Farms comprise a number of interacting biological and non-biological components, which impact on nutrient management, and changes in one component can affect one or more other components (Rotz et al. 2005). For example, a reduction in fertiliser application reduces available feed, which requires either a reduction in stocking rate or an increase in supplemental feed, and if stocking rate is reduced, effluent is reduced. Wetland and riparian development and sediment traps can also impact on farm systems by taking land out of production, resulting in lower stock carrying capacity. Clearly, these interconnections must be considered in LUCI and the impact of changes to one component must be propagated through to other affected components to ensure realistic mitigation scenarios are modelled. However, direct effects of a component change versus inter-relational effects between farm components are not necessarily easy to isolate and not always elucidated in mitigation related literature.

A final point relates to quantification of economic costs and benefits related to mitigations. In New Zealand nutrient mitigations employed at farm scale are paid for by the enterprise and little, if any, compensatory funding is available. As a result the economics of mitigations at enterprise scale is a key concern for land owners (Monaghan et al. 2007a). LUCI currently does not consider economics, thus quantification of mitigation costs is not considered here. McDowell et al. (2013) review a range of nutrient mitigation strategies for New Zealand and compare relative costs and effectiveness.

\subsection{FERTILISER MITIGATIONS}

Fertiliser inputs are important to maintain or increase agricultural production and it is estimated that $40-60 \%$ of current global crop production is attributable to fertiliser applications (Johnston and Bruulsema 2014; Bindraban et al. 2015). However, fertiliser application is also identified as a major contributor to diffuse water pollution and must be carefully managed (Rotz et al. 2005; Cherry et al. 2008).

New Zealand agriculture has traditionally focused on pastoral farming. Under this regime pastures are planted with a mixed clover/grass cover and lime, $\mathrm{P}, \mathrm{K}, \mathrm{S}$ and $\mathrm{Mg}$ fertiliser applied to stimulate clover growth and thereby N-fixation (Haynes and Williams 1993). However, over the last 2-3 decades New Zealand pastoral agriculture has diversified and 
intensified and a wider variety of fertiliser types and nutrient contents are now used (MacLeod and Moller 2006).

Magnitude of nutrient inputs, including fertiliser, is a key driver of nutrient losses (Rotz et al. 2005; Monaghan et al. 2007a). Fertiliser associated nutrient losses are often categorised as direct or indirect. Direct loss to water refers to leaching or runoff losses directly from fertiliser after application. In a pasture system, indirect loss results from increased pasture production, which is eaten and excreted by pasture animals, with nutrients lost from excreta (Haynes and Williams 1993; Shepherd and Lucci 2011; Cameron et al. 2013). Direct fertiliser losses can generally be controlled through the use of good fertiliser management practices. Indirect losses are more challenging to address and require consideration of the whole farm system (Shepherd and Lucci 2011). Quantification of direct vs indirect losses would be of use for parameterisation of fertiliser related mitigation in $\mathrm{LUCl}$. Where possible this is quantified, however explicit differentiation between direct and indirect losses is not always elucidated in the literature.

Literature documenting good fertiliser management practices often refers to the $4 R$ Nutrient Stewardship framework (Figure 6.1) of Right amount, Right source, Right time and Right place (Roberts 2007; Johnston and Bruulsema 2014). The Fertiliser Association of New Zealand also broadly follow this framework. However, they use the acronym CRAFT to

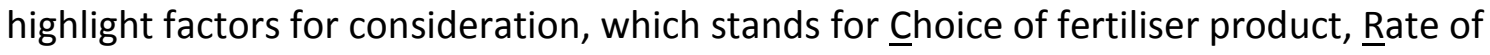
application, Application technique, Frequency of application, and Timing of application. Here fertiliser related mitigations are discussed under four broad headings - amount, source or type, timing and place, with a focus on pastoral land covers.

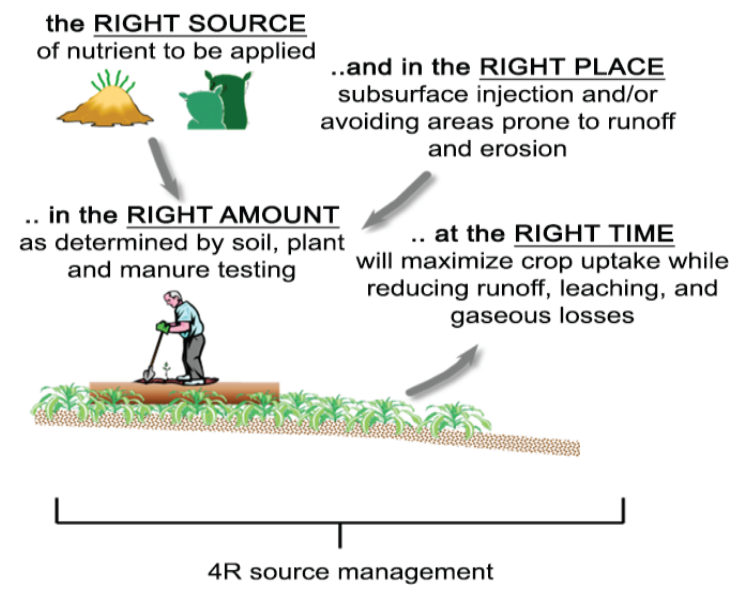

Figure 6.1 4R Nutrient Stewardship concept (Sharpley 2016). 


\subsubsection{Amount: The Effects of Variable Fertiliser Applications}

\section{Nitrogen}

Indirect loss of fertiliser $\mathrm{N}$ to water via excreta, particularly $\mathrm{N}$ leaching of urine, is considered to be the main concern from grazed pastures (Haynes and Williams 1993; Di and Cameron 2002a; Monaghan et al. 2007a; Monaghan et al. 2008; Cameron et al. 2013). However, as stated previously, direct losses of fertiliser $\mathrm{N}$ can occur if good management practice is not followed. Here studies investigating $\mathrm{N}$ leaching losses reported as annual specific load at a range of fertiliser application rates are investigated and summarised in Table 6.1. The majority of these studies do not differentiate between direct and indirect $\mathrm{N}$ losses and Table 6.1 reports total losses, whether direct or indirect. However, Ledgard et al. (1999) estimate direct leaching losses from pasture fertilised with $>400 \mathrm{~kg} \mathrm{~N} \mathrm{ha}^{-1} \mathrm{yr}^{-1}$ at approximately $10 \%$ and Shepherd and Lucci (2011) and Puha et al. (2008) note that direct losses of $30-50 \%$ of $\mathrm{N}$ applied in winter can occur. An additional complication with the literature investigated is the variety of other variables present between the studies e.g. rainfall, soil order, and stock type and rate. As is clear from earlier chapters, these factors are influential $\mathrm{N}$ loss variables.

Nitrate leaching loss under no fertiliser ranges from $5.8-74 \mathrm{~kg} \mathrm{~N} \mathrm{ha}^{-1} \mathrm{yr}^{-1}$ with a mean of 28.3 $\mathrm{kg} \mathrm{N} \mathrm{ha}^{-1} \mathrm{yr}^{-1}$ (Table 6.1). Under fertilised fields $12-204 \mathrm{~kg} \mathrm{~N} \mathrm{ha}^{-1} \mathrm{yr}^{-1}$ is leached with a mean of $79 \mathrm{~kg} \mathrm{~N} \mathrm{ha}^{-1} \mathrm{yr}^{-1}$. Figure 6.2 shows annual nitrate leached as a function of annual fertiliser $\mathrm{N}$ applied with a linear $\mathrm{r}^{2}$ value of 0.5304 . This indicates a moderate positive trend of increasing nitrate leaching with increasing annual $\mathrm{N}$ fertiliser applications and implies a reduction in $\mathrm{N}$ fertiliser application will likely reduce $\mathrm{N}$ leaching.

However, variability is evident. For example, even with no fertiliser application losses are up to $74 \mathrm{~kg} \mathrm{~N} \mathrm{ha}^{-1} \mathrm{yr}^{-1}$ and with fertiliser applications of $400 \mathrm{~kg} \mathrm{~N} \mathrm{ha}^{-1} \mathrm{yr}^{-1}$ losses can be as low as $41.1 \mathrm{~kg} \mathrm{~N} \mathrm{ha}^{-1} \mathrm{yr}^{-1}$. In the case of these two examples, likely contributing factors include soil order, rainfall, and stock type. This highlights how differences in geo-climatic variables and the farm system influence losses and these factors must be considered in mitigation tools. It is also clear from the data only a limited range of factors is included e.g. only three soil orders and this will hamper parameterisation. 
Table 6.1 Summary of $\mathrm{N}$ losses, reported as annual specific load, from New Zealand studies of variable $\mathrm{N}$ fertiliser application

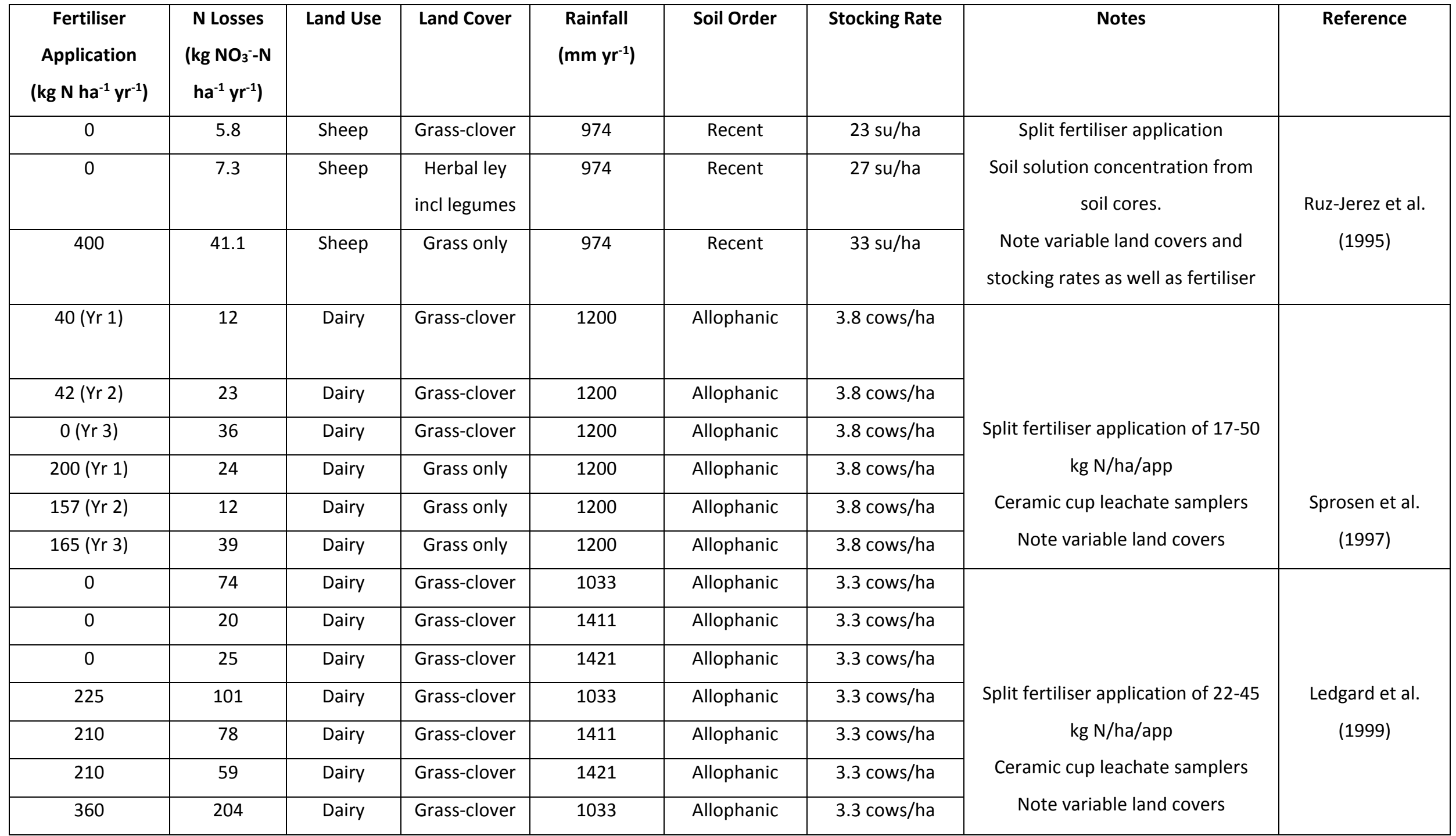




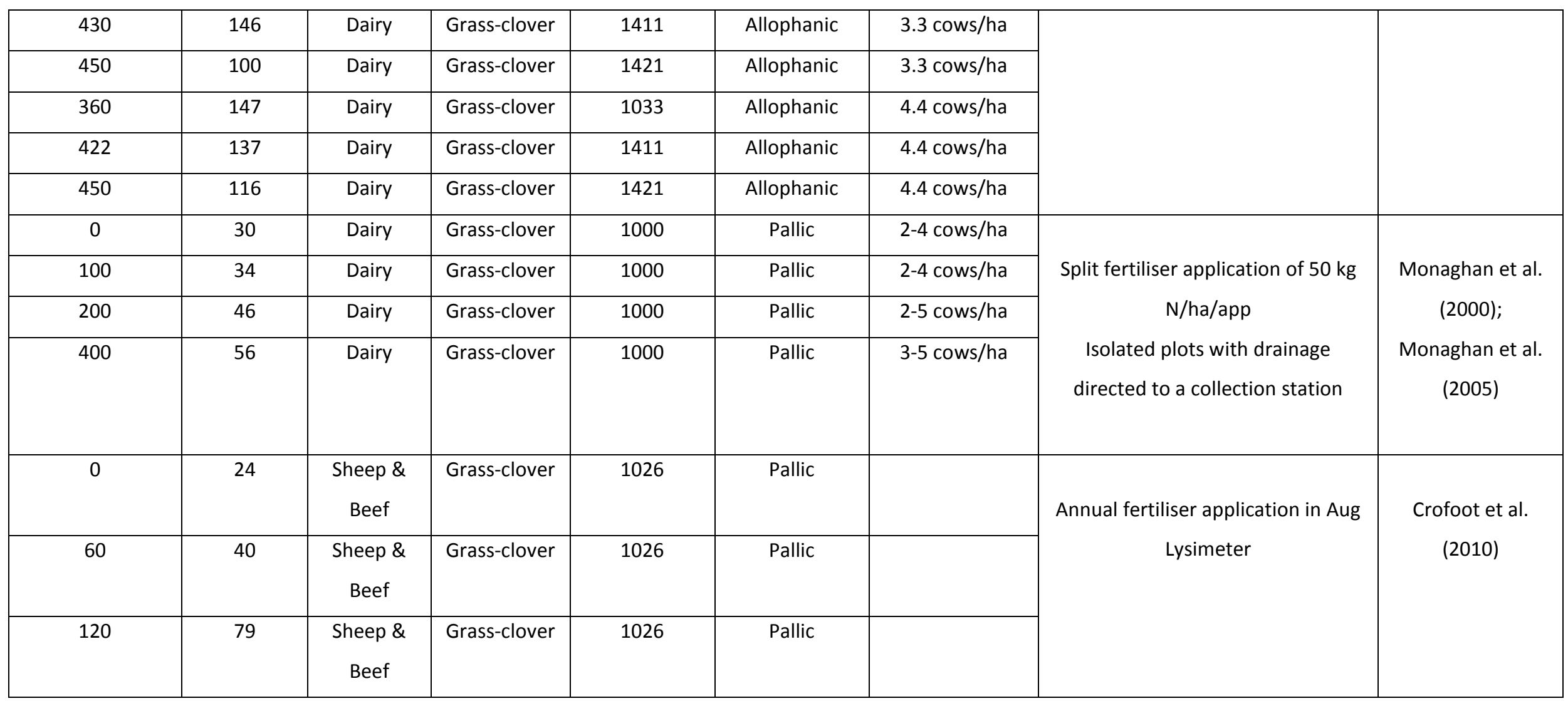




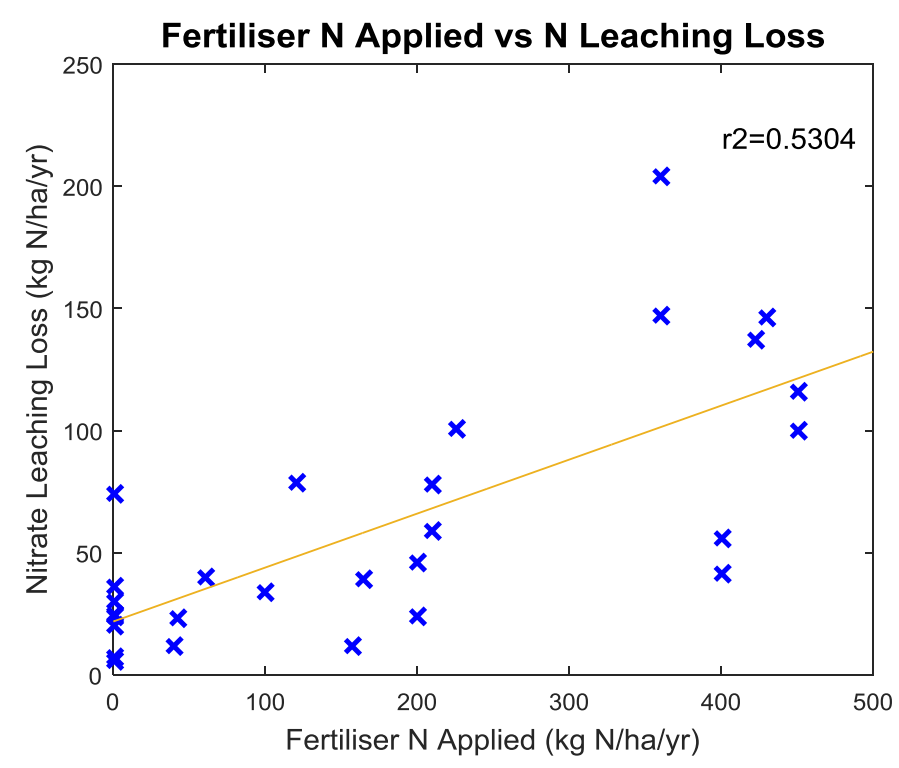

Figure 6.2 Graph showing annual nitrate leaching (including direct and indirect losses) as a function of annual fertiliser $\mathrm{N}$ applied

\section{Phosphorus}

Few individual New Zealand studies detail the effects of variable $\mathrm{P}$ fertiliser application on $\mathrm{P}$ losses. Table 6.2 summarises measured annual P loss from pasture reported by Sharpley and Syers (1979). Under no fertiliser application 0.85-1.28 $\mathrm{kg} \mathrm{TP} \mathrm{ha}^{-1} \mathrm{yr}^{-1}$ is lost and P fertilised losses range from 0.11-6.22 $\mathrm{kg} \mathrm{TP} \mathrm{ha}^{-1} \mathrm{yr}^{-1}$. Clearly, there is little range in amount of fertiliser applied and at applied fertiliser of $50 \mathrm{~kg} \mathrm{P} \mathrm{ha}^{-1} \mathrm{yr}^{-1}$ there is considerable variability of loss. The highest two loss measurements are from higher annual rainfall areas, but other variables could contribute e.g. stocking rates or Olsen P may be variable. Unfortunately these specifics are not elucidated.

Table 6.3 summarises P concentration in "overland flow" generated from simulated rainfall on intact soil turf in a plywood overland flow box from McDowell et al. (2003). Here mean concentrations are shown for each fertiliser regime. Figure 6.3a shows $\mathrm{P}$ loss as a function of P fertiliser applications. This indicates P concentration of runoff generally increases with increasing $\mathrm{P}$ fertiliser applications, although the relationship is not strong with an $r^{2}$ value of 0.3761 and caution must be applied given the very low number of data points. Figure $6.3 \mathrm{~b}$ shows $\mathrm{P}$ loss as a function of initial Olsen $\mathrm{P}$ values. This indicates initial Olsen $\mathrm{P}$ is a clear contributing factor, although the low number of data points must be noted. In addition, fertiliser solubility appears to influence losses with lower concentration from less soluble 
reactive phosphate rock (RPR) than superphosphate at the same rate of application and similar Olsen P. (Although this observation is only based on one RPR sample). The clear influence of Olsen $\mathrm{P}$, mirrors the influence of soil variables such as Olsen $\mathrm{P}$ and $\mathrm{P}$ retention, seen in Sections 4.3 and 4.4. Again, the influence of geo-climatic variables and the farm system on P losses should be considered in mitigation tools and a limited range of factors is featured here.

As for $\mathrm{N}$, the issue of direct versus indirect losses from fertiliser application exists. Direct losses of $\mathrm{P}$ from fertiliser occur where $\mathrm{P}$ fertiliser application coincides with a rainfall event and direct loss decreases exponentially with time (McDowell et al. 2003; Hart et al. 2004; McDowell and Catto 2005). Approximately 100 days after fertiliser application $\mathrm{P}$ concentrations in runoff will likely be similar to that before fertilisation (McDowell et al. 2003). McDowell and Catto (2005) indicate direct $P$ loss from a winter application of $30 \mathrm{~kg} \mathrm{P}$ $\mathrm{ha}^{-1}$ of superphosphate equates to approximately $1 \%$ of the initial application. Direct loss of P fertiliser can largely be controlled by timing applications to increase the period between application and the next rainfall event. In addition, the risk of direct losses can be estimated by fertiliser solubility as presented in McDowell and Catto (2005). 
Table 6.2 Summary of $P$ losses, reported as annual specific load, with variable $P$ fertiliser application

\begin{tabular}{|c|c|c|c|c|c|c|c|}
\hline $\begin{array}{c}\text { Fertiliser } \\
\text { Application } \\
\left(\mathrm{kg} \mathrm{P} \mathrm{ha}^{-1} \mathrm{yr}^{-1}\right)\end{array}$ & 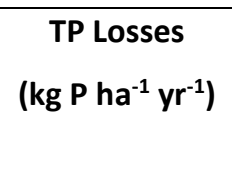 & Land Use & Land Cover & $\begin{array}{l}\text { Rainfall } \\
\left(\mathrm{mm} \mathrm{yr} \mathrm{r}^{-1}\right)\end{array}$ & Soil Order & Notes & Reference \\
\hline 0 & 0.85 & Ungrazed & Pasture & 970 & Pallic & \multirow{9}{*}{$\begin{array}{l}\text { Surface and tile drain } \\
\text { runoff collected } \\
\text { manually }\end{array}$} & \multirow{9}{*}{$\begin{array}{l}\text { Sharpley and } \\
\text { Syers (1979) }\end{array}$} \\
\hline 0 & 1.28 & Ungrazed & Pasture & 1170 & Pallic & & \\
\hline 0 & 0.87 & Ungrazed & Pasture & 910 & Pallic & & \\
\hline 50 & 3.67 & Dairy & Pasture & 970 & Pallic & & \\
\hline 50 & 5.63 & Dairy & Pasture & 1170 & Pallic & & \\
\hline 50 & 3.77 & Dairy & Pasture & 910 & Pallic & & \\
\hline 50 & 1.48 & Dairy & Pasture & 970 & Pallic & & \\
\hline 50 & 6.22 & Dairy & Pasture & 1170 & Pallic & & \\
\hline 50 & 0.52 & Dairy & Pasture & 910 & Pallic & & \\
\hline
\end{tabular}

Table 6.3 Summary of P losses, reported as concentration, from New Zealand studies of variable P fertiliser application (SP=superphosphate, RPR=Reactive Phosphate Rock)

\begin{tabular}{|c|c|c|c|c|c|c|c|}
\hline $\begin{array}{c}\text { Fertiliser } \\
\text { Application } \\
\left(\mathrm{kg} \mathrm{P} \mathrm{ha}^{-1} \mathrm{yr}^{-1}\right)\end{array}$ & $\begin{array}{c}\text { Average } \mathrm{P} \\
\text { Concentration } \\
\left(\mathrm{mg} \mathrm{L}^{-1}\right)\end{array}$ & Land Cover & $\begin{array}{l}\text { Rainfall } \\
\left(\mathrm{mm} \mathrm{yr}^{-1}\right)\end{array}$ & Soil Order & $\begin{array}{c}\text { Initial Olsen P } \\
\left(\mathrm{mg} \mathrm{kg}^{-1}\right)\end{array}$ & Notes & Reference \\
\hline 0 & 0.214 & Pasture & Simulated -5 events & Brown & 5.8 & \multirow{5}{*}{$\begin{array}{l}\text { Intact soil turf } \\
(1050 \times 2000 \mathrm{~mm})\end{array}$} & \multirow{5}{*}{$\begin{array}{c}\text { McDowell et al. } \\
\text { (2003) }\end{array}$} \\
\hline $18(\mathrm{SP})$ & 1.002 & Pasture & Simulated -5 events & Brown & 18.5 & & \\
\hline $23(S P)$ & 1.119 & Pasture & Simulated -5 events & Brown & 20.3 & & \\
\hline 23 (RPR) & 0.302 & Pasture & Simulated -5 events & Brown & 18.8 & & \\
\hline $37(S P)$ & 1.886 & Pasture & Simulated -5 events & Brown & 53 & & \\
\hline
\end{tabular}



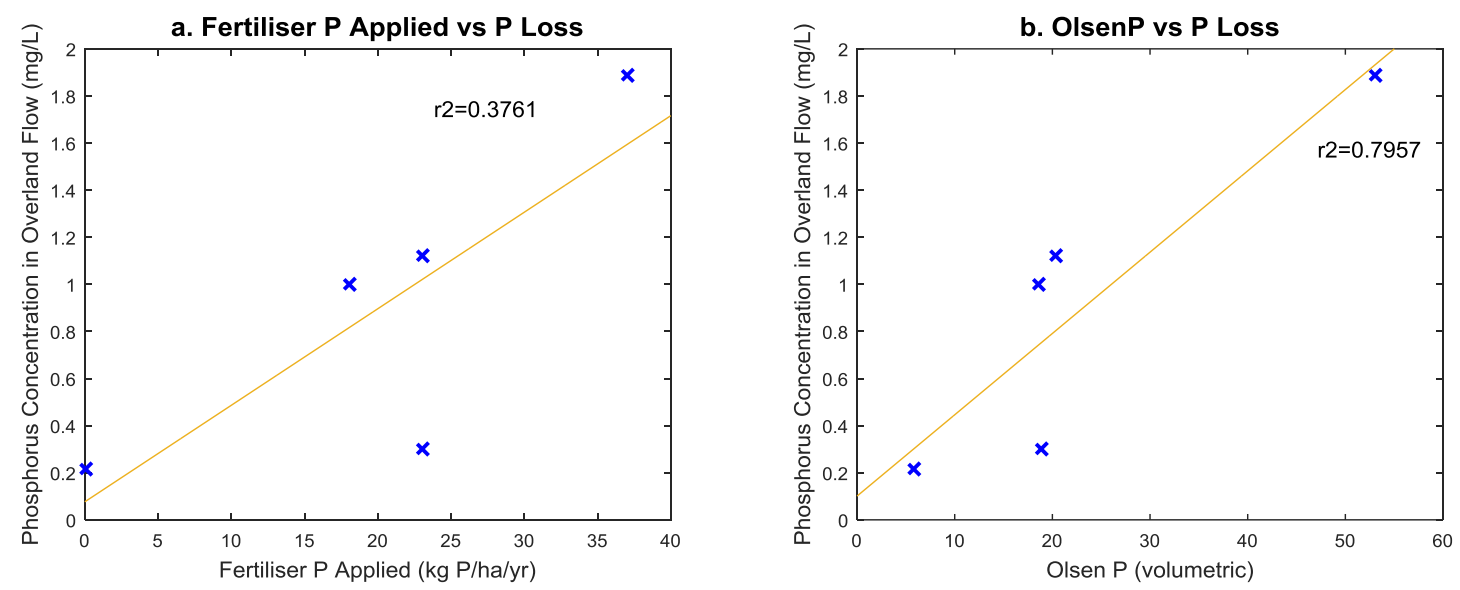

Figure 6.3a $\mathrm{P}$ concentration in overland flow as a function of annual fertiliser $\mathrm{P}$ applied and $6.3 \mathrm{~b} P$ concentration in overland flow as a function of initial soil Olsen $P$

\section{Plant Requirements and Nutrient Soil Reserves}

Both crop nutrient requirements and soil reserves are important considerations in decisions around fertiliser applications and, as highlighted previously, soil P reserves particularly influence $P$ losses. Ideally just enough nutrient should be provided to result in optimum growth response and minimum loss to the environment.

Plant requirements are determined by growth stage and desired yield. The Fertiliser Association of New Zealand (2013) recommend lower rates of $\mathrm{N}$ fertiliser are applied more frequently to match crop or pasture growth and soil moisture conditions. For pasture, if more than $200 \mathrm{~kg} \mathrm{~N} \mathrm{ha}^{-1}$ of fertiliser is required, it should be applied in split dressings of $50 \mathrm{~kg} \mathrm{~N} \mathrm{ha}^{-1}$ and if more than $100 \mathrm{~kg} \mathrm{P} \mathrm{ha}^{-1}$ of fertiliser is required, it should be applied in split dressings.

All soils have a P fixation capacity relating to soil type and current soil $\mathrm{P}$ reserves and in New Zealand soil $\mathrm{P}$ retention and Olsen $\mathrm{P}$ are routinely considered when determining fertiliser requirements (McLaren and Cameron 1996; FLRC 2015). Three classes of $P$ retention (also known as anion storage capacity) are commonly referred to in New Zealand agronomic literature - low (0-30\%), medium (31-85\%) and high (86-100\%) (McLaren and Cameron 1996; FLRC 2015). Table 6.4 relates these classes to NZSC soil orders. 
Table 6.4 NZSC soil orders in relation to P retention classes. Note - Gley soils have variable $P$ retention(McLaren and Cameron 1996)

\begin{tabular}{|l|c|c|c|}
\hline P Retention Class & Low & Medium-High & High \\
\hline NZSC Soil Orders & Organic & Brown & Allophanic \\
& Pallic & Pumice & Granular \\
& Podzol & Oxidic & \\
& Semi Arid & Melanic & \\
& Recent & & \\
& Raw & & \\
& Ultic & & \\
& & & \\
\hline
\end{tabular}

In soils with high $\mathrm{P}$ retention, higher rates of fertiliser application are required to increase readily available $\mathrm{P}$ because a higher proportion of fertiliser $\mathrm{P}$ will be adsorbed by the soil (FLRC 2015). Table 6.5 indicates how much extra fertiliser above maintenance requirements (ie. fertiliser required to maintain the same soil reserves after inputs and outputs) is needed to lift Olsen P by one unit for three soil parent material types.

Table 6.5 Amount of additional nutrient required per hectare to raise Olsen P test by one unit (FLRC 2015).

\begin{tabular}{|l|c|c|c|}
\hline & \multicolumn{3}{|c|}{ Soil Parent Material } \\
\hline Soil Test & Sedimentary & Ash & Pumice \\
\hline Olsen P & $4-7 \mathrm{~kg} \mathrm{P} \mathrm{ha}^{-1}$ & $7-18 \mathrm{~kg} \mathrm{P} \mathrm{ha}^{-1}$ & $4-15 \mathrm{~kg} \mathrm{P} \mathrm{ha}^{-1}$ \\
\hline
\end{tabular}

Soil $\mathrm{N}$ tests are not routinely used in New Zealand. By comparison to $\mathrm{P}, \mathrm{N}$ pools and transformations occur frequently so N quickly fluctuates (Groffman and Rosi-Marshall 2012). This makes testing of limited use as field conditions can change before results are received. Additionally, sample $\mathrm{N}$ transformations can occur en-route to the lab if not appropriately stored and quickly transported (McLaren and Cameron 1996; Hill Laboratories 2016). However, recent work by Curtin et al. (2017) has identified a soil N test that can be used to predict $\mathrm{N}$ supply potential for a range of New Zealand soil types and land uses and they are advocating its use.

\subsubsection{Fertiliser Type}

The most widely applied fertilisers in New Zealand are urea, ammonium sulphate, diammonium phosphate (DAP), superphosphate, and potassic superphosphate (McLaren 
and Cameron 1996; Fleming 2003; Statistics NZ 2012). Although many other fertilisers are also available (Ballance Agri-nutrients 2016; Ravensdown 2016).

Fertiliser elemental $\mathrm{N}$ and $\mathrm{P}$ content and solubility are important considerations in terms of nutrient losses to water and these details are provided by fertiliser suppliers. Higher elemental nutrient application is broadly related to higher losses. More soluble fertilisers also present an increased export risk. $\mathrm{N}$ fertilisers may be soluble, such as urea, or controlled release, which consist of coated soluble fertilisers. The coating temporarily prevents the release of $\mathrm{N}$ into the soil, potentially enabling better control over $\mathrm{N}$ release and better coordination of $\mathrm{N}$ release with $\mathrm{N}$ plant demand (Edmeades 2015). P fertiliser may be water soluble e.g. superphosphate, less water soluble e.g. dicalcic superphosphate or slow release e.g. rock phosphate (RPR). As stated above, McDowell and Catto (2005) found the risk of direct P loss can be estimated by fertiliser solubility. $\mathrm{P}$ loss directly after fertilisation largely comprises of dissolved reactive $\mathrm{P}$ (DRP) and fertiliser solubility is closely related to DRP concentrations at this time (McDowell and Catto 2005).

\section{$\underline{\text { 6.2.3 Timing and Placement }}$}

Timing of fertiliser applications must consider plant growth stage and nutrient requirements, and future rainfall or irrigation events (Fertiliser Association of New Zealand 2013). Both $\mathrm{N}$ and $\mathrm{P}$ fertiliser applications should be timed to avoid near future rainfall or irrigation events resulting in drainage or runoff and areas of already wet soil should be avoided (McDowell and Catto 2005; Monaghan et al. 2009; Fertiliser Association of New Zealand 2013; FLRC 2015).

Technological advances are aiding fertiliser placement. For example, detailed mapping of farms and crop requirements allows precise fertiliser targeting and placement where it is needed (Betteridge et al. 2008; Wilson 2015). Such maps also allow aerial broadcast methods of spreading that avoid areas where fertiliser is not required or desired, such as waterbodies (Chok et al. 2016). Placement of fertiliser in the soil, close to seeds or plants, rather than on the soil can decrease nutrient losses (McLaren and Cameron 1996). Time and cost involved with using some of these techniques can be a barrier to 
uptake, but this is changing as technologies become cheaper and pressures increase to consider the environmental impact of fertiliser use (Betteridge et al. 2008; Wilson 2015). In summary, studies investigating the effects of variable fertiliser application of $\mathrm{N}$ and $\mathrm{P}$ broadly indicate magnitude of fertiliser inputs influences the amount of nutrient lost. However, this relationship is complicated by the influence of geo-climatic and management factors and interrelationships between farm components. Teasing out the individual effects and relationships of these variables is not easy, especially with only limited data.

Without changing the whole farm system, direct fertiliser losses are best targeted. This can be done by using fertiliser best management practices, such as those advocated by the Fertiliser Association of New Zealand (2013) and summarised above.

\subsection{EFFLUENT APPLICATION}

In New Zealand dairy and piggery effluent and slurry are commonly applied to land as a means of disposal and to add beneficial nutrients to pastures or crops (Houlbrooke et al. 2004; Wang et al. 2004). Unlike fertiliser, effluent nutrient content is highly variable and very often unknown. Like fertiliser, nutrient losses from effluent are influenced by geoclimatic and management variables, and effluent is influenced by and influences other farm components such as fertiliser and stocking rate. Here effluent nutrient content is investigated in Section 6.3.1, followed by quantification and discussion of losses in Section 6.3.2 and mitigation options in Section 6.3.3.

\section{$\underline{\text { 6.3.1 Nutrient Content }}$}

Effluent nutrient content is related to feed content (especially feed additives), breed and life-cycle of livestock, and treatment and storage variables. Table 6.6 summarises reported TN and TP dairy and piggery effluent concentrations for New Zealand. Mean dairy TN concentrations range from 72-363 $\mathrm{mg} \mathrm{L}^{-1}$ and TP concentrations range from 31$69 \mathrm{TP} \mathrm{mg} \mathrm{L}^{-1}$. Mean piggery TN concentrations range from $230-1420 \mathrm{mg} \mathrm{L}^{-1}$ and TP concentrations range from 65-200 TP $\mathrm{mg} \mathrm{L}^{-1}$. $\mathrm{N}$ concentrations in dairy effluent have increased over time because less wash down water is used per cow and increased $\mathrm{N}$ fertiliser use has increased $\mathrm{N}$ content in feed and therefore excreta (Longhurst et al. 2000). Broadly, $20-25 \%$ of dairy effluent, $15 \%$ of dairy sludge (pond solids which are 
generally removed and spread approximately every 5 years) and $60-85 \%$ of piggery effluent $\mathrm{N}$ content is in plant available mineral form (Longhurst et al. 2000; Di and Cameron 2002a).

Table 6.6 Effluent concentrations as reported in New Zealand studies.

\begin{tabular}{|l|c|c|l|}
\hline \multicolumn{1}{|c|}{ Effluent Type } & TN $\left.\mathbf{m g ~ L}^{-\mathbf{1}^{*}}\right)$ & TP $\left(\mathbf{m g ~ L}^{-\mathbf{1}^{*}}\right)$ & \multicolumn{1}{c|}{ Reference } \\
\hline Dairy & $138-662$ & & Di et al. (1998) \\
\hline Dairy & $120-350$ & & Silva et al. (1999) \\
\hline Dairy & $181-506$ & $21-82$ & $\begin{array}{l}\text { Longhurst et al. } \\
\text { (2000) }\end{array}$ \\
\hline Dairy & 72 & & Sukias et al. (2001) \\
\hline Dairy & $150-340$ & $23-123$ & $\begin{array}{l}\text { Di and Cameron } \\
\text { (2002b) }\end{array}$ \\
\hline Dairy & 80 & 31 & $\begin{array}{l}\text { Hawke and } \\
\text { Summers (2003) }\end{array}$ \\
\hline Dairy & $44-628$ & $9.4-105$ & Saggar et al. (2004) \\
\hline Piggery & 230 & 65 & $\begin{array}{l}\text { Lowe (1993) as } \\
\text { cited in Wang } \\
\text { (2004) }\end{array}$ \\
\hline Piggery & 1420 & & $\begin{array}{l}\text { Cameron et al. } \\
\text { (1995) }\end{array}$ \\
\hline Piggery & $85-1300$ & 200 & Saggar et al. (2004) \\
\hline
\end{tabular}

${ }^{*}$ Please note references originally report losses in $\mathrm{g} \mathrm{m}^{-3}$, but are reported in $\mathrm{mg} \mathrm{L}^{-1}$ here for consistency. One $\mathrm{g} \mathrm{m}^{-3}$ is equivalent to $1 \mathrm{mg} \mathrm{L}^{-1}$.

Effluent is not a 'balanced' nutrient source and applying effluent to sufficiently supply one nutrient may result in over or undersupply of other nutrients. In New Zealand oversupply of potassium is commonly a limiting factor to application of dairy shed effluent in New Zealand (A.Roberts, personal communication, 17 May 2017), while Houlbrooke et al. (2004) suggest that in New Zealand dairy effluent supplies sufficient N, but that further $\mathrm{P}$ additions are often required. In contrast, Edmeades (2003) investigation into long-term world-wide studies of the effects of manure (which includes animal wastes and green manures) suggests that when adding for sufficient $\mathrm{N}$ supply, $\mathrm{P}$ tends to be oversupplied. However, these manures tend to be more solid than dairy effluent and are from animals largely fed a grain diet (A.Roberts, personal communication, 27 November 2017).

Considering that effluent is generally applied to only a small proportion of farm land, an oversupply of nutrients seems likely. Knowing nutrient composition of effluent can help 
to ensure no more than plant requirements are applied. Lab analysis can confirm

effluent nutrient content, but considering seasonal and even daily variability of nutrient content, this can only ever be indicative (Longhurst et al. 2000). Nutrient budgeting is an alternative and recommended as an accurate estimate of nutrients applied in effluent (A. Metherell, personal communication, 9 May 2017).

\section{$\underline{6.3 .2}$ Nutrient Losses}

Table 6.7 shows leaching losses of $\mathrm{NO}_{3}-\mathrm{N}$ from effluent fertilised New Zealand pasture. Losses associated with dairy effluent range from $6.3-131 \mathrm{~kg} \mathrm{~N} \mathrm{ha}^{-1} \mathrm{yr}^{-1}$. The two piggery effluent losses reported are very similar at 10.5 and $12 \mathrm{~kg} \mathrm{~N} \mathrm{ha}^{-1} \mathrm{yr}^{-1}$ which represents 5$6 \%$ of total $\mathrm{N}$ applied as effluent.

Figure 6.4 shows nitrate leaching losses for dairy as a function of effluent $\mathrm{N}$ applied. This indicates a moderate positive linear relationship with $r^{2}$ value of 0.6589 between amount of effluent $\mathrm{N}$ applied and $\mathrm{N}$ lost through leaching. However, this is clearly influenced by the point with $>1000 \mathrm{~kg} \mathrm{~N} \mathrm{ha}^{-1} \mathrm{yr}^{-1}$ applied and exclusion of these point results in an $r^{2}$ value of 0.0807

Table 6.7 Leaching losses of $\mathrm{NO}_{3}{ }^{-}-\mathrm{N}$ from effluent fertilised pasture as reported in New Zealand literature

\begin{tabular}{|c|c|c|c|}
\hline Effluent Type & $\begin{array}{l}\text { Application Rate } \\
\left(\mathrm{kg} \mathrm{N} \mathrm{ha}^{-1} \mathrm{yr}^{-1}\right)\end{array}$ & $\begin{array}{c}\text { Losses } \\
\left(\mathrm{kg} \mathrm{NO}_{3}^{-}-\mathrm{N} \mathrm{ha}^{-1} \mathrm{yr}^{-1}\right)\end{array}$ & Reference \\
\hline Dairy & 400 & $8-25$ & Di et al. (1998) \\
\hline Dairy & 200 & 6.3 & \multirow[t]{2}{*}{ Silva et al. (1999) } \\
\hline Dairy & 400 & 10 & \\
\hline Dairy & 100 & 18 & \multirow[t]{3}{*}{ Roach et al. (2001) } \\
\hline Dairy & 200 & 20 & \\
\hline Dairy & 400 & 50 & \\
\hline Dairy & 511 & 33 & \multirow[t]{2}{*}{ Singleton et al. (2001) } \\
\hline Dairy & 1518 & 131 & \\
\hline Dairy & 200 & 55 & \multirow{4}{*}{$\begin{array}{l}\text { Di and Cameron } \\
\qquad(2002 b)\end{array}$} \\
\hline Dairy & 200 & 7.6 & \\
\hline Dairy & 400 & 78.3 & \\
\hline Dairy & 400 & 18.7 & \\
\hline Piggery & 200 & 10.5 & \multirow[t]{2}{*}{ Cameron et al. (1995) } \\
\hline Piggery & 200 & 12 & \\
\hline
\end{tabular}




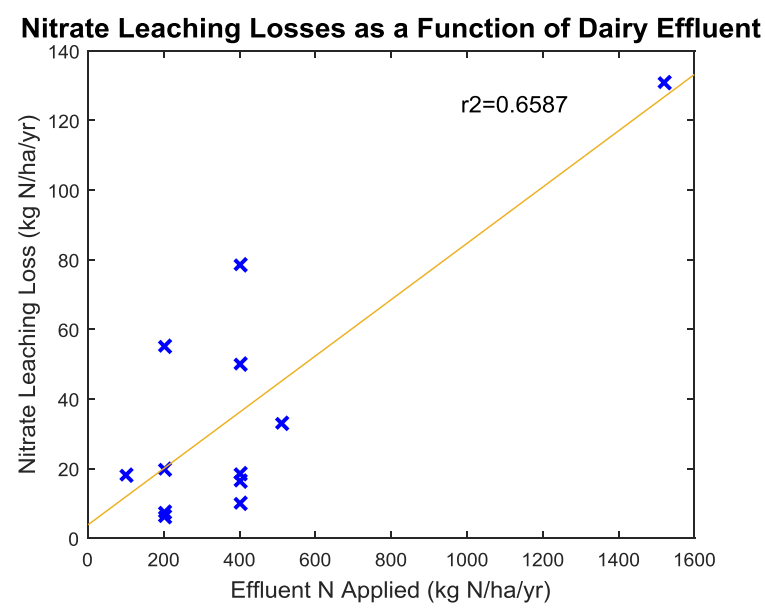

Figure 6.4 Nitrate leaching losses as a function of dairy effluent applied to pasture and reported in New Zealand studies.

Table 6.8 shows total $\mathrm{N}$ losses from effluent fertilised pasture reported in New Zealand literature. Figure 6.5a shows nitrogen loss as a function of effluent $\mathrm{N}$ applied. An $\mathrm{r}^{2}$ value of 0.9509 is reported, but this clearly is highly influenced by the sample with losses of $150 \mathrm{~kg} \mathrm{~N} \mathrm{ha-1} \mathrm{yr}^{-1}$ and only five samples are included. Figure $6.5 \mathrm{~b}$ shows only those samples where effluent is applied via deferred irrigation (which is described further in Section 6.3.3). An $r^{2}$ value of 0.9089 is reported, but again only three samples are included. Very broadly, figure 6.5 and Table 6.8 indicate higher effluent $\mathrm{N}$ applications appear to result in higher $\mathrm{N}$ losses and deferred irrigation methods do result in lower $\mathrm{N}$ losses.

Table 6.8 Total N losses from effluent fertilised pasture reported in New Zealand literature

\begin{tabular}{|c|c|c|c|c|}
\hline $\begin{array}{c}\text { Effluent } \\
\text { Type }\end{array}$ & $\begin{array}{l}\text { Application Rate } \\
\left(\mathrm{kg} \mathrm{N} \mathrm{ha}^{-1} \mathrm{yr}^{-1}\right)\end{array}$ & $\begin{array}{c}\text { Losses } \\
\left(\mathrm{kg} \mathrm{N} \mathrm{ha-1}^{-1} \mathrm{yr}^{-1}\right)\end{array}$ & Notes & Reference \\
\hline Dairy & 1125 & 150 & & $\begin{array}{l}\text { Macgregor et } \\
\text { al. (1979) as } \\
\text { cited in } \\
\text { Houlbrooke et } \\
\text { al (2004) }\end{array}$ \\
\hline Dairy & 30.1 & 12.6 & $\begin{array}{l}\text { Applied to wet } \\
\text { soil }\end{array}$ & \multirow{4}{*}{$\begin{array}{l}\text { Houlbrooke et } \\
\text { al. (2004b) }\end{array}$} \\
\hline Dairy & 236 & 3 & \multirow{3}{*}{$\begin{array}{l}\text { Deferred } \\
\text { irrigation }\end{array}$} & \\
\hline Dairy & 95 & 0 & & \\
\hline Dairy & 154 & 0.4 & & \\
\hline
\end{tabular}



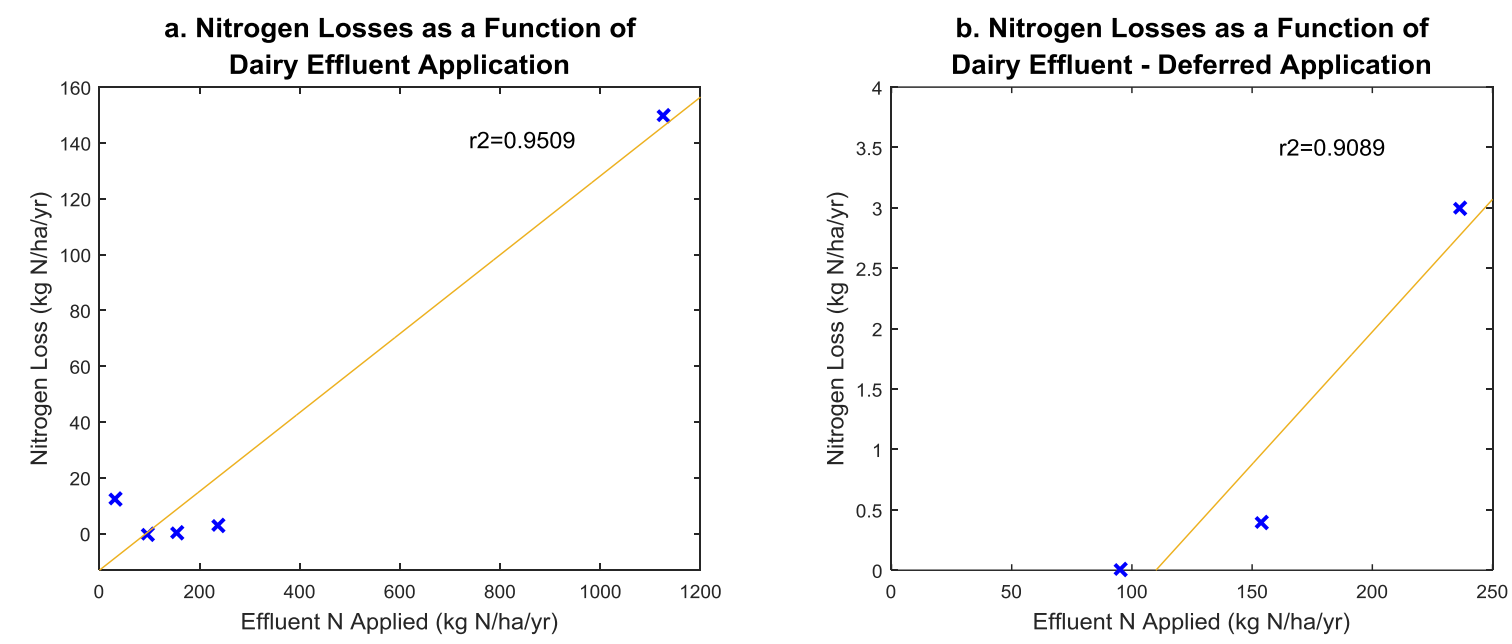

Figure 6.5 a. Nitrogen losses as a function of dairy effluent application and b. Nitrogen losses as a function of deferred dairy effluent application

Fewer studies investigate P loss from effluent blocks (Table 6.9). Figure 6.6a shows phosphorus loss as a function of effluent $\mathrm{P}$ applied. An $\mathrm{r}^{2}$ value of 0.1132 is reported. Figure $6.6 \mathrm{~b}$ shows only those samples where effluent is applied via deferred irrigation (which is described further in Section 6.3.3) and an $r^{2}$ value of 0.4436 is reported. Like $N$, little can firmly be concluded from this data, although it appears deferred irrigation methods do result in lower $\mathrm{P}$ losses. Four of the five samples together indicate $\mathrm{P}$ losses increase with P effluent applications. Although this is clearly not always the case, particularly where effluent is applied to already wet soils.

Table 6.9 P loss from effluent fertilised pasture reported in New Zealand literature

\begin{tabular}{|c|c|c|c|c|}
\hline $\begin{array}{l}\text { Effluent } \\
\text { Type }\end{array}$ & $\begin{array}{c}\text { Application Rate } \\
\left(\mathrm{kg} \mathrm{P} \mathrm{ha}^{-1} \mathrm{yr}^{-1}\right)\end{array}$ & $\begin{array}{c}\text { Losses } \\
\left(\mathrm{kg} \mathrm{P} \mathrm{ha}^{-1} \mathrm{yr}^{-1}\right)\end{array}$ & Notes & Reference \\
\hline Dairy & 125 & 1.6 & & $\begin{array}{l}\text { Macgregor et } \\
\text { al. (1979) as } \\
\text { cited in } \\
\text { Houlbrooke et } \\
\text { al (2004) }\end{array}$ \\
\hline Dairy & 4.4 & 1.9 & $\begin{array}{l}\text { Applied to wet } \\
\text { soil }\end{array}$ & \multirow{4}{*}{$\begin{array}{l}\text { Houlbrooke et } \\
\text { al. (2004b) }\end{array}$} \\
\hline Dairy & 32 & 0.5 & \multirow{3}{*}{$\begin{array}{l}\text { Deferred } \\
\text { irrigation }\end{array}$} & \\
\hline Dairy & 16 & 0 & & \\
\hline Dairy & 31 & 0.08 & & \\
\hline
\end{tabular}



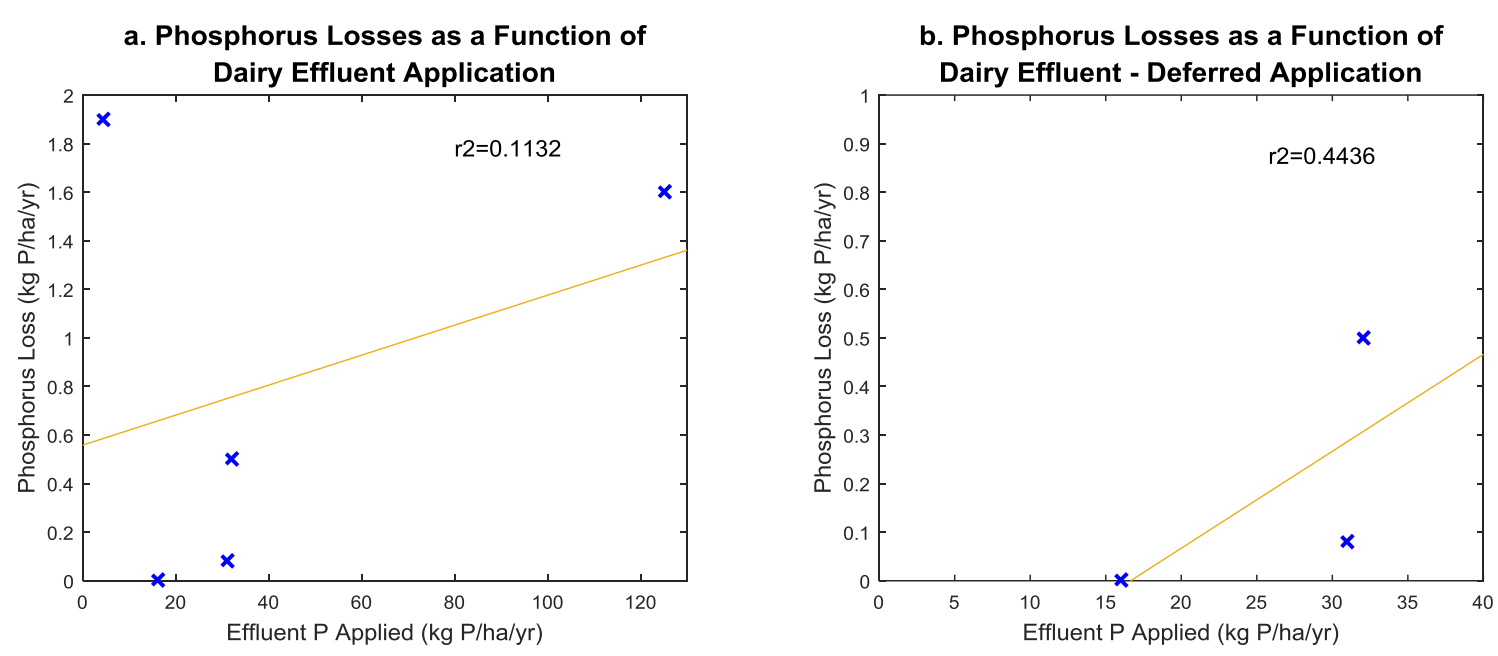

Figure 6.6 a. Phosphorus losses as a function of dairy effluent application and b. Phosphorus losses as a function of deferred dairy effluent application

Houlbrooke et al. (2004) note nutrient losses from applied effluent are particularly influenced by effluent management, both prior to and during spreading, and soil variables. For example, whether effluent is raw or pond treated, depth and rate of application, whether fields are drained, inherent soil drainage variables, soil moisture conditions and rain events can all influence losses. Careful management of effluent storage and application processes can minimise losses and these are discussed following.

\section{$\underline{\text { 6.3.3 Mitigation Strategies }}$}

In some cases raw effluent is sprayed daily to land, but, to mitigate against nutrient losses, pond treatment and storage prior to land application is recommended. Two pond systems exist, whereby wastes from farm yards, sheds, feed pads and dairy platforms are washed first into an anaerobic pond, which then discharge into a facultative pond. During this process solids settle and the effluent is microbially digested. In the past effluent was commonly released from pond two directly to waterways, but is now land applied.

Most recently built effluent systems include only one pond for storage and application is made to nearby pasture or cropland (usually $\geq 10 \%$ of total farm area). Application is usually via spraying irrigator. Many regional councils apply maximum $\mathrm{N}$ application limits, usually between $150-200 \mathrm{~kg} \mathrm{~N} \mathrm{ha}^{-1} \mathrm{yr}^{-1}$. Pond solids, or slurry, are removed and 
spread every 5 or so years (Longhurst et al. 2000; Bolan et al. 2004; Houlbrooke et al. 2004; Houlbrooke et al. 2004b; Gourley et al. 2012).

To further mitigate against nutrient losses, deferred effluent irrigation is recommended. A number of authors note higher losses of $\mathrm{N}$ and $\mathrm{P}$ can occur when effluent is applied to already wet soils. Macgregor et al. (1979) found $60 \%$ of all $N$ losses and $38 \%$ of all $P$ losses occurred during winter drainage. Houlbrooke et al. (2004b) found $40 \%$ of effluent $\mathrm{N}$ input and $43 \%$ of effluent $\mathrm{P}$ input can be lost if applied to already wet soil. Deferred effluent irrigation involves monitoring soil moisture conditions and only irrigating the appropriate amount at the appropriate rate, when soil water deficit is sufficient to prevent drainage. This method requires sufficient effluent storage and the ability to monitor soil water conditions, but can result in elimination of losses via surface drainage and losses of only $1 \%$ of total nutrient applied via effluent in direct drainage water (Houlbrooke et al. 2004b).

Non-uniform effluent application by traveling spray irrigators can be problematic with maximum applications occurring close to the outside of the irrigator leading to higher nutrient losses. Remedies include applying effluent at soil water deficits that are greater than or equal to the maximum, rather than mean, depth of application, and setting the irrigator to roll at maximum speed, applying a little effluent often (Monaghan and Smith 2004). Low-rate (K-line) sprinkler application systems have been shown to reduce nutrient losses compared to travelling irrigators, particularly if there is no choice but to irrigate when soils are wet (e.g. if effluent storage is already full) (Monaghan et al. 2010a).

Constructed wetlands to further treat effluent from an effluent pond is an option and is discussed in Section 6.5. Healy et al (2007) suggest sand filters, in conjunction with constructed wetlands could further reduce effluent nutrient content. Craggs et al. (2004) investigated a dairy effluent advanced pond system consisting of four stages - an anaerobic pond (equivalent to the first pond in a traditional two pond system), a high rate pond, a pair of algae settling ponds, and a maturation pond. This method treats wastewater more reliably and efficiently than standard two pond systems and was shown to decrease ammoniacal nitrogen and total phosphorus. It is particularly recommended in areas where land disposal is limited. 
Bolan et al. (2004) showed that adding bark or zeolite to the second pond in a two pond effluent system can reduce $\mathrm{N}$ and $\mathrm{P}$ concentrations. These added components are then land spread. Pattnaik et al. (2007) suggests multi-soil-layer (MSL) technology, consisting of aerobic and anaerobic layers through which water is passed and filtered, has the potential to remove a high percentage of inorganic $\mathrm{N}$ and phosphate from dairy effluent. Reducing total amount of effluent applied is also an option. Methods of achieving this could include only milking once per day, diverting rainwater away from effluent ponds (A. Metherell, personal communication, 9 May 2017), reducing stock or increasing effluent application area. Currently effluent tends to be applied to a limited area within a farm (usually those areas closest to ponds or collection points). Gourley et al. (2012) suggest barriers to increasing application area in Australia are inadequate infrastructure to apply effluent to a wider area, and limited regulatory requirements and enforcement. Cost to extend effluent application equipment to a wider farm area could also be a barrier.

Finally, direct injection of effluent in to soil is commonly used overseas (Houlbrooke et al. 2004). It is unclear why this method is less popular in New Zealand, possibly because specialist equipment is required. Advantages of this system include better use of nutrients as they are placed at the plant root system, reduced odour and improved pasture palatability. Volatilisation is also reduced using this method, although emissions of nitrous oxide can be increased (Eckard et al. 2010; Northland Regional Council 2016).

\subsection{STOCKING RATE}

Grazing animals influence nutrient loss from pasture and forage cropland through deposition of excreta and compaction of soil (Monaghan et al. 2005; Monaghan et al. 2007a). Higher stocking rates are therefore likely to lead to higher nutrient losses by increasing the amount of excreta deposited and increasing soil compaction. Again, stocking rates are inextricably linked to $\mathrm{N}$ and $\mathrm{P}$ inputs, particularly from fertiliser, effluent and supplementary feed. Therefore, any changes to stocking rate as a mitigation strategy would have to be made commensurate with changes to these other farm components, and vice versa. Here stocking rate is not investigated per se, but 
losses from individual animals and their excretion behaviour are discussed and quantified where possible.

\subsubsection{Losses from Animal Excreta}

Pastoral animal excretions are an important return of nutrients to the plant-soil system and it increases the rate of nutrient cycling within the pasture system. However, these returns are highly concentrated and distributed in an inefficient, spatially varied manner. This leads to oversupply of nutrients in excretal areas and undersupply elsewhere (Williams and Haynes 1990).

Published estimates of $\mathrm{N}$ and $\mathrm{P}$ in animal excretions vary between animal species, between individual animals of the same species, and can vary for an individual animal over time because excretions are influenced by animal size, productivity, diet, water intake, housing and seasonal weather conditions (Betteridge et al. 1986; Haynes and Williams 1993; Smith and Frost 2000). It is estimated that $60-90 \%$ of ingested $\mathrm{N}$ is returned to the soil as urine and dung by pasture grazing animals. In both sheep and cows, increases in dietary $\mathrm{N}$ increase urinary $\mathrm{N}$ content, but not dung $\mathrm{N}$ content. The loading of $\mathrm{N}$ under cow and sheep urine patches is estimated as equivalent to $750 \mathrm{~kg} \mathrm{~N}$ $\mathrm{ha}^{-1} \mathrm{yr}^{-1}$ (Selbie et al. 2015) and $500 \mathrm{~kg} \mathrm{~N} \mathrm{ha}^{-1} \mathrm{yr}^{-1}$ respectively (Di and Cameron 2002a). P is largely returned to the soil in dung with a strong correlation between $\mathrm{P}$ intake and dung P content. Little P is lost in urine (Haynes and Williams 1993; Di and Cameron 2002a; Monaghan et al. 2007a; Luo and Kelliher 2014).

Table 6.10 summarises total annual $\mathrm{N}$ excretions for dairy cattle, beef cattle, sheep and deer, and total annual P excretions for dairy and beef cattle only. No data reporting total annual P excretions for sheep or deer are found, although for sheep these could possibly be modelled using the method of Saggar et al. (1990). Smith and Frost (2000) comment that animal production systems change over time which affects how much $\mathrm{N}$ and $\mathrm{P}$ is excreted and they suggest only data less than 10-15 years old reliably documents current $\mathrm{N}$ and $\mathrm{P}$ in animal excretions. In New Zealand the most significant recent changes pertain to dairy farming only. 
Table 6.10 Average total N and P excreted for dairy cattle, beef cattle, sheep and deer (Source: Haynes and Williams (1993); Betteridge et al. (2010)) .

\begin{tabular}{|l|c|c|}
\hline \multicolumn{1}{|c|}{ Animal Type } & $\begin{array}{c}\text { Average TN Excreted } \\
\text { (kg/head/yr) }\end{array}$ & $\begin{array}{c}\text { Average TP Excreted } \\
\text { (kg/head/yr) }\end{array}$ \\
\hline Dairy Cattle & 123.1 & 8 \\
\hline Beef Cattle & 50.4 & 6.4 \\
\hline Sheep & 14.1 & \\
\hline Deer & 29.1 & \\
\hline
\end{tabular}

Moir et al. (2011) found during monitoring over a 4 year period that on average dairy cattle urine patches covered $23 \%$ of field area. For sheep on hill country, $60 \%$ of dung and $55 \%$ of urine was found to be deposited on $15-30 \%$ of total field area (Haynes and Williams 1993). Topography and feed, trough, gate and tree locations influence spatial distribution of excreta because stock congregate or "camp" in areas that provide shelter and/or food and water. Betteridge et al. (2010) monitored cattle and sheep excretions in a field of variable slope and elevation. They found cattle camp in low elevation, low slope areas, while sheep camp in high elevation, low slope areas. They also note excreta is transported from higher elevations to low elevation, low slope areas via gravity or water transport. Increased deer deposits are found along fence lines due to frequent pacing (McDowell et al. 2006).

Stock management and paddock configuration can influence spatial distribution of excreta and associated losses. For example, higher stocking rate encourages more even distribution of excreta, although higher loadings result, and placement of troughs, feed etc should be in areas less connected to waterways. Excreta deposits on "nonproductive" farm areas eg. tracks and raceways are estimated at 2-11 kg N/head/yr and 0.5-3 kg P/head/yr for dairy cattle (Haynes and Williams 1993).

\subsubsection{Soil Damage}

Most grazed pasture is damaged by compaction to some extent, however the extent of this damage is usually limited to the top $50-150 \mathrm{~mm}$ of soil and can be reversed or avoided (Greenwood and Mckenzie 2001). Compaction usually occurs during grazing of wet soil. This reduces the ability of water and nutrients to infiltrate, thereby increasing the likelihood of surface runoff. Mitigation strategies, other than reducing stocking rate, 
to ameliorate or avoid damage include feedpad use and wintering barns (Clark et al. 2007).

\subsection{WETLANDS}

Over the last 150 years, $90 \%$ of natural wetlands have been drained for use as urban or agricultural land in New Zealand (Peters and Clarkson 2010). Today, as concern heightens around water quality in association with intensified agriculture (PCE 2015a), wetland development and management to enhance filtering capability is advocated as a nutrient ( $\mathrm{N}$ and $\mathrm{P}$ ) management strategy on New Zealand farms (Environment Canterbury 2006; McKergow et al. 2007; Dairy NZ 2013; Monaghan and De Klein 2014; Waikato Regional Council 2015; Environment Southland 2016b; Taranaki Regional Council 2016a). However, nutrient retention by wetlands is highly dependent on individual characteristics of the wetland and surrounding area, and how it is managed. Therefore, these variables must be considered in any wetland mitigation model and are discussed below.

\subsubsection{Wetland Function - Nutrient Sink or Source?}

Wetlands are areas of permanently or intermittently wet land (Peters and Clarkson 2010). On New Zealand farms commonly found natural wetlands include freshwater seeps and springs, depressional wetlands, and riparian margins (McKergow et al. 2007; McKergow et al. 2012) which are defined as land surrounding a stream or river, lake, reservoir or wetland. These systems represent the interface between terrestrial and aquatic ecosystems. They receive runoff from surrounding land and are at times flooded by the associated water body (Parkyn 2004; Aarons and Gourley 2012; Renouf and Harding 2015). Increasingly constructed wetlands are also being investigated and installed in the farm environment (McKergow et al. 2007; Tanner and Sukias 2011).

Characterised as 'the kidneys of the landscape', wetlands filter waste and nutrients from incoming water (Mitsch and Gosselink 2007). Both particulate and soluble N and P can be intercepted. Wetlands are generally fed by surface water and/or groundwater, although some are only rainwater fed. Surface water introduces particulate and soluble nutrients to the wetland. Groundwater only introduces soluble nutrients. Particulates are intercepted via physical settling as surface water slows within the wetland 
environment and coarser particles settle before finer. This process is particularly important for $\mathrm{P}$ interception because $\mathrm{P}$ tends to sorb to soil particles (McKergow et al. 2007; Mitsch and Gosselink 2007).

Dissolved nutrients enter wetlands via inflows, though also develop within wetlands as biogeochemical processing of deposited particulate nutrient occurs. Dissolved nutrients are taken up by plants, lost to outflows or, in the case of $\mathrm{N}$, may be denitrified. Denitrification is the only process of permanently removing $\mathrm{N}$ from a wetland that does not involve export to a downstream water body (Fisher and Acreman 2004; McKergow et al. 2007; Mitsch and Gosselink 2007). For P, permanent wetland removal can only occur through export to a downstream water body.

The wetland environment is usually considered a nutrient sink. However, it can also be a nutrient source - a point that is often overlooked (Fisher and Acreman 2004; Mitsch and Gosselink 2007). Under normal low surface flow conditions wetlands and riparian margins usually act as sinks, particularly if plants are present to slow flow and allow particulate deposition and infiltration of water (Smith 1989; Williamson et al. 1996). However, during heavy rainfall or flood events soluble nutrients can flush more quickly through the wetland environment, avoiding plant up take, sorption or denitrification, and particulates can bypass the wetland or are even entrained from within the wetland (Collier et al. 1995a; McKergow et al. 2012; Roberts et al. 2012; Wilcock et al. 2012).

TN removal by riparian buffers has been shown to range between $10-100 \%$, with higher removal rates associated with longer residence times in the soil matrix (Burns and Nguyen 2002; Collins et al. 2009). However, some authors have reported increased nitrate- $\mathrm{N}$ losses to the stream network as a result of preferential subsurface flow (including artificial drains) by-passing the wetland (Parkyn 2004; Collins et al. 2009). Channelized flow in riparian zones also acts as a by-pass mechanism (Williamson et al. 1996).

Wetland retention of soluble $\mathrm{P}$ is generally less than for particulate $\mathrm{P}$ (Fisher and Acreman 2004; Collins et al. 2009). Reviewing riparian zone performance, Collins et al (2009) found TP retention is $30-85 \%$, but only $20-50 \%$ for dissolved P (Table 6.11). Wilcock et al (2012) found TP retention was $93 \%$ and average filterable reactive $P$ 
retention was $-53 \%$ in an on-farm headwater seep wetland. Roberts et al (2012) reviewed $\mathrm{P}$ retention in vegetated buffers reporting retention rates of $41-95 \%$ for TP and $-71-95 \%$ for DRP. Over time wetlands and riparian margins can become a $\mathrm{P}$ source if $\mathrm{P}$ saturation occurs, limiting P-fixation (Cooper et al. 1995; Roberts et al. 2012).

Table 6.11 Percent P retention by wetlands as reported in New Zealand and international literature.

\begin{tabular}{|c|c|c|}
\hline \multicolumn{2}{|c|}{ \% retention } & \multirow{2}{*}{ Reference } \\
\hline TP & DRP & Collins et al. (2009) \\
\hline $30-85$ & $20-50$ & Wilcock et al. (2012) \\
\hline 93 & -53 & Roberts et al. (2012) \\
\hline $41-95$ & $-71-(+) 95$ & \\
\hline
\end{tabular}

\subsubsection{On-Farm Management of Natural Wetlands}

How efficiently a managed wetland and associated buffer zone reduces nutrient export to downstream waterways depends on hydrology, soil type, vegetation type and variety, width and length of buffer, surrounding land characteristics, and surrounding land use and management (Collier et al. 1995b; Parkyn 2004; Collins et al. 2009). Currently in New Zealand active on-farm management of waterways and associated wetlands and riparian margins is voluntary, but highly encouraged by industry bodies and regional authorities. More recent legislation is likely to result in the introduction of regulatory measures to curb nutrient losses to water (McDowell et al. 2016a), which could include mandatory wetland and riparian management.

\section{Fencing}

McKergow et al. (2012) found that cattle grazing within wetland areas for only $9 \%$ of time, accounted for $34 \%$ of TN export and significantly elevated instream $\mathrm{N}$ exports compared to both storm and base flow $\mathrm{N}$ exports during non-grazed periods. At a minimum, on-farm 'management' of wetlands and riparian margins should include fencing so that stock cannot defecate directly in water, erode banks, and compact and disturb soil (Bewsell et al. 2007). Exactly how far a fence is placed from a water body will depend on desired outcome and how much land farmers are happy to lose to riparian margins. This is further discussed below. 


\section{Width}

Fenced riparian buffers surrounding wetlands and water bodies is recommended (Dairy NZ 2016b; Environment Southland 2016b). The width of buffers is identified by Parkyn et al. (2003) as a key predictor of stream health. As a general rule wider buffer zones remove more particulates (Collier et al. 1995b; Parkyn 2004), but precise width required to intercept particulate nutrients in overland flow depends on a number of variables.

Buffers located in steeper terrain should be wider to slow water flow and allow particulate settlement (Collier et al. 1995b), although effectiveness can be reduced if flow is channelized or there is a lack of good groundcover (Williamson et al. 1996). Soil drainage is influential. Good soil drainage allows water to percolate through. This filters particulates and allows uptake of dissolved nutrients by plants. Additionally, infiltration excess overland flow is less likely to occur in well drained soils. If soil clay content in incoming water is high deposition only occurs once water flow has reduced sufficiently and this also requires wider buffers. Clay can also fill buffer soil pore spaces, reducing infiltration (Collier et al. 1995b).

Soluble nutrients, present in both surface and subsurface flows, must be moved through the soil matrix to encourage plant uptake and denitrification - both spatially and temporally variable processes. Therefore, determining specific buffer widths required to remove soluble nutrients is not clear. For both processes though, water residence time is influential with longer residence providing more uptake and denitrification opportunity (Collier et al. 1995b). Considering this, a wider buffer zone is likely to provide more opportunity for uptake or denitrification. However, plant uptake depends on plant type and growth stage (see below) and denitrification requires the 'right' conditions - denitrifying bacteria, anaerobic conditions, a supply of carbon and the 'right' temperature and $\mathrm{pH}$. If any of these are lacking, denitrification may not occur or may not fully complete resulting in the release of nitrous oxide, a powerful greenhouse gas (Cooper 1990; Fisher and Acreman 2004).

Collier et al. (1995b) developed a method to determine optimal buffer widths for mitigation of particulates. Mapped categories (low, medium, high) of topography, soil drainage and soil clay content are layered and a look up table, based on layered results, is used to determine optimal buffer width as a percent of uphill slope length. An 
estimate of efficiency is also provided. This map based, layered method lends itself to application in a GIS and could possibly be appropriate for application in LUCI to estimate optimal buffer widths for mitigation of particulates.

For soluble nutrients, Collier et al. (1995b) and Cooper (1990) recommend identification, enhancement and management of organic soils in buffer zones as an important strategy to encourage denitrification. Cooper (1990) suggest these areas can reduce nitrate loads to water bodies by $32-98 \%$.

Dosskey et al. (1997) indicate a buffer strip of up to $8 \mathrm{~m}$ is required to filter particulates from agricultural land in the US, while $15-30 \mathrm{~m}$ is required to remove soluble nutrients. The NZ Fertiliser Code of Practice for Nutrient Management (2013) suggests vegetated riparian buffers of at least $10 \mathrm{~m}$ which may need further adjustment to account for slope By contrast, a survey of Canterbury buffer zones found most were no more than $5 \mathrm{~m}$ wide (Renouf and Harding 2015). This suggests many riparian buffers in New Zealand may not be of sufficient width to fully intercept particulate and soluble nutrients. Literature aimed at farmers does not generally stress the importance of buffer width or the need for variable widths under variable circumstances (Environment Southland ; Taranaki Regional Council ; Waikato Regional Council). Likely barriers to installation of wider buffers are cost of buffer development and maintenance, and the 'cost' of agricultural land loss, both of which are generally borne by land owners.

\section{Vegetation and Planting}

Planting of riparian areas is recommended to encourage plant uptake and create a 'slow water' environment, more conducive to deposition, infiltration and denitrification. A range of native and exotic plants, from grasses to shrubs to trees, are recommended and found in managed wetland and riparian margins (Williamson et al. 1996; Parkyn et al. 2003; Collins et al. 2013; Renouf and Harding 2015; Environment Southland 2016a; Taranaki Regional Council 2016b). Additional benefits derived from wetland and riparian planting include provision of fish, animal, and insect habitat and corridors, and shading of water bodies. This reduces water temperature which is beneficial to aquatic fauna and helps control nuisance in-stream flora (Parkyn 2004). On-going management of wetland and buffer vegetation is often required to maintain nutrient interception ability 
and to discourage growth and spread of weeds (Aarons and Gourley 2012; Renouf and Harding 2015). Dense groundcover, such as grass, slows surface water sufficiently to encourage deposition, but under trees such groundcover may die away (Smith 1989; Williamson et al. 1996).

Native and exotic plants are used in buffer zones. Exactly which plants are used depends on what land owners are trying to achieve. Exotics are often recommended because they grow quickly to stabilise stream banks and control erosion (Collier et al. 1995b; Environment Southland 2016a). However, Marden et al. (2005) investigated twelve indigenous plant species and found they too provide fast growing, good bank protection for low-order streams, although are less effective as stream order increases. Additionally, there are natives well suited to all New Zealand sub-climates and environments and they provide habitat for native fauna (Franklin et al. 2015; Renouf and Harding 2015; Environment Southland 2016a; Waikato Regional Council 2016b). Although New Zealand natives are adapted to a low $\mathrm{N}$ environment and do not generally take up as much $\mathrm{N}$ as some exotics, Franklin et al (2015) concluded that they are still of use in riparian planting in terms of $\mathrm{N}$ attenuation.

New Zealand riparian planting guides identify two hydrological two zones - the lower bank zone, which is subject to regular flooding, and the upper bank zone, which is only flooded irregularly (Figure 6.7) (Dairy NZ 2014; Environment Southland 2016a). Lower bank zone plants must tolerate frequent, prolonged inundation. Sedges, grasses and flaxes are well suited to these conditions (Environment Canterbury 2011; Environment Southland 2016a; Taranaki Regional Council 2016b), but may not be deep rooted enough to prevent erosion (Collier et al. 1995b). A mix of taller trees and shrubs are recommended in the upper bank zone to take up subsurface nutrients, for bank stability and habitat provision (Environment Canterbury 2011; Aarons and Gourley 2012; Renouf and Harding 2015; Environment Southland 2016a). A third outer dense groundcover plant zone is also sometimes recommended to filter particulates (Environment Canterbury 2011; Environment Southland 2016a; Taranaki Regional Council 2016b). Dairy NZ (2016b) recommend close fencing and bank planting with native grasses for drains. 
Invasive exotic weeds can be problematic in riparian buffers and can spread along these corridors. Like trees, they can shade dense groundcover to the extent that it dies away and is no longer an effective particulate filter (Williamson et al. 1996; Hughes and Quinn 2014). Nitrogen fixing exotic weeds such as gorse, lupin and broom (Parfitt et al. 2006) may be additional sources of $N$ to waterbodies (Hughes and Quinn 2014). Regular maintenance to control weeds may be required during the first years of buffer development. Diverse planting on a generous buffer (at least $5 \mathrm{~m}$ wide) can encourage a 'self-sustaining habitat' that is better able to out-compete invasive weeds (Renouf and Harding 2015).

As discussed above, nutrient saturation in wetland and riparian zones can occur, limiting nutrient retention, particularly in the case of P. Aarons and Gourley (2012) suggest as plants mature in the upper bank zone, strategic removal and replanting can help to maintain nutrient uptake rates. Commercial wood or fruit crops could be options (Parkyn 2004). Roberts et al. (2012) suggest above-ground vegetation removal is a more effective P removal technique for wetland areas than addition of soil amendments or tillage to increase soil sorptive ability. McKergow et al. (2012) suggest periodic sheep grazing of riparian zones may encourage pasture growth, thereby encouraging plant uptake of N. Although returns via excreta could negate any benefits from such a strategy.

Waterbody shading by plants can lower water temperature which benefits aquatic fauna and suppresses nuisance aquatic plants, but can also decrease in-stream $\mathrm{N}$ uptake, which largely occurs due to the presence of aquatic plants (Cooper 1990; Hughes and Quinn 2014). 


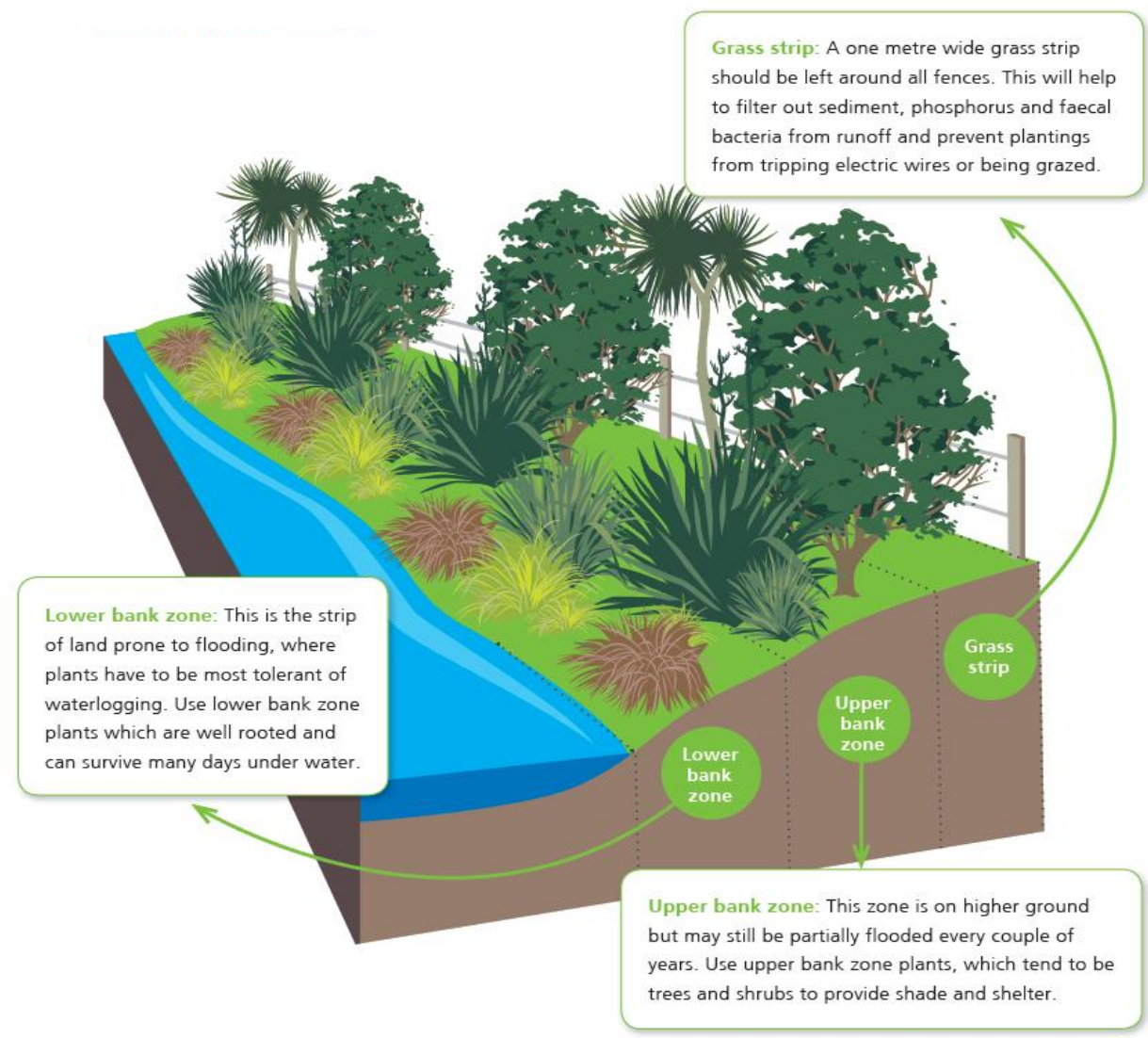

Figure 6.7 Planting zones in the riparian margin (Dairy NZ 2014)

\subsubsection{Constructed Wetlands}

Constructed wetlands are created to treat contaminated water from various sources (e.g. sewage treatment, mine waste, urban storm water, and agricultural runoff) by emulating natural wetland processes (Mitsch and Gosselink 2007). While natural wetlands can also be used in this way, constructed wetlands can be placed where required, can be tailored to optimise nutrient attenuation and their use avoids contamination of sensitive or endangered wetland environments (Tanner and Kloosterman 1997; Tanner et al. 2010).

\section{Constructed Wetland Types and Design}

There are two types of constructed wetland - surface-flow wetlands and subsurface flow wetlands. Both types consist of a sealed channel with wetland vegetation, however surface flow wetlands have a soil substrate with flowing water above, while sub-surface flow wetlands contain a gravel substrate through which water slowly flows (Figure 6.8) (Tanner and Kloosterman 1997; Mitsch and Gosselink 2007). 
Understanding of wetland nutrient uptake suggests that surface wetlands can readily trap and process both particulate and dissolved nutrients, while sub-surface wetlands are likely to better process dissolved nutrients, although no explicit reference to this has been found. Mitsch \& Gosselink (2007) suggest that the main reason for using subsurface wetlands is that they require less space, while surface wetlands provide additional benefits such as habitat for fauna. Tanner and Kloosterman (1997) suggest using a sub-surface wetland after a surface wetland because they provide enhanced, more consistent treatment. Most New Zealand on-farm constructed wetland literature features surface wetlands only (Tanner et al. 2005; Tanner and Sukias 2011; Praat et al. 2015), although subsurface wetland trials processing dairy effluent have been conducted (Tanner et al. 1995).

Wetland construction guidance is provided for treating dairy shed effluent that has already been through two pond treatment (Tanner and Kloosterman 1997) and for the treatment of subsurface drainage water (Tanner et al. 2010). How efficiently a constructed wetland removes nutrients depends on environmental factors, such as rainfall patterns and variability, soil properties, groundwater levels and land and effluent management, and construction and design variables. In general longer wetland residence times will increase nutrient attenuation. To achieve this wetlands must be of sufficient size to process incoming water and nutrient loads, must distribute flows as evenly as possible throughout the wetland, and must provide appropriate plants and soil or other amendments to encourage nutrient uptake (Tanner and Kloosterman 1997; Mitsch and Gosselink 2007; Tanner et al. 2010). Mitsch and Goselink (2007) emphasis the need to create an appropriate hydrological regime and then establish appropriate vegetation. They state that if wetland creation fails, it is generally the hydrology that is at fault.

Water residence time within a wetland is related to the size of the wetland and the wetland to catchment area ratio (Zedler 2003). Tanner et al. (2010) indicate that a wetland covering $1 \%$ of a catchment and processing tile drainage water will remove 12 $32 \%$ of incoming nitrate- $\mathrm{N}$, while a wetland covering $5 \%$ of a catchment will remove 38 $68 \%$ of incoming nitrate-N. Tanner and Kloosterman (1997) provide detailed wetland size guidelines, based on dairy herd size, for processing dairy shed wastewater. 


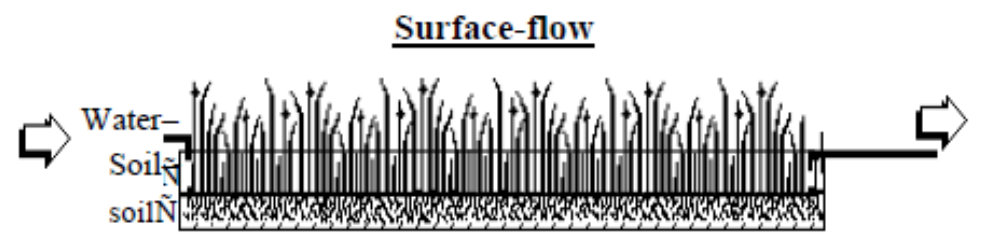

Wastewater flows along shallow channels, through the lower stems of wetland plants rooted in flooded soil

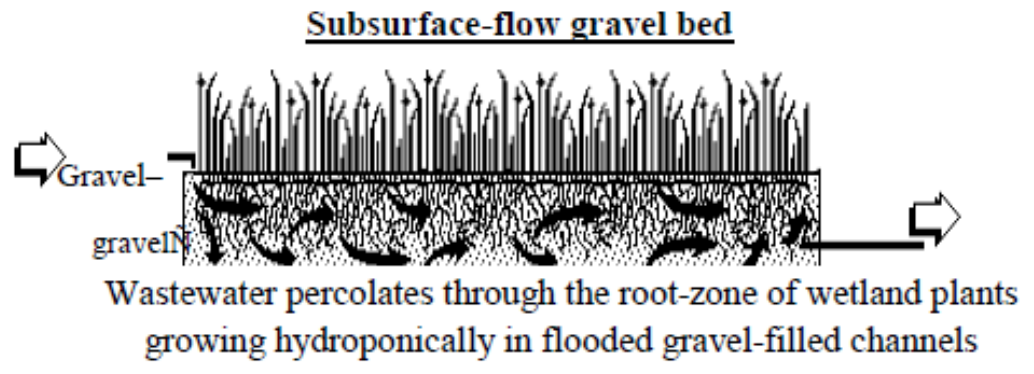

Figure 6.8 Constructed wetlands types (Tanner and Kloosterman 1997).

Water flow through a constructed wetland must ideally be steady and utilise the whole wetland. Water input mechanisms should encourage even flow distribution along the head of the wetland and the wetland shape should not include too many highly curved edges that can cause flow dead-zones. Length-to-width ratios of between 3:1 and 10:1 are recommended, depending on the total wetland size. Flow velocities in very long skinny wetlands can be excessive during high flow events (Tanner and Kloosterman 1997; Mitsch and Gosselink 2007; Tanner et al. 2010).

Constructed wetland nutrient attenuation is enhanced by the addition of plants (Tanner et al. 1999; Mitsch and Gosselink 2007). Plants within the inundation zone are the nutrient processors, while edge plants stabilise banks and suppress weeds (Tanner et al. 2010). Plants used in constructed wetlands must tolerate local climate and hypertrophic waterlogged conditions, must be readily propagated and established, must remove pollutants, and must not be pest plants (Tanner 1996). Plant recommendations for constructed wetlands are offered by Tanner (1996), Tanner and Kloosterman (1997) and Tanner et al. (2010).

Substrate soil and/or soil amendments influence nutrient attenuation. Constructed wetlands should be water tight to prevent leaching to groundwater. This requires either 
a compact clay lining or plastic liner if suitable clay is unavailable. The plant growing medium is deposited on this lining (Tanner et al. 2010). P-sorbing materials can also be added to enhance P retention (Ballantine and Tanner 2010; Tanner et al. 2010).

Ballantine and Tanner (2010) reviewed a number of soils, natural product and industrial and waste by-products that can be used in constructed wetlands to encourage higher rates of $\mathrm{P}$ retention. Allophane, limestone, tephras, tree bark, shells, alum, domestic waste treatment residues and fly ashes provided the best results.

\section{Constructed Wetland Performance}

Table 6.12 summarises New Zealand study results into constructed wetland performance. Tanner et al (1995) explored nitrogen and phosphorus removal from dairy farm wastewater flowing, at various rates, through unplanted and planted subsurface gravel bed wetlands. TN removal in the unplanted wetland varied from $12-41 \%$, with removal generally increasing as flow slowed. In the planted wetland TN removal varied from $48-75 \%$. Notably in the unplanted wetland $\mathrm{NH}_{4}$ removal rates were sometimes negative (i.e. $\mathrm{NH}_{4}$ was generated by the wetland). This did not occur in the planted wetland. TP removal ranged from $12-36 \%$ in the unplanted wetland and $37-74 \%$ in the planted wetland.

Tanner et al. (2005) investigated nutrient export for two years from a constructed surface flow wetland receiving water from subsurface drains on a dairy farm in Waikato. TN attenuation was 79\% in Year 1 and $21 \%$ in Year 2. TP attenuation was $-70 \%$ in Year 1 and $12 \%$ in Year 2 . They suggest attenuation variability was likely due to seasonal temperature and rainfall event variability. Temperature influences denitrification and the breakdown of nutrient rich organic material, while large rainfall events or events in close succession can reduce wetland residence time which is important for nutrient removal.

The above wetland was further studied by Tanner and Sukias (2011) in conjunction with two other constructed wetlands receiving subsurface drain water - one in Northland and one in Southland. Annual TN removal by the wetlands ranged from 7-63\%. However, while nitrate- $\mathrm{N}$ was quite efficiently removed, ammonium and organic- $\mathrm{N}$ were generated within the wetland and exported at times. Overall the wetlands were also found to be a source of P. 12-115\% more of input TP was exported. The authors state 
that this result contrasts with TP attenuation rates in many overseas studies of constructed wetlands. However, they also note that most of the overseas studies are conducted on cropland where most TP runoff is in particulate form, while $P$ in subsurface drain water is largely in dissolved form. Additionally, they note that wetland maturation factors, such as reduced uptake in mature plants, senescence of plants, changes to soil $\mathrm{P}$ retention and saturation of $\mathrm{P}$ sorption sites, could also account for TP export.

Praat et al. (2015) document results from a constructed wetland processing subsurface drain water in Wairarapa. Monitoring over only four months (Feb-May) indicated that $38-80 \%$ of imported TN was removed by the wetland per month. For the first three months imported DRP was reduced by $38-64 \%$ per month, but in the final month of monitoring the wetland became a source of $\mathrm{P}$ with 2.3 times DRP being exported compared to $\mathrm{P}$ imported. The authors conclude that nitrate- $\mathrm{N}$ is attenuated by this wetland, but it is likely a source of $P$.

Table 6.12 Nutrient retention of constructed wetlands

\begin{tabular}{|c|c|c|c|}
\hline \multicolumn{2}{|c|}{ \% Incoming Nutrient Retained } & \multirow{2}{*}{ Particulars } & Reference \\
\cline { 1 - 2 } $\mathbf{N}$ & $\mathbf{P}$ & & \\
\hline $12-41(\mathrm{TN})$ & $12-36(\mathrm{TP})$ & Unplanted & Tanner et al. (1995) \\
\hline $48-75(\mathrm{TN})$ & $37-74(\mathrm{TP})$ & Planted & \\
\hline $71(\mathrm{TN})$ & $-70(\mathrm{TP})$ & Yr 1 Drain water & Tanner et al. (2005) \\
\hline $21(\mathrm{TN})$ & $12(\mathrm{TP})$ & Yr 2 Drain water & \\
\hline $7-63(\mathrm{TN})$ & $-115--21(\mathrm{TP})$ & Drain water & $\begin{array}{c}\text { Tanner and Sukias } \\
\text { (2011) }\end{array}$ \\
\hline $38-80(\mathrm{TN})$ & $38-64(\mathrm{DRP})$ & Drain water & Praat et al. (2015) \\
\hline
\end{tabular}

\subsubsection{Barriers to Wetland Construction or Restoration}

It is uncertain how many constructed or restored wetlands with the aim of reducing agricultural runoff (as opposed to septic tank effluent) are on New Zealand farms. Myers et al. (2013) indicate that wetland loss rather than gain is the trend and that small, privately owned on-farm wetlands are most likely to be lost, largely because wetlands on public land often have protected status. Certainly regional councils and industry bodies advocate using wetlands for nutrient attenuation. In particular they emphasise the need for riparian wetland restoration by fencing and planting, rather than 
restoration of other wetland types or installation of constructed wetlands (Environment Canterbury 2011; Dairy NZ 2016b; Taranaki Regional Council 2016a). However, a demonstration wetland has been recently constructed in a previous natural wetland on a Waikato farm, with support from a number of authorities and industry bodies and using the principles of constructed wetlands. The aim of the project is to provide farmers with advice and knowledge on wetland design and performance to reduce nutrient losses (Dairy NZ 2016a). Both the financial implications of construction and maintenance as well as nutrient attenuation and initial results are due in December 2016 (Piddock 2015). However, a search in December 2017 found no published results.

The Dairy NZ study referred to above, with its focus on finances, points to what is likely to be one of the main barriers to on-farm wetland development. Indeed, McDowell et al. (2013) identify constructed wetland development cost as high to very high compared to other mitigation options. Financial investment does not only include initial development, but also on-going maintenance and a loss of agricultural land. Tanner et al. (2015) investigated using remnant wetlands to develop constructed wetlands in Southland. However, many farmers had spent considerable money draining these areas in recent years and were opposed to their reversion. Additional concerns included slowing runoff and jeopardising upland drainage function.

McLeod et al. (2006) found an almost universal desire to look after the environment amongst farmers for both aesthetic reasons and nutrient attenuation. However, there was a clear difference amongst farmer types. Dairy farmers generally agreed that waterways and wetlands should be fenced, while many sheep and beef farmers felt because they manage stock differently they don't need to exclude them from wetlands and waterways. They also showed more concern around the cost of fencing. It seems likely that increased targeting of dairy farms in terms of wetland nutrient mitigation options has had an impact. Perhaps a similar focus on other farming types would yield similar results.

\subsubsection{Catchment Scale Wetland Management}

Most research on wetland nutrient attenuation efficacy is conducted at the site scale (Collins et al. 2009), but in-stream water quality assessments are often conducted at 
catchment scale. Linkages between these scales are important when evaluating wetland performance and planning improvements to catchment scale water quality (Parkyn 2004).

Tanner (2013) investigated whether it is better to have many smaller wetlands at the head of a catchment or fewer larger wetlands at the bottom of a catchment. Generally wetlands perform best when they have a slow steady flow entering them and this is more likely to occur lower down the catchment while smaller wetlands in headwaters are more likely to be overwhelmed during high flow events. Zedler (2003) concurs stating that upstream wetlands trap few nutrients. However, in a recent study McDowell et al. (2017) found on average $77 \%$ of national $N$ and P load to waterbodies is sourced from low order streams ( $<1 \mathrm{~m}$ wide and $30 \mathrm{~cm}$ deep) on flatter agricultural land, suggesting wetlands and riparian buffers may be required more widely.

At the catchment scale Zedler (2003) suggests when wetland loss exceeds $80-90 \%$ of original cover, eutrophication (and flooding) risk greatly increases. Mitsch and Gosselink (2007) suggest that wetland restoration that equates to less than $1 \%$ of the total Mississippi catchment would be sufficient to significantly reduce nitrogen entering the Gulf of Mexico hypoxic zone.

\subsection{SEDIMENT TRAPS}

A number of structures can be defined as sediment traps. McDowell et al. (2013) define two types of sediment trap -a pond or earth reservoir located at the outlet to a zeroorder catchment, and in-stream sediment traps. McKergow et al. (2007) suggest only the in-stream version is a "trap", while Barber (2014) discusses 'silt traps' in a horticultural environment describing a reservoir type structure that encourages the deposition of fines prior to entry of water to drains. In a broader sense any structure or landform that slows water sufficiently to allow deposition of sediment is a sediment trap. This includes wetlands, lakes and estuaries. For the purposes of this review though the focus will be on small scale structures specifically built for trapping sediment and will include instream sediment traps, silt traps and detainment bunds. Constructed wetlands could also be included in this category, but have already been reviewed above. These 
structures do not appear to be commonly used in New Zealand and data quantifying their effects is sparse.

\subsubsection{In-stream Sediment Traps}

In-stream sediment traps are stream bed excavations that aim to trap coarse sediment (sand and gravel) and prevent it moving further downstream, which would reduce channel capacity and habitat quality (Hudson 2005; McKergow et al. 2007). Hudson (2005) suggests that such traps should be located in straighter sections of channel where access by digging equipment is possible. As a guide, the trap should be 1.5 times wider than the stream width, the length should be 4-10 times the trap width, and it should be $1.5 \mathrm{~m}$ deeper than the stream bed (Figure 6.9). Traps require periodic emptying, particularly after storm events, to ensure they maintain trapping capability. For more detail on the location, construction and maintenance of in-stream sediment traps see Hudson (2005) and Hudson (2002).

Trapping efficiency is not well documented. If excavated and maintained correctly, McKergow et al. (2007) suggest up to $90 \%$ of fine sand can be removed. McDowell et al. (2013) give no quantitative indication of efficiency, but state that traps are excellent at retaining coarse sediment, but less so for fine sediment. As a result, they have low $\mathrm{P}$ trapping effectiveness. Additionally, sediment traps may become sources of sediment and nutrients during high flows (McDowell et al. 2013). More recently Canterbury University ecologists trialled sediment traps in a small, lowland agricultural stream. They found over an 8 month period $60-70 \%$ of sediment between $<63 \mu \mathrm{m}-1 \mathrm{~mm}$ was trapped (CAREX 2014; Harding et al. n.d.). It is unclear if this includes clay sized particles, to which P sorbs. 


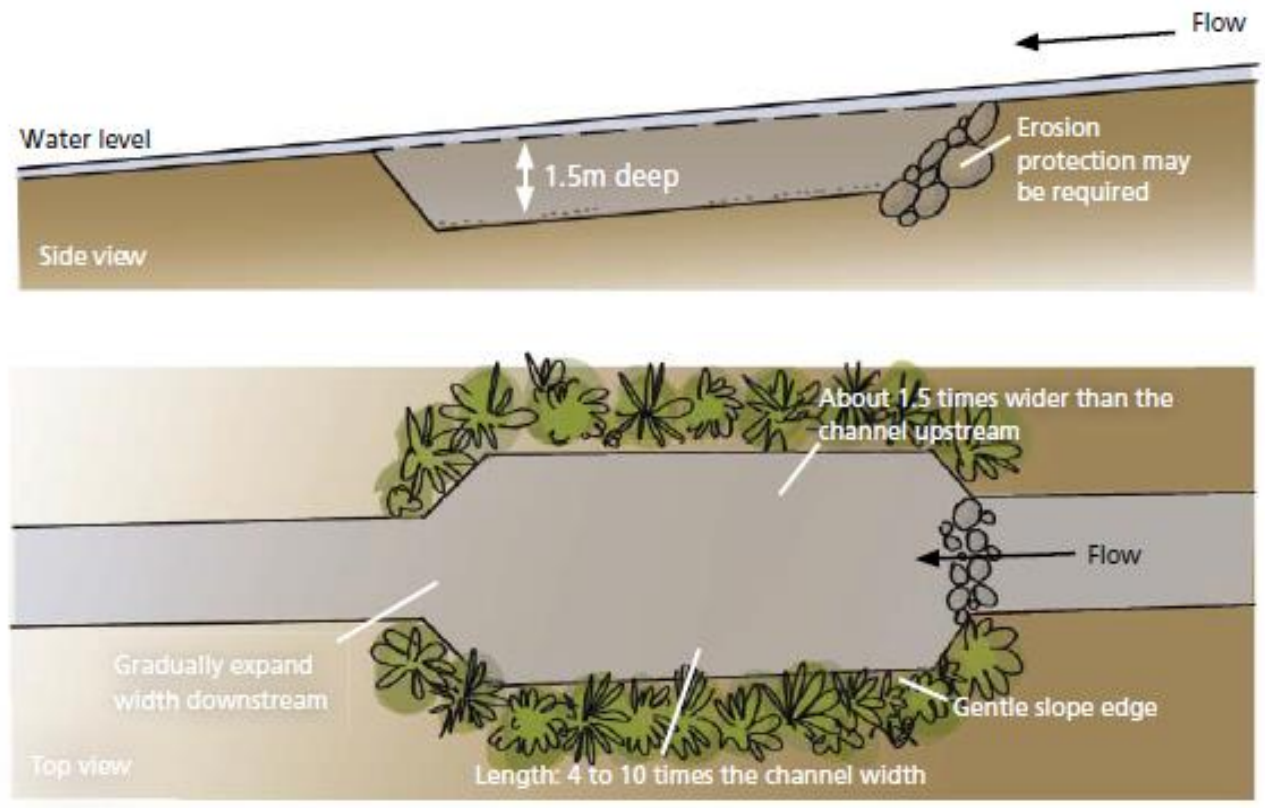

Figure 6.9 Diagram showing in-stream sediment trap construction (Hudson 2005).

\section{$\underline{6.6 .2 ~ S i l t ~ T r a p s ~}$}

Barber (2014) suggests silt traps to impound field runoff for a time, allowing suspended soil to settle. For best results the field should be broken into smaller sections, each with its own silt trap, and other methods of soil loss control should be used. Figure 6.10 shows a silt trap with snorkel in the foreground. Water is allowed to enter the trap and is slowly discharged at the other end. It is recommended traps be at least 3 times longer than width. Water generally exits the trap in to a drain. No data was found regarding silt trap effectiveness. 


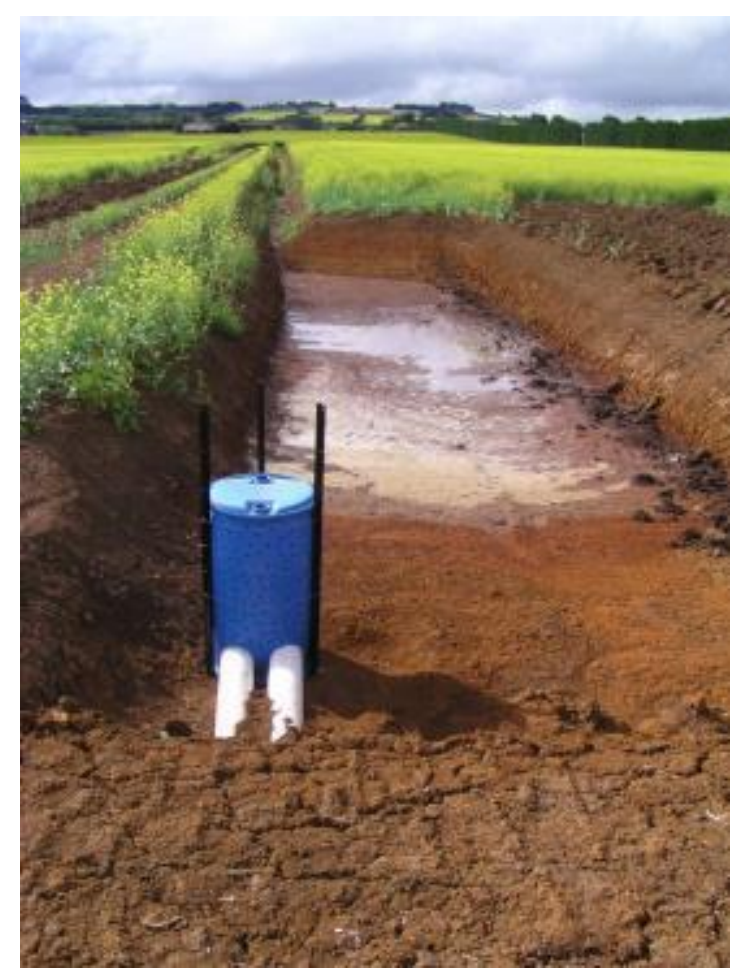

Figure 6.10 Silt trap with the blue snorkel in the foreground for slowly decanting the trap (Barber 2014).

\subsubsection{Detainment Bund}

Detainment bunds play a similar role to silt traps, but are generally used on pastoral areas. The construction consists of a 1-2m high earth dam or 'bund' situated perpendicular to an ephemeral stream channel so that it retains water in storm events. The detained water is slowly decanted via a decant pipe and riser from behind the bund over a 3 day period. This timeframe allows sediment to settle without adversely affecting the underlying pasture (Figure 6.11) (Clarke et al. 2013; BoPRC 2016; Rotorua Te Arawa Lakes Strategy Group 2017). Initial study of detainment bunds recommended a storage capacity behind the bund of $120 \mathrm{~m}^{3}$ per 1 ha upstream contributing area. PeryerFursdon (Unknown) suggests this capacity is too small to treat water thoroughly. 
Trials undertaken in the Lake Rotorua catchment indicate bunds are significant sinks for particulate $P$, but not for dissolved $P$ or $N$ (Clarke et al. 2013). Although there could be some danger that these retained $\mathrm{P}$ laden sediments could become a $\mathrm{P}$ source in future (Clarke et al. 2013; Peryer-Fursdon et al. 2015). To help combat this issue and mitigate dissolved nutrients Clarke et al. (2013) recommend detainment bunds are used in conjunction with other mitigations, such as downstream constructed wetlands. PeryerFursdon et al. (2015) suggest more of these structures should be present in the high rainfall, steeper topography of the Lake Rotorua catchment (where to-date research on detainment bunds has occurred) to trap sediment and reduce overland flow into the lower catchment.

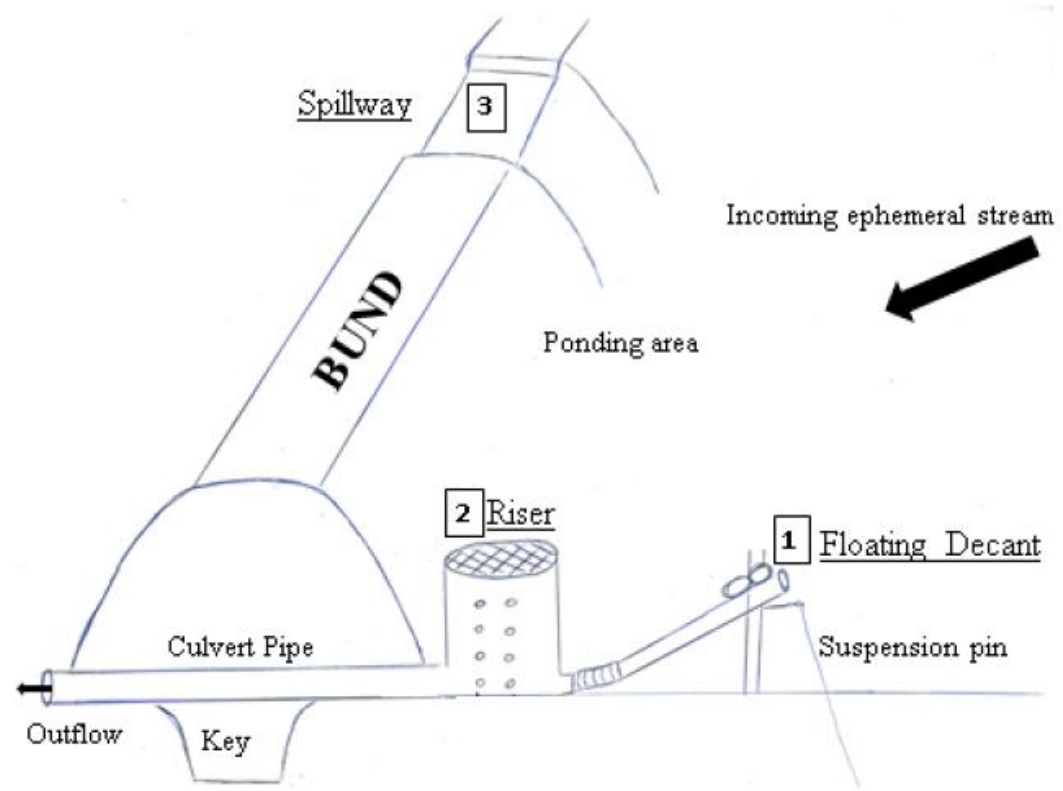

Figure 6.11 Diagram showing detainment bund construction (Clarke 2013).

\section{$\underline{6.7 \text { DISCUSSION AND CONCLUSIONS }}$}

Five mitigation strategies are investigated here. The aim is provision of information and quantification around strategy options, variables, practices and effects that may be of use in the further development and parameterisation of mitigations in $\mathrm{LUCl}$. Three nutrient source based strategies and two nutrient pathway based strategies are investigated. 


\section{Nutrient Source Related Mitigations}

For fertiliser, literature pertaining to nitrate leaching losses at variable fertiliser application rates is more prevalent than either literature detailing total nitrogen losses or $\mathrm{P}$ losses at variable fertiliser application rates. Review of the literature indicates very broadly that as fertiliser $\mathrm{N}$ or $\mathrm{P}$ applications increase, $\mathrm{N}$ or $\mathrm{P}$ losses increase. However, in both cases the relationship is not strong and it is clear other variables are influential such as rainfall for $\mathrm{N}$ and Olsen $\mathrm{P}$ for $\mathrm{P}$. Mitigations related to fertiliser application focus on minimising direct losses of fertiliser using the 4R framework, or similar.

Similarly, more literature is found reporting nitrate leaching losses from applied effluent, than is found for either total $\mathrm{N}$ losses or $\mathrm{P}$ losses. Very generally, it appears nutrient losses increase as effluent application rate increases with timing of applications according to soil moisture particularly important. It is likely other geo-climatic and management variables are influential. Mitigations related to effluent application focus on largely on carefully managing storage and application.

Here stocking rates per se are not discussed, but individual animal losses via excretion and patterns of excretory behaviour are discussed. Maximum possible stocking rate is highly dependent on provision of feed, which is dependent on fertiliser and effluent applications and/or provision of supplementary feed.

Results from fertiliser, effluent and stocking rate investigations highlight the multivariate influences on $\mathrm{N}$ and $\mathrm{P}$ losses to water, also seen and discussed in previous chapters. In terms of modelling mitigations, trying to elucidate and isolate a clear relationship between fertiliser or effluent application and $\mathrm{N}$ or $\mathrm{P}$ losses is challenging. Breaking data down in to soil, climate, management groups would appear to be an obvious approach, but lack of variability amongst studies prevents this.

In addition, the farm system must be considered in any mitigation models. There are clear links between fertiliser, effluent and stocking rate, and changes in one component may require changes or have effects on the other components. These interrelationships must be accounted for in mitigation models to ensure unrealistic farm systems are not modelled. Teasing these relationships out, while also considering geo-climatic variables, is not within the scope of this research and is likely a considerable job. In addition, 
minimal data is a constraint. Rotz et al. (2005) suggest investigation of farms systems, where data limitations exist, is best done through farm models.

\section{Nutrient Pathway related Mitigations}

Natural and constructed wetlands are investigated here. Wetland performance as a nutrient sink can be variable and is linked to many factors e.g. buffer width, soil type, topography, plant type, animal management, climate etc. Clearly these factors need consideration in wetland mitigation models. Sediment traps are not commonly featured in the literature. Presumably because they are a less used mitigation in New Zealand. As a result clear quantification of their effectiveness is not reported. However, research related particularly to detainment bunds is on-going and they may become a more popular mitigation option in future. 


\section{MODEL EVALUATION: TWO CASE STUDIES}

\subsection{INTRODUCTION}

In Chapter 5, N and P export coefficient generating algorithms were presented and parameterised. This chapter applies LUCI N and P models, including the new pastoral algorithms, to two New Zealand catchments and explores and assesses model performance at this wider scale. It should be noted that at the time these case studies were conducted, the LCM had not yet been incorporated into LUCI water quality models. Section 7.2 presents results from 4 increasingly detailed applications of LUCI N and P water quality models in a small (85ha) agricultural catchment in Manawatu, North Island, New Zealand. This application particularly illustrates how easily location specific data is incorporated into $\mathrm{LUCl}$ analyses and shows how this improves predictions compared to using regional default input data only.

Section 7.3 presents results from application of three LUCl ecosystem service submodels:- the $\mathrm{N}$ and $\mathrm{P}$ water quality models, and agricultural productivity model. In addition, LUCl trade-off analysis is applied. This study is conducted in the larger (502 $\mathrm{km}^{2}$ ), more complex catchment of Lake Rotorua, Bay of Plenty, North Island, New Zealand. Not only does this case study provide assessment of LUCI water quality models at catchment scale, but it also more broadly illustrates LUCl's value as an investigative and illustrative tool to assist stakeholders with ecosystem service assessment, management and decision making.

To assess LUCI N and P models at the catchment scale, $\mathrm{LUCl}$ in-stream predictions are compared with measured in-stream water quality data. To reiterate from Chapter 3 , limitations associated with measured in-stream water quality data exist and must be considered as a factor in any measured versus modelled in-stream comparisons. Papers summarising results from these studies are available in Appendix A (Trodahl et al. 2017a; Trodahl et al. 2017b). 


\subsection{CASE STUDY 1: TUAPAKA CATCHMENT, MANAWATU}

Results of four applications of LUCI water quality models to the Tuapaka catchment are presented, with each application using increasingly detailed input data. These are compared to OVERSEER predictions and in-stream nitrogen $(N)$ and phosphorus $(P)$ measurements.

\subsubsection{Study Area}

The 85 ha study area is situated to the east of Palmerston North, New Zealand, in the foothills of the Tararua Ranges (Figure 7.1). Terrain is rolling to steep hill with a mix of brown and pallic soil orders. Ninety percent of the catchment is in pastoral grassland used largely for sheep and beef farming, while the remaining $10 \%$ is forested. Sixty three hectares of the catchment is within Massey University's Tuapaka Agricultural Experimental Station. Massey University have developed a detailed soil map for the experimental farm (Pollok and McLaughlin 1986) and have collected meteorological and

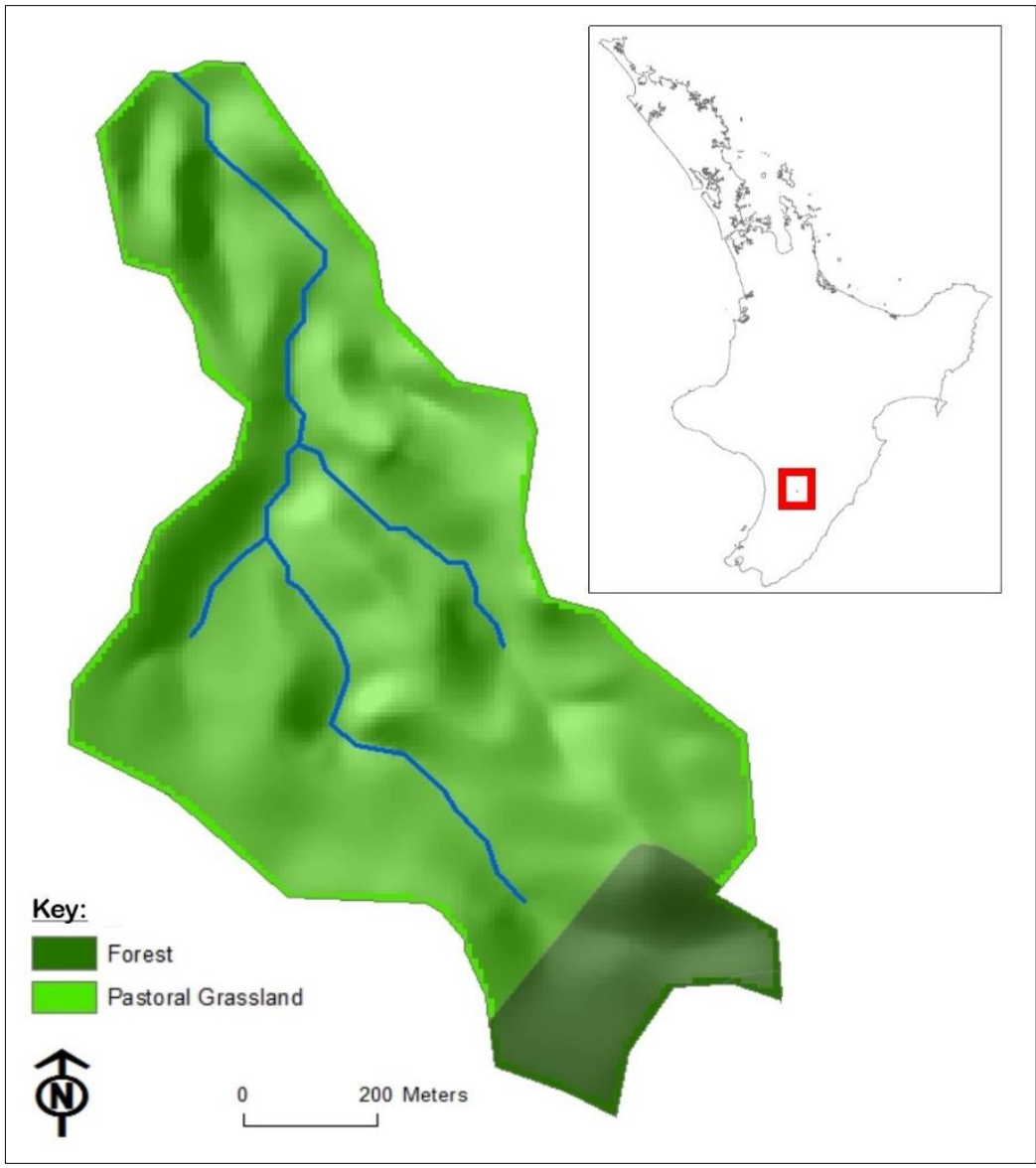
water quality data within the catchment.

Meteorological data includes rainfall and evapotranspiration from June 2013-June 2015. Ten minute flow data and monthly in-stream water quality sampling ( $\mathrm{N}$ and $\mathrm{P}$ ) were also collected for this period and a further year of monitoring is being undertaken. In addition, Massey University applied OVERSEER to the catchment.

Figure 7.1 Terrain and land cover map of Tuapaka catchment showing location in the North Island (inset) 
Burkitt et al. (2016) compared actual water quality measurements, taken between June 2013 and June 2014, and OVERSEER predictions of $\mathrm{N}$ and $\mathrm{P}$ loss within the catchment. This work is extended here by conducting a comparative analysis between actual water quality measurements from June 2013-June 2015, OVERSEER predictions of $\mathrm{N}$ and P loss, and LUCI water quality predictions. In addition, sensitivity of LUCI's N and P predictions, to input datasets of varying resolution and accuracy, is investigated.

\subsubsection{Method}

Four LUCI water quality model applications are made to the Tuapaka catchment using increasingly detailed and catchment specific input data with each successive application (Table 7.1). Application 1 uses only default national and regional input datasets. For Application 2, nationally available spatially varying annual average rainfall and evapotranspiration data by NIWA (Tait et al. 2006; Woods et al. 2006b) is replaced by raster surfaces derived from actual rainfall and evapotranspiration data collected from June 2013-June 2014. Derivation was achieved by applying the difference between actual and modelled climate variables at the point of measurement to the NIWA raster climate surfaces. Application 3 uses the above climate surfaces with the addition of Massey University's soil map for the Tuapaka Agricultural Experimental farm, increasing spatial detail around soil variability. Application 4 uses the climate surfaces based on actual data, the detailed soil data and actual farm input information from OVERSEER $\mathrm{xml}$ files. Output from the LUCI water quality models, including maps and in-stream loads, are compared to actual water quality data and OVERSEER predictions.

Table 7.1 Data input details between the four LUCI applications

\begin{tabular}{|c|c|c|c|}
\hline LUCl Application & Climate Data & Soil Data & Farm Input Data \\
\hline Application 1 & National $^{1}$ & National $^{2}$ & Regional default ${ }^{3}$ \\
\hline Application 2 & $\begin{array}{l}\text { Raster derived from } \\
\text { actual rain \& evap }\end{array}$ & National $^{2}$ & Regional default ${ }^{3}$ \\
\hline Application 3 & $\begin{array}{l}\text { Raster derived from } \\
\text { actual rain \& evap }\end{array}$ & $\begin{array}{l}\text { Massey University } \\
\text { Tuapaka Soil Map }\end{array}$ & Regional default ${ }^{3}$ \\
\hline Application 4 & $\begin{array}{l}\text { Raster derived from } \\
\text { actual rain \& evap }\end{array}$ & $\begin{array}{l}\text { Massey University } \\
\text { Tuapaka Soil Map }{ }^{4}\end{array}$ & $\begin{array}{l}\text { Actual farm input } \\
\text { (OVERSEER xml) }\end{array}$ \\
\hline \multicolumn{4}{|c|}{$\begin{array}{l}{ }^{1} \text { Rain and evapotranspiration surfaces developed by NIWA (Tait et al. 2006; Woods et al. 2006b) } \\
{ }^{2} \text { NZFSL } \\
\text { https://soils.landcareresearch.co.nz/contents/SoilData FSL Maps.aspx?currentPage=SoilData FSL Ma }\end{array}$} \\
\hline \multicolumn{4}{|c|}{$\begin{array}{l}\text { ps\&menultem=SoilData } \\
{ }^{3} \text { Regional farm input defaults developed by LUC }\end{array}$} \\
\hline
\end{tabular}




\subsubsection{Results and Discussion}

A number of maps and data are generated by the $\mathrm{LUCl}$ water quality models allowing exploration of TN or TP loads and concentrations both in-stream and on land. The results are presented as a map with DEM grid cells coloured according to their total nutrient loads, from low total nutrients in red to high nutrient loads in green. (Note: this colour scheme is now reversed in the latest version of LUCI). Nitrogen load maps from the four applications of $\mathrm{LUCl}$ are shown in Figure 7.2a-d. While the highest and lowest TN loads remain the same for all four applications, it is clear that Application 4, with the addition of actual farm nitrogen input data for Tuapaka Agricultural Experimental farm, has lower nitrogen loads within this area (Figure 7.2d).

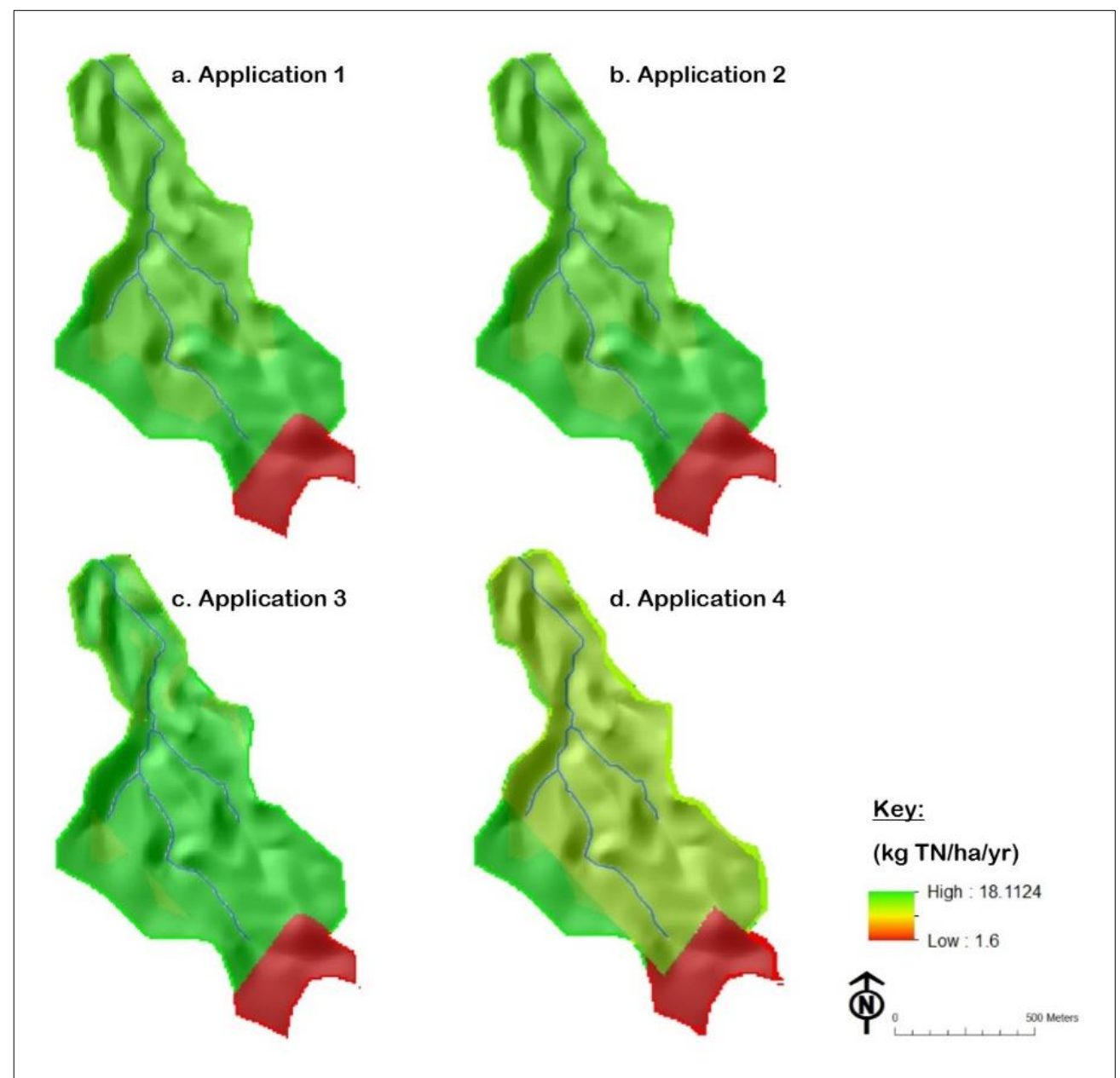

Figure 7.2 Nitrogen load maps from Applications 1-4 of LUCI to the Tuapaka catchment, showing the effect of increasingly detailed input data from Application 1 (7.2a) to Application 4 (7.2d). 
Accumulated nitrogen load, classified into 3 groups, from LUCl Applications 1-4 is shown in Figure 7.3a-d. These indicate pathways where water and nitrogen converge in the landscape. Spatially explicit identification of these pathways illustrate existing opportunities to intercept nutrients before they enter the stream network. Like Figure 7.2, maps from Applications 1-3 are very similar. Figure 7.3d, however, more clearly identifies pathways of very high load, enabling specific spatial targeting of those areas for intervention and mitigation.

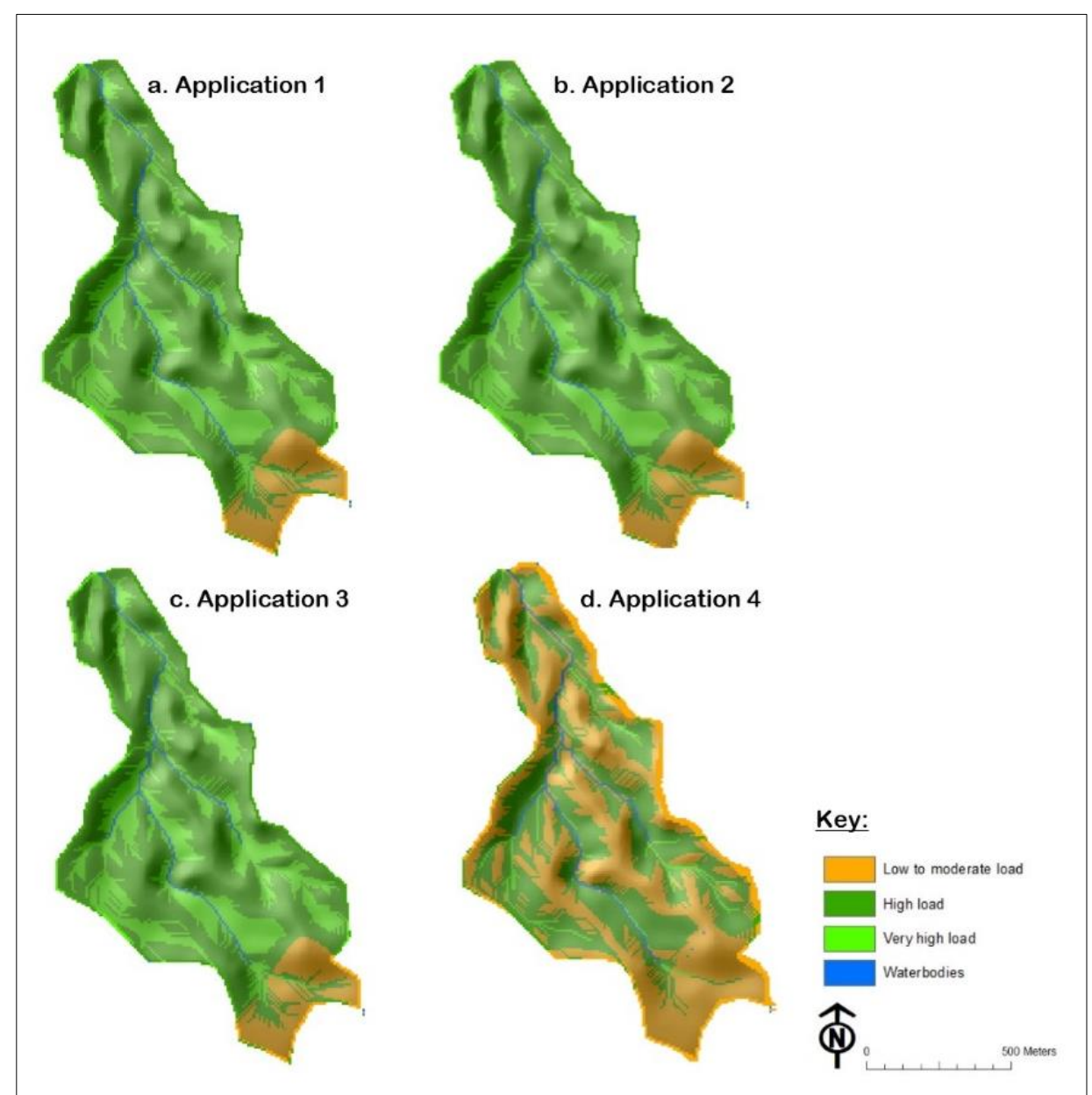

Figure 7.3 Accumulated nitrogen load maps from Applications 1-4 of LUCI to the Tuapaka catchment, showing the effect of increasingly detailed input data from Application 1 (7.3a) to Application 4 (7.3d).

Figure 7.4 shows P load maps from Applications 1-4. Figures 7.4a and 7.4b are very similar with highest P loads sourced from steeper pastoral grassland and lowest loads from forested areas and flatter pastoral grassland in the upper catchment. With the addition of the detailed soil map in Application 3 (Figure 7.4c), highest P loads are reduced to $8.8 \mathrm{~kg} \mathrm{TP} \mathrm{ha}^{-1} \mathrm{yr}^{-1}$ from $12.3 \mathrm{~kg} \mathrm{TP} \mathrm{ha}^{-1} \mathrm{yr}^{-1}$ in Applications 1 \& 2. This is because Massey University's soil map indicates low $\mathrm{P}$ retention pallic soils only make up 
$20 \%$ of the catchment compared to $80 \%$ with the national soil map. A further reduction in highest $\mathrm{P}$ loads (to $5.6 \mathrm{~kg} \mathrm{TP} \mathrm{ha}^{-1} \mathrm{yr}^{-1}$ ) occurs with addition of actual farm inputs in Application 4 (Figure 7.4d).

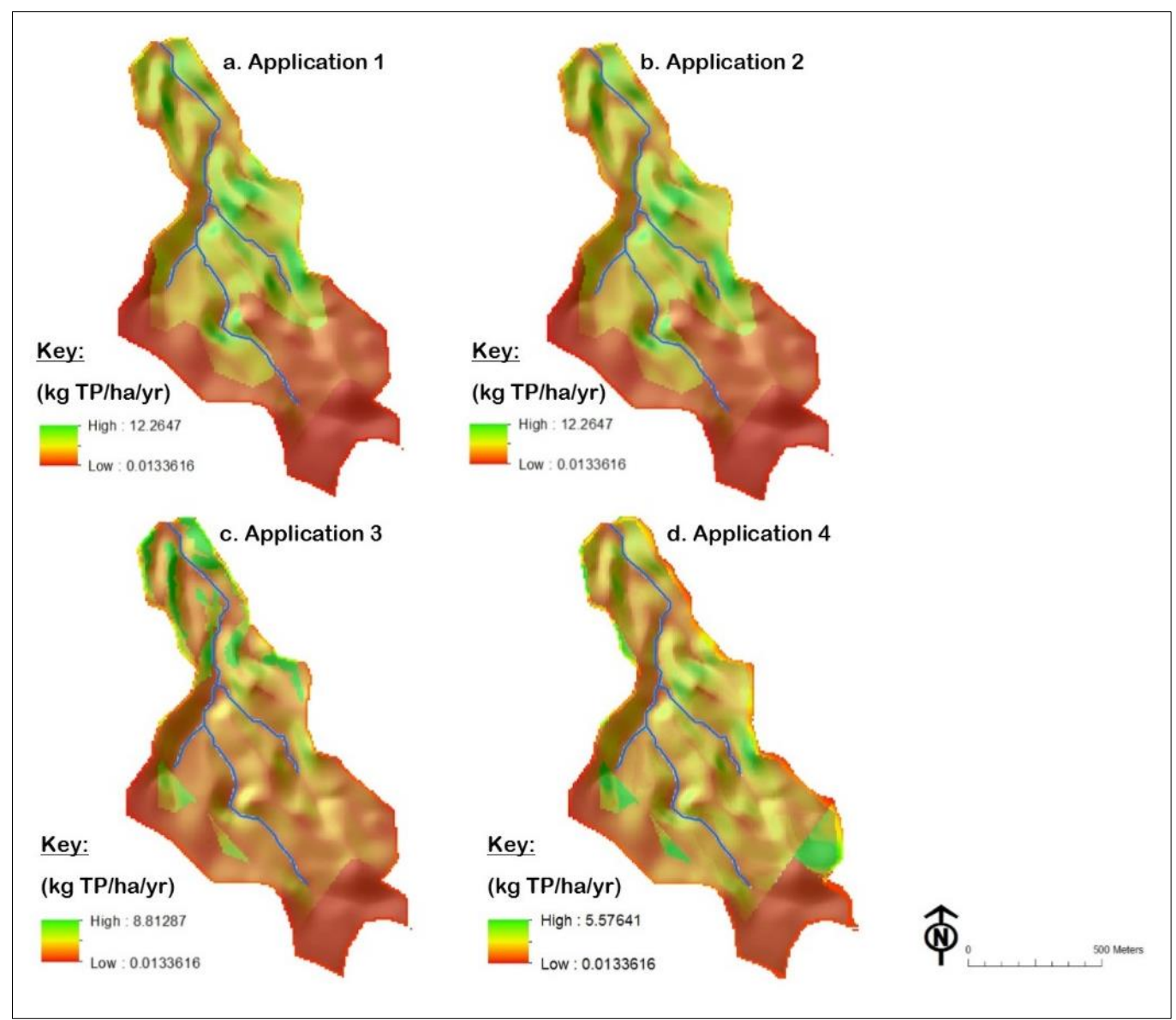

Figure 7.4 Phosphorus load maps from Applications 1-4 of LUCI to the Tuapaka catchment, showing the effect of increasingly detailed input data from Application 1 (7.4a) to Application 4 (7.4d).

Figure 7.5a-d shows classified accumulated P load maps from LUCI Applications 1-4. Like Figure 7.3, pathways of water and $\mathrm{P}$ convergence in the landscape are identified where opportunities exist to intercept nutrients before they enter the stream network. As with $\mathrm{N}$, it is clear the addition of actual, more detailed data better defines pathways, allowing for highly spatially targeted interventions and mitigations.

Table 7.2 summarises $\mathrm{N}$ and $\mathrm{P}$ concentration and specific load from measured water quality data, OVERSEER, and the four LUCI applications. Average concentration and specific load, based on measurements from June 2013-June 2015, are shown in row 1 with the range in brackets. OVERSEER estimates of $\mathrm{N}$ and $\mathrm{P}$ annual average loses are 
shown in row 2, and below that, predictions of $\mathrm{N}$ and $\mathrm{P}$ in-stream concentration and specific load for each of the four LUCl applications.

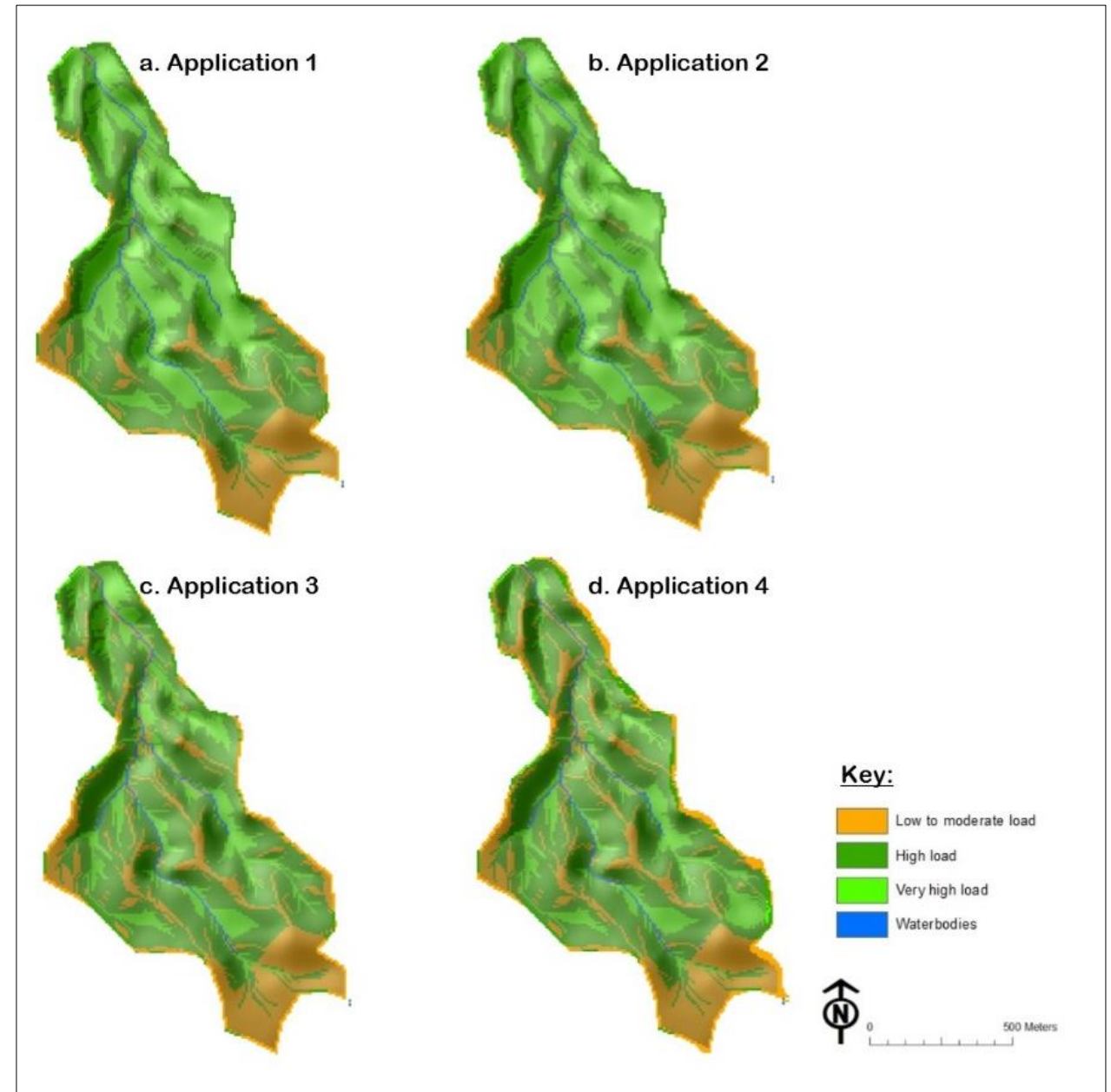

Figure 7.5 Accumulated phosphorus load maps from Applications 1-4 of LUCI to the Tuapaka catchment, showing the effect of increasingly detailed input data from Application 1 (7.5a) to Application 4 (7.5d).

Table 7.2 - Measured and modelled concentration and specific load for the Tuapaka catchment. Note for Row 1 mean is presented with range in brackets.

\begin{tabular}{|l|c|c|c|c|}
\hline Model/Measured & $\begin{array}{c}\text { NITROGEN } \\
\text { Concentration } \\
\text { (mg N/L) }\end{array}$ & $\begin{array}{c}\text { NITROGEN } \\
\text { Specific Load } \\
\text { (kg N/ha/yr) }\end{array}$ & $\begin{array}{c}\text { PHOSPHORUS } \\
\text { Concentration } \\
\text { (mg N/L) }\end{array}$ & $\begin{array}{c}\text { PHOSPHORUS } \\
\text { Specific Load } \\
\text { (kg P/ha/yr) }\end{array}$ \\
\hline Measured & $\begin{array}{c}0.61 \\
(0-1.5)\end{array}$ & $\begin{array}{c}2.37 \\
(1.67-3.07)\end{array}$ & $\begin{array}{c}0.025 \\
(0-0.1)\end{array}$ & $\begin{array}{c}0.12 \\
(0.06-0.18)\end{array}$ \\
\hline Overseer & & 8 & & 0.8 \\
\hline LUCl Application 1 & 2.16 & 7.39 & 0.22 & 0.77 \\
\hline LUCl Application 2 & 2.34 & 7.39 & 0.25 & 0.77 \\
\hline LUCl Application 3 & 2.43 & 7.7 & 0.1 & 0.33 \\
\hline LUCl Application 4 & 1.76 & 6.23 & 0.08 & 0.28 \\
\hline
\end{tabular}


It is clear from the maps and Table 7.2 there is little difference in outcome between LUCI Application 1 and Application 2. Rainfall and evapotranspiration data from Massey University indicates a difference of $10 \%$ compared to annual average rainfall and evapotranspiration for the area from NIWA data. In terms of excess rainfall (i.e. rainfall less evapotranspiration) the difference between measured and modelled data is only $7 \%$. Clearly these differences are not sufficient to significantly change LUCI output for $\mathrm{N}$ or $\mathrm{P}$. The addition of detailed soil data in Application 3 has a clear impact on sources, concentrations and loads of $\mathrm{P}$ due to significant decreases of pallic soil within the catchment. Detailed farm input data also decreases loads for both $\mathrm{N}$ and $\mathrm{P}$.

These results highlight the important influence of farm inputs for $\mathrm{N}$ loss and soil plus farm inputs for $\mathrm{P}$ loss and indicate location specific soil and farm data is preferable, where available, for use in LUCI. Additionally, the ease with which actual and specific data can be incorporated into LUCI is demonstrated.

There are clear differences between LUCI predictions and measured concentrations and specific loads (Table 7.2). While uncertainties exist around water quality measurements, particularly at the monthly sampling scale (Letcher et al. 2002; Johnes 2007; Krueger et al. 2012; Lloyd et al. 2016), this analysis suggests that further development to improve representation of nutrient attenuation in the catchment may improve the accuracy of LUCI predictions. The export coefficient algorithms quantify nutrient losses from each grid square, but further attenuation is applied as these nutrients cascade through the catchment. Currently, two catchment scale attenuation factors lump into one linear coefficient the impact of losses, lags and/or transformations from root zone to stream, and a similar factor represents within-stream attenuation. However, attenuation variability at the scales within which $\mathrm{LUCl}$ operates could be better represented.

\subsubsection{Conclusion}

Application of the newly developed multivariate, algorithmic approach to EC calculation allows small-scale variability within land covers to be considered, which enhances farm to catchment scale water quality modelling in LUCl. Exploration of effects of data resolution and detail on $\mathrm{N}$ and $\mathrm{P}$ exports using this method in $\mathrm{LUCl}$ on the Tuapaka catchment indicates catchment or farm specific data is preferable, where available. 
However, clear differences exist between measured and LUCI predicted nutrient losses at the catchment scale. Notwithstanding uncertainty around measured water quality data, improved understanding and representation of nutrient attenuation in the catchment is likely to improve the accuracy of LUCI predictions. Currently, attenuation is broadly accounted for in LUCl with catchment wide root zone to stream and in-stream attenuation factors applied for $\mathrm{N}$ and $\mathrm{P}$ respectively. Development of attenuation factors that account for small scale spatial variability within catchments and recognise different processes (lag times, biogeochemical transformations, etc.) is desired. This, in addition to development of an export coefficient algorithmic approach for other land cover types that is based on data from those land covers, are areas for further investigation and development.

\subsection{CASE STUDY 2: LAKE ROTORUA CATCHMENT, BAY OF PLENTY}

LUCI water quality and agricultural productivity models are applied to the Lake Rotorua catchment in New Zealand. $\mathrm{N}$ and $\mathrm{P}$ sources, sinks and pathways in the landscape are identified and trade-offs and synergies between water quality and agricultural productivity investigated. While the focus for assessment here is $\mathrm{N}$ and $\mathrm{P}$ water quality models, agricultural productivity and trade-off tools, which have not been developed as part of this research project, are also applied to demonstrate LUCl's utility for farm and catchment management.

\subsubsection{Study Site}

Lake Rotorua is situated in the Bay of Plenty, New Zealand (Figure 7.6). The lake is a volcanic caldera with significant geothermal resources and springs in the surrounding catchment. The contributing surface water catchment is $502.1 \mathrm{~km}^{2}$. In addition, there are significant groundwater resources. It is estimated that an additional area of $35 \mathrm{~km}^{2}$ to the north-west of the catchment also contributes groundwater to the Lake Rotorua system (White et al. 2014). The catchment is largely comprised of porous allophanic and pumice soils, although the west of the catchment consists of less porous podzol soils. Smaller areas of recent, organic and raw soil are also present.

Land cover within the catchment is largely agricultural $\left(210 \mathrm{~km}^{2}\right) .1 \%$ of agricultural land cover is crops and orchards. The remaining agricultural land is pastoral with $25 \%$ of this 
in dairy farming and 75\% in dry stock (sheep and beef) farming (BoPRC 2012b). There is negligible irrigation or artificial drainage on agricultural land within the catchment due to high rainfall and porous soils. Commercial forestry covers $74.9 \mathrm{~km}^{2}$, and noncommercial forest and shrubland $95.8 \mathrm{~km}^{2}$. The largest urban area in the catchment is the city of Rotorua $\left(20.8 \mathrm{~km}^{2}\right.$ ) with a population of just over 53000 (Te Ara 2016).

Lake Rotorua has suffered from well-documented reductions in water quality in recent decades. Past and present anthropogenic drivers of declining water quality include intensification of pastoral farming, septic tanks and sewage treatment plant discharge. However, natural sources of $\mathrm{N}$ and $\mathrm{P}$ are also present due to the area's geology and volcanism and, in some sub-catchments, these represent a significant proportion of the nutrient load (Williamson and Cooke 1982; Rutherford et al. 2011; Tempero et al. 2015).

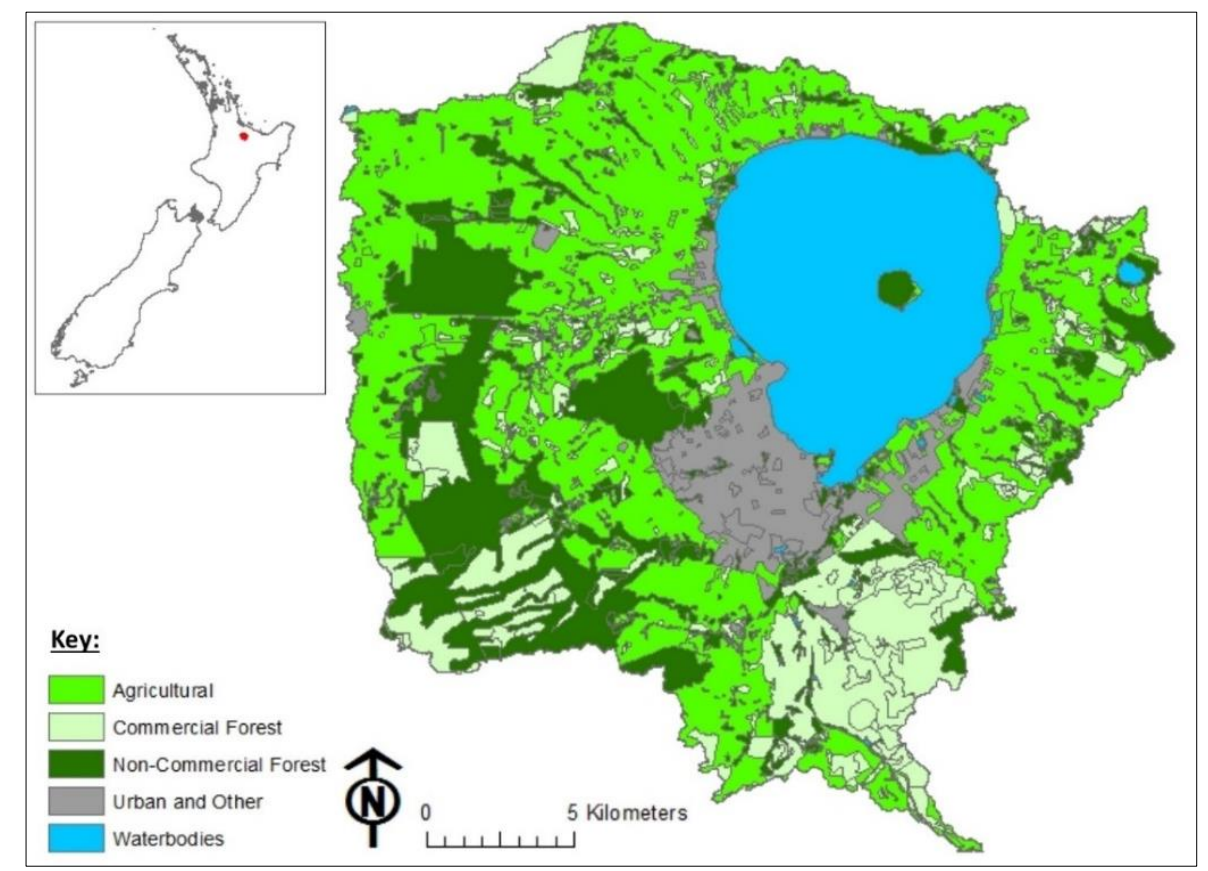

Figure 7.6 Lake Rotorua catchment and land cover

Land management strategies to reduce nutrient input to the lake are used to varying degrees and include riparian protection from stock (fencing and planting), efficient fertiliser use, detention dams, tree planting for erosion control, land use change and improved septic and sewage treatment (Rotorua Te Arawa Lakes Strategy Group 2016). Recent local government regulation now limits nitrogen and phosphorus export to a 2001-2004 benchmark for properties over $4000 \mathrm{~m}^{2}$. This benchmark is established for each property using OVERSEER (BoPRC 2012a). 
Despite hydrological complexity and diverse nutrient sources in the Rotorua catchment, LUCI water quality models are applied here because long term, fairly comprehensive hydrological and nutrient data for 11 sub-catchments is available. In addition, farmers are concerned that the new regulatory measures to limit nutrient losses to waterways within the catchment will negatively impact the viability of agricultural enterprise in the region (McRae 2015). LUCl can assist with decision making around this complex issue by providing information to stakeholders, and farmers respond positively to the visual, spatially explicit nature of the LUCI framework (Scott 2015). Although the focus of this thesis is LUCl's N and P water quality models, the agricultural productivity tool is applied and a trade-off analysis conducted to assess the likely impact of reducing $\mathrm{N}$ and $\mathrm{P}$ export to water on agricultural productivity. This is key information for farmers and other stakeholders.

\subsubsection{Method}

\section{Base Data}

The base data for this application includes a $5 \mathrm{~m}$ by $5 \mathrm{~m}$ DEM derived from LiDAR data from Bay of Plenty Regional Council (BoPRC), land cover data from the New Zealand Land Cover Database (LCDB4), soil data from the New Zealand Fundamental Soils Layer (NZFSL), stream network data from the National Institute of Water and Atmospheric Research (NIWA) River Environment Classification (REC), rainfall and evapotranspiration surfaces from NIWA (Tait et al. 2006; Woods et al. 2006b), and locations of spring additions of water $\left(\mathrm{m}^{3} / \mathrm{s}\right)$ to the river network developed by the author from information provided by BoPRC. Further information, on all but the author developed springs data, is found in Chapter 3 and Table 1.1.

\section{LUCI Models Applied}

\section{Water Quality Models}

LUCI N and P water quality models are thoroughly described in previous chapters. Here the pastoral land cover export coefficient generating algorithms are applied. However, export coefficients for other land cover categories, including urban, are derived from New Zealand literature and summarised in Table 7.3 (Alexander et al. 2002a; Quinn and Stroud 2002; Davies-Colley and Wilcock 2004; Lin 2004; Meneer et al. 2004; McQueen et 
al. 2006; Parfitt et al. 2006; Al Bakri et al. 2008; McDowell and Wilcock 2008; Cox et al. 2012; Davis et al. 2012; Magesan et al. 2012; Cameron et al. 2013; Davis 2014; Baillie and Neary 2015).

As discussed in Case Study 1, representation of attenuation variability in LUCl water quality models is a focus for future improvement. Here an attenuation factor of 0.5 for $\mathrm{N}$ is applied, which has been shown to be appropriate when applying OVERSEER N exports in one small catchment scale application (Power et al. 2002), although this requires wider confirmation (Arbuckle 2015). Given other sources of uncertainty, observed versus modelled instream nitrogen concentrations seem reasonable with this attenuation factor (see later results), so no additional calibration of the factor is attempted for this study. An attenuation factor of 0.7 for $P$ is estimated and applied based on differences between observed and modelled phosphorus in-stream concentrations, although no corroborating evidence from other studies is currently available to ascertain whether this is more generally representative.

To calculate ECs at the farm or small catchment scale, where direct communication with farmers is possible, actual management data can be used, as in Case Study 1. For larger catchment scale applications, such as this, individual farm details are usually not known and regional averages, derived in Chapter 5, are applied. Table 7.3 shows ECs used for this study for pastoral land covers based on the new algorithms with regional average input variables. Pastoral ECs for P also consider slope in degrees. A range of pastoral ECs on soils found in the Lake Rotorua catchment for slopes of $2-15^{\circ}$ is shown in Table 7.3. The average slope value for agricultural land in this catchment is $10^{\circ}$.

\section{Agricultural Productivity}

The agricultural productivity model predicts optimal utilisation based on evaluation of slope, fertility, aspect, drainage and elevation. Reasonably flat, fertile, well-draining soils are considered of highest value for agricultural production. As slope increases, and/or soils become seasonally to permanently waterlogged (as can occur on very flat, poorly draining soils), and/or soil fertility decreases, estimated productive value lowers.

Drainage and fertility are determined soil data variables. Aspect is DEM determined. LUCl currently considers north facing slopes most productive in the Southern 
Hemisphere, and up-weights fertility and drainage (i.e. soils with positive aspect receive a bonus to fertility and drainage

Table 7.3 - ECs used for this application of LUCI N and P export to water tools. ECs for $\mathrm{P}$ consider slope in degrees and the above gives the range of ECs for pastoral land for slopes of $2-15^{\circ}$. The average slope values for agricultural land in the Lake Rotorua catchment is $10^{\circ}$. Forest cover ECs show a range because there are a variety of forest types with a variety of nutrient ECs.

\begin{tabular}{|l|l|l|l|}
\hline Land Cover & Soil Order & $\begin{array}{l}\text { Nitrogen EC } \\
\text { (kg N/ha/yr) }\end{array}$ & $\begin{array}{l}\text { Phosphorus EC } \\
\text { (kg P/ha/yr) }\end{array}$ \\
\hline Pastoral & Allophanic & 25.4 & $0.02-0.06$ \\
\hline & Organic & 13.8 & $0.14-0.47$ \\
\hline & Podzol & 18.1 & $0.26-0.79$ \\
\hline & Pumice & 25.8 & $0.05-0.25$ \\
\hline & Recent & 26.8 & $0.06-0.27$ \\
\hline & Raw & 22.6 & $0.04-0.11$ \\
\hline Orchard \& Perennial Crops & & 6.8 & 0.05 \\
\hline Short-rotation Crops & & 10.6 & 1.6 \\
\hline Urban & & 6.8 & 1 \\
\hline Non-commercial Forest & & $2.4-2.9$ & $0.2-0.4$ \\
\hline Shrubland & & 6 & 0.7 \\
\hline Commercial Forest & & $1.2-1.6$ & $0.2-2.2$ \\
\hline
\end{tabular}

scores). Here, slopes $\leq 5^{\circ}$ are considered very productive, between $5^{\circ}$ and $15^{\circ}$, somewhat productive, and slopes $>15^{\circ}$, of lower production value. Often an elevation threshold is used to reflect temperature or other variations impacting productivity. For this application no threshold is implemented because increasing rainfall as elevation increases in the well-draining Bay of Plenty soils, reduces drought and compensates for any productivity deterioration caused by decreasing temperature. Slope, elevation and cut-off fertility thresholds can be changed to account for local conditions and practices.

Current land utilisation is determined from land cover data. By comparing current and optimal agricultural use, LUCI identifies locations appearing under or over utilised and suggests where change in land use or management could be beneficial. Areas of current optimal use are also identified for protection. For further detail on LUCI agricultural productivity algorithms see Jackson et al. (2014) and Jackson et al. (2013a). 


\section{Trade-off and Synergy Identification}

$\mathrm{LUCl}$ trade-off tools identify opportunities to improve delivery of multiple ecosystem services, while protecting areas already delivering multiple ecosystem services of high quality. When individual ecosystem services are analysed, each terrestrial cell is categorised into one of five provisioning categories - very high existing service, high existing service, moderate or marginal service with little capacity to improve, small or degrading service with significant capacity to improve, very small or rapidly degrading service with significant capacity to improve.

During trade-off analysis, this categorisation is further reduced to three categories $-a)$ high existing good, b) bad or negligible existing good with potential to improve, and c) negligible existing good but negligible opportunity to improve significantly. These categories, for two or more single ecosystem services, are layered to identify parts of the landscape where trade-offs versus win-win situations exist and where management interventions could enhance or protect multiple ecosystem services. Areas with only multiple "high existing good" are flagged as win-win situations where status quo should be preserved. Areas with multiple "bad or negligible existing good with potential to improve" are flagged as win-win situations for potential change. Areas where trade-offs exist (i.e. where significant improvements of a service would likely go in tandem with degradation of other services) are separately categorised, as are areas where there are no obvious advantages in either preserving the status quo or implementing management change.

A numerical value is assigned to each of the three categories described above and used to calculate trade-offs and synergies among ecosystem services. Five calculation methods are available - equally weighted arithmetic, conservative, standard, weighted additive, and a combined "conservative and weighted additive" approach. The equally weighted arithmetic method for multiple ecosystem service trade-off and synergy identification is used here in the absence of any clear reason to use a different approach. Two-way and three-way analyses between agricultural productivity and $\mathrm{N}$ and P exports to water are applied. For further detail on LUCI trade-off algorithms see Jackson et al. (2014) and Jackson et al. (2013a). 
To explore the extent to which targeting zones of high accumulated load rather than input loads over the catchment might reduce loss of agricultural productivity, two separate analyses were conducted (by other members of the LUCI development team) for loads and accumulated loads, both aiming to reduce loading to waterways of both $\mathrm{N}$ and P. Load and accumulated load outputs from LUCI were each classified into 10 classes using Jenks's natural breaks (implemented via ArcGIS software). A zone for each class was created and the average value of each attribute was calculated using zonal statistics. Four pasture production classes were assigned based on likely pasture dry matter production for each productive environment identified in the predicted optimal agricultural utilisation layer, with values ranging from 6000 to $12000 \mathrm{~kg}$ dry matter/ha. The agricultural productivity, $\mathrm{N}$ and $\mathrm{P}$ layers were overlaid resulting in 88 combinations for load and 352 combinations for accumulated load. The area of each of these combined zones was found and area weighted total loads calculated in a spreadsheet. A simplex method (implemented via Lindo Systems Inc.'s What'sBest! Excel Add-in) was used to find the areas required to achieve varying degrees of $\mathrm{N}$ and $\mathrm{P}$ load mitigation with minimal impact on agricultural productivity. The same method was used to identify areas with large amounts of accumulated load. The contributing areas above these points, and their associated direct loadings were then calculated to establish the total $\mathrm{N}$ and $\mathrm{P}$ load that could potentially be intercepted in these zones of high accumulated load.

\section{$\underline{\text { 7.3.3 Results }}$}

\section{Water Quality}

\section{Nitrogen}

Strong spatial gradients in the total generated $\mathrm{N}$ loads exist in the Lake Rotorua catchment (Figure 7.7) and are linked to combined land cover and soil order categories. The highest TN loads are associated with pastoral land situated on porous allophanic, pumice and recent soils, while pastoral land in the west of the catchment over podzol soils has lower TN loads. The lowest TN loads are associated with both commercial and non-commercial forests and shrubland on all soil types. Urban areas are moderate sources of TN. 
When accumulated TN load is considered at the catchment scale (Figure 7.8) the same pattern of highest loads associated with pastoral land is observed. When considered at smaller spatial scales, however, this is not exclusively the case. A close-up view of a mixed land-use portion of the landscape (Figure 7.8 inset) reveals that even in forested areas (largely amber) there are clear pathways of high to very high accumulated TN loads where water converges in the landscape.

Investigation of model performance for each sub-catchment, by comparing over and under predicted in-stream TN concentrations with LCDB4 land cover and with groundwater characteristics from Tempero et al (2015) and Morgenstern et al (2006), shows no clear pattern. This indicates no particular bias associated with LUCl's land cover based EC's. However, in the four sub-catchments where groundwater is likely sourced from beyond sub-catchment boundaries (Hamurana, Awahou, Waiowhero and Waiohewa), LUCl under predicted in-stream TN concentrations by $55-90 \%$ of observed concentrations. In addition, Waiohewa sub-catchment has notably high ammonium input from a local geothermal source (Williamson and Cooke 1982). In one other subcatchment (Waingaehe) where groundwater is likely sourced from within the catchment bounds yet has very long ( $>100$ years) lag times, $\mathrm{LUCl}$ over predicted in-stream TN concentrations by $69 \%$ (Table 7.4 and Figure 7.9). At the six sites where neither of the above situations apply, most sub-catchment predictions are no more than $20 \%$ different from observed TN concentrations. The one exception is a small sub-catchment (Lynmore) to the south-east for which little groundwater data is available. LUCI under predicted TN concentrations for this catchment by $49 \%$. Hoare (1984) also noted particularly high nitrate concentrations in this stream. He attributed it to septic tank leachate, although since the early 1980's this area has been connected to Rotorua's sewage treatments works. Possibly, this small sub-catchment also receives groundwater from surrounding sub-catchments and/or volcanic $\mathrm{N}$ influences prevail. 


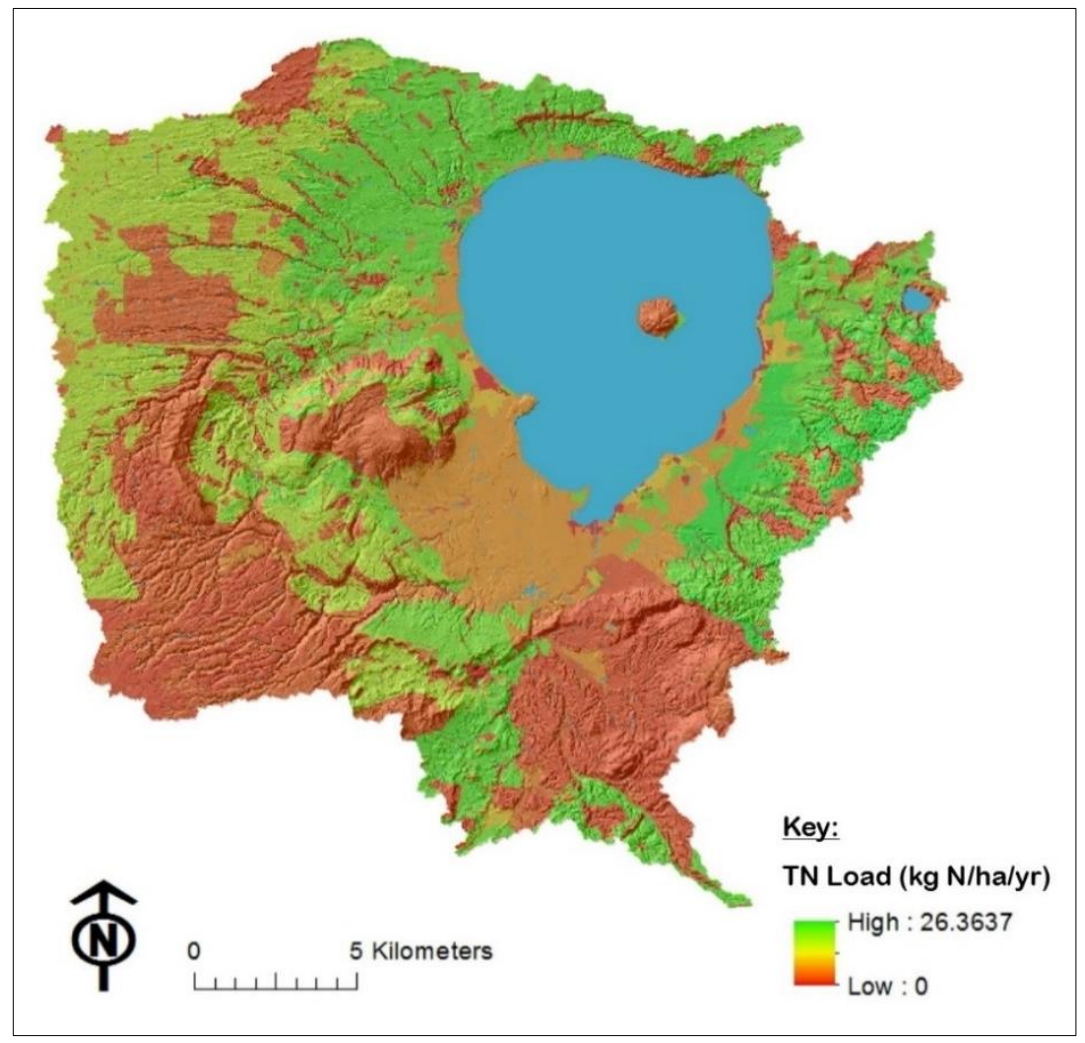

Figure 7.7 TN load generated in Lake Rotorua catchment

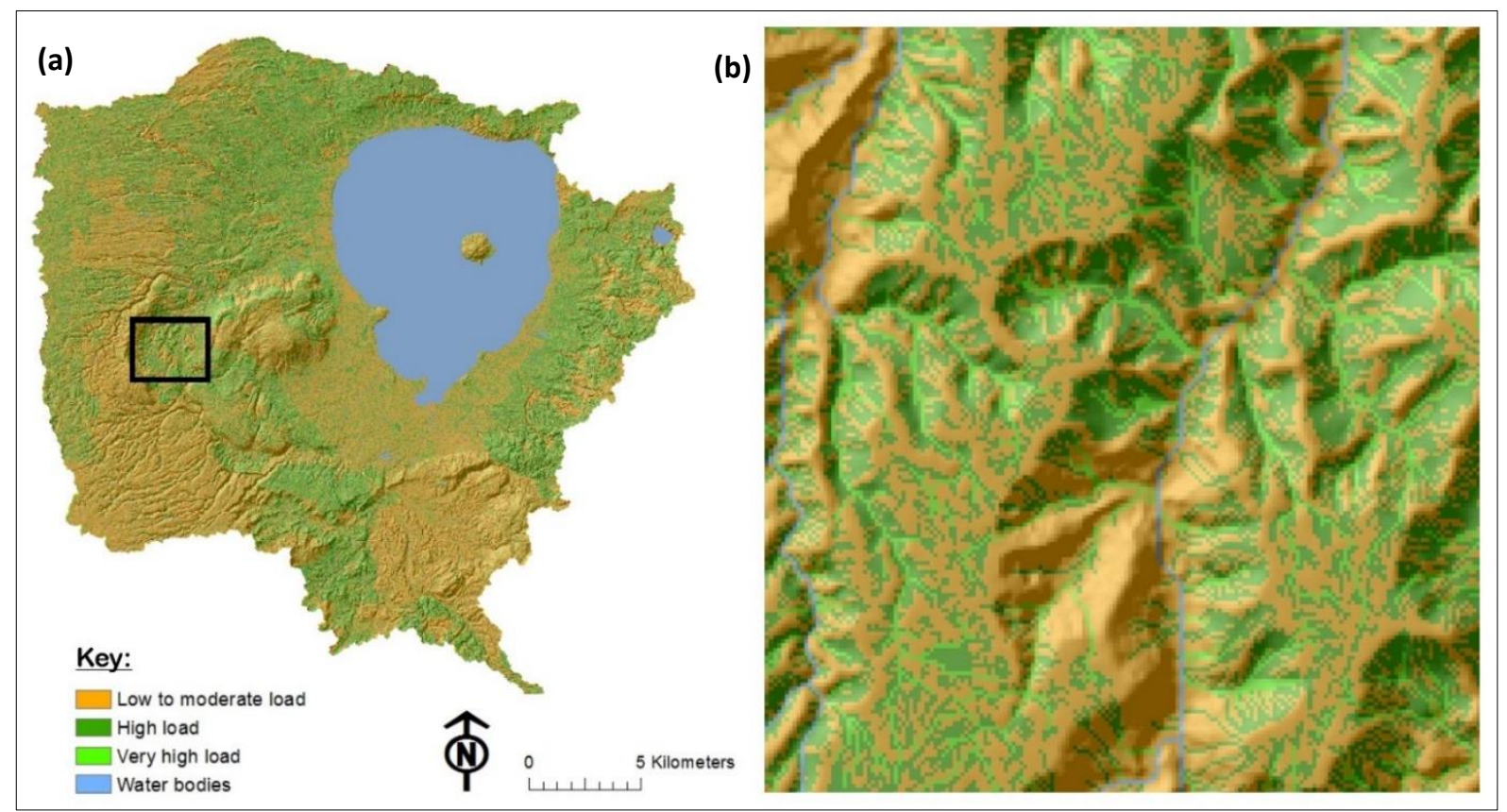

Figure 7.8 Accumulated TN load for whole Lake Rotorua catchment (a) and close up (b) 
Table 7.4 Observed and predicted TN concentrations for 11 Lake Rotorua subcatchments with detail on groundwater (GW) vs surface water (SF) dominance (where available).

\begin{tabular}{|l|r|r|r|l|}
\hline $\begin{array}{c}\text { Catchment } \\
\text { Name }\end{array}$ & $\begin{array}{r}\text { Observed } \\
\text { TN (mg/lt) }\end{array}$ & $\begin{array}{r}\text { Predicted } \\
\text { TN (mg/lt) }\end{array}$ & $\begin{array}{c}\text { \% diff from } \\
\text { observed (100\%) }\end{array}$ & Notes on Catchment \\
\hline Hamurana & 0.77 & 0.1 & -87.01 & $\begin{array}{l}\text { GW from out of } \\
\text { catchment }\end{array}$ \\
\hline Awahou & 1.28 & 0.48 & -62.50 & $\begin{array}{l}\text { GW possibly from out } \\
\text { of catchment }\end{array}$ \\
\hline Waiteti & 1.41 & 1.45 & 2.84 & SF Dominated \\
\hline Ngongotaha & 0.99 & 1.16 & 17.17 & SF Dominated \\
\hline Waiowhiro & 1.05 & 0.43 & -59.05 & $\begin{array}{l}\text { GW possibly from out } \\
\text { of catchment }\end{array}$ \\
\hline Utuhina & 0.91 & 0.73 & -19.78 & 50/50 SF/GW \\
\hline Puarenga & 1.14 & 1.05 & -7.89 & SF Dominated \\
\hline Lynmore & 3.01 & 1.54 & -48.84 & Historically high NO ${ }^{-}$ \\
\hline Basley Rd & 2.28 & 2.7 & 18.42 & \\
\hline Waingaehe & 1.48 & 2.5 & 68.92 & $\begin{array}{l}\text { GW Dom from within } \\
\text { catchment, but long lag } \\
\text { time }\end{array}$ \\
\hline Waiohewa & 3.01 & 1.34 & -55.48 & GW from Hells Gate \\
\hline
\end{tabular}

Figure 7.9a, showing observed versus LUCI predicted TN concentrations for all data, reports a linear $\mathrm{R}^{2}$ value of 0.2733 . Excluding Lynmore and Waiohewa sub-catchments, both noted for their elevated $\mathrm{N}$ concentrations (Williamson and Cooke 1982; Hoare 1984), a linear $R^{2}$ value of 0.7084 is seen (Figure $7.9 b$ ). By comparison, measured versus CLUES predicted TN concentration resulted in $\mathrm{R}^{2}$ values of 0.0066 (including outliers) and 0.3966 (excluding outliers) in the Auckland region (Semadeni-Davies et al. 2015) and 0.454 in Waikato (Elliott et al. 2011). Comparison between observed and LUCI predicted TN concentrations for Wales show an $\mathrm{R}^{2}$ of 0.8582 . To-date applications of $\mathrm{LUCl}$ in the UK have all used the "one export coefficient per land cover category" method (as opposed to the algorithmic method applied here) using UK ECs with a longer history of testing and application compared to New Zealand. In addition, Wales is not subject to the same groundwater and volcanic complexity as seen in the Rotorua catchment. 

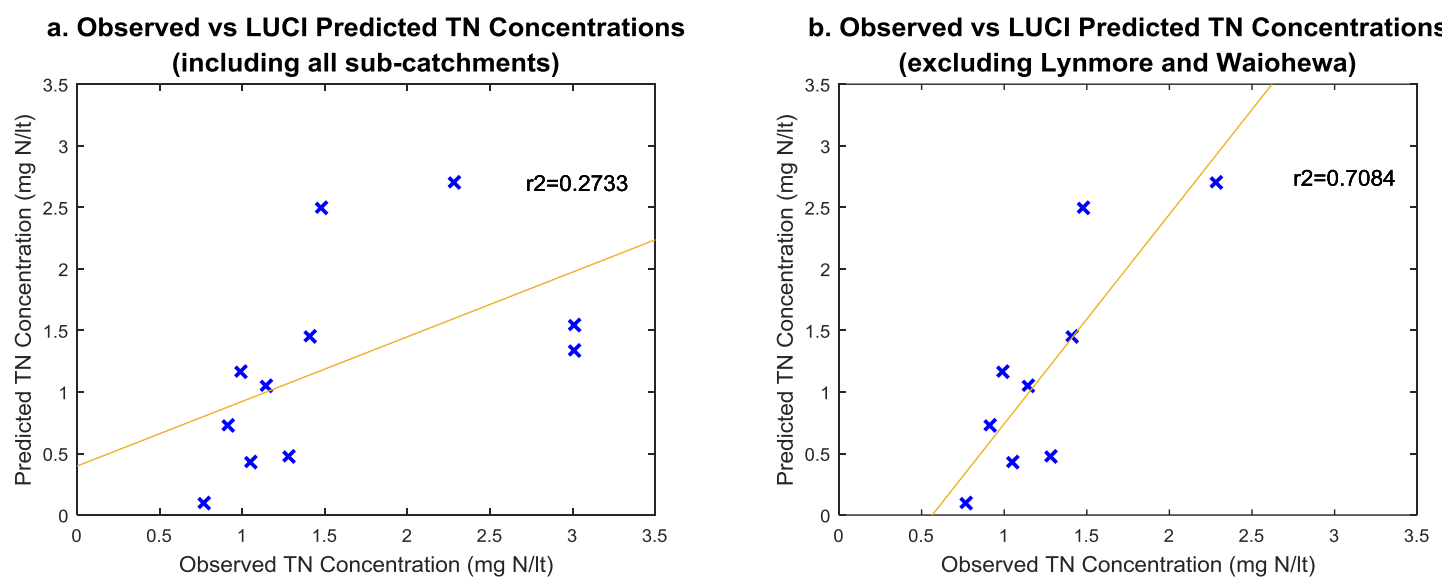

Figure 7.9a Observed vs LUCI predicted TN concentrations for all 11 Lake Rotorua subcatchments and 7.9b Observed vs $\mathrm{LUCl}$ predicted TN concentrations for 9 Lake Rotorua sub-catchments.

\section{Phosphorus}

There are strong spatial gradients in the total generated P loads in the Lake Rotorua catchment which are linked to land cover and soil, but also highly influenced by topography (Figure 7.10). Pastoral land on steeper slopes is associated with highest $\mathrm{P}$ loads. Moderate P loads are associated with pastoral land on moderate slopes, urban land cover and newly harvested commercial forest. Intact forest areas are associated with the lowest loads.

When accumulated TP load is considered at the catchment scale (Figure 7.11) the same pattern of highest loads associated with pastoral land is observed. At smaller spatial scales, this pattern is still clear (Figure 7.11 inset) although even in forested areas (largely amber) there are clear pathways of high to very high accumulated TP loads where water converges in the landscape.

LUCl appears to have a tendency to over-predict P concentrations in surface water dominated catchments and under-predict in groundwater dominated catchments (Table 7.5). No clear patterns are evident between percent over- and under-predicted and catchment land-cover characteristics indicating no particular bias associated with LUCl's land cover based EC's. Figure 7.12a shows observed TP concentrations versus LUCI predicted TP concentrations and reports a linear $R^{2}$ value of 0.002 . White et al. (2004) report groundwater concentrations of $\mathrm{PO}_{4}{ }^{3-}-\mathrm{P}$ in the Rotorua catchment of $0.1-0.4 \mathrm{mg} / \mathrm{L}$. If the lower limit of $0.1 \mathrm{mg} / \mathrm{L}$ is added to the six catchments with significant groundwater 
resources, a linear $\mathrm{R}^{2}$ value of 0.6009 is reported. If, in addition, attenuation is increased to 0.8 for $P$, a linear $R^{2}$ value of 0.6025 is reported (Figure $7.12 b$ ), although no specific evidence suggests increasing attenuation is necessarily warranted. By comparison, predicted CLUES TP vs measured TP concentration resulted in $\mathrm{R}^{2}$ values of 0.11 (including outliers) and 0.1113 (excluding outliers) in the Auckland region (SemadeniDavies et al. 2015).

It appears likely groundwater and volcanic complexity in the Rotorua catchment complicate P loss prediction, which even without these complexities is acknowledged as challenging to model at catchment scale (Meals et al. 2010; Jarvie et al. 2013) and, as discussed in Chapter 3, uncertainty around observed P measurements is a known issue (Krueger et al. 2012; Lloyd et al. 2016).

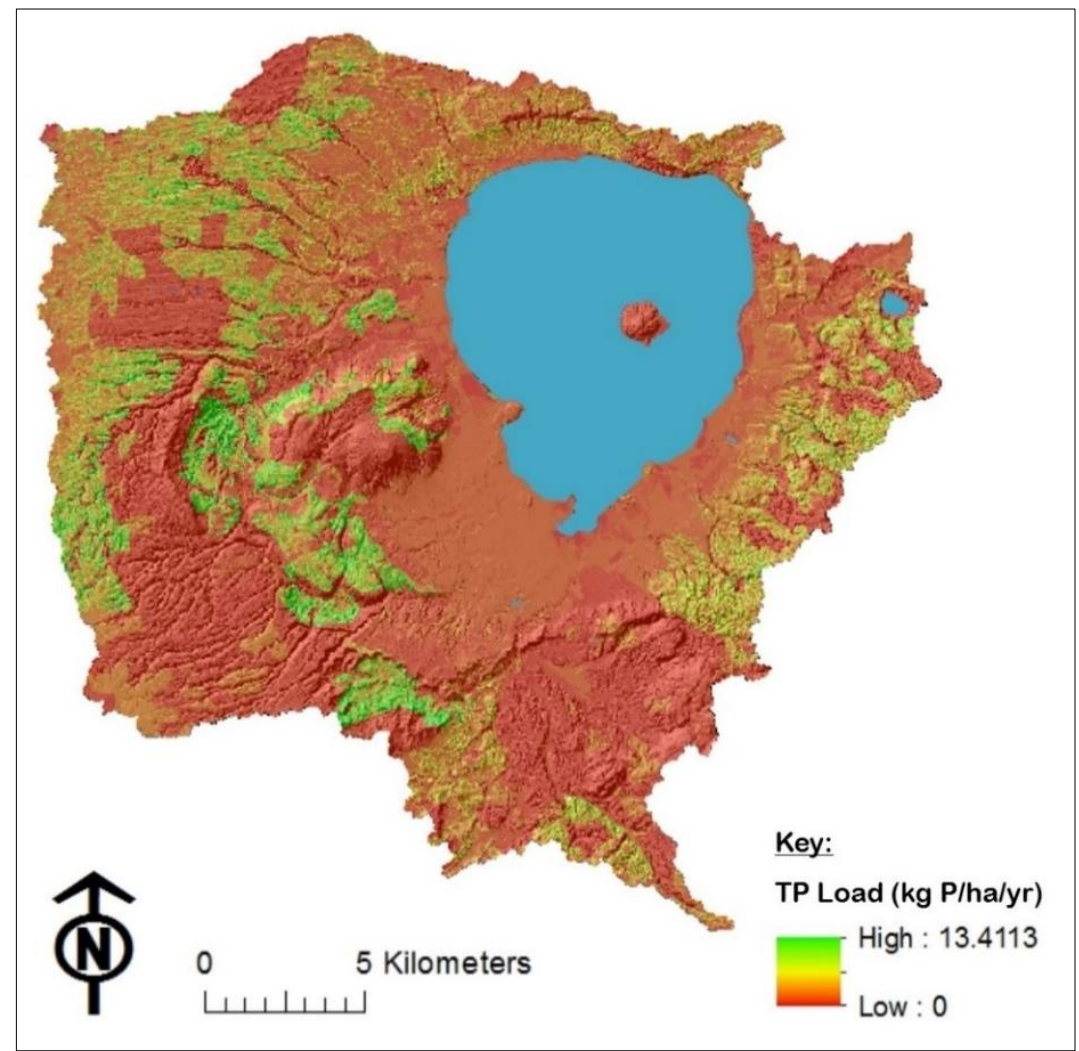

Figure 7.10 TP load generated in the Lake Rotorua catchment 


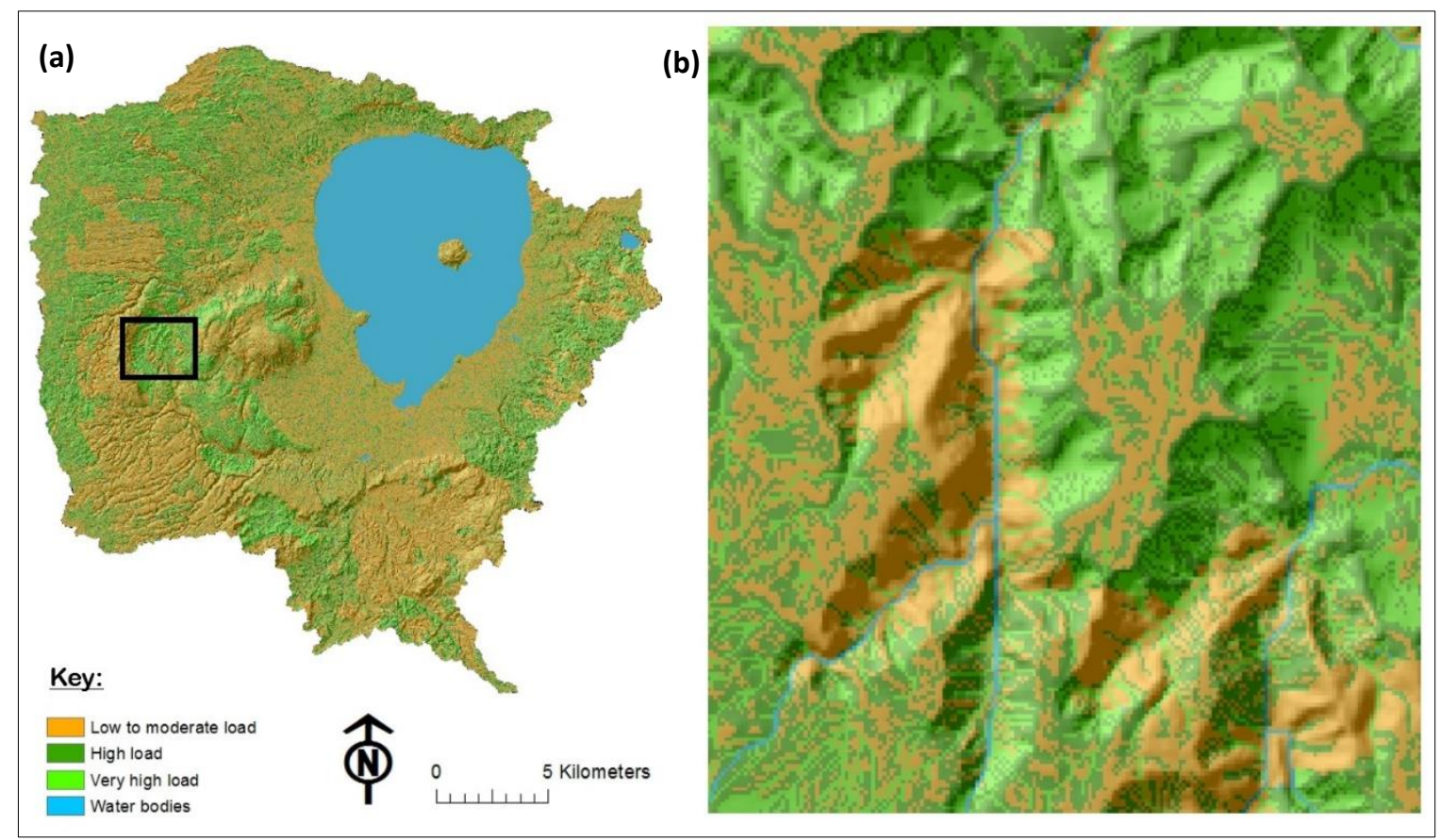

Figure 7.11 Accumulated TP load for whole Lake Rotorua catchment (a) and close up (b)

Table 7.5 Observed and predicted TP concentrations for 11 Lake Rotorua subcatchments

\begin{tabular}{|l|r|r|r|l|}
\hline $\begin{array}{c}\text { Catchment } \\
\text { Name }\end{array}$ & $\begin{array}{r}\text { Observed } \\
\text { TP (mg/L) }\end{array}$ & $\begin{array}{c}\text { Predicted } \\
\text { TP (mg/L) }\end{array}$ & $\begin{array}{c}\text { \% diff from } \\
\text { observed (100\%) }\end{array}$ & \multicolumn{1}{|c|}{ Notes on Catchment } \\
\hline Hamurana & 0.08 & 0.003 & -97 & GW from out of catchment \\
\hline Awahou & 0.07 & 0.027 & -61 & $\begin{array}{l}\text { GW possibly from out of } \\
\text { catchment }\end{array}$ \\
\hline Waiteti & 0.05 & 0.099 & 98 & SF Dominated \\
\hline Ngongotaha & 0.05 & 0.117 & 134 & SF Dominated \\
\hline Waiowhiro & 0.05 & 0.027 & -46 & $\begin{array}{l}\text { GW possibly from out of } \\
\text { catchment }\end{array}$ \\
\hline Utuhina & 0.07 & 0.048 & -31 & $50 / 50$ SF/GW \\
\hline Puarenga & 0.07 & 0.066 & -6 & SF Dominated \\
\hline Lynmore & 0.06 & 0.066 & 10 & \\
\hline Basley Rd & 0.05 & 0.126 & 152 & \\
\hline Waingaehe & 0.12 & 0.129 & 8 & $\begin{array}{l}\text { GW Dom from within } \\
\text { catchment, but long lag time }\end{array}$ \\
\hline Waiohewa & 0.08 & 0.057 & -29 & GW from Hells Gate \\
\hline
\end{tabular}



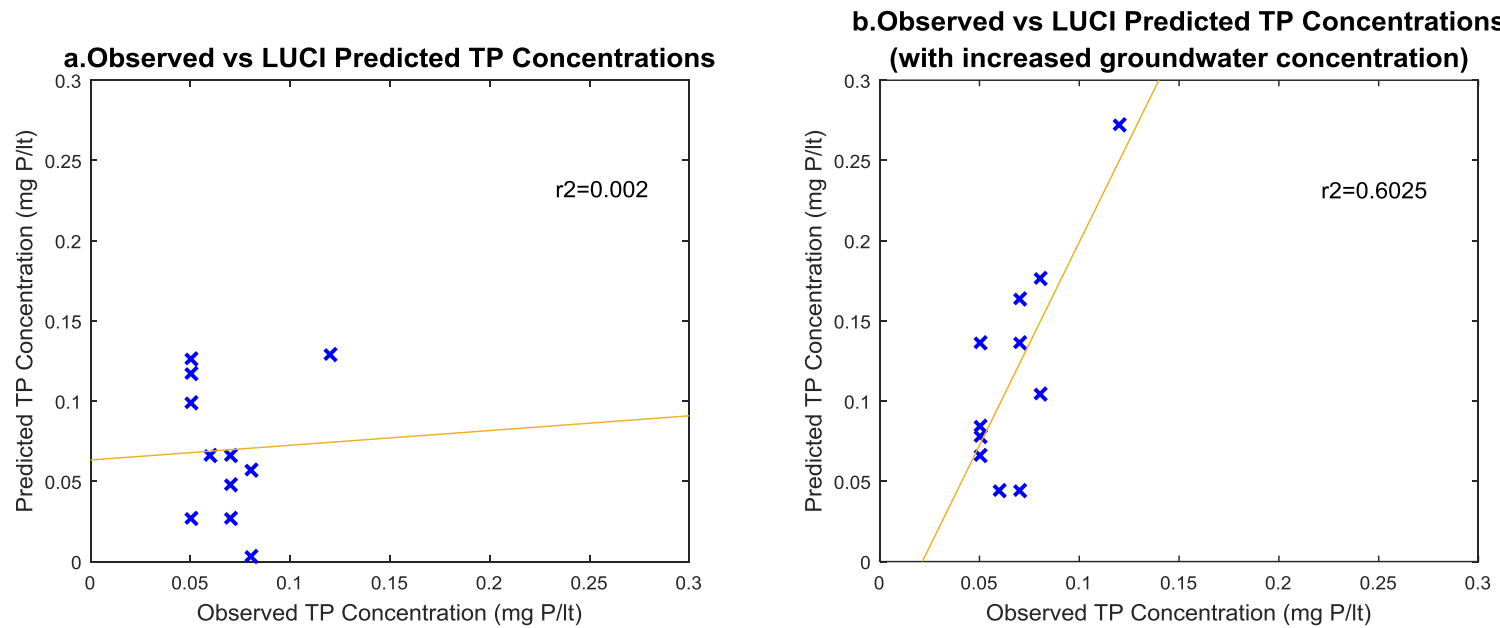

Figure 7.12 Observed vs predicted TP concentrations for 11 Lake Rotorua subcatchments

\section{Agricultural Productivity}

Estimates of current agricultural use, based on national land cover information, considers all arable and high producing grassland to be highly productive. Low producing grassland is considered to be of lower production value, and the dominant other land uses of commercial and non-commercial forestry areas within the catchment are classified as non-productive. Urban areas are excluded from the analysis (Figure 7.13a).

Predicted optimal agricultural utilisation, based on an analysis of slope, soil fertility, aspect and soil drainage characteristics by LUCI indicates $106.3 \mathrm{~km}^{2}$ of the catchment has very high to high productive capacity. This land is concentrated on flatter lowlands and highlands within the catchment (Figure 7.13b). This finding contrasts with the amount of existing agricultural land cover, an area of $206.8 \mathrm{~km}^{2}$. LUCl predicted a moderate productive capacity for an area of $140.6 \mathrm{~km}^{2}$, which surrounds highly productive land where slopes begin to steepen, and marginal to negligible productive capacity for $142.1 \mathrm{~km}^{2}$ of the catchment, on the steepest slopes and wetland areas surrounding the lake.

Figure 7.13c compares current and optimal agricultural land use indicating that, if both current and predicted utilisation maps are correct, only $36.6 \%\left(184 \mathrm{~km}^{2}\right)$ of the catchment is being used at optimal or close to optimal production levels, while almost half $(46.3 \%)$ of the catchment falls into categories of sub-optimal agricultural use (i.e. 
$139.4 \mathrm{~km}^{2}$ in non-optimal use and agricultural production is not realised on $93.4 \mathrm{~km}^{2}$ of the catchment). This analysis suggests potential to improve agricultural productivity exists on $18.4 \%$ of the catchment area, but that agricultural over use could be a problem on $27.9 \%$ of the catchment area.

\section{Trade Off and Synergy Identification}

Given that sources and pathways of $\mathrm{N}$ and $\mathrm{P}$ frequently correspond, it is unsurprising to observe similar spatial patterns between agricultural productivity and exports of these nutrients (Figure $7.14 \mathrm{a} \& \mathrm{~b}$ ). Forty-seven $\mathrm{km}^{2}$ or $11.4 \%$ of the catchment potentially provides opportunities to improve both TN export and agricultural productivity (bright green areas Figure $7.14 a$ ), while $61 \mathrm{~km}^{2}$ or $14.7 \%$ of the catchment potentially provides opportunities to improve both TP export and agricultural productivity (bright green areas Figure $7.14 b)$. There are no areas within the catchment where agricultural productivity is high and TN or TP export to waterways is low.

Opportunities are high to reduce both TN and TP export to waterways within the catchment (Figure 7.14c) because sources and pathways for $\mathrm{N}$ and $\mathrm{P}$ frequently coincide. $154 \mathrm{~km}^{2}$ or $37 \%$ of the catchment (bright green) offers opportunities for reducing both TN and TP export and a further $65 \mathrm{~km}^{2}$ or $15.7 \%$ of the catchment (dark green) offers opportunities to reduce one of these.

Three way trade off and synergy analysis indicates $119 \mathrm{~km}^{2}$ or $28.7 \%$ of the catchment provides opportunities to improve all services and, importantly, that no part of the catchment currently provides well for all three services (Figure 7.15). 


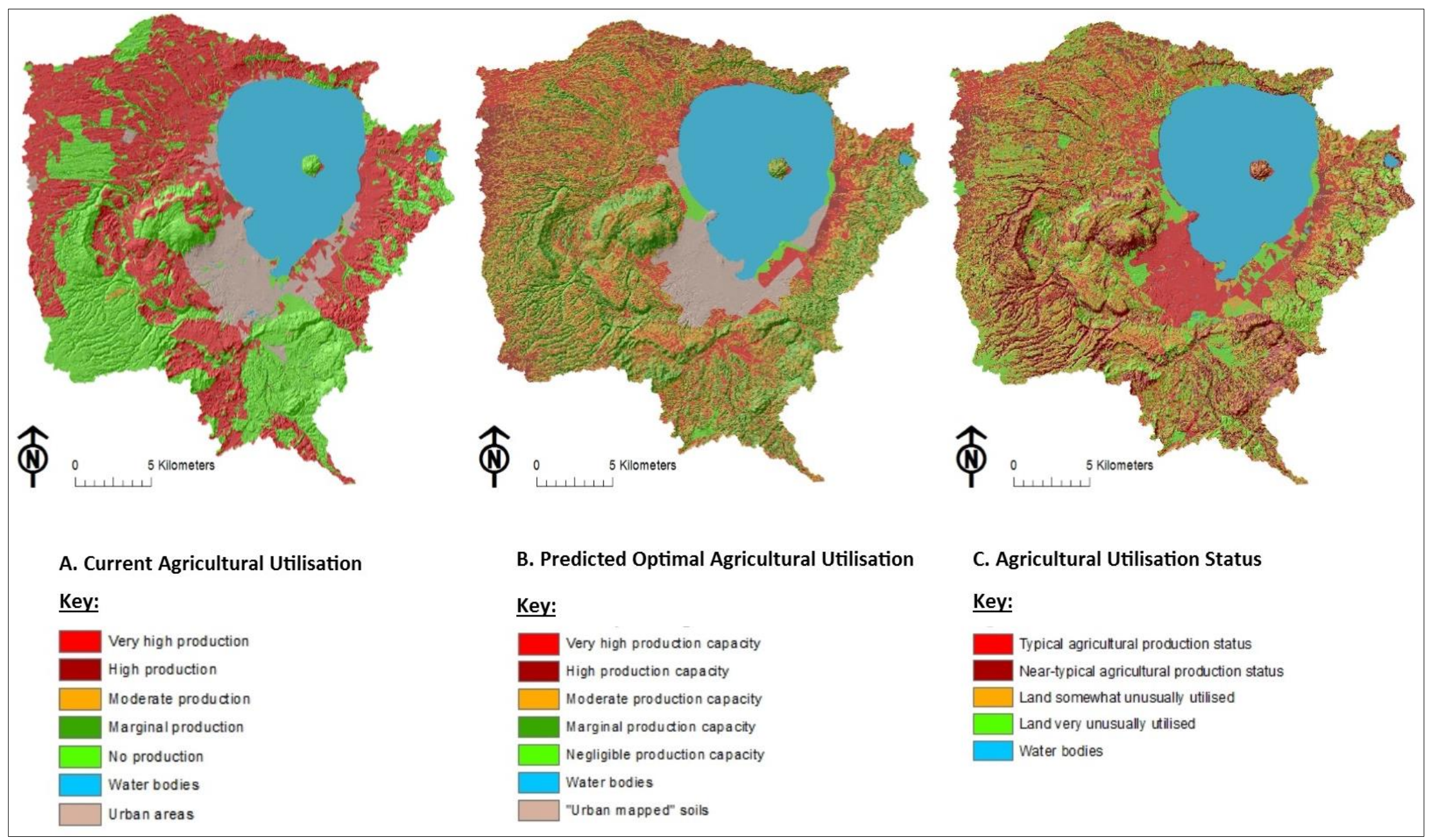

Figure 7.13 LUCl agricultural productivity maps for the Lake Rotorua catchment 


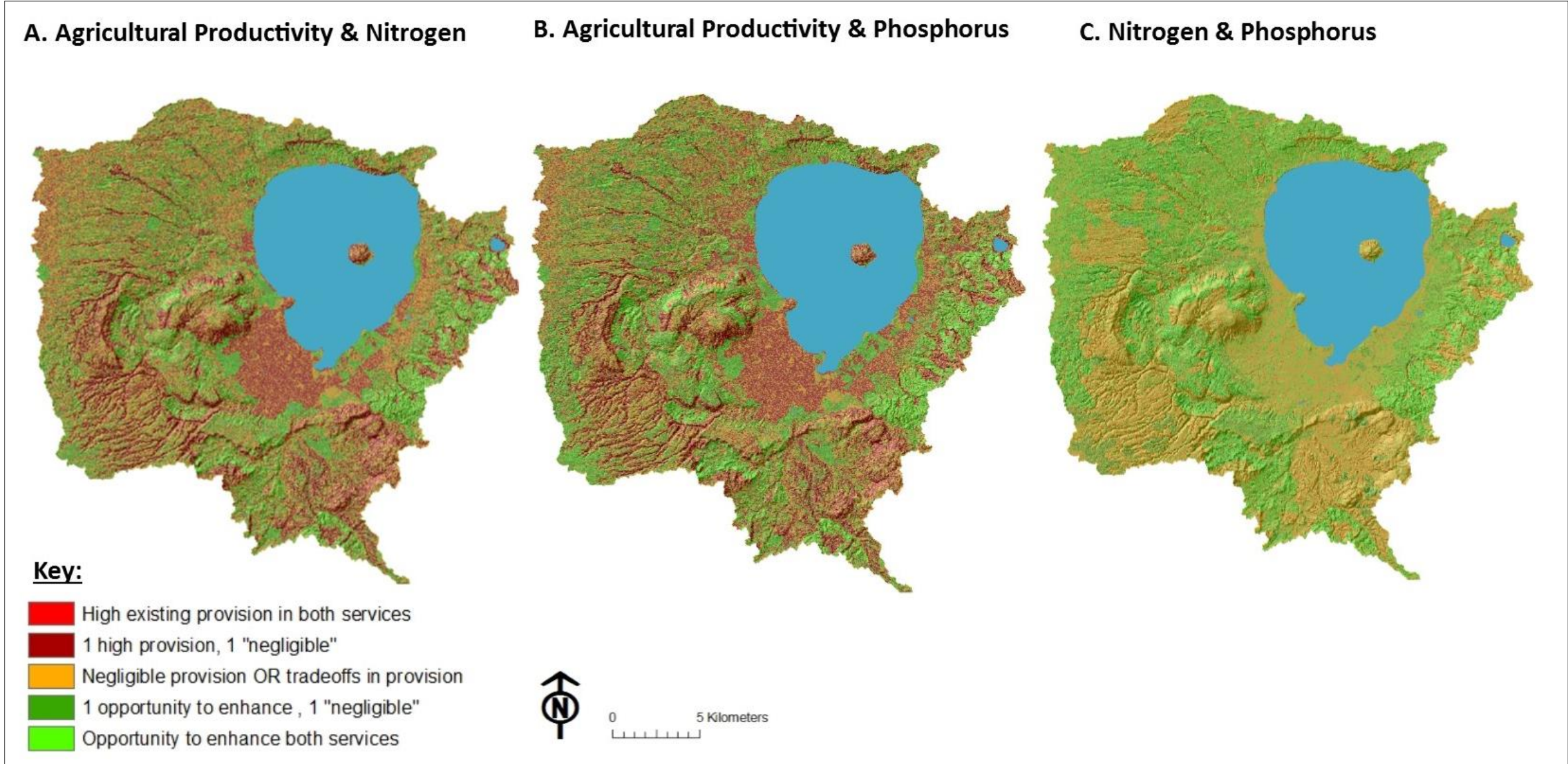

Figure 7.14 Two way trade off and synergy identification between TN, TP and Agricultural Productivity for the Lake Rotorua catchment 


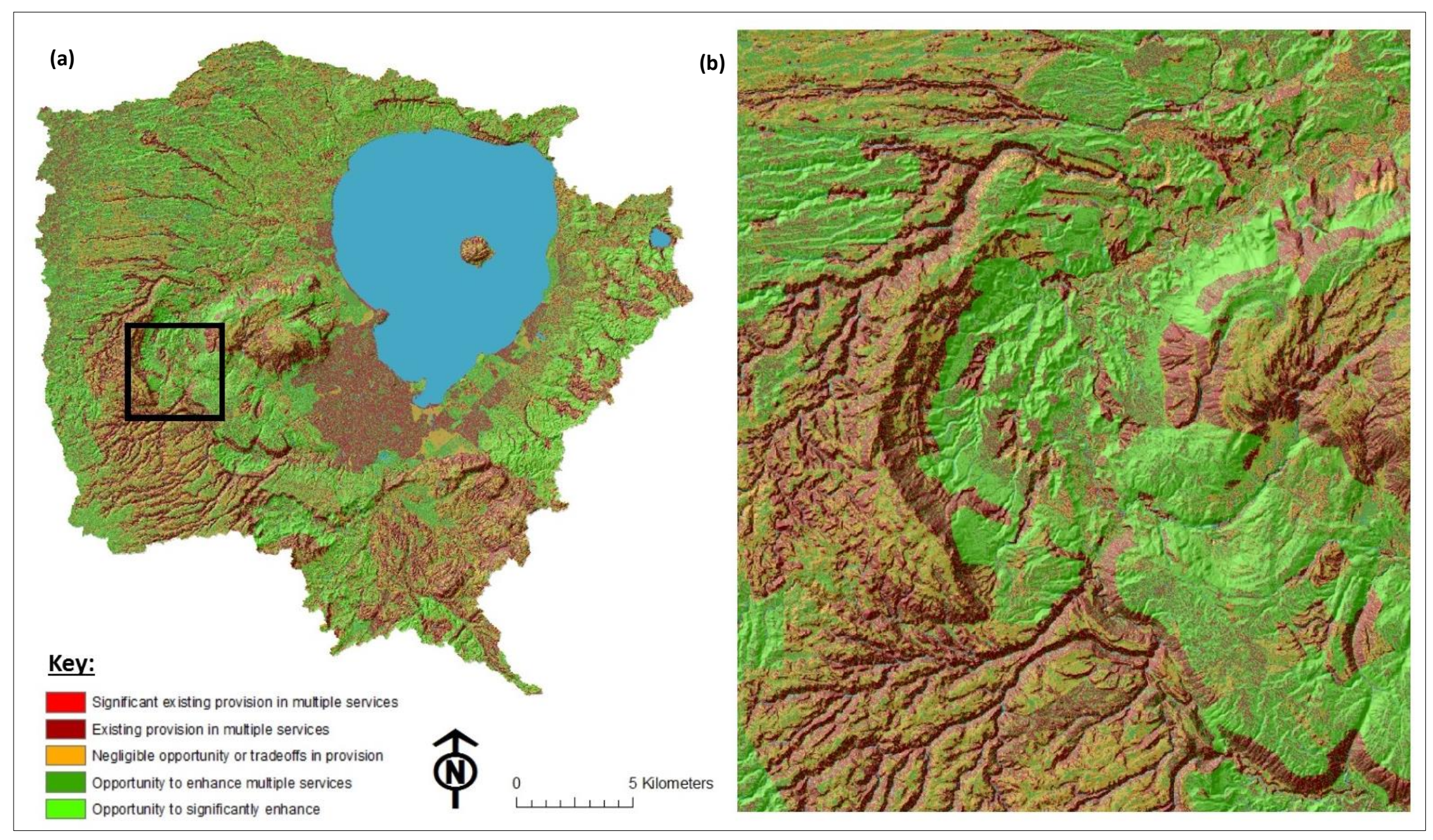

Figure 7.15 Three way trade off and synergy identification between TN, TP and Agricultural Productivity for the whole Lake Rotorua catchment (a) and a close up (b) 
The analysis investigating targeted zones of load and accumulated load with consideration of agricultural productivity shows that achieving significant reductions in in-stream loading via targeting direct loading of $\mathrm{N}$ and $\mathrm{P}$ cannot be achieved without significant loss of productivity, although spatial optimisation does allow the percentage loss in production to be lower than the percentage gains for water quality outcomes. For example, $20 \%$ of both $\mathrm{N}$ and P loading could be mitigated by targeting $17 \%$ of agricultural land area, with $12 \%$ of total agricultural production impacted, while achieving 50\% reduction in both loadings would impact $46 \%$ of agricultural land area and $37 \%$ of total agricultural production. Targeting 5\% reductions in loading could be achieved via modifications to $4.2 \%$ of agricultural land impacting $3 \%$ of production.

Taking an approach targeting accumulated load requires a much smaller footprint on agricultural land. Targeting $1 \%$ of agricultural area achieved a reduction of approximately $6.5 \%$ in loading, while targeting $1.5 \%$ resulted in an $8.4 \%$ reduction.

\section{$\underline{\text { 7.3.4 Discussion }}$}

\section{Water Quality}

Nitrogen

Nitrogen export analysis results demonstrate LUCl's ability to provide clear guidance for positioning of nutrient mitigation solutions. Various opportunities exist to reduce $\mathrm{N}$ export to waterways and Figures $7.7 \& 7.8$ suggest two general strategies for reduction: targeting $\mathrm{N}$ sources and targeting $\mathrm{N}$ pathways. $\mathrm{N}$ sources on farms can be lessened by reducing the amount or frequency of $\mathrm{N}$ fertiliser, changing from cattle to sheep farming, using feedpads or housing to minimise winter grazing, improving effluent management or reducing stocking rates (Monaghan et al. 2008).

While a more strategic approach to source reductions is recommended, as an indicative scenario a blanket halving of $\mathrm{N}$ fertiliser inputs to all pastoral land in the Lake Rotorua catchment indicates this would result in reduced $\mathrm{N}$ loads of $12.7 \%$ on recent soils, $13.8 \%$ on allophanic soils, $20.2 \%$ on pumice soils and $22.7 \%$ on podzols. In-stream N loads at stream confluences with Lake Rotorua would reduce by $11-20 \%$ depending on sub-catchment characteristics. 
$\mathrm{N}$ pathways, where water and nutrients converge within the landscape and make their way to the stream network, are depicted in bright green in Figure 7.8. These pathways represent opportunities to intercept nutrients. Targeted placement of nutrient interception at these locations can mitigate $\mathrm{N}$ generated from all up-catchment areas. $\mathrm{N}$ pathways, as identified in classified accumulated $\mathrm{N}$ load using a minimum threshold accumulation of $1 \mathrm{~kg} \mathrm{yr}^{-1}$ (Figure 7.8), cover $36.7 \mathrm{~km}^{2}$ or $7.3 \%$ of the Lake Rotorua catchment area. Focusing $\mathrm{N}$ interception in these areas alone would be highly effective, resulting in significant $\mathrm{N}$ removal using only $7.3 \%$ of the catchment land area. Interception strategies are numerous and should be chosen in conjunction with land and farm managers, but could include planting vegetation or restoring wetlands. Chapter 6 offers a comprehensive review of a limited number of nutrient interception mitigation strategies. McDowell et al. (2013) summarise a wider range of strategies in less detail, but include an assessment of relative cost vs effectiveness.

Sub-catchment scale analysis indicates improved representation of groundwater residence times and pathways, and associated nutrient transport is important, particularly where groundwater is sourced from outside the surface catchment and/or where lag times are significant. Future work will utilise the method of Jackson et al. (2006), which allows the history of land management change and variable residence times within a catchment or sub-catchment to be explicitly accounted for. This has previously quantified the lag times in river response to changing management that occur as a consequence of groundwater residence times (Jackson et al. 2007; Jackson et al. 2008). However, the method requires the collation of a long-term dataset of historical land use change and a robust understanding of the pathways and residence times for groundwater movement within the catchment. Despite these higher data requirements, the method is necessary to overcome a major drawback of the EC approach, and the typical assumption in policy, that current water quality is directly (and only) associated with current land cover and/or management.

\section{Phosphorus}

As with $\mathrm{N}$, although the model requires further enhancement, $\mathrm{LUCl}$ provides clear guidance for positioning of mitigation solutions in its current form. Sources of agricultural $\mathrm{P}$ to waterways can be reduced using similar targeted management strategies as those described for agricultural $\mathrm{N}$ sources, although further attention to the effects of slope is of particular 
importance. $\mathrm{P}$ readily binds to clays and metal-oxides in soil. As a result, it tends to move attached to sediment, which occurs more frequently on exposed steeper slopes (Bennett and Schipanski 2012). Retirement or conversion of steep pasture to natural or commercial forest cover is an option. As can be seen in the results, intact forestry blocks largely remain in-situ with little $\mathrm{P}$ loss. However, once trees are harvested, $\mathrm{P}$ is more likely to be lost to waterways with sediment run-off. Strategies to reduce soil loss during forest harvest include minimising logging roads, retaining waste wood on-site, and the maintenance of riparian buffer zones (Baillie and Neary 2015).

In a similar manner to $\mathrm{N}$, areas of very high TP accumulated loads occur where water and nutrients converge in the landscape (Figure 7.11). Again, these are ideal locations for targeted interception. As with $\mathrm{N}$, a variety of $\mathrm{P}$ interception strategies exist (see Chapter 6 and McDowell et al. (2013)) and should be chosen in conjunction with land and farm managers.

Additionally, areas of $\mathrm{N}$ and $\mathrm{P}$ sources and pathways within the Rotorua catchment frequently correspond (Figures 7.7, 7.8, 7.10 and 7.11). Therefore, significant land areas exist with opportunities to improve both $\mathrm{N}$ and $\mathrm{P}$ export to water simultaneously. This synergy is discussed further in Trade-off \& Synergy Identification.

In general, a highly targeted source or pathway approach for $\mathrm{N}$ and/or $\mathrm{P}$ requires detailed and precise understanding of farm environments, but may achieve significant reductions in generated and exported nutrient loads without significantly impacting production. Such an approach traditionally relies on individual farmer skills and management, which have been identified as crucial factors when balancing nutrient reductions with productivity (Anastasiadis and Kerr 2013; Dewes 2013). However, frameworks such as LUCl can assist more farmers to take a highly targeted and strategic approach.

\section{Agricultural Productivity}

The analysis shows large areas of the Rotorua catchment are currently in high agriculturally productive land uses. Much of this area however may not be suited to these levels of production. In addition there are also under-utilised areas within the catchment. Clearly this analysis could be used as a basis for discussion around land use suitability. 
However, the analyses are somewhat limited because current agricultural use is based on national land cover information, which is admittedly broad-brush and lacks much capacity to distinguish variations in production in pastoral landscapes. Additionally, commercial forest productivity areas are not currently included and could be included. Commercial forestry is often used in New Zealand as a means of maintaining production on steeper terrain. In addition, production forests can act as nutrient sinks, carbon stores, and may protect soil from erosion and moderate flooding (Baillie and Neary 2015). Furthermore, LUCl could help to identify ideal locations for conversion to commercial forest.

\section{Trade-off \& Synergy Identification}

$\mathrm{LUCl}$ indicates there are significant areas within the catchment where both agricultural productivity and $\mathrm{N}$ or $\mathrm{P}$ loss could be improved. However, difficulty arises in choosing a strategy that might address both issues, because agriculturally productive areas are identified as significant nutrient sources (Figure 7.7 and 7.10) and nutrient pathways are most prevalent on agricultural land. Illustrating this point further, Figures 7.14a and 7.14b show there are no areas within the catchment where both services are currently well provided for, that is, there are no areas where agricultural productivity is high and TN or TP export to waterways is low. In contrast, opportunities are high to improve both TN and TP export to waterways within the catchment (Figure 7.14c) because sources and pathways for $\mathrm{N}$ and $\mathrm{P}$ frequently coincide.

Clearly if water quality is to be improved, it is likely to come at the expense of agricultural land because most of the nutrient interception pathway opportunities exist on agricultural land. However, entire pathways may not be required for adequate nutrient interception, rather interceptions could be strategically placed in receiving areas to mitigate the largest uphill area possible. Additionally, due to shared pathways for $\mathrm{N}$ and $\mathrm{P}$ movement, single mitigation options that target both nutrients can be effective.

Furthermore, analysis suggests targeting zones of nutrient convergence in the landscape may be highly beneficial in maintaining productivity levels. The current method requires some modification to its classification techniques to quantify potential for larger reductions in water loading. It is important to note these results are conservative and perhaps underplay the full potential of such an approach; the analysis on accumulated load overestimates the amount of area required for interception as the accumulated load is 
spatially connected and non-additive. For this illustrative calculation steepest descent was used, but methods of weighting flow via all downwards slopes will also be explored in future. A more refined analysis would also estimate the reduction in agricultural production from a particular mitigation practice because measures such as totally removing livestock from pastoral land or planting up pastoral land to intercept upslope nutrients are effectively a total loss of production, while other management changes such as reducing fertiliser input would only result in a partial reduction.

Clearly there are options available within the Lake Rotorua catchment to reduce nutrient export to waterways and keep loss of agricultural productivity to a minimum. As illustrated above, options on agricultural land involve strategically managing nutrient sources and targeting nutrient pathways with interception strategies that address both $\mathrm{N}$ and $\mathrm{P}$ and consider productivity. Implementation of these mitigations is necessitated by current water quality regulation. $\mathrm{LUCl}$ can support this process at the farm and catchment scale and ongoing improvements to the model will further enhance this capability for agricultural land.

Wider consideration of the suitability of land for production purposes should also be reviewed and appropriate land uses favoured. Options for land moderately or marginally suited for production include commercial forestry or complete retirement. Changes in land use may face resistance from landowners as it will represent a financial loss. At the catchment and community scale agricultural land losses can be partly offset by improving production on land that is less subject to nutrient losses and improvements to water quality, which will likely lead to wider environmental and social benefits e.g. improved aquatic biodiversity, increased recreational opportunities, more opportunities for wild food gathering. While strategies such as conversion to commercial forestry can currently be considered in $\mathrm{LUCl}$, further refinements to incorporate a wider range of agriculturally productive land uses would be useful.

\section{$\underline{\text { 7.3.4 Conclusion }}$}

Comparison of LUCI predicted catchment scale in-stream N and P concentrations and observed data in the Lake Rotorua catchment indicate both the $\mathrm{N}$ and P models would benefit from further enhancement. In particular, better incorporation and representation of groundwater pathways, residence times and resulting lags would be beneficial. However, 
even as is, $\mathrm{LUCl}$ catchment scale results are comparable to variability seen in other catchment scale water quality models and uncertainty around measured water quality values is a further consideration.

Significant opportunities exist within the Lake Rotorua catchment to improve $\mathrm{N}$ and $\mathrm{P}$ exports to water and agricultural productivity at the level of individual services, but multiple ecosystem service analysis reveals that interventions aimed at improving water quality are likely to come at the expense of agriculturally productive land. Yet this study also highlights opportunities to improve water quality while minimizing the loss of productivity on agricultural land. This includes identifying, at a fine spatial scale, the most appropriate locations to intercept nutrient pathways, and to increase production on agricultural land that is currently at lower risk of nutrient loss.

Overall, this case study demonstrates the utility of $\mathrm{LUCl}$ in multiple ecosystem service decision making at both the farm or block scale, where LUCI can assist individual land owners to take a highly targeted and strategic approach to land and ecosystem service management, and at the catchment or regional scale, where $\mathrm{LUCl}$ can better inform stakeholders with planning and management of landscape scale processes and resources.

\subsection{DISCUSSION AND SUMMARY}

Application of LUCI water quality models in Case Studies 1 and 2 illustrate and highlight LUCl's highly detailed and spatially explicit nature. Sources and pathways of $\mathrm{N}$ and $\mathrm{P}$ are clearly identified enabling implementation of highly spatially targeted mitigations. In addition, Case Study 2 demonstrates LUCl's ability to consider other ecosystem services and evaluate trade-offs and synergies between ecosystem services. In the context of water quality, the ability to evaluate potential trade-offs and synergies with agricultural productivity is particularly pertinent.

While both case studies demonstrate LUCI's clear ability to guide decision making at both the farm and catchment scale, they also highlight limitations associated with evaluating water quality models against actual in-stream water quality data and they point to a number of areas for model improvement. Catchment scale water quality models are often assessed by comparing predicted nutrient losses with actual in-stream water quality data. Case Study 1 indicates model predictions are improved with the addition of increasingly detailed 
catchment and/or farm specific data. Although even the most detailed application (Application 4) predicts N and P concentrations and loads 2-3 times measured means (but close to highest measured values) (Table 7.2). Case Study 2 indicates variable accuracy when comparing predicted and measured in-stream nutrient concentrations, particularly for $\mathrm{P}$, in multiple sub-catchments (Figures 7.9 and 7.12). Despite this, it is not clear current LUCI instream predictive ability for New Zealand is any poorer than similar catchment scale water quality models used in New Zealand. However, LUCI clearly brings superior spatial detail compared to many other catchment scale water quality models and it is likely relative nutrient losses from land units of variable climate, soil, topography and land management are representative. Further applications of $\mathrm{LUCl}$ water quality models at a variety of scales would better verify this and a number of potential areas for model improvement are highlighted by the case studies.

In particular, both case studies suggest better, site specific representation of nutrient losses, lags and transformations, both between the root zone and stream network and within the stream network, could improve LUCl predictive ability. Recent work by Singh et al. (2017) in the Rangitikei Catchment offers a promising avenue for investigation to improve representation of $\mathrm{N}$ attenuation between the root zone and stream network based on soil type and underlying geology. Case Study 2 suggests better representation of groundwater systems and associated lags could improve LUCI predictions, particularly in hydrologically complex catchments.

Case Study 1 clearly indicated farm specific input data for pastoral land cover algorithms is preferable to average regional default inputs. At large scale, this is difficult to achieve. However, pastoral land cover export coefficients could be improved by disaggregation of pastoral land cover to pastoral land use (i.e. disaggregation in to dairy, beef, sheep etc.) and application of land use specific average regional default inputs. Development of land use specific average regional nutrient inputs is available from the Ravensdown dataset. Instead, the challenge is disaggregation of land cover to land use in the absence of land use data. Development of a "likely land use" algorithm based on known land use characteristics may be a possible solution, although this would introduce additional uncertainty. A second option, is to gain access to land use data. Such data is available, but not freely, and there can be issues around land owner privacy. 
Although Case Study 2 showed no particular bias associated with current export coefficients from the variety of land covers in Lake Rotorua catchment, development of an algorithmic approach to export coefficient calculation is desired for land covers other than pasture and based on land cover specific data (as discussed in previous chapters). This relies on locating suitably detailed land cover specific nutrient loss data, which currently is not publicly available, but may be held in New Zealand research institutes.

Indeed lack of data is a confounding issue. Case Study 1 highlighted the importance of more detailed, site specific soil data, which significantly improved LUCI in-stream P predictions. Full S-Map national coverage and public access to data pertaining to pedo-transfer functions would improve soil representation and finer scale national DEM coverage would improve hydrological routing in LUCI. However, representative measured in-stream water quality data is of particular importance for water quality modelling. As discussed in Section 3.3, more frequent long-term sampling, including during storm events, and better spatial coverage with multiple nested sampling sites within any one catchment, would undoubtedly assist with assessing and developing water quality models.

These case studies point to areas for improvement to LUCI water quality models. However, even as is, the utility of the models is evident. $\mathrm{N}$ and $\mathrm{P}$ sources and pathways are identified with spatial detail seen in few other water quality models allowing spatially explicit targeting of mitigations. In addition, scenarios and options can be explored and trade-offs and synergies with other ecosystem services evaluated. While efforts to improve LUCI water quality models are on-going, it is nevertheless already a valuable decision making tool for both farm and catchment scale management. 


\section{CONCLUSIONS}

\subsection{INTRODUCTION}

Globally, freshwater and marine environments have been degraded due to nutrient contamination from diffuse sources, and many countries now mandate control of diffuse nutrient losses to water. Water quality models are valuable tools for decision making in the context of this widespread issue as they enable exploration of current and future scenarios.

To model diffuse nutrient losses, many catchment scale water quality models require some form of estimated nutrient loss, or export coefficient, from land units within the catchment of interest. To be representative export coefficients must consider climate, soil, topography, and land cover and management variables. A number of methods of export coefficient derivation are used. Many early export coefficient models considered only land cover and/or use, sometimes extended to consider geo-climatic variables by application of 'expert judgement' (Reckhow et al. 1980; Beaulac and Reckhow 1982; Johnes 1996; Young et al. 1996) and some models still take this approach (Baginska et al. 2003; Robinson and Melack 2013). Opportunities to more easily estimate diffuse nutrient losses for a wide variety of land uses and geo-climatic variables increased with the advent of field to farm scale computer based nutrient models. Using this approach export coefficients for commonly found land uses within the area of interest are derived using broadly representative or dominant catchment geo-climatic variables (Rutherford et al. 2009; Rutherford et al. 2011; Anthony et al. 2012; Semadeni-Davies et al. 2016).

This thesis posits that using readily available spatial data, site-specific geo-climatic and land cover and management variables can be considered to derive site-specific export coefficients. Therefore, the principle aim of my research was to develop algorithms that calculate site-specific $\mathrm{N}$ and $\mathrm{P}$ export coefficients, using spatial data pertaining to geoclimatic and land cover and management variables, for application in LUCI water quality models. The application context is New Zealand, but the method could be extended to other regions and environments. Four objectives were achieved in pursuit of this aim: 
Objective 1 Data Review: Three categories of New Zealand data were reviewed. Data detailing $\mathrm{N}$ and $\mathrm{P}$ losses for a variety of New Zealand climates, soils, topography, land cover and land uses were collated and investigated to identify suitable information from which to develop algorithms. Spatial data (suitable for use in ArcGIS), for identification and positioning of important nutrient loss variables and their combinations, were identified. Instream water quality data, against which to assess output from the $\mathrm{N}$ and $\mathrm{P}$ algorithms applied in $\mathrm{LUCl}$, were reviewed.

Objective 2 Algorithm Development and Parameterisation: Data identified as suitable for algorithm development were more fully explored. This largely entailed investigation of the Ravensdown dataset, a large set of pastoral farm input and output data from nutrient budgeting tool, OVERSEER. Using this data, supplemented with data identified in Objective 1 for other land cover categories, algorithm input variables and forms were developed, algorithm constants were parameterised, and default regional algorithm inputs were parameterised.

\section{Objective 3 Parameterisation of 5 Categories of Mitigations Available in LUCI:}

An important aspect of modelling $\mathrm{N}$ and $\mathrm{P}$ losses at farm to catchment scale is assessment of options to reduce nutrient losses. Five categories of mitigations were investigated, including documenting the quantified effect of strategies, where possible. Resulting data will be used by the wider LUCI development team to update and improve mitigation models already featured in $\mathrm{LUCl}$ and to develop new ones. Mitigations explored include reduced and strategic fertiliser application, reduced and strategic effluent application, reduced stocking rate, wetland and riparian margin development and management, and sediment traps.

Objective 4 Algorithm Application in LUCI Water Quality Models: Developed N and P algorithms, integrated into LUCI water quality models, were applied to two New Zealand case study catchments: Tuapaka catchment in Manawatu and Lake Rotorua catchment in Bay of Plenty. These applications provide considerably more nuanced, detailed maps and data showing $\mathrm{N}$ and $\mathrm{P}$ sources and pathways, compared to LUCl's previously used 'one export coefficient per land cover' approach. Results also indicate absolute nutrient loss values are variable compared to in-stream water quality measurements. However, these differences appear comparable to those seen with similar water quality models. In addition, the issue of representativeness of in-stream water quality measurements exists. 
This chapter presents the main conclusions of my thesis. Section 8.2 summarises specific contributions to water quality modelling using export coefficients and to water quality modelling in New Zealand using LUCI. Section 8.3 discusses the main conclusions from my work, and Section 8.4 makes recommendations for future work and development associated with this research.

\subsection{MAIN CONTRIBUTIONS}

\section{Robust analysis of underlying data and models used for the development of export} coefficient generating algorithms: Data pertaining to $\mathrm{N}$ and $\mathrm{P}$ losses from New Zealand land covers provides the base from which algorithms are developed and parameterised. Core pastoral algorithms are based on the large Ravensdown dataset of nutrient inputs and outputs from nutrient budgeting tool, OVERSEER. A major contribution of my work is the elucidation of the main drivers and relationships among predictor $\mathrm{N}$ and $\mathrm{P}$ loss variables within the Ravensdown dataset and the underlying OVERSEER models, in particular for the $P$ model. Further, I extended the core pastoral algorithms to other land covers by addition of Land Cover Multipliers, which are based on my investigation and analysis of literature reporting $\mathrm{N}$ and $\mathrm{P}$ losses for a variety of New Zealand land covers.

\section{Development and parameterisation of algorithms that derive $\mathbf{N}$ and $\mathrm{P}$ export coefficients}

for New Zealand land covers and consider influential variables, and their combinations, associated with climate, soil, topography and land management: The algorithms developed here further facilitate a movement beyond the traditional "one export coefficient per land use" approach to water quality modelling using export coefficients. Pastoral algorithms utilise spatially explicit climate, soil, topography and actual farm data to calculate export coefficients unique to each site. This represents an advance on commonly used techniques of field to farm export coefficient derivation, based on a limited number of "typical farm" scenarios associated with representative or dominant combinations of climate, soil, and topography.

For non-agricultural land covers, it is still common to use the "one export coefficient per land cover" approach. Here an attempt was made to also consider site-specific variables for non-pastoral land covers. However, a lack of non-pastoral land cover data, that is similar in breadth and detail to the Ravensdown dataset, is a major limitation. Instead, I have 
developed an alternative method of calculating other land cover export coefficients that considers influential geo-climatic and land management variables. This was achieved through extension of pastoral algorithms with a Land Cover Multiplier, which represents the ratio between the mean of reported nutrient losses from the land cover in question and high producing grassland. Although algorithms are developed here for application in LUCI, they are potentially of use in any export coefficient based catchment scale water quality model.

Demonstration of the utility of the algorithmic export coefficient approach applied in LUCI water quality models to two New Zealand catchments: Implementation of the developed algorithms in LUCI water quality models provides a particularly powerful decision support tool. The developed algorithms use spatial data to calculate site specific export coefficients, which LUCI positions and cascades through the catchment at the DEM grid square scale. This provides particularly detailed information and maps of nutrient sources, sinks and pathways within the catchment. In addition, $\mathrm{LUCl}$ can combine water quality analyses with other ecosystem service analyses to identify areas where land use or management changes could result in benefits to multiple ecosystem services.

In my study, these qualities are clearly demonstrated through application of the models in two New Zealand catchments: Tuapaka catchment in Manawatu and Lake Rotorua catchment in Bay of Plenty. These case studies represent the first catchment scale applications of the improved LUCI water quality models in New Zealand and demonstrate LUCl's highly visual and spatially explicit nature, which can particularly assist with communication of information and decision making. I identify areas for improvement of this approach.

\section{Review of available data in preparation for fuller parameterisation of mitigations in LUCl:} Modelling of mitigation options is a desirable capability for water quality models. Five mitigation strategies, identified as particularly important for on farm modelling, are implemented in $\mathrm{LUCl}$, but require further parameterisation for optimal use. My study identified, investigated and documented data for use, by the wider LUCl development team, in parameterising these mitigation options in $\mathrm{LUCl}$. 


\subsection{MAIN CONCLUSIONS}

\subsubsection{Algorithmic Export Coefficient Models}

Review of export coefficient literature (Section 2.4) indicates that, no matter how export coefficients are derived, they generally incorporate a limited range of variables. For example, they may only consider land use or cover, or may be extended to characterise broadly representative or dominant geo-climatic and land management variables. In contrast, this study develops algorithms capable of calculating site specific export coefficients for $\mathrm{N}$ and $\mathrm{P}$ based on spatially explicit geo-climatic, land cover and land management data.

Development of such algorithms relies on availability of sufficiently detailed data quantifying $\mathrm{N}$ and $\mathrm{P}$ losses for a wide range and combinations of climate, soil, topography, land cover and land management. Review of New Zealand literature reported $\mathrm{N}$ and $\mathrm{P}$ losses for a variety of land covers (Section 3.4), indicated that it is not sufficiently broad or detailed for algorithm development. Instead, access to a large dataset of nutrient inputs and outputs from nutrient budgeting tool, OVERSEER, was used here. The Ravensdown dataset provided an excellent opportunity to develop export coefficient generating algorithms for pastoral land cover.

Algorithm development was comprised of two steps, development of algorithm form, and optimisation to parameterise algorithm constants. Development of algorithm form proved somewhat challenging. Guided by understanding of nutrient cycling and understanding of OVERSEER, algorithm input variables were selected and a multiple regression approach was developed (Chapter 4). While this proved suitable for $\mathrm{N}$, it was clearly less suitable for $\mathrm{P}$ when applied at the farm to catchment scale. In particular, differences in the scale of slope representation between OVERSEER, which only applies one slope value to an entire block, and $\mathrm{LUCl}$, which considers slope at the DEM grid square scale, appeared to be problematic. Instead an alternative approach for $\mathrm{P}$ algorithms was developed with some similar elements to the approach reported by McDowell et al. (2005). Final P algorithm form and parameterisation was undertaken by the wider LUCI development team and is particularly based on investigations of OVERSEER's P model reported in Section 4.4. 
Parameterisation of $\mathrm{N}$ algorithm constants was conducted using automatic optimisation (Chapter 5). This is a quick and easy method of deriving parameters, but it yielded poor measures of fit between $\mathrm{N}$ losses from my algorithms and $\mathrm{N}$ losses from OVERSEER predictions. However, it should also be noted that the algorithms I developed represent simplified versions of OVERSEER. They do not fully replicate OVERSEER N losses because they consider fewer input and management variables. Further assessment of the $\mathrm{N}$ and $\mathrm{P}$ algorithms at catchment scale is discussed below.

My results from optimisation do point to areas of potential algorithm improvement. For example, farms with higher $\mathrm{N}$ losses appear less well represented by the algorithms. These are likely more intensively managed farms (e.g. dairy), and inclusion of additional nutrient inputs, such as supplemental feed, may improve the predictive ability of my algorithms relative to OVERSEER predictions.

Difficulties in developing and parameterising the algorithms presented here highlight issues around using other models to develop export coefficients. All models simplify reality and include assumptions and limitations, which are not always clear or fully recorded in the associated literature. In the case of OVERSEER, documentation has become more transparent in recent years, but it is still not entirely clear how the models work. For example, in documentation of OVERSEER's P model only a limited number of equations are explicitly documented, and text descriptions of model functioning are somewhat ambiguous. A further complication to developed algorithm and OVERSEER output comparison, is that OVERSEER output itself is somewhat uncertain. Until comprehensive data is available detailing measured $\mathrm{N}$ and $\mathrm{P}$ losses from pasture with a wide variety of geoclimatic and management variables, neither OVERSEER nor the developed algorithms can be fully evaluated at field scale.

For non-pastoral land covers, an algorithmic approach, based on land cover specific data similar in scope to the Ravensdown data, would be ideal. However, publicly available data is not sufficient for the development of such an approach. Other data sources may offer more opportunities. For example, crop data from the Ravensdown dataset could be used to develop crop algorithms, and other models could be used to derive algorithms (e.g. SPASMO). Alternatively, a wider range of measured or modelled data may be available from private organisations or New Zealand CRI's. 
Instead, this study extended pastoral algorithms with addition of an LCM, which represents the ratio between the mean of reported nutrient losses from the land cover in question and high producing grassland (Section 5.4). My use of pastoral algorithms allows for incorporation of site-specific details, such as climate and soil variables. The LCM then increases or decrease the pastoral algorithm output to account for differences between losses from the land cover in question and pastoral land covers.

It is difficult to determine the accuracy of both LCMs and resulting $\mathrm{N}$ or $\mathrm{P}$ losses from nonpastoral land covers. LCMs are based on quite limited data and comparative scale issues exist between land covers. For example, most short-rotation crop measurements are point scale leaching losses only, while most pasture measurements are at small catchment scale. Where a source of data is unavailable for development of an algorithmic approach for nonpastoral land covers, further investigation and refinement of the LCM approach could include collection of more actual measurement data from single land cover areas.

Regional average pastoral algorithm inputs are developed for areas where actual farm data is unavailable. These could be disaggregated according to pastoral land use (i.e. dairy, sheep etc.) to provide more representative inputs. However, commensurate land use data needs to be available to apply this approach or a method of estimating likely land use could be developed. Regional inputs to the pastoral algorithms applied in conjunction with LCM for other land covers would still be required. Moving beyond my LCM approach for other land covers represents a significant effort, which was beyond the scope of this thesis.

\subsubsection{Application of Developed Algorithmic Export Coefficient Models in LUCI}

Developed algorithms were applied here to two diverse New Zealand catchments (Chapter 7). Case Study 1 features the agricultural Tuapaka catchment in Manawatu. LUCI was applied four times in the catchment, with each successive application including increasingly detailed, site specific data. My results illustrate the importance of farm specific data for both the $\mathrm{N}$ and $\mathrm{P}$ models, and indicate spatially detailed soil data is particularly important for the P model. Comparisons of in-stream LUCl predicted and measured $\mathrm{N}$ and $\mathrm{P}$ concentrations showed that LUCI predictions were closer to highest measured concentrations rather than mean concentrations. LUCI N and P predicted loads were higher 
than the measured loads. Improved representation of site-specific attenuation may improve LUCl's predictive ability.

Case Study 2 featured the multi-land use Lake Rotorua catchment in Bay of Plenty. This application not only included LUCI water quality models, but also the agricultural productivity model and demonstrated LUCI trade-off tools. Catchment complexities including naturally occurring volcanic nutrient sources and significant groundwater resources made water quality for this catchment somewhat challenging to model. Comparison of in-stream LUCl-predicted and measured $\mathrm{N}$ concentrations yielded variable results. This variability was linked to sub-catchment groundwater vs. surface water domination and unusual $\mathrm{N}$ sources such as those from a geothermal area, Hell's Gate. Comparison of in-stream LUCI predicted and measured P concentrations was similarly variable and linked to sub-catchment groundwater vs. surface water domination and groundwater derived $\mathrm{P}$ sources from volcanic rock and water interaction. Better incorporation and representation of groundwater pathways, residence times and resulting lags would improve predictions of $\mathrm{N}$ and $\mathrm{p}$ exports for this catchment.

These results highlight a number of points regarding the application of the newly modified $\mathrm{LUCl}$ water quality models. Case study 1 reinforces the key message that site specifics are important in terms of nutrient losses and it emphasises the need for an export coefficient approach, such as the algorithms presented here, that considers these specifics. Case Study 2 indicates that inclusion of other nutrient sources, such as natural volcanic sources, can be locally important. Both case studies indicate that improved representation of site-specific attenuation factors, including better groundwater representation, may improve LUCl's predictive ability. In LUCI, the export coefficient algorithms quantify nutrient losses from each grid square, but further attenuation is applied as these nutrients cascade through the catchment. Currently, attenuation is broadly accounted for with catchment-wide root zone to stream and in-stream attenuation factors applied for $\mathrm{N}$ and $\mathrm{P}$ respectively, and these can be increased or decreased for the whole catchment. However, development of a method of applying variable attenuation factors that account for small scale spatial variability within catchments and recognise different processes (i.e. lag times, biogeochemical transformations, etc.) may improve predictions. For example, such an approach could apply the findings of Singh et al. (2017), which indicate soil and rock type can be used to estimate 
attenuation for $\mathrm{N}$. In addition, better representation of groundwater residence times and pathways could improve predictions.

However, although improvement to predictive ability is always desired, these case studies also illustrate how the developed algorithms applied in LUCI N and P water quality models now provide more nuanced, highly spatially explicit information on nutrient sources, sinks and pathways. In addition, Case Study 2 illustrates LUCl's ability to model other ecosystem services and to perform trade off analysis among them.

\subsubsection{Implications of Data Review}

My study includes four data reviews - a review of data for algorithm development, a review of spatial data pertaining to influential nutrient loss variables, a review of in-stream water quality measurements and a review of data related to mitigation strategies. These reviews highlight a number of data constraints.

While a number of reviews of reported New Zealand export coefficients have been conducted in the past, they largely focus on pastoral versus forested land covers and provide little detail of individual study specifics. In contrast, the review here includes a wider range of land covers, summarises study specifics where available and attempts to distinguish intra-land cover data groups according to land management, soil, climate, and topography. Results of this review indicate a clear lack of data quantifying $\mathrm{N}$ and $\mathrm{P}$ losses for a wide range of geo-climatic, land cover and land management (Section 3.4). However, access to the Ravensdown dataset has enabled development of algorithms for pastoral land covers and this dataset could also potentially be used for the development of algorithms for crop land covers. However, no data of similar range and detail is found for other land covers. Instead I developed an alternative approach for non-pastoral land covers using LCM, based on the New Zealand export coefficient data reviewed. Although, the LCM developed are also somewhat uncertain due to data limitations. In addition, lack of actual, measured $\mathrm{N}$ and $\mathrm{P}$ losses from a wide variety of geo-climatic and management variables for New Zealand pastoral land covers, means prediction accuracy of $\mathrm{N}$ and $\mathrm{P}$ algorithms, as well as OVERSEER predictions, cannot be robustly assessed.

Detailed spatial data provides the information required to apply the developed $\mathrm{N}$ and $\mathrm{P}$ algorithms in LUCI. Review of this data highlights three particular areas where improved 
spatial detail would likely enhance LUCI water quality model output and predictions. These include a finer scale national coverage DEM, national S-map coverage and full access to the soil attribute database, and land use data. Land use data would be particularly useful for disaggregating pastoral land covers according to animal type, for use as a proxy to land management and intensity. Where actual farm data is not available for use in $\mathrm{LUCl}$, regional farm inputs according to land use could be developed, hopefully better reflecting actual inputs.

In-stream water quality measurements are a further constraint to full assessment of model accuracy. As discussed above, comparison between in-stream LUCI predictions and measurements indicates some variability. It is likely that better representation of attenuation associated with losses, lags and/or transformations would improve model predictions. However, it is also clear from water quality literature that New Zealand instream $\mathrm{N}$ and $\mathrm{P}$ measurement protocols are generally less than ideal. To improve representativeness, measurements need to be taken more frequently, in more places, under variable conditions, and should include nested measurements within catchments. Such improvements would result in better water quality information and would assist with improving water quality models.

Data pertaining to the five identified mitigation strategies tends to be qualitative rather than quantitative and doesn't span a wide range of geo-climatic and management variables. In addition, literature featuring sediment traps is particularly sparse. A further complication results from farm complexity and interactions between mitigations and farm components. Ideally all direct and indirect effects and implications arising from a mitigation must be included in LUCl's mitigation models. However, teasing out specific effects and implications from the literature is not easy and likely requires more time and analysis than was available here. An alternative may be to use models, such as OVERSEER, to investigate individual effects and implications of mitigations on individual farm components.

In summary, lack of data is a constraint associated with this research. It limits algorithm development, mitigation parameterisation, application of the algorithms and water quality models, and assessment of model accuracy at field to catchment scales. Improved data coverage would help with further development and assessment of both $\mathrm{LUCl}$ and other water quality models. Specific initial areas for address could include algorithm development 
for crop land covers using the Ravensdown data, collaboration with short and perennial crop, and forest experts to develop algorithms for these land covers using their expertise and data, and further work to tease out the effects of mitigation strategies applied in a complex farm system.

\subsection{RECOMMENDATIONS FOR FUTURE WORK AND DEVELOPMENT}

Although this research represents an advance to the export coefficient approach to water quality modelling, a number of limitations exist. Specifically, current pastoral algorithms represent simplified versions of OVERSEER. As such, they can never fully replicate OVERSEER predictions and they implicitly include assumptions and uncertainty associated with the OVERSEER model. Additionally, neither the developed algorithms nor OVERSEER can be truly validated until more comprehensive data detailing losses from a wider variety of New Zealand pastoral climate, soil, topography and management types and combinations, is available. Furthermore, because the other land cover algorithms include the same pastoral algorithm base, they also suffer from the same issues, and the LCM developed here are largely based on very limited data. Once these algorithms are fed into $\mathrm{LUCl}$, it is also clear that further work is required to refine the representation of attenuation as nutrients are cascaded through the catchment in LUCI. Following are recommendations for future work and development which address these limitations and suggest how and where the algorithms and models could be significantly improved and further tested.

Improve export coefficient generating pastoral algorithms: The pastoral algorithms presented here could be improved. For example, more intensively managed farms may be better represented with additional nutrient inputs and/or management factors included in the algorithms. Here, soil orders were separately parameterised, but algorithms have the same form. An alternative approach where soil order specific algorithm forms are developed with soil order specific inputs, may yield better predictions. Inclusion of more detailed soil properties and processes would also be desirable. Soil drainage, profile characteristics and chemical properties could be further investigated using OVERSEER. On a more aspirational level, soil microbial activity and $\mathrm{P}$ biogeochemical cycling, could be included. It is also possible a move away from OVERSEER as a basis for algorithm development may improve predictive ability. To assess any improvements though further actual $\mathrm{N}$ and $\mathrm{P}$ loss 
measurement data is required. In particular, measurements must encompass a wider range of soil orders and climate regions.

Develop export coefficient generating algorithms for other land covers: Ultimately an algorithmic approach to export coefficient derivation for other land covers using land cover specific data, is desired. Certainly the Ravendown dataset offers the possibility of developing export coefficients for short-rotation crop covers. Additionally, other field to farm scale nutrient loss models could be used to investigate, develop and train other land cover algorithms. It is also possible that a wider range of measured or modelled data may be available, either privately or from New Zealand CRI's. Partnering with such organisations may be one way to gain access to the type of data required and also to collaborate with researchers who have expertise related to particular land covers and land management, as has been done here with Ravensdown.

Improve representation of attenuation processes in LUCI water quality models: Case studies 1 and 2 highlight the need for better representation of site specific nutrient attenuation through losses, lags and transformations. Currently, attenuation is broadly accounted for in LUCl with catchment wide attenuation factors applied for $\mathrm{N}$ and $\mathrm{P}$, which can be increased or decreased to calibrate LUCI in-stream predictions. However, these may over or underrepresent site-specific attenuation. Particular areas for improvement include enhanced groundwater representation in $\mathrm{LUCl}$ and a number of projects are currently working towards this. Additionally, work by Singh et al (2017) investigating $N$ attenuation between the root zone and stream network based on soil type and underlying geology, offers promising insight that could be included in $\mathrm{LUCl}$. Addition of more detailed soil and plant processes may also assist progress toward this goal.

\section{Collect and develop higher spatial and/or temporal resolution national spatial data and}

water quality data: Lack of data impedes application and assessment of water quality models including the improved LUCI water quality tools. Increased spatial and/or temporal resolution of national spatial data and water quality data could enhance model output and predictive ability. In particular, more detailed DEM, soil and land use spatial data, and instream water quality data that is collected more frequently, in more locations and under variable conditions, are required. 
Apply LUCI widely in New Zealand: Ultimately the aim of algorithm development and application in LUCl water quality models is to inform and assist with improving water quality in New Zealand and elsewhere. It is clear that further improvements could be made to both the algorithms developed here and to LUCl's water quality models. However, it is also clear that currently LUCI can provide detailed, timely, spatially explicit information on relative nutrient sources, sinks and pathways that land managers find useful (Scott 2015), even if absolute predictions do not always match measured losses. Wider application of LUCI water quality models would immediately assist individual land owners and regional land managers with decision making pertaining to this urgent issue. In addition, understanding of the conditions under which LUCI water quality models perform best and understanding of where they need refinement will increase the more LUCI water quality models are applied and tested. Furthermore, $\mathrm{LUCl}$ offers the ability to consider other topical ecosystem services (e.g. carbon sequestration and agricultural productivity) and to conduct trade-off analyses.

Parameterise and test the developed algorithms in other regions and environments: The same or a similar algorithmic approach to export coefficient derivation could be applied elsewhere. This may or may not include use of the algorithms within LUCI water quality models. Although, as discussed above, LUCl clearly has a number of advantages over many other catchment scale water quality models including comparatively fast application times, spatially explicit and comparatively fine scale information on nutrient sources, sinks and pathways, and the ability to model additional ecosystem services and conduct trade off analyses between ecosystem services.

To apply the developed algorithms in other countries or regions, either independently or within $\mathrm{LUCl}$, would first require some work to match local soil classifications and land covers to New Zealand soil orders and land covers. This would then allow the most appropriate algorithms to be positioned according to local soil and land cover data. Locally appropriate algorithm inputs would also require identification, particularly around agricultural management variables e.g. fertiliser and effluent applications, stocking rates etc. Additionally, quantification of local differences in $\mathrm{N}$ and $\mathrm{P}$ losses between pastoral land cover and other land covers would be required. 


\subsection{FINAL SUMMARY}

My thesis has successfully developed an algorithmic export coefficient approach for $\mathrm{N}$ and $\mathrm{P}$ that utilises spatially explicit geo-climatic, land cover and land management data to calculate site-specific export coefficients. Application of the developed algorithms in LUCI results in consideration of influential variables at the DEM grid square scale $\left(\leq 15^{2} \mathrm{~m}^{2}\right.$ for New Zealand) to derive and position grid square specific export coefficients. LUCI then cascades water and nutrients through the catchment grid square-by-grid square, thereby explicitly considering intra-basin configuration and identifying nutrient sources, sinks and pathways at fine scale.

Like most models, both the developed algorithms and LUCI water quality models can always be improved. However, lack of data is a constraint to further model development, application and evaluation of results. Despite these limitations, the improved LUCI water quality models now offer the ability to investigate nutrient sources, sinks and pathways, in spatially explicit fine scale detail. In addition, model runs are comparatively quick and other ecosystem services and service trade-offs can be investigated. In New Zealand and globally, interest and urgency is growing to improve water quality and other ecosystem services. Current LUCI decision support models can be of great assistance with this task. 


\section{REFERENCES}

Aarons, S. R. \& C. J. P. Gourley, 2012. The role of riparian buffer management in reducing off-site impacts from grazed dairy systems. Renewable Agriculture and Food Systems 28(1):1-16.

Abell, J. M., D. P. Hamilton \& J. C. Rutherford, 2013. Quantifying temporal and spatial variations in sediment, nitrogen and phosphorus transport in stream inflows to a large eutrophic lake. Environmental Science Processes and Impacts 15:1137.

Abell, J. M., D. Ozkundakci, D. P. Hamilton \& S. D. Miller, 2011. Relationships between land use and nitrogen and phosphorus in New Zealand lakes. Marine and Freshwater Research 62:162-175.

Adams, J. A. \& J. M. Pattinson, 1985. Nitrate leaching losses under a legume-based crop rotation in Central Canterbury, New Zealand. New Zealand Journal of Agricultural Research 28:101-107.

Addiscott, T. M. \& N. A. Mirza, 1998. Modelling contaminant transport at catchment or regional scale. Agriculture Ecosystems \& Environment 67:211-221.

Al Bakri, D., S. Rahman \& L. Bowling, 2008. Sources and management of urban stormwater pollution in rural catchments, Australia. Journal of Hydrology 356:299-311.

Alexander, R. B., A. H. Elliott, U. Shankar \& G. B. McBride, 2002a. Estimating the sources and transport of nutrients in the Waikato River Basin, New Zealand. Water Resources Research 3812 .

Alexander, R. B., P. J. Johnes, E. W. Boyer \& R. A. Smith, 2002b. A comparison of models for estimating the riverine export of nitrogen from large watersheds. Biogeochemistry 57/58:295-339.

Allen, R. B., P. J. Bellingham, R. J. Holdaway \& S. K. Wiser, 2013. New Zealand's Indigenous Forests and Shrublands. In Dymond, J. R. (ed) Ecosystem services in New Zealand conditions and trends Manaaki Whenua Press, Lincoln. 
Anastasiadis, S. \& S. Kerr, 2013. Mitigation and Heterogeneity in Management Practices on New Zealand Dairy Farms. Motu Economic and Public Policy Research, 37.

Andersen, J. H., J. Carstensen, D. J. Conley, K. Dromph, V. Fleming-Lehtinen, B. G.

Gustafsson, A. B. Josefson, A. Norkko, A. Villnas \& C. Murray, 2017. Long-term temporal and spatial trends in eutrophication status of the Baltic Sea. Biological Reviews 92:135-149.

Anthony, S., I. Jones, P. Naden, P. Newell-Price, D. Jones, R. Taylor, R. D. Gooday, G. Hughes, Y. Zhang, L. Fawcett, D. Simpson, A. Turner, C. Fawcett, D. Turner, J. Murphy, A. Arnold, J. Blackburn, C. Duerdoth, A. Hawczak, J. Pretty, P. Scarlett, C. Laize, T. Douthwright, T. Lathwood, M. Jones, D. Peers, H. Kingston, M. Chauhan, D. Williams, A. Rollett, J. Roberts, G. Old, C. Roberts, J. Newman, W. Ingram, M. Harman, J. Wetherall \& G. Edwards-Jones, 2012. Contribution of the Welsh agrienvironment schemes to the maintenance and improvement of soil and water quality, and to the mitigation of climate change. Welsh Government, 477. Anthony, S. G., M. Silgram, A. L. Collins \& L. E. Fawcett, 2009. Modelling nitrate river water quality for policy support. International Journal of River Basin Management 7(3):259-275.

ANU, 2017. ANUDEM Vrsn 5.3. In: Australian National University.

http://fennerschool.anu.edu.au/research/products/anudem-vrsn-53 Accessed 06 September 2017.

Arbuckle, C., 2015. Stocktake of Regional Council Uses of OVERSEER. Aspiring Environmental.

Arheimer, B., M. Lowgren, B. C. Pers \& J. Rosberg, 2005. Integrated Catchment Modeling for Nutrient Reduction: Scenarios Showing Impacts, Potential, and Cost of Measures. AMBIO: A Journal of the Human Environment 34(7):513-520.

Arun, P. V., 2013. A comparative analysis of different DEM interpolation methods. The Egyptian Journal of Remote Sensing and Space Sciences 16:133-139.

Asurequality, 2017. AgriBase. In: Asurequality. https://www.asurequality.com/oursolutions/agribase/ Accessed 06 September 2017. 
Baginska, B., T. Pritchard \& M. Krogh, 2003. Roles of land use resolution and unit-area load rates in assessment of diffuse nutrient emissions. Journal of Environmental Management 69:39-46.

Bagstad, K. J., D. J. Semmens, S. Waage \& R. Winthrop, 2013. A comparative assessment of decision-support tools for ecosystem services quantification and valuation. Ecosystem Services 5:27-39.

Baillie, B. R. \& D. G. Neary, 2015. Water quality in New Zealand's planted forests: a review. New Zealand Journal of Forestry Science 45(7):18.

Ballance Agri-nutrients, 2016. Key Fertiliser Products. In. http://www.ballance.co.nz/OurProducts/Key-fertiliser-products Accessed 18 October 2016.

Ballantine, D. J. \& C. C. Tanner, 2010. Substrate and filter materials to enhance phosphorus removal in constructed wetlands treating diffuse farm runoff: a review. New Zealand Journal of Agricultural Research 53(1):71-95.

Ballinger, J., 2011. Natural buffer placement and downstream flood mitigation in rural Hawkes Bay, New Zealand. Victoria University of Wellington.

Barber, A., 2014. Erosion \& Sediment Control Guidelines for Vegetable Production. Agrilink NZ, Auckland.

Bargh, B. J., 1977. Output of water, suspended sediment and phosphorus and nitrogen forms from a small forested catchment. New Zealand Journal of Forestry Science 7(2):162171.

Bargh, B. J., 1978. Output of water, suspended sediment, and phosphorus and nitrogen forms from a small agricultural catchment. New Zealand Journal of Agricultural Research 21:29-38.

Beaulac, M. N. \& K. H. Reckhow, 1982. An examination of land use - nutrient export relationships. Water Resources Bulletin 18(6):1013-1021.

Benavidez, R., B. Jackson, D. Maxwell \& E. Paringit, 2016. Improving predictions of the effects of extreme events, land use, and climate change on the hydrology of watersheds in the Philippines. Paper presented at the IAHS 373, Germany. 
Bennett, E. M. \& M. E. Schipanski, 2012. The Phosphorus Cycle. In Weathers, K. C., D. L. Strayer \& G. E. Likens (eds) Fundamentals of Ecosystem Science. Elsevier, Boston.

Bergström, S. \& L. P. Graham, 1998. On the scale problem in hydrological modelling. Journal of Hydrology 211:253-265.

Betteridge, K., W. G. K. Andrewes \& J. R. Sedcole, 1986. Intake and excretion of nitrogen, potassium and phosphorus by grazing steers. The Journal of Agricultural Science 106(02):393-404.

Betteridge, K., D. Costall, S. Balladur, M. Upsdell \& K. Umemura, 2010. Urine distribution and grazing behaviour of female sheep and cattle grazing a steep New Zealand hill pasture.

Animal Production Science 50:624-629.

Betteridge, K., E. Schnug \& S. Haneklaus, 2008. Will site specific nutrient management live up to expectation? Agriculture and Forestry Research 4(58):283-294.

Beven, K. J., 2012. Rainfall-Runoff Modelling -The Primer, 2nd Edition edn. Wiley-Blackwell, Chichester.

Beven, K. J., 2009. Environmental Modelling - An uncertain future? Routledge, Abingdon. Bewsell, D., R. M. Monaghan \& G. Kaine, 2007. Adoption of Stream Fencing Among Dairy Farmers in Four New Zealand Catchments. Environmental Management 40:201-209.

Bhatterei, S., 2009. Spatially explicit assessment of tradeoffs and synergies amongst key ecosystem services in Sasumua watershed, Kenya. Bangor University.

Bindraban, P. S., C. Dimkpa, L. Nagarajan, A. Roy \& R. Rabbinge, 2015. Revisiting fertilisers and fertilisation strategies for improved nutrient uptake by plants. Biol Fertil Soils 51:897911.

Bolan, N. S., L. Wong \& D. C. Adriano, 2004. Nutrient removal from farm effluents. Bioresource Technology 94:251-260.

BoPRC, 2012a. What is Rule 11? In: Bay of Plenty Regional Council (ed). Rotorua. BoPRC, 2012b. Improving water quality in Lake Rotorua: Information on the way land is used. Bay of Plenty Regional Council, Rotorua. 
BoPRC, 2016. Dairy farmers take action to protect water. In.

https://www.boprc.govt.nz/news-centre/media-releases/media-releases-2016/may2016/dairy-farmers-take-action-to-protect-water/ Accessed 03 February 2017.

Bottomley, P. J. \& D. D. Myrold, 2007. Biological N Inputs. In Paul, E. A. (ed) Soil Microbiology, Ecology, and Biochemistry. Elsevier, Amsterdam, 365-387.

Bouraoui, F. \& B. Grizzetti, 2014. Modelling mitigation options to reduce diffuse nitrogen water pollution from agriculture. Science of the Total Environment 468-469:1267-1277.

Breuer, L., K. B. Vache, S. Julich \& H. Frede, 2008. Current concepts in nitrogen dynamics for mesoscale catchments. Hydrological Sciences Journal 53(5):1059-1074.

Broad, S. T. \& R. Corkrey, 2011. Estimating annual generation rates of total P and total N for different land uses in Tasmania, Australia. Journal of Environmental Management 92:16091617.

Bryant, J. R., V. O. Snow, R. Chicota \& B. H. Jolly, 2011. The effect of situational variability in climate and soil, choice of animal type and $\mathrm{N}$ fertilisation level on nitrogen leaching from pastoral farming systems around Lake Taupo, New Zealand. Agricultural Systems 104:271280.

Burkitt, L., M. Bretherton, R. Singh \& M. Hedley, Comparing Nutrient Loss Predictions Using OVERSEER and Stream Water Quality in a Hill Country Sub-Catchment. In: Currie, L. D. \& R. Singh (eds) Integrated Nutrient and Water Management for Sustainable Farming, Massey University, Palmerston North, 2016. Fertilizer and Lime Research Centre, p 9.

Burns, D. A. \& L. Nguyen, 2002. Nitrate movement and removal along a shallow groundwater flow path in a riparian wetland within a sheep-grazed pastoral catchment: results of a tracer study. New Zealand Journal of Marine and Freshwater Research 36:371385.

Buxeda, N., 2017. The water battle in election 2017: a beginner's guide. In: The Spinoff. https://thespinoff.co.nz/politics/21-08-2017/the-water-battle-in-election-2017-a-beginnersguide/ Accessed 21 August 2017. 
Cameron, K. C., H. J. Di \& J. L. Moir, 2013. Nitrogen losses from the soil/plant system: a review. Annals of Applied Biology 162(2):145-173.

Cameron, K. C., A. W. Rate, P. L. Carey \& N. P. Smith, 1995. Fate of nitrogen in pig effluent applied to a shallow stoney pasture soil. New Zealand Journal of Agricultural Research 38:533-542.

Cao, W., W. B. Bowden, T. Davie \& A. Fenemor, 2009. Modelling Impacts of Land Cover Change on Critical Water Resources in the Motueka River Catchment, New Zealand. Water Resources Management 23(1):137-151.

CAREX, 2014. CAREX News: Newsletter of the Freshwater Ecology Research Group. Freshwater Ecology Research Group, University of Canterbury, Christchurch.

Caruso, B. S., 2000. Spatial and temporal variability of stream phosphorus in a New Zealand high-country agricultural catchment. New Zealand Journal of Agricultural Research 43:235249.

Chambers, P. A. \& A. R. Dale, 1997. Contribution of Industrial, Municipal, Agricultural and Groundwater Sources to Nutrient Export, Athabasca, Wapiti and Smoky Rivers 1980 to 1993. Northern River Basins Study, Edmonton, 108.

Cherry, K. A., M. Shepherd, P. J. A. Withers \& S. J. Mooney, 2008. Assessing the effectiveness of actions to mitigate nutrient loss from agriculture: A review of methods. Science of the Total Environment 406:1-23.

Chislock, M. F., E. doster, R. A. Zitomer \& A. E. Wilson, 2013. Eutrophication: Causes, Consequences, and Controls in Aquatic Ecosystems. Nature Education Knowledge 4(4).

Chok, S., M. Grafton, I. Yule, M. White \& M. Manning, Improving aerial topdressing in New Zealand through particle ballistics modelling and accuracy trials. In: Currie, L. D. \& R. Singh (eds) Integrated nutrient and water management for sustainable farming, Massey University, Palmerston North, 2016. Occasional Report No. 29. Fertilizer and Lime Research Centre. 
Cichota, R. \& V. O. Snow, 2009. Estimating nutrient loss to waterways - an overview of models of relevance to New Zealand pastoral farms. New Zealand Journal of Agricultural Research 52:239-260.

Clark, A. J., R. A. C. Nottage, L. Wilcocks, J. M. Lee, C. Burke, E. Kalaugher, J. Roche, P. Beukes, M. Lieffering, P. C. D. Newton, F. Y. Li, R. Vibart, E. I. Teixeira, H. E. Brown, A. L. Fletcher, G. Hernandez-Ramirez, A. Soltani, S. Viljanen-Rollison, A. Horrocks, P. Johnstone, B. Clothier, A. Hall, S. Green, A. Dunningham, M. U. F. Kirschbaum, D. Meason, T. Payn, D. B. G. Collins, R. A. Woods, H. Rouse, M. J. Duncan, T. H. Snelder \& B. Cowie, 2012. Impacts of Climate Change on Land-based Sectors and Adaptation Options. In: Clark, A. J. \& R. A. C. Nottage (eds) Technical Report to the Sustainable Land Management and Climate Change Adaptation Technical Working Group. Ministry for Primary Industries, 408.

Clark, D. A., J. R. Caradus, R. M. Monaghan, P. Sharp \& B. S. Thorrold, 2007. Issues and options for future dairy farming in New Zealand. New Zealand Journal of Agricultural Research 50(2):203-221.

Clarke, D., 2013. The performance of Detainment Bunds (DBs) for attenuating phosphorus and sediment loss from pastoral farmland. Waikato University.

Clarke, D., J. Paterson, D. Hamilton, J. Abell, M. Scarsbrook, K. Thompson, R. Moore \& A. Bruere, Overview of using detainment bunds for mitigating diffuse-source phosphorus and soil losses from pastoral farmland. In: Currie, L. D. \& C. L. Christensen (eds) Accurate and efficient use of nutrients of farms, Palmerston North, 2013. Fertilizer and Lime Research Centre, Massey University.

Clesceri, N. L., S. J. Curran \& R. I. Sedlak, 1986. Nutrient Loads to Wisconsin Lakes: Part 1. Nitrogen and Phosphorus Export Coefficients. Journal of the American Water Resources Association 22(6):983-990.

Clothier, B. \& S. Green, The Leaching and Runoff of Nutrients from Vineyards. In: Currie, L. D. \& M. J. Hedley (eds) Science and policy: nutrient management challenges for the next generation, Massey Universiyt, Palmerston North, 2017. Fertilizer and Lime Research Centre. 
Clothier, B. E., S. R. Green, I. Vogeler, M. M. Greven \& R. Agnew, 2006. CAA transport in soil from treated-timber posts: pattern dynamics from the local to regional scale. Hydrology and Earth System Sciences Discussions 3(4):2037-2061.

Collier, K. J., A. B. Cooper, R. J. Davies-Colley, J. C. Rutherford, C. M. Smith \& R. B. Williamson, 1995a. Managing Riparian Zones: A contribution to protecing New Zealand's rivers and streams. Volume 1: Concepts. NIWA, Wellington.

Collier, K. J., A. B. Cooper, R. J. Davies-Colley, J. C. Rutherford, C. M. Smith \& R. B. Williamson, 1995b. Managing Riparian Zones: A contribution to protecting New Zealand's rivers and streams. Volume 2: Guidelines. NIWA \& Department of Conservation, Wellington.

Collins, A. L., G. Hughes, Y. Zhang \& J. Whitehead, 2009. Mitigating diffuse water pollution from agriculture: riparian buffer strip performance with width. CAB Reviews: Perspectives in Agriculture, Veterinary Science, Nutrition and Natural Resources 4(039).

Collins, K. E., C. Doscher, H. G. Rennie \& J. G. Ross, 2013. The Effectiveness of Riparian 'Restoration' on Water Quality - A Case Study of Lowland Streams in Canterbury, New Zealand. Restoration Ecology 21(1):40-48.

Columbus, J., P. Sirguey \& R. Tenzer, 2011. A free fully assessed 15 metre digital elevation model for New Zealand. Survey Quarterly(66):16-19.

Cooke, G. W., 1976. A review of the effects of agriculture on the chemical composition and quality of surface and underground waters Agriculture and Water Quality. vol 32. MAFF Technical Bulletin, London, 5-58.

Cooke, J. G., 1988. Sources and Sinks of Nutrients in a New Zealand Hill Pasture Catchment II. Phosphorus. Hydrological Processes 2:123-133.

Cooke, J. G., The Effect of Land Use on Water Quality in New Zealand. In: Land Use in Relation to Water Quantity and Quality, Nelson, New Zealand, 1979. Nelson Catchment Board and Regional Water Board.

Cooke, J. G. \& A. B. Cooper, 1988. Sources and Sinks of Nutrients in a New Zealand Hill Pasture Catchment III. Nitrogen. Hydrological Processes 2:135-149. 
Cooper, A. B., 1990. Nitrate depletion in the riparian zone and stream channel of a small headwater catchment. Hydrobiologia 202:13-26.

Cooper, A. B., C. M. Smith \& M. J. Smith, 1995. Effects of riparian set-aside on soil characteristics in an agricultural landscape. Implications for nutrient transport and retention. Agriculture, Ecosystems and Environment 55:61-67.

Cooper, A. B. \& C. E. Thomsen, 1988. Nitrogen and phosphorus in streamwaters from adjacent pasture, pine and native forest catchments. New Zealand Journal of Marine and Freshwater Research 22(2):279-291.

Cox, J. W., D. P. Oliver, N. K. Fleming \& J. S. Anderson, 2012. Off-site transport of nutrients and sediment from three main land-uses in the Mt Lofty Ranges, South Australia. Agricultural Water Management 106:50-59.

Craggs, R. J., J. P. Sukias, C. T. Tanner \& R. J. Davies-Colley, 2004. Advanced pond system for dairy-farm effluent treatment. New Zealand Journal of Agricultural Research 47:449-460.

Crofoot, A. N., E. W. Crofoot, C. J. Hoogendoorn, A. J. Litherland \& C. B. Garland, 2010. Nleaching in hill country; farmer led research. Proceedings of the New Zealand Grassland Association 72:55-60.

Curtin, D., M. H. Beare, K. Lehto, C. S. Tregurtha, W. Qiu, R. Tregurtha \& M. Peterson, 2017. Rapid Assays to Predict Nitrogen Mineralization Capacity of Agricultural Soils. Soil Science Society of America Journal 81(4):979-991.

Dairy NZ, 2016a. Waikato Wetlands Showcase. In. http://www.dairynz.co.nz/media/2374647/waikato-wetlands-showcase-flyer.pdf.

Dairy NZ, 2013. Nutrient management on your dairy farm. In.

https://www.dairynz.co.nz/media/3361747/Nutrient management on your dairy farm.p df.

Dairy NZ, 2014. Getting riparian planting right in Otago. Your step-by-step guide for successful riparian planting. In. http://www.dairynz.co.nz/media/1569771/riparian-mgmtotago.pdf. 
Dairy NZ, 2016b. Waterway technical notes: Practical approaches to waterway management. In. https://www.dairynz.co.nz/media/4329877/waterway-technicalnotes.pdf.

Davies-Colley, R. \& B. Wilcock, 2004. Water quality and chemistry in running waters. In Harding, J., P. Mosley, C. Pearson \& B. Sorrell (eds) Freshwaters of New Zealand. New Zealand Hydrological Society \& New Zealand Limnological Society.

Davies-Colley, R. J. \& J. W. Nagels, 2002. Effects of dairying on water quality of lowland streams in Westland and Waikato. Proceedings of the New Zealand Grassland Association 64:107-114.

Davies-Colley, R. J., D. G. Smith, R. C. Ward, G. G. Bryers, G. B. McBride, J. M. Quinn \& M. R. Scarsbrook, 2011. Twenty Years of New Zealand's National Rivers Water Quality Network: Benefits of Careful Design and Consistent Operation. Journal of the American Water Resources Association 47(4):750-771.

Davis, M., 2014. Nitrogen leaching losses from forests in New Zealand. New Zealand Journal of Forestry Science 44(2).

Davis, M., G. Coker, M. Watt, D. Graham, S. Pearce \& J. Dando, 2012. Nitrogen leaching after fertilising young Pinus radiata plantations in New Zealand. Forest Ecology and Management 280:20-30.

Dewes, A. M., Healthy Business + Healthy Catchments: Can we have our cake and eat it too? In: Rivers Workshop: Solution to Pollution, Massey University Palmerston North, February 2013.

Di, H. J. \& K. C. Cameron, 2002a. Nitrate leaching in temperate agroecosystems: sources, factors and mitigating strategies. Nutrient Cycling in Agroecosystems 46:237-256.

Di, H. J. \& K. C. Cameron, 2002b. Nitrate leaching and pasture production from different nitrogen sources on a shallow stoney soil under flood-irrigated dairy pasture. Australian Journal of Soil Research 40:317-334. 
Di, H. J., K. C. Cameron, S. Moore \& N. P. Smith, 1998. Nitrate leaching and pasture yields following the application of dairy shed effluent or ammonium fertilizer under spray or flood irrigation: results of a lysimeter studay. Soil Use and Management 14:209-214.

Diack, E. E., 2015. Nutrient Concentrations in the Rivers of the Southern Alps: A Proxy Indicator for Reference Water Quality Conditions in New Zealand. Otago University.

Dillon, P. J. \& W. B. Kirchner, 1975. The Effects of Geology and Land Use on the Export of Phosphorus from Watersheds. Water Research 9:135-148.

Ding, X., Z. Shen, Q. Hong, Z. Yang, X. Wu \& R. Liu, 2010. Development and Test of the Export Coefficient Model in the Upper Reach of the Yangtze River. Journal of Hydrology 383:233244.

Dingman, S. L., 2002. Physical Hydrology, Second edn. Waveland Press, Long Grove.

Dominati, E., A. Mackay, S. Green \& M. Patterson, 2014. A soil change-based methodology for the quantification and valuation of ecosystem services from agro-ecosystems: A case study of pastoral agriculture in New Zealand. Ecological Economics 100:119-129.

Dosskey, M. G., R. C. Schultz \& T. M. Isenhart, 1997. How to Design a Riparian Buffer for Agricultural Land. Forestry Publications.

Downes, M. T., C. Howard-Williams \& L. A. Schipper, 1997. Long and short roads to riparian zone restoration: nitrate removal efficiency. Paper presented at the The Proceedings of the International Conference on Buffer Zones.

Drewry, J. J., L. T. H. Newham, R. S. B. Greene, A. J. Jakeman \& B. F. W. Croke, 2006. A review of nitrogen and phosphorus export to waterways. Marine and Freshwater Research 57:757-774.

Eckard, R. J., C. Grainger \& C. A. M. De Klein, 2010. Options for the abatement of methane and nitrous oxide from ruminant production: A review. Livestock Science 130:47-56.

Edmeades, D. C., 2003. The long term effects of manures and fertilisers on soil productivity and quality: a review. Nutrient Cycling in Agroecosystem 66:165-180.

Edmeades, D. C., 2015. The evaluation of a controlled release nitrogen fertiliser. Journal of New Zealand Grasslands 77:147-152. 
Elliott, A. H., R. B. Alexander, G. E. Schwarz, U. Shankar, J. Sukias \& G. B. McBride, 2005. Estimation of nutrient sources and transport for New Zealand using the hybrid mechanisticstatistical model SPARROW. Journal of Hydrology (NZ) 44(1):1-27.

Elliott, A. H., A. F. Semadeni-Davies, U. Shankar, J. R. Zeldis, D. M. Wheeler, D. R. Plew, G. J. Rys \& S. R. Harris, 2016. A national-scale GIS-based system for modelling impacts of land use on water quality. Environmental Modelling \& Software 86:131-144.

Elliott, S., G. B. McBride, U. Shankar, A. Semadeni-Davies, J. M. Quinn, D. Wheeler, L. Wedderburn, B. Small, A. Hewitt, R. Gibb, R. L. Parfitt, B. Clothier, S. Green, S. Harris \& G. Rys, 2008. CLUES Spatial DSS: From Farm-Scale Leaching Models to Regional Decision Support. Paper presented at the iEMSs 2008: International Congress on Environmental Modelling and Software Integrating Sciences and Information Technology for Environmental Assessment and Decision Making 4th Biennial Meeting of iEMSs.

Elliott, S., A. Semadeni-Davies \& U. Shankar, Clues Catchment Modelling- Lessons from Recent Applications. In: Currie, L. D. \& C. L. Christensen (eds) Adding to the Knowledge Base for the Nutrient Manager, Massey University, Palmerston North, 2011. Fertilizer and Lime Research Centre.

Elliott, S. \& B. Sorrell, 2002. Lake Managers' Handbook Land-Water Interactions. Ministry for the Environment, Wellington.

Emmett, B., M. Abdalla, S. Anthony, S. Astbury \& Others, 2015. Glastir Monitoring \& Evaluation Programme. Second year annual report. NERC \& Centre for Ecology \& Hydrology, Bangor, 1001.

Emmett, B., M. Abdalla, S. G. Anthony, S. Astbury \& Others, 2014. Glastir Monitoring \& Evaluation Programme. First year annual report. NERC \& Centre for Ecology \& Hydrology, Bangor.

Emmett, B., D. Cooper, S. Smart, B. Jackson, A. Thomas, B. Cosby, C. D. Evans, H. Glanville, J. E. McDonald, S. K. Malham, M. Marshall, S. Jarvis, P. Rajko-Nenow, G. P. Webb, S. Ward, E. Rowe, L. Jones, A. J. Vanbergen, A. Keith, H. Carter, M. G. Pereira, S. Hughes, I. Lebron, A. J. Wade \& D. L. Jones, 2016. Spatial patterns and environmental constraints on ecosystem services at a catchment scale. Science of the Total Environment. 
Endreny, T. A. \& E. F. Wood, 2003. Watershed Weighting of Export Coefficients to Map Critical Phosphorus Loading Areas. Journal of the American Water Resources Association February:165-181.

Envirolink, 2015. Decision Support Systems Directory. In: Envirolimk. http://tools.envirolink.govt.nz Accessed 13 Jan 20152015.

Environment Canterbury, 2011. Riparian Zones. A guide to the protection of Canterbury's rivers, streams and wetlands. In.

https://api.ecan.govt.nz/TrimPublicAPI/documents/download/1891874.

Environment Canterbury, 2006. A guide to managing waterways on Canterbury farms. In. http://ecan.govt.nz/publications/General/Managingwaterways.pdf.

Environment Southland, 2016a. Riparian Plants for Southland. In.

http://www.es.govt.nz/Document\%20Library/Factsheets/Good\%20management\%20practic e\%20factsheets/Riparian\%20Management/riparian planting species booklet - web.pdf.

Environment Southland, 2016b. Riparian Management. In.

http://www.es.govt.nz/services/land-sustainability/Pages/Riparian-management.aspx Accessed 26 August 2016.

EuropeanCommission, 2014. The EU Water Framework Directive - integrated river basin management for Europe. In. http://ec.europa.eu/environment/water/waterframework/index en.html Accessed 03July 2014.

Fahey, B. D. \& R. J. Jackson, 1997. Environmental effects of forestry at Big Bush Forest, South Island, New Zealand: 1 Changes in Water Chemistry. Journal of Hydrology (NZ) 36(1):43-71.

Fertiliser Association of New Zealand, 2013. Code of Practice for Nutrient Management. Fertiliser Association of New Zealand.

Filippelli, G. M., 2008. The Global Phosphorus Cycle: Past, Present, and Future. Elements 4:89-95.

Fisher, J. \& M. C. Acreman, 2004. Wetland nutrient removal: a review of the evidence. Hydrology and Earth System Sciences 8(4):673-685. 
Fleming, P. H. E., 2003. Farm Technical Manual. Lincoln University, Christchurch.

FLRC, 2015. Sustainable Nutrient Management in New Zealand Agriculture. Fertiliser \& Lime Research Centre, Massey University, Palmerston North.

Foley, J., N. Ramankutty, K. Brauman, E. Cassidy, J. Gerber, M. Johnston, N. Mueller, C. O'Connell, D. Ray, P. West, C. Balzer, E. Bennett, S. R. Carpenter, J. Hill, C. Monfreda, S. Polasky, J. Rockström, J. Shehan, S. Siebert, D. Tilman \& D. Zaks, 2011. Solutions for a cultivated planet. Nature 478:337-342.

Folke, C., A. Jansson, J. Rockström, P. Olsson, S. R. Carpenter, F. S. Chapin, A. Crepin, G. Daily, K. Danell, J. Ebbesson, T. Elmqvist, V. Galaz, F. Moberg, M. Nilsson, H. Osterblom, E. Ostrom, A. Persson, G. Peterson, S. Polasky, W. Steffen, B. Walker \& F. Westley, 2011. Reconnecting to the Biosphere. AMBIO: A Journal of the Human Environment 40:719-738.

Fowler, D., M. Coyle, U. Skiba, M. Sutton, N. Cape, S. Reis, L. Sheppard, A. Jenkins, B. Grizzetti, J. Galloway, P. Vitousek, A. Leach, A. F. Bouwman, K. Butterbach-Bahl, F. Dentener, D. Stevenson, M. Amann \& M. Voss, 2013. The global nitrogen cycle in the twenty-first century. Philosophical Transactions of the Royal Society B 368.

Franklin, H. M., N. M. Dickinson, C. J. D. Esnault \& B. H. Robinson, 2015. Native plants and nitrogen in agricultural landscapes of New Zealand. Plant Soil 394:407-420.

Frink, C. R., 1991. Estimating nutrient exports to estuaries. Journal of Environmental Quality 20:717-724.

Galloway, J., A. Townsend, J. Erisman, M. Bekunda, Z. Cai, J. Freney, L. Martinelli, S. Seitzinger \& M. Sutton, 2008. Transformation of the Nitrogen Cycle: Recent Trends, Questions, and Potential Solutions. Science 320.

Galloway, J. N., J. D. Aber, J. W. Erisman, S. P. Seitzinger, R. W. Howarth, E. B. Cowling \& B. J. Cosby, 2003. The Nitrogen Cascade. BioScience 53(4):341-356.

Galloway, J. N., A. M. Leach, A. Bleeker \& J. W. Erisman, 2013. A chronology of human understanding of the nitrogen cycle. Philosophical Transactions of the Royal Society B 368. 
Gentile, R., S. Green, K. Mason, C. Van den Dijssel, P. Johnstone \& B. Clothier, 2014. Land Management Practices and Nutrient Losses from Farms on the Poverty Bay Flats. Plant \& Food Research.

Gostick, K. G., 1982. Agricultural Development and Advisory Service recommendations to farmers on manure disposal and recycling. Philosophical Transactions of the Royal Society B 296:309-332.

Gourley, C. J. P., S. R. Aarons \& J. M. Powell, 2012. Nitrogen use efficiency and manure management practices in contrasting dairy production systems. Agriculture, Ecosystems and Environment 147:73-81.

Gray, C. W., D. Wheeler \& R. W. McDowell, 2016. Review of the phosphorus loss submodel in OVERSEER. AgResearch.

Green, S., M. Black, S. Mahupuku, J. Herrick, C. van den Dijssel, N. Arnold, J. Liu \& B. Clothier, Monitoring the Soil Water Balance and Drainage Losses from Kiwifruit Orchards in the Bay of Plenty Region. In: Currie, L. D. \& M. J. Hedley (eds) Science and policy: nutrient management challenges for the next generation, Massey University, Palmerston North, 2017. Fertilizer and Lime Research Centre.

Greene, S., P. J. Johnes, J. P. Bloomfield, S. M. Reaney, R. Lawley, Y. Elkhatib, J. Freer, N. Odoni, C. J. A. Macleod \& B. Percy, 2015. A geospatial framework to support integrated biogeochemical modelling in the United Kingdom. Environmental Modelling \& Software $68: 219-232$.

Greenwood, K. L. \& B. M. Mckenzie, 2001. Grazing effects on soil physical properties and the consequences for pastures: a review. Australian Journal of Experimental Agriculture 41:1231-1250.

Grimvall, A. \& P. Stalnacke, 1996. Statistical Methods for Source Apportionment of Riverine Loads of Pollutants. Environmetrics 7:201-213.

Grizzetti, B., F. Bouraoui, G. Billen, H. van Grinsven, A. C. Cardoso, V. Thieu, J. Garnier, C. Curtis, R. Howarth \& P. Johnes, 2011. Nitrogen as a threat to European water quality. In Sutton, M. A., et al. (eds) The European Nitrogen Assessment: Sources, Effects and Policy Perspectives. Cambridge University Press, Cambridge, 379-404. 
Groffman, P. M. \& E. J. Rosi-Marshall, 2012. The Nitrogen Cycle. In Weathers, K. C., D. L. Strayer \& G. E. Likens (eds) Fundamentals of Ecosystem Science. Elsevier, Boston.

Hair, J. F., W. C. Black, B. J. Babin, R. E. Anderson \& R. L. Tatham, 2006. Multivariate Data Analysis, Sixth edn. Pearson Prentice Hall, Upper Saddle River.

Hanrahan, G., M. Gledhill, W. A. House \& P. J. Worsfold, 2001. Phosphorus Loading in the Frome Catchment, UK: Seasonal Refinement of the Coefficient Modeling Approach. Journal of Environmental Quality 30(5).

Harding, J. S., N. P. C. Glenjarman, C. M. Fenbria, K. L. Hogsden \& A. R. McIntosh, n.d. CAREX: Trialling sediment traps and the sand wand to remove excessive fine sediment in agricultural waterways. In: University of Canterbury,

http://www.biol.canterbury.ac.nz/ferg/The\%20Mackenzie\%20Project/CAREX/Handouts\%20 \&\%20Publications/CAREX\%20poster 2 sediment tools.pdf.

Harmel, D., S. Potter, P. Casebolt, K. H. Reckhow, C. Green \& R. Haney, 2006. Compilation of measured nutrient load data for agricultural land uses in the United States. Journal of the American Water Resources Association 42(5):1163-1178.

Harmel, D., S. Qian, K. H. Reckhow \& P. Casebolt, 2008. The MANAGE Database: Nutrient Load and Site Characteristic Updates and Runoff Concentration Data. Journal of Environmental Management 37:2403-2406.

Harmel, R. D., R. M. Slade \& R. L. Haney, 2010. Impact of Sampling Tachniques on Measured Stormwater Quality Data for Small Streams. Journal of Environmental Quality 39:1734-1742.

Harpole, W. S., J. T. Ngai, E. E. Cleland, E. W. Seabloom, E. T. Borer, M. E. S. Bracken, J. J. Elser, D. S. Gruner, H. Hillebrand, J. B. Shurin \& J. E. Smith, 2011. Nutrient co-limitation of primary producer communities. Ecology Letters 14:852-862.

Hart, M. R., B. F. Quin \& M. L. Nguyen, 2004. Phosphorus Runoff from Agricultural Land and Direct Fertilizer Effects: A Review. Journal of Environmental Quality 33(6):1954-1972.

Hawke, R. M. \& S. A. Summers, 2003. Land application of dairy farm effluent: results from a case study, Wairarapa, New Zealand. New Zealand Journal of Agricultural Research 46:339346. 
Haynes, R. J. \& P. H. Williams, 1993. Nutrient cycling and soil fertility in the grazed pasture ecosystem. Advances in Agronomy 49:119-199.

Healy, M. G., M. Rodgers \& J. Mulqueen, 2007. Treatment of dairy wastewater using constructed wetlands and intermittent sand filters. Bioresource Technology 98:2268-2281.

Heathwaite, A. L., 2003. Making process-based knowledge useable at the operational level: a framework for modelling diffuse pollution from agricultural land. Environmental Modelling and Software 18:753-760.

Herath, I., S. Green, R. Singh, D. J. Horne, S. van der Zijpp \& B. Clothier, 2013. Water footprinting of agricultural products: a hydrological assessment for the water footprint of New Zealand's wines. Journal of Cleaner Production 41:232-243.

Hewitt, A. \& T. Shepherd, 1997. Structural vulnerability of New Zealand soils. Australian Journal of Soil Research 35:461-474.

Hewitt, A. E., 2010. New Zealand Soil Classification. Manaaki Whenua Press, Lincoln.

Hill Laboratories, 2016. Understanding Soil Nitrogen Tests. In. http://www.hilllaboratories.com/file/fileid/45371.

Hoare, R. A., 1984. Nitrogen and phosphorus in Rotorua urban streams. New Zealand Journal of Marine and Freshwater Research 18:451-454.

Houlbrooke, D. J., D. J. Horne, M. J. Hedley, J. A. Hanley, D. R. Scotter \& V. O. Snow, 2004b. Minimising surface water pollution resulting from farm-dairy effluent application to molepipe drained soil. I. An evaluation of the deferred irrigation system for sustainable land treatment in the Manawatu. New Zealand Journal of Agricultural Research 47:405-415.

Houlbrooke, D. J., D. J. Horne, M. J. Hedley, J. A. Hanley \& V. O. Snow, 2003. The impact of intensive dairy farming on the leaching losses of nitrogen and phosphorus from a mole and pipe drained soil. Proceeedings of the New Zealand Grassland Association 65:179-184.

Houlbrooke, D. J., D. J. Horne, M. J. Hedley, J. A. Hanley \& V. O. Snow, 2004. A review of literature on the land treatment of farm-dairy effluent in New Zealand and its impact on water quality. New Zealand Journal of Agricultural Research 47:499-511. 
Houlbrooke, D. J., D. J. Horne, M. J. Hedley, V. O. Snow \& J. A. Hanley, 2008. Land application of farm dairy effluent to a mole and pipe drained soil: implications for nutrient enrichment of winter-spring drainage. Australian Journal of Soil Research 46:45-52.

Howarth, R., D. Swaney, G. Billen, J. Garnier, B. Hong, C. Humborg, P. J. Johnes, C. Morth \& R. Marino, 2012. Nitrogen fluxes from the landscape are controlled by net anthropogenic nitrogen inputs and by climate. Frontiers in Ecology and the Environment 10(1):37-43.

Hudson, H. R., 2002. In-channel coarse sediment trap Best Management Practice. Ministry for Agriculture and Forestry.

Hudson, H. R., 2005. Sustainable Drainage Management Best Management Practice 4:

Coarse sediment trap. In. http://www.wet.org.nz/wpcontent/uploads/2012/03/COARSE SED TRAP.pdf.

Hughes, A. O. \& J. M. Quinn, 2014. Before and After Integrated Catchment Management in a Headwater Catchment: Changes in Water Quality. Environmental Management 54:12881305.

lerodiaconou, D., L. Laurenson, M. Leblanc, F. Stagnitti, G. Duff, S. Salzman \& V. Versace, 2005. The consequences of land use change on nutrient exports: a regional scale assessment in south-west Victoria, Australia. Journal of Environmental Management 74:305316.

INCA, 2017. INCA - Integrated Catchment Model. In: University of Reading. http://www.reading.ac.uk/geographyandenvironmentalscience/research/INCA/gesINCA.aspx Accessed 30 August 2017.

Jackson-Blake, L. A., A. J. Wade, M. N. Futter, D. Butterfield, R. M. Couture, B. A. Cox, J. Crossman, P. Ekholm, S. J. Halliday, L. Jin, D. S. L. Lawrence, A. Lepisto, Y. Lin, K. Rankinen \& P. G. Whitehead, 2016. The INtegrated CAtchment model of phosphorus dynamics (INCA-P): Description and demonstration of new model structure and equations. Environmental Modelling and Software 83:356-386.

Jackson, B., S. Astbury, D. Cooper, M. Craythorne, D. Maxwell, O. Reuland, A. Thomas \& M. Trodahl, 2014. LUCl v 0.4 Help Documentation. 
Jackson, B., C. Browne, A. Butler, D. Peach, A. J. Wade \& H. Wheater, 2008. Nitrate transport in Chalk catchments: monitoring, modelling and policy implications. Environmental Science \& Policy 11:125-135.

Jackson, B., D. Cooper, J. Hall, B. Emmett \& J. Bullock, 2013b. The Provision of Ecosystem Services in the Environmental Stewardship Scheme Work Package 2 Report to Natural England. 43.

Jackson, B., T. Pagella, F. Sinclair, B. Orellana, A. Henshaw, B. Reynolds, N. Mcintyre, H. Wheater \& A. Eycott, 2013a. Polyscape: A GIS mapping framework providing efficient and spatially explicit landscape-scale valuation of multiple ecosystem services. Landscape and Urban Planning 112:74-88.

Jackson, B., H. Wheater, S. Mathias, N. Mcintyre \& A. Butler, 2006. A simple model of variable residence time flow and nutrient transport in the chalk. Journal of Hydrology 330:221-234.

Jackson, B., H. Wheater, A. J. Wade, D. Butterfield, S. Mathias, A. Ireson, A. Butler, N. Mcintyre \& P. Whitehead, 2007. Catchment-scale modelling of flow and nutrient transport in the Chalk unsaturated zone. Ecological Modelling 209:41-52.

Jackson, B. M., A. K. Metherell, A. H. C. Roberts, M. I. Trodahl \& M. White, 2016. Adaption of the LUCI framework to account for detailed farm management: a case study exploring potential for nutrient mitigation using data from the Southland Demonstration Farm. In: Currie, L. D. \& R. Singh (eds) Integrated nutrient and water management for sustainable farming. Fertilizer and Lime Research Centre, Massey University, Palmerston North.

Jarvie, H. P., A. N. Sharpley, P. J. A. Withers, J. T. Scott, B. E. Haggard \& C. Neal, 2013. Phosphorus Mitigation to Control River Eutrophication: Murky Waters, Inconvenient Truths, and "Postnormal" Science. Journal of Environmental Quality 42:295-304.

Jeje, Y., 2006. Export Coefficients for Total Phosphorus, Total Nitrogen and Total Suspended Solids in the Southern Alberta Region. A Review of Literature. Alberta Environment, Calgary, 22. 
Johnes, P. J., 1996. Evaluation and management of the impact of land use change on the nitrogen and phosphorus load delivered to surface waters: the export coefficient modelling approach. Journal of Hydrology 183:323-349.

Johnes, P. J., 2007. Uncertainties in annual riverine phosphorus load estimation: Impact of load estimation methodology, sampling frequency, baseflow index and catchment population density. Journal of Hydrology 332:241-258.

Johnes, P. J., R. Foy, D. Butterfield \& P. M. Haygarth, 2007. Land use scenarios for England and Wales: evaluation of management options to support 'good ecological status' in surface freshwaters. Soil Use and Management 23:176-194.

Johnes, P. J. \& A. L. Heathwaite, 1997. Modelling the impact of land use change on water quality in agricultural catchments. Hydrological Processes 11:269-286.

Johnes, P. J. \& P. E. O'Sullivan, 1989. Nitrogen and Phosphorus Losses from the Catchment of Slapton Ley. Field Studies 7:285-309.

Johnston, A. M. \& T. W. Bruulsema, 2014. 4R Nutrient Stewardship for Improved Nutrient Use Efficiency. Procedia Engineering 83:365-370.

Jorgensen, S. E., 1980. Lake Management. Pergamon, Oxford.

Khadam, I. M. \& J. J. Kaluarachchi, 2006. Water quality modeling under hydrologic variability and parameter uncertainty using erosion-scaled export coefficients. Journal of Hydrology 330:354-367.

King, K. W., M. R. Williams, M. L. Macrae, N. R. Fausey, J. Frankenberger, D. R. Smith, P. J. A. Kleinman \& L. C. Brown, 2015. Phosphorus Transport in Agricultural Subsurface Drainage: A Review. Journal of Environmental Quality 44(2):467-85.

Kleinman, P. J. A., A. N. Sharpley, R. W. McDowell, D. N. Flaten, A. R. Buda, L. Tao, L. Bergstrom \& Q. Zhu, 2011. Managing agricultural phosphorus for water quality protection: principles for progress. Plant and Soil 349:169-182.

Kleinman, P. J. A., A. N. Sharpley, P. J. A. Withers, L. Bergstrom, L. T. Johnson \& D. G. Doody, 2015. Implementing agricultural phosphorus science and management to combat eutrophication. AMBIO: A Journal of the Human Environment 44(2):S297-S310. 
Kottek, M., J. Grieser, C. Beck, B. Rudolf \& F. Rubel, 2006. World Map of Koppen-Geiger Climate Classification updated. Meteorol Z 15:259-263.

Krueger, T., J. N. Quinton, J. Freer, C. J. A. Macleod, G. S. Bilotta, R. E. Brazier, J. M. B. Hawkins \& P. M. Haygarth, 2012. Comparing empirical models for sediment and phosphorus transfer from soils to water at field and catchment scale under data uncertainty. European Journal of Soil Science 63:211-223.

Krysanova, V. \& M. White, 2015. Advances in water resources assessment with SWAT - an overview. Hydrological Sciences journal 60(5):771-783.

Lambert, M. G., B. P. Devantler, P. Nes \& P. E. Penny, 1985. Losses of nitrogen, phosphorus, and sediment in runoff from hill country under different fertiliser and grazing management regimes. New Zealand Journal of Agricultural Research 28(3):371-379.

Landcare Research, 2003. Land Use New Zealand (LUNZ) Map. Landcare Research.

Landcare Research, 2017a. SoilsPortal: The New Zealand Soil Classification. In: Landcare Research. https://soils.landcareresearch.co.nz/describing-soils/nzsc/soil-order/ Accessed 12 June 2017.

Landcare Research, 2017b. Describing Soils - Series Names. In. https://soils.landcareresearch.co.nz/describing-soils/series-names/Accessed 13 September 2017.

Ledgard, S. F., J. W. Penno \& M. S. Sprosen, 1999. Nitrogen inputs and losses from clover/grass pastures grazed by dairy cows, as affected by nitrogen fertilizer application. Journal of Agricultural Science 132:215-225.

Lee, S., S. Hwang, S. Lee, H. Hwang \& H. Sung, 2009. Landscape ecological approach to the relationships of land use patterns in watersheds to water quality characteristics. Landscape and Urban Planning 92:80-89.

Letcher, R. A., A. J. Jakeman, M. Calfas, S. Linforth, B. Baginska \& I. Lawrence, 2002. A comparison of catchment water quality models and direct estimation techniques. Environmental Modelling \& Software 17:77-85. 
Letcher, R. A., A. J. Jakeman \& W. S. Merritt, 1999. Review of Techniques to Estimate Catchment Exports. Environment Protection Authority, Sydney.

Li, Y., S. Niu \& G. Yu, 2016. Aggravated phosphorus limitation on biomass production under increasing nitrogen loading: a meta-analysis. Global Change Biology 22:934-943.

Lilburne, L., T. Webb, D. Palmer, S. McNeill, A. Hewitt \& S. Fraser, Pedo-transfer functions from S-Map for mapping water holding capacity, soil-water demand, nutrient leaching vulnerability and soil services. In: Currie, L. D. \& C. L. Christensen (eds) Nutrient management for the farm, catchment and community, Palmerston North, 2014. vol Occasional Report No. 27. Fertilizer and Lime Research Centre, Massey University.

Lin, J. P., 2004. Review of Published Export Coefficient and Event Mean Concnetration (EMC) Data. Wetlands Regulatory Assistance Program, 15.

Lindström, G., B. Johansson, M. Persson, M. Gardelin \& S. Bergström, 1997. Development and test of the distributed HBV-96 hydrological model. Journal of Hydrology 201:272-288.

LINZ, 2017. LINZ Data Service - National Elevation. In: Land Information New Zealand. https://data.linz.govt.nz/group/national-elevation/data/ Accessed 03 October 2017.

LINZ, 2016. NZ 8m Digital Elevation Model (2012). In: Land Inforation New Zealand. https://data.linz.govt.nz/layer/1768-nz-8m-digital-elevation-model-2012/metadata/ Accessed 14 December 2016.

Lloyd, C. E. M., J. E. Freer, P. J. Johnes, G. Coxon \& A. L. Collins, 2016. Discharge and nutrient uncertainty: implications for nutrient flux estimation in small streams. Hydrological Processes 30:135-152.

Loehr, R. C., 1974. Characteristics and comparative magnitude of non-point sources. Journal of the Water Pollution Control Federation 46(8):1849-1872.

Longhurst, R. D., A. H. C. Roberts \& M. B. O'Connor, 2000. Farm dairy effluent: A review of published data on chemical and physical characteristics in New Zealand. New Zealand Journal of Agricultural Research 43:7-14.

Lord, E. I. \& S. G. Anthony, 2000. MAGPIE: A modelling framework for evaluating nitrate losses at national and catchment scales. Soil Use and Management 16:167-174. 
Lord, E. I., S. G. Anthony \& R. D. Gooday, 2009. Assessing the impact of Nitrate Vulnerable Zones in England on nitrate loss from agricultural land. International Journal of River Basin Management 7(3):233-243.

Lowe, H., Accumulation and interim nutrient concentration of pasture irrigated with treated piggery effluent. In: Proceedings of the New Zealand Land Treatment Collective Technical Session No 9: Land application of farm wastes, Palmerston North, 1993.

Lu, J., D. Gong, Y. Shen, M. Liu \& D. Chen, 2013. An inversed Bayesian modeling approach for estimating nitrogen export coefficients and uncertainty assessment in an agricultural watershed in eastern China. Agricultural Water management 116:79-88.

Luo, J. \& F. Kelliher, 2014. Partitioning of animal excreta $\mathrm{N}$ into urine and dung and developing the N2O inventory. Ministry for Primary Industries, Wellington.

Macgregor, A. N., J. D. Stout \& R. J. Jackson, 1979. Quality of drainage water from pasture treated with dairy shed effluent. Progress in Water Technology 11:11-17.

MacLeod, C. \& H. Moller, 2006. Intensification and diversification of New Zealand agriculture since 1960: An evaluation of current indicators of land use change. Agriculture, Ecosystems and Environment 115:201-218.

Magesan, G. N., H. Wang \& P. W. Clinton, 2012. Nitrogen cycling in gorse-dominated ecosystems in New Zealand. New Zealand Journal of Ecology 36(1):21-28.

Marapara, T. R., 2016. Eco-hydrology interactions between trees, soil and water in terrestrial and wetland areas: The effect of tree planting on water flow dynamics in Wairarapa Wetlands, New Zealand. Victoria University of Wellington.

Marden, M., D. Rowan \& C. Phillips, 2005. Stabilising characteristics of New Zealand indigenous riparian colonising plants. Plant and Soil 278:95-105.

Marschner, P. \& R. Zdenko (eds), 2007. Nutrient Cycling in Terrestrial Ecosystems. SpringerVerlag, Berlin.

Marston, F., W. Young \& R. Davis, 1995. Nutrient Generation Rates Data Book. CSIRO, Sydney. 
Mateo-Sagasta, J. \& J. Burke, 2010. Agriculture and water quality interactions: a global overview. FAO.

Mather, P. M., 1976. Computational Methods of Multivariate Analysis in Physical Geography. John Wiley \& Sons, London.

Mathworks, 2017. Choosing the Algorithm. In.

https://au.mathworks.com/help/optim/ug/choosing-the-algorithm.html\#brppuoz Accessed 27 March 2017.

Mattikalli, N. M. \& K. S. Richards, 1996. Estimation of Surface Water Quality Changes in Response to Land Use Change: Application of the Export Coefficient Model Using Remote Sensing and Geographical Information System. Journal of Environmental Management 48:263-282.

May, L., W. A. House, M. Bowes \& J. McEvoy, 2001. Seasonal export of phosphorus from a lowland catchment: upper River Cherwell in Oxfordshire, England. The Science of the Total Environment 269:117-130.

McColl, R. H. S. \& A. R. Gibson, 1979. Downslope movement of nutrients in hill pasture, Taita, New Zealand. New Zealand Journal of Agricultural Research 22(1):151-161.

McColl, R. H. S., E. White \& A. R. Gibson, 1977. Phosphorus and nitrate run-off in hill pasture and forest catchments, Taita, New Zealand. New Zealand Journal of Marine and Freshwater Research 11(4):729-744.

McDowell, R. W., 2007. Water Quality in Headwater Catchments with Deer Wallows. Journal of Environmental Quality 36:1377-1382.

McDowell, R. W., 2008. Water quality of a stream recently fenced off from deer. New Zealand Journal of Agricultural Research 51:291-298.

McDowell, R. W., B. J. F. Biggs, A. N. Sharpley \& L. Nguyen, 2004. Connecting Phosphorus Loss from Agricultural Landscapes to Surface Water Quality. Chemistry and Ecology 20(1).

McDowell, R. W. \& W. Catto, 2005. Alternative fertilisers and management to decrease incidental phosphorus loss. Environmental Chemical Letters 2:169-174. 
McDowell, R. W., N. Cox \& T. H. Snelder, 2017. Assessing the Yield and Load of Contaminants with Stream Order: Would Policy Requiring Livestock to Be Fenced Out of High-Order Streams Decrease Catchment Contaminant Loads? Journal of Environmental Quality 46:1038-1047.

McDowell, R. W., R. M. Dils, A. L. Collins, K. A. Flahive, A. N. Sharpley \& J. Quinn, 2016a. A review of the policies and implementation of practices to decrease water quality impairment by phosphorus in New Zealand, the UK, and the US. Nutrient Cycle Agroecosystem 104:289-305.

McDowell, R. W., G. Lucci, G. Peyroux, H. Yoswara, M. Brown, I. Kalmakoff, N. Cox, P. Smale, D. Wheeler, N. Watkins, C. Smith, R. M. Monaghan, R. W. Muirhead, W. Catto \& J. Risk, 2016b. An Assessment of MitAgator: a farm-scale tool to estimate and manage the loss of contaminants from land to water. Transactions of the American Society of Agricultural and Biological Engineers 59(2):537-543.

McDowell, R. W., G. Lucci, G. Peyroux, H. Yoswara, N. Cox, M. Brown, D. Wheeler, N. Watkins, C. Smith, R. M. Monaghan, R. W. Muirhead, A. Stafford, J. Risk \& A. B. Old, 2015. MitAgator: a tool to estimate and mitigate the loss of contaminants from land to water. In: Currie, L. D. \& L. L. Burkitt (eds) Moving farm systems to improved attentuation. Fertilizer and Lime Research Centre, Palmerston North, 9.

McDowell, R. W., R. M. Monaghan \& P. L. Carey, 2003. Potential phosphorus losses in overland flow from pastoral soils receiving long-term applications of either superphosphate or reactive phosphoate rock. New Zealand Journal of Agricultural Research 46:329-337.

McDowell, R. W., R. M. Monaghan \& D. Wheeler, 2005. Modelling phosphorus losses from pastoral farming systems in New Zealand. New Zealand Journal of Agricultural Research 48:131-141.

McDowell, R. W., D. Stevenson, V. Cave, R. J. Paton \& M. Johnson, 2006. Effects of shelter belts on fence-line pacing of deer and associated impacts on water and soil quality. Soil Use and Management 22:158-164. 
McDowell, R. W., D. M. Wheeler, C. A. M. DeKlein \& A. J. Rutherford, 2008. Deer and environment: Overseer upgrade. Proceedings of the New Zealand Grassland Association 70:95-99.

McDowell, R. W. \& R. J. Wilcock, 2008. Water quality and the effects of different pastoral animals. New Zealand Veterinary Journal 56(6):289-296.

McDowell, R. W., R. J. Wilcock \& D. P. Hamilton, 2013. Assessment of Strategies to Mitigate the Impact or Loss of Contaminants from Agricultural Land to Fresh Waters. Ministry for the Environment, Wellington, 41.

McFarland, A. M. S. \& L. M. Hauck, 2001. Determining nutrient export coefficients and source loading uncertainty using in-stream monitoring data. Journal of the American Water Resources Association 37(1):223-236.

McGechan, M. B. \& C. F. E. Topp, 2004. Modelling environmental impacts of deposition of excreted nitrogen by grazing dairy cows. Agriculture, Ecosystems and Environment 103:149164.

McKergow, L. A., J. C. Rutherford \& G. C. Timpany, 2012. Livestock-Generated Nitrogen Exports from a Pastoral Wetland. Journal of Environmental Quality 41:1681-1689.

McKergow, L. A., C. C. Tanner, R. M. Monaghan \& G. Anderson, 2007. Stocktake of diffuse pollution attenuation tools for New Zealand pastoral farming systems. National Institute of Water and Atmospheric Research, Hamilton, 102.

McLaren, R. G. \& K. C. Cameron, 1996. Soil Science. Oxford University Press, Oxford. McLeod, C., L. Hunt, C. Rosin, J. Fairweather, A. Cook \& H. Campbell, 2006. New Zealand Farmers and Wetlands. Agriculture Research Group on Sustainability.

McQueen, J. C., W. C. Tozer \& B. D. Clarkson, 2006. Consequences of Alien N2-Fixers on Vegetation Succession in New Zealand. In Allen, R. B. \& W. G. Lee (eds) Biological Invasions in New Zealand. Springer, Berlin, 295-306.

McRae, A., 2015. Fears that lake clean-up will hit farmers' profit. RadioNZ. 
Me, W., J. M. Abell \& D. P. Hamilton, 2015. Effects of hydrological conditions on SWAT model performance and parameter sensitivity for a small, mised land use catchment in New Zealand. Hydrology and Earth System Sciences 19:4127-4147.

MEA, 2005a. Ecosystems and Human Well-being: Current State and Trends, Volume 1. In: Hassan, R., R. Scholes \& N. Ash (eds). Millenium Ecosystem Assessment, Washington. MEA, 2005b. Ecosystems and Human Well-being: Synthesis. Millenium Ecosystem Assessment, Island Press, Washington DC, 155.

Meals, D. W., S. A. Dressing \& T. E. Davenport, 2010. Lag Time in Water Quality Response to Best Management Practices: A Review. Journal of Environmental Quality 39:85-96.

Meneer, J. C., S. F. Ledgard \& A. G. Gillingham, 2004. Land Use Impacts on Nitrogen and Phosphorus Loss and Management Options for Intervention. AgResearch for Environment Bay of Plenty.

MfE, 2016a. Reforming how we manage fresh water - an overview. In: Ministry for the Environment. http://www.mfe.govt.nz/fresh-water/reform-programme/reforming-how-wemanage-fresh-water Accessed 8 November 2016.

MFE, 2013. Freshwater reform 2013 and beyond. Ministry for the Environment, Wellington. MfE, 2016b. Regional councils' implementation programmes. In: Ministry for the Environment. http://www.mfe.govt.nz/fresh-water/national-policy-statement/regionalcouncils-implementation-programmes Accessed 8 November 2016.

Mishra, A., B. L. Benham \& S. Mostaghimi, 2006. Sediment and nutrient losses from fieldscale cropland plots treated with animal amnure and inorganic fertilizer. Water, Air, and Soil Pollution 175:61-76.

Mitchell, C., 2017. 'The fight will continue': Water quality to remain an issue under new National Government. In: Stuff.co.nz.

https://www.stuff.co.nz/environment/96869562/water-nat-lead-the-fight-will-continuewater-quality-to-remain-an-issue-under-new-national-government Accessed 24 September 2017. 
Mitsch, W. J. \& J. G. Gosselink, 2007. Wetlands, Fourth Edition edn. John Wiley \& Sons, Hoboken.

Moir, J. L., K. C. Cameron, H. J. Di \& U. Fertsak, 2011. The spatial coverage of dairy cattle urine patches in an intensively grazed pasture system. Journal of Agricultural Science 149:473-485.

Monaghan, R. M., P. L. Carey, R. J. Wilcock, J. J. Drewry, D. J. Houlbrooke, J. M. Quinn \& B. S. Thorrold, 2009. Linkages between land management activities and stream water quality in a border dyke-irrigated pastoral catchment. Agriculture, Ecosystems and Environment 129:201-211.

Monaghan, R. M. \& C. A. M. De Klein, 2014. Integration of measures to mitigate reactive nitrogen losses to the environment from grazed pastoral dairy systems. Journal of Agricultural Science 152:S45-S56.

Monaghan, R. M., C. A. M. De Klein \& R. W. Muirhead, 2008. Prioritisation of farm scale remediation efforts for reducing losses of nutrients and faecal indicator organisms to waterways: A case study of New Zealand dairy farming. Journal of Environmental Management 87:609-622.

Monaghan, R. M., M. J. Hedley, H. J. Di, R. W. McDowell, K. C. Cameron \& S. F. Ledgard, 2007a. Nutrient management in New Zealand pastures - recent developments and future issues. New Zealand Journal of Agricultural Research 50:181-201.

Monaghan, R. M., D. J. Houlbrooke \& L. C. Smith, 2010a. The use of low-rate sprinkler application systems for applying farm dairy effluent to land to reduce contaminant transfers. New Zealand Journal of Agricultural Research 53:389-402.

Monaghan, R. M., R. J. Paton \& J. J. Drewry, 2002. Nitrogen and phosphorus losses in mole and tile drainage from a cattle-grazed pasture in eastern Southland. New Zealand Journal of Agricultural Research 45:197-205.

Monaghan, R. M., R. J. Paton, L. C. Smith \& C. Binet, 2000. Nutrient losses in drainage and surface runoff from a cattle-grazed pasture in Southland. Proceedings of the New Zealand Grassland Association 62:99-104. 
Monaghan, R. M., R. J. Paton, L. C. Smith, J. J. Drewry \& R. P. Littlejohn, 2005. The impacts of nitrogen fertilisation and increased stocking rate on pasture yield, soil physical condition and nutrient losses in drainage from a cattle-grazed pasture. New Zealand Journal of Agricultural Research 48:227-240.

Monaghan, R. M., A. Semadeni-Davies, R. W. Muirhead, S. Elliott \& U. Shankar, 2010b. Land use and land management risks to water quality in Southland. AgResearch.

Monaghan, R. M. \& L. C. Smith, 2004. Minimising surface water pollution resulting from farm-dairy effluent application to mole-pipe drained soils. II. The contribution of preferential flow of effluent to whole-farm pollutant losses in subsurface drainage from a West Otago dairy farm. New Zealand Journal of Agricultural Research 47:417-428.

Monaghan, R. M., R. J. Wilcock, L. C. Smith, B. Tikkisetty, B. S. Thorrold \& D. Costall, 2007b. Linkages between land management activities and water quality in an intensively farmed catchment in southern New Zealand. Agriculture, Ecosystems and Environment 118.

MONERIS, 2017. MONERIS-Projects. In. http://www.moneris.igb-

berlin.de/index.php/projects-worldwide.html Accessed 31 August 2017.

Morgenstern, U. \& D. Gordon, 2006. Prediction of Future Nitrogen Loading to Lake Rotorua. GNS Science Report, 28.

Myers, S. C., B. R. Clarkson, P. N. Reeves \& B. D. Clarkson, 2013. Wetland management in New Zealand: Are current approaches in policies sustaining wetland ecosystems in agricultural landscapes? Ecological Engineering 56:107-120.

Neary, D. G., 1978. Management Impacts on Nutrient Fluxes in Beech-Podocarp-Hardwood Forests. New Zealand Journal of Ecology 1:19-26.

Neset, T. S. \& D. Cordell, 2012. Global phosphorus scarcity: identifying synergies for a sustainable future. Journal of the Science of Food and Agriculture 92(1):2-6.

LCDB v4.1 - Land Cover Database version 4.1, Mainland New Zealand 2012. Landcare Research. https://Iris.scinfo.org.nz/layer/423-Icdb-v41-land-cover-database-version-41mainland-new-zealand/. 
NIWA, 2017. National River Water Quality Network (NRWQN). In.

https://www.niwa.co.nz/freshwater/water-quality-monitoring-and-advice/national-riverwater-quality-network-nrwan Accessed 08 March 2017.

NIWA, 2015. CLUES - Catchment Land Use for Environmental Sustainability model. In: National Institute of Water and Atmospheric Research. https://www.niwa.co.nz/freshwaterand-estuaries/our-services/catchment-modelling/clues-\%E2\%80\%93-catchment-land-usefor-environmental-sustainability-model Accessed 14 Jan 20152015.

Norris, M., P. Johnstone, S. Green, G. van der Klei, C. van den Dijssel, P. Wright, G. Clark, S. Thomas, D. Mathers \& A. Halliday, Rootzone Reality - a Network of Fluxmeters Measuring Nutrient Losses Under Cropping Rotations. Summary of Year 1 and Year 2 Results. In: Currie, L. D. \& M. J. Hedley (eds) Science and policy: nutrient management challenges for the next generation, Massey University, Palmerston North, 2017. Fertilizer and Lime Research Centre.

Northland Regional Council, 2016. Effluent reduction model could be dairying 'game changer'.

NZ Govt, 2016. New Zealand Economic and Financial Overview 2016. New Zealand Treasury, Wellington.

NZ Govt, 2014. National Policy Statement for Freshwater Management 2014. New Zealand Government, Wellington.

NZ Govt, 2017. National Policy Statement for Freshwater Management 2014: Updated August 2017 to incoprorate amendments from the National Policy Statement for Freshwater Amendment Order 2017. New Zealand Government, Wellington.

Omernik, J. M., 1976. The Influence of Land Use on Stream Nutrient Levels U.S. Environmental Protection Agency, Corvallis OR.

Ongley, E. D., Z. Xiaolan \& Y. Tao, 2010. Current status of agricultural and rural non-point source pollution assessment in China. Environmental Pollution 158:1159-1168.

OVERSEER, 2017a. OVERSEER Nutrient Budgets. In. http://overseer.org.nz/ Accessed 15 March 2017. 
OVERSEER, 2017b. OVERSEER Technical Information: Technical Manual Chapters. In. http://overseer.org.nz/technical-information Accessed 17 March 2017.

Owens, L. B., R. W. Van Keuren \& W. M. Edwards, 2003. Non-Nitrogen Nutrient Inputs and Outputs for Fertilized Pastures in Silt Loam Soils in Four Small Ohio Watersheds. Agriculture, Ecosystems and Environment 97:117-130.

Parfitt, R. L., G. J. Salt \& L. F. Hill, 2002. Clear-cutting reduces nitrate leaching in a pine plantation of high natural N status. Forest Ecology and Management 170:43-53.

Parfitt, R. L., L. A. Schipper, W. T. Baisden \& A. Elliot, 2006. Nitrogen inputs and outputs for New Zealand in 2001 at national and regional scales. Biogeochemistry 80:71-88.

Parfitt, R. L., B. A. Stevenson, J. R. Dymond, L. A. Schipper, W. T. Baisden \& D. J. Ballantine, 2012. Nitrogen inputs and outputs for New Zealand from 1990 to 2010 at national and regional scales. New Zealand Journal of Agricultural Research 55(3):21-262.

Parkyn, S. M., 2004. Review of Riparian Buffer Zone Effectiveness. Ministry of Agriculture and Forestry, Wellington.

Parkyn, S. M., R. J. Davies-Colley, N. J. Halliday, K. J. Costley \& G. F. Croker, 2003. Planted Riparian Buffer Zones in New Zealand: Do They Live Up to Expectations? Restoration Ecology 11(4):436-447.

Parshotam, A., S. Elliott, U. Shankar \& S. Wadhwa, 2013. National nutrient mapping using the CLUES model. Prepared by NIWA for the Parliamentary Commissioner for the Environment, Hamilton.

Pattnaik, R., R. S. Yost, G. Porter, T. Masunaga \& T. Attanandana, 2007. Improving multi-soillayer (MSL) system remediation of dairy effluent. Ecological Enginering 32:1-10.

Paul, E. A. (ed) 2007. Soil Microbiology, Ecology, and Biochemistry. Elsevier, Amsterdam. PCE, 2013. Water quality in New Zealand: Land use and nutrient pollution. Parliamentary Commissioner for the Environment, Wellington, 82.

PCE, 2015a. Water quality in New Zealand: Land use and nutrient pollution - Update Report. Parliamentary Commissioner for the Environment, Wellington. 
PCE, 2015b. Update Report - Water quality in New Zealand: Land use and nutrient pollution. Parliamentary Commissioner for the Environment, Wellington.

Pechlivanidis, I. G., B. M. Jackson, N. R. McIntyre \& H. S. Wheater, 2011. Catchment Scale Hydrological Modelling: A Review of Model Types, Calibration Approaches and Uncertainty Analysis Methods in the Context of Recent Developments in Technology and Applications. Global NEST Journal 13(3):193-214.

Peryer-Fursdon, J., Unknown. Detainment Bund Hydrology Review. In: Rotorua Te Arawa Lakes Programme. http://www.rotorualakes.co.nz/vdb/document/723 Accessed 03 February 2017.

Peryer-Fursdon, J., J. M. Abell, D. Clarke, D. Ozkundakci, D. P. Hamilton \& L. Pearson, 2015. Spatial variability in sediment phosphorus characterisitics along a hydrological gradient upstream of Lake Rotorua, New Zealand. Environmental Earth Science 73:1573-1585.

Peters, M. \& B. Clarkson (eds), 2010. Wetland restoration: a handbook for New Zealand freshwater systems. Manaaki Whenua Press, Lincoln.

Piddock, G., 2015. Wetland development future-proofs farm. In: Stuff.co.nz. http://www.stuff.co.nz/business/farming/67758755/wetland-development-futureproofs$\underline{\text { farm. }}$.

Pollok, J. \& B. McLaughlin, 1986. A user-friendly guide to the soils of Tuapaka Farm, vol Publication No. 3. Massey University Tuapaka Farm Series, Palmerston North.

Power, I. L., S. F. Ledgard \& R. M. Monaghan, 2002. Nutrient Budgets for Three Mixed Farming Catchments in New Zealand. MAF, Wellingtob.

Praat, J., J. Sukias, T. Faulkner \& A. Bichan, 2015. Benefits and costs of a constructed wetland on a Wairarapa dairy farm. Journal of New Zealand Grasslands 77:173-176.

Price, S. J., R. R. Sherlock, F. M. Kelliher, T. M. McSeveny, K. R. Tate \& L. M. Condron, 2003. Pristine New Zealand forest soil is a strong methane sink. Global Change Biology 10:16-26.

Puha, M. R., W. M. King, V. T. Burggraaf \& A. H. C. Roberts, 2008. Pasture production gains from strategic winter nitrogen applications on a North Island sheep and beef hill country farm. Proceedings of the New Zealand Grassland Association 70:117-121. 
Quinn, J. M. \& M. J. Stroud, 2002. Water quality and sediment and nutrient export from New Zealand hill-land catchments of contrasting land use. New Zealand Journal of Marine and Freshwater Research 36:409-429.

Rabotyagov, S. S., C. L. Kling, P. W. Gassman, N. N. Rabalais \& R. E. Turner, 2014. The Economics of Dead Zones: Causes, Impacts, Policy Challenges, and a Model of the Gulf of Mexico Hypoxic Zone. Review of Environmental Economics and Policy 8(1):58-79.

Radcliffe, D. E., J. Freer \& O. Schoumans, 2009. Diffuse Phosphorus Models in the United States and Europe: Their Usages, Scales, and Uncertainties. Journal of Environmental Quality 38:1956-1967.

Radio NZ, 2017a. 'Sad and frightening' One Plan issues - Horizons chair. In: Radio New Zealand. http://www.radionz.co.nz/news/country/336926/sad-and-frightening-one-planissues-horizons-chair Accessed 10 August 2017.

Radio NZ, 2017b. Farmers pledge to improve water - but how? In: Radio NZ.

http://www.radionz.co.nz/national/programmes/ninetonoon/audio/201855769/farmerspledge-to-improve-water-but-how Accessed 23 August 2017.

Rast, W. \& G. F. Lee, 1983. Nutrient loading estimates for lakes. Journal of Environmental Engineering 109(2):502-517.

Ravensdown, 2016. Products - Fertiliser. In.

http://www.ravensdown.co.nz/products/fertiliser Accessed 17 October 2016.

Reckhow, K. H., M. N. Beaulac \& J. T. Simpson, 1980. Modeling Phosphorus Loading and Lake Response Under Uncertainty a Manual and Compilation of Export Coefficients. U.S. Environmental Protection Agency, Washington D.C.

Renouf, K. \& J. S. Harding, 2015. Characterising riparian buffer zones of an agriculturally modified landscape. New Zealand Journal of Marine and Freshwater Research 49(3):323332.

Risk, J. T., A. B. Old, G. R. Peyroux, M. Brown, H. Yoswara, D. M. Wheeler, G. M. Lucci \& R. W. McDowell, 2015. MitAgator - in action solutions for managing nitrogen, phosphorus, 
sediment and E.coli loss. In: Currie, L. D. \& L. L. Burkitt (eds) Moving farm systems to improved attenuation. Fertilizer and Lime Research Centre, Palmerston North, 7.

Roach, C. G., R. D. Longhurst \& S. F. Ledgard, 2001. Land application of farm dairy effluent for sustainable dairy farming. Proceedings of the New Zealand Grassland Association 63:5357.

Roberts, T. L., 2007. Right product, right rate, right time and right place ... the foundation of best management practices for fertilizer. In: International Plant Nutrition Institute. http://www.ipni.net/ipniweb/portal/4r.nsf/0/A48058320B3F0BF785257DF100726184/\$FFILE Roberts 2007 4Rs.pdf.

Roberts, W. M., M. I. Stutter \& P. M. Haygarth, 2012. Phosphorus Retention and Remobilization in Vegetated Buffer Strips: A Review. Journal of Environmental Quality 41:389-399.

Robertson, G. P. \& P. M. Groffman, 2007. Nitrogen Transformations. In Paul, E. A. (ed) Soil Microbiology, Ecology, and Biochemistry. Elsevier, Amsterdam, 341-364.

Robinson, D. A., B. M. Jackson, B. E. Clothier, E. J. Dominati, S. C. Marchant, D. M. Cooper \& K. L. Bristow, 2013. Advances in Soil Ecosystem Services: Concepts, Models, and Applications for Earth System Life Support. Vadose Zone Journal 12(2).

Robinson, T. H. \& J. M. Melack, 2013. Modeling nutrient export from coastal California watersheds. Journal of the American Water Resources Association 48(4):793-809.

Rockström, J., W. Steffen, K. Noone, A. Persson, F. S. Chapin, E. Lambin, T. M. Lenton, M. Scheffer, C. Folke, H. J. Schellnhuber, B. Nykwist, C. A. de Wit, T. Hughes, S. van der Leeuw, H. Robhe, S. Sorlin, P. K. Snyder, R. Costanza, U. Svedin, M. Falkenmark, L. Karlberg, R. W. Corell, V. J. fabry, J. Hansen, B. Walker, D. Liverman, K. Richerdson, P. Crutzen \& J. Foley, 2009. Planetary Boundaries: Exploring the Safe Operating Space for Humanity. Ecology and Society $14(2)$.

Rosen, M. R., R. R. Reeves, S. Green, B. Clothier \& N. Ironside, 2004. Prediction of Groundwater Nitrate Contamination After Closure of an Unlined Sheep Feedlot. Vadose Zone Journal 3(3):990-1006. 
Rotorua Te Arawa Lakes Strategy Group, 2016. Lake Rotorua. In.

http://www.rotorualakes.co.nz/rotorua Accessed 06January 2016.

Rotorua Te Arawa Lakes Strategy Group, 2017. Detainment bunds. In.

http://www.rotorualakes.co.nz/detainment-bunds.

Rotz, C. A., F. Taube, M. P. Russelle, J. Oenema, M. A. Sanderson \& M. Wachendorf, 2005. Whole-Farm Perspectives of Nutrient Flows in Grassland Agriculture. Crop Science 45(6):2139-2159.

Rutherford, J. C., R. B. Williamson \& A. B. Cooper, 1987. Nitrogen, phosphorus, and oxygen dynamics in rivers. In Viner, A. B. (ed) Inland Water of New Zealand. Department of Scientific and Industrial Research, Wellington, 139-166.

Rutherford, K., 2012. Modelling the effects of land use on nutrients entering the Tukituki River, Hawkes Bay. National Institute of Water \& Atmospheric Research, Hamilton.

Rutherford, K., C. Palliser \& S. Wadhwa, 2009. Nitrogen exports for the Lake Rotorua catchment - calibration of the ROTAN model. National Institute of Water and Atmospheric Research, Hamilton.

Rutherford, K., C. Palliser \& S. Wadhwa, 2011. Prediction of nitrogen loads to Lake Rotorua using the ROTAN model. National Institute of Water and Atmospheric Research, Hamilton.

Rutherford, K. \& D. Wheeler, Wetland Nitrogen Removal Modules in Overseer. In: Currie, L. D. \& C. L. Christensen (eds) Adding to the knowledge base for the nutrient manager, Massey University, Palmerston North, New Zealand, 2011. vol Occassional Report No. 24. Fertilizer and Lime Research Centre.

Rutledge, D., R. Price, C. Briggs \& S. Cowell, 2009. Geospatial Land-use Classification for New Zealand: Review and Recommendations. vol 5. Official Statistics Research, Statistics New Zealand, Wellington, 54.

Ruz-Jerez, B. E., R. E. White \& P. R. Ball, 1995. A comparison of nitrate leaching under clover based pastures and nitrogen-fertilized grass grazed by sheep. Journal of Agricultural Science 125:361-369. 
Saggar, S., N. S. Bolan, R. Bhandral, C. B. Hedley \& J. Luo, 2004. A review of emissions of methane, ammonia, and nitrous oxide from animal excreta deposition and farm effluent application in grazed pastures. New Zealand Journal of Agricultural Research 47:513-544.

Saggar, S., A. D. MacKay, M. J. Hedley, M. G. Lambert \& D. A. Clark, 1990. A NutrientTransfer Model to Explain the Fate of Phosphorus and Sulphur in a Grazed Hill-Country Pasture. Agriculture, Ecosystems and Environment 30:295-315.

Schoumans, O. F., M. Silgram, D. J. J. Walvoort, P. Groenendijk, F. Bouraoui, H. E. Anderson, A. Lo Porto, H. reisser, G. Le Gall, S. G. Anthony, B. Arheimer, H. Johnsson, Y. Panagopoulos, M. Mimikou, U. Zweynert, H. Behrendt \& A. Barr, 2009. Evaluation of the difference of eight model applications to assess diffuse annual nutrient losses from agricultural land. Journal of Environmental Monitoring 11:540-553.

Schwarz, G. E., A. B. Hoos, R. B. Alexander \& R. A. Smith, 2006. The SPARROW Surface Water-Quality Model: Theory, Application and User Documentation. U.S. Geological Survey. Scott, N. A., 2015. Facilitating Land-Use Decisions through the Modelling of Ecosystem Service Trade-offs. Victoria University of Wellington.

Sebestyen, S. D., J. B. Shanley, E. W. Boyer, C. Kendall \& D. H. Doctor, 2014. Coupled hydrological and biogeochemical processes controlling variability of nitrogen species in streamflow during autumn in an upland forest. Water Resources Research 50:1569-1591.

Selbie, D. R., E. Buckthought \& M. A. Shepherd, 2015. Chapter Four - The Challenge of the Urine Patch for Managing Nitrogen in Grazed Pasture Systems. Advances in Agronomy 129:229-292.

Semadeni-Davies, A. \& A. Elliot, 2014. CLUES modelling of E. coli concentrations in the Waikato and Waipa River catchments. Paper presented at the 21st Century Watershed Technology Conference, Waikato University, Hamilton, New Zealand, 1-6 Nov 2014.

Semadeni-Davies, A., S. Elliott \& U. Shankar, 2016. CLUES - Catchment Land Use for Environmental Sustainability User Manual. Fifth Edition: CLUES 10.3 edn. National Institute of Water and Atmospheric Research, Auckland. 
Semadeni-Davies, A., A. Hughes \& S. Elliott, 2015. Assessment of the CLUES model for the implementation of the National Policy Statement on Freshwater Management in the Auckland region. Prepared by NIWA for Auckland Council.

Sharpley, A. N., 2016. Managing agricultural phosphorus to minimize water quality impacts. Scientia Agricola 73(1):1-8.

Sharpley, A. N., H. P. Jarvie, A. Buda, L. May, B. Spears \& P. Kleinman, 2013. Phosphorus Legacy: Overcoming the Effects of Past Management Practices to Mitigate Future Water Quality Impairment. Journal of Environmental Quality 42(1308-1326).

Sharpley, A. N., P. J. A. Kleinman, R. W. McDowell, M. Gitau \& R. B. Bryant, 2002. Modeling phosphorus transport in agricultural watersheds: Processes and possibilities. Journal of Soil and Water Conservation 57(6).

Sharpley, A. N. \& J. K. Syers, 1979. Phosphorus inputs into a stream draining an agricultural watershed. Water, Air, and Soil Pollution 11:417-428.

Sharps, K., D. Masante, A. Thomas, B. Jackson, J. Redhead, L. May, H. Prosser, B. Cosby, B. Emmett \& L. Jones, 2017. Comparing strengths and weaknesses of three ecosystem services modelling tools in a diverse UK river catchment. Science of the Total Environment 584585:118-130.

Shen, Z., Q. Liao, Q. Hong \& Y. Gong, 2012. An overview of research on agricultural nonpoint source pollution modelling in China. Separation and Purification Technology 84:104111.

Shepherd, M. \& G. Lucci, Fertiliser advice - what progress can we make? In: Currie, L. D. \& C. L. Christensen (eds) 24th Annual FLRC Workshop, Massey University, Palmerston North, 2011. Fertilizer and Lime Research Centre.

Shi, J., R. Davis \& J. Densham, 2006. Better Land for Better Water: Modelling land-use change to improve water quality in England. RSPB, WWF, Water UK, UK, 77.

Shrestha, S., F. Kazama \& L. T. H. Newham, 2008. A framework for estimating pollutant export coefficients from long-term in-stream water quality monitoring data. Environmental Modelling and Software 23:182-194. 
Silva, R., K. Cameron, H. Di \& T. Hendry, 1999. A lysimeter study of the impact of cow urine, dairy shed effluent and nitrogen fertilizer on drainage water quality. Australian Journal of Soil Research 37:357-369.

Sims, J. T., R. R. Simard \& B. C. Joern, 1998. Phosphorus Loss in Agricultural Drainage: Historical Perspective and Current Research. Journal of Environmental Quality 27(2):277293.

Singh, R., A. Elwan, D. J. Horne, A. Manderson, M. Patterson \& J. Roygard, Predicting LandBased Nitrogen Loads and Attenuation in the Rangitikei River Catchment - The Model Development. In: Currie, L. D. \& M. J. Hedley (eds) Science and Policy: Nutrient Management Challenges for the Next Generation, Massey University, Palmerston North, 2017. Fertilizer and Lime Research Centre.

Singleton, P. L., C. D. A. McLay \& G. F. Barkle, 2001. Nitrogen leaching from soil lysimeters irrigated with dairy shed effluent and having managed drainage. Australian Journal of Soil Research 39:385-396.

SMHI, S. M. a. H. I., 2017. HYPE. In: Swedish Meteorological and Hydrological Institute. https://www.smhi.se/en/research/research-departments/hydrology/hype-1.7994 Accessed 01 September 2017.

Smith, C. M., 1989. Riparian pasture retirement effects on sediment, phosphorus, and nitrogen in channellised surface run-off from pastures. New Zealand Journal of Marine and Freshwater Research 23:139-146.

Smith, J. \& P. Smith, 2007. Environmental Modelling An Introduction. Oxford University Press, Oxford.

Smith, K. A. \& J. P. Frost, 2000. Nitrogen excretion by farm livestock with respect to land spreading requirements and controlling nitrogen losses to ground and surface waters. Part 1: cattle and sheep. Bioresource Technology 71:173-181.

Snow, V. O., I. R. Johnson \& A. J. Parsons, 2009. The single heterogeneous paddock approach to modelling the effects of urine patches on production and leaching in grazed pastures. Crop \& Pasture Science 60:691-696. 
Soranno, P. A., K. S. Cheruvelil, E. G. Bissell, M. T. Bremigan, J. A. Downing, C. E. Fergus, C. T. Filstrup, E. N. Henry, N. R. Lottig, E. H. Stanley, C. A. Stow, P. Tan, T. Wagner \& K. E. Webster, 2014. Cross-scale interactions: quantifying multi-scale cause-effect relationships in macrosystems. Front Ecol Environ 12(1):65-73.

Sprosen, M. S., S. F. Ledgard \& E. R. Thom, 1997. Nitrate leaching is similar in N2-fixing grassclover pasture and $\mathrm{N}$-fertilised grass-only pasture at similar $\mathrm{N}$ inputs. Proceedings of the New Zealand Grassland Association 59:125-128.

Stafford, A. \& G. Peyroux, 2013. Clearview (Ballance PGP) - a First Look at Solutions for Improving Nitrogen and Phosphorus Management. Paper presented at the 26th Annual FLRC Workshop, Massey University, Palmerston North.

Statistics NZ, 2012. Agricultural Production Statistics. In: Statistics New Zealand.

www.sttats.govt.nz/browse for stats/industry sectors/agriculture horticulture forestry/2 012-agricultural-census-tables.aspx\# Accessed 15 May 2015.

StatisticsNZ, 2016. Urban and rural migration. In: Statistics New Zealand. http://www.stats.govt.nz/browse for stats/population/Migration/internalmigration/urban-rural-migration.aspx Accessed 12 July 2016.

Steffen, W., K. Richardson, J. Rockström, S. E. Cornell, I. Fetzer, E. M. Bennett, R. Biggs, S. R. Carpenter, W. de Vries, C. A. de Wit, C. Folke, D. Gerten, J. Heinke, G. M. Mace, L. M. Persson, V. Ramanathan, B. Reyers \& S. Sorlin, 2015. Planetary boundaries: Guiding human development on a changing planet. Science 347(6223).

Sukias, J. P. S., C. C. Tanner, R. J. Davies-Colley, J. W. Nagels \& R. Wolters, 2001. Algal abundance, organic matter, and physico-chemical characteristics of dairy farm facultative ponds: implications for treatment performance. New Zealand Journal of Agricultural Research 44:279-296.

SWAT, 2017. SWAT Soil \& Water Assessment Tool. In. http://swat.tamu.edu/ Accessed 03 May 2017.

Tait, A., R. Henderson, R. Turner \& X. Zheng, 2006. Thin plate smoothing spline interpolation of daily rainfall for New Zealand using a climatological rainfall surface. International Journal of Climatology:2097-2115. 
Tanner, C. C., 1996. Plants for constructed wetland treatment systems - A comparison of the growth and nutrient uptake of eight emergent species. Ecological Engineering 7:59-83.

Tanner, C. C., 2013. Bottoms or tops? - Optimising location of wetlands in catchments to maximise efficiency. Paper presented at the 26th Annual Fertiliser and Lime Research Centre, Massey University, Palmerston North.

Tanner, C. C., J. S. Clayton \& M. P. Upsdell, 1995. Effect of Loading Rate and Planting on Treatment of Dairy Farm Wastewaters in Constructed Wetlands - II, Removal of Nitrogen and Phosphorus. Water Resources 29(1):27-34.

Tanner, C. C. \& V. C. Kloosterman, 1997. Guidelines for Constructed Wetland Treatment of Farm Dairy Wastewaters in New Zealand. NIWA.

Tanner, C. C., M. L. Nguyen \& J. P. S. Sukias, 2005. Nutrient removal by a constructed wetland treating subsurface drainage from grazed dairy pasture. Agriculture, Ecosystems and Environment 105:145-162.

Tanner, C. C., J. Sukias \& D. F. Burger, Realising the Value of Remnant Farm Wetlands as Attenuation Assets. In: Currie, L. D. \& L. L. Burkitt (eds) 28th Annual FLRC Workshop, Moving Farm Sytems to Improved Attenuation, Massey University Palmerston North, 2015. Fertilizer \& Lime Research Centre.

Tanner, C. C. \& J. P. S. Sukias, 2011. Multiyear Nutrient Removal Performance of Three Constructed Wetlands Intercepting Tile Drain Flows from Grazed Pasture. Journal of Environmental Quality 40:620-633.

Tanner, C. C., J. P. S. Sukias \& M. P. Upsdell, 1999. Substratum Phosphorus Accumulation During Maturation of Gravel-bed Constructed Wetlands. Water Science Technology 40(3):147-154.

Tanner, C. C., J. P. S. Sukias \& C. R. Yates, 2010. New Zealand Guidelines: Constructed Wetland Treatment of Tile Drainage. National Institute of Water and Atmospheric Research.

Taranaki Regional Council, 2016a. Riparian Management. In: Taranaki Regional Council. http://www.trc.govt.nz/environment/freshwater/riparian-management/ Accessed 26 August 2016. 
Taranaki Regional Council, 2016b. Plants for riparian margins. In: Taranaki Regional Council. https://www.trc.govt.nz/assets/Documents/Guidelines/Land-infosheets/LM25plants-forriparian-margins09.pdf Accessed 26 August 2016.

Te Ara, 2016. Rotorua City. In: Te Ara Encyclopedia of New Zealand. http://www.teara.govt.nz/en/volcanic-plateau-places/page-4 Accessed 16 June 2016. Tempero, G., C. McBride, J. Abell \& D. Hamilton, 2015. Anthropogenic Phosphorus Loads to Lake Rotorua. The University of Waikato, Hamilton.

Thompson, S., I. Gruner \& N. Gapare, 2003. New Zealand Land Cover Database Version 2: Illustrated Guide to Target Classes. Ministry for the Environment, Wellington, 126.

Timar, L., 2016. Yield to Change: Modelling the Land-use Response to Climate-Driven Changes in Pasture Production. Motu Economic and Public Policy Research, Wellington, 29. Trodahl, M., L. Burkitt, M. Bretherton, J. Deslippe, B. Jackson \& A. Metherell, Developing N \& P Export Coefficients for Rural Landscape Modelling in LUCI. In: Currie, L. D. \& M. J. Hedley (eds) Science and policy: nutrient management challenges for the next generation, Massey University, Palmerston North, 2017a. vol Occasional Report No. 30. Fertilizer and Lime Reserach Centre.

Trodahl, M., J. R. Deslippe \& B. Jackson, Improving predictions of N \& P export to waterways from rural landscapes in New Zealand using LUCI. In: Currie, L. D. \& R. Singh (eds) Integrated nutrient and water management for sustainable farming, Palmerston North, 2016. $\mathrm{p} 7$.

Trodahl, M. I., B. M. Jackson, J. R. Deslippe \& A. K. Metherell, 2017b. Investigating trade-offs between water quality and agricultural productivity using the Land Utilisation and Capability Indicator (LUCI) - A New Zealand application. Ecosystem Services:388-399.

Tsakiris, G. \& D. Alexakis, 2012. Water quality models: An overview. European Water 37:3346.

Udawatta, R. P., J. J. Krstansky, G. S. Henderson \& H. E. Garrett, 2002. Agroforestry Practices, Runoff, and Nutrient Loss: A Paired Watershed Comparison. Journal of Environmental Quality 31(4). 
Uncles, R. J., A. I. Fraser, D. Butterfield, P. J. Johnes \& T. R. Harrod, 2002. The prediction of nutrients into estuaries and their subsequent behaviour: application to the Tamar and comparison with the Tweed, U.K. Hydrobiologia 475/476.

University of Delaware, 2017. Nitrogen Cycling in Agriculture. In.

http://extension.udel.edu/factsheets/nitrogen-cycling-in-agriculture/ Accessed 04 May 2017.

University of Idaho, 2016. The Textural Triangle. In. http://oneplan.org/Water/soiltriangle.asp 2016.

USGS, 2009. SPARROW MODELING - Enhancing Understanding of the Nation's Water Quality. In. https://pubs.usgs.gov/fs/2009/3019/pdf/fs 2009 3019.pdf.

Uttormark, P. D., J. D. Chapin \& K. M. Green, 1974. Estimating Nutrient Loadings of Lakes from Non-Point Sources. U.S. Environmental Protection Agency, Washington D.C., 112. van Groenigen, J. W., D. Huygens, P. Boeckx, T. W. Kuyper, I. M. Lubbers, T. Rutting \& P. M. Groffman, 2015. The soil N cycle: new insights and key challenges. Soil 1:235-256.

Vassiljev, A., I. Blinova \& P. Ennet, 2008. Source apportionment of nutrients in Estonian rivers. Desalination 226:222-230.

Venohr, M., U. Hirt, J. Hofmann, D. Opitz, A. Gericke, A. Wetzig, S. Natho, F. Neumann, J. Hurdler, M. Matranga, J. Mahnkopf, M. Gadegast \& H. Behrendt, 2011. Modelling of Nutrient Emissions in River Systems - MONERIS - Methods and Background. International Review Hydrobiology 96(5):435-483.

Vervoort, R. W., M. L. Radcliffe, M. L. Cabrera \& M. Latimore, 1998. Field-Scale Nitrogen and Phosphorus Losses From Hayfields Receiving Fresh and Composted Broiler Litter. Journal of Environmental Quality 27:1246-1254.

Vitousek, P. M., J. D. Aber, R. W. Howarth, G. E. Likens, P. A. Matson, D. W. Schindler, W. H. Schlesinger \& D. G. Tilman, 1997. Human Alteration of the Global Nitrogen Cycle: Sources and Consequences. Ecological Applications 7(3):737-750. 
Vollenweider, R. A., 1968. Scientific fundamentals of stream and lake eutrophication, with particular reference to nitrogen and phosphorus. Organization for Economic Co-operation and Development Paris.

Wade, A. J., P. G. Whitehead \& L. C. M. O'Shea, 2002. The prediction and management of aquatic nitrogen pollution across Europe: an introduction to the Integrated Nitrogen in European Catchments project (INCA). Hydrology and Earth System Sciences 6(3):299-313. Waikato Regional Council, 2016a. Fencing streams and rivers. In: Waikato Regional Council. http://www.waikatoregion.govt.nz/Environment/Natural-resources/Land-andsoil/Managing-Land-and-Soil/Managing-farm-runoff/Fencing-streams-and-rivers/ Accessed 26 August 2016.

Waikato Regional Council, 2015. Nutrient Management. In: Waikato Regional Council. http://www.waikatoregion.govt.nz/PageFiles/30016/factsheets/CNM\%20factsheet\%20nutri ent\%20management\%20plans 10.pdf Accessed 26 August 2016.

Waikato Regional Council, 2016b. Planting Guides. In.

http://www.waikatoregion.govt.nz/Environment/Natural-resources/Biodiversity/Plantingguides/ Accessed 29 August 2016.

Wang, H., G. N. Magesan \& N. S. Bolan, 2004. An overview of the environmental effects of land application of farm effluents. New Zealand Journal of Agricultural Research 47:389-403.

Wang, J., J. Shao, D. Wang, J. Ni \& D. Xie, 2015. Simulation of the dissolved nitrogen and phosphorus loads in different land uses in the Three Gorges Reservoir Region - based on the improved export coefficient model. Environmental Science: Processes \& Impacts 17:1976.

Watkins, N. \& D. Selbie, 2015. Technical Description of OVERSEER for Regional Councils. Report for Bay of Plenty regional Council.

Webb, T. H., L. R. Lilburne \& G. S. Francis, 2001. Validation of the GLEAMS simulation model for estimating net nitrogen mineralisation and nitrate leaching under cropping in Canterbury, New Zealand. Australian Journal of Soil Research 39:1015-1025. 
Wellen, C., A. Kamran-Disfani \& G. B. Arhonditsis, 2015. Evaluation of the Current State of Distributed Watershed Nutrient Water Quality Modeling. Environmental Science \& Technology 49:3278-3290.

Wheeler, D., 2016a. OVERSEER Technical Manual: Charateristics of Soils. AgResearch. Wheeler, D., 2016b. OVERSEER Technical Manual: Hydrology. AgResearch. Wheeler, D., 2016c. OVERSEER Technical Manual: Introduction. AgResearch, Hamilton. Wheeler, D., R. Cichota, V. Snow \& M. Shepherd, A revised leaching model for Overseer nutrient budgets. In: Currie, L. D. \& C. L. Christensen (eds) Adding to the knowledge base for the nutrient manager, Massey University Palmerston North, 2011. vol Occasional Report No. 24. Fertilizer and Lime Research Centre.

Wheeler, D. M., 2016d. OVERSEER Technical Manual: Characteristics of Pasture. AgResearch. White, M., M. Gambone, H. Yen, P. Daggupati, K. Bieger, D. Deb \& J. Arnold, 2016. Development of a cropland management dataset to support U.S. SWAT assessments. Journal of the American Water Resources Association 52(1):269-274.

White, M., D. Harmel, H. Yen, J. G. Arnold, M. Gambone \& R. Haney, 2015. Development of sediment and nutrient export coefficients for U.S. Ecoregions. Journal of the American Water Resources Association 51(3):758-775.

White, P. A., S. G. Cameron, G. N. Kilgour, E. Mroczek, G. Bignall, C. Daughney \& R. R. Reeves, 2004. Review of groundwater in the Lake Rotorua catchment. Institute of Geological \& Nuclear Sciences.

White, P. A., A. Lovett, C. Tschrittler \& M. Cusi, 2014. Lake Rotorua catchment boundary relevant to Bay of Plenty Regional Council's water and land management policies. GNS Science, 99.

White, P. J. \& J. P. Hammond, 2009. The Sources of Phosphorus in the Waters of Great Britain. Journal of Environmental Quality 38:13-26.

Whitehead, P. G., H. M. Baulch, D. A. Butterfield, S. K. Oni, P. J. Dillon, M. Futter, A. J. Wade, R. North, E. M. O'Connor \& H. P. Jarvie, 2011. Modelling phosphorus dynamics in multi- 
branch river systems: A study of the Black River, Lake Simcoe, Ontario, Canada. Science of the Total Environment 412:315-323.

Wijkman, A. \& J. Rockström, 2012. Bankrupting nature: denying our planetary boundaries. Routledge, Abingdon.

Wilcock, R. J., 1986. Agricultural run-off: a source of water pollution in New Zealand? NZ Agricultural Science 20:98-103.

Wilcock, R. J., K. Betteridge, D. Shearman, C. R. Fowles, M. R. Scarsbrook, B. S. Thorrold \& D. Costall, 2009. Riparian protection and on-farm best management practices for restoration of a lowland stream in an intensive dairy farming catchment: a case study. New Zealand Journal of Marine and Freshwater Research 43:803-818.

Wilcock, R. J., R. M. Monaghan, R. W. McDowell, P. Verburg, J. Horrox, C. Chague-Goff, M. J. Duncan, A. Rutherford, G. Zemansky, M. R. Scarsbrook, A. E. Wright-Stow, C. HowardWilliams \& S. Cotton, 2013. Managing pollutant inputs from pastoral dairy farming to maintain water quality of a lake in a high-rainfall catchment. Marine and Freshwater Research 64:447-459.

Wilcock, R. J., R. M. Monaghan, J. M. Quinn, A. M. Campbell, B. S. Thorrold, M. J. Duncan, A. W. McGowan \& K. Betteridge, 2006. Land-use impacts and water quality targets in the intensive dairying catchment of the Toenepi Stream, New Zealand. New Zealand Journal of Marine and Freshwater Research 40:123-140.

Wilcock, R. J., K. Muller, G. B. van Assema, M. A. Bellingham \& R. Ovenden, 2012. Attenuation of Nitrogen, Phosphorus and E. coli Inputs from Pasture Runoff to Surface Waters by a Farm Wetland: the Importance of Wetland Shape and Residence Time. Water Air Soil Pollution 223:499-509.

Wilcock, R. J., J. W. Nagels, H. J. Rodda, M. B. O'Connor, B. S. Thorrold \& J. W. Barnett, 1999. Water quality of a lowland stream in a New Zealand dairy farming catchment. New Zealand Journal of Marine and Freshwater Research 33(4):683-696.

Williams, P. H. \& R. J. Haynes, 1990. Influence of improved pastures and grazing animals on nutrient cycling within New Zealand soils. New Zealand Journal of Ecology 14:49-57. 
Williamson, R. B., 1993. Urban Runoff Data Book. National Institute of Water and Atmospheric Research, Hamilton.

Williamson, R. B. \& J. G. Cooke, 1982. Water quality of the Waiohewa Stream, Rotorua. New Zealand Journal of Marine and Freshwater Research 16(3-4):327-337.

Williamson, R. B., C. M. Smith \& A. B. Cooper, 1996. Watershed Riparian Management and Its Benefits to a Eutrophic Lake. Journal of Water Resources Planning and Management January/February:24-32.

Wilson, H. M., 2005. The Export Coefficient Approach to Prediction of Nutrient Loadings: Errors and Uncertainties in the British Experience. In O'Sullivan, P. E. \& C. S. Reynolds (eds) The Lakes Handbook: Volume 2. Blackwell Publishing, Oxford, 331-353.

Wilson, J., Practical Uses of Smart Technologies. In: Currie, L. D. \& L. L. Burkitt (eds) Moving farm systems to improved attenuation, Massey University, Palmerston North, 2015. Fertilizer and Lime Research Centre.

Winter, J. G. \& H. C. Duthie, 2000. Export Coeffcient Modeling to Assess Phosphorus Loading in an Urban Watershed. Journal of the American Water Resources Association 36(5):10531061.

Woods, R., V. Bidwell, B. Clothier, S. Green, S. Elliott, U. Shankar, S. Harris, A. Hewitt, R. Gibb, R. L. Parfitt \& D. Wheeler, 2006a. The CLUES Project: Predicting the Effects of Land-use on Water Quality - Stage II. NIWA, Christchurch, 106.

Woods, R., S. Elliott, U. Shankar, J. Schmidt, V. Bidwell, J. Bright, S. Harris, D. Wheeler, S. F. Ledgard, B. Clothier, S. Green, A. Hewitt \& R. Gibb, 2004. Predicting the effects of landuse on water quality - Stage 1. National Institute of Water \& Atmospheric Research, Christchurch, 97.

Woods, R., J. Hendrikx, R. Henderson \& A. Tait, 2006b. Estimating mean flow of New Zealand rivers. Journal of Hydrology 45(2):95-110.

Worrall, F. \& T. P. Burt, 1999. The impact of land-use change on water quality at the catchment scale: the use of export coefficient and structural models. Journal of Hydrology 221:75-90. 
Young, C., 2017. Concerns raised over nitrates' effects on babies. In: RadioNZ.

http://www.radionz.co.nz/news/national/341701/concerns-raised-over-nitrates-effects-onbabies Accessed 17 October 2017.

Young, W. J., F. M. Marston \& J. R. Davis, 1996. Nutrient Exports and Land Use in Australian Catchments. Journal of Environmental Management 47:165-183.

Zedler, J. B., 2003. Wetlands at your service: reducing impacts of agriculture at the watershed scale. Frontiers in Ecology and Environment 1(2):65-72.

Zobrist, J. \& P. Reichert, 2006. Bayesian estimation of export coefficients from diffuse and point sources in Swiss watersheds. Journal of Hydrology 329:207-223. 
10 APPENDIX A: CASE STUDY PAPERS 


\title{
Investigating trade-offs between water quality and agricultural productivity using the Land Utilisation and Capability Indicator (LUCI)-A New Zealand application
}

\author{
Martha I. Trodahl ${ }^{\mathrm{a}, \star}$, Bethanna M. Jackson ${ }^{\mathrm{a}}$, Julie R. Deslippe ${ }^{\mathrm{b}}$, Alister K. Metherell ${ }^{\mathrm{c}}$ \\ a School of Geography, Environment \& Earth Sciences, Victoria University of Wellington, New Zealand \\ ${ }^{\text {b }}$ School of Biological Sciences, Victoria University of Wellington, New Zealand \\ ' Ravensdown Ltd., 292 Main South Road, Christchurch, New Zealand
}

\section{A R T I C L E I N F O}

\section{Keywords:}

Land utilisation \& capability indicator

Water quality

Nitrogen

Phosphorus

Agricultural productivity

Trade-offs and synergies

\begin{abstract}
A B S T R A C T
Concern for the impacts of rural land-use intensification on ecosystem services is growing world-wide, especially with regard to water quality management. The Land Utilisation \& Capability Indicator (LUCI) is a GIS framework that considers impacts of land use on multiple ecosystem services in a holistic and spatially explicit manner. Due to its fine spatial scale and focus on the rural environment, LUCI is well-placed to help both farm and catchment managers to explore and quantify spatially explicit solutions to improve water quality while also maintaining or enhancing other ecosystem service outcomes.

LUCI water quality and agricultural productivity models were applied to a catchment in the Bay of Plenty, New Zealand. Nitrogen $(\mathrm{N})$ and phosphorus (P) sources, sinks and pathways in the landscape were identified and trade-offs and synergies between water quality and agricultural productivity were investigated. Results indicate that interventions to improve water quality are likely to come at the expense of agriculturally productive land. Nonetheless, loss of agriculturally productive land can be minimised by using LUCI to identify, at a fine spatial scale, the most appropriate locations for nutrient intervention. Spatially targeted and strategic nutrient source management and pathway interception can improve water quality, while minimising negative financial impacts on farms. Our results provide spatially explicit solutions to optimize agricultural productivity and water quality, which will inform better farm, land and catchment management as well as national and international policy.
\end{abstract}

\section{Introduction}

Understanding of the importance of ecosystem services and a concern for their degradation has increased globally in recent years (Braat and de Groot, 2012; MEA, 2005). The impacts of agricultural land use on ecosystem services associated with freshwater and nutrient cycling are of particular concern (MEA, 2005; Muller et al., 2015). New Zealand's economy relies heavily on primary agricultural production (Govt, 2015), yet these industries are implicated in a decline of key environmental indicators. Recently public attention has focused on deteriorating fresh water quality of streams, rivers and lakes, leading to new and pending local government legislation and regulation (MFE, 2013; Govt, 2014; PCE, 2013). These policies put farmers and land managers under increased pressure to reduce farm nutrient losses to the environment while ensuring production and profitability goals are met. However, paths linking diffuse nutrient loss at the farm scale to downstream water quality can be varied and uncertain. Models and decision support tools are useful for assessing and communicating nutrient movement through landscapes, as well as determining their impacts and potential mitigations (Heathwaite, 2003).

LUCI (the Land Utilisation and Capability Indicator), an extension of the Polyscape framework described in Jackson et al. (2013a), aims to investigate the cumulative impact of individual sub-field ecosystem service interventions within larger catchments. It shares a number of features in common with other decision support frameworks, but also has unique features that make it particularly suitable for evaluating the impacts of small-scale management at larger scales. Bagstad et al (2013) identified LUCI as the only tool suitable for both landscape and site scale modelling in a recent comprehensive international review of generalizable ecosystem service models.

The LUCI framework considers impacts of land use on multiple ecosystem services in a holistic and spatially explicit manner. A number of ecosystem service stocks and associated indicators and processes are considered by LUCI and it determines how the configuration and

\footnotetext{
* Corresponding author.
} 


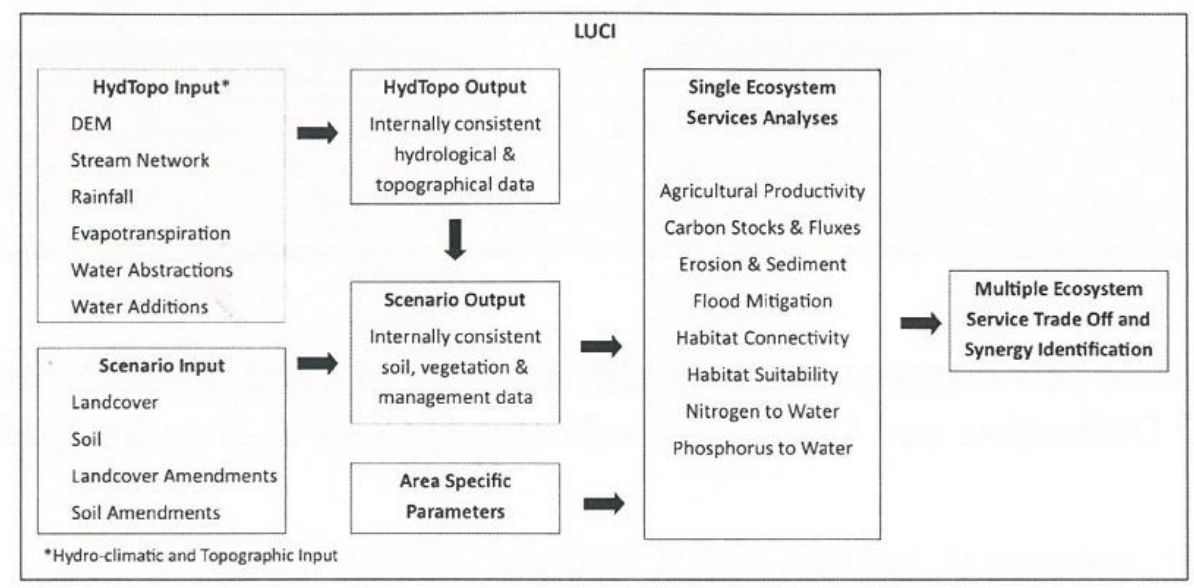

Fig. 1. LUCI Process Diagram.

placement of landscape features affect each of these. Individual ecosystem services can be assessed and the interrelationships between ecosystem services can be analysed to identify trade-offs and synergies between them (Fig. 1). LUCI uses readily available national data and is computationally efficient, accomplishing highly spatially explicit catchment-scale analyses within minutes to hours. Minimum data requirements for LUCI are a digital elevation model (DEM), land cover and soil data. However, applications can be easily supplemented with additional national or local data if it is available. LUCI is readily applicable to a number of countries and a wide range of environments, and it has been extensively applied in New Zealand (eg. Ballinger, 2011, Scott, 2015, Jackson et al., 2016, Marapara, 2016, Trodahl et al. 2016), Wales (e.g. Jackson et al., 2013a, Robinson et al., 2013, Emmett et al., 2014, Emmett et al., 2015, Emmett et al., 2016), and elsewhere (Benavidez et al., 2016; Bhatterei, 2009; Jackson et al., 2013b).

This paper reports the first application of LUCI in a groundwater dominated catchment, which is also the first application to use both nitrogen $(\mathrm{N})$ and phosphorus $(\mathrm{P})$ water quality and agricultural productivity tools in conjunction with a trade-off analysis. Additionally, newly developed, novel algorithms that update the $\mathrm{N}$ and $\mathrm{P}$ predictions to account for impacts of detailed farm management are applied. The study is a result of a collaboration between LUC developers and a New Zealand farmer-owned co-operative (Ravensdown), which is incorporating farm management information into the framework to enhance LUCI's capabilities to support on-farm decision making (Jackson et al., 2016; Trodahl et al., 2016). The objectives of this study were to identify nitrogen and phosphorus sources and sinks in a complex landscape and to investigate trade-offs and synergies between water quality outcomes and agricultural productivity.

\section{Study site}

Lake Rotorua is situated in the Bay of Plenty, North Island, New Zealand (Fig. 2). The lake is a volcanic caldera with significant geothermal resources and springs in the surrounding catchment. The contributing surface water catchment is $502.1 \mathrm{~km}^{2}$. In addition, there are significant groundwater resources. It is estimated that an additional area of $35 \mathrm{~km}^{2}$ to the north-west of the catchment also contributes groundwater to the Lake Rotorua system (White et al., 2014). The catchment is largely comprised of porous allophanic and pumice soils, although the west of the catchment consists of less porous podzol soils. Smaller areas of recent, organic and raw soil are also present. See Hewitt (2010) for New Zealand soil order descriptions.

Land cover within the catchment is largely agricultural $\left(210 \mathrm{~km}^{2}\right)$. $1 \%$ of agricultural land cover is crops and orchards. The remaining agricultural land is pastoral with $25 \%$ of this in dairy farming and $75 \%$ in dry stock (sheep and beef) farming (BoPRC, 2012a). There is negligible irrigation or artificial drainage on agricultural land within the catchment due to high rainfall and porous soils. Commercial forestry covers $74.9 \mathrm{~km}^{2}$, and non-commercial forest and shrubland $95.8 \mathrm{~km}^{2}$. The largest urban area in the catchment is the city of Rotorua $\left(20.8 \mathrm{~km}^{2}\right)$ with a population of just over 53000 (TeAra, 2016).

Lake Rotorua has suffered from well-documented reductions in water quality in recent decades. Past and present anthropogenic drivers of declining water quality include intensification of pastoral farming, septic tanks and sewage treatment plant discharge. However, natural sources of $\mathrm{N}$ and $\mathrm{P}$ are also present due to the area's geology and volcanism and, in some sub-catchments, these represent a significant proportion of the nutrient load (Rutherford et al., 2011; Tempero et al., 2015; Williamson and Cooke, 1982).

Land management strategies to reduce nutrient input to the lake are used to varying degrees and include riparian protection from stock (fencing and planting), efficient fertiliser use, detention dams, tree planting for erosion control, land use change and improved septic and sewage treatment (Rotorua Te Arawa Lakes Strategy Group, 2016). Recent local government regulation now limits nitrogen and phosphorus export to a 2001-2004 benchmark for properties over $4000 \mathrm{~m}^{2}$. This benchmark is established for each property using OVERSEER", a New Zealand, non-spatial farm nutrient budgeting model with widespread use amongst farmers, farm consultants and local government (BoPRC, 2012b; OVERSEER, 2016; Wheeler and Shepherd, 2013).

Despite the hydrological complexity and diverse nutrient sources in the Rotorua catchment, we chose it for the application of the LUCI models in this study because of the availability of long term, comprehensive hydrological and nutrient data. In addition, farmers are concerned that the new regulatory measures to limit nutrient losses to waterways within the catchment will negatively impact the viability of agricultural enterprise in the region (McRae, 2015). LUCI can assist with decision making around this complex issue by providing information to stakeholders, and farmers respond positively to the visual, spatially explicit nature of the LUCI framework (Scott, 2015). We applied LUCI's Nitrogen to Water, Phosphorus to Water and Agricultural Productivity models to the Lake Rotorua surface catchment.

\section{Method}

\subsection{Base data}

Base data for this application included a $5 \mathrm{~m}$ by $5 \mathrm{~m}$ DEM derived from LiDAR data from Bay of Plenty Regional Council (BoPRC), land 


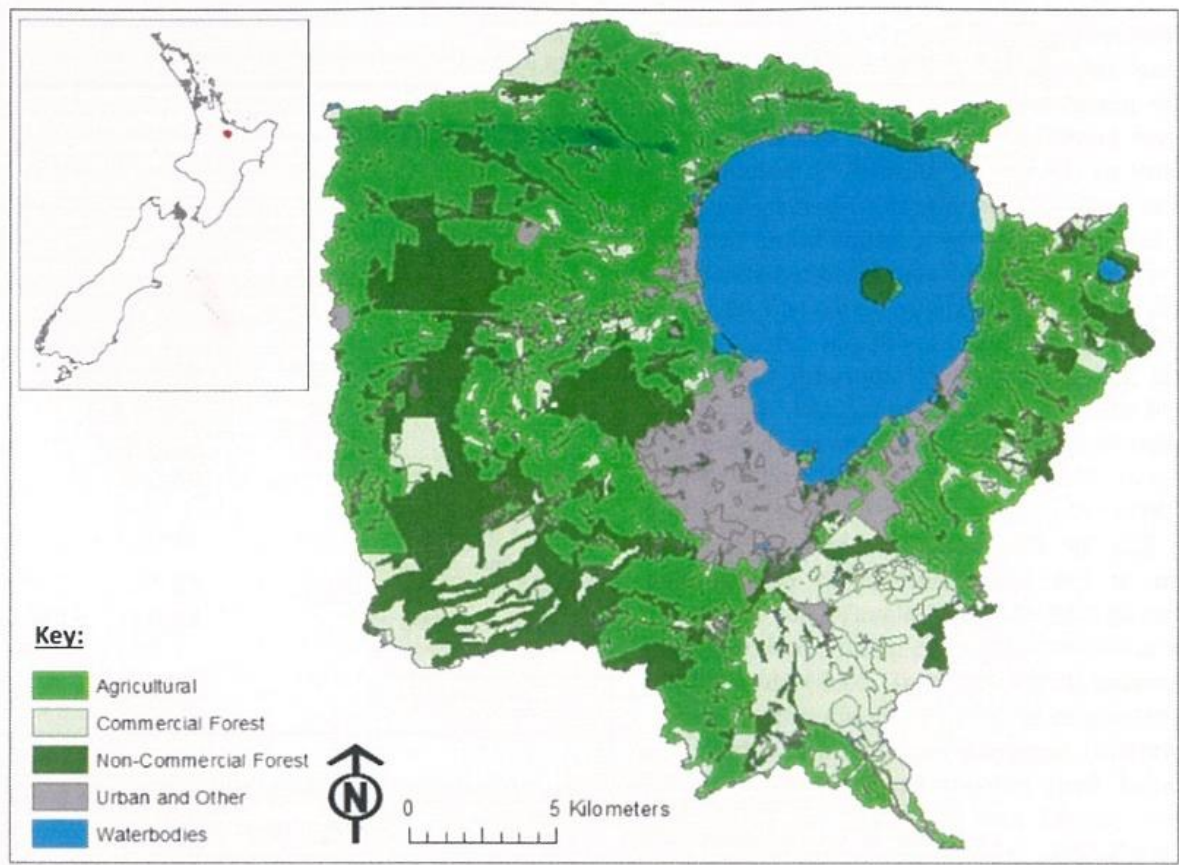

Fig. 2. Lake Rotorua catchment.

Table 1

Summary of input data.

\begin{tabular}{|c|c|c|c|c|}
\hline Data name & $\begin{array}{l}\text { Period } \\
\text { covered }\end{array}$ & $\begin{array}{l}\text { Data } \\
\text { type }\end{array}$ & Resolution & $\begin{array}{l}\text { Information } \\
\text { on-line? }\end{array}$ \\
\hline DEM & 2011 & Raster & $5 \mathrm{~m} \times 5 \mathrm{~m}$ & No \\
\hline LCDB4 & $2012 / 13$ & $\begin{array}{l}\text { Vector } \\
\text { Polygon }\end{array}$ & $\begin{array}{l}\text { Variable - from } \\
\text { Spot-5 satellite } \\
\text { imagery }\end{array}$ & Yes $^{2 t}$ \\
\hline NZFSL & $\begin{array}{l}\text { Based on } \\
\text { soil } \\
\text { surveys } \\
\text { from } \\
1930 \text { 's- } \\
\text { present }\end{array}$ & $\begin{array}{l}\text { Vector } \\
\text { Polygon }\end{array}$ & $\begin{array}{l}\text { Variable } \\
\text { depending on } \\
\text { original soil map } \\
\text { resolution }\end{array}$ & Yes $^{b}$ \\
\hline REC & 2010 & $\begin{array}{l}\text { Vector } \\
\text { Polyline }\end{array}$ & Variable & Yes $^{c}$ \\
\hline Rainfall & $\begin{array}{l}1960- \\
2006\end{array}$ & Raster & $1000 \mathrm{~m} \times 1000 \mathrm{~m}$ & No \\
\hline Evapotranspiration & $\begin{array}{l}1960- \\
2006\end{array}$ & Raster & $500 \mathrm{~m} \times 500 \mathrm{~m}$ & No \\
\hline
\end{tabular}

${ }^{a}$ LCDB https://lris.scinfo.org.nz/layer/423-lcdb-v41-land-cover-database-version41-mainland-new-zealand/

${ }^{b}$ NZFSL https://soils.landcareresearch.co.nz/contents/SoilData_FSL_Maps.aspx? currentPage $=$ SoilData_FSL_Maps \& menuItem $=$ SoilData

${ }^{c}$ REC https://www.niwa.co.nz/freshwater-and-estuaries/management-tools/riverenvironment-classification-0

cover data from the New Zealand Land Cover Database (LCDB4), soil data from the New Zealand Fundamental Soils Layer (NZFSL), stream network data from the National Institute of Water and Atmospheric Research (NIWA) River Environment Classification (REC), rainfall and evapotranspiration surfaces from NIWA (Tait et al., 2006; Woods et al. 2006), and locations of spring additions of water $\left(\mathrm{m}^{3} / \mathrm{s}\right)$ to the river network developed by the authors from information provided by BoPRC (Table 1).

\subsection{LUCI maps}

The LUCI ecosystem service models generate maps and data that summarise the results of each analysis. In default mode, LUCI maps use a "traffic-light" system. Areas that are recommended for protection due to high existing ecosystem service provision are highlighted in red - red indicates "stop" and think before making any changes here. Areas where ecosystem service provision is negligible and could be significantly improved are highlighted in green - green indicates "go", make changes and improvements. Orange indicates that existing provision is not high, but there is also little opportunity to enhance it. This colour scheme can be altered where appropriate; for example to accommodate colour blindness or for other reasons. Currently this is done manually, in-built options to easily change this colour scheme will be available in future.

\subsection{Water quality - nitrogen and phosphorus}

Many water quality models exist to evaluate nutrient export to waterways in relation to land cover, use and management at a variety of spatial and temporal scales, e.g. SWAT, SPARROW, INCA, MONERIS, CLUES and OVERSEER (Alexander et al., 2002b; Bouraoui and Grizzetti, 2014; Cichota and Snow, 2009; Elliott et al., 2008; Radcliffe et al., 2009; Schoumans et al., 2009; Schwarz et al., 2006; Selbie et al., 2013; Tsakiris and Alexakis, 2012). LUCI's unique fine spatial detail coupled with computationally efficient algorithms differentiates it from these models and enables farm to catchment to national scale analysis to be simultaneously performed.

LUCI functions at the DEM scale and most LUCI algorithm calculations and valuations are produced at this scale. A $5 \mathrm{~m}$ by $5 \mathrm{~m}$ DEM resolution is considered optimal for most applications, because this scale is typically sufficient to resolve the necessary detail while maintaining tractable processing times (Jackson et al., 2013a, 2016). Water quality models within LUCI use an enhanced, spatially representative export co-efficient (EC) approach to model total nitrogen (TN) and total phosphorus (TP) exports to water. ECs are defined as the "mass of a [contaminant] per unit area per unit time" (White et al., 2015) and quantified in $\mathrm{kg} \mathrm{ha}^{-1} \mathrm{yr}^{-1}$. LUCI spatially positions ECs in association with land cover categories at the DEM scale $\left(5 \mathrm{~m}^{2}\right)$ and point source nutrients are positioned where they enter the stream network. Particulate and dissolved nutrients are then cascaded through the landscape as water (rainfall, springs, etc.) accumulates and moves 
through the catchment. For every grid cell in the landscape and stream network, cumulative annual nutrient load and annual average concentration is calculated. The model identifies spatially explicit nutrient pathways and current and potential 'sinks' where nutrients can be intercepted, avoiding entry to the stream network. A proportion of water and nutrients is also routed to groundwater reserves. Currently these reserves exit back to water bodies via a simple linear reservoir, but future development of groundwater and associated nutrient movement accounting for distributions of residence times will be implemented using the method described in Jackson et al. (2006).

A criticism of models that employ an EC approach is that they usually consider only land use or cover, but climate, soil, topography, and land management often have significant effects on nutrient exports (Abell et al., 2011; Ding et al., 2010; Khadam and Kaluarachchi, 2006; Robinson and Melack, 2013; Shi et al., 2006; White et al., 2015). Developing appropriate ECs for New Zealand that consider these variables is a key aim of the LUCI-Ravensdown collaboration. Pastoral land cover makes up 32\% of New Zealand's land area and is an important contributor to deteriorating water quality, both nationally and within the study catchment (Rutherford et al., 2009). Here, ECs for pastoral land cover are calculated by LUCI using algorithms derived from a large ( $>14000$ samples), pastorally based national dataset. The dataset consists of detailed farm nutrient input and management variables that have been entered and run using OVERSEER ${ }^{*}$ to generate nutrient loss predictions, which are also included in the dataset. Because OVERSEER" is a farm scale nutrient budgeting model, nutrient losses are only considered to the root zone or edge of field and losses, transformations and/or lags occurring from root zone to stream and/or or in-stream are not accounted for.

We applied an attenuation factor of 0.5 for $\mathrm{N}$, which has been shown to be appropriate when applying OVERSEER ${ }^{\circ} \mathrm{N}$ exports in one small catchment scale application (Power et al., 2002), although this requires wider confirmation (Arbuckle, 2015). Given other sources of uncertainty, observed versus modelled instream nitrogen concentrations seemed reasonable with this attenuation factor (see later results), so we attempted no additional calibration of the factor for the purposes of this study. An attenuation factor of 0.7 for $\mathrm{P}$ was estimated based on differences between observed and modelled phosphorus in-stream concentrations, although no corroborating evidence from other studies is currently available to ascertain whether this is more generally representative.

To calculate ECs at the farm or small catchment scale, where direct communication with farmers is possible, actual management data can be used. For larger catchment scale applications, such as this, individual farm details are usually not known and regional averages based on OVERSEER ${ }^{\circ}$ data, literature values and national spatial data are applied. Table 2 shows ECs for pastoral land covers used for this application based on our new algorithms with regional average input variables. Pastoral ECs for P consider slope in degrees. Table 2 shows a range of pastoral ECs on soils found in the Lake Rotorua catchment for slopes of $2-15^{\circ}$. The average slope values for agricultural land in this catchment is $10^{\circ}$.

ECs for other land cover categories, including urban, have been identified largely, though not exclusively, from New Zealand literature (Al Bakri et al., 2008; Alexander et al., 2002a; Baillie and Neary, 2015; Cameron et al., 2013; Cox et al., 2012; Davies-Colley and Wilcock, 2004; Davis, 2014; Davis et al., 2012; Lin, 2004; Magesan et al., 2012; McDowell and Wilcock, 2008; McQueen et al., 2006; Meneer et al., 2004; Parfitt et al., 2006; Quinn and Stroud, 2002). In cases where multiple ECs for the same land cover were identified, we applied the average value (Table 2).

\subsection{Agricultural productivity}

The agricultural productivity model predicts optimal utilisation based on an evaluation of slope, fertility, aspect, drainage and eleva-
Table 2

ECs used for this application of LUCI N and P export to water tools. ECs for P consider slope in degrees and the above gives the range of ECs for pastoral land for slopes of 2 $15^{\circ}$. The average slope values for agricultural land in the Lake Rotorua catchment is $10^{\circ}$. Forest cover ECs show a range because there are a variety of forest types with a variety of nutrient ECs.

\begin{tabular}{llll}
\hline Land cover & Soil order & $\begin{array}{l}\text { Nitrogen EC } \\
\text { (kg N/ha/yr) }\end{array}$ & $\begin{array}{l}\text { Phosphorus EC } \\
\text { (kg P/ha/yr) }\end{array}$ \\
\hline Pastoral & Allophanic & 25.4 & $0.02-0.06$ \\
& Organic & 13.8 & $0.14-0.47$ \\
& Podzol & 18.1 & $0.26-0.79$ \\
& Pumice & 25.8 & $0.05-0.25$ \\
& Recent & 26.8 & $0.06-0.27$ \\
$\begin{array}{l}\text { Orchard \& } \\
\text { perennial crops }\end{array}$ & Raw & 22.6 & $0.04-0.11$ \\
$\begin{array}{l}\text { Short-rotation } \\
\text { crops }\end{array}$ & 6.8 & 0.05 \\
$\quad \begin{array}{l}\text { Urban } \\
\text { Non-commercial }\end{array} \quad$ & 10.6 & 1.6 \\
$\quad$ forest & & 6.8 & 1 \\
$\begin{array}{l}\text { Shrubland } \\
\text { Commercial forest }\end{array}$ & & $2.4-2.9$ & $0.2-0.4$ \\
\hline
\end{tabular}

tion. Reasonably flat, fertile, well-draining soils are considered to be of highest value for agricultural production. As slope increases, and/or soils become seasonally to permanently waterlogged (as can occur on very flat, poorly draining soils), and/or soil fertility decreases, estimated productive value lowers. Drainage and fertility are determined using variables from soil data. Aspect is determined from the DEM, with north facing slopes being most productive in the Southern Hemisphere, and is used to up-weight fertility and drainage (i.e. soils with a positive aspect receive a bonus to their fertility and drainage scores). For this application, slopes $\leq 5^{\circ}$ are considered very productive, between $5^{\circ}$ and $15^{\circ}$, somewhat productive, and slopes $>15^{\circ}$ to be of lower production value. Often an elevation threshold is used to reflect temperature or other variations impacting productivity; for this application no threshold was implemented. This is because increasing rainfall and hence reduced drought as elevation increases in the welldraining soils in the Bay of Plenty is thought to compensate for any deterioration in productivity caused by decreasing temperature. Slope, elevation and cut-off fertility thresholds can be changed to account for local conditions and practices.

Current land utilisation is determined from land cover data. By comparing current and optimal agricultural use, LUCI identifies locations that appear to be under or over utilised and suggests where a change in land use or management could be beneficial. Areas that are currently used optimally are also identified for protection. For further detail on the agricultural productivity algorithms see Jackson et al. (2014) and Jackson et al. (2013a).

\subsection{Trade-off and synergy identification}

LUCI trade-off tools identify opportunities to improve the delivery of multiple ecosystem services, while protecting areas that already deliver multiple ecosystem services of a high quality. When individual ecosystem services are analysed, each cell in the terrestrial landscape is categorised into one of five provisioning categories - very high existing service, high existing service, moderate or marginal service with little capacity to improve, small or degrading service with significant capacity to improve, very small or rapidly degrading service with significant capacity to improve.

For trade-off analysis, this categorisation is then further reduced into three categories - a) high existing good, b) bad or negligible existing good with potential to improve, and c) negligible existing good but negligible opportunity to improve significantly. These categories, for two or more single ecosystem services, are then layered to identify 
parts of the landscape where trade-offs versus win-win situations exis and where management interventions could enhance or protect multiple ecosystem services. Areas with only multiple "high existing good" are flagged as win-win situations where status quo should be preserved. Areas with multiple "bad or negligible existing good with potential to improve" are flagged as win-win situations for implementation of change. Areas where trade-offs exist - where significant improvements of a service would likely go in tandem with degradation of other services - are separately categorised, as are areas where there are not obvious advantages in either preserving the status quo or implementing management change.

A numerical value is assigned to each of the three categories described above and used to calculate trade-offs and synergies among ecosystem services. Five calculation methods are available - equally weighted arithmetic, conservative, standard, weighted additive, and a combined "conservative and weighted additive" approach. The equally weighted arithmetic method for multiple ecosystem service trade-off and synergy identification was used for this application in the absence of any clear reason to use a different approach. We performed two-way and three-way analyses between agricultural productivity and $\mathrm{N}$ and $\mathrm{P}$ exports to water. For further detail on the trade-off algorithms see Jackson et al. (2014) and Jackson et al. (2013a).

To explore the extent to which targeting zones of high accumulated load rather than input loads over the catchment might reduce loss of agricultural productivity, two separate analyses were conducted for loads and accumulated loads, both aiming to reduce loading to waterways of both $\mathrm{N}$ and P. Load and accumulated load outputs from LUCI were each classified into 10 classes using Jenks's natural breaks (implemented via ArcGIS software). A zone for each class was created and the average value of each attribute was calculated using zonal statistics. Four pasture production classes were assigned based on likely pasture dry matter production for each productive environment identified in the predicted optimal agricultural utilisation layer, with values ranging from 6000 to $12000 \mathrm{~kg}$ dry matter/ha. The agricultura productivity, $\mathrm{N}$ and $\mathrm{P}$ layers were overlaid resulting in 88 combinations for load and 352 combinations for accumulated load. The area of each of these combined zones was found and area weighted total loads calculated in a spreadsheet. A simplex method (implemented via Lindo Systems Inc.'s WhatsBest! Excel Add-in) was used to find the areas required to achieve varying degrees of $\mathrm{N}$ and $\mathrm{P}$ load mitigation with minimal impact on agricultural productivity. The same method was used to identify areas with large amounts of accumulated load. The contributing areas above these points, and their associated direct loadings were then calculated to establish the total $\mathrm{N}$ and $\mathrm{P}$ load that could potentially be intercepted in these zones of high accumulated load.

\section{Results}

\subsection{Water quality}

\subsubsection{Nitrogen}

Strong spatial gradients in the total generated $\mathrm{N}$ loads exist in the Lake Rotorua catchment (Fig. 3) and are linked to combined land cover and soil order categories. The highest TN loads are associated with pastoral land situated on porous allophanic, pumice and recent soils, while pastoral land in the west of the catchment:over podzol soils has lower TN loads. The lowest TN loads are associated with both commercial and non-commercial forests and shrubland on all soil types. Urban areas are moderate sources of TN.

When accumulated TN load is considered at the catchment scale (Fig. 4) the same pattern of highest loads associated with pastoral land is observed. When considered at smaller spatial scales, however, this is not exclusively the case. A close-up view of a mixed land-use portion of the landscape (Fig. 4 inset) reveals that even in forested areas (largely amber) there are clear pathways of high to very high accumulated TN loads where water converges in the landscape.

Model performance at the sub-catchment scale was investigated by comparing over and under predicted in-stream TN concentrations with sub-catchment land cover from LCDB4 and groundwater characteristics from Tempero et al. (2015) and Morgenstern and Gordon (2006). Notably there was no clear pattern associated with sub-catchment land cover category proportions and over or under prediction of TN concentrations indicating no particular bias associated with LUCI's land cover based EC's. Our analysis showed that in the four subcatchments where groundwater is likely sourced from beyond subcatchment boundaries LUCI under predicted in-stream TN concentrations by $55-90 \%$ of observed concentrations and in one other subcatchment where groundwater is likely sourced from within the catchment bounds, yet has very long ( $>100$ years) lag times, LUCI over predicted in-stream TN concentrations by $69 \%$. At the six sites where neither of the above situations applied, most sub-catchment predictions were no more than $20 \%$ different from observed TN concentrations. The one exception to this is a small sub-catchment to the south-east for which little groundwater data is available. LUCI under predicted TN concentrations for this catchment by $49 \%$. Hoare (1984) also noted particularly high nitrate concentrations in this stream. He attributed it to septic tank leachate, although since the early 1980's this area has been connected to Rotorua's sewage treatments works. Quite possibly, this small sub-catchment is also receiving groundwater from surrounding sub-catchments.

\subsubsection{Phosphorus}

There are strong spatial gradients in the total generated P loads in the Lake Rotorua catchment which are linked to land cover and soil, but also highly influenced by topography (Fig. 5). Pastoral land on steeper slopes is associated with highest P loads. Moderate P loads are associated with pastoral land on moderate slopes, urban land cover and newly harvested commercial forest. Intact forest areas are associated with the lowest loads.

When accumulated TP load is considered at the catchment scale (Fig. 6) the same pattern of highest loads associated with pastoral land is observed. At smaller spatial scales, this pattern is still clear (Fig. 6 inset) although even in forested areas (largely amber) there are clear pathways of high to very high accumulated TP loads where water converges in the landscape.

Model performance at the sub-catchment scale was investigated prior to application of an attenuation factor by comparing predicted instream TP concentrations with observed. LUCI over-predicted P concentrations by $28-740 \%$ in all but one catchment, there LUCI under-predicted the $\mathrm{P}$ concentration by $88 \%$. No clear patterns were evident between percent over-prediction and catchment land-cover characteristics indicating no particular bias associated with LUCI's land cover based EC's. Our attenuation factor of 0.7 was calibrated based on this data and information. $\mathrm{P}$ is recognised as somewhat challenging to model, particularly at the catchment scale (Jarvie et al., 2013; Meals et al., 2010) and further refinement of our P model is on-going. Additionally, uncertainty around observed $\mathrm{P}$ measurements is also a known challenge (Krueger et al., 2012; Lloyd et al., 2016).

\subsection{Agricultural productivity}

Estimates of current agricultural use, based on national land cover information, considers all arable and high producing grassland to be highly productive. Low producing grassland is considered to be of lower production value, and the dominant other land uses of commercial and non-commercial forestry areas within the catchment are classified as non-productive. Urban areas are excluded from the analysis (Fig. 7a).

Predicted optimal agricultural utilisation, based on an analysis of slope, soil fertility, aspect and soil drainage characteristics by LUCI indicates $106.3 \mathrm{~km}^{2}$ of the catchment has very high to high productive 


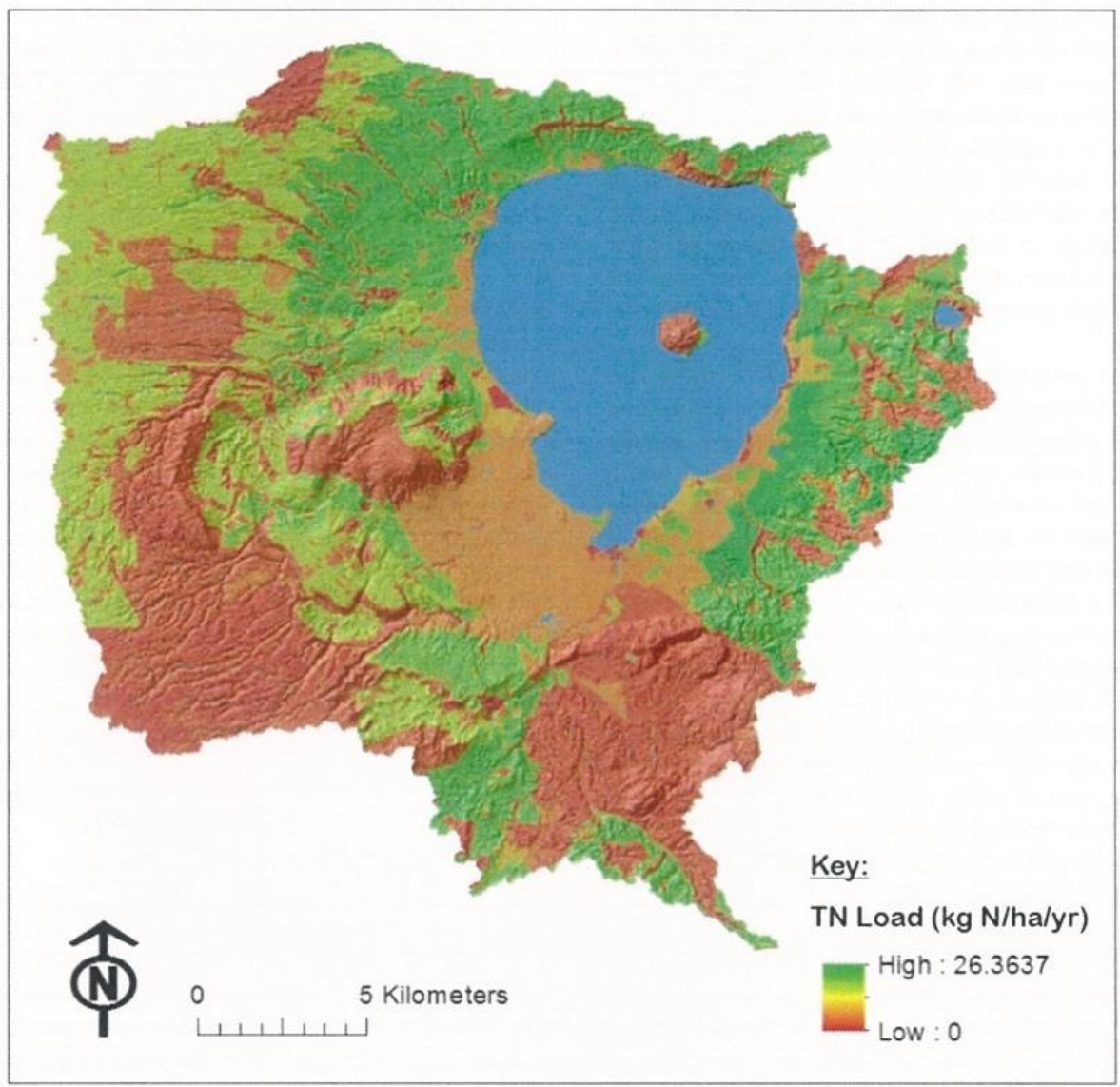

Fig. 3. TN load generated in lake rotorua catchment. (For interpretation of the references to color in this figure, the reader is referred to the web version of this article.)

capacity. This land is concentrated on flatter lowlands and highlands within the catchment (Fig. 7b). This finding contrasts with the amount of existing agricultural land cover, an area of $206.8 \mathrm{~km}^{2}$. LUCI predicted a moderate productive capacity for an area of $140.6 \mathrm{~km}^{2}$, which surrounds highly productive land where slopes begin to steepen, and marginal to negligible productive capacity for $142.1 \mathrm{~km}^{2}$ of the catchment, on the steepest slopes and wetland areas surrounding the lake.

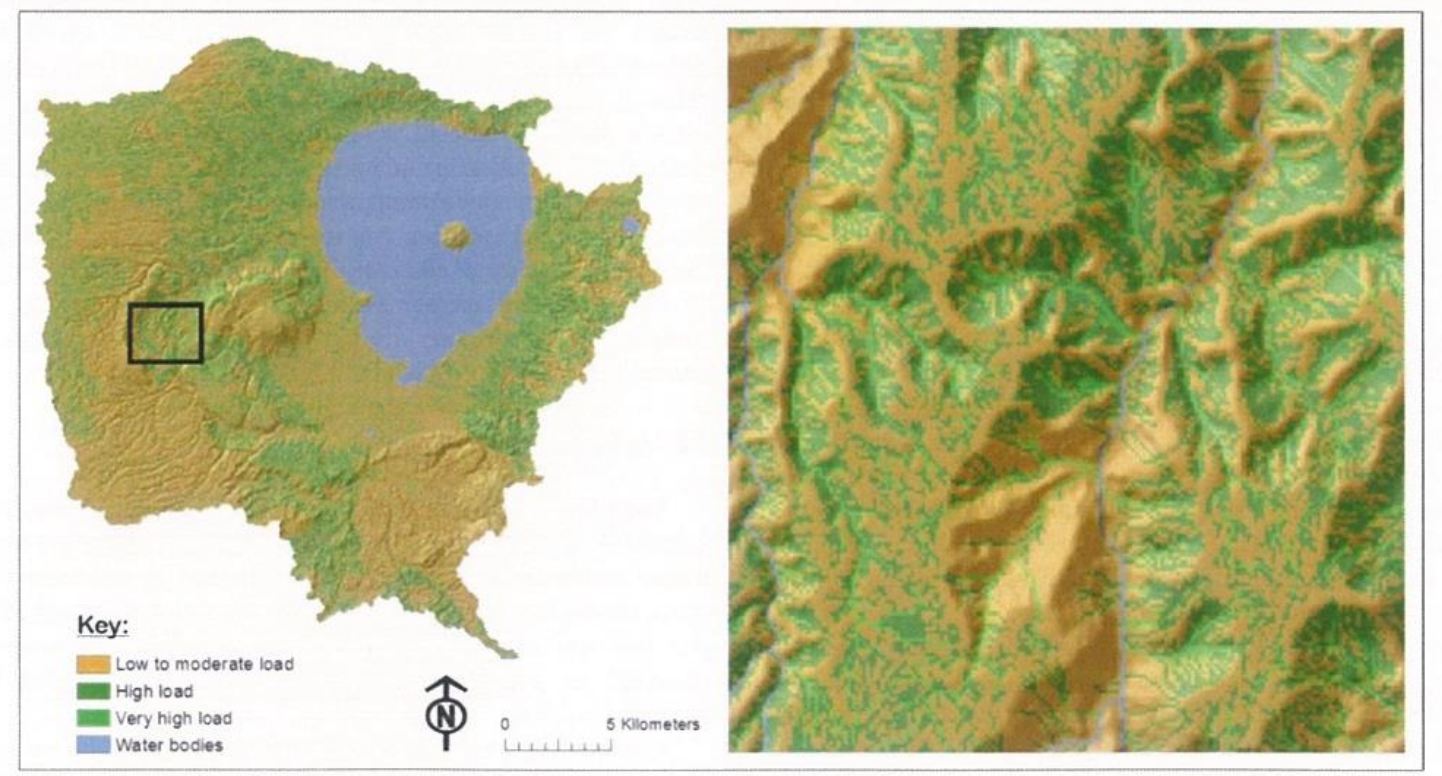

Fig. 4. Accumulated TN load in lake rotorua catchment. (For interpretation of the references to color in this figure, the reader is referred to the web version of this article.) 


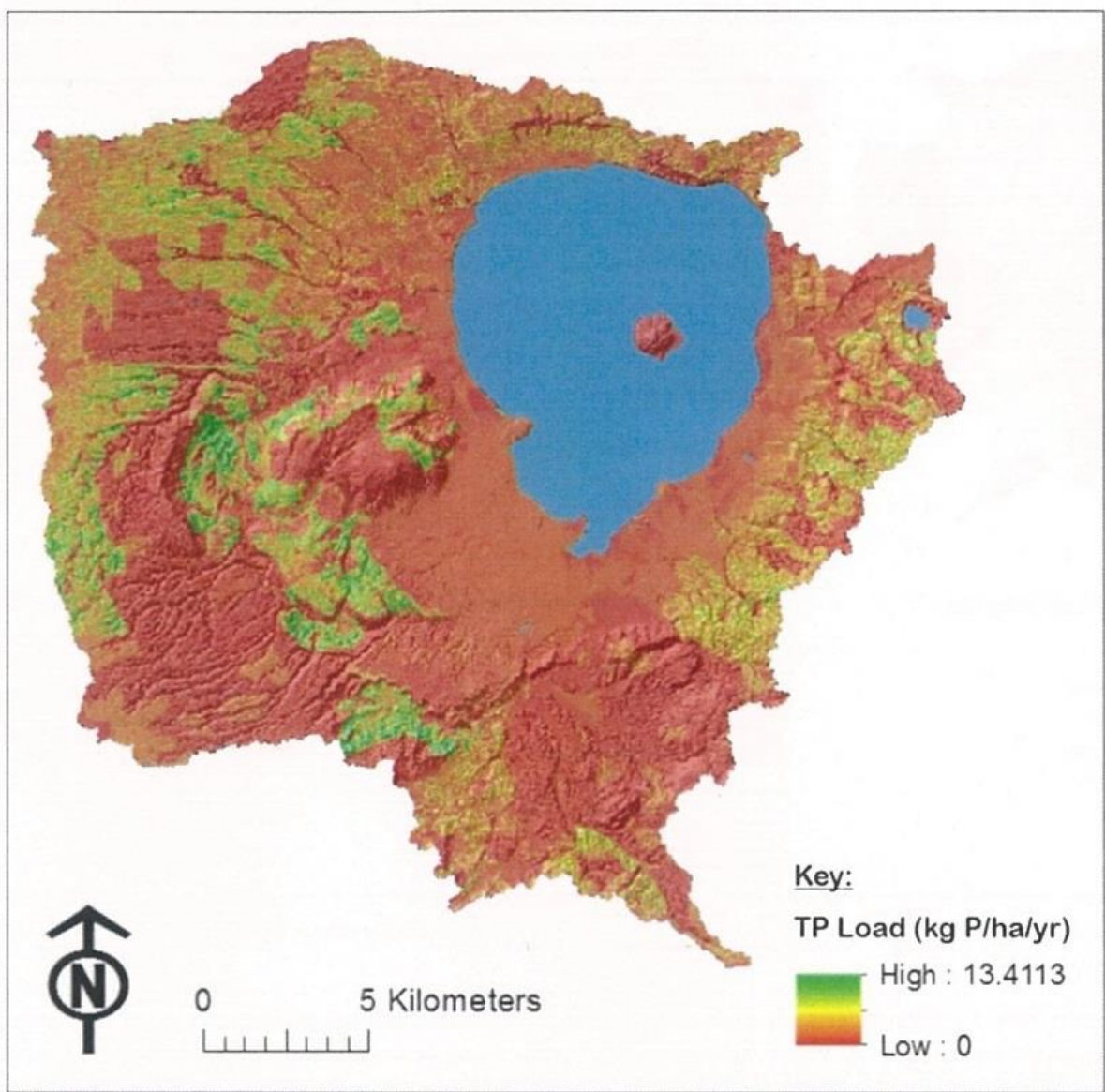

Fig. 5. TP load generated in lake rotorua catchment. (For interpretation of the references to color in this figure, the reader is referred to the web version of this article.)

Fig. 7c compares current and optimal agricultural land use indicating that, if both current and predicted utilisation maps are correct, only $36.6 \%\left(184 \mathrm{~km}^{2}\right)$ of the catchment is being used at optimal or close to optimal production levels, while almost half (46.3\%) of the catchment falls into categories of sub-optimal agricultural use (i.e. $139.4 \mathrm{~km}^{2}$ in non-optimal use and agricultural production is not realised on

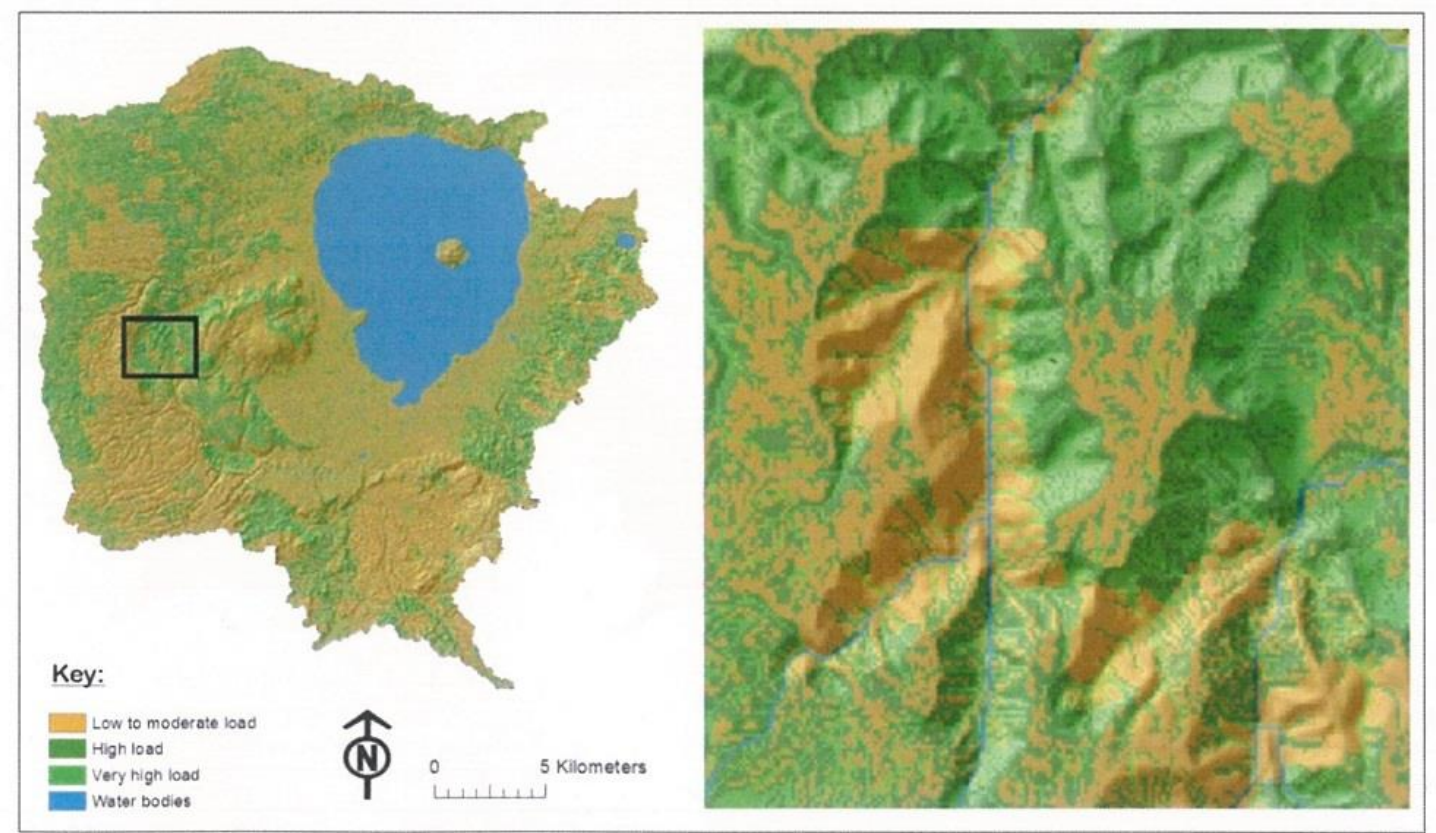

Fig. 6. Accumulated TP load in lake rotorua catchment. (For interpretation of the references to color in this figure, the reader is referred to the web version of this article.) 


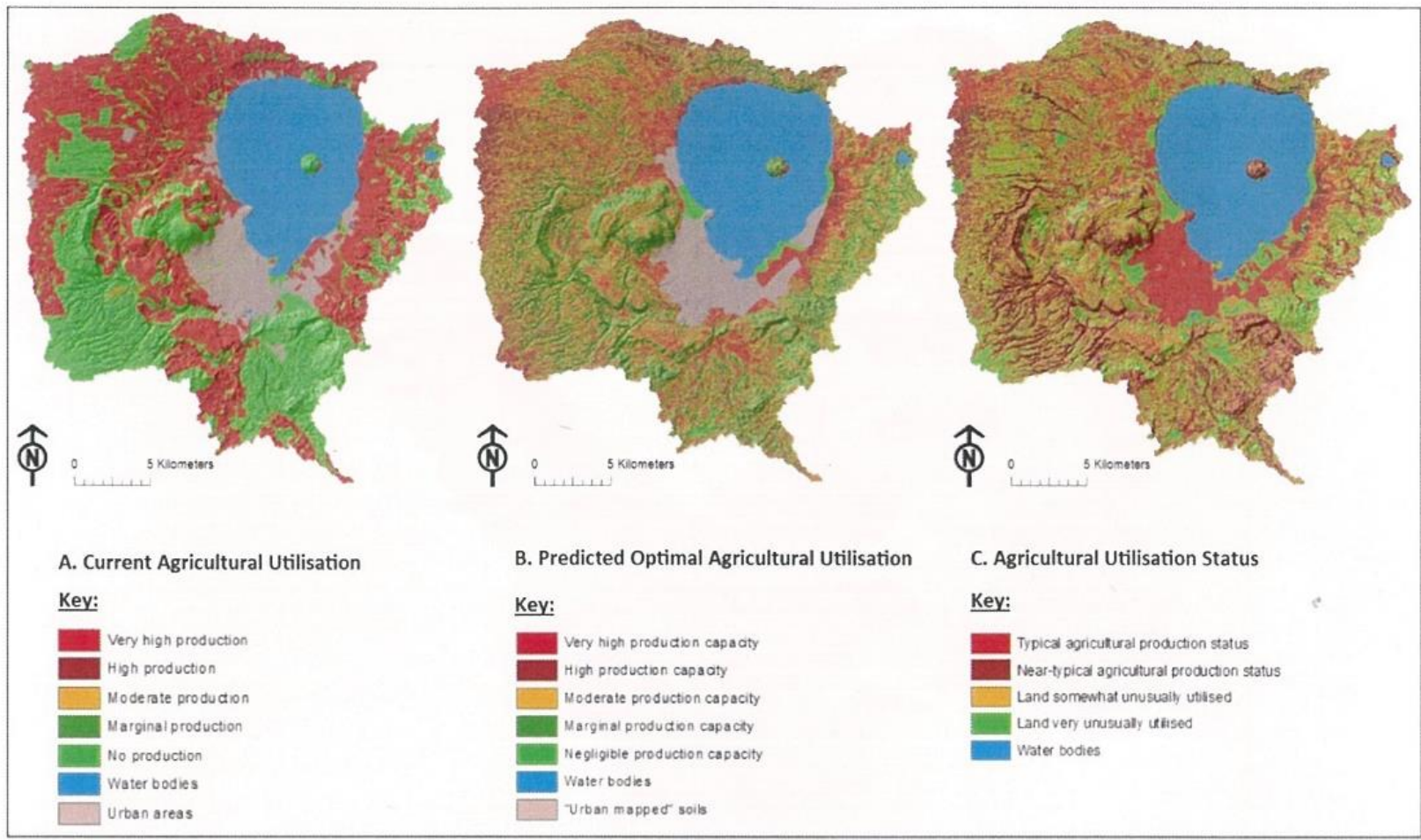

Fig. 7. LUCI agricultural productivity maps for the lake rotorua catchment. (For interpretation of the references to color in this figure, the reader is referred to the web version of this article.)

$93.4 \mathrm{~km}^{2}$ of the catchment). Our analysis suggests that potential to improve agricultural productivity exists on $18.4 \%$ of the catchment area, but that agricultural over use could be a problem on $27.9 \%$ of the catchment area.

\subsection{Trade off and synergy identification}

Given that sources and pathways of $\mathrm{N}$ and $\mathrm{P}$ frequently correspond, we were unsurprised to observe similar spatial patterns between agricultural productivity and exports of these nutrients (Fig. 8a and b). Forty-seven $\mathrm{km}^{2}$ or $11.4 \%$ of the catchment potentially provides opportunities to improve both TN export and agricultural productivity (bright green areas Fig. $8 \mathrm{a}$ ), while $61 \mathrm{~km}^{2}$ or $14.7 \%$ of the catchment potentially provides opportunities to improve both TP export and agricultural productivity (bright green areas Fig. 8 b). There are no areas within the catchment where agricultural productivity is high and TN or TP export to waterways is low.

Opportunities are high to reduce both TN and TP export to

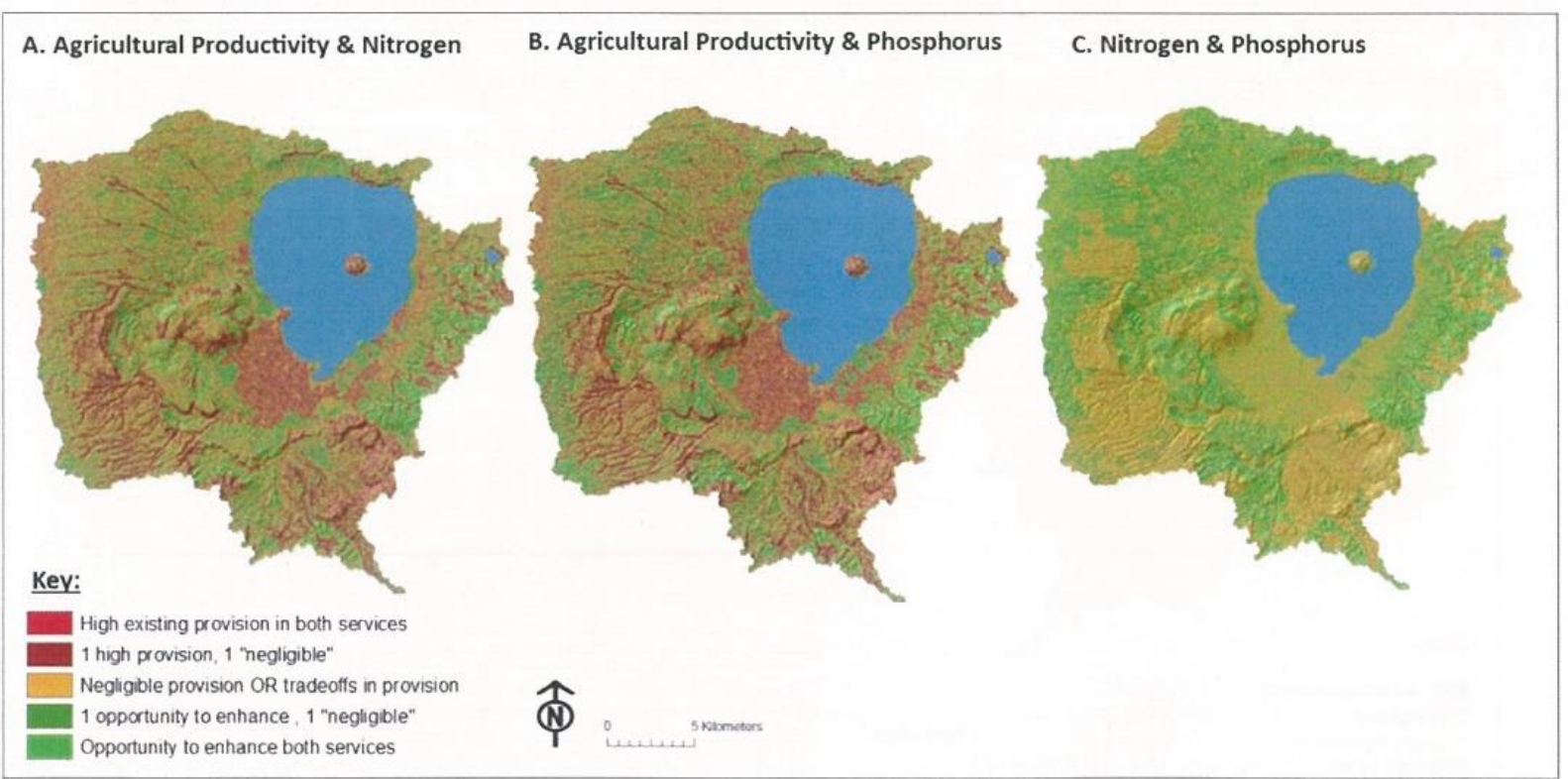

Fig. 8. Two way trade off and synergy identification between TN, TP andagricultural productivity for the lake rotorua catchment agricultural productivity for the lake rotorua catchment. (For interpretation of the references to color in this figure, the reader is referred to the web version of this article.) 


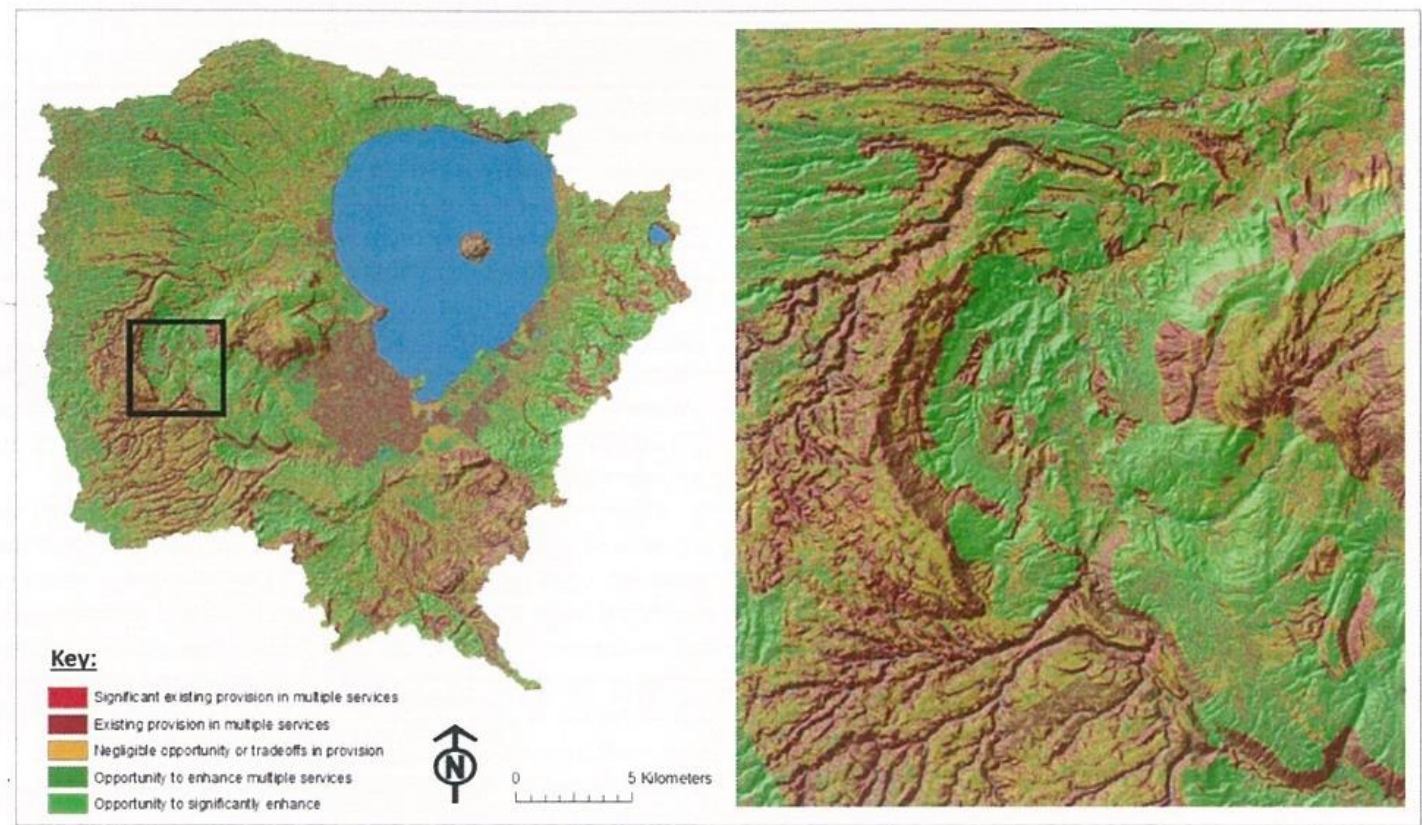

Fig. 9. Three way trade off and synergy identification between TN, TP and agricultural productivity for the lake rotorua catchment. (For interpretation of the references to color in this figure, the reader is referred to the web version of this article.)

waterways within the catchment (Fig. 8c) because sources and pathways for $\mathrm{N}$ and $\mathrm{P}$ frequently coincide. $154 \mathrm{~km}^{2}$ or $37 \%$ of the catchmen (bright green) offers opportunities for reducing both TN and TP export and a further $65 \mathrm{~km}^{2}$ or $15.7 \%$ of the catchment (dark green) offers opportunities to reduce one of these.

Three way trade off and synergy analysis indicates $119 \mathrm{~km}^{2}$ or $28.7 \%$ of the catchment provides opportunities to improve all services and, importantly, that no part of the catchment currently provides well for all three services (Fig. 9).

Our analysis investigating targeted zones of load and accumulated load with consideration of agricultural productivity shows that achieving significant reductions in in-stream loading via targeting direct loading of $\mathrm{N}$ and $\mathrm{P}$ cannot be achieved without significant loss of productivity, although spatial optimisation does allow the percentage loss in production to be lower than the percentage gains for water quality outcomes. For example, $20 \%$ of both $\mathrm{N}$ and $\mathrm{P}$ loading could be mitigated by targeting $17 \%$ of agricultural land area, with $12 \%$ of total agricultural production impacted, while achieving 50\% reduction in both loadings would impact $46 \%$ of agricultural land area and $37 \%$ of total agricultural production. Targeting 5\% reductions in loading could be achieved via modifications to $4.2 \%$ of agricultural land impacting $3 \%$ of production.

Taking an approach targeting accumulated load requires a much smaller footprint on agricultural land. Targeting $1 \%$ of agricultural area achieved a reduction of approximately $6.5 \%$ in loading, while targeting $1.5 \%$ resulted in an $8.4 \%$ reduction.

\section{Discussion}

\subsection{Water quality}

\subsubsection{Nitrogen}

The results from our nitrogen export analysis demonstrate LUCI's ability to provide clear guidance for positioning of nutrient mitigation solutions. Various opportunities exist to reduce $\mathrm{N}$ export to waterways and Figs. 3 and 4 suggest two general strategies for reduction: targeting $\mathrm{N}$ sources and targeting $\mathrm{N}$ pathways. $\mathrm{N}$ sources on farms can be lessened by reducing the amount or frequency of $\mathrm{N}$ fertiliser, changing from cattle to sheep farming, using feedpads or housing to minimise winter grazing, improving effluent management or reducing stocking rates (Monaghan et al., 2008).

While a more strategic approach to source reductions is recommended, as an indicative scenario we applied a blanket halving of $\mathrm{N}$ fertiliser inputs to all pastoral land in the Lake Rotorua catchment. LUCI indicates that this will result in reduced $\mathrm{N}$ loads of $12.7 \%$ on recent soils, $13.8 \%$ on allophanic soils, $20.2 \%$ on pumice soils and $22.7 \%$ on podzols. In-stream $\mathrm{N}$ loads at stream confluences with Lake Rotorua will reduce by $11-20 \%$ depending on the characteristics of sub-catchments.

$\mathrm{N}$ pathways, where water and nutrients converge within the landscape and make their way through to the stream network, are depicted in bright green in Fig. 4. These pathways are where opportunities to intercept nutrients exist. Targeted placement of nutrient interception at these locations can mitigate $\mathrm{N}$ generated from all up-catchment areas. We found that $\mathrm{N}$ pathways, as identified in classified accumulated $\mathrm{N}$ load using a minimum threshold accumulation of $1 \mathrm{~kg} / \mathrm{yr}$ (Fig. 4), cover $36.7 \mathrm{~km}^{2}$ or $7.3 \%$ of the Lake Rotorua catchment area. Focusing $\mathrm{N}$ interception in these areas alone would be a highly effective land-use in that significant N-removal would be accomplished for the catchment using only $7.3 \%$ of the catchment land area. Interception strategies are numerous and should be chosen in conjunction with land and farm managers, but could include planting vegetation, restoring wetlands or installing denitrification beds. Strategies for nutrient source and pathway mitigation from agricultural land in New Zealand are comprehensively assessed by McDowell et al. (2013).

Our sub-catchment scale analysis indicates improved representation of groundwater residence times and pathways, and associated nutrient transport is important, particularly where groundwater is sourced from outside the surface catchment and/or where lag times are significant. Future work will utilise the method of Jackson et al. (2006), which allows the history of land management change and variable residence times within a catchment or sub-catchment to be explicitly accounted for. This has previously quantified the lag times in river response to changing management that occur as a consequence of groundwater residence times (Jackson et al., 2008, 2007). However, the method requires the collation of a long-term dataset of historical 
land use change and a robust understanding of the pathways and residence times for groundwater movement within the catchment. Despite these higher data requirements, the method is necessary to overcome a major drawback of the EC approach, and the typical assumption in policy, that current water quality is directly (and only) associated with current land cover and/or management.

\subsubsection{Phosphorus}

As with $\mathrm{N}$, although our model could be further enhanced, LUCI provides clear guidance for positioning of mitigation solutions in its current form. Sources of agricultural P to waterways can be reduced utilising similar targeted management strategies as those described for agricultural N sources (Section 5.1.1), although further attention to the effects of slope is of particular importance. P readily binds to clays and metal-oxides in soil. As a result, it tends to move attached to sediment, movement of which occurs more frequently on exposed steeper slopes (Bennett and Schipanski, 2012). Retirement or conversion of steep pasture to natural or commercial forest cover is an option. As can be seen in our results, intact forestry blocks largely remain in-situ with little P loss. However, once trees are harvested, P is more likely to be lost to waterways with sediment run-off. Strategies to reduce soil loss during forest harvest include minimising logging roads, retaining waste wood on-site, and the maintenance of riparian buffer zones (Baillie and Neary, 2015).

In a similar manner to $\mathrm{N}$, areas of very high TP accumulated loads occur where water and nutrients converge in the landscape (Fig. 6). Again, these are ideal locations for targeted interception. A number of interception strategies exist and are reviewed elsewhere (McDowell et al., 2013). As with N, P interception strategies should be chosen in conjunction with land and farm managers.

Additionally, areas of $\mathrm{N}$ and $\mathrm{P}$ sources and pathways within the Rotorua catchment frequently correspond (Figs. 3-6). Therefore, there are significant land areas where opportunities to improve both $\mathrm{N}$ and $\mathrm{P}$ export to water simultaneously, exist. This synergy is discussed further in Section 5.3.

In general, a highly targeted source or pathway approach for $\mathrm{N}$ and/ or $\mathrm{P}$ requires detailed and precise understanding of farm environments, but may achieve significant reductions in generated and exported nutrient loads without significantly impacting production. Such an approach traditionally relies on individual farmer skills and management, which have been identified as crucial factors when balancing nutrient reductions with productivity (Anastasiadis and Kerr, 2013; Dewes and Business, 2013). However, frameworks such as LUCI can assist more farmers to take a highly targeted and strategic approach.

\subsection{Agricultural productivity}

Our analysis shows that large areas of the Rotorua catchment are currently in high agriculturally productive land uses. Much of this area however may not be suited to these levels of production. In addition there are also under-utilised areas within the catchment. Clearly this analysis could be used as a basis for discussion around land suitability for various land uses.

However, our analyses are somewhat limited because current agricultural use is based on national land cover information, which is admittedly broad-brush and lacks much capacity to distinguish variations in production in pastoral landscapes. Additionally, commercial forest productivity areas are not currently included and could be included. Commercial forestry is often used in New Zealand as a means of maintaining production on steeper terrain. In addition, production forests can act as nutrient sinks, carbon stores, and may protect soil from erosion and moderate flooding (Baillie and Neary, 2015). Furthermore, LUCI could help to identify ideal locations for conversion to commercial forest.

\subsection{Trade-off \& synergy identification}

LUCI indicates there are significant areas within the catchment where both agricultural productivity and $\mathrm{N}$ or $\mathrm{P}$ loss could be improved. However, difficulty arises in choosing a strategy that might address both issues, because agriculturally productive areas are identified as significant nutrient sources (Figs. 3 and 5) and nutrient pathways are most prevalent on agricultural land. Illustrating this point further, Fig. $8 \mathrm{a}$ and $\mathrm{b}$ show there are no areas within the catchment where both services are currently well provided for, that is, there are no areas where agricultural productivity is high and TN or TP export to waterways is low. In contrast, opportunities are high to improve both TN and TP export to waterways within the catchment (Fig. 8c) because sources and pathways for $\mathrm{N}$ and $\mathrm{P}$ frequently coincide.

Clearly if water quality is to be improved, it is likely to come at the expense of agricultural land because most of the nutrient interception pathway opportunities exist on agricultural land. However, entire pathways may not be required for adequate nutrient interception, rather interceptions could be strategically placed in receiving areas to mitigate the largest uphill area possible. Additionally, due to shared pathways for $\mathrm{N}$ and $\mathrm{P}$ movement, single mitigation options that target both nutrients can be effective.

Furthermore, our analysis suggests targeting zones of nutrient convergence in the landscape may be highly beneficial in maintaining productivity levels. The current method requires some modification to its classification techniques to quantify potential for larger reductions in water loading. It is important to note these results are conservative and perhaps underplay the full potential of such an approach; our analysis on the accumulated load overestimates the amount of area required for interception as the accumulated load is spatially connected and non-additive. For this illustrative calculation we used steepest descent, but in future will also explore methods of weighting flow via all downwards slopes. A more refined analysis would also estimate the reduction in agricultural production from a particular mitigation practice because measures such as totally removing livestock from pastoral land or planting up pastoral land to intercept upslope nutrients are effectively a total loss of production, while other management changes such as reducing fertiliser input would only result in a partial reduction.

Clearly there are options available within the Lake Rotorua catchment to reduce nutrient export to waterways and keep loss of agricultural productivity to a minimum. As illustrated above, options on agricultural land involve strategically managing nutrient sources and targeting nutrient pathways with interception strategies that address both $\mathrm{N}$ and $\mathrm{P}$ and consider productivity. Implementation of these mitigations is necessitated by current water quality regulation. LUCI can support this process at the farm and catchment scale and ongoing improvements to the model will further enhance this capability for agricultural land.

Wider consideration of the suitability of land for production purposes should also be reviewed and appropriate land uses favoured. Options for land moderately or marginally suited for production include commercial forestry or complete retirement. Changes in land use may face resistance from landowners as it will represent a financial loss. At the catchment and community scale agricultural land losses can be partly offset by improving production on land that is less subject to nutrient losses and improvements to water quality, which will likely lead to wider environmental and social benefits e.g. improved aquatic biodiversity, increased recreational opportunities, more opportunities for wild food gathering. While strategies such as conversion to commercial forestry can currently be considered in LUCI, further refinements to incorporate a wider range of agriculturally productive land uses would be useful. 


\subsection{Contribution to putting an ES approach into practice}

As is illustrated above, LUCI can provide highly visual, spatially explicit, quantitative analysis of a number of single ecosystem services and multiple ecosystem service trade-off and synergy identification. Additionally, it is easy to use with moderate GIS skills and analyses can be generated in minutes to hours. These characteristics make LUCI an ideal tool for landscape management at a number of scales and by a variety of stakeholders. For example at the farm or block scale, LUCI can assist individual land owners to take a highly targeted and strategic approach to land and ecosystem service management and at the catchment or regional scale, LUCI can better inform stakeholders with planning and management of landscape scale processes and resources.

\section{Conclusion}

Here we demonstrate that significant opportunities exist within the Lake Rotorua catchment to improve $\mathrm{N}$ and $\mathrm{P}$ exports to water and agricultural productivity at the level of individual services. However, our multiple ecosystem service analysis reveals that interventions aimed at improving water quality are likely to come at the expense of agriculturally productive land. Our study highlights the utility of LUCI in identifying opportunities to improve water quality while minimising the loss of productivity on agricultural land. This includes identifying, at a fine spatial scale, the most appropriate locations to intercept nutrient pathways, and to increase production on agricultural land that is currently at lower risk of nutrient loss. These capabilities will be further enhanced as work progresses to include detailed soil, climate, topographical and land management variables for land covers other than pasture, to include a wider range of mitigation strategies, and to better incorporate and represent the impacts of catchment residence times and groundwater pathways, and hence lags in responses of waterways to changes in farm or other catchment management.

\section{Acknowledgements}

The authors thank Ravensdown and Callaghan Innovation (Grant No. ARLAB1402/PROP-41381-RDFELLOW-ARLAB) for funding support and Ravensdown and Bay of Plenty Regional Council for data for this project. Particular thanks to Alistair MacCormick from Bay of Plenty Regional Council and Ants Roberts and Mike White from Ravensdown for helpful assistance and feedback.

\section{References}

Abell, J.M., Ozkundakci, D., Hamilton, D.P., Miller, S.D., 2011, Relationships between land use and nitrogen and phosphorus in New Zealand lakes, Mar. Freshw. Res. 62, $162-175$.

Al Bakri, D., Rahman, S., Bowling, L., 2008. Sources and management of urban stormwater pollution in rural catchments, Australia. J. Hydrol. 356, 299-311.

Alexander, R.B., Elliott, A.H., Shankar, U., McBride, G.B., 2002a. Estimating the sources and transport of nutrients in the Waikato river basin, New Zealand. Water Resour. Res., 3812 .

Alexander, R.B., Johnes, P.J., Boyer, E.IW., Smith, R.A., 2002b. A comparison of models for estimating the riverine export of nitrogen from large watersheds. Biogeochemistry 57/58, 295-339.

Anastasiadis, S., Kerr, S., 2013. Mitigation and heterogeneity in management practices on New Zealand dairy farms. Motu Econ. Public Policy Res., 37.

Arbuckle, C., 2015. Stocktake of regional council uses of OVERSEER. Aspiring Environmental

Bagstad, K.J., Semmens, D.J., Waage, S., Winthrop, R., 2013. A comparative assessment of decision-support tools for ecosystem services quantification and valuation. Ecosyst. Serv. 5, 27-39.

Baillie, B.R., Neary, D.G., 2015. Water quality in New Zealand's planted forests: a review. N. Z. J. For. Sci. $45(7), 18$.

Ballinger, J., 2011. Natural Buffer Placement and Downstream Flood Mitigation in Rural Hawkes Bay. Victoria University of Wellington, New Zealand.

Benavidez, R., B. Jackson, D. Maxwell, E. Paringit, 2016. Improving Predictions of the Effects of Extreme Events, Land Use, and Climate Change on the Hydrology of Watersheds in the Philippines. Paper Presented at the IAHS 373, Germany.

Bennett, E.M., Schipanski, M.E., 2012. The phosphorus cycle. In: Weathers, K.C.. Strayer, D.L., Likens, G.E. (Eds.), Fundamentals of Ecosystem Science. Elsevier,
Boston.

Bhatterei, S., 2009. Spatially Explicit Assessment of Tradeoffs and Synergies Amongst Kev Ecosystem Services in Sasumua Watershed. Bangor University, Kenya.

BoPRC, 2012a. Improving water quality in Lake Rotorua: Information on the Way Land is Used. Bay of Plenty Regional Council, Rotorua.

BoPRC, 2012b. What is Rule 11? In: Council, B. o. P. R. (ed). Rotorua

Bouraoui, F., Grizzetti, B., 2014. Modelling mitigation options to reduce diffuxe nitrogen water pollution from agriculture. Sci. Total Environ. 468-469, 1267-1277.

Braat, L.C., de Groot, R., 2012. The ecosystem services agenda: bridging the world of natural science and economics, conservation and development, and public and private policy. Ecosyst. Serv. 1, 4-15.

Cameron, K.C.. Di, H.J., Moir, J.L., 2013. Nitrogen losses from the soil/plant system: a review. Ann. Appl. Biol. 162 (2), 145-173.

Cichota, R., Snow, V.O., 2009. Estimating nutrient loss to waterways - an overview of models of relevance to New Zealand pastoral farms. N.Z. J. Agric. Res. 52, 239-260.

Cox, J.W.. Oliver, D.P., Fleming, N.K., Anderson, J.S., 2012. Off-site transport of nutrients and sediment from three main land-uses in the Mt Lofty ranges, South Australia. Agric. Water Manag. 106, 50-59.

Davies-Colley, R., Wilcock, B., 2004. Waterquality and checmistry in running waters. In: Harding, J., Mosley, P., Pearson, C., Sorrell, B. (Eds.), Freshwaters of New Zealand. New Zealand Hydrological Society \& New Zealand Limnological Society, Christchurch.

Davis, M., 2014. Nitrogen leaching losses from forests in New Zealand. N. Z. J. For. Sci. 44 (2).

Davis, M., Coker, G., Watt, M., Graham, D., Pearce, S., Dando, J., 2012. Nitrogen leaching after fertilising young Pinus radiata plantations in New Zealand. For. Ecol. Manag. 280, 20-30.

Dewes, A.M., Business, Healthy, 2013. Healthy catchments: cancan we have our cake and eat it too? (February 2013)Rivers Workshop: Solution to Pollution. Massey University Palmerston North, Palmerston North.

Ding, X., Shen, Z., Hong, Q., Yang, Z., Wu, X., Liu, R., 2010. Development and test of the export coefficient model in the upper reach of the Yangtze river. J. Hydrol. 383. 233-244.

Elliott, S., McBride, G.B., Shankar, U., Semadeni-Davies, A., Quinn, J.M., Wheeler, D., Wedderburn, L., Small, B., Hewitt, A., Gibb, R., Parfitt, R.L., Clothier, B., Green, S., Harris, S., Rys, G., 2008. CLUES Spatial DSS: from farm-scale leaching models to regional decision support. Paper presented at the iEMSs: In: Proceedings of the International Congress on Environmental Modelling and Software Integrating Sciences and Information Technology for Environmental Assessment and Decision Making 4th Biennial Meeting of iEMSs.

Emmett, B., Abdalla, M., Anthony, S. G., Astbury, S., \& Others, 2014. Glastir monitoring \& evaluation programme. First year annual report. In: Hydrology, N. C. f. E. (ed) CEH Project no NEC04780, Bangor.

Emmett, B., Abdalla, M., Anthony, S., Astbury, S., and Others, 2015. Glastir monitoring \& evaluation programme. Second year annual report. NERC/Centre for Ecology \& Hydrology. Bangor, 1001.

Emmett, B., Cooper, D., Smart, S., Jackson, B., Thomas, A., Cosby, B., Evans, C.D., Glanville, H., McDonald, J.E., Malham, S.K., Marshall, M., Jarvis, S., Rajko-Nenow, P., Webb, G.P., Ward, S., Rowe, E., Jones, L., Vanbergen, A.J., Keith, A., Carter, H., Pereira, M.G., Hughes, S., Lebron, I., Wade, A.J., Jones, D.L., 2016. Spatial patterns and environmental constraints on ecosystem services at a catchment scale. Sci. Total Environ.. http://dx.doi.org/10.1016/j.scitotenv:2016.04.004, (Epub ahead of print).

Govt, N.Z., 2014. National Policy Statement for Freshwater Management 2014. New Zealand Government, Wellington.

Govt, N.Z., 2015. New Zealand Economic and Financial Overview 2015. New Zealand Government, Wellington, 52 .

Heathwaite, A.L., 2003. Making process-based knowledge useable at the operational level: a framework for modelling diffuse pollution from agriculutral land. Environ. Model. Softw. 18, 753-760.

Hewitt, A.E., 2010. New Zealand Soil Classification. Manaaki Whenua Press, Lincoln.

Hoare, R.A., 1984. Nitrogen and phosphorus in Rotorua urban streams. N. Z. J. Mar. Freshw. Res. 18, $451-454$.

Jackson, B., Wheater, H., Mathias, S., Mcintyre, N., Butler, A., 2006. A simple model of variable residence time flow and nutrient transport in the chalk. J. Hydrol. 330, 221-234.

Jackson, B., Wheater, H., Wade, A.J., Butterfield, D., Mathias, S., Ireson, A., Butler, A., Mcintyre, N.. Whitehead, P., 2007. Catchment-scale modelling of flow and nutrient transport in the chalk unsaturated zone. Ecol. Model. 209, 41-52.

Jackson, B., Browne, C., Butler, A., Peach, D., Wade, A.J., Wheater, H., 2008. Nitrate transport in Chalk catchments: monitoring, modelling and policy implications. Environ. Sci. Policy 11, 125-135.

Jackson, B., Pagella, T., Sinclair, F., Orellana, B., Henshaw, A., Revnolds, B., Mcintyre, N., Wheater, H., Evcott, A., 2013a. Polvscape: a GIS mapping framework providing efficient and spatially explicit landscape-scale valuation of multiple ecosvstem services. Landsc. Urban Plan. 112, 74-88,

Jackson, B., Cooper, D., Hall, J., Emmett, B., Bullock, J., 2013b. The Provision of Ecosystem Services in the Environmental Stewardship Scheme Work Package 2 Report to Natural England. vol. 43.

Jackson, B., Astbury, S., Cooper, D., Craythorne, M., Maxwell, D., Reuland, O., Thomas, A., Trodahl, M., 2014. LUCI v 0.4 Help Documentation.

Jackson, B.M., Metherell, A.K., Roberts, A.H.C., Trodahl, M.I., White, M., 2016. Adaption of the LUCI framework to account for detailed farm management: a case study exploring potential for nutrient mitigation using data from the Southland demonstration farm. In: Currie, L.D., Singh, R. (Eds.), Integrated Nutrient and Water Management for Sustainable farming. Fertilizer and Lime Research Centre Massey University, Palmerston North. 
Jarvie, H.P., Sharpley, A.N., Withers, P.J.A., Scott, J.T., Haggard, B.E., Neal, C., 2013. Phosphorus mitigation to control river eutrophication: murkv waters, inconvenien truths, and "postnormal" science, J. Environ. Qual, 42, 295-304.

Khadam, I.M., Kaluarachchi, J.J., 2006. Water quality modeling under hydrologie variability and parameter uncertainty using erosion-scaled export coefficients. J. Hydrol. 330, 354-367.

Krueger, T., Quinton, J.N., Freer, J., Macleod, C.J.A., Bilotta, G.S., Brazier, R.E., Hawkins, J.M.B., Haygarth, P.M., 2012. Comparing empirical modełs for sediment and phosphorus transfer from soils to water at field and catchment scale under dat uncertainty. Eur. J. Soil Sci. 63, 211-223.

Lin, J.P.. 2004. Review of published export coefficient and Event Mean Concnetration (EMC) data. Wetl. Regul. Assist. Program, 15.

Lloyd, C.E.M., Freer, .J.E., Johnes, P.J.. Coxon, G., Collins, A.L., 2016. Discharge and nutrient uncertainty: implications for nutrient flux estimation in small streams. Hydrol. Process. 30, 135-152.

Magesan, G.N., Wang, H., Clinton, P.W., 2012. Nitrogen cycling in gorse-dominated ecosystems in New Zealand. N. Z. J. Ecol. 36 (1), 21-28.

Maranara, T.R. 2016. Eco-hydrology Interactions Between Trees, Soil and Water in Terrestrial and Wetland Areas: The Effect of Tree Planting on Water Flow Dynamics in Wairarapa Wetlands. Victoria University of Wellington, New Zealand.

McDowell, R.W., Wilcock, R.J., 2008. Water quality and the effects of different pastoral animals. N. Z. Vet. J. $56(6), 289-296$

McDowell, R.W., Wilcock, R.J., Hamilton, D.P., 2013. Assessment of Strategies to Mitigate the Impact or Loss of Contaminants from Agricultural Land to Fresh Waters, Ministry for the Environment, Wellington, 41.

McQueen, J.C., Tozer, W.C., Clarkson, B.D., 2006. Consequences of alien N2-fixers on vegetation succession in New Zealand. In: Allen, R.B., Lee, W.G. (Eds.), Biological Invasions in New Zealand. Springer, Berlin, 295-306.

McRae, A. 2015. Fears that lake clean-up will hit farmers' profit. RadioNZ.

MEA, 2005. Ecosystems and Human Well-being: Current State and Trends, vol.1. In: Hassan, R., R. Scholes \& N. Ash (eds). Millenium Ecosystem Assessment. Washington.

Meals, D.W., Dressing, S.A., Davenport, T.E., 2010. Lag time in water quality response to best management practices: a review. J. Environ. Qual. 39, 85-96.

Meneer, J.C., Ledgard, S.F., Gillingham, A.G., 2004. Land use impacts on nitrogen and phosphorus loss and management options for intervention. Intervention AgResearch for Environment Bay of Plenty.

MFE, 2013. Freshwater Reform 2013 and Bevond. Ministry for the Environment, Wellington.

Monaghan. R.M., De Klein, C.A.M., Muirhead, R.W., 2008. Prioritisation of farm scale remediation efforts for reducing losses of nutrients and faecal indicator organisms to waterways: a case study of New Zealand dairy farming. J. Environ. Manag. 87, 609-622.

Morgenstern, U., Gordon, D., 2006. Prediction of future nitrogen loading to lake rotorua. GNS Sci. Rep., 28.

Muller, A., Sukhdev, P. Miller, D., Sharma, K. Hussain, S., 2015. TEEB for agriculutre $\&$ food: towardstowards a global study on the economics of eco-agri-food systems. U. Nations Environ. Program..

OVERSEER, 2016. OVERSEER, 2016. In. 〈http://www.overseer.org.nz) (accessed 17.07. 16.).

Parfitt, R.L., Schipper, L.A., Baisden, W.T., Elliot, A., 2006. Nitrogen inputs and outputs for New Zealand in 2001 at national and regional scales. Biogeochemistry 80, 71-88.

PCE, 2013. Water Quality in New Zealand: Land Use and Nutrient Pollution. Parliamentary Commissioner for the Environment, Wellington, 82.

Power, I.L., Ledgard, S.F., Monaghan, R.M., 2002. Nutrient Budgets for Three Mixed Farming Catchments in New Zealand. MAF, Wellingtob.

Quinn, J.M., Stroud, M.J., 2002. Water quality and sediment and nutrient export from New Zealand hill-land catchments of contrasting land use. N. Z. J. Mar. Freshw. Res.
$36,409-429$

Radcliffe, D.E., Freer, J., Schoumans, O., 2009. Diffuse phosphorus models in the united states and europe: their usages, scales, and uncertainties. J. Environ. Qual. 38 , 1956-1967.

Robinson, D.A., Jackson, B.M., Dominati, B.E. Clothier, E.J., Marchant, S.C., Cooper, D.M., Bristow, K.L., 2013. Advances in soil ecosystem services: concepts, models and applications for earth system life support. Vadose Zone J. 12 (2).

Robinson, T.H., Melack, J.M., 2013. Modeling nutrient export form coastal Californi watersheds. J. Am. Water Resour. Assoc. 48 (4), 793-809.

Rotorua Te Arawa Lakes Strategy Group, 2016. Lake Rotorua (http://www.rotorualakes. co.nz/rotorua) (accessed 06.01.16.)

Rutherford, K., Palliser, C., Wadhwa, S., 2009. Nitrogen Exports for the Lake Rotorua Catchment - Calibration of the Rotan Model. National Institute of Water and Atmospheric Research, Hamilton.

Rutherford, K., Palliser, C., Wadhwa, S., 2011. Prediction of Nitrogen Loads to Lake Rotorua Using the ROTAN Model. National Institute of Water and Atmospheric Research Ltd., Hamilton.

Schoumans, O.F., Silgram, M. Walvoort, D.J.J., Groenendijk, P., Bouraoui, F., Anderson, H.E., Lo Porto, A., reisser, H., Gall, G. Le, Anthony, S.G., Arheimer, B., Johnsson, H., Panagopoulos, Y., Mimikou, M., Zweynert, U., Behrendt, H., Barr, A., 2009. Evaluation of the difference of eight model applications to assess diffuse annual nutrient losses from agricultural land. J. Environ. Monit. 11, 540-553.

Schwarz, G.E., Hoos, A.B., Alexander, R.B., Smith, R.A., 2006. The SPARROW Surface Water-quality Model: Theory, Application and User Documentation. U.S. Geological Survey.

Scott, N.A., 2015. Facilitating Land-use Decisions Through the Modelling of Ecosystem Service Trade-offs. Victoria University of Wellington, Wellington.

Selbie, D.R., Watkins, N.L., Wheeler, D.M., Shepherd, M.A., 2013. Understanding the distribution and fate of nitrogen and phosphorus in OVERSEER. In: Proceedings of the New Zealand Grassland Association, vol. 75, pp. 113-118.

Shi, J., Davis, R., Densham, J., 2006. Better Land for Better Water: Modelling Land-use Change to Improve Water Quality in England. RSPB, WWF, Water UK, UK, 77.

Tait, A., Henderson, R., Turner, R., Zheng, X., 2006. Thin plate smoothing spline interpolation of daily rainfall for New Zealand using a climatological rainfall surface. Int. J. Climatol.

TeAra, T.E.O.N.Z., 2016. Rotorua City. In. (http://www.teara.govt.nz/en/volcanicplateau-places/page-4) (accessed 16.05.16.)

Tempero, G.. McBride, C., Abell, J., Hamilton, D., 2015. Anthropogenic Phosphorus Loads to Lake Rotorua. The University of Waikato, Hamilton.

Trodahl, M., Deslippe, J.R., Jackson, B., 2016. Improving predictions of N \& P export to waterways from rural landscapes in New Zealand using 1.UCI. (Palmerston North) In: Currie, L.D., Singh, R. (Eds.), Integrated Nutrient and Water Management for Sustainable Farming, 7.

Tsakiris, G., Alexakis, D., 2012. Water quality models: an overview. Eur. Water 37, 33-46.

Wheeler, D., Shepherd, M.A., 2013. OVERSEER Technical Manual: Introduction. AgResearch Ltd, Hamilton.

White, M., Harmel, D., Yen, H., Arnold, J.G., Gambone, M., Haney, R., 2015. Development of sediment and nutrient export coefficients for U.S. Ecoregions. J. Am. Water Resour. Assoc. 51 (3), 758-775.

White, P.A., Lovett, A., Tschrittler, C., Cusi, M., 2014. Lake rotorua catchment boundary relevant to bay of plenty regional council's water and land management policies. GNS Sci., 99.

Williamson, R.B., Cooke, J.G., 1982. Water quality of the Waiohewa stream, rotorua. N. Z. J. Mar. Freshw. Res, 16 (3-4), 327-337.

Woods, R., Hendrikx, J., Henderson, R., Tait, A., 2006. Estimating mean flow of New Zealand rivers. J. Hydrol. 45 (2), 95-110. 
Trodahl, M., Burkitt, L., Bretherton, M., Deslippe, J., Jackson, B. \& Metherell, A., 2017. Developing N \& P Export Coefficients for Rural Landscape Modelling in LUCI. In: Science and policy: nutrient management challenges for the next generation. (Eds L.D. Currie and M.J. Hedley). http://flrc.massey.ac.nz/publications.html. Occasional Report No. 30. Fertilizer and Lime Research Centre, Massey University, Palmerston North, New Zealand. 9 pages.

\title{
DEVELOPING N AND P EXPORT COEFFICIENTS FOR RURAL NEW ZEALAND LANDSCAPE MODELLING IN LUCI
}

\author{
Martha Trodahl $^{1}$, Lucy Burkitt ${ }^{2}$, Mike Bretherton ${ }^{2}$, Julie Deslippe ${ }^{3}$, Bethanna Jackson ${ }^{1}$ \\ \& Alister Metherell ${ }^{4}$ \\ ${ }^{I}$ School of Geography, Environment \& Earth Sciences, Victoria University of Wellington, Wellington \\ ${ }^{2}$ Fertiliser and Lime Research Centre, Massey University, Palmerston North \\ ${ }^{3}$ School of Biological Sciences, Victoria University of Wellington, Wellington \\ ${ }^{4}$ Ravensdown Ltd, Christchurch \\ Email:Martha.Trodahl@vuw.ac.nz
}

\section{Introduction}

Increasingly legislation and regulation require New Zealand farmers and land managers to reduce nutrient losses from their land to water. A number of models and methods are routinely used to assist with the task of identifying stocks and fluxes of nutrients in watersheds, but few offer quantification and solutions at fine spatial scale, yet are easily applied.

The Land Utilisation \& Capability Indicator (LUCI) is an option in this regard. A bespoke version of LUCI is currently under development for the Ravensdown co-operative that will assist New Zealand farmers and other land managers with decision-making concerning farm ecosystems. LUCI is particularly well-suited to assessing how on-farm activities affect water quality. One aim of the collaboration is to develop algorithms that consider influential nutrient loss variables (e.g. rainfall, soil type, fertiliser use and topography) and calculate export coefficients at fine scale for use in LUCI water quality models.

This paper discusses the need for a multivariate, algorithmic approach to export coefficient calculation and demonstrates its use in the Tuapaka catchment east of Palmerston North, a largely agricultural area. Here we present results of 4 applications of LUCI water quality models to the Tuapaka catchment, each using increasingly detailed input data. These are compared to OVERSEER ${ }^{\circledR}$ predictions and in-stream nitrogen $(\mathrm{N})$ and phosphorus $(\mathrm{P})$ measurements.

\section{$\underline{\text { LUCI }}$}

LUCI, an extension of the Polyscape framework described in Jackson et al. (2013a), is a GIS framework that considers impacts of land use on multiple ecosystem services in a holistic and spatially explicit manner. A number of sub-models within the framework assess ecosystem service stocks and associated indicators and processes, including water quality (total nitrogen (TN) and total phosphorus (TP)). Mass transport in LUCI is driven by unique hydrological routing algorithms which operate at the underlying digital elevation model (DEM) scale. This allows modelling of the entire range of scales, from sub-field to national, simultaneously. LUCI uses readily available national data that can be easily supplemented 
with local knowledge including detailed farm management. Ecosystem service tools can be run for individual ecosystem service analysis and to analyse interrelationships between ecosystem services, identifying trade-offs and synergies among them.

LUCI water quality models use an enhanced, spatially representative export coefficient approach to model TN and TP exports to water. Within the GIS framework, annual total nutrient exports, or export coefficients (ECs), are spatially-positioned at the DEM grid-square scale and cascaded through the landscape as water and sediment accumulate and move through the catchment. For each grid-cell, both on land and in the stream network, cumulative annual nutrient load and annual average concentration is calculated. This method identifies nutrient sources and current or potential intercepting nutrient sinks. While valuable, there are issues with using the export coefficient approach.

\section{The Export Coefficient Approach}

ECs are defined as the "mass of a [contaminant] per unit area per unit time" (White et al. 2015), commonly quantified in $\mathrm{kg} \mathrm{ha}^{-1} \mathrm{yr}^{-1}$. They are generally used in catchment scale water quality models to represent diffuse pollution associated with specific land covers and/or uses. ECs are most commonly described in association with export coefficient models (ECM), the simplest forms of which calculate the total catchment contaminant load by summing areaaveraged loads from individual sources within the catchment. However, ECs are also sometimes used in more complex, mechanistic models to represent diffuse pollution from various sources (Lu et al. 2013; Shrestha et al. 2008).

Most commonly ECs sourced from literature are linked to land cover or use with minimal reference to other influential variables. However, to be representative ECs must also consider climate, soil, topography, land cover, land use and management, and scale of measurement or derivation (Grimvall and Stalnacke 1996; White et al. 2015). Clearly, many of these factors are considerably spatially varied, even at small scales. Thus, the capability to determine ECs that consider this small scale variability is important.

A multivariate, algorithmic approach to EC calculation for use in LUCI has allowed us to address small-scale variability within pastoral land covers in New Zealand. Using a large (>14 000 pastoral blocks) dataset of OVERSEER ${ }^{1}$ input and output from Ravensdown, algorithms that consider climate, soil, topography, and management variables were derived using a non-linear multiple regression approach (see Jackson et al. (this issue) for further detail). LUCI water quality models use these algorithms to calculate an EC for each pastoral land cover DEM scale grid square. Currently ECs for other land covers are calculated using the same algorithms, but then scaled to respect relative differences between literature-based pasture and non-pasture land cover ECs. Development of algorithms specific to those other land cover categories would be preferred, but a lack of data hinders their derivation.

\section{Case Study: Tuapaka Catchment}

The study area is an 85ha catchment situated to the east of Palmerston North in the foothills of the Tararua Ranges (Fig. 1). Terrain is rolling to steep hill with a mix of brown and pallic soil orders. Ninety percent of the catchment is in pastoral grassland used largely for sheep and beef farming, while the remaining $10 \%$ is forested. Sixty three hectares of the catchment is within Massey University's Tuapaka Agricultural Experimental Station. Massey University have developed a detailed soil map (Pollok and McLaughlin 1986) for the experimental farm and have collected meteorological and water quality data within the catchment. Meteorological data includes rainfall and evapotranspiration from June 2013-June 2015. Ten minute flow data and monthly in-stream water quality sampling $(\mathrm{N}$ and $\mathrm{P}$ ) have also been 
collected for this period and a further year of monitoring is currently being undertaken. In addition, OVERSEER ${ }^{\circledR}$ has been applied to the area.

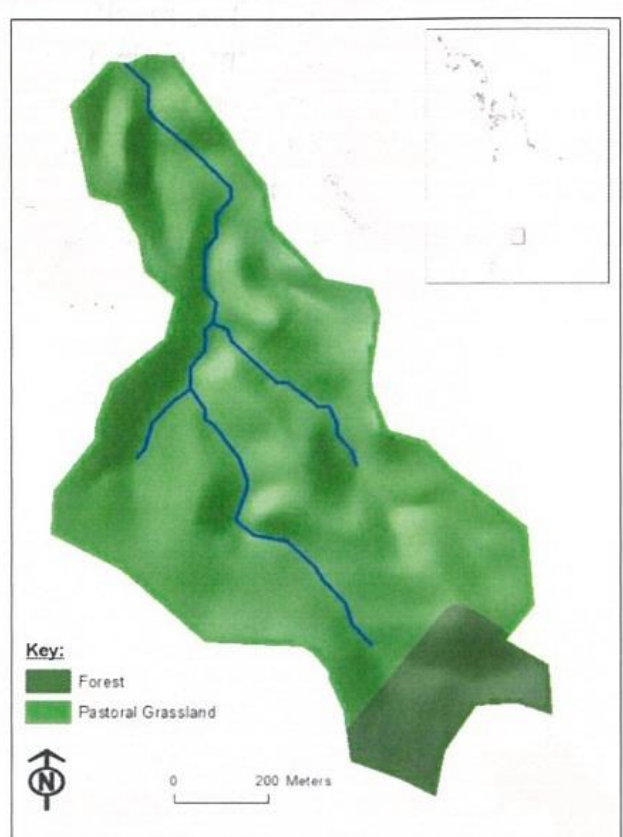

Fig. 1 - Tuapaka catchment

Comparison between actual water quality measurements taken between June 2013 and June 2014 and OVERSEER ${ }^{\circledR}$ predictions of $\mathrm{N}$ and $\mathrm{P}$ loss within this catchment were made by Burkitt et al (2016). This study builds on that work by conducting a comparative analysis between actual water quality measurements from June 2013-June 2015, OVERSEER ${ }^{\circledR}$ predictions of $\mathrm{N}$ and P loss, and LUCI water quality predictions. In addition, the sensitivity of LUCI's TN and TP predictions to input datasets of varying resolution and accuracy is investigated.

\section{Method}

LUCI water quality models were applied four times to the catchment using increasingly detailed and catchment specific input data with each application (Table 1). Application 1 used only the default national datasets. For Application 2, nationally available spatially varying annual average rainfall and evapotranspiration data by NIWA (Tait et al. 2006; Woods et al. 2006) was replaced by raster surfaces derived from actual rainfall and evapotranspiration data collected from June 2013-June 2014. Derivation was achieved by applying the difference between actual and modelled climate variables at the point of measurement to the NIWA raster climate surfaces. Application 3 used the above climate surfaces with the addition of the Massey University soil map for the Tuapaka Agricultural Experimental farm. This provided more spatial detail around soil variability. Application 4 used the climate surfaces based on actual data, the detailed soil data and actual farm input information from the OVERSEER ${ }^{\circledR}$ $\mathrm{xml}$ files. Output from the LUCI water quality models, including maps and in-stream loads, were then compared to actual water quality data and OVERSEER ${ }^{\circledR}$ predictions.

\begin{tabular}{|c|c|c|c|}
\hline LUCI Application & Climate Data & Soil Data & Farm Input Data \\
\hline Application 1 & National $^{1}$ & National $^{2}$ & Regional default $^{3}$ \\
\hline Application 2 & $\begin{array}{l}\text { Raster derived from } \\
\text { actual rain \& evap }\end{array}$ & National $^{2}$ & Regional default $^{3}$ \\
\hline Application 3 & $\begin{array}{l}\text { Raster derived from } \\
\text { actual rain \& evap }\end{array}$ & $\begin{array}{l}\text { Massey University } \\
\text { Tuapaka Soil Map }\end{array}$ & Regional default $^{3}$ \\
\hline Application 4 & $\begin{array}{l}\text { Raster derived from } \\
\text { actual rain \& evap }\end{array}$ & $\begin{array}{l}\text { Massey University } \\
\text { Tuapaka Soil Map }^{4}\end{array}$ & $\begin{array}{l}\text { Actual farm input } \\
\text { (OVERSEER xml) }\end{array}$ \\
\hline \multicolumn{4}{|c|}{$\begin{array}{l}\text { Rain and evapotranspiration surfaces developed by NIWA (Tait et al. 2006; Woods et al. 2006) } \\
{ }^{2} \text { NZFSL } \\
\text { https://soils.landcareresearch.co.nz/contents/SoilData_FSL_Maps.aspx?currentPage=SoilData_FSL_Maps\&men } \\
\frac{\text { UItem=SoilData }}{{ }^{3} \text { Regional farm input defaults developed by LUCI developers }} \\
{ }^{4} \text { Pollock and McLaughlin } 1986\end{array}$} \\
\hline
\end{tabular}

Table 1 - Data input details between the four LUCI applications 


\section{$\underline{\text { Results and Discussion }}$}

A number of maps and data are generated by the LUCI water quality models allowing exploration of TN or TP loads and concentrations both in-stream and on land. The results are presented as a map with DEM grid cells coloured according to their total nutrient loads, from low total nutrients in red to high nutrient loads in green (Trodahl et al. In Press). Nitrogen load maps from the four applications of LUCI are shown in Fig 2a-d. While the highest and lowest TN loads remained the same for all four applications, it is clear that Application 4, with the addition of actual farm nitrogen input data for Tuapaka Agricultural Experimental farm, has lowered nitrogen loads within this area (Fig 2d).

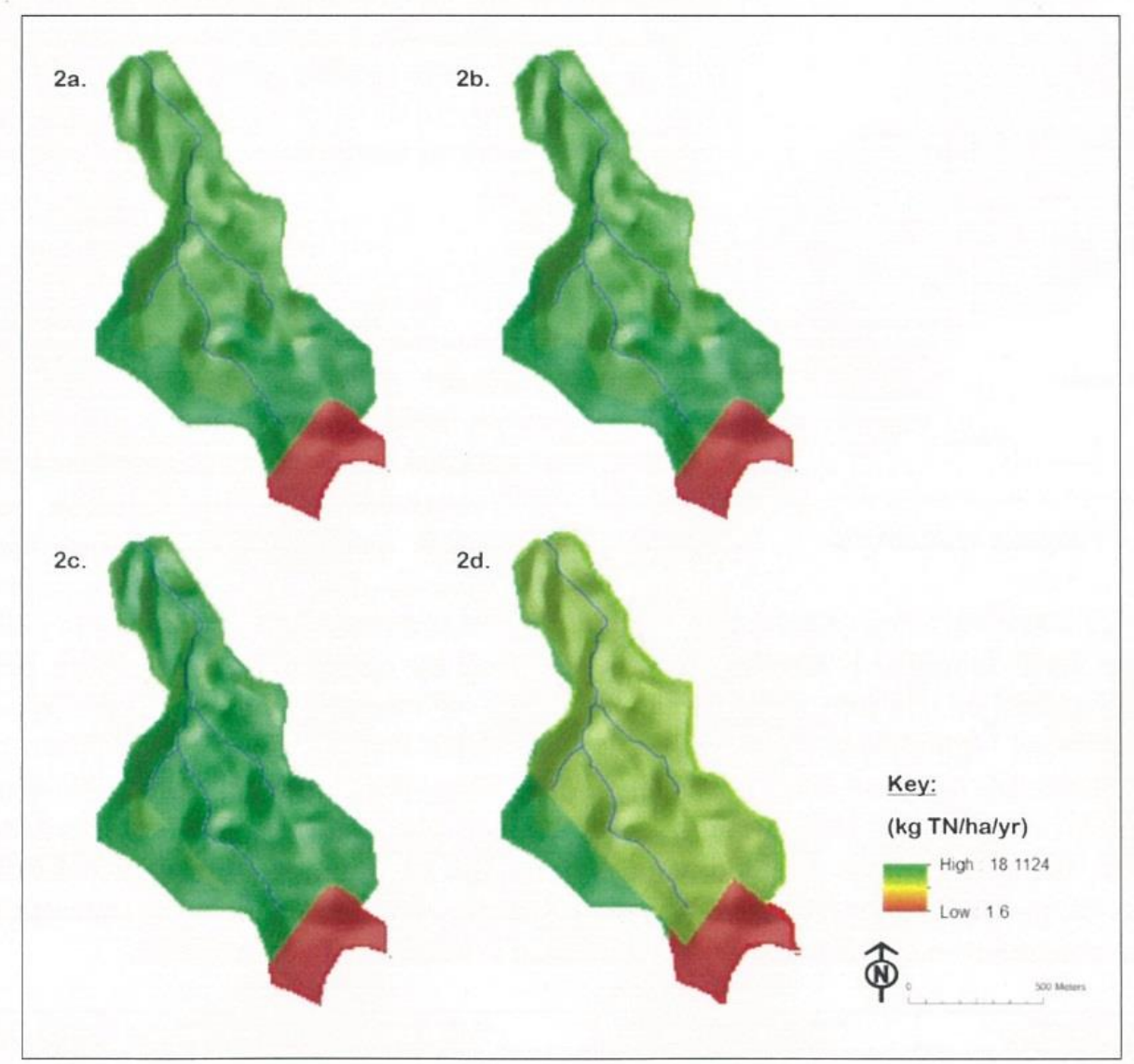

Fig 2 - Nitrogen load maps from LUCI Application 1 (2a), Application 2 (2b), Application 3 (2c) and Application 4 (2d).

Accumulated nitrogen load, classified into 3 groups, from LUCI Applications 1-4 is shown in Fig 3a-d. These indicate pathways where water and nitrogen converge in the landscape. Spatially explicit identification of these pathways illustrate where opportunities exist to intercept nutrients before they enter the stream network. Like Fig 2, maps from Applications 1-3 are very similar. Fig 3d, however, more clearly identifies pathways of very high load allowing more specific spatial targeting of areas for interventions and mitigations. 


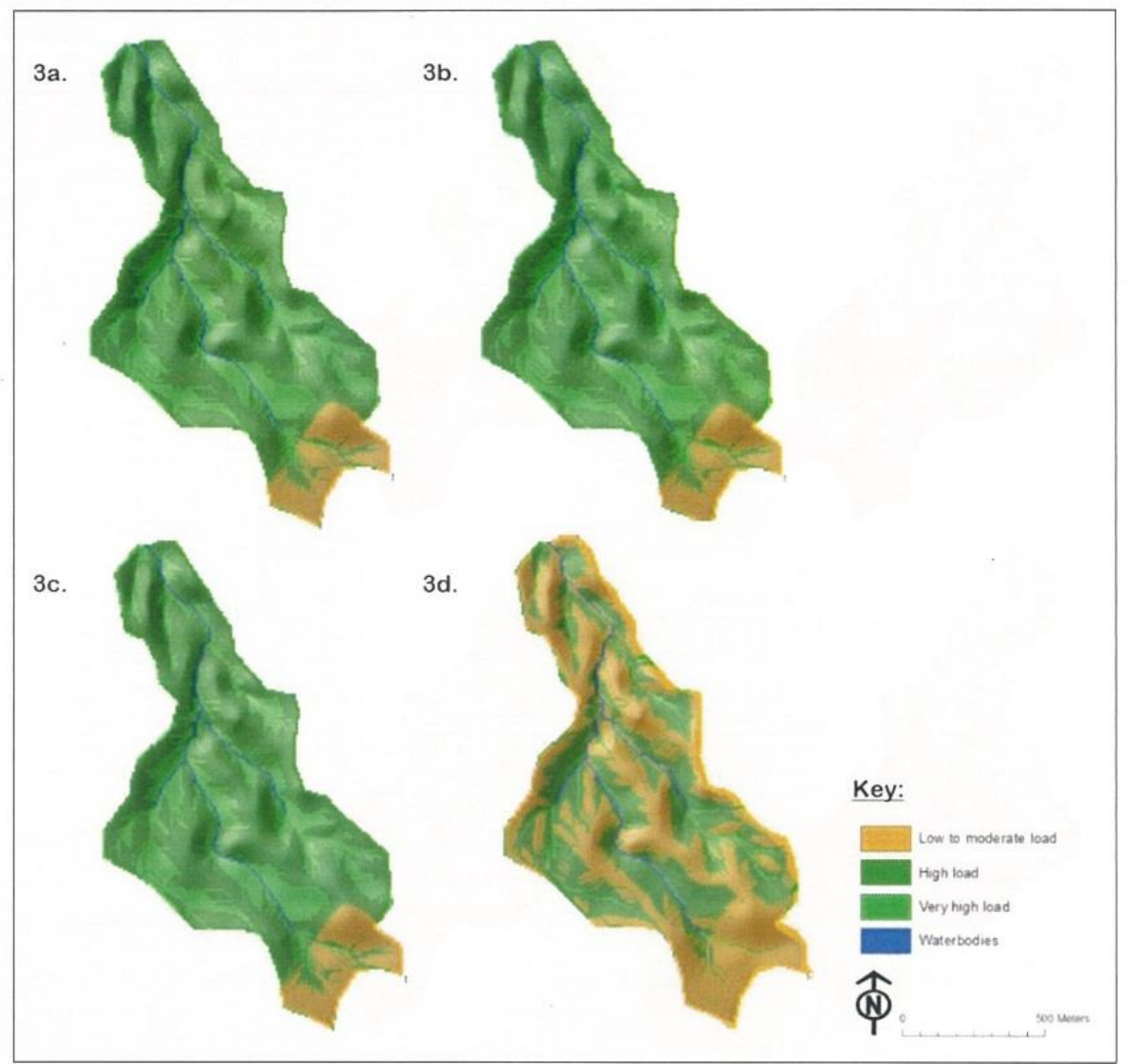

Fig 3 - Accumulated nitrogen load maps from LUCI Application 1 (3a), Application 2 (3b), Application 3 (3c) and Application 4 (3d).

Fig 4 shows $\mathrm{P}$ load maps from Applications 1-4. Figs $4 \mathrm{a}$ and $4 \mathrm{~b}$ are very similar with the highest P loads sourced from the steeper pastoral grassland and lowest loads from the forested area and flatter pastoral grassland in the upper catchment. With the addition of the detailed soil map in Application 3 (Fig 4c), the highest P loads reduced to $8.8 \mathrm{~kg} \mathrm{TP} / \mathrm{ha} / \mathrm{yr}$ from $12.3 \mathrm{~kg} \mathrm{TP} / \mathrm{ha} / \mathrm{yr}$ in Applications 1 \& 2. This is because the Massey University soil map indicates low P retention pallic soils only make up $20 \%$ of the catchment compared to $80 \%$ with the national soil map. A further reduction in the highest $\mathrm{P}$ loads (to $5.6 \mathrm{~kg} \mathrm{TP} / \mathrm{ha} / \mathrm{yr}$ ) is seen with the addition of actual farm inputs in Application 4 (Fig 4d).

Classified accumulated P load maps from LUCI Applications 1-4 are shown in Fig 5a-d. Like Fig 3, these show pathways of water and $\mathrm{P}$ convergence in the landscape where opportunities exist to intercept nutrients before they enter the stream network. As with $\mathrm{N}$, it is clear the addition of actual, more detailed data better defines pathways, allowing for more specific spatial targeting of interventions and mitigations.

Table 2 summarises $\mathrm{N}$ and $\mathrm{P}$ specific load from measured water quality data, OVERSEER ${ }^{\circledR}$, and the four LUCI applications. Average specific load, based on measurements from June 2013-June 2015, is shown in row 1 with the range over the two years in brackets. OVERSEER $^{\circledR}$ estimates of $\mathrm{N}$ and $\mathrm{P}$ annual average loses are shown in row 2 , and below that, predictions of $\mathrm{N}$ and $\mathrm{P}$ specific load for each of the four LUCI applications. 


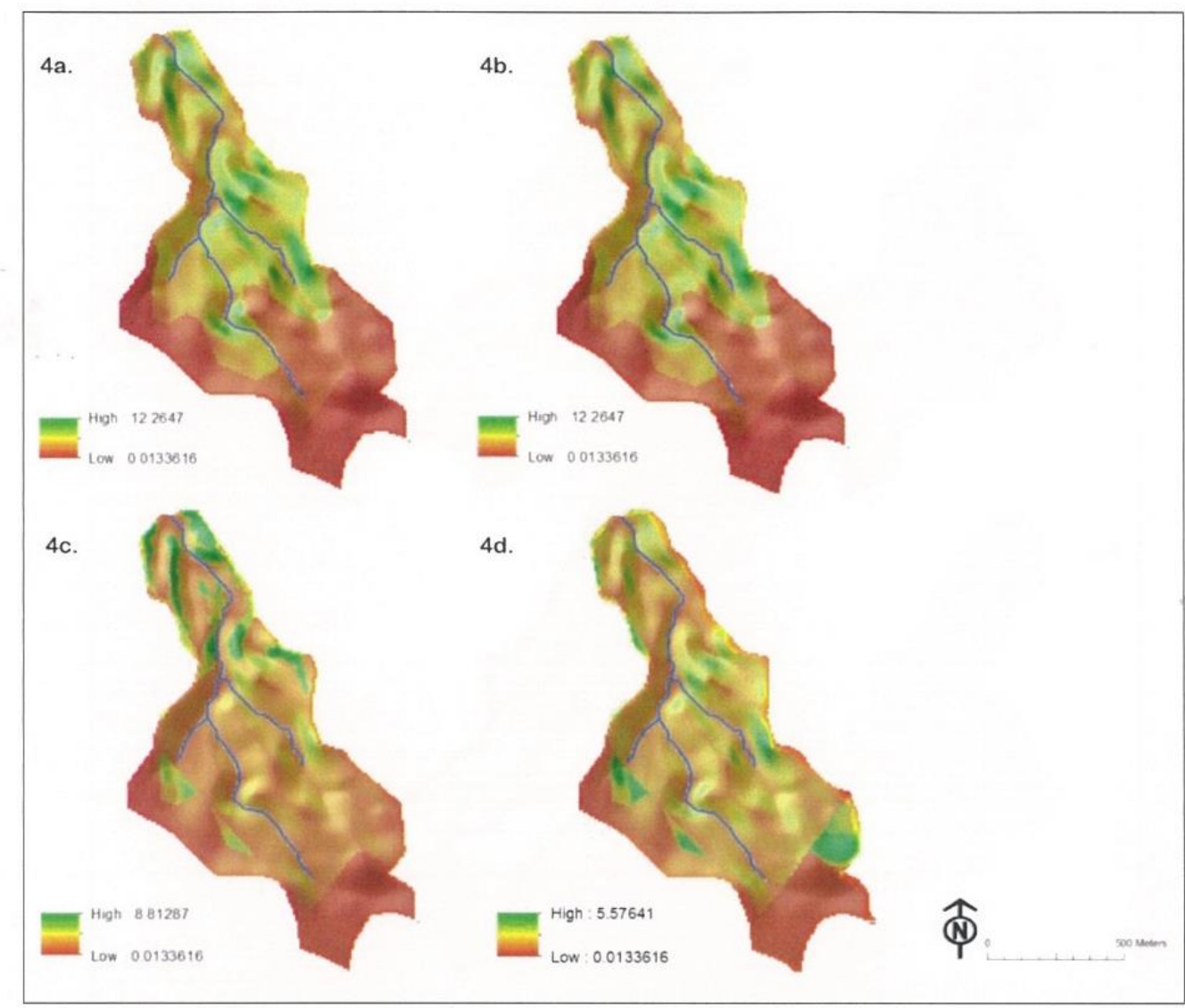

Fig 4 -Phosphorus load maps from LUCI Application 1 (4a), Application 2 (4b), Application 3 (4c) and Application 4 (4d).

It is clear from the maps and Table 2 that there is little difference between the outcomes from LUCI Application 1 and Application 2. The rainfall and evapotranspiration data from Massey University indicated a difference of $10 \%$ compared to annual average rainfall and evapotranspiration for the area from the NIWA data. In terms of excess rainfall (ie. rainfall less evapotranspiration) the difference between the measured and modelled data was only $7 \%$. Clearly these differences were not sufficient to significantly change LUCI output for N or P. The addition of detailed soil data in Application 3 had a clear impact on sources and loads of P due to significant decreases of pallic soil within the catchment. Detailed farm input data also decreased loads for both $\mathrm{N}$ and $\mathrm{P}$. These differences indicate that using data specific to a catchment or farm is preferable for use in LUCI, where it is available. Additionally, this highlights the ease with which actual and specific data can be incorporated for use in LUCI.

Clearly there are differences between LUCI predictions and measured specific loads (Table 2). While uncertainties exist around water quality measurements, particularly for $P$ at the monthly sampling scale (Johnes 2007; Krueger et al. 2012; Lloyd et al. 2016), this analysis suggests that further development to improve representation of nutrient attenuation in the catchment may improve the accuracy of LUCI predictions. Currently two catchment scale attenuation factors lump into one linear coefficient the impact of losses, lags and/or transformations from root zone to stream, and a similar factor represents within-stream attenuation. However, attenuation variability at the scales within which LUCI operates could be better represented. 


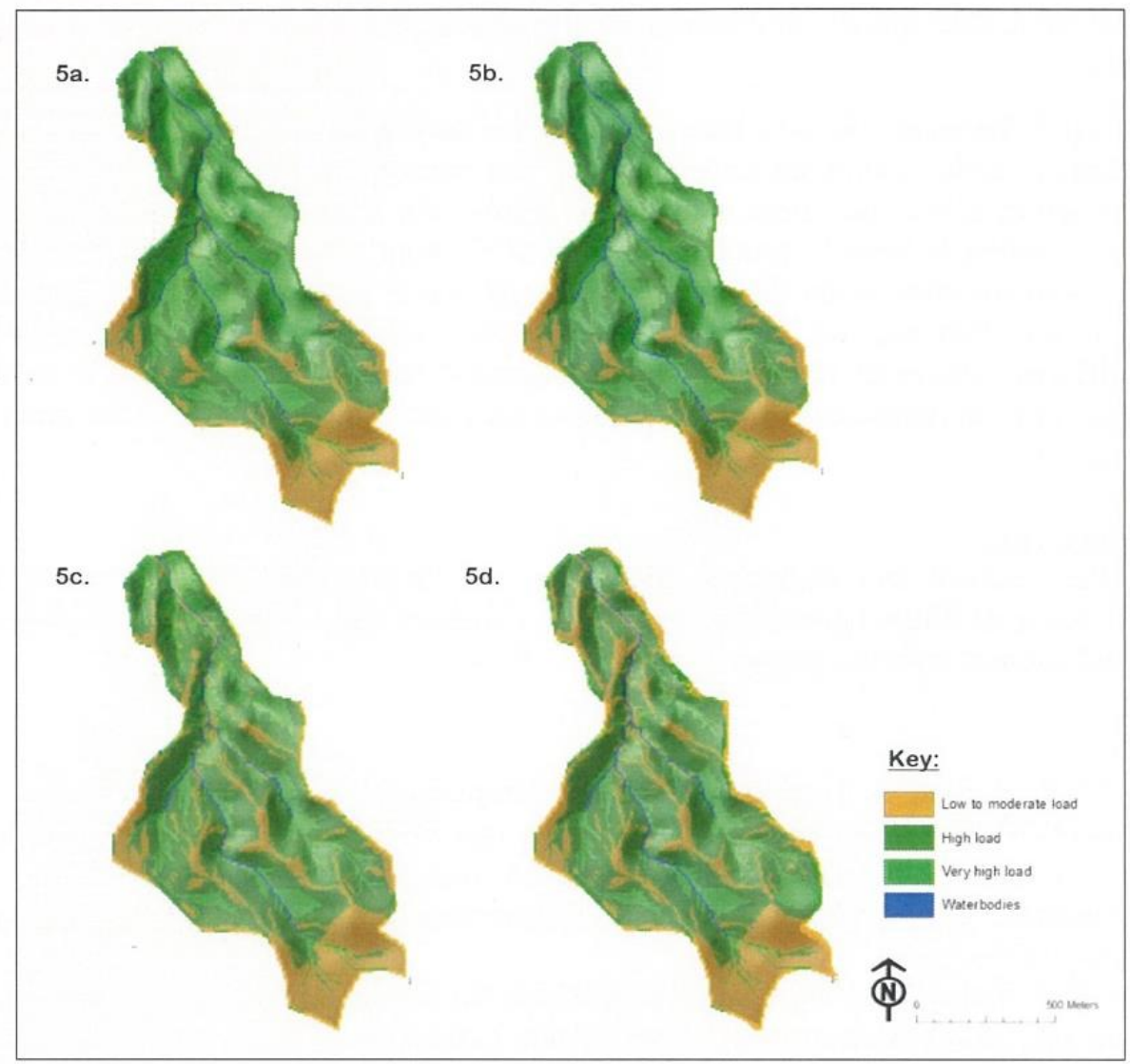

Fig 5 -Nitrogen Load maps from LUCI Application 1 (5a), Application 2 (5b), Application 3 (5c) and Application 4 (5d).

\begin{tabular}{|l|c|c|}
\hline Model/Measured & $\begin{array}{c}\text { NITROGEN } \\
\text { Specific Load (kg N/ha/yr) }\end{array}$ & $\begin{array}{c}\text { PHOSPHORUS } \\
\text { Specific Load (kg P/ha/yr) }\end{array}$ \\
\hline Measured & 2.37 & 0.12 \\
$(1.67-3.07)$ & $(0.06-0.18)$ \\
\hline Overseer & 8 & 0.8 \\
\hline LUCI Application 1 & 7.39 & 0.77 \\
\hline LUCI Application 2 & 7.39 & 0.77 \\
\hline LUCI Application 3 & 7.7 & 0.33 \\
\hline LUCI Application 4 & 6.23 & 0.28 \\
\hline
\end{tabular}

Table 2 - Measured and modelled specific load for the Tuapaka catchment. Note for Row 1 mean is presented with range in brackets.

\section{Conclusion}

Development of a novel multivariate, algorithmic approach to EC calculation has allowed us to address small-scale variability within pastoral land covers, enhancing farm to catchment scale water quality modelling in LUCI. Exploration of the effect of data resolution and detail on TN and TP exports using this newly developed method in the Tuapaka catchment 
indicates that using data specific to a catchment or farm is preferable for use in LUCI, where it is available.

However, clear differences still exist between measured nutrient losses and LUCI predictions at the catchment scale. Improved understanding and subsequent better representation of nutrient attenuation in the catchment is likely to improve the accuracy of LUCI predictions. Currently, attenuation is broadly accounted for in LUCI with catchment wide root zone to stream and in-stream attenuation factors applied for $\mathrm{N}$ and $\mathrm{P}$ respectively. Development of attenuation factors that account for small scale spatial variability within catchments and recognise different processes (lag times, biogeochemical transformations, etc.) is desired. This, in addition to development of EC algorithms for other land cover types, are areas for further investigation.

\section{Acknowledgements}

Thanks to Ravensdown and Callaghan Innovation for funding this project and to Ants Roberts and Michael White (Ravensdown) and the Fertilizer and Lime Research Centre for assistance and support with this project.

\section{References}

Burkitt, L., M. Bretherton, R. Singh \& M. Hedley, Comparing Nutrient Loss Predictions Using OVERSEER and Stream Water Quality in a Hill Country Sub-Catchment. In: Currie, L. D. \& R. Singh (eds) Integrated Nutrient and Water Management for Sustainable Farming, Massey University, Palmerston North, 2016. Fertilizer and Lime Research Centre, p 9.

Grimvall, A. \& P. Stalnacke, 1996. Statistical Methods for Source Approtionment of Riverrine Loads of Pollutants. Environmetrics 7:201-213.

Jackson, B., T. Pagella, F. Sinclair, B. Orellana, A. Henshaw, B. Reynolds, N. Mcintyre, H. Wheater \& A. Eycott, 2013a. Polyscape: A GIS mapping framework providing efficient and spatially explicit landscape-scale valuation of multiple ecosystem services. Landscape and Urban Planning 112:74-88.

Johnes, P. J., 2007. Uncertainties in annual riverine phosphorus load estimation: Impact of load estimation methodology, sampling frequency, baseflow index and catchment population density. Journal of Hydrology 332:241-258.

Krueger, T., J. N. Quinton, J. Freer, C. J. A. Macleod, G. S. Bilotta, R. E. Brazier, J. M. B. Hawkins \& P. M. Haygarth, 2012. Comparing empirical models for sediment and phosphorus transfer from soils to water at field and catchment scale under data uncertainty. European Journal of Soil Science 63:211-223.

Lloyd, C. E. M., J. E. Freer, P. J. Johnes, G. Coxon \& A. L. Collins, 2016. Discharge and nutrient uncertainty: implications for nutrient flux estimation in small streams. Hydrological Processes 30:135-152.

Lu, J., D. Gong, Y. Shen, M. Liu \& D. Chen, 2013. An inversed Bayesian modeling approach for estimating nitrogen export coefficients and uncertainty assessment in an agricultural watershed in eastern China. Agricultural Water management 116:79-88.

Pollok, J. \& B. McLaughlin, 1986. A user-friendly guide to the soils of Tuapaka Farm, vol Publication No. 3. Massey University Tuapaka Farm Series, Palmerston North.

Shrestha, S., F. Kazama \& L. T. H. Newham, 2008. A framework for estimating pollutant export coefficients from long-term in-stream water quality monitoring data. Environmental Modelling and Software 23:182-194. 
Tait, A., R. Henderson, R. Turner \& X. Zheng, 2006. Thin plate smoothing spline interpolation of daily rainfall for New Zealand using a climatological rainfall surface. International Journal of Climatology:2097-2115.

Trodahl, M. I., B. M. Jackson, J. R. Deslippe \& A. K. Metherell, In Press. Investigating tradeoffs between water quality and agricultural productivity using the Land Utilisation and Capability Indicator (LUCI) - A New Zealand application. Ecosystem Services doi:http://dx.doi.org/10.1016/j.ecoser.2016.10.013.

White, M., D. Harmel, H. Yen, J. G. Arnold, M. Gambone \& R. Haney, 2015. Development of sediment and nutrient export coefficients for U.S. Ecoregions. Journal of the American Water Resources Association 51(3):758-775.

Woods, R., J. Hendrikx, R. Henderson \& A. Tait, 2006. Estimating mean flow of New Zealand rivers. Journal of Hydrology 45(2):95-110. 